\title{
Las mujeres en la izquierda chilena durante la Unidad \\ Popular y la dictadura militar (1970-1990)
}

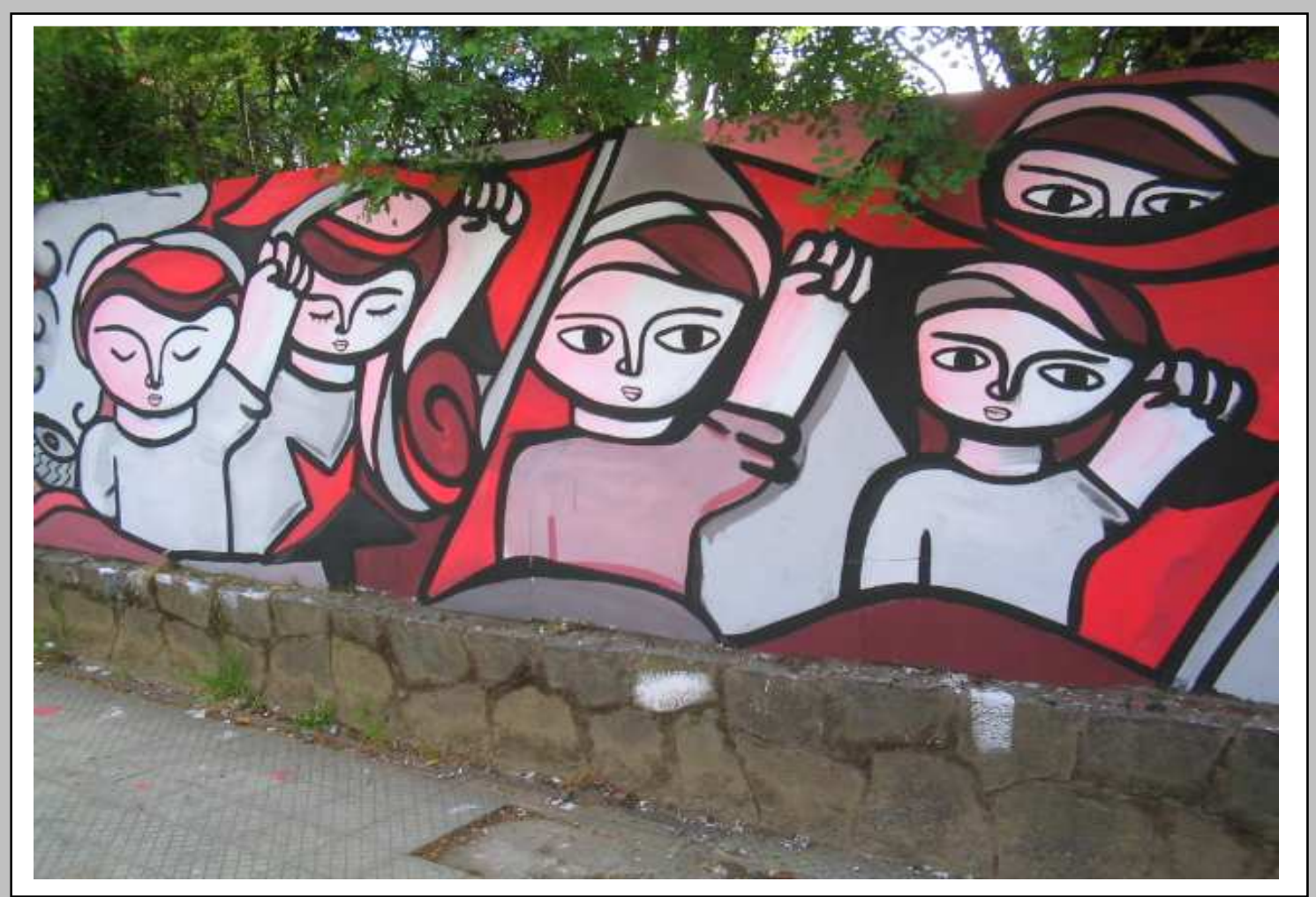

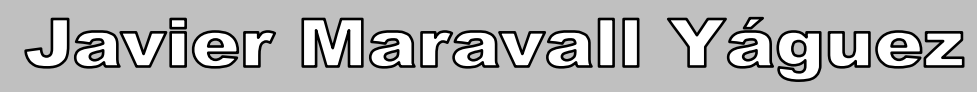


-"Las mujeres en la izquierda chilena durante la Unidad Popular y la dictadura militar (1970-1990)".

Doctorando: Javier Maravall Yáguez.

Director de Tesis: Álvaro Soto Carmona.

Departamento de Historia Contemporánea.

Universidad Autónoma de Madrid (UAM), 2012.

Proyecto financiado por la Agencia Española de Cooperación internacional (AECI), Ministerio de Asuntos Exteriores, Gobierno de España, 2003-2005. 
A la memoria de Elisabeth 


\section{ÍNDICE}

INTRODUCCIÓN ...................................................................................... 5

Objetivos............................................................................................................................... 9

Metodología ............................................................................................................ 10

a) Las fuentes escritas ............................................................................................ 13

b) Las fuentes orales y el método cualitativo ................................................... 14

Marco Referencial: la perspectiva de género.................................................. 15

Muestreo .............................................................................................................................. 16

Trabajo de Campo.......................................................................................................... 18

CAPÍTULO 1: LA MUJER EN LOS GOBIERNOS DE LA UNIDAD

POPULAR (1970-1973) ................................................................................... 22

1.1 El proyecto socialista y las mujeres: transformaciones y pervivencias en las relaciones de género ........................................................... 26

1.2 La reactivación de la militancia femenina: miristas, comunistas y socialistas..................................................................................... 39

CAPÍTULO 2: LA DICTADURA MILTAR: EL ROL DE LA MUJER EN EL “NUEVO ORDEN” (1973-1990) ........................................ 54

2.1 Las mujeres pro-dictadura .............................................................................. 54

2.2 Las políticas de género bajo el gobierno militar....................................... 62

2.3 El ideario de "mujer pinochetista" .............................................................. 72

CAPÍTULO 3: LAS MUJERES EN LA OPOSICIÓN A LA DICTADURA: MILITANCIA CLANDESTINA, EXILIO Y MOVILIZACIÓN SOCIAL (1973-1990) ......................................................................................... 76

3.1 Las militantes ante el golpe de Estado: el repliegue a la Clandestinidad 77 
3.2 El quehacer político en la sombra: comunistas, miristas y socialistas

3.2.1 Enlace, correo y difusión de propaganda ........................................ 86

3.2.2 Formación y participación militar ........................................................ 91

3.3 La militancia en reclusión................................................................. 98

3.3.1 Recopilación de información sobre la desaparición

forzada de personas......................................................................................... 100

3.3.2 La vida en prisión: estrategias de supervivencia

y solidaridad 105

3.4 La militancia en el exilio: La denuncia internacional y la toma de conciencia feminista

3.5 El retorno a Chile

3.6 EI liderazgo de la mujer en las agrupaciones pro-derechos humanos.

3.7 Discriminación de género en la vida partidaria 136

3.7.1 Acoso sexual 137

3.7.2 La sobrecarga en las tareas domésticas y en el cuidado integral de los hijos 140

3.7.3 Dificultades en el acceso a las responsabilidades partidarias 148

3.7.4 Otras discriminaciones 150

3.7.5 El discurso imperante en la izquierda: primero el derrocamiento de la dictadura, después la igualdad de género 152

3.8 Mujeres en la doble militancia: el caso del Partido Socialista. 161

\section{CAPÍTULO 4: LA TORTURA SEXUAL COMO ESTRATEGIA} REPRESIVA CONTRA LAS PRISIONERAS POLÍTICAS

4.1 La represión contra las mujeres: la tortura sexual como estrategia militar

4.2 La instrumentalización de la maternidad 190

4.3 Las secuelas 199

4.4 La colaboración bajo tortura: las quebradas 205

4.5 Mujeres en el aparato represivo. 212

4.6 Lumi Videla, un caso paradigmático 215 
4.7 Prisioneros políticos: ¿víctimas de la tortura sexual? ........................... 222

4.8 Principales centros de la tortura sexual .............................................. 227

4.9 La perspectiva de género en las investigaciones sobre Violaciones de derechos humanos: del Informe Rettig al Informe Valech

5. CONCLUSIONES

6. FUENTES Y BIBLIOGRAFÍA 268 
-"Y aquí en este lugar espantoso, donde se vivía minuto a minuto en una situación límite yo vi a muchos, a decenas que ya no están con nosotros... Si te golpean tanto, si te torturan, si te matan es porque tienes algo que ellos quieren, que ellos necesitan, que ellos no tienen, que ellos quieren arrebatarte y eso puede ser información, puede ser dignidad, puede ser valentía, puede ser fuerza interior, pueden ser principios, pueden ser razones poderosas para luchar, vivir y morir.

Puede ser amor inconmensurable a tu pueblo, a los seres humanos desvalidos, puede ser tu decisión de ponerte al lado de los débiles cuando era tan fácil optar junto a los poderosos. Puede ser ese tremendo sentido que esa juventud tan especial de los años sesenta y setenta le habían dado a sus vidas. Y a ellos, a los que estaban aquí en la Villa Grimaldi, torturándonos, a nosotros les faltaba todo eso, todo eso que a nosotros nos sobraba"

\footnotetext{
${ }^{1}$ Testimonio de Gladis Díaz, ex-prisionera sobreviviente y militante del Partido Comunista de Chile. Esta cita se encuentra enmarcada en una vitrina en el interior de "La Torre", situada en el recinto de lo que fue el centro de detención y tortura Villa Grimaldi, hoy conocido como Parque por la Paz. Testimonio recogido en grabación realizada el sábado 15 de noviembre de 2003, Parque por la Paz Villa Grimaldi, Santiago de Chile, Chile.
} 


\section{INTRODUCCIÓN}

La inclusión de la perspectiva de género en las investigaciones sobre violaciones de los derechos humanos en tiempos de dictadura militar, ha sido tardía cuando no obviada. Esa circunstancia se explica por el peso consuetudinario de la mentalidad androcéntrica en el conocimiento universal, en donde tradicionalmente se ha otorgado a la mujer un papel subsidiario.

El ámbito de los estudios históricos en América Latina no ha estado ajeno a estas influencias, lo que ha imposibilitado el tratamiento riguroso de la mujer como sujeto de historia en el devenir de los procesos político-sociales contemporáneos de este continente.

Este hecho, irremediablemente, ha traído consigo la falta de rigor a la hora de historiar, especialmente en los estudios sobre delitos de lesa humanidad ${ }^{2}$ que se cometieron contra la población civil femenina, en este caso, durante la instauración y desarrollo de dictaduras militares y, por otra parte, la invisibilización de las aportaciones de este colectivo en los procesos de transformación social y recuperación democrática en aquellos países que las sufrieron.

Tan sólo en los últimos años esta tendencia se ha ido revirtiendo gracias, primeramente, a la incansable labor de denuncia de las diversas organizaciones feministas y agrupaciones de mujeres y, segundo, a la presión de muchas mujeres académicas del ámbito científico para incluir la perspectiva de género y así poder transformar la mirada patriarcal imperante.

\footnotetext{
${ }^{2}$ El Estatuto de Roma de la Corte Penal Internacional (17 de julio de 1998) define (artículo 7) crímenes de lesa humanidad como cualquiera de los actos siguientes: "Cuando se cometa como parte de un ataque generalizado o sistemático contra una población civil y con conocimiento de dicho ataque: a) Asesinato; b) Exterminio; c) Esclavitud; d) Deportación o traslado forzoso de población; e) Encarcelación u otra privación grave de la libertad física en violación de normas fundamentales de derecho internacional; f) Tortura; g) Violación, esclavitud sexual, prostitución forzada, embarazo forzado, esterilización forzada u otros abusos sexuales de gravedad comparable; h) Persecución de un grupo o colectividad con identidad propia fundada en motivos políticos, raciales, nacionales, étnicos, culturales, religiosos, de género definido en el párrafo 3. Ver www.definicionlegal.com/definicionde/Crimeneslesahumanidad.
} 
Desde la década de los setenta del pasado siglo XX asistimos a la organización de amplias redes de mujeres en torno a la solidaridad y la denuncia de aquellos delitos que vulneraron sus derechos existenciales y que ponía de relieve la discriminación que este colectivo venía sufriendo en sus respectivos países en conflicto.

A las desapariciones forzadas de miles de mujeres se añadía el uso de la violación y la tortura sexual como arma de guerra contra las prisioneras. Estos delitos no estaban entonces contemplados por las organismos internacionales encargados de velar por los derechos humanos allá donde se produjeran, ni por los países suscritos a los diferentes acuerdos de cooperación en dicha materia, lo que ha impedido que la acción de la justicia esclareciera estos hechos.

La producción de conocimiento feminista durante la década de los ochenta, fruto en buena medida de los sucesivos encuentros internacionales de toda una heterogeneidad de organizaciones de mujeres, permitió dar un nuevo enfoque en el estudio sobre violaciones de los derechos humanos (DDHH) desde el ámbito de la jurisdicción internacional.

De esta forma, y por primera vez, empezaba a tratarse la violación como un arma de guerra utilizada específicamente contra las mujeres por su condición de género, aplicando el análisis desde el marco de dominación patriarcal que se reproducía con especial intensidad en el terreno castrense.

Por otra parte, a finales del siglo XX, la irrupción de los medios de comunicación y las nuevas tecnologías en el escenario bélico permitió visualizar y difundir crímenes de estas características, favoreciendo la sensibilización de la opinión pública a escala mundial e incrementado la presión de las organizaciones de derechos humanos sobre los gobiernos para que se involucraran, por fin, en la legislación y la persecución de aquellos delitos que vulnerasen los derechos fundamentales de las mujeres.

Por este motivo, conflictos del pasado reciente como el de los Balcanes (1991-1995) y la primera Guerra del Golfo en Irak (1991-1992) marcaron un punto de inflexión ya que las proporciones de la catástrofe humanitaria que trajeron tras de sí, pudieron apreciarse en tiempo real en cualquier rincón del globo. Los primeros testimonios de mujeres 
víctimas de la violación y la tortura sexual empezaban a sucederse, situación que forzó a que algunos organismos internacionales como el Tribunal de la Haya, se decidieran a incorporar de forma transversal la perspectiva de género en el estudio de las violaciones de derechos humanos (mainstreaming).

No obstante, en los inicios del nuevo siglo, el fortalecimiento del derecho internacional en esta materia, parece tornarse todavía como un reto pendiente ya que aún queda por definir una estrategia unitaria en la regulación de medidas de protección a las víctimas de la violencia de género y en la penalización de aquellos delitos que vulneren sus derechos.

En materia de represión política, Chile se ha perfilado como un caso paradigmático en la medida que han ido apareciendo, en los últimos años, investigaciones que han incorporado la perspectiva de género a la hora de abordar el impacto que los diecisiete años de dictadura militar (1973-1990) tuvieron sobre el conjunto social del país.

Por esta razón, se ha considerado oportuno analizar este caso concreto con vistas a dilucidar cómo se conforman los procesos de represión hacia las mujeres, haciendo especial hincapié en la repercusiones que para ellas tuvo el hecho de participar en la oposición a la dictadura, y siempre en el marco de su trasgresión con los roles de género asignados por el ideario patriarcal ${ }^{3}$.

Por tanto, la violación de los derechos humanos de las mujeres sólo puede abordarse bajo los parámetros de subordinación a la que han estado sometidas desde los primeros tiempos de la historia de la humanidad y, muy especialmente, en los períodos de irrupción militar como cortapisa a los intentos de democratización, ampliación de derechos de ciudadanía y de transformación social. Es en este punto donde las mujeres

\footnotetext{
${ }^{3}$ Las bases del Patriarcado tienen su origen en la organización social y cultural androcéntrica que asigna roles diferenciados a hombres y mujeres desde su nacimiento. El dominio y el control del varón sobre la mujer a través del uso de la violencia ha sido el modus operandi principal para mantener un orden de privilegios y control masculino que se mantiene hasta nuestros días. La Violencia de Género o violencia contra las mujeres es el resultado del cuestionamiento de un sistema transversal que adquiere mayores proporciones en tiempos de conflictividad militar. Ver Fernández Vargas V., "Las Mujeres y las Guerras: una visión sin prejuicios", en Maquieira D’Angelo y otras, Democracia, Feminismo y Universalidad en el siglo XXI, Ed. Universidad Autónoma de Madrid (UAM), Madrid, 2005, p. 757.
} 
han sufrido el castigo contra su sexualidad por el hecho de ocupar los espacios y lugares que por tradición correspondían a los hombres.

También, hemos querido atender a las aportaciones que como activistas realizaron entorno a la defensa de la democracia, las libertades y la denuncia de los represores. En este sentido, su lugar existencial no solo ha de tratarse bajo el paradigma de victimarias sino, también, como sujetos activos de política y de transformación social, porque, de lo contrario, nuevamente las mujeres quedarían relegadas a un plano subsidiario y pasivo.

La presente investigación nos sumerge en lo que las militantes sobrevivientes de los lugares de detención de la dictadura militar (1973-1990) transmiten desde el recuerdo de sus propias experiencias vitales, de su compromiso político y social en la construcción de un Chile democrático y de su lucha contra la impunidad en unos delitos que no prescriben en el tiempo. 


\section{Objetivos}

Los objetivos marcados en la investigación han estado enfocados en el estudio de tres hitos fundamentales:

\section{a) La militancia política de las mujeres en el gobierno de la Unidad Popular y en la oposición a la dictadura militar (1970-1990):}

Se trata de abordar desde la perspectiva de género cuáles fueron las tareas partidarias desempeñadas por las mujeres que militaban en los partidos más representativos de la izquierda chilena (Partido Comunista, Partido Socialista y Movimiento de Izquierda Revolucionaria) desde el gobierno democrático de Salvador Allende hasta la clandestinidad en dictadura. Este objetivo incluye también el análisis de las dificultades y discriminaciones de género que las activistas pudieron experimentar en sus respectivas formaciones políticas a lo largo del devenir militante.

\section{b) La represión contra las prisioneras políticas:}

Se propone analizar el alcance que la represión de la dictadura militar de Augusto Pinochet (1973-1990) tuvo en la salud integral de las entrevistadas en los diferentes lugares de detención que se extendían a lo largo de Chile y si ello obedeció a una estrategia específica de género.

\section{c) La labor de las mujeres sobrevivientes:}

Visualizar la labor político-social de las mujeres que sobrevivieron a la represión en torno a la denuncia y esclarecimiento de los hechos represivos, como aportación fundamental a la reconstrucción de la memoria histórica del pasado reciente chileno y en su recuperación democrática. 


\section{Metodología:}

La investigación se enmarca dentro de la corriente historiográfica Historia del Tiempo Presente $^{4}$ cuya metodología se basa en el estudio compartido de las fuentes escritas del pasado reciente y las orales del presente.

La combinación de ambas fuentes responde a la necesidad de aumentar el grado de precisión en el análisis de los hechos que han sido objeto de estudio, ya que permite contar con información directa ("testimonios orales"), que si bien puede tener el riesgo de la imparcialidad, también puede tornarse como un complemento revelador que permita una comprensión más ajustada de los hechos.

Resulta evidente que la memoria ${ }^{5}$ individual y colectiva por sí sola no es ciencia histórica, pero sí puede configurase como una parte fundamental a la hora de historiar un determinado período de tiempo. Por esta razón podemos considerarla como una valiosa fuente que puede otorgar una perspectiva diferente a la obtenida por métodos tradicionales de investigación, siempre y cuando la información quede rigurosamente contrastada con fuentes escritas si es que las hubiere. Ello daría la objetividad necesaria para verificar o desmentir los hechos y permitiría contar con detalles inéditos que de otra manera no podrían avistarse: "los historiadores pueden utilizar la memoria como una fuente cuando someten los recuerdos a un análisis crítico. Pueden hacer una historia de la memoria, convertir a ésta en el objeto de su investigación"”.

La riqueza de matices que puede otorgar el recuerdo de lo vivido, por ejemplo, a través de la microhistoria oral ${ }^{7}$ en donde un determinado sujeto rescata cómo y de que manera vivió un acontecimiento, si bien comporta un grado subjetivo que depende de su voluntad (selectiva o distorsionada), puede significar también una oportunidad de reconocer hechos coincidentes reflejados en otras fuentes y ayudar a contextualizarlos

\footnotetext{
${ }^{4}$ Ver Aróstegui Sánchez, J., La historia vivida sobre la historia del presente, Alianza, Madrid, 2004.

${ }^{5}$ Ver Cuesta Bustillo, J., Memoria e Historia, Marcial Pons, 1998.

${ }^{6}$ Ver Winn P., “El pasado está presente: historia y memoria en el Chile contemporáneo”, en Historizar el pasado vivo en América Latina, http://etica.uahurtado.cl/historizarelpasadovivo/es_contenido.php

${ }^{7}$ Ver Folguera Crespo, P., Cómo se hace Historia Oral, Eudema, UAM, 1993.
} 
con más precisión. Porque al fin y al cabo quienes verdaderamente se perfilan como los protagonistas de un determinado acontecimiento son aquellos que lo vivieron en primera persona, unos testimonios vivos de una época pasada que podrían verter más luz sobre las innumerables lagunas con las que se encuentra un historiador.

Otro elemento que se ha tenido en cuenta en la elaboración de la investigación es la neutralidad con la que se debía trabajar a la hora de interpretar la información. La historia del horror y la represión sobre la población civil puede generar sin duda todo tipo de sensacionalismos y posicionamientos ideológicos enfrentados que podrían empañar la labor investigadora. Historiar para conocer con más detalles el pasado reciente ha sido la línea conductora de este trabajo, independientemente de que ello sirva para legitimar o deslegitimar a un determinado colectivo de individuos.

Hobsbawn $^{8}$ ya advertía sobre las limitaciones de historiar un período de tiempo tan limitado como el siglo $\mathrm{XX}$ y en donde los mismos historiadores podían ser parte integrante de los acontecimientos, lo que irremediablemente introduciría elementos subjetivos. De esta manera se podría pensar que quienes decidieron, por ejemplo, indagar sobre las violaciones de los derechos humanos cometidas durante la Segunda Guerra Mundial fueron en muchos casos los mismos que habían vivido de una manera más directa o indirecta lo ocurrido (como parte "afectada" y no neutral).

Si bien es cierto que el individuo puede recordar de forma interesada en base a sus propios deseos o necesidades, también cabe la posibilidad de que incorpore detalles altamente enriquecedores que de otra manera sería imposible obtener y en donde el historiador ha de estar muy atento en cómo interpreta la información y de qué manera la contrasta:

"La microhistoria adquiere un rol muy significativo para que se puedan entender procesos complejos poco conocidos. Si los detalles importan para entender los procesos históricos, en este caso aún tendrían más relevancia.... Hacer historia de procesos con poca documentación escrita, como fue la represión en Chile, obliga al historiador a entrevistar al

\footnotetext{
${ }^{8}$ Ver Hobsbawn, E., Age of Extremes. The Short Twentieth Century 1914-1991. Vintage Books, New York, 1996.
} 
mayor número de personas posible que se vieron envueltas en él, lo que le conduce a insertarse en la técnica y la metodología propias de la historia oral"9

En este caso, al abordarse la represión sufrida de un determinado colectivo, la totalidad de las personas entrevistadas de una u otra manera fueron víctimas de los hechos, lo que ha obligado al investigador a tener sumo cuidado a la hora de trabajar con la información vertida. Asimismo, se han tenido en cuenta otros elementos referidos al lenguaje no verbal como la gesticulación, el estado de ánimo de la entrevistada, pausas y silencios, etc.

Las víctimas, en diversos grados, han pasado por procesos traumáticos con un claro impacto en su salud mental y física, y en muchos casos todavía continúan con diversos problemas de salud. Ello podría distorsionar el recuerdo de lo vivido al estar sujetas a las huellas físico-emocionales que la represión dejó en sus vidas, y es en este punto en donde las fuentes escritas nos han servido para corroborar o desmentir lo relatado: expedientes médicos, declaraciones judiciales, testimonios escritos pertenecientes a organizaciones de derechos humanos, expedientes de la Cruz Roja Internacional, fichas policiales, documentos de expulsión del país, fotografías de los lugares de detención, nombres de los agentes, métodos utilizados, etc.

Aunque, por ejemplo, la entrevistada sobre o infra dimensionara su participación política o la represión sufrida, también se podría indagar si existe información escrita al respecto. De ser así, ya existirían dos fuentes que podrían ser comparadas, es decir, se darían las condiciones para poder historiar. En caso contrario la información quedaría desechada sin afectar a la labor del investigador.

\footnotetext{
${ }^{9}$ Ver Camacho Padilla F., "Combates entre la memoria y la historia de Chile: conflictos sobre el pasado reciente", Review of Latin American Studies, Issue No 5, september 2009, Stockholms Universitet, p. 9192.
} 


\section{a) Las fuentes escritas:}

Se han consultado y analizado los testimonios escritos de aquellas presas sobrevivientes que acudieron a los diversos organismos de defensa de los derechos humanos que operaron en Chile durante el período 1973-1990. Estas fuentes se consideran primarias al tratarse de declaraciones que se realizaron en un período relativamente inmediato a la puesta en libertad de quienes los prestaron. La documentación original utilizada ha sido:

-Archivo de la Corporación Nacional para la Defensa de los Derechos del Pueblo (CODEPU, Santiago de Chile): Consta de un archivo digital con diferentes declaraciones y testimonios de tortura así como los nombres y cargos de los agentes represores.

-Archivo de la Fundación Vicaría de la Solidaridad (Santiago de Chile). En él se encuentran miles de testimonios escritos sobre desaparición forzada de personas y represión política en los primeros años de la dictadura.

-Archivo Rettig: Ubicado en el Departamento de Historia Contemporánea de la Universidad Autónoma de Madrid, España. Consta de 450.000 documentos correspondientes a toda la información recogida por la Comisión Nacional de Verdad y Reconciliación para la elaboración del Informe Rettig (1991).

-Bibliotecas: Biblioteca general del Partido Socialista de Chile (PSCH, Santiago de Chile). Biblioteca del Partido Comunista de Chile (PCCH, Santiago de Chile). Biblioteca de la Corporación La Morada (Santiago de Chile). Biblioteca de la Facultad Latinoamericana de Ciencias Sociales (FLACSO, Santiago de Chile). 


\section{b) Las fuentes orales y el método cualitativo:}

En los últimos años y dentro del marco de las ciencias sociales, han ido adquiriendo una mayor consistencia la utilización de las fuentes orales como principal vía de investigación. El uso de los testimonios directos como fuente de información prioritaria se proyecta como una nueva metodología que diversas disciplinas han ido incorporando, no sin dificultades, bajo el supuesto de que lo presente puede significar en un futuro tener "fuentes directas del pasado". Así, las nuevas corrientes sociológicas, historiográficas y periodísticas ya vienen utilizando dicha metodología en diversos campos, entre ellos, en el ámbito de aquellos procesos que vulneran o han vulnerado los derechos humanos.

Desde una perspectiva general la metodología de carácter cualitativo está centrada en la obtención de datos primarios por la vía de la entrevistas en profundidad partiendo de una pequeña muestra (44 testimonios). En cuanto a la estructura, el cuestionario fue prediseñado en base a los objetivos, aunque con un carácter flexible que estimulara a las entrevistadas a traspasar un discurso construido y ser espontáneas en sus respuestas.

La investigación ha estado sobre todo encaminada a analizar los discursos, porque el principal interés se ha concentrado no tanto en verificar o no determinadas hipótesis sino en conseguir desplegar toda la riqueza de información obtenida a lo largo de los encuentros.

Por este motivo se ha considerado que para cumplir con los objetivos, la metodología cualitativa podía ser un recurso sumamente valioso. En primer lugar, porque se caracteriza por su modo flexible y desestructurado de captar la información lo que amplía las posibilidades de análisis; en segundo, porque posibilita conocer de primera mano como las personas entrevistadas comprenden e interpretan sus propias experiencias vitales en relación a lo que reflejan las fuentes escritas. Finalmente, porque permite la adaptación de los diferentes métodos de investigación a los nuevos datos que van surgiendo en el transcurso del estudio. 


\section{Marco referencial: la perspectiva de género:}

Este estudio se sustenta, en términos generales, en tres aspectos:

1) La perspectiva de género, entendida no como una metodología ni como una variable más, sino como un enfoque que vertebra cualquier investigación y desde el que se analizan todas las variables asociadas.

2) El enfoque de género permite desarticular las verdaderas implicaciones que conlleva la invisibilización de la desigualdad, cuestionando y promoviendo la transformación de las identidades asignadas en razón de sexo, profundamente arraigadas y naturalizadas en todos los ámbitos sociales.

3) El término igualdad entre mujeres y hombres se refiere exclusivamente a la igualdad de trato, derechos y oportunidades. Respetando las diferencias de sexo, de lo que se trata es de eliminar las desigualdades que, basándose en esas diferencias, han atribuido a los hombres un lugar dominante en las relaciones de poder.

Asimismo, se atenderán a dos factores fundamentales en el desarrollo de la investigación:

1) Los avances de las mujeres hacia la igualdad en todas las esferas de la sociedad (ámbito público, doméstico y privado). El análisis estará enfocado en el estudio de los tipos de reacción, los estímulos y las posibles resistencias ante los procesos de cambio iniciados entorno a la igualdad de género y reposicionamiento de los papeles asignados tradicionalmente a hombres y mujeres.

2) La violencia de género. Se incluirán las posibles variables interpretativas respecto a la existencia, causalidad y mantenimiento de la violencia de género, los comportamientos de tolerancia y oposición a la misma y el impacto que esta ha tenido en la salud integral de las víctimas. 


\section{Muestreo:}

El trabajo de campo se enmarca dentro de la investigación cualitativa y la selección de personas informantes, siguiendo el procedimiento de representación estructural y no estadístico. En este tipo de muestreo las personas son seleccionadas de forma deliberada para ofrecer una variedad de opiniones en relación a la materia estudiada. Se trata de elegir a personas representativas que puedan ofrecer información relevante.

Uno de los aspectos que condiciona el número de personas seleccionadas es la saturación como el momento de la investigación, a partir del cual no se encuentra información adicional en relación al tema de investigación entre la muestra seleccionada. Es decir, que aunque realizáramos más entrevistas, no añadirían más información relevante a lo ya obtenido. El muestreo cualitativo no pretende en ningún momento la representación estadística, sino la representación tipológica o socioestructural, correspondiente a los objetivos.

La selección de la muestra no suele estar definida completamente antes de iniciar la investigación, ya que en función de los contactos que se van realizando y la información a la que se va teniendo acceso, se pueden definir mejor algunas características de las personas informantes o incorporar otras no previstas en la fase inicial.

El presente estudio recoge un total de 44 entrevistas individuales en audio a ex-

prisioneras políticas residentes en la ciudad de Santiago de Chile, de una duración aproximada de 120 minutos cada una y realizada por el propio autor.

Los criterios a la hora de realizar las entrevistas han estado encaminados a poder incluir el mayor número posible de variables en cuanto a militancia política se refiere (trabajo de base, cuadros medios y puestos de responsabilidad en las formaciones políticas) y a incorporar los tres ámbitos partidarios más representativos de la izquierda política en dictadura: Partido Socialista, Partido Comunista y Movimiento de Izquierda Revolucionaria. 
Lo que se pretendía en cada caso era crear un espacio distendido de reflexión, en el que las entrevistadas pudieran poco a poco trascender el discurso razonado para poder así manifestar con mayor espontaneidad lo que constituyen sus verdaderos pensamientos, sensaciones y emociones en torno a sus experiencias en la militancia y la reclusión.

En su totalidad, estos encuentros han sido grabados en formato audio con el permiso expreso de las entrevistadas, a quienes se les garantizó en algunos casos el anonimato a la hora de difundir la autoría de los fragmentos citados. Durante el transcurso, el entrevistador registró, además, notas e información in situ, lo que ha permitido una elaboración posterior más ajustada del análisis.

En todos los caso, las transcripciones -que ha realizado el mismo autor- han sido literales, respetando la riqueza del lenguaje y dando especial atención a la heterogeneidad de los matices.

Una vez definidos los criterios de selección de candidatas, se utilizó la técnica denominada Bola de Nieve ${ }^{10}$ : se localizan candidatas que se ajusten a los criterios determinados, a través de los cuales se contacta con otras mujeres del mismo perfil.

\footnotetext{
${ }^{10}$ Ver Covas S., Maravall J., Bonino L., Hombres con valores igualitarios: historias de vida, logros alcanzados y cambios pendientes, Ministerio de Igualdad, Gobierno de España, Diciembre 2009, Madrid, España, p.11.
} 


\section{Trabajo de Campo:}

La investigación sobre el terreno ha tenido una duración de dos años (2003-2005), gracias a la financiación de la Agencia Española de Cooperación Internacional en Chile y a la colaboración del Departamento de Historia Contemporánea de la Universidad Autónoma de Madrid (UAM).

El punto de partida fue el mes de octubre de 2003 coincidiendo con los diversos actos organizados en Santiago de Chile con motivo del $30^{\circ}$ aniversario del golpe militar en torno a la memoria de las victimas.

El primer contacto fue en uno de los actos celebrados en el Parque por la Paz Villa Grimaldi (Santiago de Chile), el que fue el más importante centro de tortura y reclusión de la Dirección de Inteligencia Nacional (DINA) y en donde tuvimos la oportunidad de conversar con su vicepresidenta, Margarita Romero, quien muy interesada por la investigación, se prestó a darnos su testimonio y a facilitarnos otros contactos de mujeres que estuvieron recluidas allí.

De esta forma, los primeros encuentros empezaron a sucederse en el mes de diciembre de 2003. Antes de iniciar el trabajo de campo, se determinó un periodo de tiempo para valorar las condiciones y posibles dificultades que podían derivarse en el abordaje de las experiencias extremas sufridas, lo que nos llevó a consultar a diversos terapeutas en la materia con el ánimo de no generar situaciones que pudieran perjudicar a las entrevistadas.

En esta línea, recuperar la información de los episodios represivos fue una tarea compleja ya que, en numerosas ocasiones, los encuentros tuvieron que interrumpirse o posponerse a otro momento, respetando los tiempos y necesidades de cada entrevistada. Así, más allá de obtener información precisa sobre las experiencias de tortura y militancia vividas, el objetivo estuvo fundamentalmente enfocado a generar un espacio de reflexión libre y abierto que pudiera facilitar también un clima terapéutico y reparador. 
No obstante, la dificultad de rememorar las experiencias de tortura y reclusión se hizo visible en las primeras entrevistas ya que los hechos no se abordaron con la profundidad deseada como sí se logró posteriormente. Conforme fueron transcurriendo los encuentros el entrevistador fue ajustando las preguntas acorde a los objetivos definidos siguiendo la metodología cualitativa.

Algunas de las mujeres trasladaron, al término de las entrevistas, que aunque ya habían prestado testimonios en otros organismos de derechos humanos era la primera vez que incorporaban una reflexión completa de sus trayectorias políticas utilizando la perspectiva de género.

Otras reflejaron que estos espacios supusieron una oportunidad idónea para plasmar en palabras sus experiencias más personales de las que poco habían hablado por miedo, por pudor o por diversas razones, lo que nos lleva a considerar que en cierta forma se generó un feedback entre el entrevistador y la entrevistada.

Como se ha reflejado en los objetivos, debían abordarse no sólo las experiencias de represión sufridas sino también el grado de activismo político que las declarantes desempeñaron en el período estudiado; ello podía facilitar una ínter actuación en donde pudieran recoger los posibles elementos críticos o desencuentros con sus respectivas formaciones políticas en relación a las posibles discriminaciones de género que pudieron existir. Sin embargo, parte de las entrevistadas han relatado continuar con su militancia partidaria, lo que, inevitablemente, ha conllevado la aparición, en algunos casos, de resistencias a la hora de establecer un análisis crítico no condicionado.

Hay que añadir que la formación de algunas mujeres en tácticas militares y su participación en acciones armadas durante el período estudiado trajo consigo un nuevo inconveniente a la hora de reflejar estos hechos con precisión, ya que ellas mismas quisieron relatar su participación aunque siempre preservando su identidad por las posibles consecuencias jurídico-penales derivadas de asumir la responsabilidad en un determinado acto.

Por otra parte, la mayoría de los testimonios son fruto de encuentros previos en donde la candidata decidía libremente sí conceder o no la entrevista una vez revisado los ítems 
programados. En ocasiones algunas mujeres se negaron a testimoniar si se utilizaba grabadora por considerar que no se quería dar el paso de registrar algunos hechos en una cinta. Por esta razón, algunas entrevistas, aunque fueron realizadas en formato-papel, fueron incorporadas también en la elaboración final de las conclusiones.

Algunas entrevistas no se han trascrito en su totalidad a petición de las entrevistadas y

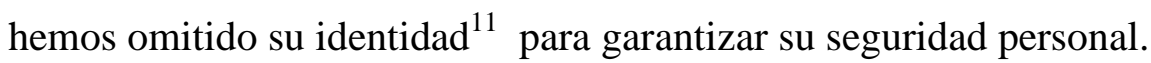

Como se ha mencionado, la investigación ha preservado el anonimato de las entrevistadas a la hora de incorporar sus citas. No obstante, ellas han querido dejar constancia de su participación en el estudio facilitándonos sus nombres y las formaciones políticas a las que pertenecieron.

Entre ellas, se encuentran dos generaciones de mujeres. Por un lado, la más longeva, aquellas que iniciaron su participación política en la década de los treinta y cuarenta del pasado siglo XX y cuyo rango de edad oscila entre los 75-85 años. Por otro, las mujeres que comenzaron su activismo en la década de los sesenta y setenta con edades comprendidas entre los 45 y 65 años de edad. Finalmente, destacar que la mayoría de ellas continúa militando, tanto en partidos como en organizaciones sociales de mujeres o agrupaciones de derechos humanos.

Podemos decir que gracias a esta aportación se ha podido trabajar y comparar los testimonios escritos hace treinta años con los orales realizados en el presente. Dicha combinación ha resultado ser muy eficaz a la hora de reconstruir lo hechos, lugares y métodos de tortura que utilizaron los organismos represores de la dictadura. Por ello, queremos agradecer especialmente el apoyo y la disponibilidad que todas las entrevistadas brindaron para que esta investigación fuera posible.

Es necesario recordar que aplicar la tarea investigadora en el universo de las violaciones de los derechos fundamentales conlleva asumir una serie de riesgos por la implicación

\footnotetext{
${ }^{11}$ La información contenida en los testimonios reproduce tan sólo las declaraciones literales de las
} entrevistadas. 
moral y el impacto que algunos hechos pueden provocar a la hora de abordar la temática.

Sí bien es cierto que los testimonios aquí analizados nos introducen en un terreno complejo y funesto como es la tortura en toda su amalgama, también pueden perfilarse como una oportunidad de abordar los grandes aportes que las entrevistadas hicieron en la construcción de un Chile democrático. Así, su desempeño militante traspasó fronteras, trasgredió roles tradicionales e imprimió un impulso fundamental en la búsqueda de la verdad, la justicia y la reparación de las víctimas. 


\section{CAPÍTULO 1: LA MUJER EN LOS GOBIERNOS DE LA UNIDAD POPULAR (1970-1973)}

El movimiento de mujeres en Chile, como en la mayoría de los países europeos tuvo un despertar tardío (finales del siglo diecinueve) y sus primeros pasos partieron de grupos atomizados de mujeres (principalmente de la burguesía) que de forma progresiva fueron fraguando demandas en torno a los derechos básicos de ciudadanía (igualdad educativa, jurídica, laboral y electoral).

Por una parte, las primeras conquistas se lograron en el ámbito educativo gracias a las movilizaciones y presiones de diversos grupos de mujeres de procedencia social acomodada que desde tertulias informales, irían tomando conciencia de unos derechos nunca antes tenidos en cuenta.

La mayoría de ellas, por su condición privilegiada y aún sin disponer de una formación educativa formal, habían accedido a las obras de precursoras feministas ${ }^{12}$ europeas como Olimpia de Gouges ${ }^{13}$ o Mary Wollstonecraft ${ }^{14}$, lo que les dotó de una sólida conciencia sobre su potencial como agentes de cambio. De esta forma, en 1875 dieron su primer golpe de mano al lograr presionar a los altos cargos de la administración para que tomaran en consideración algunas de sus demandas, entre las principales, el acceso de la mujer a la educación y a las urnas. Miguel Luis Amunátegui, ministro de Educación por aquel entonces, terminó posibilitando la entrada de las mujeres en la universidad que debía hacerse efectiva en 1877.

\footnotetext{
${ }^{12}$ Ver Aguado, A., Culturas políticas y feminismos, Fundación Instituto Historia Social, Madrid, 2010.

${ }^{13}$ Autora teatral y activista revolucionaria (1748-1793) fue la protagonista de la contestación femenina en la Francia revolucionaria. En 1791 publicó la Declaración de los Derechos de la Mujer y de la Ciudadana (1791) que era, de hecho, un calco de la Declaración de Derechos del Hombre y del Ciudadano aprobada por la Asamblea Nacional en agosto de 1789.

${ }^{14}$ Precursora del movimiento feminista británico, Wollstonecraft (1759-1797) redactó su principal obra Vindicación de los Derechos de la Mujer (1792) con una gran influencia en la larga tradición del feminismo anglosajón. Contraria al absolutismo de los reyes, señaló la conexión existente entre ese sistema político y las relaciones de poder entre los sexos.
} 
Cuatro décadas después apareció en escena una generación de mujeres que sin pertenecer necesariamente a los estratos más pudientes de la sociedad, representaban a aquellas que habían accedido por primera vez a los estudios superiores, lo que de alguna manera les permitió abrirse un hueco en el ámbito laboral e institucional.

Un ejemplo representativo fue el caso de Amanda Labarca ${ }^{15}$, quién logró en 1915 hacerse con un puesto en la Facultad de Filosofía y Pedagogía de la Universidad de Chile, todo un hito puesto que fue la primera mujer que lo hacía en el país. Desde allí, promovió el Círculo de Lectura de Señoras (1922), una agrupación de mujeres profesionales cuyo objetivo fue facilitar que las chilenas tuvieran acceso a la vida cultural del país. En el seno de esta agrupación tuvo su génesis el Consejo Nacional de Mujeres (CNM, 1922) cuyos principales esfuerzos se centraron en la campaña prosufragio femenino durante la década de los veinte y los treinta.

El CNM además, presionó para que se hicieran efectivos otros derechos en el campo de la maternidad, la herencia o el trabajo. Muestra de ello fue que en 1925 se aprobó del decreto ley $\mathrm{n}^{\circ} 321$, que concedía la patria potestad a la madre en caso de muerte o inhabilitación del marido y el derecho de la mujer casada a la libre administración de sus bienes fruto de su trabajo.

En paralelo, se formaron otras agrupaciones con un marcado carácter político cuyas demandas venían a coincidir con sus coetáneas. El Partido Cívico Femenino (PCF, 1919), primera formación política oficial de mujeres en Chile, reivindicaba el sufragio universal, medidas para protección de la maternidad y la infancia, la abolición de las leyes que impedían la igualdad jurídica y laboral y el derecho a constituirse en organizaciones sindicales.

Por otra parte, la Unión Cívica Femenina (Valparaíso, 1928), agrupación liderada por Felisa Vergara, logró, tras años de intensas movilizaciones, que las mujeres pudieran participar en 1934 en las elecciones municipales a partir de los 21 años de edad.

\footnotetext{
15 Amanda Labarca fue una de las pioneras del movimiento feminista chileno. Entre sus logros está la fundación, en 1915, del Círculo de Lectura. En 1916 pasó a ocupar el cargo de directora del Liceo para niñas Rosario Orrego. Pese a los problemas con los sectores más conservadores pudo desempeñar una labor de difusión de sus ideas. "Feministoria" en Morgan R., Falcon L., Mujeres del Mundo: ochenta países vistos por sus mujeres, Vindicación Feminista, Madrid 1993, pp. 227-234.
} 
Un año después de la primera consulta electoral con participación femenina en Chile, nació el Movimiento Pro Emancipación de las Mujeres (MENCH, 1935), bajo la dirección de Olga Pobrete, proponiendo un discurso en donde la emancipación de la mujer adquiría un carácter integral mucho más allá de los derechos políticos.

Se podría decir que el MENCH bien representaba la apuesta feminista más transgresora de aquel momento, dado que incorporaba una reflexión mucho más profunda sobre la subordinación de la mujer, abogando por su empoderamiento personal "dentro y fuera de casa" $"$. Pero además, se exigía que el Estado formara parte en este proceso mediante medidas de protección institucional y la creación de un nuevo marco jurídico que protegiera y asegurara el ejercicio pleno de sus derechos. Esta organización logró reagrupar a mujeres de diferentes estratos sociales conformando una estructura sólida (Congresos Nacionales de 1937 y 1940), que llegaría a contar con más de 20.000 activistas por todo el país.

Gracias al trabajo del MENCH y a otras organizaciones de mujeres, en 1945 se consiguió que el congreso aceptara debatir una reforma constitucional que incluyera iguales derechos electorales. El proceso culminó el 9 de enero de 1949 con el reconocimiento oficial del sufragio femenino y el cierre de un ciclo de cincuenta años de lucha sufragista.

A principios de los años cincuenta, estas organizaciones de mujeres fueron perdiendo fuerza hasta diluirse, ya que desde muchos sectores sociales y políticos se consideraba que lograda la igualdad electoral ya no había motivos para seguir escuchando y apoyando la causa de las mujeres.

Sin los apoyos necesarios, pronto las agrupaciones dejaron de funcionar produciéndose un trasvase de ex sufragistas a los partidos políticos que contaban con mayor presencia social, política y presupuestaría. Algunas pensaron que desde allí podrían continuar con la reivindicación de aquellas demandas que no se habían conseguido (divorcio, igualdad jurídica, derechos laborales, derechos de maternidad, etc.), otras, por el contrario,

\footnotetext{
${ }^{16}$ En el diario editado por el MENCH, La Mujer Nueva, se discutían temas tan delicados para la época como el uso de métodos anticonceptivos, las diferentes formas de alienación de la mujer o la prostitución.
} 
terminaron militando en los partidos políticos por considerar que había otros objetivos prioritarios más allá de las demandas específicas de género, como la instauración de un régimen democrático más justo para el conjunto de la población:

-“Trabajé en un movimiento que dirigía Elena Cafarena y Amanda Labarca, es decir, con el Movimiento de Emancipación de la Mujer. Después de vivir todo el proceso de lucha por el derecho a voto de la mujer terminé de retirándome del MENCH para pasar a trabajar plenamente en el partido" ${ }^{, 7}$

-"De hecho el MENCH renació en 1983 tras décadas de invisibilidad, se retomaron muchas de las ideas de nuestras predecesoras"

-"Gran parte de los avances con respecto a la situación de desigualdad de las chilenas han sido provocados por las luchas de las organizaciones feministas y no de las formaciones políticas. Las mujeres de la izquierda política han reivindicado siempre sus problemas como trabajadoras y no como mujeres y esto es algo que necesariamente ha de cambiar para abordar de una forma seria y responsable las necesidades específicas que tenemos"19

En otras palabras, la falta de nuevos horizontes y posibilidades reales de organización autónoma hizo que muchas activistas pasaran a depender de unas organizaciones lideradas por hombres y ausentes de perspectiva de género. Esta circunstancia paralizó las demandas pro-igualitarias, lo que implicó que la situación de desigualdad de las mujeres no variara sustancialmente durante los siguientes veinte años (1950-1970). Solo con la llegada de la Unidad Popular se abrieron nuevos cauces que permitieron un despertar de las mujeres en la lucha por sus derechos, gracias al acceso a la universidad, los partidos políticos y los sindicatos

\footnotetext{
${ }^{17}$ Ver Anexo. Entrevista $N^{\mathrm{o}} 16$.

${ }^{18}$ Ver Anexo. Entrevista $\mathrm{N}^{\mathrm{o}} 7$.

${ }^{19}$ Ver Anexo. Entrevista No 44.
} 


\subsection{El proyecto socialista $y$ las mujeres: transformaciones $y$ pervivencias en las relaciones de género.}

-"Y serán los trabajadores de la industria los que impidan al mal patrón discriminar en la remuneración que debe recibir la mujer. No sólo será la mujer la que debe defender sus derechos, sino que será la obligación de los trabajadores no permitir, no tolerar, no aceptar que se la explote más"20 (Salvador Allende Gossens, 1970)

¿Cambió sustancialmente la situación general de las chilenas en el mandado del presidente Salvador Allende Gossens? ¿Existió una sensibilidad especial de la Unidad Popular en esta materia? Si la hubo, ¿cómo se materializó? ¿Hasta qué punto perciben las mujeres que vivieron en aquellos años su compromiso político, que el proyecto socialista generó oportunidades concretas para el desarrollo de sus derechos? ¿Establecen elementos críticos en este sentido con las formaciones políticas a las que pertenecieron?

El abordaje de estas incógnitas se presenta como un paso imprescindible en el análisis histórico porque puede ayudar a comprender bajo qué circunstancias se fraguó una generación de mujeres única e irrepetible en la historia reciente de Chile, y que sufriría años después, el rigor represivo de la dictadura.

Pero también es importante analizar cuál fue el desempeño de las mujeres en la vida política, en este caso, en el ámbito de la izquierda más representativa (PS, MIR y PC), sus dificultades y desafíos, los logros obtenidos y las consecuencias que tuvieron para ellas el hecho de ocupar unos espacios tradicionalmente monopolizados por los hombres.

Desde una perspectiva general, el triunfo electoral de Salvador Allende Gossens en 1970 abrió un período de florecimiento político y social en todo el país, en donde se trató de allanar el camino hacia la equiparación de derechos de ciudadanía entre hombres y mujeres, muy ralentizado desde que en 1949, las chilenas obtuvieran el derecho a voto.

\footnotetext{
${ }^{20}$ Corvalán, L., El gobierno de Salvador Allende, LOM Ediciones, Santiago de Chile, 2003, p.32.
} 
En el programa electoral de la Unidad Popular (17 de diciembre de 1969) aunque no se abordó el problema de la discriminación de la mujer en profundidad, sí que se incluyeron algunos aspectos importantes hasta entonces ignorados como la igualdad jurídica entre sexos: "En el plano de los sueldos y salarios se eliminarán todas las diferencias entre hombres y mujeres....la mujer casada gozará de plena capacidad jurídica" ${ }^{21}$.

También se hicieron esfuerzos para facilitar un mayor acceso de las mujeres a la educación y la salud, especialmente con las campesinas analfabetas que tenían los mayores indicadores de pobreza en el país. En el plano de la educación superior, Allende aumentó las becas y ayudas para aquellas mujeres con bajos recursos y que contaran con méritos académicos.

Hay que mencionar que aunque las carreras universitarias elegidas por las mujeres tendían a reproducir las áreas tradicionales de trabajo asignadas por la socialización de género (Cuidados y Educación), gracias a estas medidas, la tendencia comenzó a variar cuando algunas de ellas accedieron a facultades hasta entonces exclusivas para hombres: "La mayoría de la gente que estaban militando en la célula de la universidad eran mujeres que venían de "carreras femeninas" como psicología o trabajo social",22

\section{Presencia de hombres y mujeres en la Universidad por carreras (1971)}

\begin{tabular}{|l|c|c|}
\hline Carreras & Mujeres \% & Hombres \% \\
\hline Ingeniería & 5.7 & 94.3 \\
\hline Pedagogía & 60.8 & 39.2 \\
\hline Letras & 57 & 43 \\
\hline Arte & & 44.6 \\
\hline
\end{tabular}

\footnotetext{
${ }^{21}$ Ver Cleary E., El papel de las mujeres en la política de Chile: acerca de proceso de emancipación de mujeres chilenas durante la dictadura militar de Pinochet, ISIS internacional, Alemania Federal, 1987, p. 62.

${ }^{22}$ Ver Anexo. Entrevista No 44.
} 
Fuente, elaboración propia a partir de la información obtenida en los informes de la Comisión Económica para América Latina (CEPAL), Ver Cleary E., El papel de las mujeres en la política de Chile: acerca del proceso de emancipación de mujeres chilenas durante la dictadura militar de Pinochet, ISIS internacional, Alemania Federal, 1987, p. 50

No obstante, pronto aparecieron obstáculos a la hora de poner en práctica las iniciativas destinadas a favorecer la igualdad. Hay que recordar que las críticas desde el feminismo chileno a la gestión del gobierno socialista han estado encaminadas al hecho de que, en este breve período, no se estableció un análisis del verdadero origen de la subordinación histórica de las mujeres en Chile. Ello, y como argumentaban, pasaba necesariamente por transformar los roles tradicionales asignados por un orden consuetudinario que otorgaba privilegios a los hombres y que dejaban siempre a "la otra mitad de la población" como ciudadanas de segunda categoría.

Es cierto que el porcentaje de mujeres en las instituciones y órganos de gobierno bajo la UP fue muy minoritaria, y que la mayoría de medidas institucionales, fueron sobre todo de protección social y no acciones que verdaderamente posibilitaran su emancipación y bienestar, pero el hecho de que algunas accedieran a espacios nunca antes ocupados por mujeres daban muestra de que algún movimiento se estaba produciendo. En cualquier caso, aplicar la igualdad efectiva de género en la realidad chilena de aquel momento se tornó como una apuesta extraordinariamente difícil de llevar a cabo en la medida que la sociedad "no estaba preparada ni dispuesta a un cambio cultural de tal envergadura",23

Existió además otra dificultad a la hora de aprobar propuestas igualitarias a través de los proyectos de ley en la cámara de diputados, debido a la férrea oposición del Partido Demócrata Cristiano ${ }^{24}$, segunda formación política con mayor representación parlamentaria y muy conservadora en temas como divorcio o la interrupción del

\footnotetext{
${ }^{23}$ Ver Anexo. Entrevista No 7.

${ }^{24}$ El Partido Demócrata Cristiano de Chile (PDC), tuvo su génesis el 28 de julio de 1957, fruto de la unificación de diversas agrupaciones cristianas como la Falange Nacional y el Partido Conservador Social Cristiano. El PDC ha conseguido la presidencia de la República de Chile en tres ocasiones con Eduardo Frei Montalva (1964 -1970), Patricio Aylwin Azócar (1990 - 1994) y Eduardo Frei Ruiz-Tagle (1994 2000).
} 
embarazo: "Siempre supe que los cambios propuestos por la UP iban a ser muy difíciles de materializar por la fuerte oposición de la derecha y el ejército",25

La documentación oficial de la época, muestra que el principal objetivo de Allende en materia de género fue crear un Ministerio de la Familia que regulara los derechos de las chilenas en cuestiones clave como maternidad y ayudas estatales para las mujeres en situación de riesgo social: "El gobierno propone la creación de un Ministerio que permita conquistar sus derechos y asumir sus responsabilidades como ciudadanas de primera categoría", 26 .

No obstante, en 1972, el congreso rechazó el proyecto ministerial y en su defecto se aprobó la creación de la Secretaría Nacional de la Mujer (SERNAM), con un rango de subsecretaría de Estado dependiente de la Secretaría Nacional de Gobierno y por ende con menos poder de influencia y recursos.

El SERNAM debía crear los cimientos del futuro Ministerio de la Familia y así lo quería el ejecutivo que, ante estas dificultades, pensó que la secretaría sería el primer paso para generar la infraestructura institucional necesaria para abordar los problemas derivados de la discriminación de las mujeres.

No obstante, y pese a estas limitaciones, algo se pudo hacer. Concretamente, la Secretaría puso en marcha diferentes proyectos que iban desde la formación educativa de mujeres del ámbito popular hasta la creación de jardines infantiles ${ }^{27}$ y comedores comunes, el impulso de los Centros de Madres ${ }^{28}$ (CEMAS), la creación de la Junta de

\footnotetext{
${ }^{25}$ Ver Anexo. Entrevista No 16.

${ }^{26}$ Medida n ${ }^{\text {o } 11, ~ P r o g r a m a ~ E l e c t o r a l ~ d e ~ l a ~ U n i d a d ~ P o p u l a r ~(1969), ~ V e r ~ C l e a r y ~ E ., ~ p .64 ~}$

${ }^{27}$ En los tres años de gobierno de Salvador Allende se inauguraron jardines infantiles por todo el país que atendían a 10.000 niños de los estratos sociales más desfavorecidos. Ibíd., p.65.

${ }^{28}$ El movimiento Pro Emancipación de las Mujeres de Chile (MEMCH, 1935) fundó en 1940 los primeros CEMAS como respuesta al aumento de pauperización de las zonas populares de Santiago, proyecto que se extendería hasta la UP. Según Cleary la Unidad Popular no logró cambiar su función puesto que se mantenían las labores de siempre: "Allí aprendían a tejer, a coser y a realizar otro tipo de trabajos a mano, cuya venta contribuía al presupuesto familiar, sin que ellas cambiaran su habitual rol específico de mujer”. Ibíd., p. 66.
} 
Abastecimientos y Precios $^{29}$ (JAP) y la abolición del régimen de sociedad conyugal como paso previo a la igualdad jurídica.

Hay que destacar que los centros de madres tuvieron su génesis durante el gobierno del demócrata cristiano Eduardo Frei Montalva (1964-1970), a través de la ley no 16.880 del 7 de agosto de 1968, como un intento para que las mujeres, independientemente de su origen socioeconómico, tuvieran una mayor participación social pero sin salirse de sus roles de "madres, esposas y cuidadoras". Este proceso culminó en 1973, momento en el que llegaron a operar más de 600 centros que movilizaban a 20.000 mujeres a lo largo de todo el territorio nacional.

Estas medidas, aunque tuvieron muchas dificultades de llevarse a la práctica, dieron al gobierno una cierta popularidad entre el electorado femenino, tradicionalmente tendente a votar a la derecha.

Así, en las elecciones presidenciales celebradas en septiembre de 1970, el 38.5\% de las mujeres que ejercieron su derecho a voto optaron por la candidatura de Jorge Alessandri, el $30.9 \%$ por Radomiro Tomic y el 30.6\% por Salvador Allende. Esta tendencia sufrió un considerable giro en las elecciones municipales de 1971 al aumentar en catorce puntos porcentuales (43.6\%) el apoyo femenino al proyecto de la Unidad Popular.

En el plano de la participación de las mujeres en las tareas de gobierno y de representación política se produjeron algunos avances significativos. En 1970, Mireya Baltra, dirigente del Partido Comunista asumió la cartera del Ministerio de Trabajo. Por su parte, Julieta Campusano (PC) y María Elena Carrera (PS) ocuparon cada una un asiento en el Congreso y en el Senado.

\footnotetext{
${ }^{29}$ Gonzalo Martner define las JAP en su trabajo Los esfuerzos de planificación de la Unidad Popular (Ed. Siglo XXI) de la siguiente manera: "Son unidades vecinales donde están representadas las distintas organizaciones de masas y los comerciantes minoristas que voluntariamente se incorporan a ellas". Ibíd., p. 67.
} 


\section{Mujeres en el Parlamento (1965-1973)}

\section{Diputadas}

\begin{tabular}{|l|c|c|c|}
\hline Año & Mujeres & Total & Porcentaje \\
\hline $1965-69$ & 12 & 147 & 8.2 \\
\hline $1969-73$ & 9 & 150 & 6.0 \\
\hline $1973 *$ & 14 & 150 & 9.3 \\
\hline
\end{tabular}

\section{Senadoras}

\begin{tabular}{|l|c|c|c|}
\hline Año & Mujeres & Total & Porcentaje \\
\hline $1965-69$ & 2 & 45 & 4.4 \\
\hline $1969-73$ & 1 & 50 & 2.0 \\
\hline $1973 *$ & 1 & 50 & 2.0 \\
\hline
\end{tabular}

Fuente, elaboración propia a partir de la información obtenida en Valdés T., "Entre la modernización y la equidad: mujeres, mundo privado y familias", en Chile en los noventa, Dolmen Ediciones, Santiago de Chile, 1998. * (Datos referidos a la segunda legislatura de Salvador Allende -marzo a septiembre de 1973)

Aunque algunas mujeres lograron posicionarse en puestos de decisión y responsabilidad, las entrevistadas aducen que siempre se las consideró bajo el prisma de "mujeres excepcionales" que por sus aptitudes de compromiso, gestión y liderazgo, lograron destacarse del resto, aunque sin "llegar a hacer sombra" a los dirigentes masculinos.

Además, en los testimonios, queda reflejado que los partidos de la izquierda o el mismo gobierno de Allende, acogieron a estas activistas pero siempre en aquellos espacios tradicionalmente ocupados por las mujeres, a saber, en los ministerios de sanidad, educación y política social. Muchas de las entrevistadas no parecen haber advertido esta relación de circunstancias, aún mostrándose críticas en otros asuntos relacionados con el legado de la UP: 
-"Cuando entré al PS ocupé rápidamente cargos directivos. Primero, porque yo daba el perfil de mujer dirigente por mi experiencia en la Salud. Trabajé en la democratización de la salud en Chile y contra la jerarquización de los servicios sanitarios" ${ }^{\text {"30 }}$

-"En el gobierno de Allende yo era cuadro dirigente y también me pusieron a cargo de los exiliados políticos de América Latina...Brasil, Nicaragua... Llegaron grupos muy numerosos y en condiciones muy penosas" ${ }^{31}$

-"Fueron tiempos de cambio y de mucha efervescencia política. Yo fui amiga personal de Salvador Allende. Yo era de Valparaíso y el compañero Allende vivió mucho tiempo allí. Cuando llegué a las Juventudes Socialistas él era el secretario provincial del partido en Valparaíso...Fue una relación de amistad que se mantuvo durante muchos años. Cuando llegó al gobierno él me nombró directora general de la Junta Nacional de Jardines Infantiles"

-"Posteriormente, pasé a trabajar en la comuna de San Miguel como dirigente comunal del partido...Allí establecimos un comité de mujeres para organizar y mejorar las condiciones de vivienda, cesantía, salud, etc. Empezamos a trabajar con algunas reivindicaciones dirigidas a mejorar la situación de las mujeres como el establecimiento de guarderías infantiles para las trabajadoras, el derecho a tener una silla en el trabajo, a la colación..."33

Por otra parte, desde el Ministerio de Trabajo, se impulsaron medidas en materia de empleo, salario y programas de subvenciones públicas. En concreto, se estableció por ley el montepío por el que la mujer pasaba a percibir del 50 al 100\% de la jubilación del esposo si hubiera fallecido. Dicho logro, aunque aparentemente menor, permitió a muchas viudas disponer de una mayor independencia económica y libertad.

También, el permiso de maternidad se ampliaba de cuatro a seis semanas y el salario mínimo industrial aumentaba de 12 a 20 escudos, estableciéndose por decreto, igual salario para hombres y mujeres. A este hecho se añadía la intención de Allende de que cada niño recibiera medio litro de leche al día (el presidente consideró esta medida como política específica hacia las mujeres bajo el paradigma mujer-madre-cuidadora)

Sin embargo, los mayores esfuerzos estuvieron enfocados en la extensión de los Centros de Madres que si bien reproducía su rol doméstico tradicional femenino, supuso un punto de encuentro que generó una mayor participación política y social de las mujeres, dentro del marco de los programas de desarrollo de las zonas más desfavorecidas del país.

\footnotetext{
${ }^{30}$ Ver Anexo. Entrevista No 19.

${ }^{31}$ Ver Anexo. Entrevista $N^{\circ} 11$.

${ }^{32}$ Ver Anexo. Entrevista No 27.

${ }^{33}$ Ver Anexo. Entrevista No 31 .
} 
Como se ha mencionado anteriormente, la valoración de la gestión de Allende, en cuánto a políticas de género se refiere, suele ser crítica entre las entrevistadas, y muy especialmente con las que desarrollaron con los años una conciencia feminista o proigualitaria. En este sentido, la mayoría reconoce que si bien hubo un despertar político de la mujer en los partidos y por tanto una mayor presencia en el espacio público, las medidas gubernamentales tendieron a reproducir los estereotipos patriarcales, razón por la cual no se dio un cambio cualitativo en los derechos de las mujeres y en el lugar subsidiario que ocupaban: "Mireya Balta, ministra del trabajo en aquella época, impulsó leyes que directamente favorecían a la mujer, auque siempre relacionándolo con la familia, como los jardines infantiles, la subvenciones a la jubilación de las dueñas de casa, etc.",34

En relación a esta percepción, también, el conjunto de las entrevistadas coincide en que la Unidad Popular desarrolló políticas en defensa de la dignidad de la mujer pero en términos de protección social y no de equiparación de derechos reales de ciudadanía, lo que la colocaba nuevamente en su lugar de siempre (roles intactos):

-"Durante el período de la Unidad Popular los grupos de mujeres se habían nucleado en torno a los roles tradiciones de la mujer. En definitiva, los centros de madres tenían un sello muy tradicional en relación al rol doméstico que tenían que desempeñar las compañeras. Se organizaban reuniones y se debatían temas como los problemas que pudieran tener en el ámbito doméstico y económico" ${ }^{35}$

-"El tema de la visión de género en Chile es algo más actual. El gobierno de la UP desarrolló políticas en defensa de la dignidad de la mujer como jefa de hogar y de los niños.... Fueron medidas en términos de protección. La participación política y laboral era muy escasa" ${ }^{\prime 36}$

-"El gobierno de la UP puso en marcha algunas políticas hacia las mujeres pero siempre en la órbita de la familia. No hubo ninguna profundización en el tema de género"37

La escritora y militante socialista Patricia Villanueva, recogía en varios artículos esta situación al resaltar que si bien la llegada de Allende al poder significó un robustecimiento de la conciencia política de los sectores explotados, especialmente el de

\footnotetext{
${ }^{34}$ Ver Anexo. Entrevista $N^{\circ} 7$.

${ }^{35}$ Ver Anexo. Entrevista $N^{\circ} 19$.

${ }^{36}$ Ver Anexo. Entrevista No 23.

${ }^{37}$ Ver Anexo. Entrevista $\mathrm{N}^{\mathrm{o}} 24$.
} 
las mujeres, "también sería erróneo ignorar que la plataforma electoral del candidato de la izquierda no postuló una política específica hacia la mujer" ${ }^{38}$.

Ello pudo deberse a que se dio una mediatización política de las mujeres al seguir considerándolas siempre desde un lugar subsidiario, esto es, como compañeras, madres, hijas y hermanas de los trabajadores. En otras palabras, su lugar en el recorrido del socialismo chileno estaba en la retaguardia de lo doméstico y privado aunque pudieran participar en el público en calidad de ayudistas.

Julieta Kirkwood, socialista y precursora de la segunda oleada del movimiento feminista durante las décadas de los 70 y 80, ya alertaba que el gobierno de Allende continuó reproduciendo el modelo patriarcal en cuanto a que hombres y mujeres seguían ocupando los mismos espacios de antaño, y en un marco en donde la izquierda trató de disputar a la derecha su potencial electoral y su rol como defensora y sostenedora de la estructura familiar, en unos fundamentos morales comunes a la gran mayoría de los partidos políticos:

-"En uno de los intentos del golpe de Estado, estábamos en la calle, durante el Tancazo. Allende salió al balcón y se dirigió a la población una vez pasado el peligro: -Compañeros, la sedición ha sido aplacada...vayan a sus casas y besen a sus mujeres-. Nosotras, un grupo de mujeres que estábamos allí nos preguntamos: $-i \mathrm{Y}$ nosotras quiénes somos, a quiénes vamos a ver-. Esa era la mentalidad de Allende, la mentalidad de la época"39

-"La familia proletaria es defendida como el núcleo revolucionario básico; dejando intocadas las redes interiores jerárquicas y disciplinarias que la conforman históricamente; a la familia burguesa opone una familia proletaria de calcadas funciones de subordinación y jerarquía inter-sexos" ${ }^{\prime 0}$

La autora relata en sus escritos que la Unidad Popular dio por hecho que la mujer y el hombre tenían la misma presencia en los medios de producción y en la sociedad y que la instauración de un régimen socialista traería de manera automática la igualdad de derechos. Pero como refleja, el ochenta por ciento de las mujeres en 1972 estaban

\footnotetext{
${ }^{38}$ Ver Villanueva P., Cuadernos de Orientación Socialista, № 19, Santiago de Chile, noviembre 1984.

${ }^{39}$ Ver Anexo. Entrevista No 22.

${ }^{40}$ Ver Kirkwood J., Chile: la mujer en la formulación política, Revista Signos, mayo/Junio 1984, Santiago de Chile, p. 42.
} 
relegadas al trabajo doméstico no remunerado, con lo que esa liberación no iba a suponer un cambio sustancial ya que al fin y al cabo "ellas permanecería en su lugar de siempre":

\begin{abstract}
-"Los partidos de la izquierda en ese período responden con dificultad a expresar la problemática femenina. La desconocen. Presumen que no existe. Las mujeres mismas desde la izquierda tampoco la admiten y se han integrado a protestar por la sociedad en su conjunto y no hablan más de "problemas femeninos". En este espacio ideológico, en lo que a la dimensión femenina se refiere, se desenvuelven los 1000 días de la Unidad Popular"

-"En los años de la UP la presencia de la mujer fue significativa pero nunca hubo una entidad organizada dentro del partido que recogiera cuestiones de género. El partido era quién programaba los objetivos políticos, las prioridades, etc. Creo que los partidos de izquierda han tenido en mente la posibilidad de realizar proyectos para la mujer, pero esto no se reflejó en la práctica. En Chile, la cultura patriarcal ha estado muy arraigada en la sociedad y esto también se reflejó en los partidos" ${ }^{\text {"2 }}$
\end{abstract}

Otra cuestión relevante a la que apuntan algunas mujeres es la ausencia de una conciencia feminista entre las militantes en aquella época, lo que irremediablemente hacía que la mayoría de ellas no se sintieran discriminadas en el ejercicio de sus derechos. Pero también las ex-militantes han reconocido que en ese tiempo, y especialmente en sus primeros años de participación política, ni ellas mismas cuestionaban los lugares y espacios que unos y otras ocupaban en aras de su socialización de género, percibiendo el conjunto de la militancia como un todo sin diferenciación sexual alguna:

-"Las mujeres socialistas, durante los tres años del gobierno de la Unidad Popular, fueron muy activas y comprometidas con el proceso... pese a que el tema de género en aquella época no era una prioridad. El tema mujer no era un objetivo dentro del PS, más allá de la cuestión de género, todas nos sentíamos militantes" ${ }^{\text {,3 }}$

-"No nos sentimos marginadas ni excluidas del proyecto de Allende. Además, el presidente creó la Secretaría de la Mujer, una institución que abría un nuevo ciclo en donde los temas de género empezaban a tratarse por primera vez. De hecho, algunos sectores de mujeres tuvieron mucho miedo por las medidas de la UP porque vieron amenazada su calidad de vida" 44

\footnotetext{
${ }^{41}$ Ibíd., p. 44.

${ }^{42}$ Ver Anexo. Entrevista No 21.

${ }^{43}$ Ver Anexo. Entrevista $\mathrm{N}^{\circ} 20$.

${ }^{44}$ Ver Anexo. Entrevista $N^{\circ} 18$.
} 
-"Las mujeres jugábamos un papel revolucionario en donde no sentíamos ninguna discriminación porque no nos planteábamos funciones de liderazgo en el partido. No reconocíamos o no nos dábamos cuenta de nuestra discriminación. Eran temas que no se debatían"45

-"El partido, mirado con una perspectiva rigurosa de género, en ese tiempo se podría decir que no tenía una política de género. Pero en términos prácticos, la presencia de la mujer fue una realidad muy visible. Recuerdo a la Julieta Campusano y Mireya Balta, que eran mujeres líderes y muy entregadas a la causa comunista" ${ }^{\circ 6}$

Lo que parece quedar claro es que sólo con el transcurrir de los años, y sobre todo al finalizar la dictadura, pudieron adquirir conciencia de aquellas situaciones en la vida partidaria que las pudo haber discriminado en tiempos de Allende. De hecho, la mayoría entiende que esta falta se dio, por la percepción generalizada entre la militancia femenina de que la transformación estructural hacia un régimen socialista conllevaría per se la igualdad efectiva entre hombres y mujeres, y cuando ello no se produjo (con la llegada de la democracia) fue cuando muchas “abrieron los ojos y despertaron”.

Pero también, y como se verá a lo largo de la investigación, cuando algunas activistas entraron en contacto con agrupaciones de mujeres en el exilio en tiempos de dictadura, pudieron adquirir una nueva mirada feminista que si bien las cuestionaba (como mujeres pero también como militantes de sus partidos), también las hacía crecer íntegramente. Ello contribuyó a que pudieran mirar de otra manera lo ocurrido en Chile, lo que necesariamente también cuestionaría el proyecto al que pertenecieron, el representado por Allende, y cómo este tomó o no en cuenta a las chilenas.

-"En este tiempo todavía no tenía una posición de género definida. Pensaba que la lucha de las mujeres debía integrarse en la lucha general del partido. Hasta 1990, el tema de género, no era una cuestión preponderante en el Partido Socialista"47

-"Hubo muchas compañeras jóvenes que se incorporaron a la vida pública, hubo diputadas, concejalas, etc. Ahora bien, nosotras nunca pensamos en términos de política de género, era algo más general. Nunca hubo una política de género consciente, eso no existió en la UP”48

\footnotetext{
${ }^{45}$ Ver Anexo. Entrevista No 19.

${ }^{46}$ Ver Anexo. Entrevista $N^{\circ} 32$.

${ }^{47}$ Ver Anexo. Entrevista N 23.

${ }^{48}$ Ver Anexo. Entrevista No 32.
} 
-"No había ninguna conciencia o visión crítica de género. No se cuestionaban las tareas de la mujer en el partido. No había ninguna conciencia feminista entre nosotras... Recuerdo que las mujeres tenían muchas dificultades a la hora de ejercer el derecho a voto puesto que casi siempre tenían que cuidar de sus hijos. Nosotras tratamos de ayudarlas haciéndonos cargo de sus tareas domésticas para que fueran a votar",49

-"El tema de género lo asumí muchos años después. Yo era de las que pensaba que la emancipación de la mujer pasaba por la liberación de la clase obrera. Este cuento me lo creí muchísimos años. Después desarrollé mi visión de género. Había compañeras que trabajaban en la comisión política y desempeñaban tareas bastante importantes pero sin tener una visión de género" 50

Otro de los logros cuestionados es el que tiene que ver con el aumento de la participación política de las mujeres en los partidos de la izquierda. En este sentido, si bien existió una incorporación notable en la estructura de los partidos afines a la UP, lo cierto es que ésta estuvo centrada en las bases de las organizaciones e instituciones, sin conseguir una representación efectiva en los órganos de decisión.

Hay que recordar que las pocas militantes que ocupaban un puesto en los comités centrales (máximo órgano de cada partido), aunque tenía derecho de palabra no podía ejercer el de voto, circunstancia que ponía de manifiesto que la desigualdad era transversal (mainstreaming).

No obstante y a pesar de esta realidad, sí se produjeron algunos cambios derivados de los esfuerzos del gobierno por involucrar a las mujeres en los procesos sociales y políticos, tales como el incremento de su participación política en las instituciones, en la militancia orgánica y en las campañas electorales.

De esta forma, a mayor participación ciudadana mayor fue el apoyo electoral de las mujeres a la candidatura de Allende, y ello quedó materializado en las elecciones legislativas celebradas en marzo de 1973. Concretamente, el 39\% de las mujeres le votaron (469.193 mujeres sobre un total de 1.203.058 de los electores), cifra muy superior al 30.6\% de las papeletas que consiguió la UP en las elecciones presidenciales celebradas en septiembre de 1970.

\footnotetext{
${ }^{49}$ Ver Anexo. Entrevista $N^{\circ} 24$.

${ }^{50}$ Ver Anexo. Entrevista $\mathrm{N}^{\mathrm{o}} 25$.
} 
El gobierno de la UP incorporó en su agenda reivindicaciones que ya venían haciendo algunos colectivos de mujeres desde hacia décadas, como el divorcio, la prevención de embarazos no deseados o medidas destinadas a mejorar la conciliación familiar y laboral:

-"En este período hubo una mayor participación de la mujer en el ámbito universitario, laboral, político... La mujer empezó a acceder a otro tipo de sexualidad, de amor libre, de liberalización de las relaciones sexuales. La Junta cortó con este proceso reformador en el que se empezaba a hablar de cuestiones tan fundamentales como el aborto, igualdad, en definitiva, de una nueva reproductividad"51

-"Los objetivos principales de la UP respecto a las mujeres eran muy avanzados. Se plantearon muchos temas que incluso hoy día están candentes. El divorcio, la igualdad laboral, etc., fueron algunas de las reivindicaciones que nosotras planteamos al Gobierno. Pero sobre todo creo que hubo una presencia bien importante de las mujeres en el trabajo poblacional $^{, 52}$

Aunque la mayoría de las propuestas nunca llegaron a concretizarse, bien por falta de apoyos en el hemiciclo, bien por falta de tiempo debido al golpe de Estado de 1973, otras sí se materializaron generando efectos beneficiosos en la vida de muchas mujeres:

-“El Gobierno de la UP tuvo una especial sensibilidad por la educación y participación de las mujeres en lo público. Las mujeres trabajadoras recibieron becas para acceder a la universidad y esto se tornó en una prioridad para el Gobierno. Además, se incluyeron a muchas mujeres en la política, independientemente de su origen sociocultural. Hubo muchas compañeras jóvenes que se incorporaron a la vida pública, hubo diputadas, concejalas...,53

\footnotetext{
${ }^{51}$ Ver Anexo. Entrevista $\mathrm{N}^{\mathrm{o}} 2$.

${ }^{52}$ Ver Anexo. Entrevista $N^{\circ} 41$.

${ }^{53}$ Ver Anexo. Entrevista No 32.
} 


\subsection{La reactivación de la militancia femenina: miristas, comunistas y socialistas.}

Los tres años de gobierno de la Unidad Popular implicaron de facto, una reactivación de la participación política de la juventud chilena en los diversos partidos de la izquierda, sindicatos y asociaciones de estudiantes, como parte de una estrategia nacional que implicara a la ciudadanía en las diversas acciones institucionales programadas.

Gobernar para el pueblo pero con el pueblo fue una premisa conocida de Allende, que veía este nuevo ciclo como una oportunidad inmejorable para incorporar a los sectores más desfavorecidos del país que, por otra parte, seguían siendo su principal base social y electoral de apoyo.

Pero anteriormente, a finales de la década de los sesenta, y en el marco de las influencias culturales europeas como el mayo francés (1968), las mujeres habían tenido un mayor acceso a la formación universitaria, principal foco de cultivo del activismo social y político y en donde se fraguó una generación de chilenas politizadas que años después sufrirían el rigor represivo de la dictadura pinochetista.

¿Qué características tuvo el proceso de entrada y reactivación de la militancia femenina en este período? La mayoría de los testimonios indican que además de influir el contexto social de la época y la sensibilización del gobierno popular en la materia, existieron otros factores clave que pudieron repercutir notablemente en este tránsito.

Uno que aparece con relativa frecuencia fue el hecho de tener a un pariente cercano, generalmente el padre o hermano, en puestos de responsabilidad política, circunstancia que las entrevistadas entienden, facilitó enormemente su sensibilización y entrada en los partidos a los que pertenecieron sus parientes. Como si de estructuras endogámicas se tratara, ellas relatan que, a diferencia de quienes no contaron con estos contactos, no tuvieron que pasar por los "filtros de acceso" que el partido solía determinar para las aspirantes a participar: 
-Mi padre fue militante del Partido Comunista y participó mucho en la acción sindical en los años de González Videla. En 1964 fue dirigente de las Juventudes Comunistas. En este sentido, desde muy temprano pude vivir una realidad política muy concreta que me hizo entrar a la militancia activa a los diecisiete años, en 1969" ${ }^{54}$

-“El 11 de septiembre yo había cumplido recién los 16 años, es decir, cuando llegó Allende al poder tan sólo tenía 13 años. Además, mi padre fue ministro del interior y secretario general de gobierno en la UP"55

-"Mi padre fue sindicalista. Yo desde muy niña iba a las reuniones sindicales.... Mi padre me advirtió que a los comunistas los detenían y los mataban y que si yo me quería arriesgar en eso....

-“Entré a militar en el año 1973, todavía estaba Allende. Tenía catorce años. Mis hermanos y mi padre eran militantes del partido. Éramos una familia comunista. Mi hermano, Lautaro Carmona, no quería que militara" ${ }^{, 57}$

-"Mis inicios fueron bastante precoces. Yo entré a militar en las Juventudes Comunistas a los trece años. Mi familia siempre fue socialista y desde muy temprano fui muy consciente de que había que enfrentar el régimen militar. Mi hermano fue detenido en el año 76, en uno de los episodios más negros cuando desapareció mucha gente del comité central del Partido Comunista de Chile" 58

En la mayoría de los casos las entrevistadas pudieron interesarse por la política gracias a los referentes familiares que habían tenido, porque de otra manera, probablemente hubieran seguido otro camino. Como algunas mujeres han mencionado, que en casa un hermano, tío o padre militara en política por una causa justa, fue utilizado por ellas para sentirse "legitimadas" en un círculo social que veía con recelo cualquier transgresión de género.

También, hay que mencionar que un tercio de las mujeres provenían de familias acomodadas, lo cual, según ellas, pudo influir notablemente en su activismo porque al fin y al cabo pudieron disponer de más recursos para estudiar, ir a la universidad, viajar o conocer otras realidades.

Por otra parte, aquellas mujeres que no contaron con familiares implicados en política como elementos facilitadores de su compromiso y sensibilización, afirman que fue una figura masculina la que les permitió un acceso directo a los partidos, generalmente un

\footnotetext{
${ }^{54}$ Ver Anexo. Entrevista No 29.

${ }^{55}$ Ver Anexo. Entrevista No 25.

${ }^{56}$ Ver Anexo. Entrevista No 31 .

${ }^{57}$ Ver Anexo. Entrevista N $N^{\mathrm{o}} 33$.

${ }^{58}$ Ver Anexo. Entrevista N 30.
} 
compañero sentimental, amigo u amante (en muchos casos dirigente). En estos casos, el varón se convertía en la llave de entrada de las aspirantes pero sin dejar de ser percibidas como acompañante del dirigente, es decir como si de una extensión de éste se tratara y no como sujeto político de pleno derecho:

-“Mi compañero fue el dirigente, yo fui la esposa del dirigente. Él fue miembro del Comité Central en varias ocasiones. Mi inicio en la política tuvo que ver con el inicio de la gran mayoría de las mujeres vinculadas a los partidos, es decir, la familia, el compañero y la universidad fueron las grandes influencias a la hora de determinar la militancia",59

-"Recuerdo que las compañeras dirigentes del PC por lo general eran casadas con miembros del partido que ocupaban importantes puestos de responsabilidad. Esto no las desligaba de sus tareas domésticas y del cuidado de los hijos. Yo tuve muchos desencuentros desagradables con mis compañeros por este motivo",60

Efectivamente, los discursos apuntan a que las mujeres que no dispusieron de estos "apoyos masculinos" pudieron tener más resistencias o dificultades a la hora de acceder a los partidos; pero aún disponiendo de ellos, no dejaron de ser percibidas por sus compañeros como elementos secundarios ("hijas u esposas de") cuando no rechazadas e ignoradas si trataban de demandar las mismas responsabilidades que sus compañeros de filas.

Por otra parte, algunos testimonios refieren a que la madre, o una figura femenina próxima (abuela, tía...), ya estaba sensibilizada o militaba en política, presentándose como modelos de mujeres transgresoras con los modelos femeninos de la época y como una influencia fundamental que marcó el activismo y compromiso de las entrevistadas.

De hecho, dejan claro que fue la madre la que, finalmente, las motivó y despertó el interés por aprender, estudiar, cuestionar o progresar intelectualmente, lo cual generaba conflictos familiares, por ejemplo, debido a la oposición del padre, tíos o hermanos. De alguna manera ellas transmiten que las progenitoras no querían que sus hijas desaprovecharan una oportunidad que ellas en su día no tuvieron como la de ir a la universidad, aspirar a trabajar en el espacio público o ser económicamente independientes. En otras palabras, querían una vida mejor para sus hijas y nietas:

\footnotetext{
${ }^{59}$ Ver Anexo. Entrevista No 22.

${ }^{60}$ Ver Anexo. Entrevista $N^{\circ} 38$.
} 
-"Fue mi madre la que me animó a que estudiara una carrera universitaria... a que fuera una mujer independiente... quería que tuvieran mejores oportunidades, que no pasara por lo que ella había pasado...Además, mi madre, sin ser una mujer militante en la política, tuvo también mucho interés en estas cuestiones. Ella, en la época de la lucha por el sufragio femenino (1949) fue una mujer con mucho sentido de la igualdad en el derecho a voto. Me llevaba a muchas reuniones"

-"Mi educación familiar influyó mucho en mi decisión de continuar militando en la Jota. Mi abuela y mi tío eran militantes del PC. Mi abuelita ya me conversaba que, en sus tiempos, Recabarren había estado en su casa escondido, y todas esas anécdotas emocionantes" ${ }^{\text {} 62}$

-"Quiero señalar que yo nací en un hogar comunista, mi padre era dirigente del salitre y mi madre era militante del partido. Fue la primera mujer que estuvo en el campo de concentración de Pisagua, durante la dictadura de González Videla, con la ley Maldita. También fue dirigente del salitre. Ella rompía con los cánones de la época, mostrándose como una mujer independiente en todos los sentidos" 63

-"Mi padre y mi madre aunque no tuvieron una militancia orgánica dentro del PC, fueron personas que siempre estuvieron en contacto con gente del partido, ayudando y participando. Mi madre influyó muchísimo, al ver que las mujeres también podían comprometerse y romper con su lugar tradicional, ella desde muy joven leía el diario El Siglo. Desde temprana edad, quise conocer a la Juventud Comunista. Fui a un local del partido y me inscribí como militante comunista en 1969..."64

Todo ello refleja la importancia de los referentes familiares a la hora de optar por un camino determinado. Romper con una tradición de siglos en donde la mujer siempre quedaba relegada al hogar y los cuidados familiares, no fue fácil para ninguna de ellas, sin embargo, los ambientes familiares que favorecieron una mayor apertura cultural o política, o simplemente que las hijas fueran a la universidad, facilitó sin duda que muchas pudieran romper con lo que por tradición "se esperaba de ellas" (perfecta casada).

En efecto, dicha ruptura fue impulsada por las mujeres que precedieron a las entrevistadas, (madres, abuelas y tías), una generación que en la mayoría de los casos, aún militando en partidos, habían visto hipotecada su vida por tener que asumir en solitario el cuidado doméstico familiar, renunciando a toda expectativa de crecimiento personal o profesional.

\footnotetext{
${ }^{61}$ Ver Anexo. Entrevista $\mathrm{N}^{\circ} 43$

${ }^{62}$ Ver Anexo. Entrevista $N^{\circ} 38$.

${ }^{63}$ Ver Anexo. Entrevista $N^{\circ} 36$.

${ }^{64}$ Ver Anexo. Entrevista No 35.
} 
Como se ha mencionado anteriormente, otras vías frecuentes de acceso a la actividad política fue a través de los campus universitarios y de las poblaciones más humildes, por tratarse de los principales focos de activismo social.

Por una parte, en el ámbito universitario, las entrevistadas en su mayoría estudiaron carreras de ciencias sociales o humanidades (Derecho, Psicología, Trabajo Social y Sociología son las más frecuentes). Precisamente fueron en estas facultades donde la movilización estudiantil tuvo más relevancia y en donde el clima de participación estudiantil permitió mayores posibilidades a las estudiantes para poder incorporarse al quehacer político.

Generalmente, la militancia se compaginaba con los estudios, lo que hacía que universidad y política estuvieran estrechamente ligadas siendo ambos elementos una fuente inmejorable de formación y concienciación para las mujeres, lo que en muchas ocasiones generaba un efecto dominó entre ellas, al influirse unas en otras a la hora de adquirir un compromiso de esta índole.

Concretamente en los campus, las asociaciones de estudiantes en colaboración con las juventudes de los partidos de la izquierda, organizaban acciones dirigidas al trabajo en poblaciones y en el medio rural. Allí, las militantes realizaban tareas tradicionalmente asignadas al colectivo femenino como educadoras, suministradoras de alimentos, asesoría jurídica (muchas de las activistas estudiaron Derecho), secretarias o informantes de los proyectos de ayuda de la UP:

-"Pasé a la militancia en el ámbito universitario, en la escuela de Sociología de la Universidad de Chile en donde el movimiento estudiantil fue muy intenso. Desde allí participé en muchas actividades y movilizaciones como las campañas por la candidatura de Salvador Allende...difundíamos propaganda en las poblaciones, en las tomas de fundos... También recuerdo mi entrada en la brigada universitaria en donde se vivió con intensidad la revolución cubana"

-"Yo era parte de la brigada universitaria socialista. Las labores que desempeñábamos estuvieron centradas en el trabajo voluntario. Trabajé en una fábrica llamada Textil Progreso. También viajábamos al sur del país para realizar trabajos de alfabetización, asesoramiento a los trabajadores, organización..."66

\footnotetext{
${ }^{65}$ Ver Anexo. Entrevista No 22.

${ }^{66}$ Ver Anexo. Entrevista $N^{\circ} 23$.
} 
-“En 1968 entré a la Universidad, a los dieciocho años, y empecé a vincularme con el partido. Estudiaba y a la vez trabajaba en el ámbito campesino y en el movimiento sindical. Mis tareas consistían en la alfabetización de adultos...sobre todo de mujeres" ${ }^{\text {"67 }}$

Sin embargo, en algunos casos, la participación en los partidos comenzó durante la formación secundaria (Liceos), lugares en donde las juventudes de la izquierda tenían una importante presencia. Los institutos eran frecuentemente utilizados como lugar de "reclutamiento" de jóvenes prometedores, quizá porque podían ser más permeables a una adhesión partidaria por el tiempo de cambio que les tocó vivir (gobiernos de Allende) y servir además, de efecto llamada para otros muchos estudiantes.

Tanto el MIR como PS y el PC durante la década de los sesenta y los años de la Unidad Popular, postularon la defensa de los derechos de los jóvenes con menos recursos para que pudieran formarse y tener un futuro mejor, pero también como parte de una estrategia para lograr el apoyo social de una generación cada vez más contestataria.

-"Yo entré en el MIR en el año 68, concretamente en la Brigada de Secundaria. Desde allí nosotras hacíamos un trabajo a nivel de Liceo y formación política. A partir de aquí, me propusieron integrarme de forma completa en el partido. Entre los años 1969-1970 me tocó participar en tomas de terrenos junto con el movimiento poblador" ${ }^{\text {"68 }}$

-"Yo entré a los 13 años a militar clandestinamente a la Juventud Comunista, en la Jota.... Durante dos años milité en el Liceo pero terminé muy desilusionada porque en una huelga de canillitas (suplementeros o vendedores de diarios) teníamos órdenes de tirarles vitriolos...creo que me propusieron entrar porque me comunicaba muy bien con los estudiantes, ellos decían -esta mina tiene talento orador-"69

-"En los años de la UP yo ingresé en la Juventud Socialista. Mis tareas consistían en toda la movilización estudiantil a nivel de Liceo. Hacíamos manifestaciones de apoyo al gobierno, peleábamos por mejores condiciones en la educación, etc. Hubo una fuerte organización de los alumnos en donde se discutía mucho sobre la situación política por la que el país estaba atravesando" ${ }^{\text {,70 }}$

Para la mayoría de las entrevistadas, entrar en el partido implicaba necesariamente comenzar a realizar tareas de base o voluntariado en las juventudes, un período de

\footnotetext{
${ }^{67}$ Ver Anexo. Entrevista $\mathrm{N}^{\mathrm{o}} 18$.

${ }^{68}$ Ver Anexo. Entrevista $N^{\circ} 5$.

${ }^{69}$ Ver Anexo. Entrevista $\mathrm{N}^{\circ} 17$.

${ }^{70}$ Ver Anexo. Entrevista $\mathrm{N}^{\mathrm{o}} 26$.
} 
formación imprescindible para que las futuras militantes formalizaran su acceso. Ellas distinguen tres fases. La primera pasaba por entrar como simpatizante, para seguir después a tener un status de aspirante y terminar, finalmente, por adquirir el rango de militante.

Hay un cierto consenso entre las entrevistadas en alegar que el acceso no fue sencillo puesto que se exigía un periodo de prueba o rodaje que generara la suficiente confianza de los dirigentes para con las candidatas, aún teniendo contactos privilegiados en el interior de las formaciones.

Este modus operandi tenía como objetivo generar un filtro para evitar el intrusismo no deseado (algunas han confirmado casos de personas que se infiltraron en organizaciones de la izquierda, algunos de ellos ligados a la formación ultraderechista Patria y Libertad):

-"En las Juventudes Comunistas una tenía que hacer méritos para ir adquiriendo mayores tareas de responsabilidad. Recuerdo que eran seis meses de prueba para entrar. En ese período yo trabajé en la base, salía a la calle, vendía el diario El Siglo y participaba en las charlas,"71

-"Yo estudié en la universidad de Concepción, en dónde el MIR dio sus primeros pasos.... 1969 fue un año de integración en el ambiente mirista, es decir, un año de prueba, de rodaje. En 1970 pasé definitivamente a la militancia política" 72

-“Antes la militancia era muy distinta de lo que es hoy en día. Cuando yo entré había que hacer todo un trabajo previo de dedicación, disciplina y cumplimiento con todas las tareas que te asignaban. Esto te iba dando posibilidades de tener cierto reconocimiento de los dirigentes para así ir ascendiendo... también por una cuestión de seguridad del propio partido para que no entrara cualquiera"73

A partir de ese momento, las direcciones de las respectivas juventudes partidarias solían delegar a las militantes trabajos sociales de base, especialmente en el ámbito poblacional y campesino para pasar posteriormente a desempeñar funciones en puestos (cuadros) intermedios. En esta fase, nuevamente, los esquemas sexistas solían reproducirse con la misma intensidad que en otros espacios, ya que estas labores solían

\footnotetext{
${ }^{71}$ Ver Anexo. Entrevista $N^{\circ} 38$.

${ }^{72}$ Ver Anexo. Entrevista $\mathrm{N}^{\circ} 4$.

${ }^{73}$ Ver Anexo. Entrevista $\mathrm{N}^{\mathrm{o}} 27$.
} 
ser de carácter administrativo, apoyo logístico, propaganda o enlace con otros actores políticos y casi nunca de dirección o liderazgo:

-"Las mujeres teníamos la función de contactar con el Frente de Trabajadores Revolucionarios (FTR) con el Movimiento de Pobladores Revolucionarios (MPR), ambos frentes vinculados con el MIR y principal vía de fortalecimiento del mismo" ${ }^{\text {"74 }}$

-"Yo y otras compañeras participamos en la toma de terreno del campamento Venceremos, momentos antes de las elecciones presidenciales de 1970. Cuando ganó Allende decidimos quedarnos a vivir allí hasta hoy día. De esta forma obtuve mi casa,"75

-"Comencé a trabajar en el sector de comunicaciones del MIR. Este trabajo consistía básicamente en la distribución de información a los militantes. Teníamos centrales telefónicas para desarrollar con más fluidez las redes del partido. Todo esto tenía que compaginarlo con mis estudios y en ocasiones no resultaba nada fácil",76

-"Mi trabajo fue muy activo desde el principio. Entré en una célula para realizar tareas de tipo social. Mi trabajo consistía en hacer prácticas en la fábrica textil de Tomé. Las tareas fueron sobre todo trabajo poblacional, en el movimiento estudiantil, recoger las inquietudes de los trabajadores de la industria textil...,77

Por otra parte, en las poblaciones y el campo, muchas mujeres pudieron incorporarse a la militancia gracias a la labor que las organizaciones políticas de la izquierda hicieron en el marco de apoyo a "los proyectos populares" del gobierno de Allende, en los sectores más desfavorecidos del país. Allí, las actividades destinadas a las militantes solían denominarse como "trabajo de brigadista" y abarcaba tanto la difusión de propaganda electoral ( rallados $^{78}$ ) como el trabajo en las Juntas de Abastecimiento y Precios (JAP):

-"En el comité regional de San Miguel mi responsabilidad era ser encargada del trabajo con las mujeres, éramos una gran comisión encargada del trabajo femenino (Liliam, María Pardos, Sunilda Contreras, Yolanda Bésolo, etc.). Con nuestro trabajo nos habíamos ganado la presidencia de la Unión Comunal del Centro de Madres (con la compañera Beatriz Cepeda a la cabeza).Las tareas fueron muy variadas. Trabajamos mucho en la construcción de las JAP y contra el acaparamiento y el mercado negro"79

\footnotetext{
${ }^{74}$ Ver Anexo. Entrevista No 12.

${ }^{75}$ Ver Anexo. Entrevista $N^{\circ} 40$.

${ }^{76}$ Ver Anexo. Entrevista $N^{\circ} 5$.

${ }^{77}$ Ver Anexo. Entrevista $N^{\circ} 43$.

${ }^{78}$ Los murales o rallados proliferaron en las dos campañas electorales de la UP; en éstos aparecían consignas entremezcladas que definían perfectamente la diversidad de un proyecto de izquierdas que aglutinaba a varios partidos.

${ }^{79}$ Ver Anexo. Entrevista No 36.
} 
-"Trabajé en todo lo que tuviera que ver con el abastecimiento en la población Juan Antonio Río (Norte de Santiago), donde vivía, es decir, participé tanto en las JAP como en el abastecimiento directo que eran dos formas que el pueblo tenía para abastecer sus necesidades básicas y como forma de enfrentar el acaparamiento de mercaderías por parte de comerciantes y clase acomodada" $\$$

-"Estos productos solían estar envasados, uno de los más conocidos fue el Chancho Ching, de muy buena calidad y que venía directamente de China. Muchas mujeres influidas por estas campañas no consumían estos productos y nuestra tarea consistía en convencerlas de que era comida en buenas condiciones" ${ }^{\prime 81}$

Finalmente, al suministro de alimentos básicos a familias desprotegidas se añadían otras acciones como la formación y alfabetización de mujeres, para generar mayores posibilidades de acceso al mercado laboral:

-"Mi participación consistía en el tema de las reivindicaciones de los campesinos, en el tema de los jardines infantiles, en tomas de universidades, huelgas, la alfabetización de muchas mujeres que nunca fueron a la escuela...,"82

-"Nos dedicábamos a los trabajos voluntarios: repartir alimentos ante el desabastecimiento, trabajo poblacional, etc. También en temas de primeros auxilios, andábamos con botiquín todo el día, de aquí para allá”, ${ }^{3}$

-"En la universidad técnica me tocó asumir la tarea de encargada de trabajo voluntario. Nosotras trabajábamos con los pobladores, en las tomas de terreno, distribución de la alimentación, enseñábamos a leer a los cabros chicos" ${ }^{, 84}$

Pero, ¿existieron discriminaciones de género en el desempeño de sus actividades políticas? Todo parece apuntar a que sí. Las dificultades que fueron teniendo, tal y como ellas interpretan, quedaron materializadas por la ausencia de un feedback entre lo que ellas aportaban (organización, distribución y difusión de las campañas electorales de la izquierda, por ejemplo) y las posibilidades reales de participar en la toma de decisiones.

La labor de las activistas, apreciada y agradecida por los compañeros de filas, no era puesta en valor al no existir una representación equitativa en las cúpulas políticas, desde antaño controladas por hombres. Quizá por que subyacía la idea que como mujeres eran

\footnotetext{
${ }^{80}$ Ver Anexo. Entrevista No 15.

${ }^{81}$ Ver Anexo. Entrevista $N^{\circ} 36$.

${ }^{82}$ Ver Anexo. Entrevista No 11

${ }^{83}$ Ver Anexo. Entrevista $\mathrm{N}^{\circ} 33$.

${ }^{84}$ Ver Anexo. Entrevista No 35.
} 
lo que tenían que aportar y cumplir con estas funciones era lo que se esperaba de ellas. Tampoco hay que olvidar que en los órganos de decisión (Comités Centrales y Regionales), aunque sí podían participar, no contaban con derecho a voto (espectadoras pasivas):

-“En los años de la Unidad Popular la mujer tuvo un gran aporte en los partidos políticos. Las mujeres socialistas ayudaron mucho a que las elecciones fueran transparentes, ellas tuvieron un papel fundamental al estar presentes y atentas a que no hubiera los "acarreos" o, lo que es lo mismo, fraude electoral mediante el pago de plata para votar a un partido... ahora bien, este esfuerzo no fue correspondido porque a la hora de tomar una decisión no había ninguna mujer, salvo algún caso excepcional..." 85

-"Las mujeres, en ese tiempo, eran la retaguardia de los varones en el funcionamiento interno del partido.... Eran temas que no se debatían. En las reuniones, las opiniones de las mujeres eran menos consideradas que la de los hombres y además no podían ejercer el voto en las decisiones vitales" $\$ 86$

-"Me tocó vivir las campañas electorales de Salvador Allende. En 1971, mi participación fue muy activa en la Juventud Comunista en todo lo que fue el trabajo voluntario, propaganda, en la difusión del programa de la UP... ¿podrían haber hecho algo más por mi?, quizá si tenga la sensación de que en algunos momentos el partido se olvidó de mi...tampoco guardo rencor a los compañeros, porque fue algo voluntario, que quise hacer" 87

Algunas entrevistadas sí plantean una visión crítica hacia sus respectivas formaciones políticas en relación a la discriminación de género que pudieran haber experimentado. Así, indican que, pese al activismo de las mujeres y siendo una pieza clave en el funcionamiento de los partidos, ellas quedaban finalmente relegadas a un segundo plano cuando se adoptaban las decisiones importantes:

-"Las mujeres hacíamos aparentemente de todo. Pero en general los cuadros superiores eran ocupados por varones. Había pocas compañeras en cargos de dirección, tanto en el regional como en el central; incluso en los equipos de autodefensa nosotras estábamos siempre atrás, en un segundo plano"88

-“Todo iba encaminado a ser ayudistas. En mi base las compañeras éramos pocas, unas cinco" 89

\footnotetext{
${ }^{85}$ Ver Anexo. Entrevista No 27.

${ }^{86}$ Ver Anexo. Entrevista $N^{\circ} 19$.

${ }^{87}$ Ver Anexo. Entrevista No 32.

${ }^{88}$ Ver Anexo. Entrevista No 34 .

${ }^{89}$ Ver Anexo. Entrevista N ${ }^{\circ} 33$.
} 
-"Milité con hombres y siempre tuve la sensación de tener una relación de igual a igual. Pero esto fue con militantes de base. Esto no ocurrió con los dirigentes masculinos del MIR. Tenía esa sensación de que hablaban de ti como la mujer chiquitina, la compañera que había que proteger... Eran los hombres quienes teorizaban o tomaban las decisiones más fundamentales... ellos monopolizaban las iniciativas y el conocimiento partidario al igual que los cargos de dirección" $" 90$

-"Para los hombres quizá era más sencillo hacer carrera en el MIR. Mis prioridades no eran tanto llegar a ser dirigente del partido sino más bien el trabajo de base...ellos sí querían más protagonismo" 91

Solo unas pocas van más allá y establecen posibles hipótesis sobre las causas de estas discriminaciones. La primera sería la premisa de que pese a que la izquierda planteara postulados progresistas y/o revolucionarios, la percepción del lugar existencial de la mujer no había variado en absoluto en relación al pasado, porque la cuestión o bien no había sido planteada o sencillamente descartada. Pero quizá en aquellos años para la gran mayoría de hombres y mujeres, esta diferenciación de espacios y lugares de poder, reflejaba el orden natural de las cosas no cuestionables.

Otra hipótesis apunta a que los dirigentes o líderes de la izquierda, aún en muchos casos siendo conocedores de que las demandas de igualdad ya eran una realidad en la agenda de otras formaciones políticas internacionales (partido laborista británico, partido socialista francés, etc.) postergaron conscientemente este tipo de propuestas porque podían intuir que ello reduciría sus privilegios "masculinos", poder que por otra parte percibían que les correspondía por derecho.

De esta manera, los hombres protegían sus espacios bajo la argumentación biologicista de que ambos sexos tenían capacidades, aptitudes y limitaciones distintas y, por tanto, debían ocupar lugares diferenciados para desarrollar "sus potencialidades innatas".

Bajo este discurso, los hombres estarían más preparados para asumir funciones de liderazgo y responsabilidad al albergar en ellos las aptitudes racionales, objetivas y tangibles. Por el contrario, las activistas como mujeres dispondrían de recursos que operaban más en el plano de lo afectivo, lo moral y lo emocional.

\footnotetext{
${ }^{90}$ Ver Anexo. Entrevista $\mathrm{N}^{\circ} 4$.

${ }^{91}$ Ver Anexo. Entrevista $\mathrm{N}^{\mathrm{o}} 5$.
} 
Estas diferencias percibidas como "naturales e incuestionables" incapacitaban per se a las mujeres para desempeñar ciertas tareas que solo podían ser realizarlas por varones, de lo contrario, ellas desnaturalizarían su propia idiosincrasia. En otras palabras, el trabajo de las militantes sí bien eran valorado (porque resolvían las tareas más ominosas, porque cuidaban, porque hacían el trabajo entre bastidores, es decir, un verdadero soporte para que los partidos pudieran funcionar) finalmente terminaban siendo percibidas como menores políticas incapaces de poder tomar las decisiones importantes (histeria femenina)

Las entrevistadas también han querido reflejar que existieron casos en donde tuvieron que hacer más méritos y esfuerzos que sus compañeros a la hora de lograr un ascenso, asumir una responsabilidad o que sus ideas fueran tomadas en cuenta. Los hombres veían con recelo que las mujeres pudieran tener ideas brillantes, promocionarse, o liderar un proyecto, quizá porque ello podía hacerles sombra o cuestionarlos. De partida ellas sienten que se ponía en duda sus capacidades intelectuales, y sí alguna quería llegar al mismo nivel que los varones por lo general debía hacer un esfuerzo extra para "demostrar que sí estaba a la altura":

-“Algunos hombres no tenían reparo en alegar que las mujeres estábamos peor dotadas que los hombres en la política. Escuché hablar sobre lo diferente que era la inteligencia de la mujer con respecto a los varones porque en nosotras la parte emocional y afectiva estaba mucha más reforzada careciendo de la frialdad y la objetividad. Este discurso lo adornaban con expresiones muy sutiles. En las reuniones, las opiniones de las mujeres eran menos consideradas que la de los hombres. Esto incluso ocurre hoy día. Sólo se consideraban las ideas se eran expresadas por un varón. Había muchos hombres incapaces de desempeñar las tareas políticas y nadie cuestionaba que esto fuera porque eran varones. Sin embargo, si una mujer se equivocaba era por el hecho de ser mujer y no por ser persona" ${ }^{92}$

No obstante, algunas sí lograron posicionarse en puestos de responsabilidad política alegando que no encontraron dificultades por su condición de género aún advirtiendo que tuvieron que esforzarse más para lograrlo.

Desde una perspectiva general si bien existieron mujeres que ocuparon puestos en los comités centrales y en las comisiones políticas del PS, PC y MIR, lo cierto es que su presencia variaba del cinco al diez por ciento, y correspondía a militantes históricas que

${ }^{92}$ Ver Anexo. Entrevista No 19. 
con los años habían ascendido por su incansable compromiso (según las entrevistadas los hombres las consideraban mujeres excepcionales que se salían de la norma...)

En cualquier caso, su presencia, no implicó que desde los partidos se incorporaran políticas específicas de género para el conjunto de las activistas, porque además las dirigentes tampoco contaban con conciencia de género, o bien con apoyos suficientes (de otros hombres) para llevar a buen puerto propuestas encaminadas a favorecer la igualdad:

-"Fueron mujeres excepcionales, históricas, que pertenecieron a una vanguardia de mujeres que ya defendían el derecho a voto en los años treinta, tenemos el caso de Carmen Laso o Fidelina Herrera en el partido socialista, ellas han estado muchos años en el comité central. Yo no sufrí discriminación en aquella época, mira, Marta Melo fue secretaria general de la Federación de Mujeres Socialistas y directora de la Secretaría Nacional de la Mujer... al igual que la compañera Fidelma Allende Miranda, quién fue dirigente nacional de la Central Unitaria de Trabajadores y regidora de la municipalidad de Santiago... son ejemplos que reflejan que Allende sí tuvo esta inquietud" ${ }^{\prime 93}$

-“Aprendí muchas cosas, la fraternidad, el trabajo en equipo, etc. En el XIV congreso del partido fuimos nombradas miembros del Comité Regional de San Miguel y allí estuvimos hasta 1973, no puedo decir que mis compañeros me pusieran obstáculos" ${ }^{44}$

-"Mi militancia en las Juventudes Comunistas fue básicamente de propaganda pero no sentí machismo... porque también desempeñé un cargo en el comité regional y tuve a mi cargo varios comités locales que representaban a las diferentes poblaciones. Concretamente, yo dirigí el Comité Regional Joven Guardia, que abarcaba varias comunas de Santiago. Yo llevaba las tareas que había que hacer para el comité regional y de allí se distribuían a los comités locales" 95

En relación a la valoración general de las entrevistadas sobre lo que hizo o no Allende, casi todas coinciden en que, y pese a las discriminaciones, sí se favoreció que las chilenas participaran en política como nunca antes. Muestra de ellos es que una parte, aunque minoritaria, al ocupar lugares de relativo poder pudieron favorecer algunas acciones encaminadas a mejorar las condiciones de las chilenas; esta circunstancia daba cuenta de que algunos cambios sí se estaban produciendo ${ }^{96}$.

\footnotetext{
${ }^{93}$ Ver Anexo. Entrevista No 22.

${ }^{94}$ Ver Anexo. Entrevista No 36.

${ }^{95}$ Ver Anexo. Entrevista No 30.

96 En este período destacaron mujeres como Laura Allende Gossens, miembro del Comité Central en 1971 y María Elena Carrera, quien ocupó un asiento en el senado en 1989.
} 
Pese a ello, se podría decir que aunque el gobierno popular puso en marcha iniciativas para mejorar las condiciones de las mujeres (casi siempre en términos de protección a la infancia y maternidad) las relaciones de género no variaron, ni dentro ni fuera de los partidos de izquierdas, bien por falta de tiempo, bien porque nunca se planteó la igualdad de derechos de las mujeres como algo específico o prioritario.

Tampoco los lugares que hombres y mujeres ocupaban en la sociedad varió porque desde las instituciones se fomentaron o implementaron políticas que venían a confirmarlos: mujer en el ámbito doméstico-maternal versus hombre en el público y de liderazgo.

No obstante, Allende sí fue sensible a algunas cuestiones como el acceso y promoción de la mujer en el mundo laboral, su formación universitaria o profesional, en el marco de un proyecto que diera a Chile una generación de mujeres más preparadas. Ello no debía significar que descuidaran sus funciones femeninas tradicionales: hogar y familia. Aún reproduciendo esquemas sexistas en sus políticas, se puede decir que los tres años de gobierno socialista se abrieron nuevos cauces para que progresivamente las mujeres fueran afianzado sus derechos. Pero ¿por qué no se llegó a más? Pudieron existir múltiples factores:

-La falta de apoyos de los poderes de facto para impulsar medidas de equiparación de derechos (iglesia, ejército, oposición).

-Falta de conciencia igualitaria en los gobernantes, lo que irremediablemente conllevó a que reprodujeran esquemas patriarcales.

-Falta de tiempo para aplicar las medidas o profundizar en ellas. La irrupción del golpe militar del 11 de septiembre de 1973 anuló un proceso de transformación estructural que se proyectaba a medio y largo plazo.

No hay que olvidar que las mujeres tuvieron una presencia mayor en los partidos políticos de la izquierda que en los de la derecha, por lo menos en lo que se refiere al 
funcionamiento orgánico. Es cierto que los partidos opositores a Allende (especialmente el Partido Demócrata Cristiano) supieron canalizar las demandas de muchas mujeres de las clases medias y altas ante las restricciones alimentarias y de consumo que se dieron durante el gobierno de la UP.

Ello desembocó en la participación y adhesión de miles de chilenas a la derecha, pero a diferencia que en la izquierda, esta participación tuvo un carácter más temporal (reflejado sobre todo en las manifestaciones y marchas contra el gobierno) y limitado (las mujeres de la derecha, tras el golpe del 11 de septiembre, disminuyeron significativamente su actividad política).

Como se ha demostrado, las entrevistadas entraban a militar por sus contactos masculinos (padres y compañeros sentimentales), lo que a veces les posibilitó más facilidades de promoción en sus partidos. En cualquier caso, la mayoría de las mujeres que accedieron a estos espacios, lo hicieron en la base o en los cuadros medios, reproduciendo en sus funciones y actividades los roles de siempre: retaguardia, cuidadoras y suministradoras de apoyo, transmisoras de información (enlace), administración, gestión de necesidades médicas y alimentarias, etc.

Se podría concluir que pese a que todas reconocen que el aporte de las mujeres militantes fue fundamental para posibilitar que los proyectos de la UP se materializaran y como piezas clave de sus formaciones políticas para su correcto funcionamiento, ello no fue correspondido con un mayor protagonismo político. 


\section{CAPÍTULO 2. LA DICTADURA MILITAR: EL ROL DE LA MUJER EN EL “NUEVO ORDEN”(1973-1990)}

\subsection{Las mujeres pro-dictadura.}

Uno de los soportes legitimadores que el gobierno militar de Augusto Pinochet utilizó para configurar el nuevo orden institucional fue precisamente la de haber concretado las demandas de cambio que algunos colectivos de mujeres de las clases medias y altas del país ya venían exigiendo desde que Allende accediera al poder en 1970.

En concreto, la Junta Militar se sirvió de las reivindicaciones de las agrupaciones de mujeres que apoyaban una intervención militar para reestablecer "el orden económico, social y de género" y anular así cualquier atisbo de cambio que pudieran hacer peligrar los valores y privilegios de las clases pudientes.

Por una parte, algunas mujeres ligadas a las cúpulas castrenses más descontentas con las políticas de la UP, llevaron a cabo acciones de presión para que sus esposos militares se decidieran a hacer algo, y a la vez rechazar a aquellos "uniformados" que mostraron su apoyo al orden democrático vigente, como fue el caso del general Carlos Prats González $^{97}$.

Para las mujeres pro-dictadura, los hombres de las Fuerzas Armadas debían reaccionar como valientes guerreros con todos los medios a su alcance, y más cuando consideraban que el gobierno socialista estaba poniendo en riesgo los principios morales que decían defender. De no ser así, se convertirían en varones "blandos" o "corrompidos por el marxismo", dicho de otra manera, en el enemigo:

-“¡Maricón, maricón!”, gritaban voces femeninas. -Carlos, hay unas trescientas mujeres allí abajo. Le han dicho al conserje que quieren entregarme una carta- dijo Sofía. Estaba

\footnotetext{
${ }^{97}$ Carlos Prats González fue nombrado comandante en jefe del ejército chileno con la llegada de Allende al poder. Ocupó la cartera del Ministerio de Defensa y fue un fiel defensor del orden democrático y constitucional. El 28 de septiembre de 1974 la DINA lo asesinó en Buenos Aires junto a su esposa, en el marco de la operación cóndor. Ver Dinges J., "Operación Cóndor: una década de terrorismo internacional en el cono sur", Santiago de Chile, 2004.
} 
sorprendida por la presencia de sus amigas. Eran las esposas de generales de primera línea del Ejército. ¡Gallina, Gallina! vociferaban fuera. En la acera se oyó un repiqueteo seco. Como granizo. Eran perdigones de maíz que las mujeres arrojaban contra la casa" ${ }^{98}$

Como se ha mencionado anteriormente, los gobiernos socialistas implementaron acciones transformadoras en cuanto a que encarnaban cambios estructurales en las relaciones de poder y configuraban un nuevo reordenamiento social y económico que podían afectar a los privilegios que los poderes de facto mantenían desde hacía décadas en Chile.

Esta circunstancia movilizó a las clases sociales más privilegiadas que veían con preocupación cómo el proyecto socialista podía echar por tierra su control sobre las fuentes de riqueza del país, la educación de las futuras generaciones y el sistema de valores morales vigente hasta entonces.

En relación al papel de la mujer, criticaban que el marxismo de Allende hubiera desvirtuado "su papel natural" al estimularla para que saliera del hogar y abogaban porque se reestableciera el ideario católico de familia. En este sentido, hay que recordar que en 1973 Allende quiso debatir en el congreso proyectos de ley referentes a la legalización del divorcio y regularización de la interrupción voluntaria del embarazo.

Lo cierto es que el movimiento de mujeres pro-dictadura fue muy heterogéneo en cuanto que, si bien las primeras movilizaciones fueron promovidas por aquellas más pudientes o ligadas a las Fuerzas Armadas, con los meses y gracias también a la

\footnotetext{
${ }^{98}$ Es simbólica la presión que un grupo de esposas de los altos mandos realizaron frente al domicilio del General Carlos Prats González, el 21 de agosto de 1973. Asimismo, la acción no se limitó a la manifestación, sino que vino acompañada por un documento firmado por las principales esposas del generalato: Mireya, esposa del general Ernesto Baeza; Maruja, esposa del general Pedro Palacios; Mary, esposa del general Oscar Bonilla; Fedora, esposa del general Raúl Contreras y María Teresa, esposa del general Arturo Viveros entre otras. Ver Prats C., Memorias: testimonio de un soldado, Pehuén Editores, Santiago de Chile, 1985.

La carta iba dirigida a Sofía Cuthbert, esposa del general Prats: "Sofía: Como esposas de oficiales y madres ante todo, nos atrevemos a acercarnos hasta ti para que sirvas de portadora de un angustioso llamado que le hacemos a tu esposo... nuestros hogares han visto llegar armas que se mantienen alertas ante un peligro y eso lo lloran nuestros hijos. Nuestros hombres salen a su trabajo y quedamos en muda plegaria porque vuelvan... El desconcierto del futuro de un país que progresaba y hoy sufre el descalabro económico más desastroso del mundo no nos permite ofrecer seguridad a nuestros hijos...Te rogamos, Sofía, intercedas ante tu esposo y lleves este ruego ante tantas mujeres que lloran calladas". Ekaizer, E., Yo Augusto, Aguilar, Santiago 2003, pp. 37-38.
} 
influencia de los medios de comunicación anti-allendistas, empezaron a sumarse otras muchas cuya procedencia socioeconómica era diversa.

La oposición de alguna manera supo aprovechar la indignación de muchas chilenas ante la carestía de productos de primera necesidad y el clima de conflictividad social para canalizarla contra Allende y su gobierno. La mayoría eran amas de casa que bajo su rol doméstico representaban el ideal de mujer que los sectores más conservadores querían para Chile, a saber, como defensora y gestora de la economía y los cuidados familiares. En otras palabras, fueron las mujeres las que, en su preocupación por conseguir alimentos para sus hijos, salieron a protestar al espacio público.

Las movilizaciones solían producirse en la calle, y por lo general cerca de las instituciones gubernamentales. Aunque algunas fueron espontáneas, las más multitudinarias estuvieron planificadas de antemano. Estas protestas pronto fueron conocidas popularmente como marchas de cacerolas $u$ ollas vacías, en referencia a que los hogares del país habían quedado desabastecidos de productos de primera necesidad ${ }^{99}$ por el complot huelguista de los sectores más poderosos de la industria y el transporte.

En cualquier caso, las movilizaciones reflejaban que las mujeres reproducían claramente el rol tradicional de género en cuanto a que sus demandas no estaban centradas en la igualdad de derechos u otra reivindicación específica para ellas, sino más bien en poder disponer de recursos para seguir ocupándose del hogar (alimentación y cuidados de los hijos):

-"Recuerdo muy bien las manifestaciones con las ollas vacías durante esta época. Las amas de casa de la clase media, manipuladas por la derecha, comenzaron a marchar todas las tardes a la misma hora, golpeando las cacerolas vacías para protestar por la escasez de alimentos; para las clases pobres, por supuesto, la falta de alimento había sido siempre un modo de vida" 100

\footnotetext{
${ }^{99}$ El reajuste estructural de los principales sectores industriales de la República de Chile que se inició con mayor intensidad a partir de 1970, implicó per se un ajuste en los precios de los productos básicos y en la organización de los abastecimientos primarios. Este hecho significó la aparición de ciertas dificultades que, sin embargo, a medio plazo se preveían superables.

A este factor, se añadió las dificultades extras de aquellos sectores industriales reacios al cambio económico, quienes, en buena medida, tuvieron ciertas responsabilidades a la hora de dificultar el abastecimiento de productos de primera necesidad, especialmente en los sectores urbanos.
} 
Hay que destacar que muchas de las manifestantes solían tener una vinculación directa con las organizaciones políticas de la oposición, especialmente con el Partido Nacional, el Partido Demócrata Cristiano y Patria y Libertad, lo que les facilitó poder disponer de los recursos logísticos y financieros suficientes para poder organizarse y actuar.

Pero sería erróneo pensar que fueron solo estas mujeres las que consiguieron aunar esfuerzos para generar un bloque anti-Allende, ya que se trataba de una cuestión que también interesaba enormemente a militares, políticos y empresarios, como parte de su justificación de una intervención militar.

Un ejemplo de colaboración entre las mujeres y los sectores contrarios a la UP fue el caso de la Asociación Gremial de Chile cuya presencia femenina era muy notoria. Desde esta organización las mujeres ejercieron sucesivas presiones para que los transportistas se decidieran a ir a la huelga (lock-out de camioneros convocada para el 10 de octubre de 1972).

En abril de 1973 las mujeres volvieron a movilizarse en diversas manifestaciones, casi todas, en Santiago y con una ruta bien definida: partían de los barrios altos de la capital (Providencia) y terminaban en el centro (Alameda), lugar donde residían las principales sedes institucionales del gobierno:

-"Pobladoras, dueñas de casa, profesionales, obreros, empleadas, militantes de colectividades políticas e independientes se confundieron espontáneamente en un solo bloque bullicioso que avanzó hacia el centro de Santiago haciendo sonar las cacerolas e improvisando cantos alusivos" $" 101$

Aunque los medios de comunicación ${ }^{102}$ hicieran esfuerzos por englobar estas protestas a toda la realidad social de Chile, lo cierto es que estas concentraciones solían darse

\footnotetext{
${ }^{100}$ Marjorie Agosin, Chile: Mujeres de humo, en Mujeres del Mundo, Vindicación Feminista, Madrid, 1993, p. 230.

${ }^{101}$ El Mercurio, Protesta Femenina por las ollas vacías, 2 de Diciembre de 1971, en González Pino y otros, Los mil días de Allende, Tomo 1, Centro de Estudios Públicos, Santiago de Chile, 1997, pp. 244245.

${ }^{102}$ El diario El Mercurio dedicó a la mujer opositora 121 artículos desde noviembre de 1970 hasta junio de 1972. La revista femenina Eva, Paula y Vanidades impulsó una campaña contra las medidas del gobierno Allende con gran repercusión en el ámbito periodístico.
} 
principalmente en Santiago, mientras que en el resto del país eran prácticamente inexistentes.

Las marchas con frecuencia terminaban en enfrentamientos con las fuerzas de orden público, circunstancia que era utilizada por los partidos de la derecha para mostrar "la represión de Allende" y desprestigiar su gobierno. Por el contrario, desde el ejecutivo se denunciaba que estas manifestaciones eran frecuentemente aprovechadas por agrupaciones radicales de ideología fascista para fomentar el desorden social ${ }^{103} \mathrm{y}$ desestabilizar el país. Hay que recordar también que en las concentraciones de las ollas vacías, se exhibían consignas a favor de la patria junto con banderas, emblemas y eslóganes característicos de las corrientes más nacionalistas y reaccionarias del país:

-“Ayer nos juntamos en la plaza, todas por una misma causa, la libertad de la Patria... hoy día lloré por mi patria, la sentí entregada a manos extranjeras vendida por una ideología ajena y pensé aquello de ni al extranjero dominio sometida..., esta tarde vi en la pantalla nuestra hermosa bandera casi oculta flameando con tristeza entre miles de banderas rojas con un símbolo en el medio que no nos pertenece" 104

Este fragmento, escrito por la periodista Virginia Correa, da cuenta de lo que verdaderamente movilizaba a este colectivo. El recurso del terror al comunismo, a lo extranjero o lo importado como elemento disgregador de la patria y el ideario católico de mujer y familia, era habitual entre sus consignas. En efecto, según esta óptima, Allende, influenciado por el comunismo internacional y al adoptar sus consignas, estaba dilapidando la tradición más sagrada de Chile, circunstancia que, lejos de verse como una oportunidad de cambio para la emancipación de las mujeres, era percibida con una razón de peso para deslegitimar a su gobierno.

Otra estrategia utilizada fue la toma de contacto con diputados y senadores de la oposición para presentar sus demandas concretas y ejercer presión para que desbancasen

\footnotetext{
${ }^{103}$ Patria y Libertad, organización de ultraderecha con fuerte presencia en el ámbito universitario desarrolló estrategias para crear confrontación en el marco de las manifestaciones convocadas tanto por detractores como defensores de las políticas de la Unidad Popular. Ver Guzmán P., La Batalla de Chile, TVE, 1996.

${ }^{104}$ Artículo de Virginia Correa recogido en Tribuna, Marcha de las Mujeres Opiniones, 4 de Diciembre de 1971, pp. 251-252.
} 
al ejecutivo. Un ejemplo de ello fue la aparición en 1971 de la Agrupación de Mujeres Gremialistas (MG), compuesta por trabajadoras y esposas de empresarios que ante el anuncio de Allende de nacionalizar las principales industrias del país, decidieron organizarse ante el temor de perder su poder adquisitivo, sus empleos o no poder abastecerse de los productos de consumo. Así, ellas presionaron a través de visitas y envíos de cartas a los miembros más representativos del PDC, como la fórmula más directa para evitar que las intenciones del presidente no se hicieran realidad, y de paso, expulsarle de su cargo.

En septiembre de 1973, una comisión de las MG, formada por representantes de más de diez provincias del país, entregó a varios miembros de la oposición parlamentaria, entre ellos el senador democristiano Patricio Aylwin, una carta en el que se exigía que el congreso inhabilitara al presidente y formara nuevo gobierno:

\begin{abstract}
-"Nosotras, mujeres de trabajo, no podemos soportar más esta situación, en la que, desde que iniciamos el día con la cola del pan, estamos en un continuo estado de tensión... nuestra vida diaria es una constante lucha por hacer alcanzar nuestro presupuesto y conseguir el abastecimiento para nuestros hogares... no hay seguridad para que los niños acudan a la escuela ya que las calles se convierten en verdaderos campos de batalla. Después de tener una Asamblea General... llegamos a la conclusión de que la única solución para que el país pueda volver a la normalidad, es que el Congreso Nacional declare la inhabilidad del Presidente... en consecuencia, declaramos, que si en el plazo de una semana el Congreso Nacional no ha usado la última arma legal que le queda al país, nos veremos en la necesidad de golpear las puertas de los cuarteles de las Fuerzas Armadas, para rogarles que salven a la Patria"105
\end{abstract}

En efecto, tenían la convicción de que el conjunto de las chilenas, como amas de casa, habían sido notoriamente perjudicadas por unas medidas impulsadas por Allende (el desabastecimiento de alimentos no se percibía como el resultado de las huelgas de los empresarios y gremios ante el temor de perder poder, sino como responsabilidad directa de un gobierno económicamente ineficaz) y exigían una respuesta firme para salvaguardar lo que consideraban la columna vertebral del país, sus familias. De no atender sus demandas no tuvieron reparo en optar por la vía no legal, con la esperanza de que "los hombres de las Fuerzas Armadas sí estuvieran a la altura de las circunstancias".

${ }^{105}$ El Mercurio, "Mujeres Gremialistas piden inhabilidad de S. Allende, reunión con senadores de la oposición", 7 de septiembre de 1973, en González Pino y otros, Los mil días de Allende, Tomo II, Centro de Estudios Públicos, Santiago de Chile, 1997, pp. 893-94. 
Por tanto, se puede decir que este activismo significó la puesta en escena de una estrategia novedosa en cuanto que su radio de acción se dirigía a la élite política, en este caso, a los representantes del principal partido opositor, el Partido Demócrata Cristiano.

Dicha estrategia también pudo obedecer al deseo de muchas mujeres por participar directamente y tener protagonismo en las decisiones políticas clave y estar al tanto de la evolución de la vida parlamentaria pese a reproducir en sus demandas los roles tradicionales de género (fueron numerosos los artículos en la prensa opositora de mujeres que se oponían frontalmente a debatir cuestiones tan espinosas como el derecho al divorcio, los medios de prevención o el aborto).

Precisamente estos hechos pueden ayudar a comprender con mayor precisión el contexto de presión que se dio en los momentos previos al golpe de Estado del 11 de septiembre de 1973, por parte de un colectivo hasta hace poco ignorado por los historiadores.

Dichos acontecimientos adquieren además una clara lectura de género en cuanto a que estas agrupaciones querían constituirse como punta de lanza para el derrocamiento de la UP, y para conseguirlo desplegarían "sus estrategias femeninas de presión” en calidad de madres y esposas desesperadas.

Según las entrevistadas, las agrupaciones femeninas pro-intervención militar, se componían mayoritariamente de mujeres que disponían de contactos influyentes ya que, en definitiva, eran las esposas de militares o de empresarios más poderosos, es decir, de los agentes sociales que mejor podían impulsar o financiar un golpe.

En esta línea, ellas fueron conscientes de que un posible consenso político entre el Partido Demócrata Cristiano y Allende significaría la normalización de la vida parlamentaria y por ende, la posibilidad de que algunas reformas continuaran su curso, razón que explicaría su afán por generar crispación.

No cabe duda de que en este tipo de acciones del poder femenino conservador, también participaron mujeres de los sectores medios y obreros que influenciadas por el clima de temor hacia los cambios que podían producir las medidas socializadoras del proyecto 
socialista, también se sumaron a las protestas. Dicha circunstancia, en todo caso, no era representativa de la mayoría de las trabajadoras de Chile, que por lo general apoyaban a la UP.

En resumen se podría decir que las mujeres que conformaron los movimientos de oposición optaron por la estrategia de la presión. Esto se tradujo en dos tipos de acciones, una destinada a la movilización y demostración de poder en las calles (movilización colectiva), y otra, mediante una estrategia política más compleja a través de la presión y los contactos directos con la oposición. Aunque ello significó una ocupación del espacio público que podría interpretarse como una transgresión de sus lugares y espacios de siempre, lo cierto es que nunca perdieron su rol de madres, amas de casa u esposas, exigiendo sus demandas desde este lugar existencial, y que por otra parte, utilizaron como fuente de legitimidad. 


\subsection{Las políticas de género bajo el gobierno militar.}

-"Si el Estado representa la forma patriarcal y masculina de poder en nuestra sociedad podemos aceptar que la dictadura militar fue su manifestación extrema" 106

Desde una perspectiva general, la dictadura militar anuló todas las medidas emprendidas por la administración anterior entre las que se incluían también aquellas que habían promovido o regulado acciones destinadas a favorecer los derechos de las mujeres.

En este tema, los golpistas percibían que la UP había desvirtuado el papel de la mujer que por "naturaleza" les correspondía tener en la sociedad, al fomentar su incorporación al espacio público, mejorar sus derechos laborales o promover leyes contrarias a la moral y la familia católica. Porque sí se atacaba a lo que los militares consideraban los cimientos del país, ellos tendrían la obligación de responder como hombres bajo su rol de "guerreros". De hecho, Pinochet siempre se mostró firme a la hora de reconducir a las mujeres a su rol de siempre, porque de ello dependía la legitimación de su intervención pero además, para poder controlar a un colectivo fundamental en la gestión de las economías domésticas (potencial de la mujer como agente de consumo).

En este sentido, es reveladora la síntesis de la investigadora y feminista Diana Veneros al definir el golpe militar como la vuelta al orden patriarcal en cuanto a que "se genera un discurso represivo cuyo objetivo es producir ciudadanos para una patria depurada en la que se recuperan los valores de orden, familia y religión"107. En este punto, las chilenas jugarían el rol de transmisoras de los valores espirituales que según el gobierno militar ellas encarnaban bajo el paradigma biologicista.

Pero ¿qué subyacía a la intención de la dictadura de poner las miras en las mujeres a la hora de elaborar su proyecto de gobierno? ¿Tuvieron que ver las políticas de cambio estructural de mercado, durante los gobiernos de la UP, en cuanto el Estado se configuraba como el garante de los derechos individuales de la ciudadanía y alentaba a

\footnotetext{
${ }^{106}$ Estrada A., Hering M. y Donoso A., Familia, Género y Terapia, CODEPU, Santiago de Chile, 1996, p.23

107 Ver Veneros D., Perfiles Revelados: historias de mujeres en Chile, Ed. Universidad de Santiago, Santiago de Chile, 1997.
} 
las mujeres a participar en él? Este proceso ¿podía hacer peligrar el modelo económico que la Junta quería imponer (mínima intervención del Estado en lo económico y social) en donde las chilenas jugarían el rol de gestoras y demandantes en el abastecimiento de la economía familiar?

En efecto, los militares no percibían a las mujeres como capital humano y fuente de enriquecimiento del país a modo de sujetos activos, sino más bien como objetos pasivos en el espacio público y elementos activos en lo doméstico; un motor esencial para ellos en el despegue económico que querían conseguir a través del libre mercado pero conservando los roles de género intactos y de paso dar impulso a los índices de natalidad.

Desde una perspectiva general, el objetivo fue conseguir la implantación de un modelo que combatiera la inflación y permitiera el control económico de la Junta y sus elites. Esto tuvo una consecuencia inmediata: la desaparición del Estado de Bienestar que Allende quiso impulsar (Welfare State reduction, así lo denominaban los jóvenes economistas chilenos que estudiaron en la Facultad de Ciencias Económicas de la Universidad de Chicago) a través del recorte de los servicios sociales, como en ayudas a la educación y sanidad.

El efecto más visible de esta política fue la disminución significativa en el empleo femenino cualificado que afectó especialmente a las profesionales que se habían abierto hueco en las instituciones o en la administración. De hecho, la nueva situación en la que el Estado ya no garantizaba unos mínimos mecanismos para el cumplimiento de los derechos laborales básicos, forzó a muchas mujeres a incorporarse al mercado de trabajo en condiciones de precariedad e indefensión, cuando no eran expulsadas de sus trabajos si se tenían sospechas de ser contrarias a la dictadura.

También numerosas mujeres en edad de trabajar y con formación se fueron concentrando en los sectores menos cualificados, principalmente en servicios domésticos (el 25\% en 1987) y otras tantas a la prostitución o la marginación (en los años ochenta proliferaron las clubes nocturnos en donde cada vez más mujeres ofrecían servicios sexuales como única forma de subsistencia) 
Por otro lado, el índice de mujeres empleadas en trabajos irregulares (economía sumergida) era considerablemente más alto que el de los hombres, ya que la mayoría de ellas provenían de los sectores rurales y no contaban con formación profesional previa (hay que recordar que la dictadura anuló los programas de inserción laboral que la UP diseño para los sectores campesinos y poblacionales).

Por esta razón, la política gubernamental no sólo no favoreció unos mínimos mecanismos de adecuación del empleo femenino en el nuevo orden económico sino que, además, se anuló el marco regulador anterior, por ejemplo, a través de la retirada de ayudas y prestaciones por maternidad. Una muestra fue el decreto ley 2.200 del 15 de junio de 1978 posibilitaba el despido de las trabajadoras embarazadas por vencimiento de plazo o la conclusión del trabajo o servicio. En otras palabras, se eliminó el fuero maternal que la legislación de la Unidad Popular había aprobado y que garantizaba la protección a la mujer trabajadora.

Por consiguiente, las políticas, en relación al papel de la mujer en la sociedad chilena que la dictadura trató de impulsar, estuvieron más bien encaminadas hacia la recuperación de los roles tradicionales de género (hombre en el espacio público versus mujer en el espacio doméstico) que al impulso de la independencia de la mujer a través de la participación en la esfera pública, política y laboral; lo que algunas entrevistadas han denominado la despolitización de la mujer: "La dictadura no quería mujeres politizadas que pudieran cuestionarla, sino más bien sumisas y compradoras compulsivas... romper con el rol doméstico significaba poder estudiar, defender sus derechos y hacer frente al poder histórico que detentaban los hombres" ${ }^{\text {108 }}$

En relación a las políticas implementadas hay que destacar la creación de la Secretaría Nacional de la Mujer ${ }^{109}$ (SENAM, noviembre de 1973). Desde allí, se trató de recuperar la actividad de los Centros de Madres -CEMAS- como una fórmula que permitiría controlar la actividad diaria de miles de mujeres. Este proyecto, que ya venía funcionando desde la década de los sesenta, formaba a la población femenina más

\footnotetext{
${ }^{108}$ Ver Anexo. Entrevista $N^{\circ} 7$.

${ }^{109}$ La nueva Secretaría Nacional de la Mujer (SENAM) se fundó el 17 de octubre de 1973 y dependía de la Dirección de Organizaciones Civiles.
} 
desfavorecida del país en las labores tradicionales: bordado, gastronomía, tareas domésticas y cuidados de personas dependientes.

Otras acciones destacadas fueron la creación del Servicio Militar Femenino ${ }^{110}$ y el Cuerpo Femenino del Ejército, que servirían de apoyo médico y administrativo del conjunto de las Fuerzas Armadas.

Hay que recordar que Augusto Pinochet fue un declarado admirador de las estrategias socio-políticas del dictador español Francisco Franco Bahamonde y, en este sentido, se podría encontrar cierta similitud entre el SENAM y la Sección Femenina de Falange ${ }^{111}$ en cuanto a que permitía el adoctrinamiento y control social del conjunto de las mujeres hacia los intereses que el propio orden dictatorial pudiera tener en un determinado momento.

Muestra de ello fue el impulso de políticas destinadas a aumentar la natalidad entre las familias, la prohibición y persecución en el uso de los medios anticonceptivos o interrupción de embazados, pese a la contrariedad de que existieran clínicas privadas que lo hicieran en tiempos de dictadura:

-"Durante la UP hubo una mayor participación de la mujer en el ámbito universitario, laboral, político... La mujer empezó a acceder a otro tipo de sexualidad, de amor libre, de liberalización de las relaciones sexuales. La Junta cortó con este proceso reformador en el que se empezaba a hablar de cuestiones tan fundamentales como el aborto, igualdad, en definitiva, de una nueva reproductividad"112

\footnotetext{
${ }^{110}$ En cuanto a los organismos establecidos por la Junta Militar dirigidos a la mujer destacó, entre otros, el Servicio Militar Femenino, dirigido por el comandante de Instituciones Militares Don Nilo Floody Buxton, quien anunció la puesta en marcha de dicho proyecto en 1976 y será de "carácter voluntario, todas las aspirantes serán solteras y podrán casarse después de cuatro años como subteniente...su jornada de trabajo comenzará a las 6 horas con la diana y concluirá a las 21 con la retreta". Información recogida en La Tercera, 1 de Octubre de 1974, en Comité de Cooperación para la Paz en Chile, COPACHI, La situación general de la mujer bajo el gobierno militar de chile, Santiago, 1975, p. 3.

${ }^{111}$ Ver Folguera, P., El feminismo en España: dos siglos de Historia, Ed. Pablo Iglesias, Madrid, 2007.

${ }^{112}$ Ver Anexo. Entrevista No 2.
} 
Precisamente, fue una mujer la encargada de dirigir estos proyectos. Lucía Hiriart de Pinochet ${ }^{113}$ tuvo la responsabilidad de llevar a buen puerto el control que la dictadura quería implantar sobre las chilenas, y además servirse de una fuente legitimadora para la dictadura. La primera dama contó con el apoyo de las esposas de los integrantes de la Junta, colaboración que quedó plasmada en acciones conjuntas como las visitas relámpago a poblaciones y sectores populares a través de obras pías, caritativas y de beneficencia.

El gobierno militar puso especial énfasis en la captación y reclutamiento de mujeres de todos los estratos sociales como una forma más de aglutinar cualquier movimiento social que pudiera aparecer, y más, en un período de difícil coyuntura económica y en donde el suministro de productos de primera necesidad no estaba garantizado. En 1979, la Secretaría Nacional de la Mujer contaba con más de diez mil miembros y los Centros de Madres agrupaban en torno a 200.000 mujeres que operaban en las zonas más desfavorecidas de Chile.

Este esfuerzo de la dictadura vino dado por la imperiosa necesidad de Pinochet de legitimar y fundamentar su proyecto de cara a la ciudadanía y más concretamente a la población femenina que ante los ojos del dictador era la encargada de garantizar el adoctrinamiento de las futuras generaciones de chilenos. De esta forma, a la mujer se le reservó el papel de garante de la integridad familiar y como baluarte en la promoción y sostenimiento de los valores de la moral católica.

Las entrevistadas interpretan que las mujeres fueron utilizadas como instrumento de divulgación de los valores ideológicos del gobierno militar que, por otra parte, encajaban perfectamente con el sistema patriarcal: sumisión al varón, sacrificio y recato, no participación en la esfera pública-política y salvaguardia de los valores católicos de familia y educación: "Nosotras representábamos lo contrario a lo que la dictadura

\footnotetext{
${ }^{113}$ Lucía Hiriart, nombrada presidenta de los Centros de Madres (CEMAS) indica muy bien lo que se ha de evitar por todos los medios: "otra recomendación que se hace presente es no hacer política en los centros de madres, en aquellos en los que se detecte actividades de esta naturaleza se cambiará la directiva”. Aquí puede visualizarse la posible existencia de un sistema de detención y control probablemente dirigido por la DINA para evitar cualquier pronunciamiento político disidente.
} 
quería... no estábamos casadas, ni quietitas en la casa, teníamos trabajo, estudios... ellos querían una mujer sumisa y callada no más"114.

Por otra parte, investigaciones académicas ${ }^{115}$ publicadas recientemente dan muestra de que las mujeres, históricamente, han tendido a favorecer electoralmente a los partidos conservadores en Chile, circunstancia que podría explicarse por la influencia histórica que sobre ellas han tenido las instituciones eclesiásticas añadido, a la menor formación educativa y política de este colectivo.

Pinochet, aún consciente de este hecho y agradecido por el aporte femenino a la causa, quiso dejar atada la despolitización del conjunto de las mujeres, aún existiendo algunas en su gobierno, ya que, no podía permitirse una participación política mayor para no alterar el orden de género existente. Todo ello pasaba necesariamente por minimizar la presencia de las mujeres en el ámbito público para que no pudieran servir de ejemplo a otras tantas.

Hay que recordar que uno de los espacios en donde las mujeres habían logrado una mayor presencia fue el ámbito educativo ${ }^{116}$, especialmente como funcionarias, gracias a las facilidades que Allende puso en este sentido. Las que lo habían logrado en su mayoría eran simpatizantes de la UP, circunstancia que les costó su expulsión o degradación profesional. La Junta no podía tolerar un modelo de mujer que la cuestionaba en si misma, lo que sirvió de excusa para depurar todo el sistema educativo.

\footnotetext{
${ }^{114}$ Ver Anexo. Entrevista No 3.

${ }^{115}$ Ver Power M., La mujer de Derecha. El poder femenino y la lucha contra Salvador Allende (19641973), Centro de Investigaciones Diego Barros Arana, Santiago de Chile, 2011.

116 En 1877 se autorizó por decreto el ingreso de las mujeres a la universidad, impulsándose, en consecuencia la creación de liceos fiscales femeninos. Por otra parte, las mujeres que emprendieron estudios universitarios se inclinaron por carreras del ámbito de las letras y humanidades, así como las relacionadas con la salud y asistencia social. Concretamente, de las 8.377 mujeres que entre 1910 y 1950 se licenciaron, el 93\% correspondían a dichas carreras. Las profesoras funcionarias del Estado representaban el 38.8\% de las licenciadas, seguidas por las asistentes sociales (19.9\%), odontólogas, enfermeras, farmacéuticas y médicas. A partir de 1970 la presencia de las mujeres en las ingenierías aumentará considerablente de un 1.5 por ciento (1969) a un 5.7 por ciento (1971) al igual que en las ciencias jurídicas y sociales (57 por ciento en 1971). Ver Correa S. y otros, Historia del Siglo XX chileno, Ed. Sudamericana, Santiago de Chile, 2001, p. 40.
} 
En esta sentido, Pinochet "militarizó" la universidad y la mayoría de los cargos de responsabilidad fueron ocupados por funcionarios castrenses. Incluso algunas mujeres, vinculadas al régimen (en su mayoría esposas de militares o miembros de la clase alta chilena) y que desempeñaron algún cargo de gestión, sufrieron los efectos del dirigismo y control pinochetista. Tal es el caso de Mónica Madariaga, ministra de Justicia y Educación en la dictadura en 1978 quién se opuso a que los militares fueran rectores de la universidad, lo que le costó la salida del ministerio: "Yo tenía el desempeño ministerial de labores de asesoría jurídica al general Pinochet, tenía la versión oficial de los hechos, la denominada burbuja, que me proporcionó un grato microclima, donde cada inquietud tenía una respuesta, cada interrogante era gratamente respondido" ${ }^{117}$

La política de control universitario ${ }^{118}$ tuvo un doble efecto para la mujer, a saber, su invisibilización en un espacio vital que podía servir de catapulta para la formación y acceso al espacio público, y dos, la presión para que las profesionales ocuparan "el lugar natural que les correspondía", el espacio doméstico y en aquellas labores tradicionalmente asignadas al colectivo femenino: como mano de obra en el sector primario, servicio doméstico, costura y confección, cuidados integrales, etc.

En segundo lugar, la puesta en marcha de medidas represivas para aquellas mujeres "que se resistieran": exilio, persecución, exoneración política, tortura y desaparición forzada entre otras, bajo la argumentación de que habían dejado de ser mujeres naturales para convertirse en desviadas del marxismo.

117 Declaraciones de Mónica Madariaga, rectora de la Universidad Nacional Andrés Bello. Paradójicamente, fue un caso de mujer que tuvo una clara responsabilidad política en el proyecto pinochetista (redactó la ley de Amnistía que impide que los crímenes cometidos entre 1973-1978 sean juzgados) y a su vez un ejemplo de oposición política a la Junta por suponer una forma de cuestionamiento de las políticas emprendidas en el ámbito de la Educación. Ver Sarmiento, C., Mujeres Chilenas, TVE, 1992.

${ }^{118}$ Un claro ejemplo de represión en el ámbito universitario lo encontramos en el despido de más de 1.500 docentes y 5.000 alumnos, en la Universidad de Chile (Santiago) y en la Universidad de Concepción (Concepción). Asimismo, en el diario El Mercurio (20 de abril de 1975) encontramos un artículo titulado Invasión discutida y escrito por el decano de la Facultad de Medicina de la Universidad Católica de Santiago. En él se aboga por una drástica limitación de la matrícula femenina, ya que esta sobrepasa al $50 \%$ del alumnado. En este sentido, se señala que la mujer tiene otra meta: "el matrimonio y la crianza de los hijos, por lo cual quita injustamente un campo ocupacional al varón, al cual, de suyo, esta actividad le pertenece". Ver Comité de Cooperación para la Paz en Chile, COPACHI, La situación general de la mujer bajo el gobierno militar de chile, Santiago, 1975, p. 168. 
Un ejemplo revelador de este proceso lo encontramos en una de las entrevistadas que fue expulsada de la Facultad de la Universidad de Chile donde trabajaba como profesora titular de Filosofía. El intrusismo militar obligó a la docente a buscarse la vida como camarera y subsistir con muy pocos recursos. Fue entonces cuando comenzó a militar en el MIR y reafirmarse en su oposición al régimen:

-"No tenía en un principio ideas izquierdistas, pero el hecho de que secuestraran a mi marido, que era militante del MIR y estar sin pega hizo que me interesara por la movilización y actividad política... me habían dejado en la calle sin nada, ¿qué podía hacer?, sumarme a la lucha contra los militares no más"119

También esta política depuradora se aplicó en otros terrenos como en la sanidad, en dónde la presencia de la mujer en puestos funcionariales ya era significativa. La privatización obligó a muchas a buscar un nuevo empleo renunciando a sus expectativas de promoción. Todo esto tuvo una trágica consecuencia: el desplazamiento de un importante sector de mujeres de clase trabajadora a la marginación, a la prostitución y a trabajos de "baja remuneración"120:

-Yo me egresé en Medicina en 1972, pero por mis antecedentes en el MIR me fue imposible encontrar trabajo, no podía ejercer, solo cuando llegó la democracia encontré pega en esta clínica... trabajaba en cualquier cosa, hasta vendía tejidos ponte tú... también tuve que pedir ayuda a mis papás, a los amigos... si no me hubiera sido imposible sobrevivir" ${ }^{121}$

No obstante, el desempleo y la marginación de las mujeres que habían logrado un cierto empoderamiento profesional trajo consigo un efecto no esperado por el gobierno militar: la politización de muchas de ellas que anteriormente no habían militado (muchas entraron a engrosar la filas de la resistencia clandestina) y la aparición de

\footnotetext{
${ }^{119}$ Ver Anexo. Entrevista No 8.

${ }^{120}$ En el estudio realizado por Jane S. Jaquette se afirma que el grupo social más perjudicado desde la instauración de la Junta Militar fue el colectivo de mujeres de los estratos sociales más bajos. El desempleo y la viudez les afectaron particularmente dado que sus maridos, dirigentes del Partido Comunista Chileno y del MIR, fueron asesinados en los primeros meses de la dictadura.

El efecto inmediato fue el desamparo económico por ser mujeres económicamente dependientes, lo que obligó a muchas de ellas a dedicarse a la prostitución. Reflexiones de Chuchryk P., From Dictatorship to Democracy: The Women's Movement in Chile, en la obra general de Jaquette J., The Women's Movement in Latin America, Oxford 1994, pp. 65-95.

${ }^{121}$ Ver Anexo. Entrevista No 11.
} 
organizaciones sociales lideradas por mujeres en torno a estrategias de supervivencia económica (las llamadas Organizaciones Económicas Populares ${ }^{122}$-OEP- u ollas comunes, en donde se elaboraban productos caseros de bajo coste y el cultivo de pequeñas parcelas comunales).

Estas organizaciones sociales tuvieron un carácter espontáneo ante el déficit de protección estatal y la situación generalizada de pobreza y represión en el país, lo que en definitiva se catalizó como una fuente más de oposición a la dictadura y de regeneración social de aquellos sectores más desfavorecidos por las políticas de reajuste económico:

-"La dictadura destruyó el tejido social que poco a poco se fue reconstruyendo desde las bases. La gente empezó a reunirse en los barrios, y las organizaciones sociales adquirieron protagonismo. La movilización y organización fue extraordinaria, la dictadura dejó fuera a la mayoría, había cinco millones de pobres en Chile. Las mujeres se organizaron en las ollas comunes para sobrevivir y ayudar a los sectores populares, ayudando a los hijos que sufrieron la represión" 123

Dichas movilizaciones solían tener a las mujeres en la vanguardia, circunstancia que la Junta militar no podía tolerar porque además de transgredir su rol de género representaban voces críticas contra Pinochet, especialmente en lo referente a la vulneración de los derechos humanos contra la población civil. Además, estas mujeres empezaron a contar con el apoyo de organismos internacionales, como la Cruz Roja Internacional, incrementando más aún la inquietud de los militares.

De hecho, la dictadura presentaba a estos colectivos como el ejemplo de mujer subversiva contra la que había que combatir por cuestionar los propios cimientos de la chilenidad, argumentación que utilizarían para reprimirlas.

Se puede decir que Pinochet no ignoró la importancia que podían jugar las mujeres opositoras en la desestabilización social del régimen, porque su voz había traspasado fronteras y generado apoyos de otros países cada vez más críticos. Es decir, por su

\footnotetext{
${ }^{122}$ En 1982 existían 495 OEP en el municipio de Santiago.

${ }^{123}$ Declaraciones de María Antonieta Sad, socialista y feminista chilena con motivo de la celebración del décimo aniversario de la olla común (1991) en Sarmiento, C., Mujeres Chilenas, TVE, 1992.
} 
poder de influencia, la represión se focalizó en ellas pero también por el convencimiento de que se habían desviado de su lugar natural, circunstancia que debía corregirse con todos los medios disponibles. 


\subsection{El ideario de "mujer pinochetista".}

¿Cómo se materializó el modelo de mujer que el gobierno militar quiso implantar después del golpe?. Desde una panorámica general se pusieron en marcha diferentes medidas como campañas divulgativas y comunicados, proyectos educativos y formativos, y leyes que regularan asuntos relacionados con maternidad, trabajo y salud encaminadas a reforzar el rol doméstico de las mujeres y dificultar su emancipación. Fueron frecuentes en los discursos públicos de Pinochet las alusiones al papel que las chilenas debían desempeñar en el nuevo orden y el lugar que debían ocupar en el futuro:

-"La mujer ya cumplió para la Junta con la tarea de remover el peligro marxista del país, hoy retoma su misión en el hogar, difundiendo en éste los valores y doctrinas de sus gobernantes: ha de ser educadora y formadora de conciencias, la mujer es la gran formadora del porvenir y la gran depositaria de las tradiciones nacionales. En su misión de mujer y madre, se dan la mano el pasado y el futuro de la nación, y quien aspire, como gobernante, a proyectar en el tiempo una obra política estable, tiene que contar con la palanca espiritual de su poder" 124

Estas líneas dan muestra del papel subsidiario que las chilenas debían ocupar en la participación programática de las nuevas instituciones y organismos de gobierno (la mujer sigue considerándose como un menor político) pese a que, también participaran a su manera en el derrocamiento de Allende. La movilización política de las mujeres prodictadura fue aplaudida y bendecida por los militares, pero ahora, con el control del país asegurado, debían retornar al hogar y centrarse en lo verdaderamente era importante: asegurar el relevo generacional y las tradiciones:

-"Ninguna inspiración doctrinaria puede interpretar mejor que ésta los anhelos de la mujer, puesto que ha sido ella, a lo largo de toda la Historia, la gran defensora de los valores espirituales... La formación de las nuevas generaciones, que lo integrarán mañana, está en las manos de las madres de hoy. Educadora y formadora de conciencias, la mujer es la gran forjadora del porvenir y la gran depositaria de las tradiciones nacionales... velando por resguardar el más precioso capital de la nación: el cuidado de sus hijos, esperanza futura de la Patria." $" 125$

\footnotetext{
124 Fragmento perteneciente al Mensaje a la mujer chilena, Universidad Gabriela Mistral, 1974. Información recogida en Violación de los Derechos de la Mujer en Chile, Santiago de Chile, marzo 1977.

${ }^{125}$ Discurso pronunciado por el Comandante en Jefe de las Fuerzas Armadas y presidente de la Junta de Gobierno, Augusto Pinochet de Hiriart, en el edificio Diego Portales (Santiago) el 24 de Abril de 1974, en Valdés, T. Las Mujeres y la Dictadura militar en Chile, FLACSO, Santiago de Chile, 1987, pp. 21-25. Ver Anexo I, p. 123.
} 
Pinochet recuperó el modelo decimonónico de Ángel del Hogar, a saber, la mujer como encargada de la crianza y educación de los hijos, la gestión de la economía familiar y la transmisión del ideario católico de familia, funciones que eran interpretadas como el verdadero anhelo de cualquier chilena.

Bajo el paradigma biologicista, se proclama que las mujeres por naturaleza tienen el "monopolio de lo afectivo y lo moral", en contraposición con el saber racional, exclusivo de los varones, razón por la cual ellas estarían mejor preparadas para asumir las labores domésticas y el cuidado de los demás. Pero también, la dictadura no dejó de recordar que con el golpe se cumplieron las exigencias de muchas mujeres que opositaron contra el gobierno popular, circunstancia que entendían podían darles legitimidad para definir el papel y lugar que debían ocupar porque habían "cumplido":

\begin{abstract}
-"En la conciencia de todos los chilenos está vivo aún el recuerdo de la valerosa lucha librada por nuestras mujeres en contra del régimen marxista... La mujer quería la caída del gobierno marxista, que simbolizada la esclavitud de sus hijos; pero quería además, un nuevo orden: buscaba el amparo de una autoridad fuerte y severa, que reestableciera el orden y la moral pública en nuestro país. En su instinto femenino, ella advertía claramente que lo que se definía en esos días drásticos no era un simple juego de partidos políticos: era la resistencia a muerte de la nación. Y en esto, su clarividencia fue mucho mayor que la de algunos señores políticos..."126
\end{abstract}

En el discurso también aparecen las atribuciones de los gobernantes masculinos. En esta línea, el concepto de masculinidad refleja las características propias del ámbito castrense sólo atribuibles a los hombres que se configuran como soldados y gobernantes. Ellos por sus capacidades innatas (inteligencia racional) debían de ocuparse del espacio público siendo los principales beneficiarios de los cuidados ofrecidos por las mujeres:

-"Como hombre, como soldado y como gobernante, no creo poder rendirles mayor homenaje que el de recordar la responsabilidad que significa para los hombres de armas la fe que ellas depositaron públicamente en nosotros... al Gobierno a considerar a la mujer como piedra fundamental de la reconstrucción de Chile... aspiramos a crear una nueva institucionalidad, de inspiración nacionalista y portaliana, arraigada en las más nobles

${ }^{126}$ Ibíd., p. 123. 
tradiciones de nuestra historia... en ella la importancia de la familia como piedra angular de la sociedad"127

Por consiguiente, en el nuevo reordenamiento institucional la mujer solo tenía cabida en el plano legitimador. En principio, no se cuenta con ellas para participar per se en el poder militar, político o económico, puesto que ello podría hacer peligrar la base del orden social, el espacio doméstico-familiar. Precisamente, es en este punto donde entraron en juego los valores religiosos que se presuponía que la mujer encarnaba, esto es, el ideario Marianista o culto a las cualidades de la Virgen María: abnegación maternal, servidumbre, recato y sacrificio.

Se propone la participación activa y enérgica de la mujer, pero no engrosando la lista de los funcionarios o agentes que componen la nueva estructura institucional, sino en su labor reproductora de las futuras generaciones del Nuevo Chile (mujer como elemento maternal y no sujeto de ciudadanía). Ese activismo y energía entronca con los valores del sistema patriarcal latinoamericano, puesto que colocaba a las chilenas como forjadoras de conciencias y no constructoras de su propio futuro y aspiraciones.

Pero también Pinochet pudo ser consciente de que el control social del conjunto de las mujeres y su focalización en el hogar, garantizaría cierta estabilidad económica porque finalmente eran ellas las que se ocupaban de comprar los productos de consumo y gestionar las economías familiares.

Por otra parte, en lo referente al plano laboral, se promocionó a la mujer en los sectores técnicos que se consideraban óptimos por sus cualidades innatas: el ámbito sanitario, gestión administrativa, sector servicios, obreras de la producción en línea, etc.

Aunque la aportación laboral se agradece, la dictadura no dejó de recordar que la verdadera capacidad femenina residía en mantener el funcionamiento de ese "laboratorio silencioso" y no remunerado que es el hogar. Se acepta que ellas aporten en lo público pero sin que ello perjudicara a sus "funciones domésticas": "Chile necesita y

${ }^{127}$ Ibíd., p. 124. 
agradece el aporte técnico de sus profesionales femeninas... pero no subestima por eso la labor anónima de las mujeres que trabajan en el laboratorio silencioso del hogar" ${ }^{2}$.

Otra clave del discurso la encontramos en cómo se plantea la igualdad de derechos. Si bien se expresa que la equidad de oportunidades es legítima, se especifica que ello debe interpretarse respetando las características innatas que existen entre ambos sexos. Los principales elementos divergentes, tal y como se refleja, serían: la realidad física y la moral, "ella" sería la portadora nata de los valores que al hombre no le corresponde encarnar como la espiritualidad, la afectividad o la intuición. La fuerza y el saber recaerían sobre él.

Finalmente, se introduce una crítica al proceso de liberación femenina (fomentada especialmente durante los gobiernos de la Unidad Popular: acceso a la universidad, a las profesiones liberales del ámbito público, a la política, etc.) entendida como el principal elemento de distorsión de las capacidades naturales femeninas, y, en este sentido, la Junta debía garantizar su pleno desarrollo dentro de "la normalidad patriarcal":

-"La igualdad de derechos y oportunidades, que nadie discute, no puede confundirse con una identificación, ajena a la realidad física y moral del ser humano, en la cual, bajo una apariencia de liberación, la mujer pierde el derecho a desarrollar su auténtica personalidad y proyectar sobre la sociedad el caudal de intuición y riqueza afectiva que le es propio. Consideramos por eso que una auténtica participación de la mujer en la vida nacional deber ser ejercida con respeto a sus características, y el Estado se propone orientar su acción en este sentido" 129

\footnotetext{
${ }^{128}$ Ibíd., p. 124.

${ }^{129}$ Ibíd., p. 125.
} 


\section{CAPÍtUlO 3: LAS MUJERES EN LA OPOSICIÓN A LA DICTADURA: MILITANCIA CLANDESTINA, EXILIO Y MOVILIZACIÓN SOCIAL (1973-1990)}

Uno de los objetivos centrales de la investigación ha sido el análisis de la actividad opositora de las militantes de la izquierda en tiempos de dictadura, tanto política como social, de manera que su tratamiento abarcara no solo su posicionamiento como activista formal de un determinado partido sino también como agente de cambio social.

Partimos de la base de que las mujeres que participaron, simpatizaron o formaron parte del gobierno popular derrocado fueron las mismas que opositaron contra Pinochet, lo que no quiere decir que otras muchas se sumaran a la oposición a lo largo de la dictadura. Debido a la heterogeneidad de realidades, se han escogido los casos de militantes formales que opositaron en clandestinidad con vistas a desentrañar las actividades partidarias que desempeñaron y las vicisitudes con las que se encontraron en relación a su condición de género.

Con el ánimo de abordar estas cuestiones, se ha tratado de recoger, con la mayor precisión posible, las variables predominantes en cuanto a militancia femenina se refiere y siempre en base a lo que las entrevistadas van transmitiendo junto con los testimonios escritos que en su día realizaron. Abordar cómo interpretan sus propias experiencias, los elementos comunes y diferenciadores entre unas y otras, y cuáles fueron las claves en sus aportaciones al quehacer político, pueden facilitar una visión más amplia sobre la actividad opositora femenina. 


\subsection{Las militantes ante el golpe de Estado: el repliegue a la clandestinidad.}

Durante los meses previos al golpe de Estado, las direcciones de los principales partidos de la izquierda (MIR, PS y PC), y ante las inminentes señales de una posible intervención militar, empezaron a desarrollar diversas estrategias contrainsurgentes. Una de ellas fue la organización de una red de recursos y espacios para proteger a las direcciones y cuadros políticos ante un posible contexto de clandestinidad: pisos francos o casas de seguridad, contactos con embajadas de los gobiernos afines a Allende, etc.

En agosto de 1973, el clima político y las convulsiones sociales se recrudecieron enormemente aumentando las posibilidades de un enfrenamiento armado entre partidarios y detractores de Allende. Si bien el conjunto de la izquierda chilena fue consciente de la inminencia de un golpe de militar y un posible contexto de represión política, los testimonios dan cuenta de que nunca imaginaron su crudeza y dimensiones.

Primero, porque se pensaba que la irrupción de las Fuerzas Armadas iba a tener un carácter transitorio que dejaría paso a la restitución de la normalidad democrática liderada esta vez por los partidos políticos de la derecha; en segundo lugar, que la represión contra los componentes del gobierno popular y sus partidarios no iba a ser tan extrema ni de proporciones masivas. Todo ello tuvo una inmediata consecuencia, la indefensión y vulnerabilidad de miles de militantes por no disponer de tiempo ni de recursos para salvarse.

En efecto, el asalto a La Moneda vino precedido por un despliegue de medios militares sin precedentes en territorio chileno. Los primeros movimientos del ejército venían a poner de relieve algunas pinceladas de lo que sucedería en las siguientes semanas. A lo largo de todo el país, bases aéreas y navales operaban en perfecta coordinación sirviendo como lugares de detención clandestina y tortura. Otros espacios como estadios de fútbol, regimientos, escuelas de oficiales y una red de casas secretas se incorporaron al operativo para contener cualquier atisbo contrainsurgente. 
La sociedad chilena pudo ver y escuchar en directo los primeros estragos del golpe a través de la radio y la televisión. A lo largo de la mañana del 11 de septiembre cazas de la Fuerza Aérea $(\mathrm{FACH})$ bombardearon el recinto presidencial dejándolo literalmente en ruinas y causando el fallecimiento de Allende y gran parte de su guardia personal (GAP o Grupo de Apoyo al Presidente). De esta manera, los hechos fueron contemplados en tiempo real más allá de las fronteras de Chile en lo que fue el primer golpe de Estado televisado en tiempo real.

A medio día, el personal de gobierno que sobrevivió al asalto (parte del ejecutivo se encontraba en los edificios institucionales contiguos a La Moneda), fueron detenidos y trasladados a la Isla Dawson, un campo de concentración en el extremo sur de Chile (una zona inhóspita, desabitada y mal comunicada). Pinochet quería tener controlado a los ministros y cabecillas de Allende en un mismo lugar y lo más apartado de cualquier mira.

En Dawson, algunos prisioneros fueron ejecutados y hechos desaparecer mientras que otros sirvieron como mano de obra para hacer trabajos forzados en condiciones de frío extremo. Todavía no existen datos concretos de las personas que pasaron por allí ni del paradero de quienes fueron vistos por última vez en el recinto, lo que abre una nueva línea de investigación en la aclaración de las violaciones de derechos humanos cometidas durante la dictadura.

Al mismo tiempo, en las grandes ciudades cientos de cargos públicos, dirigentes sindicales, estudiantiles y poblacionales eran arrestados, cuando no asesinados, y trasladados a diversos centros de detención clandestina.

Desde una perspectiva general, se podría decir que el clima de caos en donde cualquiera podía ser detenido dejó al gobierno de la UP paralizado y desbordado ante unos acontecimientos que no pudieron preveer, lo que hizo prácticamente imposible organizar una contrainsurgencia eficaz y proteger a la población civil. Porque en esos días de confusión, los líderes de la izquierda no podían saber a ciencia cierta quienes habían sido detenidos o ejecutados o quienes habían sobrevivido. 
Durante las siguientes semanas, las embajadas empezaron a colapsarse ante la llegada masiva de perseguidos, que vieron en el exilio su única forma de salvación. Por el contrario, otros tantos decidieron quedarse y organizarse en clandestinidad para hacer frente a la dictadura pese al riesgo que corrían sus vidas. Todo ello generaría después divisiones dentro de la izquierda sobre la conveniencia o no de exiliarse, circunstancia que según algunas entrevistadas todavía perdura a día de hoy entre aquella generación de militantes.

Por un lado, parte de los cuadros medios de las formaciones de la izquierda se refugiaron en las casas de seguridad esperando las respectivas instrucciones de las direcciones con vistas a recomponer las redes de conexión partidarias y elaborar una estrategia común contra Pinochet. Por otro, la militancia de base se agrupó mayoritariamente en los cordones industriales, las universidades y las sedes sindicales, aguardando apoyo logístico gubernamental que nunca llegó. Por tanto, se podría decir que el grueso de la militancia de la izquierda quedó neutralizada y desorientada.

Por su parte, las mujeres que ocupaban cargos de responsabilidad política (diputadas, miembros la dirección y dirigentes), en su mayoría, partieron al exilio fundamentalmente a través de las embajadas de los países que más simpatizaban políticamente con Allende (México, Colombia, Suecia, Francia, Canadá, Finlandia y Holanda, entre otras).

Los primeros bandos de la Junta militar en lo referente a las personas buscadas incluían varios nombres de destacadas dirigentes socialistas y comunistas. Ante esta situación, los descompuestos Comités Centrales trataron de asilar al mayor número de ellas, como fueron los casos de Laura Allende Gossens ${ }^{130}$, María Elena Carrera ${ }^{131}$ o Carmen Laso

\footnotetext{
${ }^{130}$ Laura Allende Gossens, diputada por Santiago de Chile, partió a Cuba desde donde lideró una activa denuncia de las violaciones de Derechos Humanos hasta que decidió terminar con su vida el 24 mayo de 1981.

${ }^{131}$ María Elena Carrera inició su actividad política muy joven, en las universidades de Concepción y de Chile, como miembro de las Brigada Universitaria Socialista. En 1967 fue la candidata socialista para llenar el cupo dejado por el fallecimiento de su marido, por la senaduría de O'Higgins y Colchagua, siendo electa para el período de 1967 a 1969. En 1969, fue reelecta senadora, con la primera mayoría (1969-1973). En 1971 fue nombrada presidenta de las mujeres de la Unidad Popular. En 1973, partió al exilio radicándose en Perú y después en Berlín (RDA), por 14 años. A pesar de estar en el exilio continuó sus actividades políticas siendo presidenta de las mujeres chilenas en el exilio.
} 
(ambas fueron requeridas por el Ministerio de Defensa, lo que les obligó a salir forzosamente del país a través de la embajada de Colombia).

Por este motivo, los movimientos de las militantes y sus apoyos fueron variados dependiendo de su posición y relevancia en el partido:

-"El 11 de septiembre, en uno de los primeros bandos de la Junta, salió mi nombre y el de otras compañeras más teníamos que presentarnos al Ministerio de Defensa. El partido me dijo que me exiliara el mismo día del golpe. Estuve catorce años exiliada en Venezuela. Yo tenía un pariente en el cuerpo de Carabineros que facilitó mi salida"132

-"Esa tarde, me disfrazaron y me llevaron a una casa del partido. La Junta me buscaba, más por ser secretaria de la Jota (Juventudes Comunistas) que por diputada de la UP. Llegué a una casa de los compañeros de Lo Prado. Allí me recibieron asustados por mi presencia... Tuve que vagar de casa en casa más de dos meses. Tuvieron muchos problemas conmigo, hasta que me asilé en la embajada de Finlandia en los primeros días de noviembre de 1973; recuerdo que era el día de los muertos. En la embajada tuve que esperar hasta el ocho de marzo para conseguir el salvo conducto. Estuve casi cinco meses viviendo allí, hacinados y en muy malas condiciones" 133

¿Qué ocurrió con el grueso de la militancia femenina que no ocupaba puestos de responsabilidad y no pudo salir de Chile? Por una parte, la generación de mujeres más jóvenes, mayoritariamente vinculadas al ámbito estudiantil, acudieron a sus respectivas facultades en donde debían esperar instrucciones de la dirección.

El caso de la Universidad de Santiago (USACH, Estación Central) fue revelador. Allí se desplazaron militantes de todos los partidos de la izquierda con el objetivo de hacer desaparecer la documentación comprometedora y organizar la resistencia.

Sin embargo, las armas con las que contaron los estudiantes se reducían a cócteles molotov improvisados y algunas pistolas de bajo calibre, con lo que en inferioridad de condiciones y a la espera de una logística militar que nunca llegaría, no tardaron en ser

En 1988, regresó clandestinamente al país, y participó en la organización de las mujeres en torno a la Concertación de Partidos por la Democracia. En 1989, fue candidata a senadora por Santiago Oriente, pero no logró ser elegida. A pesar de esto, en 1994, se convirtió en senadora por esa zona, ocupando la vacante dejada por Eduardo Frei Ruiz-Tagle al ser electo presidente, para el periodo 1994-1998.

${ }^{132}$ Ver Anexo. Entrevista $N^{\circ} 16$.

${ }^{133}$ Ver Anexo. Entrevista No 41. 
neutralizados. De esta manera, en unos minutos el regimiento Arica $\mathrm{N}^{\mathrm{o}} 2$ rodeó la USACH y asaltó el campus dejando tras de sí varios estudiantes muertos, decenas de heridos y 1200 detenidos, entre los que se encontraban alrededor de trescientas mujeres (principalmente militantes socialistas, comunistas y miristas):

-"Nos bombardearon y balearon. Dos compañeros murieron y otros quedaron mal heridos en el interior del recinto universitario. No alcanzamos a utilizar los cócteles molotov porque la correlación de fuerzas era muy desigual. Entraron en la universidad con mucha violencia y con gran apoyo logístico porque tenían ametralladoras, francotiradores y vehículos de asalto. Nos golpearon mucho y allí mismo nos hicieron varios simulacros de fusilamiento" ${ }^{\text {"134 }}$

La mayoría de las mujeres que fueron detenidas fueron trasladadas al Estadio Nacional donde correrían distinta suerte. Decenas de ellas fueron trasladadas a otros centros de detención donde sufrirían la tortura o desaparición forzada. Otras, las menos, después de permanecer días en el estadio en condiciones infrahumanas, fueron puestas en libertad aunque con la obligación de presentarse cada quince días en los cuarteles de carabineros de sus respectivos distritos. Las que pudieron escapar de la universidad fueron desplazándose a las casas de seguridad u otros refugios, por ejemplo, en las poblaciones en donde tenían contactos:

-“El plan era que si el golpe llegaba, la dirección del partido se separaría en equipos más pequeños. Cada uno de ellos tenía sus casas de seguridad para desempeñar su trabajo. A mi me tocó juntarme con el compañero Araneda, Vega y otros dos compañeros. Estuvimos en una casa del sector sur durante varios días después de escapar" ${ }^{\text {"135 }}$

Por otra parte, las militantes de base no vinculadas al ámbito estudiantil, en su mayoría, se desplazaron a sus respectivas sedes comunales y cordones industriales que rodeaban la capital (fábricas e industrias). Allí la resistencia fue más notoria al concentrarse gran parte de la oposición social (dirigentes poblacionales, políticos, sindicales, obreros, etc.) lo que suponía un riesgo mayor a la hora de caer detenido.

\footnotetext{
${ }^{134}$ Ver Anexo. Entrevista No 23.

${ }^{135}$ Ver Anexo. Entrevista No 36.
} 
En cualquier caso, lo que parece quedar claro es que a ninguno de estos lugares llegaron instrucciones precisas ni apoyo logístico para hacer frente a los militares, con lo que el caos y el desconcierto precipitaron un desenlace fatal.

En esta línea, la militante socialista Angélica $\mathrm{Muñoz}^{136}$ relata que la directriz de la izquierda fue que las bases colaboraran activamente en la desaparición de cualquier rastro que delatara a miles de ciudadanos vinculados a ella, y evitar un efecto dominó de arrestos masivos. Por este motivo, más allá de los riesgos, muchos hombres y mujeres se desplazaron a los "lugares calientes sujetos a intervención militar" pudiendo eliminar parte de los archivos y registros para proteger la identidad de cientos de opositores.

Muñoz, al igual que otras militantes, participó en esta estrategia momentos antes de replegarse a la clandestinidad, desde donde tendría la difícil tarea de recomponer las estructuras de los partidos y localizar a una militancia dispersa:

-"Yo desarrollé la labor de contactar con los compañeros de los distintos comunales del país. La orden era quemar toda la documentación y archivos del Comité Central... me trasladé a un punto de encuentro, la industria FENSA, en donde se tenían que concentrar todos los dirigentes del PC, el MIR y el PS. Esto fue un desastre, solo nos juntamos 50 compañeros y permanecimos encerrados tres días esperando instrucciones... Sólo teníamos dos pistolas calibre 22 para defendernos con lo que no pudimos hacer mucho"137

-"Había mucho desconcierto entre mis compañeros. Lo primero que hicimos fue eliminar toda la documentación personal que nos vinculara al partido. Los carnés, documentación, informes con nombres, etc., los quemamos. Nos preparamos haciendo bombas molotov para una posible defensa" ${ }^{\text {"138 }}$

En las fábricas, el esquema se reproducía de la misma manera ya que los cuadros militantes, aislados y acorralados, no recibieron ningún tipo de ayuda del depuesto gobierno. A partir de este momento se producirán dos hechos relevantes: la exoneración política de muchas trabajadoras, y la dispersión de la militancia ante la imposibilidad de actuar en contexto de "Estado de Sitio" y control férreo de las ciudades.

\footnotetext{
${ }^{136}$ Ver Anexo. Entrevista No 21.

${ }^{137}$ Ibíd.

${ }^{138}$ Ver Anexo. Entrevista No 23.
} 
Un ejemplo de la militancia en los cordones industriales lo encontramos en el caso Natacha Molina ${ }^{139}$, quién ante la imposibilidad de crear un operativo contrainsurgente en el cordón Vicuña Maquena (Santiago de Chile), tuvo que exiliarse a través de la embajada de México:

-"Nos fuimos a la Escuela Industrial en San Miguel. La escuela fue el lugar que se nos había asignado ante la hipótesis de tener que defender el gobierno. Lo que encontramos era absolutamente ridículo: 8 a 10 armas personales, propias de un grupo escolta...ni siquiera había alimentos"

Por tanto, es presumible reflejar que el conjunto de la militancia femenina, la mayoría destinada al trabajo de base y especialmente a la función de abastecimiento de las necesidades en clandestinidad, quedó desprotegida y al desamparo de los acontecimientos, ya que tan solo unas pocas pudieron contar con el apoyo necesario para salir del país. Al no existir un plan de contrainsurgencia y protección por parte del gobierno y los partidos que lo componían para con la militancia, la recomposición tras el golpe quedó condicionada en buena medida a las iniciativas individuales y los recursos que cada militante dispusiera.

Sin embargo, muchas de ellas, al no estar en un primer momento en el punto de mira de la represión (la prioridad estaba en la captura de los hombres), permitió que pudieran operar con mayor margen de maniobra en las acciones de enlace y recomposición de unos partidos fragmentados, lo que interpretan que fue posible, también, porque ellas levantaban menos sospechas por el hecho de ser mujeres.

\footnotetext{
${ }^{139}$ Ver Anexo. Entrevista No 22.

${ }^{140}$ Ibíd.
} 


\subsection{El quehacer político en la sombra: comunistas, miristas y socialistas.}

No existen cálculos precisos sobre el porcentaje de mujeres que militaron en los partidos de la izquierda chilena al momento del golpe militar. No obstante, la mayoría de los testimonios reflejan que la participación de las mujeres en los partidos podía variar entre 10 y el 20 por ciento dependiendo de cada caso (número de puestos de responsabilidad, militantes registrados, etc.). Ello correspondería a la militancia puramente formal, con lo que quedarían pendientes los apoyos recibidos por parte de cientos de mujeres que sin estar afiliadas, se sumaron a la vida partidaria como activistas por simpatizar con "la causa".

Desde una perspectiva general, hay que mencionar que si bien la militancia política femenina durante la clandestinidad fue heterogénea, lo cierto es que buena parte de las tareas desempeñadas por las mujeres tuvieron que ver con los roles y estereotipos de género tradicionales, fuertemente arraigados en una época en la que incluso dentro de las formaciones políticas más vanguardistas el cuestionamiento de los mismos era prácticamente inexistente.

Como se ha mencionado en apartados anteriores, durante los gobiernos de la Unidad Popular las mujeres tuvieron un mayor acceso a la vida política y partidaria del país, circunstancia propiciada en buena medida por la sensibilización de Allende con respecto a la igualdad entre hombres y mujeres y por el clima de cambio social y apertura que su promesas electorales habían suscitado en buena parte del país.

Sin embargo, y como reflejan la mayoría de los testimonios, la presencia de las militantes se centraba fundamentalmente en los cuadros medios y en las bases, sin llegar a tener una verdadera representación en los órganos de decisión política. Por esta razón, en tiempos de clandestinidad, los posicionamientos de hombres y mujeres no cambiaron sustancialmente al interior de los partidos ya que, ellas siguieron reproduciendo el rol de "ayudistas y suministradoras de recursos en la retaguardia".

Sin embargo, la represión militar contra las cúpulas masculinas de la izquierda generó un vacío de poder de facto, una coyuntura que permitió que algunas mujeres empezaran a ejercer funciones de liderazgo. Así, muchas activistas empezaron a reemplazar a los 
compañeros líderes caídos, circunstancia que no hubiera sido posible en un contexto de normalización democrática. En otras palabras, fue el resultado de un cambio forzado que paradójicamente permitió que ellas pudieran acceder a espacios nunca antes ocupados.

Pero esta circunstancia no cambió a medio y largo plazo el posicionamiento de las mujeres en la mayoría de los partidos de la izquierda, y especialmente en la toma de decisiones clave, ya que pronto otros hombres ocuparon "los puestos vacíos". Efectivamente, si bien ellas se ocuparon de recomponer sus formaciones y dinamizar la resistencia cuando los hombres cayeron detenidos, no se las tuvo en cuenta cuando ellos lograron reorganizarse de nuevo.

Desde una mirada de género, a las militantes se las buscaba menos que a los dirigentes por no ser las "piedras angulares de la subversión" a lo que se añadía que levantaban menos sospechas por el hecho de ser mujeres en base a los mitos y estereotipos sexistas.

Esta circunstancia fue aprovechada por los partidos políticos pero también por las propias militantes, lo que implicó una mayor efectividad (y discreción) en la actividad clandestina, muy especialmente aquella que se desarrollaba en el espacio público, como las conexiones entre los diversos cuadros, el traspaso de información o la acogida de perseguidos en las casas de seguridad, muchas de ellas "regentadas por mujeres".

Sin embargo, esta estrategia, como se verá más adelante, tuvo un efecto perverso con el tiempo ya que los militares, pronto dieron cuenta de que las mujeres comenzaban a tener un mayor protagonismo en la lucha opositora, lo que conllevó a que las miras represivas también se enfocaran en ellas. Este proceso, desembocó en el diseño progresivo de una represión específica contra las militantes, centrada en su sexualidad, o lo que es lo mismo, la violencia de género como recurso represivo. 


\subsubsection{Enlace, correo y difusión de propaganda.}

Tras el golpe de Estado, la recomposición de las formaciones de la izquierda fue lenta y dispersa debido a la falta de recursos logísticos y humanos. En el transcurso de los siguientes meses al golpe, algunos grupos empezaron tímidamente a reorganizarse a través de reuniones clandestinas. En un primer momento, la prioridad se centró en localizar y reagrupar al conjunto de la militancia que seguía activa, y hacer un primer balance de aquellos cuadros que habían caído presos o estaban en paradero desconocido.

Aunque las estrategias de los tres partidos de la izquierda variaron, es decir, mientras que el MIR abogaba porque la dirección general permaneciera en Chile, el Partido Socialista y el Partido Comunista apostaron por exiliar con la mayor prontitud a sus dirigentes, lo cierto es que las detenciones masivas realizadas por todo el país afectaron de forma directa a las cúpulas de estas formaciones, dejándolas en una situación de inoperatividad de facto.

En este contexto, muchas mujeres comenzaron a desempeñar un papel fundamental en la reconstrucción de los partidos realizando, por ejemplo, tareas de enlace entre las diversas células disgregadas (militantes-correo) y facilitando lugares de encuentro seguros (casas de seguridad) para acoger a los perseguidos y salvaguardar la documentación comprometedora:

-"Mis tareas fueron sobre todo de enlace y trabajo como encargada de un Comité Regional...desde ahí, atendíamos a las células para la organización de actividades desde la clandestinidad"141

-"Mi labor era de reconexión porque el MIR había recibido golpes muy fuertes por la represión y estaba muy disperso. La idea era trabajar en reconectar a la gente y tareas de infraestructura, es decir, conseguir lugares seguros" ${ }^{\text {142 }}$

-"En ese período, yo estaba trabajando en una unidad de organización del MIR cuyo objetivo era la conexión con los diferentes compañeros y dirigentes que habían caído presos o que estaban siendo buscados. En la semana de mi detención, muchos compañeros habían caído. Yo estuve recorriendo las comunas y los pueblos de alrededor para advertirles del peligro que corrían, es decir, evitar un efecto dominó para que no cayera toda la estructura que operaba en Concepción" ${ }^{143}$

\footnotetext{
${ }^{141}$ Ver Anexo. Entrevista No 35.

${ }^{142}$ Ver Anexo. Entrevista No 12.

${ }^{143}$ Ver Anexo. Entrevista No 4.
} 
-"Fui muy rigurosa al acudir a un punto de encuentro. Siempre traté de sintetizar al máximo los documentos. Tuvimos una red de apoyo no sólo de militantes comunistas sino de otros compañeros sin una militancia política. Había casas para guardar documentos y otras para alojar a los compañeros" $" 144$

-"Hice labores de propaganda, enlace y, sobre todo, apoyo médico a los compañeros del Frente a partir de 1983. Fui ayudista, nunca combatiente. Las compañeras generalmente organizaban las casas de seguridad o como buzón. También todo lo que fue las visitas a las cárceles cuando algún compañero caía"145

No obstante, aunque la participación femenina aumentó, ellas mismas relatan que se siguieron reproduciendo roles y formas de subordinación que las perjudicaban. Muestra de ello es que en muchos casos, además de trabajar en el espacio público (por ejemplo como enlace) debían asumir también y por costumbre, todo aquel trabajo de carácter más interno, como las tareas administrativas en relación a la documentación interna, propaganda, apoyo logístico, abastecimiento, etc.

Ello dada cuenta de que si bien asumían los riesgos de militar en la oposición como cualquier otro varón, no era correspondido a la hora de ocupar un mismo lugar en el partido. Dicho desequilibrio no era percibido por la mayoría de las entrevistadas en aquel período, por lo que entienden una ausencia de conciencia de género entre ellas:

-"Las actividades que realicé fueron básicamente de propaganda. Salíamos a la calle a pintar las paredes, nos juntábamos varias parejas y planeábamos muy bien las tareas. Uno vigilaba, otro seleccionaba la calle, otro rayaba, etc.....También tirábamos panfletos cerca de los cuarteles de carabineros, era muy riesgoso pero éramos jóvenes y algo inconscientes"

-"Estuve alrededor de treinta y seis veces detenida. La mayoría de las veces por desórdenes o disturbios. También por llevar propaganda o documentación... Las compañeras caían presas y se ponían a trabajar, a redactar documentos, declaraciones, realizar contactos, siempre en su rol, porque no había por aquel entonces una conciencia de género entre nosotras" $" 147$

-"Había quedado con una compañera del MIR a las doce de la mañana para un traspaso de información, era mi enlace. Un hombre bien fornido se dirigió hacia mi tomándome de los brazos... me metieron en un coche, me amarraron y me pusieron scotch en los ojos.

\footnotetext{
${ }^{144}$ Ver Anexo. Entrevista No 36.

${ }^{145}$ Ver Anexo. Entrevista $N^{\circ} 37$.

${ }^{146}$ Ver Anexo. Entrevista No 33.

${ }^{147}$ Ver Anexo. Entrevista No 37.
} 
Llegamos a un lugar en donde escuché la apertura de un portón... pude notar gravilla y la presencia de un hombre que me gritaba ¡si no habla, a la parrilla con ella!",148

Como se ha mencionado anteriormente, las formaciones de la izquierda percibían que las activistas podían levantar menos sospechas a la hora de realizar acciones políticas de alto riesgo porque éstas tradicionalmente habían sido desempeñadas por los hombres, y al fin y al cabo, lo extraño era ver a una mujer realizándolas.

Ellas, al naturalizar estos esquemas como válidos, aceptaban estos cometidos sin cuestionarlos y sin tener conciencia del riesgo que corrían sus vidas o la de sus familiares. Los contactos en vía pública solían ser frecuentes y las activistas se acompañaban de sus hijos a la hora de entregar información a otro compañero, bajo la percepción de que la maternidad les serviría para ser inmunes a la garra militar. Como demuestran los testimonios, nada más alejado de la realidad, decenas de mujeres cayeron presas en estas circunstancias, y algunas todavía a día de hoy siguen en paradero desconocido al igual que sus bebés ${ }^{149}$ :

-"Muchas mujeres actuaron bajo los parámetros machistas de que la represión les iba a afectar menos por el hecho de ser mujeres. Se pensaba que la mujer podía arriesgar más sin ser tan duramente tocada por la represión; esto fue un claro reflejo de la reproducción de la mentalidad machista por las propias mujeres a la hora de movilizarse" ${ }^{\text {"150 }}$

-"La primera estampilla de la oposición socialista que salió en Chile decía "la resistencia vive" y tenía la cara de Allende. Nosotras comprábamos papel engomado, éramos especialistas en propaganda. Después, en el traslado, comprábamos paquetes de detergente, lo vaciábamos y lo rellenábamos con estampillas. Posteriormente, el paquete lo colocaba en el carrito de mi hija para poder disimular a la hora de hacer las entregas... pero al final caí detenida" 151

-"Llevaba la información en microfichas dentro de los pañales de la guagua (bebé). Esto lo hicieron muchas compañeras porque pensaban que podíamos pasar más desapercibidas" ${ }^{152}$

-"Mi rol, hasta la fecha de mi detención fue el de compañera-militante de mi esposo, es decir, yo era el enlace de los contactos, escribía a máquina las cartas de comunicación, los barretines (panfletos), y claro está, cuidar a mi hija. Recuerdo haber utilizado los pañales de mi guagua para esconder los boletines y la documentación de los contactos. Pero la función

\footnotetext{
${ }^{148}$ Ver Anexo. Entrevista No 3.

${ }^{149}$ Ver Rojas P. y otras, Todas Íbamos a Ser Reinas: estudio sobre diez mujeres embarazadas que fueron detenidas y desaparecidas en Chile, CODEPU, LOM ediciones, Santiago de Chile, 2002.

${ }^{150}$ Ver Anexo. Entrevista No 20.

${ }^{151}$ Ver Anexo. Entrevista No 23.

${ }^{152}$ Ver Anexo. Entrevista No 21.
} 
más arriesgada que se me asignó fue la de llevar y recoger la información de los contactos entre compañeros, es decir, lugares de encuentro, hora..."153

Otras entrevistadas han reflejado que ellas mismas desplegaban lo que han denominado como "tácticas intrínsicamente femeninas" (armas de mujer) por iniciativa propia, especialmente en situaciones de riesgo personal, independientemente de que fuera o no una consigna del partido.

De esta forma, las activistas consciente o inconscientemente naturalizaban lo que podríamos denominar un rol "seductor" que habían aprendido en el contexto general de su socialización de género para con los militares, como sí de un recurso sumamente valioso se tratara de evitar la captura. Esta estrategia, desde su óptica, solía dar resultado, porque al fin y al cabo, percibían que ellos iban a anteponer su visión de la mujer como "objeto sexual" (cosificación) que como sujeto opositor, por ejemplo, en las redadas, allanamientos y operativos que las Fuerzas Armadas realizaban con regularidad:

-"Me dieron una misión en el extranjero a mediados de 1984. Viajé con mi hijo de dos años. Todavía usaba pañales. Con otra compañera de la estructura, que también viajó con su hijo, jugamos el papel de mujeres que hacían turismo. Era una misión muy peligrosa. En una ocasión nos quedamos en un cerro aisladas y pudimos resolver muy bien la situación jugando nuestro rol de mujeres, con toda esta parte femenina, de seducción. Íbamos en una camioneta y nos paró la policía...me vestía de forma muy femenina, muy coqueta, preocupándome mucho del maquillaje y asumía el rol de mujer linda con su carpeta de encuestadora" 154

-“La mujer tenía una ventaja en estas acciones, es decir, el tema de la imagen, que al fin y al cabo significaba un recurso táctico. Recuerdo que nos hacíamos las coquetas para poder entrar en algún sitio y sacar información, es decir, a nosotras nos dejaban entrar en todas partes porque los militares no pensaban que una mina bonita pudiera estar metida en un grupo de extrema izquierda que atentara contra la $\mathrm{CNI}^{\prime \prime 155}$

¿Pero estas estrategias realmente salvaron a las militantes? La mayoría de quienes las utilizaron si bien pudieron librarse de la captura en algunos momentos, lo cierto es que con el tiempo terminaron siendo detenidas. Un caso revelador que confirma esta

\footnotetext{
${ }^{153}$ Ver Anexo. Entrevista No 8.

${ }^{154}$ Ver Anexo. Entrevista No 39.

${ }^{155}$ Ver Anexo. Entrevista No 30.
} 
estrategia con sesgo de género es el de Juana Andreani ${ }^{156}$, dirigente nacional del Frente Agrario Joven (FAJ) y una de las pocas integrantes del Comité Central en clandestinidad que se encargó de organizar las casas de seguridad en Santiago.

Su compromiso político tuvo que compaginarlo con su maternidad ya que su hija nació meses antes del golpe, lo que implicó que la integridad de la menor estuviera en riesgo: "A mí me persiguió Osvaldo Romo, principal torturador de la DINA... en una oportunidad la tuvo en sus brazos pero se confundió con unos sobrinos que yo tenía y no quiso correr el riesgo de detener a un niño que no fuera el mío"157

En consecuencia, se podría afirmar que las militantes bajo el rol tradicional que reproducían se convirtieron en piezas clave en la reorganización clandestina de los partidos, asumiendo las tareas de mayor riesgo. Independientemente de que unas u otras fueran adquiriendo mayor protagonismo en el trabajo clandestino, todas sin excepción coinciden en que su compromiso no fue correspondido por sus compañeros a la hora de acceder a los espacios de poder.

No deja de llamar la atención el hecho de que muchas mujeres cayeron presas en la calle, incluso a plena luz del día, y justamente cuando ejercían de enlace; por el contrario, los hombres eran capturados en enfrentamientos armados cuando no en operativos nocturnos en domicilios o casas de seguridad. Paradójicamente, las mujeres eran aprendidas en el espacio público, mientras que los varones, muchos de ellos cabecillas escondidos, lo eran en el espacio doméstico.

\footnotetext{
${ }^{156}$ Ver Anexo. Entrevista No 18.

${ }^{157}$ Ibíd.
} 


\subsubsection{Formación y participación militar.}

-"Decidieron mandarme a un curso de formación militar a finales de 1984 y volví en 1986, esto fue en Cuba. Ese año el partido lo denominó como "el decisivo". Cuando volví a Chile vine con la mochila puesta, con el fusil para hacer la revolución"158

Una de las incógnitas que la presente investigación ha querido aclarar es la que se refiere al grado de participación y formación militar que las activistas pudieron tener en los partidos de la izquierda en tiempos de dictadura. Analizar sus aportaciones y avistar si existieron dificultades y/o discriminaciones de género en este sentido, puede perfilarse como una oportunidad para contextualizar la militancia femenina en un ámbito tradicionalmente hermético para las mujeres.

La información recogida indica algunos elementos a tener en cuenta. El primero, que alrededor de un diez por ciento de las militantes socialistas, miristas y comunistas entrevistadas, sí recibió formación militar y casi siempre fuera de Chile.

Los testimonios van reflejando que algunas mujeres se incorporaron a esta actividad y casi siempre en aquellos países de la órbita comunista bajo el contexto de la guerra fría, ya que Cuba y las extintas Alemania Oriental (RDA) y la Unión Soviética (URSS) fueron los destinos de adiestramiento más frecuentes. De hecho, varias entrevistadas confirman que el gobierno de Cuba entre 1974 y 1985 permitió el acceso a decenas de militantes de la izquierda a sus escuelas y recintos militares oficiales para recibir formación.

Por una parte, los objetivos del Partido Socialista y el Partido Comunista, en cuanto a la estrategia armada se refiere, se focalizaron primeramente en formar a la militancia en el exterior para después regresar a Chile y allí materializar las acciones militares prediseñadas. Por el contrario, en el MIR se priorizó la formación y acción militar en territorio nacional porque ello debía ser la antesala de una revolución de "las masas" tal y como advertía su líder, Miguel Enríquez"159: "El MIR rechaza la vía pacífica porque

\footnotetext{
${ }^{158}$ Ver Anexo. Entrevista No 39.

${ }^{159}$ Miguel Enríquez (Talcahuano, 1944) inició su movilización política en el movimiento estudiantil del Liceo al participar activamente en las protestas estudiantiles de abril de 1957 y en la posterior campaña
} 
desarma políticamente al proletariado y por resultar inaplicable ya que la propia burguesía es la que resistirá, incluso con la dictadura totalitaria y la guerra civil, antes de entregar pacíficamente el poder"160

Paradójicamente, más del cincuenta por ciento de la militancia femenina del Movimiento de Izquierda Revolucionaria estaba compuesto por mujeres de procedencia socioeconómica burguesa, lo que no dejaba de ser un hecho contradictorio entre discurso y práctica.

Una parte de las entrevistadas que se formaron militarmente en el exilio, alegan que antes de regresar a Chile, pasaron largos períodos de tiempo (2-3 años) combatiendo en países del continente en conflicto, por ejemplo en Nicaragua, donde algunas dicen haber sido parte integrante del Frente Sandinista de Liberación Nacional (FSLN). Sin embargo, participar en experiencias de combate directo fuera de Chile, no formaba parte de un plan estratégico elaborado por los partidos para con sus militantes (como si de una parte más de la formación militar se tratara) sino más bien obedecía a las iniciativas personales de cada activista:

-“En 1984, el partido me pidió que saliera del país con rumbo a Italia para posteriormente pasar a Bulgaria. Allí estuve a cargo de un grupo político-militar. También estuve en Alemania oriental durante tres meses aprendiendo estrategias de inteligencia" ${ }^{\prime 61}$

-“¿Usted sabe a lo que viene?”, yo le dije que sí, que venía a prepararme para retornar a Chile. Acto seguido él me dijo: "Esto es una Escuela de formación militar regular en donde se imparten carreras de ingeniería de cinco años y usted está aquí por solicitud del Partido Socialista de Chile... Me plantearon que se iba a organizar un grupo para la formación de cuadros militares en Cuba. Yo dije que sí estaba dispuesta. Además insistieron en que parte de esa formación iba a centrarse en el tema de las telecomunicaciones. También recuerdo que, antes de regresar a Chile, tuvimos un curso de formación en Moscú, un curso de estrategia y trabajo conspirativo. Yo era la única mujer y éramos todos oficiales con formación militar. Me formé como radiotelegrafista en código Morse" ${ }^{\text {162 }}$

electoral de Salvador Allende Gossens (1958). En 1961 Enríquez ingresó en la Universidad de Concepción para cursar estudios en medicina. En ese mismo año entró a formar parte de la Federación Juvenil Socialista en donde pronto comenzó a distanciarse de los planteamientos del socialismo más moderado para, finalmente, fundar junto con otros militantes de la izquierda más radical, el Movimiento de Izquierda Revolucionaria (MIR, Concepción 1965). Miguel Enríquez falleció en un enfrentamiento armado con las fuerzas de seguridad del gobierno militar el 5 de octubre de 1974.

${ }^{160}$ Fragmento correspondiente a la Declaración de Principios aprobada en el Congreso Fundacional durante el mes de Agosto de 1965. Ver Arrate J. y Rojas E., Memoria de la Izquierda Chilena, Tomo I (1850-1970), Javier Vergara Editor, Grupo Z, Santiago de Chile, 2003, p. 394-395.

${ }^{161}$ Ver Anexo. Entrevista No 21.

${ }^{162}$ Ver Anexo. Entrevista No 26. 
-"En Nicaragua era la única mujer vinculada al Partido Socialista que había terminado su formación académica-militar. El PS no me había dado otra alternativa, ellos querían que estuviera en Alemania asumiendo un cargo administrativo pero mi conciencia me llevó a Nicaragua para aportar algo más concreto. Allí estuve trabajando en el ejército sandinista. Mi labor fue la formación de personal y en unidades de apoyo táctico. Allí estuve hasta $1983^{\prime \prime 163}$

¿Existió discriminación de género en este ámbito? En primer lugar, lo que se desprende de los testimonios es que, mientras las mujeres se formaban en ramas técnicas de grado medio, los varones lo hacían en aquellas en donde se podían promocionar para acceder a los puestos de mando, por ejemplo, en las ingenierías.

AsÍ, por orden de prevalencia, las mujeres se formaron principalmente en las áreas de telecomunicaciones y radiotelegrafía, inteligencia y espionaje, gestión administrativa y apoyo sanitario. Además, la formación en tácticas militares para entrar en combate directo o participar en acciones armadas de diversa índole solía dirigirse más bien hacia los hombres, quienes, finalmente, diseñaban, coordinaban o dirigían dichas estrategias:

-"En todos los ramos de las fuerzas armadas cubanas había mujeres, eran minoría pero había una presencia femenina. Hubo muchos chilenos que entraron a la Escuela para formarse militarmente. Comunistas, socialistas y miristas. La mayoría entraron a escuelas de mando. Las mujeres estaban en su mayoría estudiando en escuelas técnicas"164

-"Éramos diez mujeres en la escuela, cinco en telecomunicaciones, cuatro en artillería y una en tanque y transportes. Yo decidí quedarme porque pensé que era una buena oportunidad. La formación fue dura, de cadetes. El ejercicio físico fue muy difícil para mí. Los ramos de la carrera también fueron complejos, mucha matemática y física. Como estudiantes de ingeniería, teníamos también formación en el armamento, una vez al mes teníamos ejercicios" 165

¿Cómo se concretizó la formación militar de las mujeres en la práctica militante? La información apunta a que ellas se posicionaron como ayudistas en retaguardia para garantizar una adecuada coordinación y gestión de la estrategia político-militar de sus partidos.

\footnotetext{
${ }^{163}$ Ibíd.

${ }^{164}$ Ver Anexo. Entrevista No 11.

${ }^{165}$ Ver Anexo. Entrevista $N^{\circ} 26$.
} 
Como se ha mencionado, las telecomunicaciones, propaganda y espionaje fueron tareas frecuentes que daban cuenta de que nuevamente las militantes adquirieron un rol de enlace y suministradora de apoyos. Sólo las entrevistadas que participaron directamente en acciones armadas lo hicieron en aquellas que tenían que ver con asaltos a entidades bancarias o sedes institucionales y no en aquellos que implicaban un "enfrentamiento cuerpo a cuerpo". Pero también, y como ponen de manifiesto, el motivo que subyacía a esta estrategia solía ser principalmente económico, es decir, como vía de financiación de la actividad clandestina más allá de los objetivos militares concretos:

-“Contacté con el MIR para conseguir locales y financiación desde la clandestinidad, esto incluía algunos asaltos a bancos... entonces pasé del Grupo Político Militar $n^{\circ} 7$ al $n^{\circ} 9$, en donde hubo muy pocas mujeres"166

-"Yo participé en varios atentados a cuarteles de la CNI. En cada destacamento, que solían ser de diez personas, sólo había dos mujeres, es decir, un veinte por ciento. Aún siendo minoría participamos activamente en las acciones militares de mayor riesgo...En el Frente Patriótico Manuel Rodríguez, después de una labor de estudio sobre las tácticas políticas a desempeñar, pasé a trabajar en la denominada militancia de choque. Esto consistió en la formación de cuadros político-militares. Nos guiábamos mucho por las tácticas de defensa de Vietnam, Nicaragua, etc. Tuvimos varios cursillos militares en las montañas, con armamento y manejo de explosivos que por lo general era muy antiguo y con un deficitario mantenimiento... pero solo lo utilizamos en asalto a bancos o contra carabineros"167

-"Yo participé en otras acciones porque considero legítima la lucha armada. La reivindico porque es usada a favor del pueblo. Pero me piden cadena perpetua por algo que no hice en 1979, ni siquiera bajo tortura dije haber participado y las únicas pruebas que tienen son dos personas: una que dice que tengo la nariz parecida a alguien, y otra, que somos de la misma altura." 168

Hay que mencionar que la estrategia armada formó parte de los objetivos de las formaciones políticas de la izquierda en clandestinidad (en donde en muchos casos se buscaba conseguir una respuesta militar a nivel nacional que fuera más allá de los hechos aislados anteriormente descritos) pero, con el transcurrir de los años, empezaron

\footnotetext{
${ }^{166}$ Ver Anexo. Entrevista No 11.

${ }^{167}$ Ver Anexo. Entrevista $N^{\circ} 30$.

168 Cecilia Radrigán Plaza fue detenida el 24 de noviembre de 1981 por la Central Nacional de Informaciones (CNI). Radrigán, fue militante del MIR y condenada por la Fiscalía Militar a 114 años de cárcel y cinco días de presidio por un delito de participación en lucha armada. Información recogida en $E l$ SIGLO, No 43 (Tercera época) No 7.725 (Primera época), del 23 al 29 de septiembre de 1990. Artículo “Una mujer que sufriría 114 años de cárcel y cadena perpetua”, Pág. 18.
} 
a sucederse divisiones en el interior de los partidos en torno a la conveniencia o no de adoptar esta vía en el quehacer opositor.

Este proceso se incrementó notablemente a partir del segundo lustro de la década de los ochenta, momento en que la oposición en su conjunto, y gracias a las movilizaciones político-sociales y a la presión internacional, pudo avistar un posible cambio hacia un sistema democrático sin necesidad de utilizar las armas.

Un ejemplo de ello lo encontramos en las escisiones que el partido socialista experimentó a finales de la década de los setenta. Por una parte, la facción representada por el dirigente Carlos Altamirano ${ }^{169}$, con más presencia en Chile, apostaba por la pluralidad en el partido al incluir diversas tendencias y corrientes de pensamiento socialista, pero alejándose de la vía armada contra la dictadura.

Por el contrario, la facción de Clodomiro Almeida, cuyo apoyo principal estaba en el exterior, tenía el objetivo prioritario de establecer una sola línea en el partido asumiendo los postulados teóricos del marxismo a la hora de organizar la estructura de la organización. En este sentido, se abogaba por el acercamiento ideológico con el bloque de países comunistas de Europa del Este y por no excluir la estrategia armada en la lucha contra Pinochet.

Esta falta de consenso sobre cómo se debía afrontar el derrocamiento de la dictadura implicó que, finalmente, la mayoría de las acciones militares programadas no se llevaran a cabo. Esta circunstancia dejó paralizadas a muchas activistas que retornaron a Chile para materializar su formación, lo que generó en algunos casos una ruptura o distanciamiento ideológico con sus partidos por haber perdido "unos años muy valiosos en aras de un proyecto que se quedó en papel mojado":

-"Llegué a Chile en octubre de 1984 y ahí me incorporé al trabajo clandestino. Lo relevante de este proceso fue que después de haberme formado cinco años en Cuba, tres en Nicaragua y ocho meses en Moscú, cuando llegué a Santiago no hubo un plan estructurado por parte

\footnotetext{
${ }^{169}$ Carlos Altamirano exponía en su obra Dialéctica de una Derrota (1977) que la causa principal de la derrota de la UP fue la falta de una política militar que defendiera de forma eficaz el gobierno constitucional de Salvador Allende. No obstante, con el paso del tiempo, el propio Altamirano fue incluyendo en su discurso, elementos más políticos que armados acercándose a una postura más conciliadora que permitiera una sola dirección socialista para el restablecimiento de la democracia.
} 
del partido para incorporarme a la lucha y asumir unas tareas político-militares claras. Nada de esto ocurrió ya que no pude aplicar mis conocimientos a la lucha contra la dictadura"170

-"Mi formación militar, concretamente en el uso de armamento, no me sirvió de mucho. Sin embargo, mi aprendizaje en tácticas de espionaje me ayudó para mi posterior labor en Chile... cuando regresé a Santiago, en 1985, me desvinculé de la Agrupación para centrarme de lleno en las labores de enlace entre la Comisión Política del Partido Socialista en el interior de Chile y el PS en el exilio. Mi tarea consistió en recopilar toda la información y mandarla al exterior en microfichas. Además, mi segunda tarea consistía en velar por la seguridad del Comité Central de partido",171

-“Trabajé con el FPMR (Frente Patriótico Manuel Rodríguez) en un equipo sanitario. Fueron años muy duros. También realicé labores de enlace y aunque tuve formación militar, tuve conocimiento en explosivos, nunca llegué a desempeñar tareas de ésta índole"172

Se puede afirmar, que las mujeres que pudieron acceder a un adiestramiento militar, lo hicieron en aquellos espacios en donde los partidos percibían que les correspondían o eran más acordes a sus "aptitudes innatas femeninas", a saber:

1) Suministradora de apoyos médicos y cotidianos en la salud integral de sus compañeros: hay que recordar que varias de las entrevistadas estudiaron carreras de enfermería y medicina (licenciaturas feminizadas) y pese a no querer dirigir su militancia hacia este terreno, muchas fueron presionadas por sus direcciones para acometerlas: "En aquel período solo me quedaba un ramo para terminar Medicina y por orden del partido tuve que atender a mis compañeros, iba con el botiquín a todos lados... esto no estaba dentro de mis planes en el partido"173

2) Administradora de redes, conexiones y telecomunicaciones en la planificación de acciones militares. Son adiestradas militarmente pero en la mayoría de los casos terminan por desempeñar funciones de organización y coordinación. Las pocas que participaron directamente en acciones armadas lo hicieron en aquellas que no entrañaban un enfrentamiento cuerpo a cuerpo (espías y enlace). No obstante, en algunos casos, sí lo hicieron por iniciativa propia y en contextos bélicos externos a Chile (Nicaragua, El Salvador, etc.).

\footnotetext{
${ }^{170}$ Ver Anexo. Entrevista No 26.

${ }^{171}$ Ver Anexo. Entrevista $N^{\circ} 21$.

${ }^{172}$ Ver Anexo. Entrevista $N^{\circ} 37$.

${ }^{173}$ Ver Anexo. Entrevista No 11.
} 
Finalmente, cabe mencionar que aquellas activistas que participaron en operativos militares contra la dictadura y cayeron presas, recibieron un trato especialmente degradante porque "una mujer metralleta era lo último que podían tolerar los militares" (una mujer subversiva desempeñando "el mismo oficio que ellos").

Nuevamente, los roles de género imperaron en la ocupación de espacios y actividades político-opositoras en donde los hombres seguían comandando los destinos de sus partidos y las mujeres eran utilizadas como apoyos en la retaguardia. Todas coinciden que sus funciones de una $\mathrm{u}$ otra manera fueron claves en la lucha anti-dictadura pese a estar en un lugar subsidiario en términos de poder. 


\subsection{La militancia en reclusión.}

Se ha podido comprobar en base a los testimonios analizados que la mayoría de las activistas no ocuparon puestos de dirección política pese a que su aportación fuera fundamental en la recomposición y subsistencia de los partidos clandestinos y asumieran los peligros tanto o más que sus compañeros.

Después del golpe y con el transcurrir del tiempo, las mujeres fueron involucrándose cada vez más en la lucha contra la dictadura, bien desde el trabajo clandestino con sus organizaciones, o bien desde el ámbito de la denuncia social en las agrupaciones de mujeres pro derechos humanos. No hay que olvidar que buena parte de ellas perdieron a sus maridos, padres o hermanos, muchos dirigentes o cabecillas, lo que les condujo a que desempeñaran una la doble militancia: hacer frente a la dictadura y buscar a sus seres queridos.

Todo ello se configuró como una realidad incómoda que la dictadura no podía tolerar, más aún cuando desde el exterior se observaba cada paso que daba la Junta, razón por la cual explicaría que empezaran a reprimirlas para acallar su voz. Por el momento, no hay constancia del número exacto de mujeres que pasaron por los campos de detención o centros de tortura aunque las estimaciones de las agrupaciones de derechos humanos sitúan la cifra en torno a los 10.000 casos.

¿Qué conllevó la detención de miles de mujeres del ámbito de la izquierda? ¿Interrumpieron su compromiso político en los lugares de detención? ¿Las experiencias vividas en la reclusión modificó el vínculo con sus organizaciones? ¿Hubo un cambio de rumbo en el quehacer político tras salir de prisión? ¿Qué impacto tuvieron las acciones de las activistas en prisión?

Estas y otras cuestiones trataran de analizarse con el ánimo de visualizar todos los posibles frentes de acción política femenina y la trascendencia y significado que éstas pudieron tener en el devenir de la dictadura.

Desde una panorámica general, hay que mencionar que la mayoría de las militantes tras caer detenidas continuaron de una u otra forma, y en la medida de sus posibilidades, el activismo contra de Pinochet. Así, bajo múltiples formas, lograron agruparse frente a 
una causa común, pese a existir en muchos casos diferencias ideológicas: la denuncia de la represión, la verdad sobre el paradero de los detenidos desaparecidos y la demanda de libertades.

Otro factor a tener en cuenta es la tortura que, irremediablemente, transformó para siempre la vida de quienes la sufrieron y cuyas secuelas todavía perduran a día de hoy. Este hecho afectó de manera especial a la relación entre partido y represaliada ya que la represión venía a ser el coste más directo de la militancia.

En este sentido, continuaron estoicamente con su compromiso (se han dado casos en donde la prisionera tras ser liberada regresaba al trabajo clandestino y tiempo después volvía a caer detenida), otras rompieron definitivamente con sus formaciones por sentir que el coste era demasiado (en este perfil hay casos de mujeres que decidieron incluso colaborar con la dictadura) y finalmente, otras buscaron alternativas de resistencia menos arriesgadas (principalmente en organizaciones sociales).

Lo que queda de manifiesto es que pese a la represión sufrida, en su mayoría ellas siguieron haciendo frente a la dictadura. De hecho, en prisión aparecieron nuevas estrategias de resistencia colectiva entre mujeres de diverso signo político que de otra manera no hubieran sido posible. El sufrimiento diario y las infrahumanas condiciones de vida en las cárceles conllevaron a que unas se apoyaran en las otras para sobrevivir, compartiendo lo poco que tenían y estableciendo redes que facilitarían el contacto con el exterior.

Desde una perspectiva de género, dicho frente común permitió también que las mujeres fueran tomando conciencia sobre el lugar que ocupaban dentro de sus partidos y reflexionar sobre lo que les estaba ocurriendo en prisión por el hecho de ser mujeres o de elaborar demandas específicas para ellas. 


\subsubsection{Recopilación de información sobre la desaparición forzada de personas.}

En la medida que fueron mayormente perseguidos y detenidos los varones en aras de su mayor presencia y responsabilidad política en las formaciones de la izquierda (de los 4.000 casos de ejecutados y detenidos-desaparecidos que estiman las organizaciones de DDHH, el $6 \%$ correspondería a mujeres ${ }^{174}$ ) las activistas, al sobrevivir mayormente, se configuraron como testigos directos de la desaparición forzada o último paradero de los compañeros de filas.

Esta circunstancia, fue aprovechada por muchas de ellas para recopilar toda la información posible y traspasarla al exterior desde las cárceles, aporte que se convertiría en una pieza clave en la reconstrucción de los hechos represivos cuando las Comisiones de Verdad, Justicia y Reparación aparecieron al finalizar la dictadura.

Las prisioneras, aunque sufrieron el rigor de la tortura y también de la desaparición forzada, permanecieron más tiempo cautivas, muchas veces porque los propios militares dudaban de su implicación política directa, lo que en cierta medida las sitúo como espectadoras de lo que acontecía cada día en prisión:

-"En ese tiempo pude ver cómo sacaron a algunos compañeros y los fusilaron y otros murieron en la base Borgoño por golpes de corriente. Fueron el intendente Álvarez y el teniente Silva. Solían sacar a gente en la noche y en la mañana llegaban muy mal"175

-"Hubo mucha solidaridad. Las compañeras caían presas y se ponían a trabajar, a redactar documentos, declaraciones, contactos. Yo estuve sólo una semana detenida pero no viví la reclusión como presa política aunque mis compañeras me contaron su trabajo en las cárceles"

-“En los baños, que los llamaban pozos negros, había un hueco que comunicaba con el baño de los hombres. Desde allí comenzamos el contacto para saber qué compañeros había y a quiénes habían visto. Quizá la labor de lucha comenzó en el interior de los campos. Yo logré sacar una carta a mi familia en donde yo informaba sobre quiénes estaban y quiénes no para que lo comunicaran al resto de las familias.... cuando alguna compañera salía de Tejas Verdes informaba sobre quiénes estaban y qué compañeros y compañeras no habían vuelto" $" 177$

\footnotetext{
${ }^{174}$ Ver Informe de la Comisión Nacional sobre Prisión Política y Tortura, Comisión Nacional sobre Prisión Política y Tortura, Ministerio del Interior, Santiago de Chile, 2004.

${ }^{175}$ Ver Anexo. Entrevista No 43.

${ }^{176}$ Ver Anexo. Entrevista No 37.

${ }^{177}$ Ver Anexo. Entrevista No 14.
} 
-"En Villa Grimaldi desarrollamos estrategias de sobrevivencia elementales como la comunicación, romper el cerco de aislamiento al que estábamos sometidas, pasar información sobre compañeros, números de teléfono, qué otras prisioneras habían pasado por allí, las características de los guardias..." 178

En efecto, la labor de las prisioneras implicaba no sólo recoger in situ la situación cotidiana que vivían sino, además, informar a las agrupaciones de derechos humanos y a los partidos sobre los militantes que habían pasado por un determinado centro, aquellos que estaban desaparecidos o los nombres y cargos de quienes habían torturado o asesinado en un determinado lugar y momento.

Uno de los centros en donde las militantes tuvieron más margen de maniobra fue el campo de concentración Tres Álamos (Santiago), por tratarse de un lugar de tránsito entre una prisión y otra, y en donde las mujeres detenidas eran reconocidas oficialmente como presas políticas bajo el "Estado de Sitio". En otras palabras, quienes llegaban a Tres Álamos eran aquellas personas sobre las que se tenían más dudas de su militancia opositora, por ejemplo, los familiares, amigos u esposas de un prisionero.

En este centro, las sesiones de tortura eran poco frecuentes y se daba un mejor tratamiento a las internas ya que, tras las sucesivas protestas internacionales, Pinochet progresivamente fue permitiendo el acceso de algunas organizaciones humanitarias en determinados lugares de cara a la galería internacional. De hecho, la Cruz Roja fue elaborando listas de las presas que pasaron por allí, pudiendo realizar un seguimiento sobre el paradero y el estado de salud de cientos de reas. Su presencia, en muchos casos, sirvió de contención a la hora de hacer desaparecer opositores.

En Tres Álamos, las presas aprovechaban esta flexibilidad para recoger información de sus seres queridos en paradero desconocido, indagar e investigar sobre las torturas y desapariciones vividas por otras compañeras y qué rutas habían seguido desde el último avistamiento con vida.

Como se ha mencionado, esta situación fue posible porque en este campo se hacinaban las prisioneras "de menor riesgo" cuyo activismo opositor no había podido confirmarse, o bien aquellas que estaban en proceso de expulsión del país, a diferencia de otros

${ }^{178}$ Ver Anexo. Entrevista No 12. 
centros de detención en donde el rigor de la tortura y la desaparición forzada adquirieron mayores cotas de intensidad. Pero, además, algunos testimonios reflejan que la labor de recopilación de información también se dio en otros centros de detención, lo que da cuenta de que se trató de una actividad frecuente de las prisioneras independientemente de donde estuvieran.

Un ejemplo lo encontramos en el conocido caso de los 119 detenidos-desaparecidos. En enero de 1974, 119 presos políticos abandonaron en camiones militares el centro de tortura Villa Grimaldi (Santiago) con destino desconocido. Semanas después, aparecieron sus cuerpos sin vida en la cordillera de los Andes. La prensa pinochetista recogió este suceso como un enfrentamiento armado entre los propios militantes del Movimiento de Izquierda Revolucionaria. Sin embargo, gracias a los testimonios de algunas prisioneras miristas, como Nubia Becker Equiluz ${ }^{179}$ o Rosa Elvira Lizama ${ }^{180}$, pudo determinarse que tal enfrentamiento no existió, la fecha de la desaparición, desde dónde partieron y quienes fueron los responsables de las ejecuciones.

Sin estas aportaciones, hubiera sido imposible el esclarecimiento de este caso porque al fin de cuentas ellas fueron testigos directos, circunstancia que fue aprovechada incluso para retener en la memoria las imágenes y las voces de los represores.

Las entrevistadas interpretan que esto fue posible porque los militares no dejaron de percibirlas como prisioneras subsidiarias sin ningún poder de acción o influencia, y poco podían imaginar que años después sus testimonios serían clave en la aclaración de las violaciones de derechos humanos durante el largo mandato del dictador.

Quizá imperó entre los agentes la percepción patriarcal de que las mujeres antes de ser sujetos políticos eran acompañantes u esposas de sus maridos caídos, con lo que para ellos era comprensible que quisieran buscarlos como también ocurriría con las madres de la plaza de mayo en la dictadura argentina de Rafael Videla. En otras palabras, se subestimó el poder de acción de las mujeres:

-"Recogimos toda la información contenida en la memoria de cada una de las prisioneras sobre cada uno de los prisioneros con quienes les tocó compartir la represión: la detención, la tortura, el estado de salud y de ánimo, la prisión, la celda, etc. La información procesada

\footnotetext{
${ }^{179}$ Ver Anexo. Entrevista No 2.

${ }^{180}$ Ver Anexo. Entrevista No 3.
} 
la escribíamos en pequeños pedazos de tela con la que, a su vez, sacaban nuestras visitas para llevarlas a la Vicaría y enviarlas a la Comisión de Derechos Humanos de la OEA" 181

-"La mujer ha colaborado en muchos procesos judiciales dando su testimonio pero llegado el momento de publicar tiene menos posibilidades que los hombres; en relación a los relatos de mujeres publicados que yo he leído creo, en general, que las mujeres describen más lo que sienten y lo que les pasó, en relación a los varones. Quizá la mujer es más emotiva pero decir que los relatos de ellas son más conmovedores les quita fuerza y esto no es así. No hay afán lacrimoso, sino que ellas tienen mayor capacidad de profundizar en sus testimonios que ellos" $" 182$

-"Se oían gritos de dolor y horror y al voz de Moren Brito pidiendo agua caliente. En la mañana siguiente vi con vida a Mónica Pacheco y a la señora Gallardo Moreno, y dos horas más tarde vi dos cuerpos sin vida cerca del portón frente a la pieza de las mujeres. En la tarde de ese día dan la noticia por la televisión de que estas personas habían muerto en un enfrentamiento con personal de seguridad. La señora Mónica Pacheco tenía tres meses de embarazo. Ese día también mataron a otras siete personas que aparecen muertas en el enfrentamiento del día 19 de noviembre, todo esto yo lo conté en la Vicaría"183

Por consiguiente, buena parte de las militantes detenidas se convirtieron en testigos, garantes y trasmisoras de la memoria represiva, lo que evidenciaba, una vez más, la reproducción de un rol que por costumbre sentían que les correspondía asumir: mujer como fiel transmisora de valores y cuidados a las personas necesitadas. Incluso algunas entrevistadas interpretan que fueron las mujeres las que mejor podían llevar a cabo esta misión por sus condiciones innatas de fortaleza física y moral (el parto como ejemplo de mayor umbral del dolor): bajo esta óptica estarían más preparadas que los hombres para asumir las emociones, los cuidados y los costes de la represión.

Pese a ello, las activistas supieron ir más allá de un posicionamiento como víctimas y convertirse en sujetos activos de memoria y denuncia. Ellas recogieron el testigo de la represión y lo pasaron a otras, las mujeres que lideraban las agrupaciones de derechos humanos.

\footnotetext{
${ }^{181}$ Ver Recuerdos de una Mirista, Carmen Rojas, Santiago de Chile, 1978, p. 92.

182 Ver Relato de Urgencia/Resistencia de la Mujer Chilena durante el período de 1973-1995, Universidad de Playa Ancha, Valparaíso, 1999; autoras: S. Flores Olvárez, S. López Delgado y C. Orellana Rocha, p. 288.

${ }^{183}$ Ver Testimonio de Nubia Becker. Archivo Rettig, p. 24.1808.
} 
Los prisioneros, más ocupados en las estrategias políticas o en cuestiones ideológicas, no tuvieron en cuenta otras estrategias que implicaban asumir el coste emocional de lo acontecido. Porque ellos representaban la razón y el liderazgo en los partidos, eran en sus compañeras donde debía recaer todo lo demás. 


\title{
3.3.2 La vida en prisión: estrategias de supervivencia y solidaridad.
}

La mayoría de las entrevistadas ha relatado que su entrada en prisión, si bien fue el episodio más traumático de sus vidas (con altos costes en su salud integral), también significó una experiencia de solidaridad mutua que las unió, y en donde unas se apoyaban en otras, gracias a lo cual pudieron sobrevivir o mejorar sus precarias condiciones de vida.

Pese a que en un primer momento pudiera existir desconfianza entre las prisioneras por sus diferentes posicionamientos ideológicos (miristas, socialistas y comunistas) y temor a que hubieran reas infiltradas, todos los relatos coinciden en que estas dificultades se superaron en aras de un bien común: mejorar sus condiciones de vida y protegerse las unas a las otras de los avatares de la prisión. Porque bajo su identidad de género sintieron que tenían problemas comunes que traspasaban cualquier disenso político:

\begin{abstract}
-"Por lo general, había mucha cohesión en el interior de la cárcel. Nos llevaban comida y al final terminábamos distribuyéndola a las presas más humildes. No era fácil establecer lazos porque había mucha desconfianza por problemas de seguridad. Una no sabía al principio quién estaba allí y con quién se podía hablar. Sin embargo, logramos mucho respeto y una buena convivencia con las presas. De hecho, las presas nos cuidaron mucho cuando estuvimos en huelga de hambre" 184
\end{abstract}

Otra interpretación posible es que las mujeres, independientemente de su procedencia política, a diferencia de los hombres, pudieron superar sus divergencias ideológicas porque su objetivo fue ocuparse de lo cotidiano, algo que consideraban mucho más importante que cualquier otra aspiración política. Tampoco estuvieron sujetas a reproducir el rol de liderazgo masculino ya que era algo que sentían, no les correspondía realizar. Por ende, ellas al no ocupar lugares de poder dentro de las estructuras partidarias no tuvieron los obstáculos derivados de su pugna, lo que les permitió concentrarse en cómo mejorar su situación en la rutina carcelaria y actuar como colectivo unido por un mismo sentimiento de pertenencia.

De esta forma, las presas pudieron aunar esfuerzos para elaborar estrategias de supervivencia y solidaridad que ciertamente reproducían los roles de género

${ }^{184}$ Ver Anexo. Entrevista No 44. 
tradicionales; éstas giraban en torno a los cuidados, por ejemplo, de los hijos de mujeres detenidas desaparecidas o enfermas, en las labores de economía doméstica, organización de ollas comunes, actividades y talleres de tejido y bordado, venta de productos caseros, etc.

-"Creo que las mujeres comunistas al igual que las miristas, supieron superar sus diferencias a la hora de plantear objetivos comunes lo que por otra parte, no sucedió con los hombres que, normalmente, eran mucho más sectarios. Esto significó que la lucha y la movilización política de las mujeres fueron mucho más efectivas y reales" 185

-"Las mujeres hicieron una política diferente a la de los hombres. Este es un tema que no ha sido lo suficientemente tratado por la izquierda. Hay formas que tienen que ver con el acerbo cultural de las mujeres que sí es distinta al de los varones. La unidad y la solidaridad entre las presas fue un claro ejemplo de esta diferencia. Se cuidaban los hijos unas a otras, se llegaban a acuerdos de organización con rapidez"186

-"No sé si las mujeres fueron más heroicas que los hombres, pero por el mero hecho de tener menos responsabilidad política las mujeres estuvieron más unidas. Organizamos una estructura que funcionaba para ordenar información y dirigir la vida interna en el campo. Esto permitió crear grupos de talleres de tejido y bordado lo que significó reproducir el rol de siempre. Nosotras asumimos este rol con toda naturalidad y nadie cuestionó esta tarea. Sin embargo, esta organización solidaria permitió una clara organización de las mujeres para reivindicar mejoras en las condiciones en el interior de Tres Álamos, castigos impuestos, etc. Esta movilización no se dio con los hombres, quizá porque eran más o no supieron superar las diferencias" $" 187$

-"Creo que entre ellos hubo mucho compañerismo pero quizá los miristas que yo conocí fueron muy anticomunistas. Por otra parte, con las mujeres que conocí pude ver que este trato fue diferente, creo que ellas fueron mucho más cariñosas, hubo más respeto y la parte sentimental superó a las diferencias ideológicas" ${ }^{\text {"188 }}$

-"Los hombres tuvieron más dificultades a la hora de organizarse en el interior de las cárceles. Tuve la oportunidad de ver esto en mis visitas a los diferentes centros de reclusión. Esto se dio porque las mujeres que estuvieron recluidas no ocupaban cargos importantes de poder en los respectivos partidos. Hubo una organización entre las mujeres mucho más fluida, sobre todo con el tema del cuidado de los hijos. Había menos conflictos porque nosotras no estábamos en el poder político. Los hombres reproducían y arrastraban sus discusiones de poder en la cárcel"189

-"Estuvimos en pésimas condiciones, pero esas mismas condiciones generaron fuertes lazos de solidaridad y apoyo mutuo entre las presas políticas que estuvimos allí. Con el paso de los años, he llegado a la conclusión de que las presas tuvimos más fortaleza que los hombres sufriendo la misma represión",190

\footnotetext{
${ }^{185}$ Ver Anexo. Entrevista No 29.

${ }^{186}$ Ver Anexo. Entrevista $\mathrm{N}^{\mathrm{o}} 32$.

${ }^{187}$ Ver Anexo. Entrevista $N^{\circ} 10$.

${ }^{188}$ Ver Anexo. Entrevista No 37.

${ }^{189}$ Ver Anexo. Entrevista No 34.

${ }^{190}$ Ver Anexo. Entrevista No 20.
} 
En la mayoría de los centros de detención oficiales, no así los de los servicios secretos, las mujeres pudieron organizar las denominadas Carretas Comunes, una red de distribución de los alimentos recibidos desde el exterior para garantizar el abastecimiento intramuros como la alimentación, material sanitario, vestuario, etc. Un Consejo de Ancianas electo se encargaba de tomar las decisiones y distribuir los productos velando para que las presas en situación de mayor vulnerabilidad los recibieran, especialmente con aquellas que estaban embarazadas, enfermas o con hijos a su cargo.

Estos lazos de solidaridad fomentaron, además, encuentros de otra naturaleza en donde las mujeres podían reflexionar y compartir sus dificultades en relación a su condición de género. Dicho de otra manera, lo que les unía como mujeres sirvió para ir tomando conciencia sobre su lugar existencial dentro y fuera de los partidos y adquirir una visión más crítica para con ellos. En esta línea, muchas mujeres relatan que tras salir de prisión incorporaron una visión crítica que les llevó a querer reivindicar derechos específicos para ellas.

Así, bajo múltiples formas las activistas fueron logrando generar espacios de desarrollo más allá de los partidos en donde se habían iniciado políticamente. En sus propias palabras, "un crecimiento personal" desde un lugar colectivo de mujeres que las ayudaría enormemente a superar el trauma de la represión, mejorar su calidad de vida y poder comprometerse políticamente sin depender de jerarquías masculinas:

-"Tratamos de estar al día con el exterior para ver la mejor manera de insertarnos con nuestra problemática de presas políticas en las organizaciones sociales y poder aportar, de una u otra forma, en el proceso de liberación de nuestro pueblo. Tratamos de revertir la situación de la cárcel y transformarla en una etapa de crecimiento e ir adquiriendo una madurez política, particularmente para nosotras las más jóvenes" ${ }^{\text {"191 }}$

-“En una oportunidad, dio a luz una compañera en el interior de la prisión. Ellas ganaron un espacio para que se sacara a la mujer de la cárcel hasta que se recuperara. Aquí sí que pudo haber un elemento diferenciador ya que muchas compañeras de otros partidos se hicieron cargo del cuidado del bebé, como si fuera suyo, independientemente de que tuvieran una militancia política distinta" ${ }^{192}$

\footnotetext{
${ }^{191}$ Ver artículo de Gaëton P., "Presas Políticas: mientras haya criminales caminando por la calle no habrá paz" en El SIGLO, septiembre de 1988, N 7673, p. 20.

${ }^{192}$ Ver Anexo. Entrevista No 36.
} 
-“Allí nos organizamos en la Carreta Común. Esto fue una organización para poder amparar a las familias más humildes. Muchas mujeres estuvieron en condiciones muy precarias y nosotras hacíamos un fondo común para repartir las cosas"193

-"Hicimos un trabajo social, enseñábamos a leer a las mujeres más marginadas y realizábamos charlas sobre cuestiones puramente relacionadas con la mujer como enseñar los métodos de prevención de embarazos..."

Queda constancia de que algunas mujeres pudieron ir adquiriendo lo que podríamos denominar una conciencia feminista autodidacta al ir sufriendo, en primera persona, situaciones que las discriminaban pero también al identificarse con el sufrimiento de otras prisioneras. Se podría decir que existió en algunas reas un cierto empoderamiento personal y/o de género, al ir tomando conciencia de su lugar existencial como mujer, en este caso, en la reclusión, y un espacio compartido que, en definitiva, facilitó enormemente una supervivencia más digna para ellas.

En cualquier caso, las prisioneras no dejaban de percibirse unas a otras como suministradoras de apoyos colectivos, porque ellas son las que otorgan, en este caso, cuidados a otras compañeras sin competir como los hombres. Éstos, en orden a los imperativos del modelo masculino patriarcal, debían mostrarse "autosuficientes" y no precisar de apoyos de otros varones, no así de las mujeres, ya que quienes abastecían las necesidades cotidianas de los presos desde extramuros solían ser figuras femeninas: madres, hermanas, esposas o compañeras.

La historia contemporánea nos muestra múltiples ejemplos en donde las mujeres en un contexto de conflictividad militar, desempeñaban por inercia sociocultural el rol de suministradora de apoyos logísticos, afectivos, alimentarios o de otra índole, de las necesidades de los perseguidos y prisioneros de guerra. Estos actos, generalmente invisibilizados en los estudios históricos, supusieron una aportación fundamental para que miles de víctimas pudieran sobrevivir, circunstancia que no sería correspondida a la hora de que las mujeres ocuparan los mismos espacios de poder en las organizaciones a las que pertenecían:

\footnotetext{
${ }^{193}$ Ver Anexo. Entrevista No 27.

${ }^{194}$ Ver Anexo. Entrevista No 30.
} 
-“Tradicionalmente, las mujeres del Partido Comunista de España (PCE) durante el franquismo dedicaron su militancia política a tareas de retaguardia. La mayoría, no ocupó cargos de responsabilidad política, salvo algunas excepciones como los casos de Dolores Ibarruri, Irene Falcón, Matilde Landa, Carmen de Pedro o Neus Catalá. Entre las tareas que desempeñaron con mayor frecuencia, se encontraban la organización de manifestaciones pro-amnistía, cuidar a los militantes, recaudar dinero para el partido, visitar a los presos, enviarles paquetes, hacer la comida a los militantes en las reuniones clandestinas, etc."195

195 Ver Maravall J., La mujer en la lucha política contra el franquismo: el caso del Partido Comunista de España (1960-1975), A 70 años de la Guerra Civil en España: Un recorrido a través de la memoria histórica y literaria, Universidad de Estocolmo e Instituto Cervantes, 2006. 


\subsection{La militancia en el exilio: la denuncia internacional y la toma de conciencia feminista.}

La totalidad de las comunistas, miristas y socialistas exiliadas que han prestado sus testimonios, coinciden en que salir del país significó una interrupción forzosa de sus vidas y tener que empezar de cero en un ambiente muchas veces adverso y hostil. La mayoría salió precipitadamente del país sin disponer de medios suficientes para subsistir a medio plazo, unas por iniciativa propia ante el riesgo de ser capturadas y otras al ser expulsadas directamente por la dictadura.

Los países de destino solían ser aquellos cuyos gobiernos abanderaban políticas activas en pro de los derechos humanos (Suecia, Finlandia, Reino Unido, Francia, o Canadá), países del ámbito latinoamericano con redes de acogida de refugiados políticos o gobiernos sensibles al tema (México, Brasil, y Argentina, este último por su cercanía). Finalmente estaban aquellas naciones que habían tenido un posicionamiento afín al gobierno socialista de Allende (Cuba, URSS y RDA) y que suministraban recursos y refugio a los perseguidos.

Hay que mencionar que gran parte de las exiliadas habían cursado carreras universitarias, formación que en la mayoría de los casos no les sirvió cuando aterrizaron en estos países, para encontrar un empleo digno acorde con sus especialidades profesionales. Muestra de ello es que en casi todos los casos sólo ellas pudieron encontrar trabajos de baja remuneración y cualificación y que tenían que ver casi siempre con los sectores "tradicionalmente feminizados" como en el servicio doméstico, cuidados de personas dependientes o actividades relacionadas con la agricultura, los manufacturados o servicios domésticos.

A un sistema laboral precario y "hermético para ellas", se añadían las barreras derivadas de un idioma diferente (en los casos de países de habla no española), las dificultades económicas, fruto de una salida precipitada del país, y el impacto físico y emocional que las experiencias de persecución, tortura o pérdida de seres queridos habían dejado tras de sí:

-"Yo salí de prisión en octubre de 1974 en calidad de expulsada. Estaba en muy malas condiciones, había perdido a mi compañero, es decir, fue un periodo muy duro, y en Argentina se me vino todo abajo. Tuve fuertes depresiones...Nunca me adapté a Canadá. 
Aprendí inglés y francés y trabajé pero fueron años muy difíciles. Estuve en la provincia Alberta, cerca de Vancouver. Trabajé una temporada en un taller de costura compaginándolo con mi aprendizaje de inglés"196

El contrapeso a estas adversidades vino dado por el apoyo facilitado por los diversos movimientos sociales en torno a la Solidaridad con Chile para con los perseguidos, plataforma compuesta por ciudadanos chilenos residentes en el extranjero, agrupaciones de derechos humanos y organizaciones de cooperación internacional. Ello significó, bajo el punto de vista de las entrevistadas, un apoyo fundamental (logístico, económico y emocional) para iniciar un nuevo proyecto vital fuera de Chile, sin el que difícilmente las exiliadas hubieran podido sobrevivir. Algunas relatan que en los mismos aeropuertos de destino Comités de Bienvenida las recibieron con las manos abiertas ocupándose de sus necesidades más inmediatas (alojamiento y manutención):

-"Salimos de la cárcel al aeropuerto y de allí nos expulsaron a Londres. Llegué a fines de octubre de 1976. Yo tenía una beca de estudios y me esperaron en el aeropuerto para llevarnos a un hotel. Después me fui a un lugar en donde tenía la vacante como becaria en la Universidad. Allí nos esperaban los comités de acogida"197

-“Un compañero me llevó a una organización que acogía a exiliados chilenos. Ellos tramitaron mi residencia y el permiso para trabajar. También recibí ayuda del Alto Comisionado de Naciones Unidas (ACNUR), un subsidio por tres meses. Conseguí trabajo y pude adaptarme. Me quedé varios años"198

-"En Francia nos recibió una ONG, Francia Tierra de Asilo. Hicimos todas las gestiones administrativas para obtener el régimen de refugiadas políticas. Fuimos a Burdeos puesto que los centros de refugiados de París estaban repletos de exilados. Yo llevaba bajo el brazo mi título universitario que me acreditaba como asistente social. Yo no hablaba francés, recordaba las lecciones que había recibido en el Liceo pero no hablaba...tuve que hacer aseo y otros trabajos horribles...igual se pasaban penurias, tuve que aprender el idioma a marchas forzadas...no sé cómo lo hice"199

Pese a los obstáculos mencionados, las exiliadas siguieron desempeñando su activismo político, si cabe con más intensidad que en Chile, ya que el contexto de libertad y apoyo extranjero, favoreció un clima de mayor seguridad para retomar la lucha contra la dictadura. En esta línea, su actividad opositora se centró primordialmente en la denuncia

\footnotetext{
${ }^{196}$ Ver Anexo. Entrevista No 29.

${ }^{197}$ Ver Anexo. Entrevista No 24.

${ }^{198}$ Ver Anexo. Entrevista No 43.

${ }^{199}$ Ver Anexo. Entrevista No 3.
} 
internacional de las violaciones de los derechos humanos en Chile y en la captación de fondos para el apoyo de la militancia que seguía operando en el extranjero.

Por otra parte, algunas mujeres han declarado que partieron al exilio acompañadas de sus hijos, y muchas veces sin sus parejas, lo que implicó tenerse que hacer cargo en solitario de sus cuidados y dejar de lado la actividad política. Pero incluso aún en los casos en donde ambos progenitores habían escapado, quiénes finalmente se hacía cargo de los menores y renunciaban a la militancia era las mujeres, mientras que ellos podían dedicarse íntegramente. Los hombres tal y como ocurrió en Chile, fueron los que coparon los espacios de poder y asumieron la toma de decisiones políticas, mientras que ellas quedaban en retaguardia como suministradoras de apoyos.

Pronto algunas mujeres comenzaron a revelarse y exigir mayor protagonismo y ayuda de sus compañeros lo que generó muchos conflictos de pareja cuando no rupturas. Los partidos fueron conscientes de esta situación y reaccionaron impulsado medidas que no siempre beneficiaron a las militantes que tenían hijos a su cargo.

Un ejemplo lo encontramos en la organización de los denominados Hogares Colectivos en los países de acogida (sobre todo en Cuba), cuya labor estaría centrada en el cuidado y manutención de los hijos de aquellas mujeres que decidieran seguir militando sin que éstos corrieran el riesgo de ser capturados o fueran una dificultad para su compromiso. Sin embargo, aquellas que optaron por esta solución, con el tiempo, sintieron que no fue una decisión acertada ya que no dejó de ser una separación traumática para los menores, a lo que se añadió el hecho de no siempre estuvieron tutelados por las personas adecuadas.

Podría interpretarse que esta medida trajo consigo una discriminación de partida para las mujeres, ya que sí bien, formalmente, no se las obligaba a separarse de sus hijos, la realidad era que al tener que asumir en solitario los cuidados familiares no les quedaba mucho tiempo y energía para dedicarse a la política. Por esta razón, muchas sobrecargadas y agotadas, no tuvieron más opción de dejar a los pequeños al cuidado de otras personas para no renunciar a sus expectativas de compromiso.

Ello nos lleva a pensar que nuevamente se priorizaron las necesidades del hombre al quedar estos excluidos de los cuidados familiares y, en un contexto, en donde la mujer 
siempre tenía que hacer el esfuerzo de acoplarse a cada situación para tener las mismas opciones de participar:

-"Los Hogares de Cuba fue el culmen de todo este proceso. Fue un claro desastre, muy doloroso para los hijos que tenían que separarse de sus padres y convivir con gente que no necesariamente era la idónea. La norma era, si la pareja partía y tenían hijos, los hijos se iban a estos hogares, si no se optaba por esta vía el hombre partía y la mujer se quedaba en el exilio cuidando de los hijos. Las compañeras que se rebelaron contra este modus operandi fueron tremendamente criticadas y repudiadas, tanto por hombres como por mujeres de la militancia mirista" 200

-"Muchas compañeras asumieron también su vida personal, concretamente, su condición de madres como algo con muchas limitaciones. Un ejemplo de ello lo encontramos en las compañeras que se fueron al Frente Patriótico Manuel Rodríguez porque en muchos casos tuvieron que renunciar al cuidado de sus hijos siendo estos criados por otras personas"201

-"Nosotras tuvimos una discusión en la cárcel con compañeras que venían de Cuba y que habían dejado sus hijos en estos hogares. Otras compañeras tuvieron bebés en las cárceles Rita Peña, Marta Soto e Inés Peiró. La discusión era sobre la necesidad o no de sacar los bebés de la cárcel. Yo defendí la postura de que la guagua debía quedarse donde la madre estuviera. Discutimos mucho sobre este tema. Lo que sé hasta ahora es que la mayoría de los niños que se separaron de sus padres tienen mucho más conflictos que el Manuel y la Elisa que se criaron en la cárcel hasta los tres años",202

Hay que mencionar que algunas entrevistadas tuvieron la oportunidad de contactar en el exilio con grupos feministas o agrupaciones de mujeres. Allí, pudieron reflexionar sobre sus propias realidades y compartir las experiencias y dificultades de otras tantas en cuanto a desigualdad de género se refiere. De esta manera fueron adquiriendo una visión crítica sobre el lugar existencial que ocupaban dentro y fuera del espacio doméstico, lo que muchas veces desembocó en un distanciamiento ideológico con sus partidos, cuando no una ruptura en toda regla.

Dicho de otra manera, gracias a este encuentro ellas pudieron tomar conciencia de las discriminaciones que venían sufriendo por su condición de mujer y de las contradicciones permanentes entre sus aspiraciones políticas y las barreras que sus organizaciones les ponían. Creados los cimientos, ya se podía dar el siguiente paso: la reivindicación de derechos específicos para las mujeres dentro de las organizaciones de izquierda:

\footnotetext{
${ }^{200}$ Ver Anexo. Entrevista $N^{\circ} 10$.

${ }^{201}$ Ver Anexo. Entrevista No 42.

${ }^{202}$ Ver Anexo. Entrevista No 13.
} 
-"Las mujeres comunistas en el exilio vivimos una contradicción. En Inglaterra nosotras trabajamos mucho para compartir las tareas domésticas y el cuidado de los niños con los compañeros pero, en la realidad, eran las mujeres quienes se ocupaban de estas cosas y en el partido vivíamos esta contradicción porque, además, a finales de los setenta el movimiento feminista británico tuvo mucha fuerza y algunas de nosotras estuvimos influidas por estas propuestas tan avanzadas, especialmente si una las comparaba con la realidad de las mujeres en Latinoamérica"203

-"En Alemania, me puse a trabajar en una Federación de Mujeres y tuve que ponerme al día en todo lo referente a la cuestión de género. A partir de esta experiencia, fui tomando conciencia de los problemas de las mujeres... en el exilio tomé la convicción de dedicarme a temas de género. Soñaba en crear una casa de la mujer en Chile, para ayudar a otras mujeres" 204

Pero este proceso tuvo otro efecto que traspasó lo político. Buena parte de las entrevistadas han reconocido que sus relaciones de pareja también se vieron afectadas. Las rupturas sentimentales fueron frecuentes en el exilio, especialmente si había hijos de por medio, y por causas que apuntan a la distribución inequitativa entre los cónyuges del trabajo doméstico familiar y el tiempo personal. Lo que sí parecen reflejar con claridad es que ellas estaban molestas por no disponer de las mismas oportunidades que sus compañeros cuando se trataba de participar y promocionarse en los partidos al tener que desempeñar una doble jornada.

-"Te puedo decir que, en la experiencia del exilio, muchas mujeres militantes del PC se separaron de sus maridos al decidir no soportar ciertas cosas. Muchas de ellas decidieron continuar sus estudios y no someterse a su papel tradicional. En este punto, hubo un cierto cambio.... Las mujeres que estuvieron en el exilio cambiaron su mentalidad al cuestionar sus roles, y esto se puede ver, por ejemplo, en mis hermanas, que se han quedado estancadas en algunas cuestiones muy básicas" 205

-"Hubo mujeres que pudieron estudiar en el exilio y pudieron cambiar el modelo tradicional, pero eso fue una minoría. Casi todas las compañeras tendían a reproducir el rol de siempre"206

Cuando las mujeres señalaban estas diferencias y exigían cambios hacia la equiparación de derechos, el rechazo entre los hombres solía ser unánime bajo la argumentación de que la prioridad en aquellos momentos era el derrocamiento de Pinochet y no cualquier

\footnotetext{
${ }^{203}$ Ver Anexo. Entrevista No 32.

${ }^{204}$ Ver Anexo. Entrevista No 19.

${ }^{205}$ Ver Anexo. Entrevista No 29.

${ }^{206}$ Ver Anexo. Entrevista No 34.
} 
otra consideración específica. Lo cierto es que esas demandas tardaron mucho en ser escuchadas (hasta mediados de los años noventa los partidos políticos en Chile no incluyeron en su agenda la igualdad de género) lo que al fin y al cabo mostraba el verdadero origen de estas resistencias: que los hombres perdieran unos privilegios que ostentan desde antaño y que percibían como inherentes a su identidad.

Fue precisamente en este choque cuando muchas mujeres, ante la imposibilidad de poder manifestarse por sí solas, empezaron a organizarse colectivamente fuera de sus partidos: asociaciones independientes, prensa, grupos de reflexión, etc.:

-"Yo fui miembro del grupo de Mujeres Latinoamericanas en Londres. Allí se establecieron foros de discusión de diversa índole. Hoy todavía sigo trabajando con ellas. Sin embargo, no hubo un debate en esta organización de la situación de la mujer dentro del Partido Socialista" ${ }^{207}$

-"La toma de conciencia feminista empezó en Inglaterra, en la universidad. Pero fue un proceso lento porque al principio pensaba que la lucha de género era una desviación de la lucha de clase. Esto fue cambiando con el tiempo. Entré en un grupo de mujeres de la Socialist Society" ${ }^{\prime 208}$

-"En México comencé a compaginar mi militancia política con mi toma de conciencia feminista. Constituimos un grupo con argentinas, chilenas y mexicanas destinado a pensar temas de exilio y mujer. Fue un grupo que empezó ligado a la revista FEM en donde estaba Teresita de Barbieri y otras mujeres destacadas. Empezamos a escribir pequeños artículos que tocaban temas de reflexión feminista. En el partido no tuvimos, en este periodo, la oportunidad de poner sobre la mesa nuestras demandas, fue un momento de toma de conciencia, tuvimos que esperar a regresar a Chile para poder realizar un trabajo más concreto" 209

Se puede afirmar que las dificultades comunes que las mujeres fueron experimentando en el exilio tuvieron un nexo en común: la sobrecarga de trabajo por asumir íntegramente los cuidados de los hijos y las tareas del hogar con consecuencias directas sobre su salud (estrés, cuadros depresivos, cansancio crónico, dolencias musculares, etc.). A ello se sumaban las barreras que sus propios partidos les ponían a la hora de participar plenamente ya que, lejos de facilitar la conciliación se las presionaba para que, por ejemplo, no fueran a las reuniones con sus "hijos a cuestas" y se quedaran en casa.

\footnotetext{
${ }^{207}$ Ver Anexo. Entrevista $N^{\circ} 17$.

${ }^{208}$ Ver Anexo. Entrevista N 24.

${ }^{209}$ Ver Anexo. Entrevista No 22.
} 
Este cúmulo de circunstancias tuvo un efecto positivo ya que algunas mujeres al ir compartiendo sus experiencias y realidades, sobre todo a través de grupos de reflexión (tal y como lo hicieron sus predecesoras sufragistas a través de tertulias privadas), pudieron adquirir una conciencia más nítida de aquellas situaciones que las discriminaban y unirse por una causa común: dejar de estar subordinadas por el dominio masculino.

Es necesario recordar que en aquellos países en donde la democracia estaba más consolidada (Suecia, Francia o Inglaterra), existían redes de mujeres con fuerte presencia social, y sensibles a la situación por la que atravesaban las refugiadas políticas chilenas. Este encuentro, en palabras de algunas entrevistadas, significó para ellas un despertar feminista y el reconocimiento de problemas comunes de género (lo personal es político ${ }^{210}$ ).

Como muestran los testimonios, la primera toma de contacto con mujeres feministas y/o concienciadas generaba en las exiliadas contradicciones que las cuestionaban en todos los sentidos, especialmente en el privado y en el vínculo con la pareja. Aunque ello en un principio desembocó en un impacto que a veces se transformaba en rechazo porque, en definitiva, las cuestionaba en sí mismas, sí se mostraron interesadas por lo que las compañeras extranjeras representaban, hacían o decían, lo que suponía dejar una puerta abierta a la transformación de sus mentalidades y realidades.

Lo más frecuente era contactar con pequeñas redes y asociaciones de mujeres universitarias, culturales o populares, que establecían foros de debate, puntos de encuentro, terapias y charlas de apoyo para aquellas mujeres que lo necesitaran:

-"Eran salitas chicas en donde solíamos conversar de cosas del día a día, de los hijos, de problemas con el marido; algunas estaban separadas y te contaban qué problemas tenían... eran grupos pequeños y nos apoyábamos unas en otras, veías a compañeras que estaban en situaciones realmente difíciles, de no poder ver a los cabros"211

Se podría decir que este proceso, para las entrevistadas, fue un punto de inflexión en su forma de relacionarse con los hombres y con las organizaciones para las que militaban.

${ }^{210}$ Ver Kirkwood J., Ser Política en Chile: las feministas y los partidos, FLACSO, Santiago, 1986.

${ }^{211}$ Ver Anexo. Entrevista No 3. 
Coinciden también, en que este trabajo les dio una mayor seguridad a la hora de reivindicar sus derechos o denunciar situaciones injustas.

Disponiendo esta vez de una conciencia más sólida, su poder de acción sobre otras tantas mujeres pronto sería una realidad (el feminismo chileno durante la década de los ochenta se nutrió en buena medida de las aportaciones de aquellas mujeres que habían estado en el exilio) lo que llevó a los partidos de la izquierda años después (a partir de 1990) a tener más en cuenta las demandas de sus militantes.

No obstante durante el retorno existieron dificultades que debilitaron el movimiento de mujeres en su conjunto. Gran parte de las exiliadas al regresar a Chile, quisieron incorporar sus experiencias con el feminismo internacional en sus partidos políticos. Lejos de ser recibidas con agrado, las activistas se encontraron con un rechazo general, incluso entre las compañeras de filas que miraban con recelo un modo de hacer política novedoso y que también las cuestionaba como mujeres. Quizá estas resistencias favorecieron a que muchas de ellas abandonaran sus formaciones y decidieran transitar autónomamente a través de organizaciones específicas de mujeres (por ejemplo, la agrupación La Morada)

Quizá, la adquisición de una conciencia de género y ponerla en valor como un elemento transversal en los partidos, debía conllevar unos tiempos de asimilación, entendimiento e interiorización del que por otra parte las exiliadas sí dispusieron. Por el contrario, las que se quedaron en un Chile aislado y contenido, fueron menos permeables a la influencia del feminismo internacional que cada día adquiría un mayor número de redes y apoyos. Estos factores impidieron que gran parte de las militantes de izquierda que se quedaron en Chile pudieran identificarse con una mirada de género que sentían como ajena:

-"En el PS se criticó mucho las ideas que algunas militantes traían desde el exilio. De hecho, algunas compañeras y yo encontramos muy tradicional la estructura de poder del partido cuando retornamos a Chile. Nuestro discurso era muy distinto, queríamos que el PS reconociera que la lucha no era sólo superar la cuestión de clases sino también la subordinación de la mujer en todos los aspectos, este debía ser un debate que estuviera presente en el retorno de la democracia. Esto debía tener una repercusión orgánica dentro del partido, por ello, nosotras constituimos tiempo después la Federación de Mujeres Socialistas" ${ }^{212}$

${ }^{212}$ Ver Anexo. Entrevista No 22. 
-"Las mujeres que estuvimos en el exilio tratamos de juntar a varias compañeras de las diferentes tendencias del Partido Socialista. Generamos una organización de las mujeres con planteamientos de autonomía y de estrategias de poder. Entre 1983-1985 se empezaron a organizar desde organismos no gubernamentales estudios de la mujer, Sin embargo, al haber incorporado ideas nuevas, muchos compañeros y compañeras las rechazaron porque alegaban que se alejaban mucho de la realidad de Chile. En Birmingham, se realizó un encuentro de la Organización de Mujeres Latinoamericanas y allí se produjo un problema entre las chilenas. A mi me expulsaron del partido del núcleo de Gran Bretaña por incorporar a un grupo de mujeres lesbianas"

${ }^{213}$ Ver Anexo. Entrevista No 24. 


\subsection{El retorno a Chile.}

La actividad política de la mayoría de las activistas exiliadas después después de su regreso a Chile estuvo centrada fundamentalmente en continuar con lo que ya venían haciendo en los países de acogida, esto es, militar en sus partidos y trabajar en organizaciones de derechos humanos. Desde allí, no solo denunciaron a la comunidad internacional la represión pinochetista sino también sino que además iniciaron una búsqueda sin tregua de aquellos familiares que se encontraban en paradero desconocido.

Un ejemplo de ello lo encontramos en el caso de la ex mirista Margarita Romero ${ }^{214}$, quien entró a formar parte de la Comisión de Solidaridad con los Médicos víctimas de la represión (COSOME) tras su regreso al país. Allí, desempeñó funciones de apoyo en el retorno de los sanitarios exiliados y coordinó los respectivos procesos de denuncia sobre las violaciones de derechos humanos sufridas por este colectivo.

Ella, al igual que otras compañeras de militancia, establece una primera diferenciación de género en cuanto a las prioridades políticas después del exilio.

Por un lado, la de los hombres, enfocada en cuestiones más "prácticas y/o racionales" y que tendrían que ver exclusivamente con su desarrollo personal: reincorporarse a las actividades políticas en la lucha contra la dictadura, organizarse de cara a una transformación democrática, promocionarse en los partidos, buscarse un empleo bien remunerado, etc.

Por otro, la de las mujeres, más centrada en el plano emocional: salvaguarda de la memoria de los reprimidos, la denuncia, la búsqueda de los hijos o maridos desaparecidos, la organización de redes sociales de solidaridad o en la creación de espacios terapéuticos para las víctimas de la tortura y la prisión política.

Esto significó que las activistas priorizaran el cuidado de los otros sobre el propio, trabajando altruistamente muchas horas cada día en una causa "invisible", no remunerada y poco reconocida. Verdaderamente lo que les motivaba a hacerlo, tal y

${ }^{214}$ Ver Anexo. Entrevista $N^{\circ} 4$. 
como expresan, era que de una u otra forma les tocaba en lo personal como mujeres (bien como madres, esposas, hijas o compañeras de un desaparecido por ejemplo) o por haber sufrido ellas también el rigor de la represión militar.

Por tanto, buena parte de la actividad política de las militantes estuvo enfocada en las organizaciones sociales de base en donde primaba la denuncia y la reparación de las víctimas por encima de cualquier otro objetivo personal. Pero, además, se trataban de espacios liderados por mujeres y exentos de las jerarquías masculinas (tan frecuentes en sus partidos políticos de origen), lo que les permitía un mayor margen de crecimiento y maniobra:

-"Mientras que los hombres estaban más centrados en ocupar puestos de responsabilidad en el partido, las mujeres mantuvieron la memoria del ser colectivo... por ejemplo, a nivel de organización, uno puede ver que las ex prisioneras se reúnen mucho más que ellos"215

-"Hemos estado en organizada resistencia al frío, a la persecución, la cesantía, la indiferencia, el miedo. En el barrio, en la huelga de hambre, en los comités de defensa; en las ollas comunes, en los talleres, en los grupos de subsistencia, en las protestas... Las alianzas, los acuerdos, las propuestas, eso, por supuesto, es cosa de hombres: no nos corresponde" $" 216$

-"Participé en la Comisión Rettig en los casos de muertes provocadas por agentes del Estado. Trabajé en la CNVR (Comisión Nacional de Verdad y Reconciliación) como asistente social e investigadora. Antes de esto, trabajé en la Vicaría de la Solidaridad preparando toda la información y el material que, posteriormente, se entregó a dicha Comisión"

Entre las muchas actividades que entorno a la memoria desempeñaron las mujeres, destacan la elaboración de informes y listas con la identidad de los responsables militares que violaron los derechos humanos, la recopilación de testimonios orales y escritos de sobrevivientes y la reconstrucción de los centros de detención. Todo ello fue constituyéndose, con el tiempo, en un fondo documental de incalculable valor (Archivo de la Memoria) sin el que difícilmente las Comisiones de Justicia y Reparación de la democracia hubieran podido esclarecer los hechos represivos:

\footnotetext{
${ }^{215}$ Ver Anexo. Entrevista No 6.

${ }^{216}$ Ver Convergencia: revista del socialismo chileno y latinoamericano, $\mathrm{N}^{\circ} 11$ abril-junio 1987, Santiago de Chile, p 56.

${ }^{217}$ Ver Anexo. Entrevista No 32.
} 
-"Cuando regresé del exilio me incorporé a CODEPU y a la Agrupación de Familiares de Ejecutados Políticos. En el CODEPU tuve varios cargos, fui secretaria ejecutiva, vicepresidenta nacional. Trabajé allí hasta 2002" 218

-"Cuando llegué a Chile, entré en contacto con todas las organizaciones de DDHH para dar cuenta de la experiencia que viví en Villa Grimaldi. Por cosas de la vida, supe quién había sido la persona que me había torturado. Reconocí su voz. Esta persona en una oportunidad estuvo en mi departamento (porque había quedado en manos de la DINA) y olvidó su documentación con todos sus antecedentes en la mesa del teléfono. Él se llamaba Germán María Muñoz, él hace poco tiempo atrás se suicidó. También participé en el Informe Rettig y últimamente en la Comisión Valech" ${ }^{219}$

Asimismo, aparecen reflexiones a cerca del deterioro de la salud integral que muchas mujeres sufrieron por estar implicadas en la búsqueda de un familiar detenidodesaparecido, frecuentemente el compañero sentimental, padre o hijo. Las entrevistadas que vivieron esta situación, sienten que en cierta manera renunciaron a sus propias vidas al dedicarse casi en exclusividad a la lucha contra la impunidad y en un marco donde reproducían el rol de viudas y madres "dolientes":

-"Mi marido estaba desaparecido. Apareció muerto en el callejón Lovalle. Él se llamaba Jorge Bastías. Durante más de un año estuve buscándole hasta que apareció. Además, tuve que ponerme a trabajar para mantenerme. La única persona que le buscó fui yo. Empecé a juntarme con otras mujeres que estaban en mi misma situación, el dolor nos unió. Me hicieron pasar a una sala en donde había muchos muertos, allí reconocí a compañeros de la Jota. Después reconocí a mi marido. Me dijeron que tenía media hora para enterrarle. Además, lo pusieron en un cajón con otros dos muertos más... he tenido fuertes depresiones hasta hoy"220

-"Las viudas dolientes o los vientres vacíos, era su identidad, mujeres que habían hipotecado su vida a la búsqueda de su marido o su hijo",221

Un caso revelador es el de la ex mirista Erika Hennings ${ }^{222}$ quien afirma que, después de regresar de Francia, decidió desvincularse temporalmente del MIR para centrarse

\footnotetext{
${ }^{218}$ Ver Anexo. Entrevista $\mathrm{N}^{\circ} 15$.

${ }^{219}$ Ver Anexo. Entrevista No 27.

${ }^{220}$ Ver Anexo. Entrevista $\mathrm{N}^{\circ} 40$.

${ }^{221}$ Ver Anexo. Entrevista ${ }^{\circ} 7$.

${ }^{222}$ Ver Anexo. Entrevista No 8.
} 
exclusivamente en investigar el paradero de su compañero sentimental (Alfonso Chanfreau $^{223}$, detenido por la DINA meses antes de que ella partiera al exilio).

$\mathrm{Su}$ testimonio fue incluido por la Comisión Rettig y contribuyó decisivamente al esclarecimiento de los hechos acontecidos en el centro de tortura Londres 38 (Santiago), en donde ella también permaneció recluida durante un mes.

Primero, porque facilitó información sobre la fecha en la que se vio por última vez con vida a varios opositores con quienes compartió celda, hoy desaparecidos. Segundo, porque relató algunos nombres de los responsables del recinto, lo que finalmente permitió la captura y procesamiento de uno de ellos, Osvaldo Romo (Guatón Romo), el torturador más sanguinario de la DINA.

También, destacar las aportaciones de las activistas, Nubia Becker ${ }^{224}$ y Rosa Lizama ${ }^{225}$, ambas ex militantes del Movimiento de Izquierda Revolucionaria, en la elaboración del Informe Rettig sobre ejecuciones y desaparición forzada de opositores políticos. Por una parte, Becker fue careada con los oficiales de la DINA Miguel Krasnoff y Moren Brito en relación a la desaparición forzada de miristas en el campo de concentración Villa Grimaldi $^{226}$, e incluida como testigo directo en el caso los ejecutados políticos en el marco del Plan Zeta ${ }^{227}$.

\footnotetext{
${ }^{223}$ Alfonso Rene Chanfreau Oyarce fue detenido en Santiago en julio de 1974. Chanfreau, de 23 años de edad, fue dirigente del Movimiento de Izquierda Revolucionaria. El Informe de la Comisión Nacional de Verdad y Reconciliación (1991) recoge su caso de la siguiente manera: "Fue detenido el día 30 de julio de 1974, en su domicilio de Santiago, por miembros de la Dirección de Inteligencia Nacional (DINA). Fue visto en el centro de detención de Londres $\mathrm{n}^{\circ} 38$. También habría sido llevado a interrogatorios a Villa Grimaldi. Desde entonces, se encuentra desaparecido”. Ver Informe Rettig, Tomo 3, p. 100.

${ }^{224}$ Ver Anexo. Entrevista No 2 .

${ }^{225}$ Ver Anexo. Entrevista No 3.

${ }^{226}$ Becker prestó declaración por los detenidos-desaparecidos en el centro de tortura Villa Grimaldi: Juan Molina Mogollones, Fabián Ibarra y su esposa Sonia Ríos, Hugo Ríos Videla, Alfredo García, Hernán Cortez Ho, Hugo Monti y María Isabel Gutiérrez. Ver Archivo Digital CODEPU. Santiago de Chile, 2004.

227 "El Plan de Movilización y Operaciones para el Golpe de Estado", conocido también como Plan Zeta, según la Junta Militar, fue un plan ideado por el Movimiento de Izquierda Revolucionaria para atentar contra las Fuerzas Armadas y establecer una dictadura en Chile. Desde el MIR se negó esta acusación y la existencia de cualquier documento que demostrara esta conspiración. Muchos militantes del MIR fueron ejecutados en los Consejos Militares que la Junta estableció en los primeros meses de 1974.
} 
Por otra, Lizama desde el FASIC (Fundación de Ayuda Social de las Iglesias Cristianas) prestó testimonio sobre el último paradero de más de una treintena de militantes de diversas organizaciones políticas tras su larga reclusión en Villa Grimaldi, información muy valiosa que sería utilizada por la Comisión de la Verdad y Reconciliación Nacional en 1991.

Sin embargo, estas aportaciones en la reconstrucción de la memoria represiva, según muchas entrevistadas, no fue correspondida por los partidos de la izquierda ni por los sucesivos gobiernos de la concertación en democracia, por ejemplo, a través de una mayor representación política, reconocimiento o apoyo institucional.

Este desajuste, según los relatos, pudo transformarse un disparador para que buena parte de las militantes decidiera desvincularse de sus partidos o mostrarse distanciadas ideológicamente, ya que una y otra vez sufrían las contradicciones entre su compromiso y las discriminaciones que sus compañeros de filas les imponían.

Reflejo de ello es que aproximadamente la mitad ha reconocido que si bien no se “desconectaron totalmente del partido", la actividad en relación a lo que habían venido haciendo en años anteriores disminuyó drásticamente. Sus esfuerzos irían esta vez encaminados a reconstruir sus vidas privadas pero utilizando el movimiento social de otras tantas mujeres para hacerlo.

La justificación que dan a este cambio de rumbo se centra en el sentimiento de haber dedicado muchos años al partido (su juventud) olvidando por el camino parte de su vida personal. Por tanto, habían cumplido como militantes pero sin obtener el suficiente reconocimiento por parte los dirigentes.

Otras tantas, añaden que se sintieron desprotegidas cuando, sin apenas recursos, trataron de reconstruir sus vidas después del exilio sin que sus partidos les proporcionaran apoyos. Al trauma de volver a un país que sentían hermético y ajeno, tuvieron que

Años después, la cúpula militar editó un informe cuyo objetivo fue, entre otros, justificar los fusilamientos de militantes miristas por su implicación en el Plan Z, proyecto que no aparece en la documentación original del MIR. Ver Libro Blanco: del cambio de gobierno en Chile, 11 de septiembre de 1973, Secretaría General del Gobierno de la Republica de Chile, Santiago, 1992, pp. 54-55. 
afrontar problemas tan graves como el desempleo, la falta de vivienda o de un seguro médico básico que las cubriera.

También, recuperar las redes sociales, muy descompuestas por la represión, se tornó como una tarea compleja, dado que parte de sus amistades y familiares estaban presos, habían muerto o seguían en paradero desconocido. En situación dejó literalmente a cientos de mujeres en la más absoluta soledad, razón que explicaría su acercamiento posterior a las organizaciones de mujeres.

Hay que destacar que muchas militantes estaban "fichadas" por las fuerzas de seguridad por haber formado parte de la oposición contra Pinochet. Con unos expedientes con antecedentes, difícilmente podrían encontrar un empleo, arrendar una propiedad o pedir un crédito, lo que hizo más complicada su inserción social.

Tal y como demuestra la documentación de la época, los organismos de seguridad solían mantener un cierto control sobre la vida de las militantes, aunque hubieran salido en libertad. Muestra de ello es que se las obligaba a presentarse cada quince días en los cuarteles como parte del operativo de seguimiento.

Otro factor influyente pudo ser el terror que la dictadura implantó durante años sobre la ciudadanía como fórmula de control social, y más cuando se trataba de colaborar con el enemigo, lo que explicaría que muchas personas rechazaran tener contacto con quienes habían estado perseguidos. Así lo han expresado las mujeres que lo vivieron, como si al fin y al cabo fueran personas socialmente incómodas en un marco en donde, y pese a estar en democracia, la población sentía que las garras represoras seguían estando al acecho.

Por tanto, las exiliadas de la izquierda fueron estigmatizadas por una sociedad todavía sometida y que las miraba con recelo. Las consecuencias para las mujeres fueron catastróficas al quedar cesantes, aisladas o sin apoyos económicos y afectivos, situación desesperada que en parte solventarían gracias al apoyo de las organizaciones de derechos humanos: 
-"Fue traumático. Yo no pude volver a Chile hasta 1987 porque tenía prohibida la entrada. Tenía mi pasaporte marcado con una "L", que significaba: No puede entrar a su país. Cuando llegué todo había cambiado, no encontré a mi círculo de amigos, me encontré con mis padres que estaban absolutamente dañados con la desaparición de su hijo. Fue un momento muy difícil. Inmediatamente me integré en la Agrupación de Familiares de Detenidos-Desaparecidos para luchar por encontrar a mi hermano. Sin embargo, sí tuve problemas de adaptación a todo lo que era la vida cotidiana en el país" ${ }^{, 228}$

-"Regresé a Chile en 1982, cuando salieron las primeras listas de gente aceptada. Fue un año muy duro porque era muy difícil encontrar trabajo, con lo que tuve que regresar de nuevo a Canadá",229

-"En los siguientes meses tuve que rehacer mi vida, fueron tiempos de mucho miedo. Además tuve otra complicación porque al estar fichada por Investigaciones tuve dificultades para encontrar trabajo,"230

-“Tuvo que vivir en una media agua, en una población callampa porque no tenía ni un peso, con sus antecedentes era imposible encontrar pega... y el partido tampoco la ayudaba... si no hubiera sido por las compañeras de la agrupación no hubiera salido adelante",231

-"Muchas compañeras han sido olvidadas y han perdido todas sus oportunidades laborales porque su lucha política dejó en segundo plano su vida privada... por eso las mujeres se desmovilizaron mucho en democracia, querían recuperar sus vidas" ${ }^{\text {"232 }}$

Todas las entrevistadas coinciden en afirmar que la vuelta a Chile supuso un impacto emocional al encontrar un país muy diferente al que dejaron tras de sí, lo que les generó sentimientos dispares: de no pertenencia (apátrida), aislamiento, desorientación generalizada, etc. Además, en muchos casos, tuvieron dificultades a la hora de recomponer unas redes sociales que habían sido aniquiladas por la dictadura, lo que necesariamente las obligó a partir de cero:

-"Yo no reconocí nada... cuando yo me fui todavía existían unos lazos de solidaridad, sentí que la dictadura aplastó todo aquello" 233

-"No recordaba las calles así, tan vacías..., hasta las micros ponte tu...todo había cambiado, lujo en Las Condes y Providencia, y de Plaza Italia para abajo una pobreza que nunca antes había visto" ${ }^{234}$

\footnotetext{
${ }^{228}$ Ver Anexo. Entrevista $N^{\circ} 20$.

${ }^{229}$ Ver Anexo. Entrevista No 29.

${ }^{230}$ Ver Anexo. Entrevista No 33.

${ }^{231}$ Ver Anexo. Entrevista No 7.

${ }^{232}$ Ver Anexo. Entrevista No 42.

${ }^{233}$ Ver Anexo. Entrevista No 4 .

${ }^{234}$ Ver Anexo. Entrevista No 11
} 
-"Cambiaron hasta el nombre de las calles, una andaba perdida por ahí, me costó mucho reconocer a la gente, además había cambiado la forma de relacionarse de los chilenos, estaban con el miedo en el cuerpo... la gente no se atrevía a decir nada, me causó mucha tristeza" 235

-"Regresé a Chile a finales de 1987. El regreso fue traumático, me encontré con un país totalmente cambiado. Caminaba por la calle como ida y tuve muchos problemas para encontrarme con mis compañeros. Sólo a través del Colegio de Asistentes Sociales pude vincularme de nuevo con mis amistades"236

${ }^{235}$ Ver Anexo. Entrevista $\mathrm{N}^{\circ} 21$.

${ }^{236}$ Ver Anexo. Entrevista $N^{\circ} 43$. 


\subsection{El liderazgo de las mujeres en las agrupaciones pro-derechos humanos.}

El impacto de la represión de la dictadura sobre la población civil opositora derivó con el tiempo en una respuesta movilizadora en torno a la denuncia por parte de quienes la habían sufrido directamente y habían sobrevivido (tortura, exoneración...) o indirectamente (pérdida o detención de un familiar o ser querido).

Como se ha reflejado en apartados anteriores, fueron los hombres los que sufrieron en mayor medida la persecución política al ocupar los puestos de responsabilidad política.

Madres, esposas, compañeras o hermanas de los varones represaliados, pero también exprisioneras, empezaron a coordinarse en agrupaciones de diversa índole, aunque con un objetivo común, esclarecer los hechos represivos y lograr responsabilidades penales para quienes los hubiesen cometido.

Todas las entrevistadas coinciden en que este tipo de organización fue espontánea y no politizada ya que, más allá de cualquier diferencia ideológica, lo que unía a las activistas era el dolor que la represión había causado en sus vidas, lo que ellas mismas interpretan como el "principal disparador" de su quehacer por la verdad, la justicia y la reparación de las víctimas.

Los discursos también apuntan a que el conjunto heterogéneo de las mujeres que lo conformaron, tuvieron que transgredir el rol tradicional que como mujeres venían ocupando desde siempre, esto es, abandonar el espacio doméstico y tomar protagonismo en el público (tomando las calles), como si de una respuesta se tratara ante la “intromisión” que la dictadura había ejercido en sus vidas.

Además, dejan constancia de que algunas mujeres se acercaron a estas organizaciones por una cuestión de supervivencia al estar relegadas a la cesantía, exclusión social o la extrema pobreza. Muchas dependían económicamente de sus maridos presos, desaparecidos o asesinados, y otras tantas habían perdido sus empleos por su 
posicionamiento ideológico viendo mermadas sus posibilidades de autonomía económica:

-"La represión afectó principalmente a los hombres, y muchas mujeres quedaron en una situación muy complicada, lo que vino a significar que terminaran involucrándose en un entorno más allá del cotidiano o familiar, es decir, en el espacio público mediante la denuncia de la represión. Además, había otra vertiente de mujeres con maridos detenidosdesaparecidos, presos o cesantes, que se quedaron en una situación de pobreza extrema y tuvieron que organizarse en torno a su propia sobrevivencia, de ahí la organización de ollas comunes, talleres, etc." ${ }^{237}$

-"Muchas de las mujeres que se vieron afectadas por la pérdida de un familiar o compañero optaron por salir de la casa y no sólo trabajar en el tema de los derechos humanos o en la movilización política, sino en la búsqueda de su sustento, de un trabajo..."238

-"Fue una organización espontánea que no atendía a razones políticas en sentido estricto sino más bien a la necesidad de vida por saber qué había ocurrido con sus familiares. Ellas supieron juntarse con otras mujeres sin estas experiencias superando con ello las diferencias que pudieran existir. Las agrupaciones tuvieron una génesis basada, por una parte, en la respuesta de mujeres afectadas por la represión en calidad de personas sin vinculación política y, por otra parte, mujeres politizadas que dieron a la lucha contra la dictadura un carácter más político. Hoy en día, todavía una puede ver que conviven estos dos tipos de mujeres en las agrupaciones de Derechos Humanos" 239

-"Durante la dictadura, los hombres tendieron a militar en organizaciones como partidos políticos y sindicatos. Las mujeres tenían una fuerte presencia en el trabajo de base, en el movimiento social como en los comedores populares, ollas comunes, talleres solidarios....Desde allí, se gestó todo un movimiento de resistencia cuyo objetivo era terminar con el régimen dictatorial" 240

Algunas mujeres que participaron en estos movimientos sociales consideran que, por condicionamientos biológicos, pudieron desplegar estrategias que permitieron una acción colectiva sólida con repercusiones a escala internacional, esto es, una respuesta social que los hombres no podrían haber liderado de la misma manera por su propia idiosincrasia masculina (más protagónicos y menos emocionales).

Precisamente, las entrevistadas interpretan que las mujeres tuvieron un mayor liderazgo en estos espacios por su condición de género en su sentido más tradicional: son más sensibles pero también más resistentes para afrontar el cuidado de los demás y, por tanto, soportar la carga de buscar a un familiar o suministrar apoyos a los presos.

\footnotetext{
${ }^{237}$ Ver Anexo. Entrevista $N^{\circ} 22$.

${ }^{238}$ Ver Anexo. Entrevista $N^{\circ} 14$.

${ }^{239}$ Ver Anexo. Entrevista No 32.

${ }^{240}$ Ver Anexo. Entrevista No 24.
} 
De esta forma, reproducir el rol de "cuidadoras de la memoria" supuso que muchas mujeres terminaran renunciando a otros espacios de desarrollo personal porque, frecuentemente, iban concentrándose en la búsqueda incansable de un familiar dejando en segundo plano sus propias necesidades:

-“Por una sensibilidad especial, madres, esposas, hermanas de detenidos, presos políticos... supieron organizarse de una manera admirable. Las mujeres organizaron la Agrupación de Detenidos-Desaparecidos, la Agrupación de Presos Políticos, la Agrupación de Retornados, etc. En estas agrupaciones coexistían militantes del MIR, del PS, del PC y otras muchas mujeres sin militancia partidaria. Las violaciones a los DDHH fueron contestadas por estas mujeres. Se dio una unidad muy fuerte entre ellas. Sobre las diferencias políticas que pudieran haber, se supo poner en marcha toda una lucha destinada a liberar a los presos y a las compañeras, a exigir verdad y justicia"241

-"En un primer período, yo creo que las mujeres, al momento de la dictadura, nos agrupamos en torno a la defensa de los derechos humanos; fuimos las mujeres quienes mayoritariamente buscamos, muy imaginativamente y muy creativamente, estrategias de sobrevivencia, e intentamos recomponer el tejido social que estaba absolutamente destruido. Fue un período, a pesar de la represión, de gran solidaridad entre las mujeres y de reconocernos como hermanas" 242

Toda esta labor quedó materializada en la aparición de diversas organizaciones en de derechos humanos cuyo impacto mediático e influencia traspasó las fronteras del país:

-La Agrupación de Familiares de Detenidos-desaparecidos (AFDD, 1974).

-Fundación Vicaría de la Solidaridad (1974).

-Mujeres Por la Vida (1978).

-El Movimiento Pro-emancipación de la Mujer (MENCH, 1983).

-La Agrupación de Familiares de Ejecutados Políticos (AFEP, 1974).

-La Agrupación de familiares de Presos Políticos (AFPP, 1975).

-El Comité de Defensa de los Derechos del Pueblo (CODEPU, 1984).

Desde allí, las mujeres se dedicaron a contactar con diversos medios de comunicación ${ }^{243}$ nacionales e internacionales y organizaciones de todo tipo, para difundir las violaciones

\footnotetext{
${ }^{241}$ Ver Anexo. Entrevista No 36.

${ }^{242}$ G. Pisscheda: “Educación Popular y Liderazgo de las mujeres en la construcción de la Democracia”; Red de Educación Popular de Mujeres, CEAAL, Quito, 1990, pp. 68-74.

${ }^{243}$ El Informe de la Federación Democrática Internacional de Mujeres envió una Comisión a Santiago en los primeros meses del 1974 para visualizar de qué manera estaba afectando a las mujeres chilenas los
} 
de los derechos humanos en Chile como parte de la estrategia de presión (lobby) contra Pinochet:

-"Las mujeres fueron el verdadero motor en la lucha por la verdad y la justicia en este país. En la Agrupación de Ejecutados Políticos éramos 40 mujeres y un hombre. La mujer demostró gran valentía movilizándose contra la dictadura. Sin lugar a dudas, nosotras fuimos las constructoras del movimiento social más importante en Chile"244

-"Trabajé con mujeres visitando a presos políticos por todas las cárceles del país. Las mujeres tuvieron un gran aporte en los Derechos Humanos. Yo trabajo desde el año 76, cuando desaparecieron la mayoría de mis compañeros, en la Agrupación de DetenidosDesaparecidos. Siempre quise saber qué había pasado con Ariel, Carlos, Ezequiel, Octavio, Ricardo...,245

-"También mantuve contactos con grupos feministas como La Morada. Empezamos a plantear que las reuniones al interior del partido debían acoger el problema de género como algo necesario.... de saber que había pasado con ellas en la tortura, en las cárceles, qué pasaba con las guaguas de aquellas que habían desaparecido... Esto fue algo complejo porque en esos años todavía pesaba la mentalidad en el partido de que la mujer debía estar en la retaguardia" 246

Significativo es el caso del Comité de Derechos del Pueblo (CODEPU, 1984), desde donde se organizó un departamento de trabajo específico con mujeres que, de forma pionera, facilitaba espacios de reflexión y apoyo terapéutico a las víctimas de la prisión política y tortura.

Esta iniciativa se creó gracias en buena parte a la aportación de aquellas mujeres que habían estado fuera de Chile y que incorporaban nuevas ideas como la de asumir la problemática específica de la mujer como una línea transversal (Mainstreaming) en cualquier actuación política o social.

Muestra de ello, fue la creación de la revista clandestina Vamos Mujer, desde donde se abordaban cuestiones relacionadas como salud y género o el peso de roles tradicionales en la discriminación que las chilenas venían sufriendo.

arrestos masivos realizados durante el primer año de gobierno militar. Ver Rojas, C., Recuerdos de una Mirista, Santiago de Chile, 1978 p. 98.

\footnotetext{
${ }^{244}$ Ver Anexo. Entrevista No 15.

${ }^{245}$ Ver Anexo. Entrevista N 18.

${ }^{246}$ Ver Anexo. Entrevista No 44.
} 
Asimismo, en 1982 se organizó un encuentro nacional de mujeres pobladoras en Santiago, para debatir cuestiones tan relevantes como su participación política, salud, sexualidad, represión o derechos laborales: "Nuestro objetivo es integrar masivamente a la mujer en la lucha por la salud, la vivienda, el trabajo, los cambios sociales y jurídicos y enfrentar organizadamente la represión de la dictadura"247

Otro caso revelador fue el de la Agrupación de Familiares de Detenidos-Desparecidos (AFDD), organización que tuvo su génesis en 1974 como consecuencia de las numerosas desapariciones forzadas en los primeros meses de la dictadura. La iniciativa partió fundamentalmente de mujeres ligadas de una $\mathrm{u}$ otra forma con hombres represaliados, aunque algunas ya venían militando en partidos de izquierda desde tiempos de Allende.

La AFDD, en sus primeros pasos contó con el apoyo del Comité Pro-Paz, una organización humanista y cristiana nacida de varias corrientes religiosas y ligada a la iglesia católica, que colaboró estrechamente acogiendo y dando amparo jurídico a multitud de perseguidos. Tras ser prohibido por Pinochet en 1975, pasó a denominarse Fundación Vicaría de la Solidaridad para continuar hasta el final de la dictadura con su labor de apoyo a los familiares de las víctimas. Gracias al trabajo conjunto de ambas organizaciones se pudo crear un archivo con miles de testimonios y una red de asistencia jurídica para quién quisiera tramitar una denuncia.

La AFDD estaba organizada en una directiva con seis comisiones de trabajo (Extensión y Comunicación, Relaciones Públicas, Formación y Capacitación, Comisión Jurídica y Administrativa y Comisión Juvenil), una secretaría general y otra de finanzas. Todos los cargos eran elegidos por los familiares, la mayoría mujeres, con lo que pronto su liderazgo, al igual que ocurriera en otras agrupaciones similares, fue un hecho.

\footnotetext{
247 Fragmento perteneciente a Vamos Mujer (junio de 1982, CODEM). Hay que destacar también la formación del Movimiento de Mujeres Pobladoras (MOPUTO, Santiago, 1982) como organización que agrupaba a diversos colectivos de mujeres de sectores poblacionales. La diferencia con el CODEM residió en que esta agrupación estaba organizada y dirigida exclusivamente por mujeres pobladoras sin vinculación política con ningún partido. Los objetivos fueron la lucha contra la represión del sistema patriarcal y de la dictadura. Ver Cleary E., El papel de las mujeres en la política de Chile: acerca del proceso de emancipación de las mujeres chilenas durante la dictadura militar de Pinochet, ISIS internacional, Alemania Federal, 1987, p. 206.
} 
Una de las acciones más influyentes que pusieron en marcha fueron las huelgas de hambre en recintos públicos o edificios institucionales, con el objetivo de atraer a los medios de comunicación y exigir públicamente sus demandas (¿Dónde están?).

De entre las numerosas que se realizaron, destacó la celebrada el 22 de mayo de 1978, con una participación de más de doscientas mujeres que desafiando a las fuerzas de seguridad, decidieron establecerse en el interior de la catedral de Santiago y no moverse hasta que se aclarase el paradero de sus seres queridos. Lejos de ser escuchadas fueron sacadas a la fuerza y detenidas corriendo diversa suerte:

-"En la huelga de hambre nos tomamos la catedral de Santiago. A los nueve días de la huelga llegó la policía de investigaciones y nos tomaron presos. Tomaron la catedral con gases lacrimógenos...A nosotras nos llevaron a la COF, la Correccional de mujeres, allí continuamos la huelga de hambre, estuvimos diecinueve días...algunas compañeras lo pasaron muy mal." ${ }^{248}$

Otra acción conjunta destacada fue el acto celebrado en el Teatro Caupolicán (Santiago) el 29 de diciembre de 1983, en donde se reunieron miles de mujeres de diversas tendencias políticas unidas en la defensa de los derechos humanos. En este encuentro tuvo también su génesis la Agrupación de Mujeres por la Vida, un acto espontáneo entre diversas activistas que con el paso del tiempo se tornaría como la punta de lanza en la denuncia de la represión pinochetista:

-"Más de ocho mil mujeres de diversas posiciones políticas nos tomamos de la mano y cantamos... el contenido de este acto y su conducción estuvieron a cargo de una demócratacristiana y una comunista simbolizando así que en la acción conjunta estábamos derrotando el miedo paralizante para poner punto y final a la noche negra de la dictadura",249

-"Yo soy una de las co-fundadoras de Mujeres Por la Vida entre las que se encontraron Patricia Verdugo, Fani Poyarolo, Mónica González... Queríamos invitar a otros grupos de mujeres para organizar el Caupolicanazo de Mujeres; en Santiago había un teatro llamado Caupolicán. El 29 de diciembre de 1983, hicimos un acto de mujeres para presentar la agrupación Mujeres por la Vida. Fueron más de nueve mil”250

\footnotetext{
${ }^{248}$ Ver Anexo. Entrevista $N^{\circ} 44$.

${ }^{249}$ Diario El Siglo, № 7585, enero de 1984, p. 10.

${ }^{250}$ Ver Anexo. Entrevista No 25.
} 
Finalmente, mencionar la colaboración de buena parte de las entrevistadas en la Agrupación de Familiares de Ejecutados Políticos (AFEP). Al igual que la AFDD, la AFEP estuvo liderada por mujeres, pero con la diferencia de que sus familiares habían sido fusilados en los procesos sumarísimos de los tribunales militares en los primeros años de la dictadura (entre 1973 y 1975 se ejecutaron en Chile a más de 1500 personas).

En noviembre de 1978, se fundó la AFEP como una iniciativa para tratar los casos de ejecutados de forma independiente, ya que, al ser asesinatos consumados, los familiares podían dedicarse en exclusividad a poner en funcionamiento los proceso penales en los tribunales de justicia internacionales. Esta organización se estructuró también en diversas comisiones de forma piramidal (Propaganda, Relaciones nacionales e internacionales, Finanzas, etc.).

A diferencia de la AFDD, los familiares de la AFEP no tuvieron que sufrir la búsqueda incansable de un familiar desaparecido, circunstancia que como se ha apreciado anteriormente, mermó las vidas de muchas mujeres en su rol de viudas dolientes o vientres vacíos ${ }^{251}$ :

\begin{abstract}
-"Después de este tiempo asumí tareas en el ámbito de los derechos humanos, también trabajé con la Agrupación de Presos Políticos. Entraba mucho a las cárceles para ver en qué condiciones estaban los presos, recibíamos y administrábamos el apoyo de la Solidaridad Internacional, alimentos, ropa, etc.; organizábamos diversas actividades culturales y de apoyo a los compañeros y compañeras presos" ${ }^{, 252}$
\end{abstract}

Lo que parecen transmitir las mujeres a través de sus testimonios es que este tipo de movilizaciones tenían un efecto multiplicador al generarse espacios en donde muchas tomaban conciencia a través de otras, y de la capacidad de transformación que podían generar como colectivo en la sociedad chilena.

Por esta razón, la dictadura pronto dio cuenta de que estas acciones tenían un efecto catalizador entre la ciudadanía, ya que hacían visibles "sus cuentas pendientes" con los

\footnotetext{
${ }^{251}$ Ver Anexo. Entrevista No 7.

${ }^{252}$ Ver Anexo. Entrevista No 36.
} 
perseguidos, esta vez, desde una oposición menos politizada pero con efectos que incluso traspasaban las fronteras del país.

Por consiguiente, la oposición al régimen de Pinochet ya no venía solo desde las filas de los partidos políticos clandestinos, sino también a los familiares y seres queridos de las víctimas, con lo que la dictadura en un principio "no había contado".

El coste de este compromiso fue que muchas mujeres de las agrupaciones cayeron presas o fueron presionadas a través de diversos medios para que desistieran de su labor (exoneración, seguimiento policial, amenazas contra su integridad y la de sus familiares, etc.). De hecho, todas las entrevistadas han coincidido en que la dictadura hizo todo lo posible para neutralizar estas acciones, sirviéndose además de los medios de comunicación para presentarlas como mujeres histéricas financiadas por el "marxismo internacional" y cuyo fin último era generar una fractura social en el país.

Pero no sólo las agrupaciones tuvieron que lidiar con estos obstáculos, también estaban las resistencias que muchas víctimas a la hora de exteriorizar lo sufrido. La violencia está íntimamente ligada al silencio y la mayoría de las que la sufrieron, paradójicamente, no tuvieron dificultades en relatar lo que les había ocurrido a sus seres queridos, no así lo que les había ocurrido a ellas mismas. En otras palabras, las activistas se hicieron cargo de los costes represivos de los demás antes que de los propios: cuidadoras de las necesidades vitales de los otros, un rol de género que se mantiene hasta nuestros días.

Algunas entrevistas ha expresado su deseo de hablar de un doble sentimiento que les perturba: no saber con certeza qué ha pasado con sus seres queridos lo que les impide descansar por no poder cerrar el duelo; querer indagar sobre sus propias experiencias represivas para poder superarlas tras años de invisibilización.

En este sentido, sugieren que la reconstrucción de los hechos represivos ha de traer consigo una reivindicación del rito funerario de los desaparecidos y un esclarecimiento preciso sobre lo que les ocurrió a las personas que los buscaron. Abogan porque el silencio se torne en una fuerte voz social que exija la recuperación de los cuerpos y el procesamiento de los culpables. 
Como se ha podido demostrar, la tarea de recordar y de hallar repuestas a las preguntas ¿dónde están? o ¿quiénes fueron los responsables?, se ha configurado, en el caso chileno, como una labor dirigida y protagonizada fundamentalmente por mujeres, que pese a sus diferencias pudieron aunar esfuerzos por una causa común.

Solo con los años algunas empezaron a platearse los costes de su compromiso, especialmente aquellos relacionados con la salud mental y cuestionar si merecía la pena continuar: "En las memorias testimoniales, quienes enuncian el desaparecimiento son mujeres. En el proceso se van convirtiendo de objetos (esposas, hijas de) a sujetos de memoria",253

Verónica Matas en su artículo Memoria de los movimientos afirma que el hecho de que las agrupaciones de detenidos-desaparecidos tanto en Chile como en Argentina, estuvieran integradas y lideradas por mujeres, tuvo dos consecuencias en cuanto su identidad se refiere. Por un lado, la continuidad de los roles tradiciones (mujeres en defensa de los DDHH como madres, esposas o cuidadoras) y por otra, la modificación de los espacios de género tradicionalmente asignados, al adquirir mayor protagonismo en el público. Estas circunstancias aunque contradictorias tuvieron efectos concretos:

1) La politización y descubrimiento identitario: La identidad de las mujeres de las agrupaciones estaba dada por su lugar en la familia, sin embargo, ésta se irá redefiniendo al agruparse colectivamente y tomar conciencia sobre aquellas situaciones que las discriminaban, especialmente en lo que se refiere a la represión sufrida.

2) Las mujeres por inercia y mandato cultural tendieron a reproducir el rol de "buscadoras infatigables de sus hombres desaparecidos" (padres, hijos y parejas), lo que relegaba a un segundo plano sus necesidades y vitales y posibilidades de sanación.

3) La presencia y visibilidad de las mujeres en tiempos de dictadura les dio un cierto protagonismo que desparecería una vez finalizado el periodo autoritario, destacando la falta de correspondencia de las instituciones y los partidos políticos en relación a su aportación al proceso democrático y a la recuperación de la memoria de la represión.

${ }^{253}$ Información Recogida en Olea R. y Grau O., Volver a la memoria; Lom Ediciones, La Morada, Santiago de Chile 2001, p. 23 


\subsection{Discriminación de género en la vida partidaria.}

Cómo se ha constatado a lo largo de la investigación, las militantes comunistas, socialistas y miristas desempeñaron fundamentalmente su activismo político en los cuadros medios y bases de los partidos, a diferencia de los varones que predominaban en los puestos de dirección.

La mayoría coincide en que la presencia femenina en los comités centrales tan solo rondaba el 10 por ciento en tiempos de la Unidad Popular (1970-1973), cifra que según ellas se incrementó hasta un 20 por ciento durante la dictadura (1973-1990).

Este aumento, según ellas, fue el resultado del impacto de los diversos operativos represivos contra las cúpulas "masculinas", lo que permitió que las mujeres, de diversas formas, fueran relevando a sus camaradas caídos. En cualquier caso, ello no representaba la realidad del conjunto de la militancia femenina ya que ésta seguía anquilosada bajo el rol de ayudistas sin tener posibilidades reales de participar en la toma de decisiones:

-"Nosotras tenemos la experiencia de que cuando caía un compañero había muchas mujeres alrededor: sus hijas, sus hermanas, las madres, etc. En cambio, cuando caía una mujer nadie la iba a ver porque el trabajo de ayudista o de casa buzón no era considerado fundamental. Esta realidad la viví yo. Hubo mucho machismo en este sentido, también entre nosotras, porque nos habían educado así, para estar en todo momento con los compañeros caídos o detenidos" 254

-"Yo regresé a Chile en 1985. Tuve mucha enemistad con los compañeros del partido por el tema de las mujeres. Era muy complicado porque mientras nosotras desempeñábamos tareas de solidaridad no había ningún problema, pero cuando cuestionábamos temas de liderazgo al interior del partido los conflictos aparecían... Había muy pocos recursos para trabajar nuestros temas. Las prioridades eran otras según ellos, y esto nos dejaba muy poco margen para trabajar. Nos imponían sus criterios y había una clara manipulación"255

Por tanto, existió una primera discriminación de género que fue transversal en cuanto a que hombres y mujeres, no ocupaban los mismos espacios "de partida" en sus respectivas formaciones políticas.

\footnotetext{
${ }^{254}$ Ver Anexo. Entrevista No 37.

${ }^{255}$ Ver Anexo. Entrevista No 19.
} 
Asimismo, se ha querido indagar si existieron otras circunstancias discriminatorias en el devenir militante en base a las experiencias reflejadas en los testimonios. Los resultados los pasamos a titular a continuación:

\subsubsection{Acoso sexual}

Algunas mujeres han ido relatando experiencias que pudieron vulnerar sus derechos integrales en cuanto a su sexualidad se refiere, muy especialmente en los períodos de convivencia clandestina con los compañeros de militancia, en donde algunas fueron víctimas de acoso sexual en base a los estereotipos patriarcales y estrategias de dominio y control sobre su cuerpo.

Concretamente, en sus discursos subyace lo que se podría definir como la percepción generalizada de los varones militantes de que las activistas debían ofrecer un débito sexual para con ellos (suministradoras de las "necesidades" ajenas).

También, algunas han mencionado que el hecho de que las mujeres fueran minoría, en un espacio de hombres, las situó en una posición de especial vulnerabilidad en donde ellas, por condicionamientos culturales de género, terminaban cediendo a las presiones y acoso de los compañeros. Como si de un cuidado natural para con los hombres "guerreros" se tratara, a veces ni ellas mismas eran conscientes de estos mecanismos de control y coerción cuando se producían:

-"Como yo era compañera de un dirigente y en muchas ocasiones, sin ni siquiera darme cuenta, yo vivía el acoso sexual al igual que muchas de mis compañeras. No teníamos ni conciencia ni conocíamos estos conceptos" ${ }^{\text {256 }}$

-“Una sabía que esta presión estaba ahí, aunque no pudieras verbalizarla, debías andar con cuidado de cómo vestías o lo que ibas enseñando...."257

En algunas ocasiones en donde las militantes se negaban a cumplir los deseos masculinos, sufrían el rechazo o eran estigmatizadas "como prostitutas", recriminándolas por ejemplo, que no se acostaran con ellos, bajo el argumento de que sí

${ }^{256}$ Ver Anexo. Entrevista $\mathrm{N}^{\circ} 22$.

${ }^{257}$ Ver Anexo. Entrevista No 3. 
lo habían "hecho con otros". Además, en estas situaciones, también aparecía el estereotipo de que las compañeras que no estaban casadas, aún pudiendo tener relaciones de pareja, no eran percibidas como "objetos en propiedad de otro varón", lo que les daba vía libre para poder "abordarlas":

-"Hubo una clara discriminación, mi aspecto físico era bastante atractivo. Muchas veces me sentí acosada, y en algunos momentos en el que yo aceptaba esas insinuaciones, porque me gustaba un compañero, rápidamente los otros decían: -A esta le gusta el güeveo, es media puta-" $" 258$

-"En Nicaragua, con los llamados del partido para retornar, se produjo una situación que tiene mucho que ver con la discriminación por mi condición de mujer. Mis compañeros habían decidido que yo no podía retornar porque había desconfianza política hacia mí... Yo viví dos situaciones en Nicaragua con estos compañeros porque me acusaron de prostitución. Pidieron mi expulsión del partido. Evidentemente, no me prostituí. La rivalidad hizo que mis compañeros me descalificaran criticando mi vida privada... yo no tenía pareja estable ni era casada y utilizaron este argumento para dejarme fuera del grupo, 259

En estas estrategias de dominio y subordinación, subyacía el estereotipo de mujercuidadora que eclipsaba a la de "militante" ya que, ante todo, ella debía dedicarse a los otros, más allá de sus propios deseos o necesidades. Ello tuvo consecuencias traumáticas como embarazos no deseados, coacción y amenazas para mantener relaciones sexuales o problemas psicológicos por parte de quienes las sufrieron ("por estar en una situación de tensión constante").

Las activistas no solo tenían que defenderse de los riesgos de militar contra Pinochet, sino también de sus propios compañeros en la cotidianeidad, lo que generaba una situación de convivencia sexista de facto porque, al fin y al cabo, no eran consideradas de igual a igual, sino como un apoyo "sexual" en retaguardia:

-"En esos tiempos de clandestinidad nosotros vivíamos al límite. Cuando llegaba un compañero tenía todo servido, no sólo la comida, también en la cama. Nosotras de cierto modo nos entregamos a ellos, fue algo muy común, no sabíamos si al día siguiente íbamos a estar vivos. La consecuencia de esto es que muchos compañeros sembraron muchos hijos. Algunos militantes que murieron tuvieron varias viudas con hijos de un mismo hombre. Esta realidad solo la pueden entender aquellas personas que vivieron esos días. Las mujeres

${ }^{258}$ Ver Anexo. Entrevista $\mathrm{N}^{\circ} 39$.

${ }^{259}$ Ver Anexo. Entrevista No 26. 
en cierto modo fuimos un bálsamo para los hombres, curábamos sus heridas, les dábamos de comer, cariño, todo"260

-"Todos los compañeros que compartieron esos años conmigo trataron de tener relaciones sexuales conmigo y yo rechacé a la mayoría de ellos. Esta situación machista derivó a que ellos me hicieran la vida imposible...En esos ocho meses también se produjeron situaciones muy delicadas con mis compañeros. Durante mucho tiempo tocaban a mi puerta con la única intención de acostarse conmigo. Tuve que ser muy firme y esto me creó muchos problemas. Ellos me dijeron -es complicado que usted sea la única mujer que esté aquí, o lo resolvemos o usted tendrá que irse a otro lugar-" 261

${ }^{260}$ Ver Anexo. Entrevista N ${ }^{\circ} 37$.

${ }^{261}$ Ver Anexo. Entrevista $N^{\circ} 26$. 


\subsubsection{La sobrecarga en las tareas domésticas y en el cuidado integral de los hijos.}

La práctica totalidad de las entrevistadas coincide en que el peso cultural del sistema tradicional de género (Patriarcado) conllevó a que las activistas tuvieran que asumir en solitario aquellas tareas derivadas del ámbito doméstico y del cuidado de sus hijos, lo que afectó considerablemente sus tiempos y energías para desarrollarse en otros aspectos de sus vidas.

Concretamente, relatan que vieron mermadas sus posibilidades de expandirse profesionalmente o promocionarse en sus respectivas formaciones políticas por tener que estar condicionadas por su rol de madres, cuidadoras o amas de casa. De esta forma, hombres y mujeres no contaron con los mismos tiempos y espacios en el quehacer militante ya que ellas debían asumir el trabajo que no hacían sus compañeros.

Desde la perspectiva feminista contemporánea, la sobrecarga femenina en estos ámbitos no era tan acusada cuando la mujer se dedicaba en exclusividad a la esfera doméstica. Sin embargo, cuando tuvo posibilidades de optar al espacio público, en este caso al político, tenía que compaginar ambas cosas, lo que irremediablemente se traducía en un doble trabajo.

Las activistas podían acoplarse a los nuevos tiempos de modernidad (subiéndose al vagón de la actividad partidaria) pero sin dejar de aportar lo que tradicionalmente habían suministrado: los cuidados y trabajo doméstico. En otras palabras, tenían que asumir ambos roles (público y privado), una situación perversa y con apariencia igualitaria que algunas autoras han denominado "la transición del rol de Ángel del Hogar al de Súper-woman" ${ }^{262}$ :

-"Siempre se daba que las mujeres participaban menos que los hombres. Yo era soltera y sin hijos y tenía todo el día para militar. Pero las compañeras que eran madres sí tuvieron muchas dificultades a la hora de trabajar en el partido,"263

\footnotetext{
${ }^{262}$ Ver Matilla, M.J., Historia y Género, UAM, Madrid, 2002.

${ }^{263}$ Ver Anexo. Entrevista No 24.
} 
-"En los sectores con mayor compromiso e involucramiento con el proceso que vivía el país, habitualmente el hombre cumplía el rol político más activo, manteniéndose el patrón tradicional de relaciones al interior de la familia, lo que condicionaba una suerte de división del trabajo, aún si ambos militaban, en que la mujer se ocupaba de los hijos y de la infraestructura doméstica, representando, en medio de la inseguridad y las difíciles condiciones de vida, el componente más estable de la organización familiar ${ }^{264}$

El primer desequilibrio de género que existió en este sentido, fue el que tiene que ver con las tareas cotidianas durante la vida en clandestinidad. En la convivencia, muchas veces colectiva, las mujeres asumían el trabajo de suministro y elaboración de alimentos y todas aquellas actividades que tenía que ver con la implementación de las rutinas diarias.

Este trabajo, esperado y percibido por los hombres como aporte natural de sus compañeras, generó costes concretos en la salud de las activistas, que después de la jornada clandestina y agotadas, asumían con resignación una nueva, mientras que los militantes podían descansar o dedicarse a otras actividades exclusivamente personales:

-"Recuerdo anécdotas muy reveladoras sobre mi función de madre-esposa y militante del PS. En Costa Rica muchos de los dirigentes que venían de Europa y Chile pasaban por mi casa. Yo era una militante con cierta experiencia, había cofundado la Juventud Socialista y llevaba muchos años en la militancia universitaria, pero resulta que cuando llegaban los dirigentes la comida la hacía y la servía yo y nadie me preguntaba mi opinión. Instintivamente, estas realidades me llevaron a tener un acercamiento al feminismo",265

-"Mira, te voy a dar un detalle, las mujeres que estábamos a cargo de las casas de seguridad siempre terminábamos lavando los platos y haciendo el aseo...terminábamos pa la cagá, teníamos que estar en todo porque ellos nunca se hacían cargo de estas cosas, ni si quiera se lo planteaban, como si fuera algo natural no más",266

Precisamente, ellas argumentan que estas situaciones se daban porque se percibían como naturales e incuestionables. De hecho, las activistas reconocieron que ni ellas mismas eran muchas veces conscientes de la discriminación que sufrían, lo que indica que los roles tradicionales también estaban muy interiorizados en las militantes. Sólo, con los años, pudieron dar cuenta de estas diferencias, que las generaban sobrecarga y

\footnotetext{
${ }^{264}$ Ver Estrada A., Hering M. y Donoso A., Familia, Género y Terapia, CODEPU, Santiago de Chile, 1996, p.25.

${ }^{265}$ Ver Anexo. Entrevista No 22.

${ }^{266}$ Ver Anexo. Entrevista No 37.
} 
malestar, lo que les llevó a ir adquiriendo una mirada más crítica hacia sus compañeros de partido.

Por tanto, las militantes se configuraban como gestoras y administradoras de las necesidades diarias del grupo en clandestinidad, más allá de su identidad como militantes. Así, solían diseñar las rutinas, estar pendientes del suministro y elaboración de alimentos, la ropa, el aseo o los medicamentos.

Esta situación se complicaba aún más cuando había hijos de por medio o las militantes quedaban embarazadas, porque, al hecho tener que cuidar de sus compañeros, se añadía todo el trabajo derivado de tener que encargarse de un menor en un contexto de permanente peligro.

En este sentido, las entrevistadas han sido contundentes al afirmar que fueron ellas las que se ocuparon de los cuidados integrales de los hijos, lo que les generaba una clara sobrecarga física y emocional y las limitaba en sus espacios y movimientos.

En la mayoría de los casos, esta circunstancia enfrentaba a la mujer a un complejo dilema: renunciar a sus expectativas políticas o bien a los tiempos de dedicación de sus hijos. Otras, añaden, tuvieron que postergar la maternidad ante la imposibilidad de una conciliación real entre sus deseos y su compromiso partidario:

-"Quizá algunas sí optamos por postergar la maternidad, como fue mi caso. Otras compañeras decidieron separarse de sus hijos y no asumir su maternidad por las tareas políticas, otras consiguieron hacer ambas cosas pero con muchas dificultades"267

-"El riesgo de vida era una cosa permanente, es decir, obviamente hubo muchas renuncias de algunas militantes en cuanto al hecho de tener hijos porque era un riesgo doble. Era una entrega diaria y no había mucho tiempo para dedicarse al cuidado de los hijos y a la familia. A una le absorbía el trabajo político las veinticuatro horas"268

Si optaban por que la militancia no se resintiera en aras del cuidado de los hijos, solían recurrir a otras personas para que los cuidaran (familiares, generalmente mujeres: abuelas, madres, tías...), situación que les generaría después un sentimiento culposo

\footnotetext{
${ }^{267}$ Ver Anexo. Entrevista No 25.

${ }^{268}$ Ver Anexo. Entrevista No 42.
} 
"por haberlos abandonado". A ello se solapaba el castigo social, especialmente de sus compañeros de filas, por haber descuidado sus responsabilidades maternales.

Por esta razón, ellas entienden que esta experiencia fue una de las más traumáticas en sus vidas al sentir una deuda pendiente para con sus hijos por haber estado ausentes, lo que las atormenta y angustia ante lo que interpretan una pérdida irreparable. En algunos casos, los menores se mostraron comprensivos justificando las ausencias maternas en aras de una causa justa y noble (la lucha contra la dictadura por el bien común), pero otros, en cambio, recriminan a sus madres (no así a sus padres) no haber estado en los momentos importantes.

Lo que llama la atención es que el cuestionamiento de los comportamientos de la figura paterna queda ausente, quizá porque los hijos percibían que sus padres no habían dejado de hacer lo que se espera de ellos como hombres: valientes guerreros que abandonan el hogar para defender a sus familias:

-"Para cualquier mujer comunista ha sido muy difícil educar a nuestros hijos y formarlos en tiempos de represión. Yo tuve la suerte de haber tenido unos suegros y padres que me ayudaron mucho en este sentido. Sin embargo, mi hijo sí que me ha recriminado que durante un largo período lo dejé solo por mi implicación en la política. Sólo con el tiempo fueron dándose cuenta de las razones por las cuales yo tuve que perderme algunos momentos de su vida",269

-"Ese tiempo estuve separado de mi hijo. Cuando llegué fue muy difícil para mí. Sentí en parte que lo había abandonado. Él me mostraba juguetes que le había regalado, fue muy emotivo, como si me dijera -se que eres mi mamá, pero no te conozco, ¿quieres conocerme?-; me conmovió que no me reprochara nada. Tuve una depresión muy fuerte por haberme perdido varias etapas de su infancia" ${ }^{\text {270 }}$

-“Afectó mucho. Yo sentía una gran culpabilidad aunque por otra parte sabía que había tomado una posición y que tenía que ser consecuente con esa decisión. El riesgo que él pudo tener en algunos momentos es lo que más me perjudicó. Es difícil vivir la militancia clandestina porque uno tiene que esconderse de todo. Sabía que iba a llegar un momento en el que mi hijo me preguntara sobre estas ausencias. Mi hijo recordaba algunas cosas que no entendía: -¿por qué me dejaste tanto tiempo sólo?-; le conté todo. Pero además le agregué que yo pensaba que nada justificaba dejar un hijo abandonado, ni siquiera la revolución. Le transmití que era muy consciente de que me había saltado etapas de su vida importantes. Mi hijo me contestó: -creo que hiciste lo que tenías que hacer y me siento muy orgulloso de tener una mamá como tu y puedo decir a mis compañeros que mi mamá luchó contra Pinochet y no todos mis compañeros pueden decir eso- Tenía doce años cuando se produjo esta conversación"271

\footnotetext{
${ }^{269}$ Ver Anexo. Entrevista № 36.

${ }^{270}$ Ver Anexo. Entrevista No 39.

${ }^{271}$ Ibíd.
} 
Pero además, en la cotidianeidad clandestina, muchas activistas vivían una actividad frenética para poder "cumplir con sus tareas" y pese a ello, infatigables, acudían a las reuniones de los partidos, incluso algunas veces acompañadas de los pequeños. La reacción de sus compañeros muchas veces era de rechazo o cuestionamiento instándolas a regresar a casa (estorbaban, porque traían a los niños y eran culpabilizadas por ponerles en riesgo):

-"En las reuniones los hombres podían salir tarde pero yo vivía en San Bernardo (a 20km de mi casa) con lo que no podía quedarme mucho tiempo. Esto venía a significar perderme las conclusiones de cada reunión y momentos importantes en la toma de decisiones. Si había una mujer con hijos era imperdonable que llegara tarde o no llegara a la reunión por cuidar de sus cabros, es decir, no era una excusa para no asistir. No había ninguna consideración extra para aquellas mujeres que tenían ciertas dificultades",272

-"Yo fui muy criticada precisamente por esto. A nadie le importara que fuera una buena dirigente pero mis compañeros me veían como una mala madre porque no me ocupaba lo suficiente de mis hijos. Llevaba a mis hijos a las reuniones y ellos me decían que les ponía en riesgo. Yo he sufrido discriminación en el partido, aunque haya tenido oportunidades de acceder a la militancia, pero precisamente por esta doble carga que yo tenía. Los compañeros que vienen a las reuniones con sus hijos casi se les ven como mártires a diferencia de las compañeras que cuando acuden con sus cabros parece que vinieran sólo a molestar. Sigue siendo muy difícil la militancia para las mujeres con hijos, sobre todo para las mujeres dirigentes" ${ }^{, 73}$

-“A los dieciocho año, en 1979, me casé y tuve dos hijos. Me dediqué a criarlos y durante tres años dejé de lado mi militancia y mis estudios. Luego estudié enfermería y me egresé" 274

Hay que mencionar que han aparecido opiniones divergentes a la hora de valorar los costes y beneficios de sus decisiones en relación a esta cuestión. Algunas reflejan que pese a sentir que renunciaron a estar con sus hijos por militar, "mereció la pena" al percibir que su compromiso fue necesario para la consecución de una sociedad democrática más justa en Chile que sobrepasaba todo lo demás.

No obstante, otras sienten que esta decisión fue errónea ya que primeramente debía estar lo personal y después lo político, porque la ausencia materna terminó perjudicando a los menores generando diversos traumas psico-emocionales en ellos (dificultades de comunicación, concentración, sentimiento permanente de soledad, etc.) a lo que se

\footnotetext{
${ }^{272}$ Ver Anexo. Entrevista $N^{\circ} 44$.

${ }^{273}$ Ver Anexo. Entrevista No 34.

${ }^{274}$ Ver Anexo. Entrevista No 37.
} 
sumaba el sentimiento de pérdida por no haber compartido más tiempo con sus pequeños:

-“A finales del 79 la empresa supo de mi militancia y me despidieron. En este despido tuve que vagar por muchas empresas. Trabajaba de noche, de día, vendía pan amasado, cualquier cosa para mantener a mis hijas y nunca sin dejar de militar. Mi madre se hizo cargo de mis hijas y yo empecé a salir más de la casa. Estuve mucho tiempo separada de ellas. Si tengo una deuda con mis hijas es no haberlas visto crecer"275

En cualquier caso, todo parece indicar que es un tema que todavía remueve demasiado y les genera sentimientos encontrados, lo que puede indicar que ha sido una cuestión poco elaborada por aquellas mujeres que lo vivieron:

-"Nosotras tuvimos una discusión en la cárcel con compañeras que venían de Cuba y que habían dejado sus hijos en estos hogares. Otras compañeras tuvieron bebés en las cárceles, Rita Peña, Marta Soto e Inés Peiró. La discusión era sobre la necesidad o no de sacar los bebés de la cárcel. Yo defendí la postura de que la guagua debía quedarse donde la madre estuviera. Discutimos mucho sobre este tema. Lo que se hasta ahora es que la mayoría de los niños que se separaron de sus padres tienen mucho más conflictos que el Manuel y la Elisa que se criaron en la cárcel hasta los tres años"276

-"Supeditamos nuestros proyectos personales a un objetivo común y colectivo para construir una sociedad más justa. Yo pagué un costo muy alto por esto porque tuve problemas con mis hijas. Recuerdo que uno de ellas me dijo en una ocasión que tenía los valores trastocados porque me ocupaba más de las cosas externas que de mis propias cosas personales. Se sintió muy abandonada porque priorizaba las reuniones del partido y el trabajo político a las cosas familiares como los cumpleaños..."277

-“En 1985 estaba preparándome para volver a Chile... yo quedé embarazada y esto me generó un conflicto enorme. Este hecho cambio bastante mi perspectiva sobre la militancia, empecé a verme más como un ser humano que como una militante o una máquina. Mi padre siempre me molestó porque no me arreglaba. Me acordé de esos momentos en los que la militancia estaba por encima de todo. Todo esto cambió con mi maternidad....una compañera me comentó que mis ojos tenían otra expresión, con más vida; me dijo: -"tus ojos muestran que eres otra persona, has logrado transformar tu militancia en vida"-.Yo vivía sola en Buenos Aires con mi hija. Mi compañero vivía en Santiago y viajaba clandestinamente para vernos" ${ }^{\text {"278 }}$

\footnotetext{
${ }^{275}$ Ver Anexo. Entrevista No 40.

${ }^{276}$ Ver Anexo. Entrevista $N^{\circ} 13$.

${ }^{277}$ Ver Anexo. Entrevista $N^{\circ} 19$.

${ }^{278}$ Ver Anexo. Entrevista $\mathrm{N}^{\circ} 25$.
} 
En algunos testimonios se argumenta que esta sobrecarga pudo sostenerse por los condicionamientos naturales o biológicos de la mujer, que según esta óptica, la hacía más resistente para ocuparse del cuidado de los demás sin dejar de lado el trabajo clandestino; esta sobre-fuerza de las mujeres lejos de ser cuestionada era admirada por las propias militantes como una condición innata de unas capacidades que los hombres per se no podían tener aunque se lo propusieran:

-"Muchas de mis compañeras tenían que trabajar, ocuparse de las labores de la casa y además militaban en los cuadros militares. Esto era admirable. También, hubo compañeras que descuidaron a los hijos para desempeñar una plena militancia en el Frente"279

-"Las compañeras del PC que fueron madres en aquella época o se hacían cargo de sus hijos o los abandonaban por la lucha. Personalmente, abandoné a mis dos hijos, a mi me pesa mucho esto pero ellos con el paso del tiempo han logrado comprender que esto fue algo necesario, que yo estaba muy convencida de que nadie podía desempeñar las tareas que tenía que hacer. Esto fue la parte más terrible de mi vida. La casa de mi papá cayó, la allanaron. Lo que más me pesa es que en algunas ocasiones mi familia, mis hijos corrieron peligro por mi militancia"280

Otra cuestión en relación al cuidado de los hijos es la que tiene que ver con las dificultades en el exilio a la hora de retornar a Chile dentro del marco de una estrategia política determinada.

En este sentido, las entrevistadas reflejan que en las situaciones en las que una pareja militante tenía menores a su cargo, eran ellos los que regresaban a Chile por decisión del partido, para así continuar con la actividad opositora, mientras que ellas se quedaban en el país de acogida haciéndose cargo íntegramente de los pequeños y viendo mermadas sus posibilidades de compromiso:

-“Un ejemplo de discriminación puede ser que el Partido Socialista no organizó ningún tipo de política de retorno para nosotras. La mentalidad machista, patriarcal, operó en todo momento en el partido. Precisamente, eran los hombres los que tenían que volver a Chile mientras que las compañeras se tuvieron que quedar en el exilio cuidando a los hijos. Los compañeros regresaban solos y algunos hacían vida de solteros junto con la vida de militante clandestino. Además, por lo general, muchas mujeres tuvieron que compaginar su militancia con el trabajo, que en la mayoría de los casos era muy precario. Esta mentalidad relegaba a la mujer a un segundo plano en tanto se suponía que ella no era tan capaz para enfrentar la dictadura como sí lo eran los varones" ${ }^{\text {"281 }}$

\footnotetext{
${ }^{279}$ Ver Anexo. Entrevista No 30.

${ }^{280}$ Ver Anexo. Entrevista No 37.

${ }^{281}$ Ver Anexo. Entrevista No 20.
} 
-"Me sentí un poco discriminada cuando enviaron a mi marido a estudiar fuera y yo me quedé cuidado de mi hija. Incluso hoy en día es más difícil que una compañera se destaque en el partido",282

-“El partido jamás desarrolló una política para que las mujeres que tuvieran hijos pudieran integrarse adecuadamente a la actividad política o regresar a Chile... Yo tuve la suerte de contar con el apoyo económico y familiar para compaginar mi maternidad con mi militancia, también debo agregar que el PS me apoyó económicamente, pero esto no se dio con la mayoría de las compañeras madres"283

Por todo lo expuesto se puede afirmar que la maternidad se convirtió en una dificultad para las militantes en su actividad opositora, no así la paternidad para los varones, ya que pudieron conservar sus tiempos intactos para poder dedicarse plenamente al partido.

Muy pocas mujeres se revelaron ante esta situación, exigiendo a sus parejas mayor implicación e igualdad. En estos casos, la respuesta de los hombres solía ser de rechazo, ya que casi siempre desestimaban las demandas de sus compañeras sin transformar sus posicionamientos (al fin y al cabo querían conservar unos privilegios cotidianos que sentían como propios y/o naturales a su sexo).

Todo ello solía derivar en conflictos de pareja cuando no en ruptura, y casi siempre por iniciativa de la mujer, ya que era la más interesada en cambiar unos los roles y posicionamientos de género que la terminaban perjudicando (sienten que ellas eran las que finalmente tenían que renunciar a sus expectativas de crecimiento personal y acoplarse a las necesidades del hombre):

-"Yo militaba, tenía dos niños y también cuidaba a mi marido. De hecho, tuve muchas dificultades con mi esposo por mi militancia porque él quería que dejara la Jota para cuidar a los hijos; yo me negué siempre.... De esa forma, sentía que salía de la rutina en la que la mayoría de las mujeres estaban sumidas, es decir, relegadas al hogar, a la casa mientras que el marido salía a trabajar. Siempre me rebelé contra esto. Una vez intenté separarme de mi marido por estas discrepancias,"284

-"Tuve a mi hijo y en los primeros meses me vi obligada a renunciar a mi militancia. Después, pasé a formar parte de la orgánica del Comunal, con responsabilidades mayores. Tenía que atender a compañeros e iba con mi bebé colgando. Después se rompió mi relación de pareja, me quedé completamente sola, caí en una depresión. Aún así, seguía teniendo vínculos"

\footnotetext{
${ }^{282}$ Ver Anexo. Entrevista No 33.

${ }^{283}$ Ver Anexo. Entrevista No 21.

${ }^{284}$ Ver Anexo. Entrevista No 38.

${ }^{285}$ Ver Anexo. Entrevista No 39.
} 


\subsubsection{Dificultades en el acceso a las responsabilidades partidarias.}

¿Qué ocurrió con aquellas militantes que no tuvieron hijos? ¿Se dieron otro tipo de discriminaciones de género en los partidos de la izquierda?. Los testimonios dejan constancia de que las mujeres que no tuvieron a su cargo a menores dispusieron de más facilidades para desarrollarse tanto en lo profesional como en lo político.

Muchas de las activistas que llegaron a ocupar puestos de responsabilidad partidaria, por ejemplo, en los comités centrales y en las comisiones políticas de los partidos de la izquierda, no eran madres, y en muchos casos no por voluntad propia si no por la imposibilidad real de conciliar ambas actividades sin tener que renunciar a una de ellas.

Como si de un precio a pagar se tratara para poder cumplir con sus aspiraciones políticas, muchas mujeres entendieron que la única vía posible para dedicarse plenamente a sus aspiraciones pasaba por renunciar a su maternidad, percibiéndose ésta, tal y como ocurre hoy en día, como un obstáculo para su promoción personal.

Por tanto, se podría considerar esta circunstancia como una discriminación de género implícita, ya que, los hombres no tuvieron que renunciar a su paternidad para poder desarrollarse "políticamente/públicamente" ya que disponían de "recursos femeninos" que hicieran el trabajo que por equidad les correspondía (a través de sus parejas, madres, hermanas...).

Asimismo, existieron otras variables discriminatorias en las "altas esferas del partido", especialmente a la hora de ocupar "la silla vacía" de un dirigente caído, ya que frecuentemente era otro hombre quién lo hacía, aún sin contar con la misma experiencia dedicación y compromiso que una candidata femenina.

Otros obstáculos mencionados tienen que ver con las barreras que los dirigentes les pusieron a la hora de participar equitativamente en la toma de decisiones importantes, por ejemplo, al no tener derecho a voto a la hora de establecer la organización interna y las estrategias políticas a seguir, etc..

En efecto, las discriminación de género se dio en todos las esferas de los partidos de la izquierda opositora, como si de un obstáculo permanente y transversal se tratara. El plano de la lucha armada fue muy representativo. Aunque y como se ha analizado en 
apartados anteriores, algunas mujeres recibieron formación militar y participaron en diversos operativos, lo cierto es que ellas experimentaron un cuestionamiento de sus capacidades y aptitudes para desempeñar éstas actividades, aún estando igual de preparadas que sus compañeros.

En los relatos aparece el concepto de mujer metralleta, es decir, aquellas militantes excepcionales (superdotadas) y masculinizadas (especialmente agresivas) que habían accedido al a lucha armada.

En estos casos, minoritarios, las entrevistadas percibieron que por lo general los compañeros se mostraban temerosos ante la idea de verse con una compañera militando de igual a igual, una trasgresión poco tolerada por ellos en relación a los estereotipos sexistas de mujer que esperaban de las activistas: hombre guerrero versus delicadeza y sensibilidad femenina.

Otros mitos que se dieron con frecuencia tuvieron que ver con la diferenciación de las aptitudes intelectuales y las emocionales en base al paradigma biologicista: las primeras corresponderían a los varones y las segundas, a las mujeres, lo que en último término serviría de justificación utilizada para que ellas no pudieran desempeñar las mismas actividades:

\footnotetext{
-"Mis compañeros siempre me veían como una mujer delicada, que no podía desempeñar un trabajo miliar. Yo tuve que demostrar constantemente que podía manejar un fusil, y que sí tenía las capacidades para defenderme de la represión de la dictadura. En los cuadros militares los compañeros fueron bastante machistas. La presencia de una mujer en la formación militar era algo muy complicado. En mi caso, me encontré con mucho rechazo por parte de los hombres, tanto en los cuadros militares como en los comités locales" ${ }^{\text {"286 }}$

-"En mi caso creo que se me ha visto como una militante conflictiva. Cualquier varón que tenga una personalidad como la mía, es decir, más reivindicativa se le ve cómo alguien brillante mientras que a nosotras se nos ha visto como neuróticas, histéricas o cualquier $\operatorname{cosa}^{2287}$
}

\footnotetext{
${ }^{286}$ Ver Anexo. Entrevista No 30.

${ }^{287}$ Ver Anexo. Entrevista $N^{\circ} 34$.
} 


\subsubsection{Otras discriminaciones.}

La información analizada nos descubre también situaciones que se podrían calificar como discriminaciones más sutiles en el ámbito de la pareja y casi siempre relacionadas con las decisiones que tenían que ver con el compromiso político y clandestino.

Una que suele aparecer con relativa es la falta de autonomía de las mujeres a la hora de tomar decisiones en su vida privada, por ejemplo, cuando se trataba de abandonar o no el país, separarse de su pareja o tener un empleo.

En esta línea, algunas señalan que fueron sus maridos los que decidieron unilateralmente salir o no al exilio, regresar al país o instalarse en un determinado lugar, cumpliendo con el rol subsidiario de seguir a sus hombres sin que su opinión fuera tenida en cuenta: "los hombres partieron al exilio por política, las mujeres por amor" 288 :

-"Este tipo de decisiones fueron las que muchas mujeres tomamos en aquella época bajo la influencia y predominio del criterio de nuestros maridos. Quedarse en Chile significaba romper la relación de pareja. La decisión de salir del país fue de mi marido y no mía. Viví en Costa Rica cuatro años y siete en México. En 1979 partí a México y tuve una fuerte vinculación con el movimiento de mujeres aunque mi primera aproximación al feminismo fue teórica"289

Por otra parte, algunos estudios han aportado interesantes reflexiones sobre el rol que el varón reproducía en la militancia opositora. Por tradición cultural, ellos debían asumir un posicionamiento competitivo, protagónico y no vulnerable, lo que en opinión de algunas también suponía una carga difícil de llevar. Así, según esta óptica, fueron frecuentes los casos de hombres que siguiendo lo que se esperaba de ellos (por ejemplo, priorizar la lucha contra la dictadura sobre cualquier otro interés personal o tener que mostrarse valientes y heroicos poniendo en peligro sus vidas) tuvieron que renunciar a su vida personal y familiar sin verdaderamente quererlo:

\footnotetext{
${ }^{288}$ Ver Anexo. Entrevista No 11

${ }^{289}$ Ver Anexo. Entrevista No 22.
} 
-"El hombre militante, al fin y al cabo es heredero y formado en una cultura patriarcal autoritaria, tuvo que asumir una conducta estoica donde no tenía cabida el miedo ni la debilidad... Después en el exilio tuvo que reconstruir su vida, ¿una nueva masculinidad?...entre héroe mítico de la lucha por la patria o muerte a la figura de baja autoestima excluido de la realidad presente...Las exigencias del rol masculino, en su función de actor protagónico en la lucha política, a lo que se sumaron las crecientes y nuevas demandas que surgían de la misma conciencia y discurso de los partidos políticos de izquierda por relaciones de género más equitativas" ${ }^{290}$

Finalmente, cabe destacar la circunstancia de que cuando los esposos o compañeros cayeron presos o fueron asesinados, las militantes se veían presionadas, por imperativo social, a tener que asumir un duelo eterno para con sus esposos caídos, lo que les dejaba en una posición de eternas "viudas dolientes". Claramente, ello suponía tener que renunciar a cualquier expectativa de nueva relación sentimental o sexual con otros hombres. De no hacerlo, serían increpadas por sus camaradas bajo estereotipos sexistas que las infravaloraban:

-“Además hay algo que quiero reflejar, las mujeres que rehicimos nuestra vida sentimental fuimos tremendamente criticadas y discriminadas.... Imperó la idea de viuda doliente o el luto eterno por el compañero dentro de toda esa influencia del ideario patriarcal de muchas compañeras" $" 291$

-"Yo tuve un novio inglés y fui muy criticada por mis compañeros chilenos por no relacionarme con un compatriota...claro porque en el fondo decían por que con este y conmigo no...como si no pudiera decidir por sí sola, seguramente pensaban que eras una mujer fácil",292

\footnotetext{
${ }^{290}$ Estrada A., Hering M. y Donoso A., Familia, Género y Terapia, CODEPU, Santiago de Chile, 1996, p.25.

${ }^{291}$ Ver Anexo. Entrevista No 21.

${ }^{292}$ Ver Anexo. Entrevista $N^{\circ} 24$.
} 


\title{
3.8 El discurso imperante en la izquierda chilena: primero el derrocamiento de la dictadura, después la igualdad de género.
}

\begin{abstract}
-"Yo elaboré varios documentos respecto al rol de la mujer en el partido. Este trabajo fue rechazado en las reuniones. La idea era crear una Comisión de Mujeres al interior de la Jota que tuviera peso y relevancia en las decisiones de la Comité Central. Recuerdo que el secretario de la Juventud golpeó fuertemente la mesa diciendo que - "ino permitiré reivindicaciones socialdemócratas!-”. Sólo tres personas del Comité Central apoyaron la iniciativa. El resultado fue que me sacaron de la Comisión, es decir, me echaron."293
\end{abstract}

Las discriminaciones por razón de género anteriormente descritas son interpretadas por las entrevistadas como la consecuencia de dos factores. El primero, por la continuidad de unos roles machistas consuetudinarios e históricamente consolidados (tanto en hombres como en mujeres) que impedían una igualdad de facto en el devenir militante.

En segundo lugar, por las múltiples resistencias de los hombres a perder unos privilegios que sentían como propios (protagonismo y poder de decisión). De esta manera, aunque muchas mujeres alzaron su voz para incorporar la igualdad en los partidos como un elemento transversal, una y otra vez fueron rechazadas cuando no estigmatizadas por considerar que solo querían velar por sus propios intereses

En otras palabras, seguía existiendo, tanto en las cúpulas como en la base de las formaciones de la izquierda, la percepción de que las demandas específicas de las mujeres debían plantearse una vez logrado el cambio político estructural (una sociedad comunista, socialista o democrática) como si la desigualdad fuera a desvanecerse con el derrocamiento de la dictadura militar:

-"Yo escribí diversos documentos que recogían la cuestión de género...La visión siempre fue muy conservadora. En la época de la dictadura, el PS hizo oídos sordos a estas demandas, sólo la lucha contra el régimen militar era el objetivo y cualquier otra cosa significaba una desviación" 294

-"El partido, mirado con una perspectiva rigurosa de género, en ese tiempo se podría decir que no tenía una política de género. En lo cultural, la militancia de las mujeres en política no era algo común, era algo anormal para la mentalidad de la época. En muchas

\footnotetext{
${ }^{293}$ Ver Anexo. Entrevista No 44.

${ }^{294}$ Ver Anexo. Entrevista No 19.
} 
oportunidades no ha considerado las dificultades culturales que las mujeres comunistas han tenido para desarrollarse plenamente en el PC. Creo que ha faltado hacer una doble militancia de las mujeres en el PC, una política y una feminista. Se ha tendido ha mezclar las cosas lo que ha supuesto un claro error porque son dos luchas que, aunque compatibles, han de abordarse de forma independiente porque la problemática que se la plantea a la mujer requiere de un espacio específico" ${ }^{\text {295 }}$

-"Nunca hubo un debate o reflexión a nivel de partido sobre la condición de la mujer militante. El objetivo principal era echar a Pinochet y desestabilizar su gobierno...las preocupaciones eran otras, esto ni se cuestionaba" 296

En efecto, los tres partidos más representativos de la izquierda chilena en dictadura, tal y como ocurrió en el contexto internacional de los regímenes socialistas y comunistas, partían de la premisa de que la instauración de sus modelos políticos implicarían automáticamente la equiparación de derechos de ciudadanía entre hombres y mujeres, lo que les llevó a desestimar las reivindicaciones de igualdad mientras durase la dictadura:

-"Nos parece imperativo que el partido tome conciencia de la necesidad de contar con el más amplio apoyo de la mujer...el derrocamiento de la dictadura y la construcción de un bloque para el socialismo requiere la incorporación y participación masiva de las mujeres de las clases explotadas" 297

Como expone la historiadora Margarita Iglesias y ex militante del MIR, no existió un debate específico sobre la discriminación de la mujer en los partidos, dado que sencillamente no se contemplaba esta posibilidad. El objetivo común era acabar con la dictadura y establecer un nuevo orden social y político en donde todos $\mathrm{y}$ todas obtendrían los mismos derechos. Por esta razón, las activistas fueron rechazadas por sus dirigentes por considerar que planteaban cuestiones fuera de tiempo y lugar:

-"Las reivindicaciones y las demandas se solían hacer siempre en un plano económico porque, en el plano cultural, ideológico y social este debate nunca se dio. Dicho de otra manera, eran propuestas puntuales pero en ningún caso un debate que cuestionara el sistema cultural que no era otro que la dominación patriarcal"298

\footnotetext{
${ }^{295}$ Ver Anexo. Entrevista No 32.

${ }^{296}$ Ver Anexo. Entrevista No 30.

297 Ver Villanueva P., Cuadernos de Orientación Socialista, № 19, Secretaría Ideológica del Secretario Exterior del PSCH, Berlín, noviembre 1984, p. 52.

${ }^{298}$ Ver Anexo. Entrevista No 9.
} 
Hay que recordar que la mayoría de las militantes no disponían de una conciencia de género lo que determinó que no se sintieran discriminadas en aquella época. La mirada crítica de las militantes fue tomando forma conforme la dictadura llegó a su fin, y se fueron abrieron nuevos espacios de encuentro en libertad.

Además, parte de las exiliadas que retornaron a Chile trajeron consigo nuevas ideas que incluían la perspectiva de género en el quehacer político, una aportación que generaba resistencias incluso entre las propias mujeres:

-"Yo, al igual que otras compañeras que habíamos vivido en Europa habíamos tenido la posibilidad de estudiar, de ser parte de avances que para la mujer en Chile eran impensables. Eran códigos distintos, nosotras absorbimos otra mentalidad que pasaba por incorporar a la mujer plenamente en la vida partidaria. Incluso te diría que estas dos visiones siguen existiendo hoy en día. Yo me he encontrado recientemente con compañeras que se han negado a crear una comisión de mujeres independiente a la dirección de partido"299

De esta forma, algunas de ellas pusieron de manifiesto a través de diferentes medios, sus desacuerdos con sus partidos al no querer abanderar sus propuestas de igualdad. Tal fue el caso de la socialista Ana María Arteaga quién en su artículo "Exégesis de la participación de las mujeres" 300 , ponía sobre la mesa "la verdadera raíz de la subordinación de la mujer" más allá de cualquier circunstancia coyuntural como la dictadura. Exigían que la izquierda fuera coherente entre su discurso "revolucionario" y la práctica concreta:

-"El discurso marxista clásico respecto a la situación de explotación y opresión de la mujer no ha sido superado....comúnmente se reduce y supedita la solución del problema de la mujer a la lucha general por la eliminación de la división de la sociedad en clases y se aplaza la resolución final del problema para después de la revolución como si ello fuera su resultante automática y natural. La izquierda chilena no ha escapado de este visión parcial de la situación de explotación y opresión de la mujer, lo cual ha tenido una gran incidencia en su discurso y estrategia...Porque nuestra movilización conjunta no se limita al adversario común que hoy nos somete. Incluye otro, anterior...otro cuyo poder no se traduce en fusil, como el presente, pero que igual decide sin consulta, subordina, es esencialmente jerárquico, sordo, obstinado y excluyente" ${ }^{301}$

\footnotetext{
${ }^{299}$ Ver Anexo. Entrevista No 32 .

${ }^{300}$ Ver Convergencia: revista del socialismo chileno y latinoamericano, $\mathrm{N}^{\circ} 11$ abril-junio 1987, Santiago de Chile.

${ }^{301}$ Ibíd., p.23.
} 
Por otra parte, sí bien existieron algunas propuestas específicas dirigidas a las militantes por parte de los dirigentes, éstas tendieron a reproducir los roles y estereotipos tradicionales. Concretamente, la mayoría de las formaciones pusieron en marcha políticas encaminadas a facilitar la conciliación entre militancia política y las tareas domésticas y cuidados de los hijos, un costoso equilibrio que solían asumir finalmente las mujeres bajo el discurso biologicista como justificación:

\begin{abstract}
-"Creo que el problema de la maternidad fue una dificultad para las mujeres miristas. Mi marido era miembro del Comité regional para pasar después a ser miembro del Comité central. Cuando tuve a mi hija de una forma natural parecía que tuviera que asumir los cuidados del bebé. Esto me causó mucha rabia y frustración. Recuerdo que mandé una carta al jefe de mi marido expresando mis derechos a ejercer una militancia política como cualquier otro compañero. La respuesta suya fue que yo abría un problema de seguridad al ser pareja de un miembro de la Dirección. Es decir, mi posición era de mujer de un militante del MIR que ejercía un papel de ayudista. Esto, efectivamente, fue una pauta constante dentro del partido. La mujer dentro del MIR siempre era concebida como madre" ${ }^{\text {302 }}$
\end{abstract}

Aunque las mujeres desempeñaron una intensa actividad política en clandestinidad y en el exilio, reconocida y agradecida por los compañeros de filas, ello no debía implicar que las ellas olvidaran "sus funciones femeninas de siempre", lo que en definitiva supuso una carga extra al tener que asumir una triple jornada, la política, la doméstica y la de los cuidados formales de los menores.

En cualquier caso, algunas iniciativas pudieron tomar forma aún sin contar con el apoyo de los compañeros de filas. El Frente de Mujeres Revolucionarias, impulsado por militantes del Movimiento de Izquierda Revolucionaria, tuvo como principal objetivo contactar con mujeres de las poblaciones más desfavorecidas para abordar los problemas que pudieran tener en su cotidianeidad, lo que implicó una acción colectiva y específica de género.

También, la revista Voz de la Mujer, ligada al Partido Comunista, fue un ejemplo de organización en pro de los derechos humanos de las chilenas al perfilarse como un espacio de denuncia sobre aquellas mujeres que decidieran por voluntad propia prestar testimonio de la represión sufrida:

${ }^{302}$ Ver Anexo. Entrevista No 9. 
-“A los quince días del funcionamiento del Frente de Mujeres Revolucionarias los compañeros de la dirección nos dijeron que esto no era la prioridad, jesto no es un problema de hombres y mujeres sino de lucha de clases!, decían. No tuvimos ningún éxito, y el argumento fundamental es que era un problema de clases y no de género y que después de que lográramos avanzar en este sentido podríamos trabajar las demandas particulares"303

-"Yo planté al partido la iniciativa de las mujeres con este trabajo. De forma oficial no pusieron ningún problema, pero en la práctica, cuando mandamos los diarios, empezaron los problemas. De hecho, alegaron que no era adecuado en ese momento plantear demandas del género femenino. Era una propuesta de varias mujeres que opinaban sobre la dictadura y sobre lo que podían aportar a la lucha partidaria, que no interesó en absoluto a los jefes"304

Un reflejo de la mirada patriarcal de las formaciones de la izquierda lo encontramos también en la prensa clandestina de la época, en donde aparecen diversos artículos que dan cuenta de la pervivencia de los estereotipos sexistas.

El diario El Siglo, un referente de la prensa opositora del Partido Comunista, recogía en uno de sus numerosos escritos un homenaje a la activista asesinada por la DINA, Carmen Gloria Larenas. En el documento, se alababan "las cualidades femeninas de la militante", como la abnegación, temple y amor, aptitudes históricamente asignadas a las mujeres:

-"El corazón de todos los revolucionarios se sobrecoge por la pérdida de una combatiente en la plenitud de su vida y entregada a la lucha por los valores más altos y nobles del ser humano...en la mejilla de todos los hombres con vocación democrática hay una lágrima preñada de razones...Carmen Gloria era la menor de diez hermanos, de familia modesta....su risa, su amor, su abnegación, su temple, son herencia que enriquecerá nuestro espíritu"305

En otros casos, incluso las compañeras de las mujeres caídas al recordarlas, confirman lo que se ponían en valor de las activistas: su función como suministradoras de apoyos: "Recuerdo a Lumi Videla por su valentía, era una mujer con mucha fortaleza, que

\footnotetext{
${ }^{303}$ Ver Anexo. Entrevista $\mathrm{N}^{\mathrm{o}} 10$.

${ }^{304}$ Ver Anexo. Entrevista No 11.

${ }^{305}$ Ver diario El Siglo, Homenaje a Carmen Gloria y a todos los héroes de la juventud, № 7578 , julio de 1983, p. 6.
} 
prestaba auxilio y consuelo a los prisioneros, de algún modo incluso les conseguía algo de alimentos como pan...,306

El Siglo, solía recoger noticias relacionadas con el quehacer político de las militantes pero siempre desde la esfera doméstica y maternal y en "su posición en la retaguardia de de los varones". Otro ejemplo lo encontramos en la valoración que sus redactores realizaron sobre el IV Encuentro de la Mujer Trabajadora durante el mes de diciembre de 1981 celebrada en Santiago.

En él, se abordaron temas clave como el trabajo en pro de los derechos humanos, la situación laboral y social de las obreras, y la demanda de equiparación salarial. Sin embargo, lo que se destacó en el artículo tuvo que ver precisamente con aquellas reivindicaciones que reproducían mayormente el papel tradicional de las chilenas: ampliación del fuero maternal, extensión de las salas cuna y jardines infantiles, viviendas dignas para las "dueñas de casa" etc. Ello eclipsó otras cuestiones como las dificultades con las que las mujeres se encontraban en sus propios partidos cuando éstas demandaban igualdad.

Por tanto, se obviaron cuestiones que planteaban un debate mucho más profundo sobre la igualdad de género, por lo que podemos presumir una "defensa consciente o subconsciente de los lugares privilegiados que los hombres ostentaba: "En el encuentro ha expresado su decisión de luchar por la plan vigencia del fuero maternal, peor el cumplimiento de la ley de las salas cunas y jardines infantiles, por la igualdad de trabajo, por tener un acceso a la vivienda digna y por el reconocimiento social de las dueñas de casa",307

Por otra parte, en el documento oficial del XXIV Congreso del Partido Socialista (1983) aparecía bajo el lema "Por la emancipación de la mujer" una tímida mención a lo que presumiblemente debía de ser una línea de actuación en materia de género. El texto defendía la necesidad de readecuar el papel de la mujer en la sociedad de clases ya

\footnotetext{
${ }^{306}$ Ver declaración extrajudicial de Marcia Alejandra Evelyn Merino Vega. Diligencia de Luz Moya Díaz. Tercer Juzgado del Crimen, Santiago, Investigaciones de Chile, Inspectoría General, Departamento V, Parte no 34, Santiago, 24 de noviembre de 1992, p. 372.

307 Ver diario EL SIGLO, Mujeres exigen respeto a la vida y fin al terror pinochetista, $\mathrm{N}^{\circ} 7548$, noviembre de 1981, p. 4.
} 
que éste ha sido deformado por el capitalismo y dar mayor voz a las mujeres en la izquierda, aunque sin concretizar cómo y cuando.

Nuevamente, militante y responsabilidades doméstico-familiares aparecían estrechamente ligadas en el discurso, lo que en definitiva venía a suponer que las activistas continuarían encorsetadas en sus lugares de siempre.

Como queda de manifiesto, el contenido estaba poco definido al no explicitarse cuáles eran las demandas concretas que las socialistas reivindicaban para sí. Por ende, el documento, aunque incorporaba la cuestión de la emancipación femenina en el proyecto socialista, quedó en una mera declaración de intenciones difusas:

-"La problemática de la mujer al interior del partido requiere de un debate ideológico interno...en que se asuman auto-críticamente las insuficiencias partidarias del pasado...La readecuación de la mujer y de la familia en el proyecto de nueva sociedad que debemos diseñar... reafirmando su presencia liberadora y auténticamente femenina"308

Las entrevistadas coinciden en que a día de hoy, algunas de estas tendencias siguen reproduciéndose en sus partidos y las dificultades que siguen teniendo las mujeres a la hora de plantear sus demandas no distan mucho de las que tuvieron en los años de dictadura. Aunque si bien reconocen que desde la instauración de la democracia en Chile los avances han sido sustanciales, indican que todavía hay discriminaciones de envergadura por resolver.

Las más mencionadas refieren a la falta de un reconocimiento de aquellos problemas que las activistas sufrieron desde sus propios partidos en tiempos de clandestinidad, especialmente aquellas relacionadas con la sobrecarga de tener que cumplir con las funciones militantes y el cuidado integral de sus hijos. Esta circunstancia mermó las posibilidades de las militantes para poder desarrollase en otros espacios, lo que generó también un impacto negativo en su salud, coste que sienten no fue correspondido con apoyos concretos de sus formaciones o con una mayor representación en los espacios de poder.

\footnotetext{
${ }^{308}$ Convocatoria al XXIV Congreso del Partido Socialista de Chile, Cuadernos de Orientación Socialista, No 14/15, abril de 1983, Berlín 1983, p. 123.
} 
También aluden a que la aportación de las mujeres en la oposición contra la dictadura no fue correspondida en democracia a la hora de gozar de los mismos espacios y oportunidades que los hombres, lo que les genera un sentimiento de decepción por haber dedicado sus vidas altruistamente al partido para después no ser tenidas en cuenta:

-"Cuando se necesita a la mujer como bandera para conquistar los derechos democráticos ella adquiere un papel relevante pero parece que luego se la relega a su papel tradicional, es decir, a la crianza de los hijos y al hogar. Esta decepción no sólo me viene de los gobiernos democráticos que hemos tenido, sino del propio partido"309

-“Al partido puedo recriminarle la ceguera con la mujer. La falta de objetividad con nuestras realidades y de reproducir los discursos conservadores de siempre" ${ }^{\text {"310 }}$

-"Lo que sí te puedo decir es que el Movimiento de Mujeres fue duramente golpeado y que en el proceso de transición a la democracia los partidos políticos de izquierda se olvidaron del aporte que las organizaciones lideradas por las mujeres a la hora de planificar los objetivos partidarios ante el nuevo escenario político. Creo que el Partido Socialista sigue viendo a la mujer como un acompañamiento a la política y no como un actor con voz y voto. La mujer sigue relegada a un ámbito secundario, pese a que tenemos dos candidatas a presidentas de la República"311

-“Tan sólo a finales de la década de los noventa las mujeres han ido abriéndose un espacio dentro del partido que las ha colado en mayores cuotas de representación pero en ningún caso alcanzando niveles equitativos en los puestos de dirección con respeto a los hombres"312

-"Creo que en el partido ha predominado la estructura patriarcal y el predominio masculino. La mujer tiene que luchar doblemente para ganar espacios. Aunque hoy en día haya un respeto mayor hacia las mujeres, la estructura de dominación sigue estando copada por los hombres"313

-"Yo era padre y madre. Mis hijas tenían 11 y 12 años, era una edad muy complicada; me quedé prácticamente sin recursos y además tenía que hacer frente a una tragedia familiar. Desde el partido hubo muchas declaraciones pero ninguna acción. No participaron en el apoyo laboral y económico. No aportaron nada a la educación de mis hijas puesto que no recibieron ninguna ayuda o consideración especial. El partido fue muy ingrato en este sentido. Una sentía que después de haberse jugado el pellejo aparecían compañeros desconocidos que salían adelante. Esto fue el detonante para convencerme de que militaba en un partido machista. Había hombres que sin rodaje político aparecía como personas nuevas y ocupaban cargos de responsabilidad. A partir de este momento me convertí en activista de género"314

\footnotetext{
${ }^{309}$ Ver Anexo. Entrevista $N^{\mathrm{o}} 14$.

${ }^{310}$ Ver Anexo. Entrevista $N^{\circ} 19$.

${ }^{311}$ Ver Anexo. Entrevista $N^{\circ} 20$.

${ }^{312}$ Ver Anexo. Entrevista No 21

${ }^{313}$ Ver Anexo. Entrevista No 22.

${ }^{314}$ Ver Anexo. Entrevista No 23.
} 
En resumen, se puede afirmar que cuando las mujeres fueron necesarias y mostraron dotes de liderazgo en tiempos de dictadura, los partidos de la izquierda aplaudieron sus aportes y las dejaron hacer. Una vez finalizada, no se contó con ellas lo suficientemente para participar y liderar los nuevos retos que se abrían con la instauración de un régimen democrático (elección de representantes de las directivas, los candidatos a diputados, senadores, regidores u otros cargos, etc.)

Sin bien algunas mujeres alcanzaron espacios de poder en los partidos durante los gobiernos de la concertación (1990-2010) (Gladys Marín -Partido Comunista, Michelle Bachelet -Partido Socialista, Soledad Alvear -Partido Demócrata Cristiano...) lo cierto es que se trataron de casos aislados que no reflejaban la realidad de la militancia en su conjunto ya que su representación sigue siendo subsidiaria. 


\subsection{Mujeres en la doble militancia, el caso del Partido Socialista.}

A principios de la década de los ochenta empezaron a sucederse voces críticas de algunas mujeres ligadas al Partido Socialista para con sus dirigentes por no atender suficientemente sus demandas pro-igualitarias: más representación, poder de decisión, recursos para conciliar, órganos específicos de mujeres en los partidos para abordar cuestiones como salud, derechos reproductivos o sexualidad, etc.

Hay que recordar que durante los años de la Unidad Popular (1970-1973) hubo un incremento considerable de la población universitaria femenina, que además de formarse académica y políticamente, también accedió al conocimiento feminista a través de la lectura de textos sobre la emancipación de la mujer y la defensa de sus derechos. Todo ello serviría para que una parte de ellas empezara a plantear una mirada crítica tras los primeros años de la dictadura.

La represión militar y el impacto en las mujeres, los problemas y/o discriminaciones en el devenir militante y los desafíos que podría conllevar la llegada de un cambio democrático, las impulsó para exigir y poner en práctica sus demandas; de no ser escuchadas optarían por fórmulas alternativas de militancia, por ejemplo, fundando o entrando en agrupaciones de diversa índole (culturales, sociales, políticas, profesionales, etc.).

De esta manera, parte de las militantes socialistas experimentaron un cierto empoderamiento a través de la creación de espacios colectivos propios que también agrupaban a otras tantas de procedencia variada. En estos lugares compartirían experiencias, se formaban en el saber feminista y diseñaban estrategias de acción política para conseguir que sus demandas finalmente se cumplieran.

Las entrevistadas que militaron en el PS y que se vieron involucradas en este proceso, exponen que el análisis sobre su situación como mujeres en el partido comenzó a partir del estudio sobre la relación histórica entre el socialismo y el feminismo. 
Un ejemplo lo encontramos en el nacimiento del Movimiento de Mujeres por el Socialismo (MMS, marzo 1984), una agrupación que apostaba por trabajar de forma específica todo aquello relacionado con las mujeres pero sin dejar de colaborar con el Partido Socialista en la lucha por objetivos comunes. El MMS aglutinó a toda una heterogeneidad de mujeres (profesionales, amas de casa, feministas, independientes, militantes, artistas, etc.) identificadas con el socialismo pero demandando su propia autonomía e identidad: "Un aspecto central de la discusión fue la autonomía del Movimiento. Había consenso en rechazar cualquier dependencia de partidos, sin embargo, reconocíamos mayor cercanía con la concertación del área socialista..."315

En mayo de ese mismo año, se realizaron las primeras jornadas cuyo resultado fue la elaboración de una declaración de principios que abarcaba cuestiones nunca antes tratadas en el ámbito de la izquierda política:

-"Las propuestas son: contribuir al término de la dictadura en Chile. Ser partícipes y protagonistas en la construcción de un Proyecto Socialista para Chile. Comprometerse en la lucha por la defensa de la vida, el restablecimiento de la justicia y la recuperación de la dignidad de las personas. Luchar por poner fin a todas las formas de opresión de la mujer. Combatir el autoritarismo en las relaciones sociales y las discriminaciones sexuales. Mantener y defender nuestra autonomía como movimiento. Reconociendo la validez e importancia de los partidos políticos no queremos establecer relaciones de dependencia con ninguno de ellos. Respetar y valorar la heterogeneidad al interior del movimiento, respetando la diversidad...Está la tensión que implica mantener esta doble identidad de ser un movimiento de mujeres y un movimiento político...creemos que no habrá democracia en Chile mientras exista discriminación y opresión sexual" ${ }^{\text {316 }}$

La declaración venía a proponer que el trabajo político en torno a los derechos humanos y el derrocamiento del régimen militar debía estar acompañado de la lucha por superar los lastres discriminatorios que la mujer venía sufriendo desde siempre, y esto, debía hacerse de forma independiente.

Por consiguiente, las trabas de las chilenas ya no se reducían a una cuestión de clase ya que el sistema de dominación masculina fue adquiriendo consistencia como elemento a

\footnotetext{
${ }^{315}$ Ver Movimiento de Mujeres por el Socialismo, en Adriana Sepúlveda, Conferencia Internacional "La participación política de la mujer en el cono sur", Montevideo, Uruguay, junio de 1986, p. 101

${ }^{316}$ Ibíd., p. 104
} 
la hora de establecer las claves explicativas de la subordinación general femenina (política, social, económica y sexual).

Una de las fundadoras de este movimiento fue Julieta Kirkwood ${ }^{317}$, un ejemplo de la doble militancia y autora de obras de influencia internacional en el conocimiento del género (Ser Política en Chile 1984). Su planteamiento político abogaba por superar los obstáculos ancestrales $^{318}$ entre socialismo y feminismo, como un intento de reconciliación histórica entre el partido y aquellas militantes que se habían distanciado por no sentirse verdaderamente representadas.

El desempeño de Kirkwood venía a reflejar la necesidad de crear espacios abiertos y heterogéneos que permitieran compaginar la lucha contra la dictadura desde un partido, aunque estuviese dominado por hombres, y paralelamente trabajar políticamente desde otros lugares específicos de mujeres. Aunando ambos esfuerzos las posibilidades de transformación y mejora del bienestar de las mujeres aumentarían considerablemente.

Kirkwood, ejerció una activa militancia desde los años sesenta en el ámbito universitario; allí gracias al estudio e influencia de las obras feministas anglosajonas, adquirió una formación que le serviría años después para elaborar los cimientos de un nuevo movimiento feminista chileno.

\footnotetext{
317 Julieta Kirkwood Bañados se licenció en Sociología por la Universidad de Chile en 1968. Asimismo, se tituló en Ciencias Políticas por la misma universidad en 1969. Fue profesora-investigadora en el programa FLACSO-Santiago entre 1972-1985. Participó activamente en la creación y existencia del Círculo de Estudios de la Mujer, revista Furia, movimientos y colectivos feministas, MENCH 83, La Morada, el Centro de Estudios de la Mujer (CEM), y en el departamento femenino de la Coordinadora Nacional Sindical.

Por otra parte, participó en la Academia de Humanismo Cristiano, en la Convergencia Socialista y en Mujeres por el Socialismo, esta última fundada con el objetivo de luchar "ahora y en democracia" por la liberación y derechos de la mujer. Ver Oyarzún K., y Olea R, en Tejiendo Rebeldías, www.mujereschile.cl, 2002.

${ }^{318}$ A finales de la década de los 60 ya empiezan a surgir corrientes feministas que tratan de superar la dicotomía socialismo versus feminismo. En este sentido, surgirán en los Estado Unidos agrupaciones como Radical Women (una rama del Partidos Socialista Feminista, FSP) que combinarán tanto el análisis económico-clase (capitalismo) como el estudio del concepto Patriarcado para explicar las fuentes de opresión de las mujeres. Véase el análisis de Amorós C., Historia de la Teoría Feminista, Instituto de Investigaciones de la UCM, Madrid, 1994.
} 
En 1983, fundó el Movimiento Feminista de Mujeres de Oposición a la Dictadura (MFMOD) y el Colectivo de Mujeres por la Vida, agrupaciones que aglutinaban a miles de mujeres de diversa procedencia política y social y en donde se dieron dos formas de lucha diferentes pero no incompatibles: democracia y derechos humanos pero también la igualdad de género (democracia en el país y en la casa).

Las actividades más destacadas fueron la publicación en boletines con artículos o estudios, la formación de mujeres a través de talleres, cursos y charlas, el apoyo económico, asesoramiento jurídico ante casos de represión y denuncias contra la dictadura.

Como refleja la autora, desde estos espacios no solo se luchaba contra Pinochet sino también se hacía política desde el ser mujer, abordando sus problemas específicos tanto dentro como fuera de casa. Esta experiencia para la mayoría, fue muy beneficiosa ya que pudieron contar con un apoyo terapéutico y reparador tras largos años de dificultades.

Esta inmensa y poco reconocida labor ponía de relieve que otra forma de hacer política era posible por varias razones. Primero, porque se trataba de un espacio compuesto y liderado por mujeres que sin la presencia de una jerarquía masculina podía favorecer enormemente el desarrollo de sus derechos y/o demandas. Segundo, porque fue un movimiento que no dejó de estar conectado con otras formaciones u agrupaciones en pro de la democracia, lo que le fortaleció y dio un radio de acción más amplio.

Desde allí y de forma pionera, se plantearon cuestiones muy espinosas e históricamente ignoradas: la violencia sufrida por las mujeres en todos los ámbitos, la identidad colectiva en cuanto a grupo humano discriminado, sus derechos sexuales y reproductivos, la igualdad laboral, etc.; en palabras de Raquel Olea, un cuestionamiento de todas "las verdades y las certezas" ${ }^{, 319}$ del sistema patriarcal:

\footnotetext{
${ }^{319}$ Kirkwood en su obra, Ser política en Chile (1986) realiza un análisis sobre "lo privado y lo público, lo doméstico y lo político, sus separaciones tajantes, sus desvirtuaciones, las divisiones de géneros que desembocan en profesionalizaciones de la vida". Ver Olea R., Femenino y feminismo en transición, escrituras de la diferencia sexual, La Morada, Santiago, 2000.
} 
-"La realización de la política es algo más que una referencia al poder del Estado, a las organizaciones institucionales, a la organización de la economía y a la dialéctica del ejercicio del poder. Es también repensar la organización de la vida cotidiana de mujeres y de hombres; es cuestionar, para negar la afirmación de la necesidad vital de la existencia de dos áreas experimentales tajantemente cortadas, lo público (político) y lo privado (doméstico), que sacraliza estereotipadamente ámbitos de acción excluyentes y rígidos para hombres y mujeres" ${ }^{\text {, } 20}$

Este fragmento de la obra clave de Kirkwood, muestra que para lograr los objetivos de igualdad era imprescindible realizar un análisis sociológico global sobre los espacios que hombres y mujeres habían ocupado desde antaño (desigualdad de partida), más allá de que el sistema capitalista las hubiera oprimido aún más.

De alguna manera se planteaba que la igualdad era transversal (un adelanto de lo se conocerían años después como mainstreaming) y que afectaba al desarrollo integral de las mujeres en su conjunto, especialmente cuando se revelaban contra el dominio de los hombres.

En definitiva, la autora fue pionera al proponer un análisis estructural de la socialización en los roles consuetudinarios de género, cómo forma más práctica de transformación hacia la igualdad entre los sexos, pero también por combinar dos formas de hacer política desde lugares distintos: la lucha anti-capitalista y la anti-patriarcado.

Otro ejemplo revelador lo encontramos en la Corporación de Desarrollo de la Mujer La Morada, asociación que tuvo su génesis en 1983 cuando un grupo de mujeres, entre ellas Kirkwood, tomaron la iniciativa de crear un espacio de reflexión exclusivo sobre la subordinación de las chilenas y los problemas concretos en su cotidianeidad.

El objetivo principal de esta organización fue la formación y concienciación de las mujeres acerca de sus propias realidades y posibilidades de fortalecimiento y/o empoderamiento personal cuyo fin era mejorar su calidad de vida. Pero también desde allí muchas aprovecharon para escribir y dar forma a sus propuestas de cambio, una

\footnotetext{
${ }^{320}$ Kirkwood, J., Ser política en Chile: las feministas y los partidos, Santiago, FLACSO, 1986, p. 67.
} 
producción literaria que años después se convertiría en referente internacional del feminismo contemporáneo latinoamericano.

Entre las historiadoras del feminismo chileno hay un consenso en establecer que la aparición de La Morada significó la refundación ${ }^{321}$ del movimiento feminista chileno en el plano intelectual, aunque no hubiera una voluntad concreta para ello.

Desde un contexto general, la segunda oleada del feminismo, nacida a principios de los ochenta, fue el resultado de la aparición de una amplia red de organizaciones de mujeres que ante la pasividad de los partidos a la hora de defender sus derechos y ante la brutal represión de la dictadura, decidieron organizarse para defender su dignidad.

Pero más allá del plano de la acción colectiva, La Morada lideró la producción literaria e intelectual específicamente feminista en un tiempo de clandestinidad y persecución, lo que le otorga un valor añadido:

-"Haber conseguido la recuperación interna a la par con la recuperación de la democracia en el país; haber instalado el tema de los derechos humanos de las mujeres y valorarlos como un instrumento de activismo nacional; ser una ONG que tiene una línea editorial en la producción de conocimientos; haber logrado un perfil profesional altamente calificado y reconocido como tal, sobre todo en materia de salud mental, ciudadanía y cultura...,322

\footnotetext{
${ }^{321}$ Ver Valdés, T., De lo social a lo político: la acción de las mujeres latinoamericanas, LOM ediciones, Santiago de Chile, 2000.

${ }^{322}$ Ver “La morada, radical y feminista”, Ciudadanía, 2002, www.mujereschile.cl
} 


\section{CAPÍTULO 4: LA TORTURA SEXUAL COMO ESTRATEGIA REPRESIVA CONTRA LAS PRISIONERAS POLÍTICAS}

La represión política y social que se fraguó con el advenimiento del golpe militar aquel 11 de septiembre de 1973, primero desde la Dirección de Inteligencia Nacional (DINA) y después desde la Central Nacional de Informaciones (CNI) en colaboración con los diferentes instituciones de las Fuerzas Armadas, supuso el comienzo de una nueva etapa en donde el propio Estado iba a diseñar una estrategia represiva nunca antes vivida en Chile y con dimensiones que incluso traspasarían las fronteras del país. El impacto que dejó la represión después de diecisiete largos años (1973-1990) todavía a día de hoy permanece en la sociedad chilena y "dificulta su reconciliación"323.

La mayoría de las investigaciones sobre violaciones de derechos humanos en tiempos de Pinochet coinciden en que desde el mismo día del golpe se moldeó un Estado que tendría la capacidad y la financiación necesaria para construir una red represiva que iba más allá de los operativos de las Fuerzas Armadas. Ello quedó materializado en la creación de un organismo que, a través de la captación de militantes de agrupaciones de extrema derecha, funcionarios o civiles simpatizantes de la dictadura, se encargaría del grueso de las detenciones, torturas y desaparición forzada de opositores.

En efecto, la DINA se creó formalmente el 14 de junio de 1974 por el decreto ley $\mathrm{N}^{\mathrm{o}}$ 521 y desde ese momento se configuró como la punta de lanza del aparato represivo de la dictadura hasta finales del 1977. Después, sería sustituida por la CNI, un organismo prácticamente idéntico pero con mayores restricciones a la hora de operar (más selectivo), en parte gracias a la presión internacional sobre Pinochet pero también porque la DINA había conseguido neutralizar a las cúpulas de la izquierda clandestina y a gran parte de la militancia opositora (los última revisión del Informe Valech ${ }^{324}$ estima que unas 50.000 personas sufrieron prisión política y tortura).

\footnotetext{
${ }^{323}$ Ver Huneeus, C., Chile: un país divido, Catalonia, Santiago de Chile 2003, pp. 23-32.

${ }^{324}$ Ver Informe de la Comisión Nacional sobre Prisión Política y Tortura, Comisión Nacional sobre Prisión Política y Tortura, Ministerio del Interior, Santiago de Chile, 2011.
} 
La dirección de la DINA estaba a cargo del coronel Manuel Contreras Sepúlveda, y su principal función fue la de contener y reprimir a los partidos de izquierda que habían logrado refugiarse en la clandestinidad y que podían suponer un riesgo efectivo para la Junta. Tres fueron las organizaciones opositoras que ejercieron más resistencia: el Movimiento de Izquierda Revolucionaria, el Partido Socialista y el Partido Comunista.

Una vez neutralizada la cúpula del gobierno de Allende el siguiente paso era capturar a los dirigentes y militantes de aquellas formaciones que habían formado parte del proyecto popular, y ello se hizo a través de una estrategia que combinaba la participación de militares y civiles (muchos de ellos entrenados en centros norteamericanos de formación contrainsurgente: Escuela de las Américas ${ }^{325}$ ).

Contreras logró que Pinochet financiara un proyecto que debía garantizar la supervivencia de la dictadura ante los focos opositores que fueran surgiendo. Porque las fuerzas armadas no podían contener toda forma de oposición y menos aún en un contexto de clandestinidad, era necesario contar con una organización independiente que actuara en la sombra y allí donde los militares no llegaban.

El primer paso fue la organización una red de casas y recintos clandestinos que debían servir como base de operaciones para la tortura y desaparición forzada de opositores. El segundo, bajo el más estricto secretismo, el reclutamiento y la formación de cientos de personas para hacer posible este proyecto (funcionarios de la represión): antiguos funcionarios de la inteligencia nacional, militares, ex miembros del cuerpo de carabineros, civiles, etc.

A la represión ejercida en Chile se añadió la desatada fuera de sus fronteras. Miles de opositores salieron huyendo del país en los primeros meses tras el golpe; cientos de ellos eran dirigentes o miembros destacados del gobierno de Allende y piezas clave en la oposición a Pinochet desde el exilio. Por esta razón, la DINA tuvo luz verde para

\footnotetext{
${ }^{325}$ La Escuela de las Américas (Latin American Training Center. Ground Division) tuvo su génesis en el marco de la Doctrina de Seguridad Nacional imperante en los años setenta y su sede en Panamá. Su misión principal era fomentar o servir como instrumento para preparar a las naciones latinoamericanas a cooperar con los Estados Unidos y mantener así un equilibrio político contrarrestando la influencia creciente de organizaciones políticas de ideología marxista o movimientos de izquierda. Ver Dinges J., Operación Cóndor, una década de terrorismo internacional en el cono sur. Ediciones B Chile S.A., Santiago, p.175.
} 
actuar en el exterior y cooperar con otros organismos de inteligencia internacionales en la captura de disidentes (Operación Cóndor).

Ejemplos representativos fueron el asesinato del general Carlos Prats y su esposa en Buenos Aires, el caso del democristiano Bernardo Leighton y su esposa Anita Fresno en Roma, y el atentado con coche bomba contra Orlando Letelier (Ministro de Relaciones Exteriores y embajador en los Estados Unidos del gobierno del presidente Allende) junto con su secretaria en Washington D.C.:

-“En noviembre del 75 caíamos presos en Buenos Aires bajo la Operación Cóndor. Esto lo sé porque había tipos que en los interrogatorios no hablaban y además tenían todos nuestros antecedentes. Estuve un año presa, hasta 1976. Primero nos aislaban, después nos metían en la leonera en donde estábamos todas las mujeres, chilenas, argentinas, etc. Después nos trasladaron a Villa Devoto $^{326}$ y allí separaban a hombres y mujeres en diversos pabellones....En el interrogatorio a mi me trataron como una terrorista. Estabas amarrada y con los ojos vendados. Pensaban que nosotros formábamos parte de la Coordinadota Armada de América Latina" ${ }^{327}$

Por todo lo expuesto se podría afirmar que las operaciones de la DINA tuvieron un carácter transnacional, circunstancia que explicaría el hecho de que durante su período de operatividad se produjeran la mayoría de las ejecuciones y desapariciones forzadas de disidentes huidos.

Por otra parte, la Central Nacional de Informaciones se creó en agosto de 1977 mediante el decreto ley $\mathrm{N}^{\circ} 1878$, previa disolución de la DINA (decreto ley $\mathrm{N}^{\mathrm{o}} 1876$ ), y funcionó hasta febrero de 1990. Como se ha mencionado anteriormente, la diferencia fundamental con la institución predecesora fue que desarrolló una estrategia represiva más selectiva debido a dos factores fundamentales. Uno, por la presión internacional que obligó a Pinochet a "adulterar las tareas contrainsurgentes de cara a la galería internacional" y, dos, por la disminución de la actividad opositora, muy debilitada por los sucesivos golpes represivos en la etapa anterior.

\footnotetext{
${ }^{326}$ Centro Penitenciario en la ciudad de Buenos Aires (Argentina) que funcionó como lugar de detención de prisioneros opositores durante los años de la dictadura del general Rafael Videla (1976-1983). Ver Informe de la Comisión Nacional sobre la Desaparición de Personas (Nunca Más); Eudeba, 1985, Buenos Aires, Argentina, p.178.

${ }^{327}$ Ver Anexo. Entrevista N ${ }^{\circ} 24$.
} 
LA CNI, que dependía del Ministerio del Interior, colaboró estrechamente con otros organismos como la División de Inteligencia Regional (DIRE) y la División de Inteligencia Metropolitana (DIME). Su personal llegó a tener una activa presencia en organizaciones paramilitares de ultraderecha como el Comando Anti-subversión (CAS), Comando Vengadores Mártires (COVEMA) y la Alianza Anticomunista Chilena (ACHA).

Pese a la aparente bajada de intensidad de la represión, la CNI no dejó de ejecutar y torturar a ciudadanos chilenos hasta 1989, año en el que Pinochet condicionó el cambio democrático a que la justicia "no tocara a ninguno de sus hombres".

Desde una perspectiva general, la represión política se dio en un marco en el que no existía la separación de poderes en cuanto a que la capacidad de legislar se concentró en la cúpula de las Fuerzas Armadas (La Junta). El aparato represivo se configuró como el único mecanismo válido para sustentar el nuevo proyecto, bajo la premisa de que sólo anulando al conjunto de la izquierda chilena podría instaurarse un orden sólido cuya legitimación operaría sobre el concepto de cruzada nacional contra los disgregadores de la patria (tal y como hiciera el dictador Francisco Franco, un referente para Pinochet, tras la sublevación del 18 de julio de 1936 contra la II República).

Los mecanismos represivos que la Junta militar puso en funcionamiento tras la toma de La Moneda trataron de legitimarse en base a la "erradicación de un mal menor para alcanzar un fin de interés nacional" y que pasaba necesariamente por eliminar el legado socialista del depuesto presidente.

La subordinación del poder judicial y las garantías constitucionales a la nueva doctrina permitieron al aparato represor actuar con absoluta impunidad. Toda una estructura organizada en modo piramidal y jerarquizada permitió al comandante en jefe de las Fuerzas Armadas un grado considerable de operatividad a la hora de poner en práctica sus decisiones para oprimir a la oposición.

Aún teniendo esta capacidad de operar, el régimen y su cabeza quisieron dotar a la dictadura de un corpus legal que le otorgara una aparente legitimidad para poner en 
funcionamiento los cambios políticos y económicos estructurales fundamentados en el control y sometimiento de la población civil.

En torno a la idea de renovación nacional se creó un sistema de valores que se percibía como único y verdadero y, por tanto, cualquier cuestionamiento del mismo suponía la des-categorización de los chilenos de su ciudadanía (los propios miembros de las Fuerzas Armadas se referían a los prisioneros como humanoides) lo que daría vía libre para poder ser reprimidos.

La búsqueda de esa "legalidad impuesta" vino dada por un proceso cuyo objetivo fue establecer unas certezas absolutas incuestionables. La primera premisa fue la invalidez de cualquier propuesta alternativa al orden castrense, especialmente el representado por los partidos políticos de la izquierda chilena.

Todo ello tuvo dos claros objetivos, el primero, la cuestión económica, a saber, recuperar "la dignidad nacional" a través del desarrollo del libre mercado y la reducción del papel del Estado en los asuntos claves del país. Segundo, dejar el terreno "allanado" ante cualquier interferencia opositora para que el régimen militar pudiera llevar a cabo sus objetivos.

Para hacer posible el proyecto, las Fuerzas Armadas dirigieron y controlaron el poder ejecutivo, legislativo y judicial. La justificación que sustentó este sistema vino dado por un moldeamiento del corpus legal anterior acorde con los intereses de Pinochet.

El investigador Tomas Moulian ${ }^{328}$ denominó este proceso como un "cepo jurídico" que permitió dar cobertura legal a las acciones represivas. Para ello, los militares se asignaron la función de interpretar qué acto podía ser hostil a los intereses de la nación.

Concretamente, las Actas Constitucionales (1976) crearon el marco jurídico necesario para facilitar la represión y anular los derechos de la ciudadanía que la constitución de 1925 ya garantizaba. El Acta No 2 establecía las “bases esenciales de la institucionalidad

\footnotetext{
${ }^{328}$ Ver Moulian, T., Chile actual, anatomía de un mito, Arcis Universidad, Ed. LOM, Chile, 1998.
} 
chilena" y las medidas a adoptar si la nación era amenazada (detenciones preventivas, toque de queda, restricciones en las libertades ciudadanas, etc.).

El Acta $\mathrm{N}^{\mathrm{o}} 4$ especificaba las situaciones de emergencia en las cuales los derechos civiles y públicos podían ser restringidos: "en los casos de guerra interna o externa, conmoción interior, subversión latente y calamidad pública" se podía declarar el estado de sitio y hacer uso de los medios necesarios para preservar la seguridad nacional ${ }^{329}$. Es en este punto precisamente, donde los tribunales militares de la Junta Militar tenían la capacidad de interpretar con total libertad qué situaciones o hechos correspondían a estas situaciones.

\footnotetext{
${ }^{329}$ Pinochet, influido por el contexto mundial de la guerra fría, aplicó la Doctrina de la Seguridad Nacional como fórmula de control social. La Junta Militar interpretó que Chile se hallaba en un contexto de guerra interna porque el enemigo era real, aunque no fuera visible y no siguiera los parámetros de un ejército tradicional: "En la guerra moderna no nos enfrentamos a un ejército organizado de acuerdo con las líneas tradicionales, sino con un ejército algunas veces muy pequeño, pero consistente y efectivo, que trabaja en la clandestinidad dentro de la misma población, manipulado por determinada organización. A ese es al que hay que temer y a ese es al que hay que derrotar". Ver "Documento interno de la Comisión Rettig sobre la Doctrina de la Seguridad Nacional", p.5. Archivo Rettig, Santiago de Chile.
} 


\title{
4.1 La represión contra las mujeres: la tortura sexual como estrategia militar.
}

\begin{abstract}
-"Lo primero que me dijeron fue que me desnudara, que me sacara la ropa. Yo no entendía nada. En ese momento supe que clase de tipos eran. Mi reacción fue muy violenta porque bajo ningún concepto quería que me vulneraran mi dignidad como mujer... Posteriormente, me llevaron por unos pasillos y abrieron una puerta y me metieron en una sala plagada de mujeres. Fue algo dantesco, estaban hacinadas y tiradas en el suelo"330
\end{abstract}

Partimos de la premisa, sustentada en la teoría feminista contemporánea, de que la violación de los Derechos Humanos de las mujeres debe estudiarse bajo los parámetros de subordinación patriarcal al que han estado sometidas desde tiempos inmemoriales y no desde una mirada neutra. PNoor esta razón, se ha utilizado en el análisis el concepto de discriminación contra las mujeres durante la instauración de regímenes militares y conflictos bélicos como "toda distinción, exclusión o restricción basada en el sexo que tenga por objeto o por resultado menoscabar o anular el reconocimiento, goce o ejercicio de sus libertades fundamentales, en cualquier ámbito",331.

En Chile, la militancia política de las mujeres durante los años del gobierno de la Unidad Popular, la legislación pro-igualitaria de Allende así como su activismo en clandestinidad a partir del golpe, significaron una transgresión de sus roles tradicionales, circunstancia que iba en contra del modelo de mujer que la dictadura quería implantar. Por ende, los órganos represores pusieron sus miras en aquellas mujeres que militaban en la izquierda porque, además de ser consideradas como un

${ }^{330}$ Ver Anexo. Entrevista No 43.

331 Así lo recoge la Convención sobre la eliminación de todas las formas de Discriminación contra la Mujer, adoptada por la Asamblea Nacional de Naciones Unidas en 1979 y aplicada en 1981.Verónica Matus establece una primera pauta al afirmar que "cada Estado tiene la responsabilidad de intervenir en el abuso de los derechos humanos de las mujeres dentro y fuera de sus fronteras" porque las mujeres son privadas del ejercicio de sus derechos civiles y políticos y han sufrido la violación de sus derechos humanos por agentes del Estado.

Como relata la autora, en el caso de las mujeres, los abusos sexuales, las torturas y maltratos a que son sometidas en tiempos de conflictividad armada se cometen primordialmente por su condición sexual más allá de su implicación política determinada. Ver Matus, Verónica, Derechos Humanos, Derechos de las mujeres en J. Aylwin O., Desafios para un nuevo Contexto, Comisión chilena de Derechos Humanos, 1991, Santiago de Chile, p. 146. 
peligro subversivo, eran denostadas por representar un modelo femenino que cuestionaba el orden tradicional de género.

Aunque en los meses posteriores al golpe la acción represiva se centró en la captura de los dirigentes opositores (masculinos), con el transcurso del tiempo comenzó a fraguarse una estrategia que incluiría también la detención de mujeres, especialmente aquellas que estuvieran vinculadas con los "cabecillas de la subversión" bajo el paradigma sexista de que "capturando a la presa menor se llegaría a la mayor". En este punto, militantes, esposas, compañeras sentimentales, hermanas, madres e hijas de dirigentes y activistas opositores se convirtieron en un blanco más de la represión:

-"La mujer es usada también como rehén o elemento de presión por parte de los torturadores con el fin de obtener información...se la usa como sujeto activo de las torturas. La detención de un pariente cercano trae para la mujer sufrimientos adicionales. Así, en muchas ocasiones, se la detiene para presionar psicológicamente al pariente o bien se la somete a tensiones como allanamientos domiciliarios, llamadas telefónicas, visitas domiciliarias con el detenido en precarias condiciones físicas y psicológicas" ${ }^{\text {332 }}$

-"Les hacían oír mis interrogatorios, les presionaban conmigo porque era su hija. En cambio con mi hermano, que también estuvo detenido, esto no se hizo. Hay un uso de los hijos para sacar información, especialmente con las mujeres"

Sin embargo, no siempre las víctimas de esta estrategia fueron las mujeres con una militancia política definida o con una vinculación directa con miembros de la oposición, ya que, según los testimonios otras tantas y "no politizadas" también la sufrieron (campesinas, arpilleras, mapuches, etc.).

En esta línea, eran frecuentes los operativos militares en las poblaciones más humildes de la capital, refugio para los perseguidos, y en donde el ejército irrumpía sin freno, deteniendo a cientos de personas sin una selección previa. Las entrevistadas han relatado que junto a las activistas que se hacinaban en los centros de detención existieron grupos de mujeres del ámbito rural o poblacional que, sin ser integrantes de ningún partido u organización política, habían caído detenidas.

\footnotetext{
${ }^{332}$ Ver Comité de Cooperación para la Paz en Chile, COPACHI, La situación general de la mujer bajo el gobierno militar de chile, Santiago, 1975.

${ }^{333}$ Ver Anexo. Entrevista No 10.
} 
Según los testimonios este colectivo era especialmente vulnerable a los excesos militares por su pobreza y falta de recursos, y normalmente solían ser acusadas de haber dado apoyos a los perseguidos, (especialmente en las poblaciones más desfavorecidas de Santiago en forma de alojamiento, manutención, etc.) lo que les servía como justificación para reprimirlas:

-“A las campesinas les daban más duro, al machismo se añadía el clasismo de los agentes...una no sabe cuantas mujeres estaban allí, venían de las poblaciones y seguramente tenían a sus esposos detenidos..."334

-"Indudablemente, el factor de clase jugó un rol, fundamentalmente frente a los guardias. Todo se resumía en esto, si uno era arrogante con un guardia uno iba a tratarte de forma más sumisa, y más sabiendo que una tenía educación y venía de la burguesía" ${ }^{\text {"35 }}$

En otras palabras, cientos de mujeres que provenían de los ámbitos más desfavorecidos fueron detenidas sin filtro previo por vivir en lugares que habían sido focos de activismo político en tiempos de Allende, pero también porque la pobreza o tener un origen humilde era motivo para ser reprimidas debido al clasismo consuetudinario de las Fuerzas Armadas chilenas.

Hay que recordar que durante el gobierno de la UP se aplicaron importantes medidas destinadas a la mejora del suministro de agua y electricidad, programas de alfabetización y reinserción laboral y la expropiación de fundos y terrenos, lo que favoreció que miles de mujeres se adhirieran a la causa socialista. Por esta razón, la dictadura se afanó en destruir todo el legado de Allende, bajo la creencia de que "el virus marxista estaba por doquier".

Dicho esto, ahora la interrogante se sitúa en desvelar qué ocurrió con las prisioneras, si existieron prácticas represivas específicas por su condición de mujer y cuales fueron las consecuencias de las experiencias vividas.

\footnotetext{
${ }^{334}$ Ver Anexo. Entrevista No 3.

${ }^{335}$ Ver Anexo. Entrevista $N^{\circ} 10$.
} 
Desde una panorámica general, la antropóloga y feminista Ximena Bunster ${ }^{336}$ afirma en sus investigaciones que en los regímenes militares del Cono Sur se idearon pautas de castigo específicas dirigidas al conjunto de las militantes de la izquierda. La autora denomina la acción que emprendieron las dictaduras latinoamericanas contra las mujeres cómo esclavitud sexual femenina, fundamentada en el orden patriarcal muy arraigado en el ámbito castrense del continente. Esta especificidad represiva hacia las mujeres, según esta óptica, estaría diseñado de antemano y actuaría bajo dos parámetros, el físico y el psíquico:

-"La combinación de degradación moral culturalmente definida y el maltrato físico constituyen un escenario demencial en el cual la prisionera es sometida a una rápida metamorfosis de Madame (mujer respetable y/o madre) a prostituta",337

-"El sistema estatal y burocrático de tortura ha incorporado médicos. Hay doctores a cargo de supervisar el tormento físico y psicológico de las prisioneras, sus conocimientos científicos les permite saber cuándo un método dado de tortura debe ser suspendido si es que no se desea la muerte para la rehén" ${ }^{338}$

-"Dentro de lo que eran los aparatos represivos no creo que nada estuviera hecho al azar. Creo que hubo una clara planificación y una elaboración de con quiénes se iban a encontrar, de buscar nuestras debilidades, especialmente con las mujeres y esto claramente tenía que ver con su sexualidad"339

Desde el análisis histórico-feminista hay dos elementos culturales clave que pueden verter más luz sobre la configuración de la represión hacia las mujeres en tiempos de conflictividad militar.

El primero, el ideario patriarcal o Patriarcado, entendido como un sistema cultural panhistórico y transversal que otorga por determinismo biológico una superioridad innata del hombre sobre la mujer. En este orden de cosas, conviene recordar que los varones

\footnotetext{
${ }^{336}$ Ximena Bunster, socióloga y feminista chilena, ha realizado numerosos trabajos en los que se refleja la problemática de la tortura de prisioneras políticas bajo la Junta Militar Pinochetista (1973-1990). Ver Bunster, X., La Tortura de Prisioneras políticas: un estudio de esclavitud sexual femenina, Taller de la Red Feminista Internacional Contra la Esclavitud Sexual Femenina y el Tráfico de Mujeres, Rótterdam, 1983.

${ }^{337}$ Ibíd., p.152.

${ }^{338}$ Ibíd., p. 162.

${ }^{339}$ Ver Anexo. Entrevista No 10.
} 
han sido históricamente socializados para "ocupar espacios y lugares de poder que naturalizan y defienden en caso de ser cuestionados"340

Precisamente, el ámbito castrense chileno (tradicionalmente vetado para las mujeres), se ha caracterizado por la defensa de los valores tradicionales católicos en donde el papel de la mujer se restringía a su lugar doméstico y maternal, y todo lo que se saliera de este orden era considerado como subversivo y objeto de castigo.

Porque desde los albores de la humanidad el hombre ha ocupado el rol de soldado y/o guerrero con el protagonismo en el espacio público, y las mujeres quienes salvaguardan el doméstico (bajo el rol de madres y perfectas casadas), lo que representaban las prisioneras políticas (muchas de ellas solteras y sin hijos) suponía un cuestionamiento de la misma esencia de los valores de las Fuerzas Armadas.

Pero además, los agentes represores consideraban que los cabecillas de la subversión habían arrastrado a "sus mujeres" por el camino de la perversión al desviarlas de sus labores fundamentales (el cuidado de los hijos y el hogar).

-"La CNI y la DINA actuaron con una brutalidad terrible. Las compañeras que sufrieron abusos sexuales tuvieron que soportar no sólo una tortura física sino también una violación de su ideología, de su trasgresión. La parte sexual era la parte débil de la presa y esto lo aprovecharon muy bien. Fueron auténticos salvajes que castigaron duramente a las mujeres que pensaron diferente, a las mujeres de la izquierda. Te violaban para que nunca más fueras socialista" ${ }^{, 34}$

El segundo factor cultural y estrechamente ligado con el primero es el Marianismo o culto a la Madre Virgen, como "superioridad espiritual femenina" basada en los ideales de crianza, maternidad y castidad, modelo que, bajo el prisma militar, debía ser fielmente reproducido por el conjunto de las mujeres.

\footnotetext{
${ }^{340}$ Ver Covas S., Maravall J., Bonino L., "Hombres con valores igualitarios: historias de vida, logros alcanzados y cambios pendientes", Ministerio de Igualdad, Gobierno de España, Diciembre 2009, Madrid, España.

${ }^{341}$ Ver Anexo. Entrevista $N^{\circ} 18$.
} 
Por tanto, para la dictadura, las activistas y militantes de la oposición representaban un modelo que podía cuestionarla en sus propios cimientos. Primero, porque ellas habían transgredido su "rol natural, único y verdadero", lo que para los militares significaba dejar de ser mujeres "normales", y les servía de justificación para acometer todo tipo de aberraciones contra su sexualidad (habían dejado de ser figuras maternales para convertirse en "objetos prostituidos por el marxismo"):

-"Ellos tenían mucha rabia de que una mujer fuera capaz de estar en un grupo militar y enfrentar la dictadura. Los tipos de la CNI, tus torturadores, te preguntaban por qué no estabas en tu casa cuidando de tus niños. Por esto se ensañaron con las compañeras. Muy pocas salieron de las cárceles sin haber sido violadas o violentadas sexualmente",342

-"El valor que se otorgaba a la mujer presa era nada. A las presas políticas se las trataba como algo desechable, precisamente, por su implicación política independientemente de su procedencia social. Las mujeres respetables bajo el prisma de los militares eran aquellas que se dedicaban a lo doméstico y al cuidado de su marido e hijos. En general, se veía a la mujer política cómo algo fuera de lo normal y por ende como elementos al que no se debía respetar por ir en contra de lo que se creía que era lo normal" ${ }^{\text {"33 }}$

-"Les costó mucho asumir que hubiese mujeres que pensaran políticamente por sí mismas. Esto influyó mucho a la hora de rebajar a las mujeres detenidas, es decir, a la hora de torturarlas o de violentarlas sexualmente...nos decían que nos pusiéramos en el lugar que nos correspondía, que la política no era para las mujeres",344

-"Yo para ellos era una tonta porque estaba metida en política. Decían que me había metido en una tontera y había echado a perder mi vida. Fueron a la casa de mis padres y yo había guardado mucha documentación allí. Me pegaron y me pusieron en la parrilla diciéndome que "cómo me había metido en política teniendo a mis padres en la casa llorando"345

En segundo lugar, porque ellas representaban un modelo de mujer que venía del exterior (fruto de la influencia de los procesos de liberación feminista que se vivieron en Estados Unidos y Europa occidental a lo largo de la década de los sesenta) y que la dictadura no podía tolerar, al considerarlo parte del intrusismo internacional para desestabilizar la nación:

-"Creo que en el período de la dictadura a los militantes de la izquierda política no se les veía como personas sino como humanoides. Dentro de una concepción muy machista y patriarcal las mujeres presas rompían con los cánones tradicionales. La mujer tenía que

\footnotetext{
${ }^{342}$ Ver Anexo. Entrevista $N^{\circ} 30$.

${ }^{343}$ Ver Anexo. Entrevista No 32.

${ }^{344}$ Ver Anexo. Entrevista No 4.

${ }^{345}$ Ver Anexo. Entrevista No 13.
} 
quedarse quietita en casa sin meterse en líos. La independencia política de la mujer los enfurecía aún más y el castigo recaía en su sexualidad"346

-"Ellos te trataban como prostitutas. Te preguntaban cuestiones sobre tu vida privada cómo - ¿Con cuantos te has acostado?- mezclándolas con preguntas más serias sobre tu militancia o tus compañeros. ¡Qué importancia tenía tu vida sentimental o sexual con tus actividades políticas!....cuándo te desnudaban para torturarte solían hacer comentarios sexistas sobre tus pechos, tus piernas o tu figura-" 347

-"Recuerdo que a las presas para ducharnos nos llevaban a un lugar en donde salía agua helada del mar y nos tenían a todas desnudas allí y los soldados al lado mirando y riéndose de nosotras haciendo comentarios. Era una situación grotesca"348

Los agentes represores de la dictadura, no dejaban de ver a las prisioneras como objetos sexuales ya que sus acciones se centraban casi siempre en su sexualidad. De hecho, la totalidad de los testimonios muestran que de una u otra manera, las mujeres sufrieron alguna agresión en este sentido, independientemente de su compromiso actividad opositora.

Pero también se las instrumentalizó como un mecanismo útil para localizar o hacer hablar a los prisioneros dirigentes, objetivo prioritario de la dictadura. De esta forma, lo que van indicando los testimonios es que en muchas ocasiones los propios represores tenían dudas sobre el compromiso político de la detenida, pero bastaba con que la hubieran relacionado con algún militante varón para que también la reprimieran:

-"Mi labor consistía en la distribución de propaganda, un grupo muy aislado dentro del PC cuyo objetivo era la distribución nacional. Esta labor la continué hasta 1986, momento en el que volví a caer presa. En Tejas Verdes, ellos no tenían claro quién era yo. Querían que diera información sobre gente del MIR. Después de la tortura...los mecanismos de defensa que desarrollé hicieron que olvidara todos los nombres que pudiera saber; no me acordaba de nadie",349

No conviene olvidar que, pese a todo lo expuesto, los testimonios presentan una serie de matices que convendrían analizar. Por una parte, algunas declaraciones apuntan a que se estableció una diferencia de trato con las prisioneras que estaban en régimen conyugal

\footnotetext{
${ }^{346}$ Ver Anexo. Entrevista $\mathrm{N}^{\circ} 19$.

${ }^{347}$ Ver Anexo. Entrevista No 5.

${ }^{348}$ Ver Anexo. Entrevista No 43.

${ }^{349}$ Ver Anexo. Entrevista No 28.
} 
con respecto a las que no lo estaban y sí mantenían relaciones de pareja. Si bien los testimonios reflejan que este "status" no significó evitar el rigor de la tortura, sí refieren al hecho de que implicó un trato verbal menos agresivo y ciertos privilegios en la cotidianeidad carcelaria.

Esta circunstancia confirma el grado de interiorización de la mentalidad sexista entre los militares a la hora de reprimir en mayor o menor grado a las prisioneras según reprodujeran o no el modelo femenino tradicional. No estar casada y militar en un partido de izquierdas implicaba una degradación moral que se relacionada con la prostitución y la sexualidad femenina. Es decir, prostitutas del marxismo merecedoras de todo repudio pero que contradictoriamente atraían el deseo (sexual) de los agentes:

-"Los agentes de la DINA discriminaban especialmente a las mujeres militantes que convivían con sus parejas sin estar casadas. Las trataban como putas y a algunas se las violaban..." 350

-"Había un reproche por parte de los militares de no ser las mujeres que debíamos ser. Nos acusaba de que nuestras relaciones amorosas eran disolutas, que teníamos amantes...creo que fueron más duros en el trato con las que no estábamos casadas"

-"A nosotras nos trataron como putas, especialmente a las que no eran casadas. Yo recibí un trato diferenciado en algunas ocasiones respecto a otras compañeras que no estaban casadas. De hecho, a mi me decían "señora". Sin embargo, no siempre recibí una relación de respeto por ser casada porque estando embarazada en la Villa me produjeron un aborto fruto de la tortura...En una ocasión llegaron a la Villa dos compañeras prostitutas, aquí la diferencia de trato fue impresionante. El guardia estaba indignado porque mezclaron a estas mujeres "con sus niñas", es decir, nosotras, las prisioneras políticas... Nos trajo jabón, toallas limpias, nos permitieron un aseo general porque querían dejar claro que nosotras éramos diferentes a las prostitutas" 352

-"Nosotras éramos una generación transgresora, muy pocas de nosotras se casaron, es decir, convivíamos con nuestras parejas...Los torturadores pensaban realmente que nosotras éramos diabólicas porque se suponía que las mujeres eran las transmisoras de los valores de la sociedad....esto explica el nivel de ensañamiento que hubo contra la mujer militante, en términos de disminuirla como persona, cómo ser humano",353

-"Después de esto hubo un hecho sorprendente que me ocurrió. Me sacaron al patio y me sentaron un día entero en una silla al sol para que descansara. Creo que yo recibí un trato especial porque era casada... La mayoría de mis compañeras convivían con su pareja sin estar casadas, era muy común, y el trato con ellas fue peor..."

\footnotetext{
${ }^{350}$ Ver Anexo. Entrevista No 8.

${ }^{351}$ Ver Anexo. Entrevista $N^{\circ} 7$.

${ }^{352}$ Ver Anexo. Entrevista $N^{\circ} 12$.

${ }^{353}$ Ver Anexo. Entrevista No 5.

${ }^{354}$ Ver Anexo. Entrevista No 3 .
} 
Otro elemento presente atañe al origen socioeconómico de las prisioneras. Según algunos estudios, "la tortura hacia las mujeres atravesó las clases sociales ya que afectó de igual forma a proletarias y burguesas" ${ }^{355}$. Según los testimonios analizados no hay un consenso entre las entrevistadas a la hora de determinar si este factor fue determinante o no.

Aproximadamente 6 de cada 10 mujeres que sufrieron prisión política y tortura recuerda que su procedencia social sí jugó un papel importante a la hora de sufrirla. De hecho, afirman que las prisioneras económicamente mejor posicionadas recibieron un trato menos vejatorio que las de origen humilde y ello se traducía en poder disponer de privilegios: evitar la tortura, comida, ropa, medicamentos, facilidades de contacto con el exterior, etc.

Según las sobrevivientes, esta circunstancia fue posible porque al machismo que subyacía a la tortura se añadió el clasismo social de la época, lo que significa que en estos casos se dio una triple discriminación: ser mujer, de izquierdas y pobre.

Ellas apuntan a que los militares podían "tolerar mejor" a una opositora de clase alta que a otra sin recursos por una cuestión de mentalidad clasista, pero también los agentes pudieron frenarse con las primeras por el temor de que hubiese consecuencias. No era lo mismo torturar a la hija de un militar (también se dieron casos) o de un importante empresario que a una pobladora por quién nadie reclamaría:

-"Yo soy hija de militar y creo que a nosotras nos soltaron porque había rumores de que habían mujeres detenidas hijas de militares"356

-"Hubo un clasismo marcadísimo en el tratamiento a las presas políticas, en el Estadio Nacional, las mujeres que llegaban con abrigo de piel y sombrero eran tratadas de manera bien distinta que las compañeras de las poblaciones rurales. Sí, creo que, hubo un trato diferenciado con las mujeres de apariencia de clase más alta"357

-“Carabineros tenían un comportamiento más decente con nosotras porque hacían una distinción de clase a la hora de tratar a las presas. A las pobladoras las trataban especialmente mal porque no tenían la educación que nosotras"

\footnotetext{
${ }^{355}$ Bunster, 1983, La tortura de las prisioneras...op. cit., p. 177.

${ }^{356}$ Ver Anexo. Entrevista No 23.

${ }^{357}$ Ver Anexo. Entrevista No 1 .

${ }^{358}$ Ver Anexo. Entrevista No 44.
} 
-"Hubo otro factor importante...tu procedencia sociocultural y económica. Yo tuve la ventaja de que en ese momento era estudiante de medicina y provenía de una familia tradicional y católica, era casi doctora. Esto significaba un mayor respeto, especialmente un respeto que no recibían por ejemplo las mujeres pobladoras de procedencia social más humilde. Lo que me salvó a mi de muchas cosas...de la violación, fue mi situación de clase media acomodada.... Fue un clasismo absoluto. La mayoría de ellas eran violadas sistemáticamente sin ningún tipo de cortapisa. A nosotras no nos violaron, aunque sí nos violentaron sexualmente en la medida que te manoseaban o humillaban. Pero el trato más vejatorio la recibieron aquellas mujeres de procedencia social más baja”,359

Por el contrario, otras ex-prisioneras (el 40 por ciento aproximadamente) inciden en que si bien el clasismo imperó muchas veces entre los agentes represores (en la medida que existieron privilegios para algunas), ello no fue un factor diferencial en las sesiones de tortura y en la desaparición forzada puesto que "proletarias y burguesas" las sufrieron igualmente:

-“Gladis Díaz, una mujer profesional e importante con familia acomodada de carabineros fue igualmente torturada. Quizá en el trato verbal si se establecieron pautas diferenciadas hubo una diferencia de clase en el trato, no en la tortura....Otro ejemplo lo tenemos en el caso de una hija presa en Villa Grimaldi e hija de un almirante de la Marina, la María, que hoy está desaparecida. El Romo iba todos los días a la María Isabel y le decía -hoy día estuve con tu papá en el Ministerio de Defensa pero todavía no hemos puesto el recurso de amparo",360

-“A nivel de trato verbal, esto se daba con frecuencia, es decir, las mujeres de procedencia social baja recibieron un trato más desfavorable. Sin embargo, la tortura fue la misma para todas. Cuando te violan no hay diferencia social, cuando te ponen corriente tampoco hay diferencia social ni de edades... Existía una diferencia de trato con aquellas mujeres conocidas en el ámbito público, es decir, con ellas se cuidaban a la hora de cometer excesos. Pero a decir verdad, el factor fundamental a la hora de ser torturada era tu compromiso político. Hay compañeras que venían de una clase social acomodada o alta pero que fueron martirizadas y desaparecidas igualmente" ${ }^{\text {"361 }}$

-"También en la Villa fueron muy clasistas. Yo era casi doctora y el trato, a pesar de que nos torturaran igual, era diferente. Un soldado me comentó una vez que le diera una lista de lo que necesitábamos. Nos dejaron lavarnos lo que nos pareció maravilloso a las mujeres por la cosa del período. Nos dieron ropa y cepillos de dientes (uno para cada cinco personas). Trajeron las cosas de mi casa, esto creo que fue un acto clasista porque no se dio con otras compañeras" 362

\footnotetext{
${ }^{359}$ Ver Anexo. Entrevista No 4.

${ }^{360}$ Ver Anexo. Entrevista $N^{\circ} 5$.

${ }^{361}$ Ver Anexo. Entrevista No 6.

${ }^{362}$ Ver Anexo. Entrevista $N^{\circ} 11$.
} 
Otras van más allá y afirman que el eje vertebrador de la represión contra las mujeres fue su condición de género en cuanto a que las prisioneras habían transgredido su papel "natural femenino", circunstancia que estaba por encima de cualquier clase social o procedencia económica. Así, relatan que bajo las acciones torturadoras se esgrimía la lógica patriarcal de castigo por no ser "las mujeres, madres y esposas que tendrían que haber sido" (mujeres contra-natura):

-"Las mujeres respetables bajo el prisma de los militares eran aquellas que se dedicaban a lo doméstico y al cuidado de su marido e hijos. En general, se veía a la mujer política cómo algo fuera de lo normal y por ende como elementos al que no se debía respetar por ir en contra de lo que se creía que era lo normal" ${ }^{\prime 363}$

-"Fueron más machistas que clasistas. Yo milité en el MIR en el cual había militantes de diferentes clases...sí se establecieron diferencias con las mujeres militantes del MIR, con las jóvenes que se salían de ese rol, pero daba igual su procedencia social a diferencia de lo que pasó con la dictadura peruana....En cambio en Chile la segregación fue fundamentalmente sexual. La gente que desaparecía no sólo era pobre, desaparecían profesoras, estudiantes, militantes de clase media..."364

Por otro lado, los datos que han ido ofreciendo las fuentes documentadas, indican que la mayoría de las mujeres que fueron detenidas-desaparecidas eran estudiantes o profesionales que ocupaban cargos públicos ligados al régimen anterior (87 por ciento del total) mientras que las desempleadas, campesinas o dueñas de casa representaban solo un 13 por ciento.

Ello da cuenta, primero, que las mujeres que militaban en política contaban en la mayoría de los casos con formación académica y profesional y habían logrado un cierto grado de empoderamiento y autonomía en la sociedad; segundo, confirma la hipótesis de que finalmente la procedencia social y educativa no fue un factor determinante pare evitar la represión.

\footnotetext{
${ }^{363}$ Ver Anexo. Entrevista No 32.

${ }^{364}$ Ver Anexo. Entrevista No 2.
} 


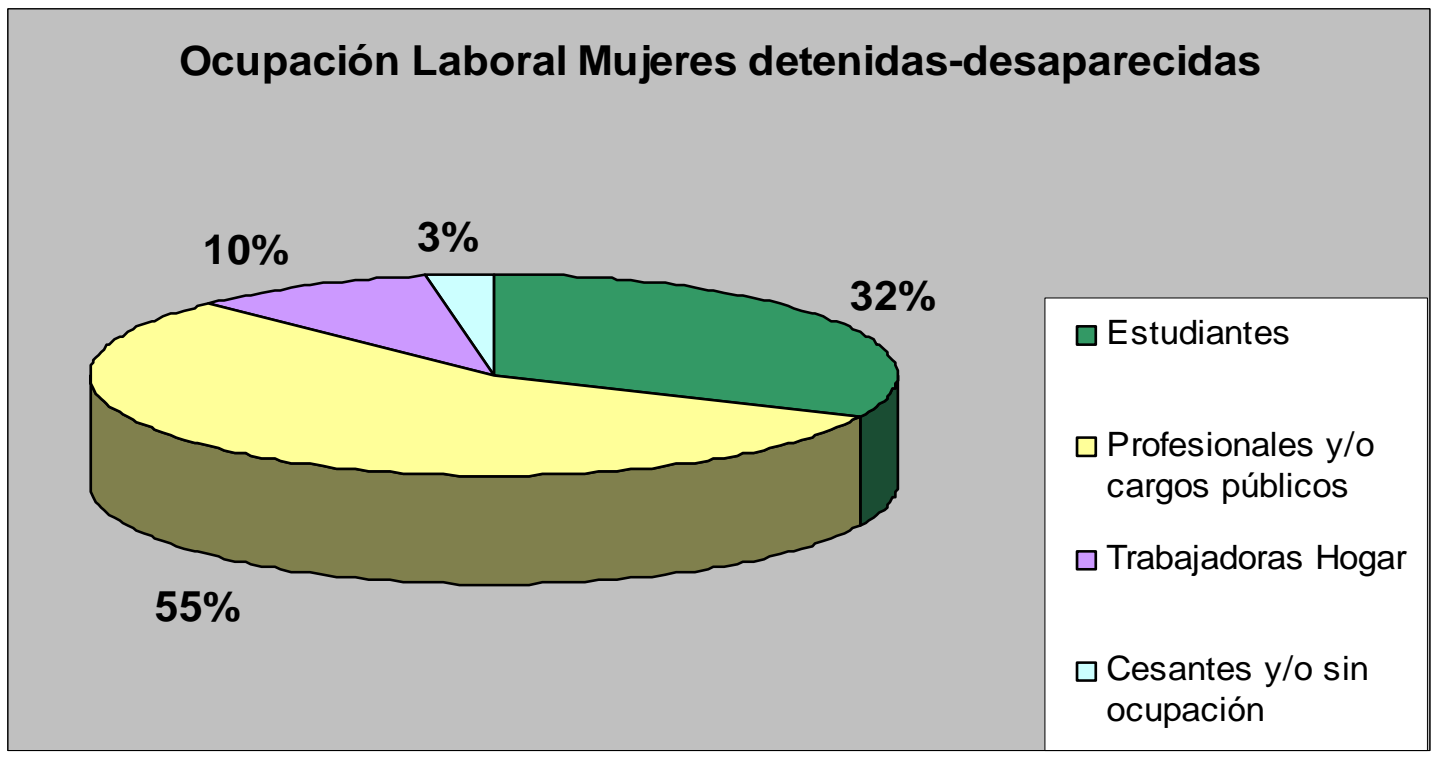

Fuente: Elaboración propia a partir de los datos ofrecidos por la AFDD, Santiago, 2005.

Lo que sí parece estar presente en todas las declaraciones, es el hecho de haber vivido una experiencia represiva de carácter sexual durante el período de reclusión. Esta constate puede indicar que, efectivamente, las conductas machistas en los campos de detención alcanzaron su grado máximo (violencia de género) atentando contra el cuerpo y la mente de la prisionera y casi siempre con premeditación y alevosía.

La dominación masculina sobre el cuerpo de las militantes se materializó en acciones forzadas de carácter sexual cuyo desencadenante podría ser múltiple: obtener información, por el deseo sexual de los agentes, como forma de humillación, etc. Todo ello podría englobarse en una forma de represión específica: la tortura sexual contra las mujeres (la represión recae sobre sus órganos genitales).

Los aspectos más frecuentes que aparecen en los sucesivos testimonios y que confirman dicha variable son: aplicación de colillas encendidas sobre los senos de la mujer, presión de los mismos con diferentes instrumentos, aplicación de corriente eléctrica en las zonas erógenas, introducción de objetos en ano y vagina, uso de animales como tormento sexual, violaciones individuales y colectivas y otro tipo de vejaciones como tocamientos y obligación a desnudarse durante el interrogatorio. 
En primer lugar, hay un consenso generalizado entre las entrevistadas en que en mayor o menor medida sufrieron situaciones de esta índole. En el transcurso de las entrevistas sus discursos van vinculado la sexualidad con la represión sufrida, unas más conscientemente y otras menos, lo que puede apuntar a que algunas han incorporado un enfoque de género en el recuerdo de lo vivido. Además, añaden, que al igual que ellas, las compañeras de militancia también fueron víctimas de estos hechos, lo que les hace determinar que las militantes en su conjunto sufrieron una represión específica por el hecho de ser mujeres:

-"La DINA estudió muy bien el perfil de la mujer militante. Se trabajó mucho para diseñar un tipo de tortura que fuera demoledora para la mujer. Fue una tortura específica, no sólo dirigido a la cosa física, sino también a sus hijos, a la familia....La represión afectó a todos los ámbitos de la mujer....Hubo un claro desarrollo de la represión hacia las mujeres. Sabían perfectamente como torturarlas para que hablaran"365

-"Yo era la única mujer dirigente con consejo de Guerra. Esa incomunicación duró diecisiete días. Estuve encerrada en un cuarto de dos metros cuadrados con una ventanita chica. El comandante Gajardo era uno de los violadores. Trató de abusar sexualmente de mí en varias ocasiones. Reaccioné muy violentamente diciendo que prefería que me mataran antes de que me violaran... Enfrente de ese cuartito había una sala en donde se violaron a muchas mujeres. Muchas de ellas eran compañeras de la industria Tomé..." 366

-"A nosotras nos violaron delante de ellos, era una forma de demostrar su poder a nuestros hombres, de derrotar a nuestros compañeros como hombres. Mientras fuimos agredidas sexualmente ningún compañero dijo nada. 25 años después conversando con un amigo le dije -cuando me violaron delante de ti tú no hiciste nada-La respuesta fue que -no se podía-, pero cuando tuvo hambre sí pudo protestar,"367

-"Ser mujer tenía una complicación extra, es decir, en la medida en que la política estaba enfocada al abuso sexual. De partida te hacían desvestirte quedándote en un estado de indefensión total. Yo no creo que haya ninguna mujer detenida que no la haya sido desvestida ni manoseada. Eso de partida, después recibías todo tipo de insultos machistas, destinados a humillarte por tu físico o cualquier defecto que tuvieras Después seguían con los golpes y las cargas de electricidad en tus zonas más sensibles, en tus genitales. También los colgamientos eran frecuentes..."368

-"La violación para nosotras era algo habitual. Una perdía la noción, no sabías cuantos hombres estaban contigo. Yo trataba de no acordarme de eso y de no sentir, lo que por otra parte a ellos les enfurecía aún más"369

\footnotetext{
${ }^{365}$ Ver Anexo. Entrevista No 35.

${ }^{366}$ Ver Anexo. Entrevista $\mathrm{N}^{\circ} 43$.

${ }^{367}$ Ver Anexo. Entrevista $N^{\circ} 12$.

${ }^{368}$ Ver Anexo. Entrevista No 4.

${ }^{369}$ Ver Anexo. Entrevista No 40.
} 
Muy pocas mujeres han declarado haber sufrido violación en la interpretación más ortodoxa del término. No obstante, los casos aumentan cuando se trata de reconocer otras vejaciones sexuales (coito no consumado) que, por otra parte, algunas declarantes no vinculan directamente con la violación de sus cuerpos. En dichos casos, la mirada de género queda ausente, las contradicciones en los relatos se hacen patentes y ellas se muestran tendentes a minorizar lo ocurrido:

-"Yo me salvé de la violación...en las sesiones de tortura una estaba desnuda, te toqueteaban, te metían los dedos en la vagina...incluso un día me hicieron masturbarme" ${ }^{370}$

-“A mi no me violaron como a otras compañeras...Un día un oficial me sacó de la celda y me llevó al segundo piso. Allí comenzó a abusar de mí sexualmente. Yo me puse a gritar y el escándalo fue enorme" ${ }^{371}$

-“Afortunadamente no me violaron aunque lo primero que yo viví es que me metieron los dedos en mi vagina y mi ano porque pensaban que podía tener algo escondido allî" ${ }^{372}$

-"A mi me llevaron directamente a la sala de tortura, después de quitarme mis pertenencias. Allí, Moren Brito, me hizo desvestirme. De hecho el me dijo -"desnúdate porque te vamos a violar". Me amarraron a una parrilla sin ropa, amarrada y con un casco con electrodos que te ponían en la frente, en la nariz, en la boca, en tus zonas íntimas.... Esta tortura la acompañaban con la introducción de objetos en los conductos vaginales y anales...qué más te puedo decir sobre esto..."373

También mencionan que en la mayoría de las mujeres víctimas de estos tormentos, siguen existiendo obstáculos a la hora de hablar de lo vivido, por considerar que las secuelas permanecen porque no fueron reparadas tras la dictadura. A ello habría que añadir lo que denominan como un sentimiento generalizado de abandono por no haber tenido el respaldo institucional y de sus formaciones políticas una vez instaurada la democracia. En otras palabras, no se facilitaron espacios de recuperación para las mujeres sobrevivientes que se vieron obligadas a acudir a otros lugares para recuperarse (ONGs principalmente).

\footnotetext{
${ }^{370}$ Ver Anexo. Entrevista No 14.

${ }^{371}$ Ver Anexo. Entrevista $N^{\circ} 10$.

${ }^{372}$ Ver Anexo. Entrevista $N^{\circ} 13$.

${ }^{373}$ Ver Anexo. Entrevista N ${ }^{\circ} 5$.
} 
La invisibilización de lo que les ocurrió fue una tónica constante en la década de los noventa, motivada por el silencio de una población todavía temerosa. Ello relegó a miles de mujeres al olvido y a no poder reconstruir sus vidas e insertarse en la sociedad:

-"Esta experiencia deja a las víctimas sin palabras para comunicar lo vivido. No existe lenguaje, lo que predomina en lo inmediato y más tarde, en el recuerdo, son el estupor, la perplejidad y, por ende, el silencio. No existe tampoco una semántica, un código que denomina la conducta del victimario: destrucción, negación, violación, amenazas de muerte, desaparecimientos...que son ocultados por la negación y el silencio"374

La periodista e investigadora Patricia Verdugo ya alertaba en su investigación "De la tortura no se habla” (Santiago, 2004) que dicho silencio significó que muchas mujeres no declararan ante la Comisión Valech en el marco de la elaboración del Informe sobre Prisión Política y Tortura (2001-2004). Las entrevistadas opinan que centenares de mujeres, víctimas de la tortura sexual, no acudieron a declarar y por tanto, ser beneficiarias de las medidas reparatorias que se establecieron para tal efecto. Las causas, aunque puedan ser múltiples, podrían estar relacionadas con ese silencio impuesto que impediría a muchas mujeres poder reconocer y afrontar lo vivido.

Finalmente, esta circunstancia pone en evidencia las cifras oficialmente reconocidas sobre mujeres víctimas de la tortura sexual (aproximadamente 4000 casos según el ICNPPT) y que algunas organizaciones de derechos humanos estiman en 10.000:

-“Todas somos parte de ese mismo pudor. Mi compañera Nubia es sobreviviente de Villa Grimaldi, llevamos siete años trabajando juntas y nunca hemos hablado de este tema. Esta es la parte más importante, es decir, ¿por qué nos cuesta tanto?; no haber relatado esta cuestión todavía a treinta años del golpe es un tema pendiente" ${ }^{375}$

-"Creo, sinceramente, que la mayoría de mis compañeras fueron violadas o agredidas sexualmente. Yo nunca pude hablar de esto con ellas. Nunca pregunté, me enteré después de amigas mías que años después testimoniaron el horror que vivieron, además, los gobiernos democráticos tampoco mostraron una sensibilidad en esto",376

-"Las mujeres dirigentes eran un blanco de la dictadura. Recién las mujeres comunistas están ahora hablando sobre lo que les pasó. Cómo fueron torturadas y violadas. También

\footnotetext{
${ }^{374}$ Ver Verdugo P., De la tortura no se habla, Ed. Catalonia, Santiago de Chile, 2004, pp. 169-173.

${ }^{375}$ Ver Anexo. Entrevista $N^{\circ} 1$.

${ }^{376}$ Ver Anexo. Entrevista No 3.
} 
está el tema de la separación de los hijos, pero esas cosas como que no se tratan ni en los partidos ni en las instituciones... de esta supuesta democracia que tenemos en Chile"377

Trascurridas casi cuatro décadas desde que Pinochet diera el golpe, parece que "el vagón de género" sigue siendo el último de la cola, ya que las medidas reparatorias de los sucesivos gobiernos de la concertación en democracia no parecen haber facilitado suficientemente la recuperación terapéutica de cientos de mujeres, o así lo expresan la mayoría de las entrevistadas.

Por otra parte, algunas defienden la necesidad de sacar a la luz sus experiencias en la tortura, por los efectos beneficiosos que tendría para su salud. Sin embargo, insisten en que no cuentan con los espacios y recursos necesarios para lograrlo. Otro obstáculo con el que se encuentran es con la falta de credibilidad o la infravaloración de lo ocurrido.

Un ejemplo representativo es el que tiene que ver una de las variables de la tortura sexual más extrema y por tanto más difícil de visualizar: el uso de animales para atentar contra la sexualidad de la detenida. Estos casos no han sido objeto de suficiente estudio debido a las dificultades lógicas de quienes la sufrieron para denunciarlo. Lo que sí constatan los informes sobre violaciones de derechos humanos en Chile, es que existieron animales específicamente adiestrados para acometer este tipo de actos, lo que muestra el alto grado de planificación de la represión hacia las prisioneras:

-"Ellos de alguna manera tenían que violentarte sexualmente. Por ejemplo, en la Venda Sexy había perros, yo tengo varias compañeras a las que violaron con perros. Sin embargo, en Villa Grimaldi utilizaban otros métodos cómo meterte en la vagina unas llaves con corriente..." 378

-"Luego todo lo que pasó con mis pechos, con mi cuerpo, la relación con los animales que ellos solían trabajar con las mujeres...es algo que todavía me afecta mucho" ${ }^{\text {,379 }}$

-"Debo decir terminantemente que en este país se usaron las técnicas de tortura más terribles contra la mujer de una forma sistemática. Se violaron mujeres con perros, se le metían ratas en la vagina y ninguna mujer podía salir de la cárcel como una mujer normal después de sufrir estas vejaciones",380

\footnotetext{
${ }^{377}$ Ver Anexo. Entrevista No 38.

${ }^{378}$ Ibíd. Ver Anexo. Entrevista No 5.

${ }^{379}$ Ibíd. Ver Anexo. Entrevista N ${ }^{\mathrm{o}} 13$.

${ }^{380}$ Ibíd. Ver Anexo. Entrevista N ${ }^{\mathrm{o}} 36$.
} 
-"Mi experiencia más traumática fue cuando me sacaron a otra pieza en donde me tuvieron tres días. Esa pieza estaba llena de ratas. Es algo de lo que no puedo hablar, se subían por todas partes...",381

Fue en este punto donde la cosificación de la prisionera adquirió mayores proporciones al utilizarla como un objeto sobre que el experimentar ("sexualmente"). Hay varias cuestiones que convendría abordar en este sentido: ¿Los agentes represores planificaron esta estrategia de forma premeditada? ¿Fueron actos espontáneos bajo los que subyacían comportamientos machistas interiorizados? ¿Ambas circunstancias pudieron influir?

Lo que parece quedar claro es que los militares sabían donde podían dañar más a las prisioneras, por las percepciones patriarcales fruto de su socialización de género, bajo la premisa de que control de su sexualidad implicaría el de la prisionera.

Hay que recordar que la educación sexual que los varones han recibido históricamente proviene fundamentalmente de la pornografía, diseñada por y para ellos, donde los tiempos y deseos masculinos se anteponían a los femeninos y en donde claramente se reproducían los roles de dominio y subordinación sexual. Desde la década de los sesenta, empezaron a fraguarse diferentes tipologías en el cine pornográfico, entre ellas, la de mantener relaciones sexuales con animales (Zoofilia).

Como han demostrado diferentes estudios en la materia, la demanda en el mercado del porno ha procedido históricamente del colectivo masculino, por lo que su diseño estaba orientado a los "deseos y necesidades de los hombres". No sería descabellado pensar que algo de esta lógica patriarcal hubiera podido influir en los militares, quienes podrían haber reproducido estos mismos esquemas para con las reas: el deseo de experimentar "sexualmente" con el cuerpo femenino y humillarlo (como recordatorio de que la mujer está por debajo del hombre) y como vía de dominación (al fin y al cabo ella es percibida como una posesión del enemigo subversivo).

${ }^{381}$ Ibíd. Ver Anexo. Entrevista No 43. 


\subsection{La instrumentalización de la maternidad.}

La maternidad y la tortura ha sido uno de los temas más complejos de analizar por las connotaciones psico-emocionales que conlleva. Sin lugar a dudas, el impacto de la represión sobre los hijos de las militantes es todavía a día de hoy un asunto poco visible y espinoso de tratar. Pese a las resistencias o dificultades, se ha tratado de obtener toda la información posible aunque siempre respetando los tiempos y decisiones de las entrevistadas.

De los testimonios orales y escritos analizados se desprende que aproximadamente un $30 \%$ de ellas se encontraban en estado de gestación o tuvieron a menores a su cargo en el momento de su detención. Todas afirman que de una u otra manera se atentó contra su maternidad o hijos.

Las entrevistadas intuyen que los agentes sabían muy bien cuál era el punto más vulnerable de las prisioneras (sus pequeños), lo utilizarían como vía de presión para obtener información. Pero además pudo entrar en juego el mito de que las mujeres por biología, al ser más resistentes al dolor, podían aguantar todo tipo de torturas (el parto como el mayor umbral del dolor):

-"Recuerdo que Osvaldo Romo, un torturador de la Villa Grimaldi decía -con las mujeres no podemos, ellas tienen los hijos y ellas resisten más el dolor, es más difícil que ellas hablen como los hombres-" 382

-“A los agentes represores les chocaba mucho que las mujeres estuvieran tanto o más preparadas que los hombres. Concretamente, según dicen, las mujeres resistieron mucho más la tortura que los hombres"383

La dimensión de la tortura sexual adquirió mayores proporciones en los casos de aquellas militantes que cayeron detenidas estando embarazadas. La mayoría ha tenido dificultades a la hora recordar lo vivido, lo que no implica que hayan sido contundentes a la hora de expresar su opinión:

\footnotetext{
${ }^{382}$ Ver Anexo. Entrevista No 37.

${ }^{383}$ Ver Anexo. Entrevista No 29.
} 
-"Pasé a la Correccional (COF) y después me llevaron seis meses al Estadio de Chile y de allí a Cuatro Álamos. Yo perdí a mi hijo, porque estando detenida tuve un aborto....Mi peor experiencia fue la pérdida de mi hijo por la tortura. Esto me lo deben, voy a querellarme contra quien haga falta. Tengo la esperanza de que se haga justicia con esto"384

-"Cuando yo caí detenida yo tenía más de dos meses de embarazo. A mi me pusieron electricidad en la vagina y me provocaron el aborto. El Romo, me puso electricidad precisamente para provocarme el aborto. Este dolor nunca lo voy a olvidar. Como mujer no puedo olvidarlo, es una cruz que una debe llevar toda la vida. Me provocaron el aborto estando amarrada en un catre sabiendo que me estaban poniendo electricidad con un objetivo tan criminal y atroz que una lo único que sentía era una tremenda impotencia por no poder salvar a mi hijo",385

-“A mi me decían "señora”. Sin embargo, no siempre recibí una relación de respeto por ser casada porque estando embarazada en la Villa me produjeron un aborto fruto de la tortura" 386

-“Conozco dos compañeras embarazadas que estuvieron antes que yo en Villa Grimaldi y perdieron a sus bebés antes de nacer. Tuvieron un aborto provocado por los golpes que recibieron...Recuerdo que un mes antes de llegar, durante el año nuevo, la guardia se emborrachó y fueron a buscar a las mujeres entre las cuales había dos embarazadas, las desnudaron para violarlas... En mi pieza me topé con otra mujer quién me dijo que mi marido estaba en el segundo piso. Ella también estaba embarazada... la torturaron mucho, la colgaron, era una mujer grande, maciza, debió ser horrible"

-“Comienzan a mojarla y golpearla con objetos contundentes, parecían tubos de goma, les señala que esta embarazada, comienzan a golpearla brutalmente, con más fuerza, en todo el cuerpo, diciéndole que iban a matar a ese bastardo" 1388

Como reflejan las citas, los agentes utilizaron como premeditación y alevosía la maternidad de las prisioneras como una herramienta más en la tortura. Sin cortapisas, ellos ni siquiera reprodujeron el rol de protectores que se podía esperar para con las embarazadas, porque ellas habían sido des-categorizadas como mujeres normales debido a su militancia en la oposición.

El Informe sobre Prisión Política y Tortura muestra que la mayoría de las mujeres que desaparecieron embarazadas militaban en el Movimiento de Izquierda Revolucionaria, formación que mayormente sufrió la represión de sus cuadros por representar la respuesta armada más organizada de la oposición a Pinochet.

\footnotetext{
${ }^{384}$ Ver Anexo. Entrevista No 28.

${ }^{385}$ Ver Anexo. Entrevista $\mathrm{N}^{\mathrm{o}} 11$.

${ }^{386}$ Ver Anexo. Entrevista $N^{\circ} 12$.

${ }^{387}$ Ver Anexo. Entrevista $N^{\circ} 3$.

${ }^{388}$ Ver testimonio de Sandra Palestro, Archivo Digital CODEPU, Santiago de Chile, p. 1462.
} 


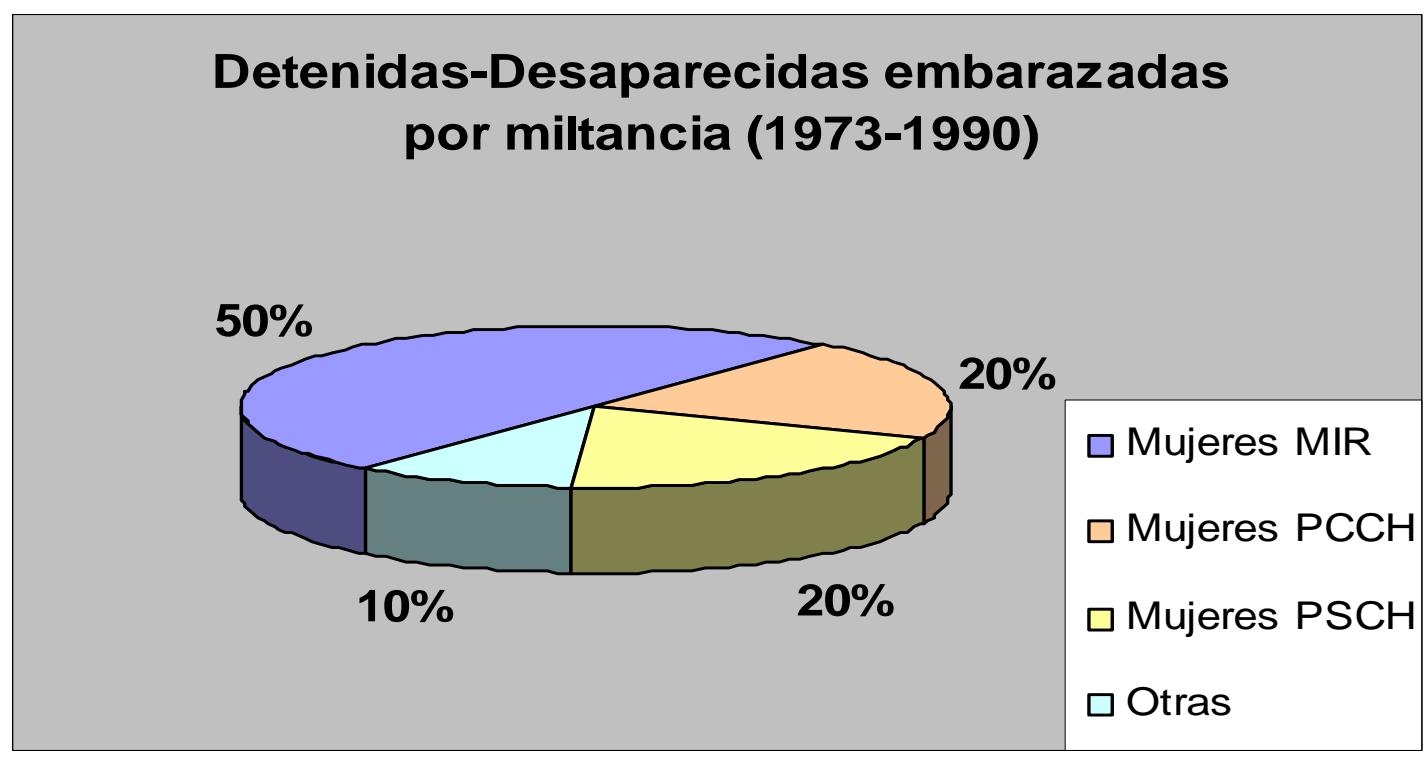

Fuente: Elaboración propia a partir de los datos ofrecidos por el ICNPPT, Santiago 2004

Especial simbolismo adquiere la humillación verbal de los agentes contra los prenatales, "unos bastardos",389, cuando sus madres no estaban casadas con los padres, una perversión moral que bajo la moral castrense había que castigar.

Por consiguiente, aparecen dos elementos diferenciadores en el proceso: uno, el uso de la maternidad como castigo a las prisioneras por ocupar un espacio (la política) que no le correspondía y no ser las madres que tendrían que haber sido; dos, como instrumento útil de presión (utilizando su sexualidad) para la obtención de información del paradero de militantes:

-"Les hacían oír mis interrogatorios, les presionaban conmigo porque era su hija. En cambio con mi hermano, que también estuvo detenido, esto no se hizo. Hay un uso de los hijos para sacar información, especialmente con las mujeres" ${ }^{, 390}$

-"En agosto de 1984, rodearon mi casa y me tomaron presa. A mi hija se la llevaron a un hogar infantil de carabineros. A mi me trasladaron a Borgoño... me encontré con militares que me decían - ¡Cómo arriesgaste a tu hija por estar en esta güeá. Trataste de hacerte la guerrillera y ahora estás cazada como mosca!"391

\footnotetext{
${ }^{389}$ Ver Anexo. Entrevista No 3.

${ }^{390}$ Ver Anexo. Entrevista No 10.

${ }^{391}$ Ver Anexo. Entrevista No 9.
} 
-"Ellos encontraron en mi casa los papeles del médico en donde decía que yo tenía ocho semanas de embarazo. Fue un nivel de desquiciamiento agotador, te decían -Flaca tení que cuidarte porque estáis embarazada- pero luego me torturaban igual" ${ }^{\text {} 392}$

-“Otras mujeres perdieron a sus bebés como consecuencia de la tortura recibida....estas cosas sí tenían que ver con un cierto icono por alterar el rol materno de las mujeres para castigarlas por no ser buenas madres" ${ }^{\text {"393 }}$

Algunas mujeres ya relataron en las agrupaciones de derechos humanos sus experiencias extremas en la tortura en relación a su maternidad. Tras salir de prisión, tuvieron el coraje de recordar y denunciar lo vivido en unos espacios que podríamos calificar de "memoria" pero también de terapia, en donde muchas mujeres pudieron hablar de lo ocurrido y contar con personal de apoyo. Sus testimonios pasaron a ser con el tiempo pruebas escritas de incalculable valor que servirían a las comisiones de verdad y justicia para esclarecer el alcance de la represión sobre la población civil.

Otro aspecto importante que reflejan los testimonios es el uso de la tortura y la amenaza de violación contra miembros de la familia de la prisionera, especialmente con los hijos para que sus compañeros militantes se decidieran a hablar. Algunas mujeres han declarado que sintieron que detrás de esta estrategia se escondía también una forma de humillar a sus compañeros bajo el paradigma de que disponiendo de los "objetos" del enemigo, el dominio y control sobre él sería mayor:

-"Ponían grabaciones con llantos de niños y también se escuchan voces que eran reales...probablemente de niños de otros presos que estaban en Borgoño y te decían: -ese es tu hija y te la vamos a violar,"394

-"Ellos marcaron ya mi rol, es decir, mi utilización como "esposa de" puesto que la DINA no tenía constancia de mi militancia política, para ellos era simplemente la esposa de un dirigente mirista....Siempre me usaron como instrumento... yo era un instrumento más de tortura para Alfonso. Ellos me decían -de ti depende la vida de Alfonso, de tu hija, de tu familia-....me utilizaban para sonsacar información a mi marido, porque Alfonso tenía información valiosísima que ellos querían tener a toda costa" 395

-“A mí siempre me amenazaron con que me iban a violar delante de Gerardo, mi compañero. También me amenazaban con mis padres y mi familia" ${ }^{\text {"396 }}$

\footnotetext{
${ }^{392}$ Ver Anexo. Entrevista No 12.

${ }^{393}$ Ver Anexo. Entrevista No 7.

${ }^{394}$ Ver Anexo. Entrevista No 40.

${ }^{395}$ Ver Anexo. Entrevista No 8.

${ }^{396}$ Ver Anexo. Entrevista No 14.
} 
-"Tenemos casos de mujeres que fueron tomadas como rehenes porque sus maridos eran militantes y se las devolvieron todas violadas y golpeadas como una forma de humillar a esos hombres que querían cambiar la sociedad y ni siquiera podían proteger a sus propias mujeres ${ }^{\text {"397 }}$

-“A mi me violaron delante de mi compañero para que hablara, esto era una práctica común, es decir, buscar la debilidad de la persona. Esto ocurrió especialmente en el primer período, nosotros fuimos los conejillos de indias, ellos aprendieron a torturar con nosotros....Ellos sabían perfectamente como hacernos hablar..."

-“Constantemente nos llamaban putas, con hijos bastardos y quizá, en este sentido, sí aludían al enemigo. Éramos no tanto las reproductoras del enemigo sino las tontas útiles del enemigo, como las putas del enemigo"399

-“A nosotras nos violaron delante de ellos, una forma de demostrar su poder a nuestros hombres, era una forma de derrotar a nuestros compañeros como hombres por no haber sabido proteger a sus hijas y esposas...,400

En el marco de este complejo proceso, los hijos de las presas fueron frecuentemente utilizados bajo múltiples formas. Como se ha podido comprobar, algunas de las prisioneras, cuando cayeron presas, tenían a dependientes a su cargo. Por lo general, en esta situación, los menores eran trasladados a las cárceles o abandonados a su suerte en el domicilio familiar; en otras ocasiones, las prisioneras se habían encargado de resguardarlos con familiares u amigos, lo que tampoco era garantía para salvaguardar su integridad.

En el peor de los casos, los menores se veían obligados a convivir en condiciones infrahumanas con sus madres, torturadas cuando no violadas, y en donde cualquier problemática de salud que pudieran tener no sería atendido, lo que conllevó que los pequeños desarrollaran enfermedades o cuadros víricos graves que les afectaría considerablemente en su desarrollo posterior:

-“A la pequeña Tamara la sacaron un día sin anunciarle nada a Helen y sin dar cuenta de su destino para presionarla. Helen casi enloqueció de dolor. La niña después de mucho tiempo fue encontrada por su abuela en un hogar de menores con signos claros de desnutrición y en un estado de angustia y terror",401

\footnotetext{
${ }^{397}$ Ver Anexo. Entrevista $N^{\mathbf{o}} 13$.

${ }^{398}$ Ver Anexo. Entrevista No 29.

${ }^{399}$ Ver Anexo. Entrevista No 1.

${ }^{400}$ Ver Anexo. Entrevista $N^{\circ} 12$.

401 Ver Testimonio de Nubia Betsie de Lourdes Becker Equiluz, en Archivo Digital del Comité de Derechos del Pueblo (CODEPU), Santiago de Chile, p. 1768.
} 
-“A mí me tocó vivir en un centro de tortura en donde vivieron niños. Se presionaban a las madres con los niños, que lloraban viendo como torturaban a sus padres, fue un tratamiento de choque. Nos trataban de prostitutas, como animales que nos apareábamos sin estar casadas, ese tipo de expresiones como que éramos unas sueltas, un tratamiento muy soez, por el propio hecho de habernos metido en la política. Existió una tortura hacia la mujer con todo aquello que tenía que ver con el tema de la maternidad, es decir, la amenaza con los hijos fue una de las torturas psicológicas más brutales. Ante ellos éramos malas madres, no solían amenazar a los hombres con sus hijos. Nos daban más duro en el plano emocional, en el plano maternal...,402

-“A algunas presas les llevaron a sus hijos a las casas de tortura para utilizarlos como mecanismos de presión. Yo recuerdo el caso de una niña con síndrome de down, hijo de un preso político, que junto a la madre, fue utilizado para quebrar a su padre...Hubo un caso muy emblemático, el de la familia Aires, en donde los torturadores llegaron a utilizar de una forma aberrante estos aspectos sexuales... hicieron que el padre violara a la hija como forma de tortura",403

A diferencia de las violaciones de derechos humanos ocurridas en otros países como en la dictadura argentina (1976-1983), en Chile no fue usual el secuestro de menores para dar en adopción ilegal a las familias afines al régimen. No obstante, este campo recientemente se está investigando, con lo que no se descartan que puedan existir casos que apunten a la existencia de esta estrategia durante la dictadura de Pinochet.

En cualquier caso, la totalidad de los testimonios reflejan con claridad que los agentes represores utilizaron la maternidad de las presas como "vía útil de presión" para lograr sus objetivos y siempre bajo el paradigma de que ellas serían más susceptibles a hablar porque al fin de cuentas, terminarían protegiendo a sus hijos bajo el rol de cuidadoras:

-"Después de la tortura me dejaron en un socavón tirándome agua permanentemente. Recuerdo que escuché voces de niños, yo pensé que me estaba volviendo loca, pensé que era todo fruto de mi cabeza....después supe que la DINA te ponía voces de niños como un claro maltrato psicológico para que una las asociara con la tus hijos. Una no era capaz de distinguir, en esas condiciones, de quiénes eran las voces. Te ponían una grabadora. Ellos me decían "ihabla porque sino le va a pasar lo mismo a tus cabros chicos que lo que a ti!". Los agentes de la DINA manejaban perfectamente la cuestión de los hijos con la mujer"404

-“Cevallos iba siguiendo a un compañero y en un momento determinado en un allanamiento a su casa encontró una foto de una niña. En la prisión, estaba la madre de este compañero y Cevallos entró a la celda y le tiró la foto en su falda. Ella se puso blanca al mirarla, y

\footnotetext{
${ }^{402}$ Ver Anexo. Entrevista $\mathrm{N}^{\mathrm{o}} 2$.

${ }^{403}$ Ver Anexo. Entrevista $N^{\circ} 6$.

${ }^{404}$ Ver Anexo. Entrevista No 28.
} 
Cevallos exclamó ¡Ya, gracias!, no necesitaba saber más. Hay claramente un elemento de inteligencia que operaba con cierta especificidad con las presas. Cevallos sabía que como madre iba a tener una reacción" 405

Por otra parte, algunos testimonios aluden al hecho de que fruto de las violaciones algunas presas quedaron embarazadas y en el mejor de los casos, si sobrevivían, pudieron dar a luz a sus hijos pero siempre bajo condiciones de grave insalubridad.

El Informe Valech $^{406}$ confirma decenas de casos de mujeres que quedaron en estado durante su reclusión, pero sin determinar cuales correspondieron a prenatales concebidos por violación o de forma consentida. De hecho, las entrevistadas afirman que muchas de las compañeras que habían quedado embarazadas por sus captores fueron vistas por última vez en prisión y con destino desconocido; nunca más aparecieron:

-"Han tenido que soportar sesiones de interrogatorio con torturas, entre las más frecuentes cabe destacar el amedrentamiento con los hijos, golpes, apliques de electricidad, interrogatorios en los que se encuentran desnudas y diversas formas de abuso sexual. En la Casa Correccional de Mujeres situada en Santiago existen dos mujeres con embarazos derivados de las violaciones y algunas otras a la espera de los exámenes médicos que les permitan dilucidar posibles embarazos"

-"No se respetaron ni a las mujeres embarazadas. A Marta Ugarte Román, una mujer muy luchadora, profesora y soltera, cayó presa y se ensañaron con ella, la violaron y después la tiraron al mar. El mar la devolvió, apareció en la Playa la Ballena, en los Molles...Se ensañaron con las mujeres porque las que sobrevivieron fueron violadas hasta con perros. Otras fueron madres de hijos de militares al ser violadas por varios... ¿quién es el padre?, no se sabe" 408

-“Tengo amigas que las violaron e incluso tuvieron hijos de militares. Tengo una compañera que vive todavía en Hungría y tiene un hijo nacido de un milico",409

-“¿Qué pasó con Águeda Jara, amiga mía, que vivió conmigo?, una mujer muy joven que cayó en el 73 a raíz de la caída del compañero Monte. Ella fue vejada, violada, por Gabriel Mena y doce bestias más. De esa vejación nació un hijo y de ella no se supo nada más.

\footnotetext{
${ }^{405}$ Ver Anexo. Entrevista $N^{\circ} 10$.

${ }^{406}$ Ver ICNPPT, Santiago de Chile, 2004.

${ }^{407}$ Ibíd., p. 257.

${ }^{408}$ Ver Anexo. Entrevista $N^{\circ} 31$.

${ }^{409}$ Ver Anexo. Entrevista No 41.
} 
Águeda fue una mujer que cuando cayó presa no había tenido relación alguna con un hombre, 410

-“Conozco muchas compañeras que tuvieron a sus hijos en las cárceles, también a otras que fueron violadas y quedaron embarazadas, desaparecidas con sus bebés en sus vientres. Para mí es difícil ahondar más en este tema..."411

Parte de las entrevistadas interpreta la desaparición forzada de prisioneras embarazadas como una forma más de ocultación de las violaciones ejercidas contra las prisioneras, ya que los bebés nacidos en cautiverio podían ser una prueba irrefutable de lo ocurrido.

Por otro lado, las que pudieron sobrevivir no parecen haber querido indagar sobre la identidad y paradero del padre. Al impacto que estas experiencias tuvieron sobre unos menores nacidos de un padre represor y ausente, y de una madre física $\mathrm{y}$ psicológicamente torturada, se añadía que la mujer debía enfrentarse a un terrible dilema: contar quién fue el padre o guardar silencio.

Generalmente, ellas optaban por la segunda opción, lo que traería consigo una serie de costes en la salud integral de la prisionera por haber "contenido durante tantos años hechos tan traumáticos": depresiones, cuadros de ansiedad, bloqueos para mantener relaciones sexuales con otros hombres, desorientación y traumas en el menor por desconocer la identidad de su padre, problemas de salud por haberse gestado en la tortura, etc.:

-"Me pusieron electricidad en mis pechos y vagina donde me introdujeron un fierrito delgado que me produjo un dolor muy intenso...debido a la corriente que me pusieron mi organismo no produjo la tan esperada alimentación que me acercaría más a mi hijo...nació con el sistema nervioso alterado" ${ }^{412}$

-“Tuve a mi hijo estando en prisión. Finalmente, salí libre cuando mi hijo cumplió cuatro meses...sí, todavía hoy tiene problemas que vienen de todo aquello, el no dice nada pero yo lo se, muchas veces le cuesta estar solo, tiene que estar haciendo cosas permanentemente, a veces me dice que siente dolor...-mamá me duele aquí y no tiene nada...como si se

\footnotetext{
${ }^{410}$ Ver Anexo. Entrevista $N^{\circ} 36$.

${ }^{411}$ Ver Anexo. Entrevista $\mathrm{N}^{\mathrm{o}} 37$.

${ }^{412}$ Ver Gaëton P., Presas Politicas: mientras haya criminales caminando por la calle no habrá paz, en El SIGLO, No 7673, septiembre de 1988, p. 21.
} 
acordara de la tortura que me hicieron, creo que algo le tuve que traspasar...yo siento que él lo vivió conmigo",413

Finalmente, al proceso traumático de recordar lo vivido se añade un sentimiento culposo que algunas mujeres van identificando por haber militado en política y no haber advertido a tiempo los riesgos de su compromiso partidario sobre sus hijos y seres queridos.

Una de las hipótesis que se barajan es que ello pudo deberse a que nunca tuvieron conciencia del grado de violencia que el golpe iba a dejar tras de sí, y mucho menos sobre aquellas personas que no tuvieron una vinculación directa con la oposición, especialmente con los menores.

Esta "falta" de previsión, que era por otra parte irremediable, se proyecta en muchos casos como un auto-reproche $\mathrm{y}$, en otros, se justifica bajo el argumento de que las militantes pertenecieron a una generación muy joven sin experiencia política sólida, lo que las situó en una situación de mayor vulnerabilidad sobre lo que les podía ocurrir:

-"Nunca imaginamos que la represión iba a ser tan dura, pensábamos que sería algo transitorio y que la DC entraría a gobernar...creo que si esto lo hubiéramos sabido muchas mujeres no hubiera puesto en riesgo a sus hijos...Si lo hubiera sabido nunca me hubiera metido en política, es lo que más te duele...i cómo no pudimos verlo y poner en riesgo a nuestros propios hijos?, la eterna pregunta...lo he hablado con compañeras y he necesitado mucha terapia...lo llevo mal" ${ }^{, 14}$

-"Estaba en la universidad. Sabíamos que iba a ver un golpe, pero en la Jota nunca pudimos imaginar el alcance de la represión militar; pensábamos que iba a ser algo temporal. Hicimos una resistencia juvenil muy inocente" 415

-"Éramos demasiado jóvenes para saber cómo iba a ser la represión, vivíamos al límite, día a día, no me paraba a pensar en lo que ocurriría al mes siguiente" 416

-"Lo peor, el tema de mi hija, es algo con lo que no puedo...ella con los años lo entendió, yo le expliqué, conversamos harto y me dice -ya mamá, está bien, era tu compromiso...pero igual me siento... esto del abandono, de haberla puesto en riesgo",417

\footnotetext{
${ }^{413}$ Ver Anexo. Entrevista No 6.

${ }^{414}$ Ver Anexo. Entrevista $N^{\circ} 11$.

${ }^{415}$ Ver Anexo. Entrevista $N^{\circ} 32$.

${ }^{416}$ Ver Anexo. Entrevista $N^{\circ} 37$.

${ }^{417}$ Ver Anexo. Entrevista No 3 .
} 


\subsection{Las secuelas.}

La mayoría de las entrevistadas que sufrieron prisión política y tortura durante la dictadura afirman que han necesitado apoyos terapéuticos (físicos y psicológicos) durante largos períodos de tiempo, y en algunos casos, continúan bajo tratamiento en la actualidad. Según sus palabras, el proceso de su recuperación integral ha sido largo y costoso y en este sentido, reflexionan sobre los obstáculos que fueron teniendo al salir de prisión y los apoyos con los que contaron para reconstruir sus vidas.

Hay que mencionar que todas se han mostrado críticas con los gobiernos de la concertación, especialmente con la primera legislatura democrática presidida por Patricio Aylwin (1990-1994), bajo la argumentación de que no se facilitaron los apoyos institucionales para su recuperación psico-médica, a lo que se añadió la invisibilización social sobre lo que les había pasado en prisión. Tampoco contaron con el respaldo suficiente de las formaciones políticas por las que tanto se habían sacrificado.

Estas dificultades obligaron a cientos de mujeres a buscar apoyos externos, algunas, las menos, pudieron costearse terapias privadas mientras que el grueso de ellas acudió a organizaciones sociales pro-derechos humanos que ya empezaba a contar con este tipo de recursos:

\footnotetext{
-"Las víctimas no hemos tenido un espacio terapéutico para hablar de lo que nos pasó, solo en el ILAS pude encontrar algo de apoyo....allí existen grupos de reflexión de mujeres sobre lo que les ocurrió en tortura...pero a nivel institucional no hay nada de esto....todo lo que tiene que ver con gastos médicos....los problemas en las piernas que he tenido, los problemas que me ocasionaron en los oídos por la técnica del teléfono...la pérdida de equilibrio...eso se lo tiene que buscar una no más...."418

-"Cuando te hablo de beneficios me refiero a tener un sistema de salud gratuito, un sistema educativo público de calidad para nuestros hijos, también las pensiones, creo que las mujeres que sufrieron tortura necesitan una garantía de tener una vejez tranquila"419
}

\footnotetext{
${ }^{418}$ Ver Anexo. Entrevista No 4.

${ }^{419}$ Ver Anexo. Entrevista No 14.
} 
Solo a partir de 2004, y bajo la presidnecia de Ricardo Lagos, la Comisión Valech en el marco de la elaboración del $\operatorname{ICNPPT}^{420}$ permitió que miles de mujeres pudieran beneficiarse de las medidas reparatorias que se establecieron a tal efecto.

Sin embargo, la mayoría aunque aplauden dicho avance, considera que las medidas fueron claramente insuficientes y tardías ya que, durante años no pudieron disponer de recursos económicos para costearse una terapia. En varios casos, la consecuencia más directa fue el empeoramiento de su salud o su fallecimiento.

En esta línea, algunas mujeres han mencionado que compañeras cercanas también víctimas de la represión, desarrollaron con los años enfermedades terminales como cánceres, leucemias o lupus. Sin establecer una relación sanitaria directa entre ambas circunstancias, las entrevistadas sí intuyen que pueda existir un nexo de unión a través de la somatización de las experiencias extremas que sufrieron en el pasado sobre sus cuerpos:

-"En mi caso, desde que cumplí treinta años he tenido muchos problemas en las rodillas porque estuve mucho tiempo colgada. Esto, significa gastos en medicinas y en definitiva una situación especial que el Estado ha de reconocernos...creo que si hubiera ido antes a rehabilitación ahora estaría mejor"

-"Margarita no tiene pega y tiene muchos problemas de salud por lo que le ocurrió...ahora está más contenta con las ayudas de reparación, por lo menos va a recibir 140 mil pesos todos los meses... pero todo lo que ha tenido que esperar, su caso es terrible, las compañeras la tuvimos que ayudar como pudimos porque ni el partido ni el gobierno tampoco se hizo cargo de nada....,"422

-"Fue un corte brusco para ella...tuvo que marcharse de Chile sabiendo que a lo mejor no volvía más y en muy malas condiciones de salud...eso lo he visto en algunas compañeras, como el dolor se traduce en enfermedades, pues mira... ella ha tenido varios cánceres y falleció el año pasado...creo que a muchas mujeres les ocurrió que no tuvieron un lugar terapéutico para superar la tortura y el exilio, esto el cuerpo lo reflejaba de alguna manera...¿¿Por qué se murió de cáncer años después?, mira no lo sé, pero puede que tenga algo que ver con la tortura...si te fijas hay casos similares, de mujeres torturadas que luego desarrollaron enfermedades terminales, Gladis Marín podría ser uno de ellos..."423

\footnotetext{
${ }^{420}$ Informe de la Comisión sobre Prisión Política y Tortura, Ministerio del Interior, Santiago de Chile, 2004.

${ }^{421}$ Ver Anexo. Entrevista No 14.

${ }^{422}$ Ver Anexo. Entrevista No 17.

${ }^{423}$ Ver Anexo. Entrevista No 11 .
} 
Otra de las consecuencias más mencionadas son las derivadas de tortura sobre la salud mental de quienes la sufrieron, un quiebre psicológico que las afectaría en todas las esferas de su desarrollo personal. Un ejemplo lo encontramos en el hecho de que todas las entrevistadas sin excepción, tuvieron dificultades a la hora de reconstruir sus vidas afectivas, especialmente con sus hijos y en ámbito de la pareja.

Así, los efectos traumáticos de la violencia de género, especialmente aquellos que atentaron contra la sexualidad de la mujer, impidieron en muchos casos que pudieran gozar, después de prisión, de una vida afectivo-sexual satisfactoria. Como ellas expresan, el trauma sexual generó una desconfianza sobre los hombres que duraría años e impediría construir nuevos vínculos:

-“A nivel psicológico siempre este asunto me va a acompañar. La tortura y la experiencia traumática no se sí es posible superarla del todo. Para mi fue complicadísimo exteriorizar lo que yo viví, encontrar pareja, todo. Yo me sentí muy aislada al salir de prisión"424

-"Después de Cuatro Álamos estuve en tratamiento psiquiátrico para vencer el miedo, no confiaba en nadie, sentí que podían tomarme presa otra vez...Tardé muchos años en poder encontrarme cómoda con un varón...y que además pudiera acompañarte en esto, es complicado...porque muchas mujeres con sus parejas no hablan de esto, de lo que les ocurrió y esto afecta claramente...el derecho a vivir tu sexualidad...también nos lo quitaron...,"425

Por otra parte, las sobrevivientes despliegan una serie de trastornos sobre sus capacidades intelectuales y cognitivas. La pérdida de memoria y la noción espaciotemporal son las más frecuentes. Suelen mencionar la aparición de diversas "lagunas" a la hora de recordar los hechos y todo cuanto aconteció, como si de una disociación mente-cuerpo se tratara:

-"Perdí la noción del tiempo...lo que se es que desperté y vi una luz blanca. Pensé que estaba en una sala de tortura pero no...estaba en Bulgaria. En ese ínter tanto no sé lo que pasó conmigo, salí del país pero no sé en que condiciones... Fue algo demasiado tenebroso, 426

-Mira, te digo que tengo muchas dudas sobre los días que estuve allí, no recuerdo cómo ni cuando me sacaron, solo que desperté en Tres Álamos y que me dolía todo el cuerpo"427

\footnotetext{
${ }^{424}$ Ver Anexo. Entrevista No 30.

${ }^{425}$ Ver Anexo. Entrevista No 28.

${ }^{426}$ Ver Anexo. Entrevista No 40.

${ }^{427}$ Ver Anexo. Entrevista No 3.
} 
-"Hay como tres meses que no recuerdo bien, salí muy afectada de la tortura, hasta mucho tiempo después no fui consciente de lo que me había pasado, solo recuerdo a mi familia...,428

-"Yo sabía que mi cuerpo me lo destruían pero yo no estaba ahí...éramos dos personas, la que ellos vejaban y yo que miraba sin dolor, desde lejos" 429

Estos problemas, en muchos casos, conllevaron la aparición de otros nuevos como depresiones postraumáticas, crisis de ansiedad, letargia o cansancio crónico. Como es de esperar, ello condicionó seriamente la inserción socio-laboral de las represaliadas que con frecuencia veían como perdían sus empleos o bien eran condenadas al ostracismo social:

-"Varias mujeres que salieron en libertad de la Casa Correccional tuvieron que seguir tratamiento psiquiátrico, presentando trastornos, probablemente irreversibles. Los hijos presentan patologías como resultado de las torturas sufridas por sus madres" ${ }^{\$ 30}$

-“Además de los problemas lumbares y bucales después de salir me encontré con que tenía antecedentes por la Ley Antiterrorista, lo que me dio muchas complicaciones a la hora de encontrar trabajo"

-“A mi hermana la detuvieron y llegó muy mal a la casa. Durante un tiempo no podía ni reconocer a su propia familia. Recuerdo su cara cuando llegó, estaba completamente pálida. Fue muy terrible superar el terror y encontrar nuevas fuerzas para reconstruir su vida... además estuvo harto tiempo sin empleo lo que la deprimió bastante...",432

Uno de los aspectos menos tratados en cuanto a las secuelas se refiere es el que tiene que ver con los menores que de una u otra manera se vieron involucrados en el proceso represivo. Todavía a día de hoy no existe un estudio exhaustivo que haya abordado este asunto, pese a que desde hace tiempo lo vienen demandando las principales organizaciones de derechos humanos.

\footnotetext{
${ }^{428}$ Ver Anexo. Entrevista $N^{\circ} 11$.

${ }^{429}$ Ver Vergara C., Mujer y Represión Política, ILAS, Santiago, 1990, p. 9.

${ }^{430}$ Información recogida en Violación de los Derechos de la Mujer en Chile, Santiago de Chile, marzo 1977, p. 119.

${ }^{431}$ Ver Anexo. Entrevista No 30.

${ }^{432}$ Ver Anexo. Entrevista $N^{\circ} 33$.
} 
Clarificar y analizar el impacto de la represión sobre los menores se presenta como una tarea altamente compleja dado que es una cuestión que no todas las mujeres desean exteriorizar, sobre todo, por los sentimientos encontrados que genera.

Un ejemplo representativo lo encontramos en los hijos que tuvieron que salir al exilio forzosamente y en pésimas condiciones. Generalmente la huída de unos padres militantes implicaba que los menores se vieran en la tesitura de tener que vivir una vida de sobresaltos que les llevaba de un país a otro, y en donde sus vidas se veían constantemente interrumpidas. En algunos casos, los hijos y tras haber experimentado un dificultoso proceso de adaptación en los países de acogida (amigos, escuela, idioma, costumbres), se veían obligados a cortar con todo y recomenzar de nuevo ante la amenaza pinochetista, lo que terminó afectándoles severamente.

Algunas entrevistadas han querido ahondar más en este asunto aunque con la condición de no registrar la información en formato audio para preservar el derecho a la intimidad de sus hijos. No obstante, se han incluido las valoraciones que hicieron al respecto. Las secuelas de los menores que sufrieron el exilio forzado fueron:

1) Sentimiento de no pertenencia a Chile (apátridas). Muchos hijos en la etapa adulta tienden a emigrar a los países que en su día los acogieron, por haber generado un vínculo con el lugar y sus gentes. De hecho, actualmente, parte reside en el extranjero y tiene arraigo familiar. Llama la atención que muchos cursaron estudios universitarios en estos países y, algunos, actualmente militan social y políticamente en diversos frentes (Amnistía Internacional, Acción contra el Hambre, Greenpeace, partidos políticos, etc.) lo que demuestra que en cierto grado "tomaron el testigo que dejaron sus madres".

2) Declaran tener problemas de salud crónicos desde que regresaron a Chile; insomnio, cuadros depresivos, ansiedad, problemas de alimentación como anorexia y bulimia, hiperactividad, drogodependencias, etc. Actualmente parte de los hijos de las entrevistadas siguen algún tipo de terapia psico-médica.

Lo que parecen transmitir las militantes que fueron madres es que de una $u$ otra forma las consecuencias de su compromiso político tuvieron un efecto en los menores que afloraría con fuerza años después y bajo las que la mayoría dicen sentirse desorientadas 
y responsables. También queda reflejado que existe cierto mutismo entre padres e hijos a la hora de visualizar este asunto.

En cualquier caso, critican la desidia de las instituciones de los gobiernos de la concertación por no haberlas apoyado. Ellas sienten que fueron parte de la recuperación democrática en Chile, aportación que no fue correspondida a la hora de recibir la ayuda para reparar "sus heridas". Se consideran víctimas de un Estado (terrorista) y exigen que sea éste quién se encargue de las medidas reparatorias que sean necesarias. En conclusión podríamos afirmar que las represaliadas y sus familiares lejos de recuperarse en democracia, empeoraron. 


\subsection{La colaboración bajo tortura: las quebradas.}

La colaboración bajo tortura probablemente es una de las cuestiones menos tratadas por los estudios en torno al esclarecimiento de las violaciones de derechos humanos en Chile. Quizá, este aspecto, sea uno de los más complejos de analizar por los posicionamientos encontrados entre aquellas personas que sufrieron sus consecuencias y las que de una u otra manera formaron parte de ella.

Los testimonios van planteando hasta que punto se puede justificar que una persona detenida pueda colaborar con los represores (¿dónde está el limite?), ya que evidentemente ello tuvo un impacto catastrófico en las personas delatadas. Sin embargo, $\mathrm{y}$ atendiendo al contexto donde se desarrollaron los acontecimientos, las testimoniantes van estableciendo elementos diferenciados en la interpretación de los hechos.

Las entrevistadas muestran que nos hayamos ante un asunto poco reflexionado como si de un tabú enquistado se tratara, debido a las numerosas dudas y contradicciones encontradas a la hora de elaborar un discurso coherente. Esta circunstancia ha conllevado a que muchas de ellas no hayan transmitido un criterio definido o bien querido pronunciarse al respecto.

La escritora y ex mirista Nubia Becker (bajo el seudónimo de Carmen Rojas) en su publicación Recuerdos de una Mirista ${ }^{433}$, incorporó algunos datos que vierten más luz sobre este proceso. En su obra se muestra como las presas sufrieron el terrible tormento psicológico por lo que le pudiera pasar a sus hijos más allá de su propia integridad física, lo que sirvió a los torturadores como mecanismo de presión ante lo que percibían como el punto más vulnerable de la prisionera.

Inevitablemente, este modus operandi conllevó a que muchas terminaran colaborando en un marco en donde, entienden, las personas no tienen un límite determinado a la hora de soportar la tortura y más cuando está en juego la vida de sus menores:

\footnotetext{
${ }^{433}$ Ver Rojas C., Recuerdos de una Mirista, Santiago de Chile, 1978.
} 
-"Recuerdo que en todo ese tiempo no sentí dolor, sino terror...pensé en mi hijo de tres años que estaba en la casa donde nos apresaron, y se me recogió el estómago de imaginar que también lo tenían y lo torturarían junto a nosotros...que a mi niño no le hagan nada... ipor dios, que no lo toquen, que no lo aterroricen!; ¿cómo lo haré para que no lo toquen?" ${ }^{34}$

-"Lo que sentía era un profundo terror por lo que le pudiera pasar a mi marido y a mi guagüita. Después me metieron en una oficina, me empujaron y me tiraron a un sillón estando yo vendada. Me empezaron a preguntar por mi marido, su nombre y su paradero... El momento máximo de terror fue cuando sentí la posibilidad de perder a mi hija. Sentí verdadero pánico... ¿ ante esto quién no habla?" ${ }^{335}$

Según Rojas, víctima también de la prisión política y tortura, este proceso enfrentaba a la mujer a un dilema difícil de sortear (confrontación de lealtades), al tener que optar bien por proteger a sus familiares o compañeros detenidos, o por el contrario, entregar la información "para salvar a su hijo".

Según las diferentes declaraciones todo parece indicar que las mujeres cuando se trataba de proteger a sus hijos terminaban colaborando (quebradas), circunstancia que no ocurría con tanta frecuencia cuando se trataba de salvaguardar la integridad propia en detrimento de los compañeros o familiares:

-"La Lumi sufrió el atroz tormento de ver a su hijo en tortura. Eso quebró su resistencia, murió una noche en tortura, cuando el Romo, tratando de forzarla, la estranguló" ${ }^{436}$

-“Algunas de mis compañeras optaron por colaborar con la DINA para salvarse de la tortura puesto que en Londres 38 y Tejas Verdes estos métodos fueron muy comunes. De hecho, yo tengo una compañera a la que amenazaron con violar a su hija y decidió colaborar...Yo no suelo a entrar en valoraciones sobre el tema de las quebradas porque una tenía que vivir esa experiencia para darse cuenta de que no estábamos preparadas para soportar esa experiencia....Era muy fácil quebrarse en esas circunstancias. Yo no puedo juzgar por esto"437

-"Creo que la tortura es terrible y no todo el mundo puede soportarla. En el caso de la Flaca Alejandra y Luz Arce simplemente ellas no tuvieron los recursos necesarios para soportar la tortura. La Flaca debe estar muy mal, porque cayó todo el aparato central del MIR. Es muy difícil soportar tanta vejación. Creo que uno no puede criticar a las quebradas, somos seres humanos y yo no soy quién para juzgarlas, de hecho, creo que ellas son víctimas. Hay

\footnotetext{
${ }^{434}$ Ibíd., p. 15.

${ }^{435}$ Ver Anexo. Entrevista No 3.

${ }^{436}$ Ver Rojas C., Recuerdos de una Mirista, Santiago de Chile, 1978, p. 74.

${ }^{437}$ Ver Anexo. Entrevista No 29.
} 
compañeras que en este tema son mucho más duras, pero yo creo que cada ser humano tiene su punto de quiebre" 438

Los fragmentos muestran una cuestión especialmente delicada entre las sobrevivientes, esto es, la confrontación entre aquellas torturadas que no entregaron información con las que sí lo hicieron (Ruptura Tácita ${ }^{439}$ ) pese a sufrir el mismo trato o hallarse en circunstancias parecidas.

Lo que parece quedar claro es que la colaboración de las mujeres bajo tortura ha sido socialmente más conocida y repudiada (han sido tres casos de mujeres los que mayor impacto han tenido en la opinión pública) que la masculina, circunstancia que nos hace pensar que este mecanismo represivo operó mayormente sobre las presas por su condición de mujeres y madres, añadido al machismo social imperante.

En efecto, Luz Arce Sandoval (PS), Marcia Alejandra Merino Vega (Flaca Alejandra, MIR) y María Alicia Uribe Gómez (Carola, MIR) fueron tres activistas clandestinas que fueron capturadas por la DINA. Tras sufrir el rigor de la tortura, entregaron información vital que afectaría seriamente a las estructuras de sus respectivas formaciones políticas. Además, con el tiempo, pasaron a colaborar permanentemente en la busca y captura de opositores (Rosa Elvira Lizama ${ }^{440}$ las denominó funcionarias de la represión ya que algunas incluso dispusieron de sueldos):

-“A la Flaca la llevaban a porotear, ella se quebró en la tortura y dio información vital sobre los puntos de encuentro en clandestinidad. La ponían una peluca y dentadura postiza y desde el auto iba señalando qué compañeros y compañeras estaban implicados",441

"Era como cualquier otra pega, ellas colaboraban y recibían un sueldo, algunas estuvieron años asî"

\footnotetext{
${ }^{438}$ Ver Anexo. Entrevista No 30.

${ }^{439}$ Ver Rojas C., Recuerdos de una Mirista, Santiago de Chile, 1978, p. 75.

${ }^{440}$ Ver Anexo. Entrevista No 3.

${ }^{441}$ Ibíd.

${ }^{442}$ Ver Anexo. Entrevista No 12.
} 
Como se ha mencionado anteriormente, persiste entre las ex prisioneras sentimientos encontraros a la hora de verter sus reflexiones y valoraciones sobre este tema. Por una parte, la mayoría hace una distinción entre las mujeres que durante la tortura dieron información en un momento puntual y las que pasaron posteriormente a colaborar de forma permanente. Estas últimas, según las declarantes, recibieron un trato privilegiado en los centros de detención que podía derivar en liberación o en la incorporación de facto en el aparato represivo, circunstancia que suele ser objeto de reproche por parte de aquellas mujeres que no lo hicieron.

No obstante, algunos testimonios desprenden cierta comprensión hacia las compañeras que colaboraron por tratarse de un problema en donde el ser humano per se tendría una intolerancia innata a la tortura, lo que según ellas entrañaría una enorme dificultad a la hora de establecer juicios de valor sobre dónde está el límite para poder hablar.

Por tanto, la línea divisoria pareciera tornarse cuando se trata de participar en la represión "como una agente más" ya que es en este punto donde delatar deja de ser espontáneo (fruto de la experiencia extrema) para pasar a ser un acto consciente:

-"La detención de mi esposo estuvo muy vinculada a Luz Arce porque ella trabajaba en el Comité Central, en donde nosotros también trabajábamos. Ella nos conocía perfectamente....Ella entregó información sobre el paradero de Alejandro Parada, incluso lo reconoce en su libro ("Ese Infierno"). Tengo sentimientos encontrados respecto a esto. Intento comprender en que circunstancias estuvo para dar información vital sobre los compañeros. Sin embargo, lo que lamento profundamente es que continuó colaborando con la DINA en calidad de funcionaria. Ella incluso sabía que yo estaba embarazada de ocho meses" 443

-"Hay que establecer una diferencia entre aquélla que entrega información bajo la tortura y la que da el paso a la colaboración posterior a la tortura. Esto último caso fue el de la Flaca Alejandra y Luz Arce, que aunque una pueda entender que en el momento de la tortura pudieran dar información, pero que claramente, su voluntad fue la de continuar colaborando",444

-"Este es un tema muy difícil porque ellas no se quebraron de un día para otro, hubo todo un proceso. La diferencia está en que algunas de ellas se constituyeron en agentes y participaron en la represión. Hubo una etapa que fueron mis compañeras pero cuando pasaron a colaborar dejaron de serlo, es decir, se transformaron en agentes con sueldos y regalías y por tanto con la misma responsabilidad en la represión"

\footnotetext{
${ }^{443}$ Ver Anexo. Entrevista No 21.

${ }^{444}$ Ver Anexo. Entrevista $\mathrm{N}^{\mathrm{o}} 10$.

${ }^{445}$ Ver Anexo. Entrevista No 12.
} 
-"No es fácil soportar la tortura. Prefiero no entrar en juicios de valor con aquellas compañeras que se quebraron. Desde el punto de vista humano es muy difícil condenar a una compañera que lo pasó tan mal. Lo que no puedo comprender es como algunas mujeres y también hombres se convirtieron en colaboradoras"

-"Creo que nadie podía juzgar a las quebradas porque la tortura fue muy dura. No todas pudieron aguantar la tortura sin dar información. Lo que hay que condenar es el atropello de los derechos humanos y al que tortura, nunca a quién es torturado"447

-"Hoy día, después de haber pasado por distintas situaciones de la vida, pienso que fueron momentos muy duros y que uno se enfrentaba en soledad a la tortura y que cada uno tiene que enfrentar lo que hizo. Creo que la Flaca Alejandra y la Luz Arce tienen más penas que yo cuando piensan en su pasado" 448

Las propias entrevistadas han reflexionado sobre la responsabilidad de la seguridad de la militancia así como la salvaguardia de la información clave de cada partido. La mayoría se inclina por responsabilizar a la dirección de las respectivas formaciones políticas, bajo la argumentación de que sería injusto que la protección de los datos de los cuadros partidarios recayera en una sola persona (la detenida).

Además, algunas han mencionado que muchas de las compañeras que hablaron en la tortura fueron marginadas y estigmatizadas para el resto de sus vidas, circunstancia que la mayoría reconoce como injusta ya que, en último término, desvirtuaría la verdadera responsabilidad de quienes violaron los derechos humanos:

-"Creo que la responsabilidad de la seguridad de los militantes no es de los individuos que están presos sino del propio partido. Creo que fue una barbaridad entregar la responsabilidad de la seguridad del PS a los militantes presos....Estimo que el quiebre de algunas personas es un límite humano y yo no estoy en condiciones de juzgar que es lo correcto y lo que no. Aquellas personas que defienden con tanta rigidez ese aguante estoico de la tortura creo que son personas que o bien no han pasado por esa experiencia o bien se han apresurado a juzgar. El que tú hayas estado en posición de entregar información clave y que finalmente la hayas entregado no es por no tu falta de responsabilidad partidaria, es porque en un contexto de tortura nadie conoce su propio límite hasta que no la sufres",449

-"Se cometió un grave error con los compañeros y compañeras que hablaron en la tortura, ${ }_{450}$ porque en vez de recuperarlos los hundimos. Tardamos mucho tiempo en asumir este error"

\footnotetext{
${ }^{446}$ Ver Anexo. Entrevista No 20.

${ }^{447}$ Ver Anexo. Entrevista $N^{\circ} 11$.

${ }^{448}$ Ver Anexo. Entrevista $N^{\circ} 13$.

${ }^{449}$ Ver Anexo. Entrevista No 17.

${ }^{450}$ Ver Anexo. Entrevista No 10.
} 
-"Lo que te pedía el partido es que te aguantaras un par de días para hacer los movimientos necesarios para trasladar a la gente a otras casas o lugares de seguridad. Esta fue la consigna....con el tiempo nos fuimos dando cuenta de que nos enfrentábamos a unos salvajes sin freno alguno. Esto, nos hizo comprender el hecho de que no todas las personas que caían presas podían soportar tanta tortura. Te daba rabia esta situación porque caían amigos y compañeros pero entendíamos la desesperación de algunos compañeros después de haber soportado tanto dolor" ${ }^{451}$

-"El partido había dicho que la Flaca Alejandra era un "ser que había que eliminar" y nosotros estábamos allí con ella. Ella estuvo una noche en la COF, ya había sido funcionaria de la DINA y había caído por unos cheques falsos....en esa época te hubiera dicho que habría que eliminarla, como pensábamos todos" ${ }^{\text {"452 }}$

Paradójicamente, algunas sobrevivientes han reconocido que también colaboraron con la dictadura de una u otra forma, tal y como lo hicieron los compañeros de militancia, y en este sentido, entienden no se existió una diferenciación de género:

-"Lo más terrible es que empezamos a ver a compañeros que salían de la tortura. Recuerdo que a un compañero lo trajeron entre dos milicos. Estaba como un guiñapo. Lo habían molido y torturado, estaba deforme e irreconocible. En ese momento supe el alcance de lo que había pasado. Este compañero se acercó a mí y me dijo -perdóname-. Ahí le reconocí. Le habían tenido tres días y tres noches en la tortura. Después me dijo algo terrible: -yo di tu nombre, me exigieron que tenía que dar un nombre" 453

En cualquier caso, existe un consenso generalizado en la inadecuación de estigmatizar a quienes sí lo hicieron ya que la responsabilidad última de la situación (que dejaba a la víctima en la tesitura de tener que optar entre sobrevivir o delatar a los demás) fue de los militares:

-"Los seres humanos somos complejos. Nadie sabe hasta que límite puede estar su resistencia ante la tortura. El hecho de colaborar es también una forma de sobrevivir, de resistir. Algunas mujeres colaboraron y se convirtieron en funcionarias de los servicios secretos y estuvieron también involucradas en crímenes....se hace mucho hincapié en estas mujeres; no se ha hecho un catastro de los hombres que también participaron con la DINA, dieron información, etc. Se conocen estos casos puntuales de mujeres pero creo que hubo muchos hombres en esta situación" ${ }^{\prime 45}$

-"Yo tengo que asumir que yo entregué a mi pareja como mi compañera me entregó a mí. Para mi fue muy terrible pensar que mi compañera denunciara a toda mi familia porque si

\footnotetext{
${ }^{451}$ Ver Anexo. Entrevista $\mathrm{N}^{\mathrm{o}} 18$.

${ }^{452}$ Ver Anexo. Entrevista $N^{\circ} 13$.

${ }^{453}$ Ver Anexo. Entrevista No 43.

${ }^{454}$ Ver Anexo. Entrevista No 37.
} 
caía mi marido caía mi hermano y toda mi familia....Yo reconocí a la mujer entre el hueco de la venda, por su físico, supe que se trataba de una compañera de la Universidad de Concepción. Ella fue una de las mujeres a las que torturaron mucho para pasar, posteriormente, a ser colaboradora de la DINA, funcionaria incluso hasta finales de la dictadura. ....Esta mujer entregó a muchos dirigentes del MIR puesto que ella los conocía. Pude notar que ella se inclinaba y susurraba al odio del teniente Marcos quién me pregunto si era familiar de Nelson Gutiérrez, un miembro de la Comisión política del MIR de Concepción" ${ }^{\text {"45 }}$

${ }^{455}$ Ver Anexo. Entrevista No 3. 


\subsection{Mujeres en el aparato represivo.}

No existe a día de hoy una cuantificación precisa de las mujeres que voluntariamente formaron parte de los órganos represivos de la dictadura. Aunque los diversos testimonios dan cuenta de que sí existió presencia femenina en estos espacios, lo cierto es que ello no se ha reflejado en ninguna investigación que determine con exactitud el número de ellas y las responsabilidades que tuvieron.

Las entrevistadas han ido incorporando información reveladora que apunta a dos hitos fundamentales. El primero, que existieron mujeres en el aparato represivo que por lo general, desempeñaban responsabilidades de apoyo logístico: guardia y custodia de las detenidas, abastecimiento de alimentos y medicamentos, matronas y secretarias, etc.

En segundo lugar, que también hubo mujeres que participaron directamente en los interrogatorios y sesiones de tortura, independientemente de que su presencia fuese minoritaria o desempeñara funciones de menor rango militar:

\footnotetext{
-"Empecé a escuchar voces y pude oír que había una mujer que parecía estar entre los agentes. Ahí me sentí totalmente desconcertada, no podía concebir que hubiera una mujer que pudiera ser torturadora y guardiana nuestra. Fue un sentimiento de incredulidad....no podía imaginarme a una mujer torturando. Ella me pegó en los oídos cuando estaba amarrada....perdí el equilibrio y la capacidad auditiva durante un tiempo"456
}

Por otra parte, se introduce una reflexión acerca de los comportamientos y actitudes de las "funcionarias" en la cotidianeidad de los campos, alegando que ellas reprodujeron esquemas claramente patriarcales por dos razones:

1) Porque al ser una minoría en un espacio de poder monopolizado por hombres, tendieron a reproducir las conductas masculinas machistas para ser valoradas como parte integrante del aparato represivo, lo que les hacía rechazar todo aquello que representaban las activistas:

\footnotetext{
${ }^{456}$ Ver Anexo. Entrevista No 4.
} 
-"Yo recuerdo un caso de una mujer que era muy competitiva. En una sesión de tortura que le hicieron a mi marido recuerdo que ella estaba muy pendiente, dijo -paren....se salió un electrodo-. Ella trataba de demostrar que era competente para participar en la represión de la DINA, es decir, era el cliché de una mujer en un ambiente masculino que lucha por integrase" 457

2) Porque las agentes tendieron a castigar a las prisioneras políticas por haber transgredido "su rol natural" (madres y esposas), que paradójicamente ellas también cuestionaban al participar aunque de forma subsidiaria, en un espacio tradicionalmente masculino como las Fuerzas Armadas.

Algunas entrevistadas incluso afirman que las represoras actuaron con más enseñamiento y crudeza con las reas que con los prisioneros, especialmente en el trato verbal y en las rutinas carcelarias. En sus discursos aparece la idea de que a las prisioneras eran castigadas por ser mujeres desviadas que habían descuidado a sus maridos e hijos por militar en política, creencia que servía de justificación para agredirlas también en su sexualidad:

-“Quizá las mujeres fueron especialmente duras en el tratamiento a las presas políticas. ...ellas tenían un trato muy negativo con nosotras, nos limitaban muchas actividades, visitas, etc. Creo que estas mujeres nos veían a nosotras como un poco más culpables, es decir, había más permisividad con ciertas actitudes con los hombres que con las mujeres presas por esta cuestión cultural de no haber sido las mujeres que tendríamos que haber sido" 458

-"Este tipo de represión también vino dado por el comportamiento de las mujeres funcionarias del Cuerpo de Carabineros. Ellas nos increpaban con insultos y vejaciones verbales. Nos decían que nuestros maridos detenidos estaban con otras mujeres en el extranjero, es decir, fue todo un mecanismo machista destinado a infravalorarnos como mujeres, ${ }^{, 459}$

También se ha preguntado a las sobrevivientes si conocieron algún caso de agresión sexual por parte de agentes femeninas hacia un preso varón para poder ahondar más en el fenómeno de la tortura sexual. Todas coinciden en que la mayoría de las agresiones de carácter sexual eran ejecutadas por hombres, y solo excepcionalmente, las mujeres

\footnotetext{
${ }^{457}$ Ver Anexo. Entrevista $N^{\circ} 12$.

${ }^{458}$ Ver Anexo. Entrevista $N^{\circ} 5$.

${ }^{459}$ Ver Anexo. Entrevista No 21.
} 
participaban directamente: "No fue una pauta generalizada. Conozco un solo caso de violación a un hombre que es bastante conocido públicamente, fue realizado por una mujer soldado. Fue un caso excepcional" ${ }^{\prime 460}$.

Los excesos que pudieron acometer algunas funcionaras de la dictadura para con los prisioneros en muy pocos casos han sido denunciados, lo que dificulta aún más la aclaración de los hechos. Es cierto que las causas penales abiertas contra aquellos que asesinaron o torturaron no suelen incluir a mujeres, entre otras cosas porque la mayoría de los cargos de responsabilidad en los centros de detención y en la jerarquía militar eran ostentados por militares varones, pero también, porque ellos solían ser los autores directos de los actos. En cualquier caso, ello no debe significar que las mujeres que participaron en la represión de la dictadura queden impunes y pasen a ser un elemento represivo colateral y minoritario que no merece ser investigado.

${ }^{460}$ Ver Anexo. Entrevista $N^{\circ} 1$. 


\subsection{Lumi Videla, un caso paradigmático.}

Lumi Videla Moya, militante del Movimiento de Izquierda Revolucionaria, fue detenida y ejecutada por la DINA en diciembre de 1974, y representa un caso muy ilustrativo de la represión específica que sufrieron las mujeres.

Primero, porque por sus características y connotaciones, puede ayudar a vislumbrar con mayor precisión aquellos elementos que conformaron la planificación de la violencia de género como estrategia represiva, especialmente con aquellas mujeres que militaron en la oposición a la dictadura. Segundo, porque representa un claro ejemplo de la militancia política femenina en los partidos de la izquierda y cómo ello también se constituyó en un elemento utilizado por la dictadura.

Lumi Videla nació en febrero de 1948, licenciada en Filosofía y Letras por la Universidad de Santiago, desarrolló una activa participación política en el movimiento estudiantil en donde pronto destacó como dirigente. Allí, conoció a Sergio Pérez Molina (Chico Pérez ${ }^{461}$ ), co-fundador y miembro de la dirección del MIR, lo que le posibilitó un acceso directo a las actividades políticas de primera línea. Esta circunstancia, confirma una vez más el hecho de que parte de las militantes accedieron a la vida partidaria a través de figuras masculinas, en este caso, el compañero sentimental.

En 1971, bajo el mandato de Allende, asumió la dirección de la Comisión Nacional de Educación Política en el Ministerio de Educación, hasta la llegada del golpe. En dictadura, pasó a dirigir el Grupo Político Militar № 2 en clandestinidad, la vanguardia armada del MIR.

A finales de 1974, una unidad de la DINA (Brigada Halcón ${ }^{462}$ ) capturó a Videla en plena calle cuando se disponía a contactar con un compañero de partido (Octavio $^{463}$, segundo responsable del aparato de organización del MIR). El proceso de detención fue

\footnotetext{
${ }^{461}$ Ver Archivo Rettig, p.171751.

${ }^{462}$ Ibíd., p.171626.

${ }^{463}$ Ibíd., p. 171628.
} 
posible gracias a la colaboración de Marcia Alejandra Merino (Flaca Alejandra ${ }^{464}$ ), también militante del MIR, quién "tras quebrarse" en la tortura, pasó a ser estrecha colaboradora de la dictadura.

En este sentido, eran frecuentes los operativos en donde se utilizaban a mujeres en la detención de opositores. Así, disfrazadas para no ser reconocidas, acompañaban a los agentes generalmente en automóviles o camionetas. Como si de un circuito del terror se tratara, recorrían durante horas las calles de Santiago hasta que identificaran a un opositor. Acto seguido, el sujeto era introducido en el coche con destino a una de las múltiples casas y centros secretos de la DINA sin saber que una de sus propias compañeras era quién le había delatado:

-"Diariamente, los hombres de la DINA le colocaban una peluca y dientes postizos y la subían en uno de sus vehículos a recorrer las calles de Santiago. Cuando la Flaca reconocía a un mirista se ponía a temblar. No podía parar de hacerlo. Entonces actuaban sus acompañantes" 465

-"Cuando estuve en Londres 38, me pude dar cuenta de que Osvaldo Romo en varias ocasiones salía con Marcia Merino con el objeto de detener personas"

Según la documentación oficial, quien estaba a cargo del operativo contra la activista fue el coronel Osvaldo Romo Mena ${ }^{467}$ y sabemos que este tuvo lugar en algún punto de la Gran Avenida de Santiago, mientras ella esperaba un autobús (micro). Como indica la propia Merino, fue ella quién reconoció a Videla y dio cuenta a los agentes que la custodiaban: "Efectivamente, recuerdo que estando en el recinto de José Domingo Cañas, en calidad de detenida, me sacó el guatón Romo...a lo que ellos llamaban

\footnotetext{
${ }^{464}$ En el Informe Rettig (1991) se recogen los hechos de la siguiente forma: "Según declaraciones de testigos entre otros Humberto Sotomayor, el sábado 21 de septiembre de 1974 es detenida Lumi Videla, horas antes que Sergio Pérez Molina, por agentes de la DINA, a cargo de Osvaldo Romo Mena, en circunstancias que fue reconocida en la vía pública por la detenida y colaboradora Marcia Alejandra Merino. Permaneció detenida en la casa de detención de la DINA, ubicada en José Domingo Cañas, comuna de Ñuñoa en Santiago, hasta el 2 de noviembre de 1974, día en el que muere en una sesión de tortura". Ibíd., p. 171625.

${ }^{465}$ Fragmento recogido en Cavallo A., Salazar M. y Sepúlveda O., La Historia oculta del régimen militar, memoria de una época 1973-1988, Mondadori, Santiago de Chile, 2001, p. 78.

${ }^{466}$ Ver declaración de testigo: Blanca Rosa Bustos Reyes. Ibíd.., p.365

${ }^{467}$ Ver Archivo Rettig, p.171625.
} 
porotear... al parecer tendría que ser la Gran Avenida, divisé a Lumi Videla y le avisé a Romo. De inmediato la subieron al interior de un vehículo"

El testimonio de otra compañera de militancia, Rosalía Amparo Martínez, fue fundamental a la hora de esclarecer los hechos en torno a la muerte de Lumi Videla. Ella, permaneció detenida en el recinto José Domingo Cañas ${ }^{469}$ del 23 de septiembre al 30 de octubre de 1974, mismo tiempo y lugar de reclusión que la mirista asesinada:

-"La testigo señala haber compartido con Marcia Merino Reyes, conocida como La Flaca Alejandra, quién tenía un status especial, medio prisionera y medio colaboradora, a la que había conocido antes en el MIR y también como alumna del Liceo Darío Salas, de donde provenía también Lumi Videla. En esos días Marcia Merino era sacada constantemente por agentes a porotear...el objetivo era conseguir el enlace de Miguel Enríquez, máximo dirigente del MIR...Videla era uno de ellos"470

En efecto, Videla fue detenida bajo una estrategia que la situaba como el primer eslabón para acceder a la cúpula del MIR. Hay que recordar, que la mayoría de las militantes desempeñaban funciones de correo y enlace bajo la premisa de que su condición de género las iba a salvaguardar mayormente de la represión.

Sin embargo, pronto la DINA se percató de esta circunstancia lo que le llevó a diseñar una estrategia específica contra ellas: son conscientes de la función de las militantes como nexo entre los cuadros partidarios, especialmente en los casos en donde las activistas mantenían un vínculo sentimental con los dirigentes: "Con el tiempo, la DINA diseñó pautas específicas de castigo. Ellos sabían perfectamente como hacernos hablar, a quienes preguntar, etc. La CNI tomó el relevo de este trabajo"471

Tras su detención, Videla fue trasladada al Centro de detención clandestina José Domingo Cañas 1367 (Santiago) en donde permaneció alrededor de mes y medio. Allí,

\footnotetext{
${ }^{468}$ Ver declaración de testigo: Marcia Alejandra Evelyn Merino Vega, Ibíd., p. 356.

${ }^{469}$ Centro de Detención de la DINA durante el período 1974-1977. Ver José Domingo Cañas 1367, Una experiencia para no olvidar, Santiago 2001, Consejo de Monumentos Nacionales, Ministerio de Educación Chile, Chile.

${ }^{470}$ Archivo Rettig, p. 171633.

${ }^{471}$ Ver Anexo. Entrevista $N^{\circ} 29$.
} 
y según lo que van relatando los testimonios, sufrió tortura y violación hasta su fallecimiento por asfixia el 3 de noviembre de 1974, momento en el que fue sacada del recinto. Dos días después, su cadáver aparecía en el interior de la embajada de Italia, ocupada en aquel momento por más de 200 refugiados políticos.

El informe forense estableció que las causas de fallecimiento fueron la asfixia, "producto de la obstrucción de boca y nariz, presentando el cuerpo claros síntomas de vejaciones sexuales y tortura" ${ }^{, 472}$. En efecto, el examen post mortem indicaba que la muerte de Videla fue intencionada ya que la prisionera no pudo autolesionarse porque en ese momento se encontraba inmovilizada. Además, las sustancias que se encontraron en el cadáver mostraban que a la prisionera se le suministró varios calmantes antes de su muerte:

-"Cadáver de un adulto sexo femenino, que mide 155 centímetros y pesa 57 kilogramos. Identificado como: LUMI VIDELA MOYA. La causa de la muerte es el estado asfíctico. El mecanismo posible del estado asfíctico podría corresponder a una sofocación por obstrucción de boca y narices estando el cuerpo en decúbito ventral. El examen químico toxicológico de la orina reveló la presencia de meprobamato, sustancia farmacológica de acción tranquilizante" ${ }^{, 473}$

Los agentes de la DINA, en una operación planificada, arrojaron el cuerpo sin vida de Lumi Videla, filtrando posteriormente a los medios de comunicación que la activista había fallecido "a manos de los asilados marxistas en el marco de una orgía" "774. Desde la sede diplomática se defendían de las acusaciones aduciendo que no existía constancia de que la joven hubiera accedido al edificio con anterioridad al hallazgo de su cuerpo.

Algunos testigos que se encontraban en ese momento dentro de la embajada confirmaron en declaraciones judiciales posteriores que la detenida no falleció en el interior del recinto sino que ya estaba muerta cuando la tiraron:

\footnotetext{
${ }^{472}$ Archivo Rettig, p. 171634.

${ }^{473}$ Informe de Autopsia No 2432/74. Ver diligencia de Luz Moya Díaz. Tercer Juzgado del Crimen, Santiago, Investigaciones de Chile, Inspectoría General, Departamento V, Parte no 34, Santiago, 24 de noviembre de 1992, p. 366.

${ }^{474}$ Fragmento del Informe Rettig recogido en T. Moulian, Chile actual, anatomía de un mito, Arcis Universidad, Ed. LOM, Chile, 1998, p. 117.
} 
-"Por razones políticas me encontraba asilado en la embajada de Italia desde el día 24 de septiembre de 1974 hasta el 04 de noviembre...nos encontrábamos de vigilancia nocturna...nos avisaron de que sintieron un ruido en la parte exterior del muro... al llegar al lugar escuchamos un ruido seco de algo pesado que tiraron por el muro desde el exterior...con las linternas alumbramos y vimos que se trataba del cuerpo sin vida de una mujer...uno de los asilados, Eugenio Sotomayor que era médico, reconoció el cadáver como el de Lumi Videla Moya" ${ }^{\text {"45 }}$

Las conclusiones del Tribunal (III Juzgado del Crimen, Santiago) que en 1992 se encargó de llevar el caso son determinantes a la hora de exponer los hechos. A saber, niegan la posibilidad de que la activista pudiera haber sido asesinada en la embajada porque ella no pudo acceder por iniciativa propia al recinto ya que en el momento de los hechos éste se encontraba custodiado por el ejército coincidiendo con el toque de queda.

También se afirma, que los responsables de delito contaron con la complicidad de los militares, puesto que hubiera sido imposible trasladar un cuerpo y tirarlo por el muro sin ser detectados por el cordón de seguridad que lo rodeaba:

-"Las medidas de seguridad de esa época frente a las representaciones diplomáticas o Embajadas, para evitar la acción masiva del recurso de asilo hacen suponer que quienes lanzaron el cuerpo de Lumi Videla, tenían una suerte de franquicia o amparo que les permitía actuar con cierta impunidad"476

Por otra parte, otros testigos apuntan a que la DINA propuso a Videla entrar a formar parte del aparato como colaboradora, proposición que la activista rechazó en sucesivas ocasiones, lo que según ellos pudo influir en su asesinato:

-"Supe por ella que había recibido proposiciones y presiones para que se transformara en colaboradora, días después su cadáver apareció en la embajada de Italia...no pudo estar asilada en dicha embajada puesto que el día anterior a su asesinato yo estuve con ella"477

-"Fui colocado en la misma pieza donde se encontraba Lumi Videla...quién logra contarme que la torturaban continuamente con el fin de poderla reclutar y cooperar con la gente de la DINA...pero me manifestó que no lo iba a hacer y que mantendría en su posición"

\footnotetext{
${ }^{475}$ Ver Archivo Rettig, Declaración de testigo: Sergio Andrés Díaz López, Diligencia Luz Moya Díaz, p. 357.

${ }^{476}$ Ibíd., p.369.

${ }^{477}$ Ver declaración de testigo: Luís Humberto Lillo Ahumada, Ibíd., p.358.
} 
También las declaraciones reflejan que durante la estancia compartida con la ejecutada pudieron percibir presiones y comportamientos de carácter sexual para con ella que iban mucho más allá de la intención de obtener información. Es en este punto, donde entraban en juego los deseos sexuales del agente, como hombre, y la cosificación de la prisionera, como objeto: "Recuerdo que Lumi se acercó a mi para decirme si conocía a Oscar...que ella nunca iba a salir viva...Me contó además que Osvaldo Romo la asediaba mucho, que tenía que ver con acceder a sus requerimientos amorosos"479

Asimismo, varias compañeras de militancia que compartieron celda con Videla han relatado que ella misma sabía que la iban a asesinar y que, en los días previos a su ejecución, les pidió que se hicieran cargo de su hijo menor:

-"Mi hermana estuvo en José Domingo Cañas y allí supo que había otras personas, entre ellas, Lumi Videla, con quién estuvo siempre juntas durante la semana que estuvo detenida...Lumi le manifestó que pensaba que la iban a matar y le pidió que se hiciera cargo de su hijo Dagoberto, que era un niño para entonces"

Finalmente añadir que, tal y como ocurrió en otros casos, fue la madre de la víctima la que denunció primeramente los hechos (las mujeres asumen el trabajo de denuncia de sus hijos), tanto en las agrupaciones de derechos humanos como en los juzgados. Pero como muestran los documentos oficiales, la progenitora denunció, además, la detención paralela del compañero sentimental de Videla, Sergio Pérez Molina, lo que abrió dos procesos de investigación al mismo tiempo: "Soy la madre de Lumi Videla Moya y suegra de Sergio Pérez Molina, los cuales fueron detenidos por agentes de la DINA...encontrándose actualmente desaparecido mi yerno y fallecida mi hija, víctimas de esta atroz represión por el solo hecho de ser dirigente del MIR"481

Este suceso refleja con claridad una estrategia represiva específica ya que se atentó contra la sexualidad de la detenida independientemente de que los objetivos fueran

\footnotetext{
${ }^{478}$ Ver declaración de testigo: Gastón Lorenzo Muñoz Briones, Ibíd.., p.360.

${ }^{479}$ Ver declaración de testigo: María Rosa Herminia Lagos Lambert, Ibíd.., p.359.

${ }^{480}$ Ver declaración de testigo: Cecilia Bottai M., Ibíd., p. 361.

${ }^{481}$ Ver Diligencia de Luz Moya Díaz. Tercer Juzgado del Crimen, Santiago, Investigaciones de Chile, Inspectoría General, Departamento V, Parte no 34, Santiago, 24 de noviembre de 1992, Ibíd., p. 355.
} 
otros. Nos encontramos, sin duda, con un acto planificado que contó con todos los medios que la dictadura tenía a su alcance para perpetrar sus crímenes.

Lumi Videla, tristemente pasará a la historia como un ejemplo claro y conciso de las consecuencias que para una mujer podía tener militar en la oposición y ocupar espacios que tradicionalmente habían estado en manos de los hombres.

Porque a ella se la castigó doblemente, por ser activista y por ser mujer, y porque la represión se enfocó fundamentalmente sobre su sexualidad, entendemos que este caso supone un paradigma en la violencia de género en tiempos de la dictadura. Además, estos hechos pudieron repetirse con otras prisioneras políticas a lo largo de diecisiete años de asesinatos y violaciones.

Parece quedar probado que a quién se buscaba en último término era al marido de Videla, el dirigente (bajo el efecto dominó también podían caer otros cabecillas de la cúpula mirista) y ella, al desempeñar funciones de enlace clandestino, se convirtió en un recurso sumamente valioso para la DINA en la captura de opositores. Pero también el hecho de que una detenida fuera pareja sentimental de un cabecilla de la izquierda representaba para los represores una oportunidad para acometer todo tipo de excesos bajo la justificación de que se debía obtener la información "bajo cualquier medio".

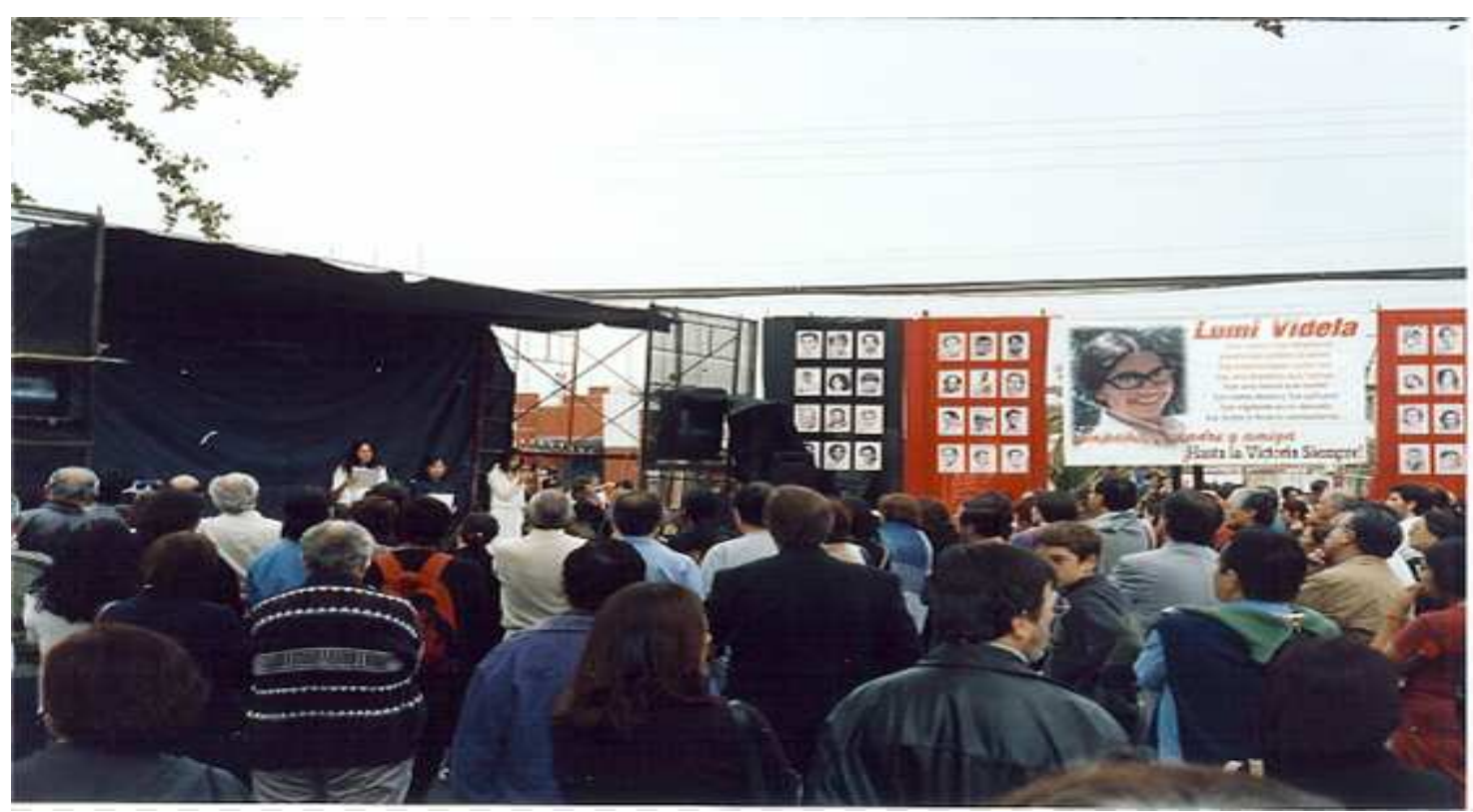

Acto conmemorativo realizado en el antiguo centro de detención y tortura José Domingo Cañas (Santiago) con motivo del $20^{\circ}$ aniversario del asesinato de Lumi Videla, diciembre de 2004. 


\subsection{Prisioneros políticos, ¿víctimas de la tortura sexual?}

-“No sé lo que me sucedió, pero esa noche no dormí, me sentía terriblemente sucio, ya no me sentía hombre, quería morir...desde ese momento ya no fuimos los mismos, nos mirábamos y sentía la vergüenza en cada uno de nosotros"482

A lo largo de la investigación y de forma colateral, han aparecido datos que indican que algunos prisioneros opositores pudieron sufrir también tortura o vejaciones de carácter sexual. Pese a que el análisis de esta cuestión en un primer momento no se incluyó como parte de los objetivos, hemos considerado oportuno dedicarle un espacio tomando como referencia dos fuentes: una, lo que las entrevistadas han ido relatando en este sentido y dos, la información oficial ${ }^{483}$ que recoge testimonios de hombres.

Es importante incluir los relatos masculinos en relación a sus experiencias de tortura porque ello puede ayudar a dilucidar con más precisión qué diferencias y similitudes se dieron en el hecho represivo en cuanto a género se refiere. Pero también por tratarse de una cuestión invisibilizada en los estudios sobre violaciones de derechos humanos que impide obtener una visión objetiva sobre los acontecimientos acaecidos.

Hay que destacar que las entrevistadas consideran que la tortura sexual, si bien fue una forma específica de represión contra las mujeres, también se aplicó con algunos hombres aunque con elementos diferenciadores.

La mayoría coincide en que éstos tenían que ver más con la forma y la intencionalidad a la hora de torturar. Mientras que a las mujeres mayoritariamente se las vejaba sexualmente por haber transgredido su rol tradicional, para satisfacer los deseos del agente o bien como forma de instrumentalizarla para la obtención de información, los hombres la sufrían como método de humillación por tratarse del enemigo derrotado.

Está práctica, frecuente a lo largo de la historia universal, se sustentaba en que los hombres vencidos eran reprimidos en su sexualidad como una forma de control para que

\footnotetext{
${ }^{482}$ Violencia sexual y represión política, ILAS, Encuentro Internacional sobre Sexualidad Humana y Educación Sexual, Santiago, Enero 1989, M. I. Castillo Vergara, p. 9.

${ }^{483}$ Ver Informes de las Comisiones de la Verdad: Informe Rettig (1991) e Informe y Valech (2004).
} 
no siguieran extendiendo su prole (castración). Con los prisioneros, el deseo sexual no era un elemento presente entre los agentes no así con las mujeres, que en la mayoría de los casos eran violadas por "placer".

Otra diferencia tiene que ver con grado de intensidad y modalidad a la hora de aplicarla la tortura en hombres y mujeres. Mientras que estos hechos afectarían de forma puntual a los hombres y casi siempre sobre su integridad física, las mujeres la sufrirían en todos los ámbitos de su desarrollo integral y bajo múltiples variables en el marco de una estrategia más global de subordinación de género (uso de la maternidad en tortura, agresiones verbales y violación en todas sus formas, humillaciones psicológicas contra su anatomía femenina, etc.).

Claramente, los testimonios dan cuenta que en la mayoría de los casos los hombres fueron víctimas de agresiones que tenían que ver más con la "violación indirecta y no carnal" (penetración anal con objetos y no pene) mientras las mujeres la sufrían in senso estricto (violaciones individuales, colectivas y sodomíticas):

-"La represión hacia los hombres no aludía a la cuestión emocional o sentimental. Fue una represión directa para la obtención de información, fue brutal, de dolor físico. Pero el tratamiento hacia las mujeres tenía que ver más con la tortura emocional, con el manejo de los sentimientos, apelar a una tortura psicológica por una parte y por otra, a la humillación de tu cuerpo, estar desnuda frente a ellos era una parte de la tortura, ellos decían cosas respecto de tu cuerpo, es el cuerpo, la emoción y el sentimiento acompañado también de una brutalidad" 484

-“Todas las mujeres que conozco fueron violentadas sexualmente. Era casi un ritual, una forma de comenzar el interrogatorio. Generalmente, si tú estudias los testimonios de aquellos hombres que han sobrevivido podrás ver que en la mayoría de los casos los interrogatorios comenzaban con golpes o insultos. Con las mujeres, el interrogatorio comenzaba con desvestirlas y manosearlas sexualmente" ${ }^{\text {"45 }}$

-"Algunos hombres se los violaban. Pero con las mujeres eran con más bronca, con más odio. Yo recuerdo haberle dicho a un torturador que su madre también era mujer, la respuesta fue sacarme la cresta,"486

-"Cualquier tipo de tortura que implique la introducción de objetos, ya sea en el ano o en la vagina ya es una forma de violación. Cuando colocaban corriente tanto a hombres como a mujeres siempre había algún tipo de introducción de algo en el ano. Por lo tanto, desde este punto de vista muy técnico, hombres y mujeres fueron violados, fueron penetrados de alguna manera, lo que pasa es que a las mujeres se las violaba en su forma más

\footnotetext{
${ }^{484}$ Ver Anexo. Entrevista No 1.

${ }^{485}$ Ver Anexo. Entrevista No 4.

${ }^{486}$ Ver Anexo. Entrevista No 14.
} 
tradicional... Indudablemente, en las mujeres hay un contexto que es diferente, que es cultural, que es el hecho del manoseo, el abuso, etc. Esto se utilizó en la SIFA. Hay compañeras que fueron violadas, yo fui objeto de abuso. Por esta razón hay una connotación cultural con las mujeres que tiene que ver mucho con la reacción que uno tiene frente a ese tipo de situaciones. Muchas mujeres estaban "dispuestas" a que les pusieran corriente pero no a que las violasen. Este era el límite. Esto es horrible, es decir, estar dispuesta a algo terrible por haber algo más terrible todavía"487

Por tanto, los agentes percibían a las presas como objetos sexuales del enemigo de las que podían disponer a su antojo, mientras que a los hombres como "cuerpos masculinos derrotados" sobre el que aplicar una victoria contundente, por ejemplo a través del castigo donde más les pudiera afectar como varones, en su dignidad masculina interpretada en su sentido más patriarcal: su potencial sexual.

Los militares, además se percibían a ellos mismos (bajo los parámetros masculinos hegemónicos y tradicionales) como hombres guerreros y sustentadores de una cruzada nacional contra la subversión marxista. Por el contrario, los activistas representaban nuevos modelos masculinos que no podían tolerar: hombres sensibles, formados intelectualmente, sensibilizados con las causas de los más desfavorecidos, respetuosos con el hecho de que sus parejas militaran en política, etc.

Por otra parte, los relatos dan cuenta de que casi todos los hombres que sufrieron vejaciones de carácter sexual, por diferentes razones, no pudieron visibilizarla al no prestar sus testimonios en las comisiones y organismos de Derechos Humanos. Ello dificultó enormemente la aclaración de lo ocurrido, lo que deja incompleto el análisis sobre las dimensiones de la violencia sexual en tiempos de Pinochet.

Mientras que la comisión Valech tan solo recoge una decena de casos de hombres que reconocieron sufrirla, en las mujeres se cuentan por miles. Ello puede significar dos cosas, que los hombres omitieran en sus declaraciones dichas experiencias extremas, dos, que en realidad se tratasen de hechos aislados y por tanto, que no obedeciera a una pauta específica represiva.

${ }^{487}$ Ver Anexo. Entrevista No 10. 
Las entrevistadas se inclinaron por la primera variable, basándose en que pudieron entrar en juego una serie de obstáculos de carácter emocional y cultural (condicionamientos de género) que impidieron que los prisioneros hablaran de lo que les había ocurrido.

En otras palabras, los hombres denunciaron menos aquellos actos que atentaron contra su sexualidad porque ello significaba exteriorizar lo más íntimo y mostrarse vulnerables (mundo de lo emocional, un espacio históricamente asignado a las mujeres) pero también por el temor a sufrir rechazo/vergüenza social (hombre violado $=$ menos hombre).

Por el contrario, las mujeres sí pudieron poner palabras a lo vivido, probablemente por una cuestión de condicionamiento sociocultural más que de diferenciación biológica, ya que la lógica patriarcal implicaba que ellas se hicieran cargo de los costes emocionales de la represión, mientras que los hombres en cambio debían de ser fuertes y contenerse:

-"La detención y paso por las cárceles de las mujeres, es una experiencia que está siendo verbalizada continuamente, la tiene a flor de piel y vive con ella, en cambio en los hombres tengo la impresión que se da un proceso de silenciar lo que les sucedió. Es decir, la mujer refiere lo que le pasó, mientras que el hombre no vuelve a hablar de lo sucedido. Esto ocurre en el espacio privado de lo cotidiano, no así en el público"488

-"Creo que a muchos hombres también los violaron. Pero al mismo tiempo hay un hecho muy claro. Primero hay que analizar que es la tortura. Para mí el hecho de desnudarte es un atentado contra tu sexualidad. Solamente esto ya es una violación de tu identidad, de tu sexualidad y tu privacidad... quizá las mujeres visualicemos más esto que los hombres. A los compañeros quizá les da más pudor hablar"489

-"Se conoce menos la vejación sexual masculina porque los hombres hablan menos, es decir, para las mujeres esto ha sido traumático pero entra dentro de esa humillación histórica que han sufrido desde siempre" 490

-"Cuando yo trabajé con algunos equipos de salud mental pude ver un hecho significativo con respecto a los hombres que habían sido torturados. Nos dimos cuenta que algunos habían sido torturados sexualmente y hubo grandes dificultades por su parte para visualizar estas experiencias" ${ }^{491}$

\footnotetext{
${ }^{488}$ Declaraciones realizadas por Víctor Espinoza, miembro de la Corporación de los Derechos del Pueblo (CODEPU) en Relato de Urgencia/Resistencia de la Mujer Chilena durante el período de 1973-1995, Universidad de Playa Ancha, Valparaíso, 1999; autoras: S. Flores Olvárez, S. López Delgado y C. Orellana Rocha, p. 282.

${ }^{489}$ Ver Anexo. Entrevista No 11.

${ }^{490}$ Ver Anexo. Entrevista No 7.

${ }^{491}$ Ver Anexo. Entrevista No 8.
} 
-“También hubo compañeros que sufrieron este tipo de represión. Es cierto que la mujer era más vulnerable a sufrir la violación pero en ocasiones se iba más allá de la cuestión de género, es decir, de humillar al preso o la presa utilizando todos los medios disponibles. También los compañeros han hablado menos que las mujeres sobre esta cuestión cultural machista",492

-"Ellas lo mencionan de forma velada, algunas lo enuncian; en el caso de los hombres, en cambio, esto es absolutamente silenciado"

Lo que parece confirmarse es que si las mujeres tuvieron resistencias para visualizar estas experiencias extremas por los traumas generados bajo tortura, en los hombres pudo ser aún más complicado porque a ello se añadía un obstáculo que tenía que ver con ponerse al mismo nivel que las violadas ( "Infra-hombres").

También algunas mujeres tuvieron dificultades para hablar de lo ocurrido pero ello pudo obedecer, según las entrevistadas, a un esfuerzo por preservar su intimidad y resguardarse del dolor que la tortura sexual había generado en sus vidas; por el contrario los hombres no lo hicieron, porque "reconocer lo sufrido" implicaba en cierta forma la pérdida de su "identidad masculina-sexual" al haber sido violentada.

En cualquier caso hay que mencionar que a día de hoy todavía no se ha constando que estas prácticas fueran frecuentes en el conjunto de los prisioneros políticos, aún existiendo casos que confirmen dichos actos. De hecho, el informe Valech $^{494}$ que incluye más 30.000 casos de víctimas de la tortura dictadura, incorpora un apartado específico sobre represión y mujer, no así con los hombres. Esta laguna podría corregirse si las instituciones facilitaran espacios terapéuticos en donde los hombres y mujeres pudieran recuperarse y exteriorizar lo vivido.

\footnotetext{
${ }^{492}$ Ver Anexo. Entrevista No 34.

493 Ver Estrada A., Hering M. y Donoso A., Familia, Género y Terapia, CODEPU, Santiago de Chile, 1996, p.110.

${ }^{494}$ Ver Informe de la Comisión Nacional sobre Prisión Política y Tortura, Ministerio del Interior, Santiago de Chile, 2004.
} 


\subsection{Principales centros de la tortura sexual.}

Como se han reflejado a lo largo de la investigación la tortura sexual fue una pauta constante utilizada contra las prisioneras políticas en la mayoría de los centros de detención de la dictadura. No obstante, y según la información que se desprende de las entrevistas, algunos de estos lugares se caracterizaron por aplicarla de una forma más sistemática.

Las mujeres sobrevivientes interpretan que sufrirla dependía del destino de la prisionera y de quienes la habían capturado, sí eran de la DINA las posibilidades aumentaban por tratarse de una organización paralela al gobierno y con un personal diferente al de las Fuerzas Armadas. En efecto, los códigos de honor era distintos: mientras que los cuerpos oficiales del ejército se mostraron más compasivos bajo la moral militar, los funcionarios de la DINA al no tratarse de militares de carrera (mercenarios del régimen), no estuvieron sujetos a ningún tipo de limitación ética. Este planteamiento, no exime a los oficiales de aplicar estas prácticas pero hay que admitir que, y según los testimonios, el grado de ensañamiento fue menor.

Villa Grimaldi ${ }^{495}$ fue el recinto secreto de detención y tortura más importante de la DINA y su operatividad tuvo una duración de cuatro años (1974-1978). Situado en la Avenida José Arrieta 8.200 (comuna de La Reina, Santiago) solía albergar a los prisioneros considerados de alto riesgo, principalmente dirigentes políticos, sindicales y militantes armados.

En el recinto existían unos camarotes independientes destinados a las mujeres. Por allí pasarían cientos de ellas de distinto signo político y procedencia social, corriendo distinta suerte dependiendo del momento en que cayeran presas. Los testimonios de aquellas que lograron salir con vida, afirman que durante su reclusión experimentaron y

\footnotetext{
${ }^{495}$ Conocido por los agentes de la DINA como Cuartel Terranova, Villa Grimaldi fue también la sede de la Brigada de Inteligencia Metropolitana, que ejercía la función de represión interna en Santiago hasta 1975. Los principales responsables de la tortura en Villa Grimaldi son: Manuel Contreras, Pedro Espinoza, Marcelo Morén Brito, Miguel Krassnoff Martchenko, Gerardo Godoy García y Ricardo Lawrence Mires. Ver Archivo Digital de la CODEPU, Santiago de Chile, p.1673.
} 
vieron como en las sesiones de tortura se aplicaban todo tipo de vejaciones sexuales. A parte de las violaciones que fueron muy frecuentes, mencionan que varias presas tuvieron abortos provocados por los choques de electricidad en la vagina, unos actos que respondía a una estrategia intencionada para con las mujeres embarazadas.

Los espacios destinados a los interrogatorios fueron:

-La Torre: una estructura de madera de tres pisos de 30 metros de altura que disponía de varias salas. En los niveles superiores existían pequeños cuartos estrechos en donde se encerraban a los presos. En la plataforma inferior existía una sala destinada a los interrogatorios y sesiones de tortura. Según los testimonios allí varias prisioneras sufrieron violaciones y parrilla eléctrica.

-Las Casas Chile: construcciones verticales de madera destinadas al aislamiento individual. Allí varias mujeres han testimoniado que permanecían de pie y a oscuras durante varios días desarrollando diferentes enfermedades infecciosas, especialmente durante los períodos de menstruación.

-Las Casas Corvi: pequeñas piezas de madera construidas en el interior de una pieza mayor, dentro de las cuales se ubicaba un camarote de dos pisos, en donde permanecían los detenidos que estaban siendo sometidos a un régimen más intenso de aislamiento. Una de estas casas era solo para mujeres en donde también se relataron casos de abusos sexuales.

-"Las mujeres convivían en unas celdas denominadas Corvi, allí solían hacinarse entre 4 y 6 presas por pieza. Las Corvi eran habitaciones de un metro cuadrado por ochenta centímetros de alto y el único respiradero era un diminuto agujero situado en la puerta que no alcanzaba los dos centímetros de diámetro... las mujeres se turnaban para descansar, mientras que unas se sentaban en el suelo las otras dos permanecían de pie"496

${ }^{496}$ Ver Anexo. Entrevista No 3. 


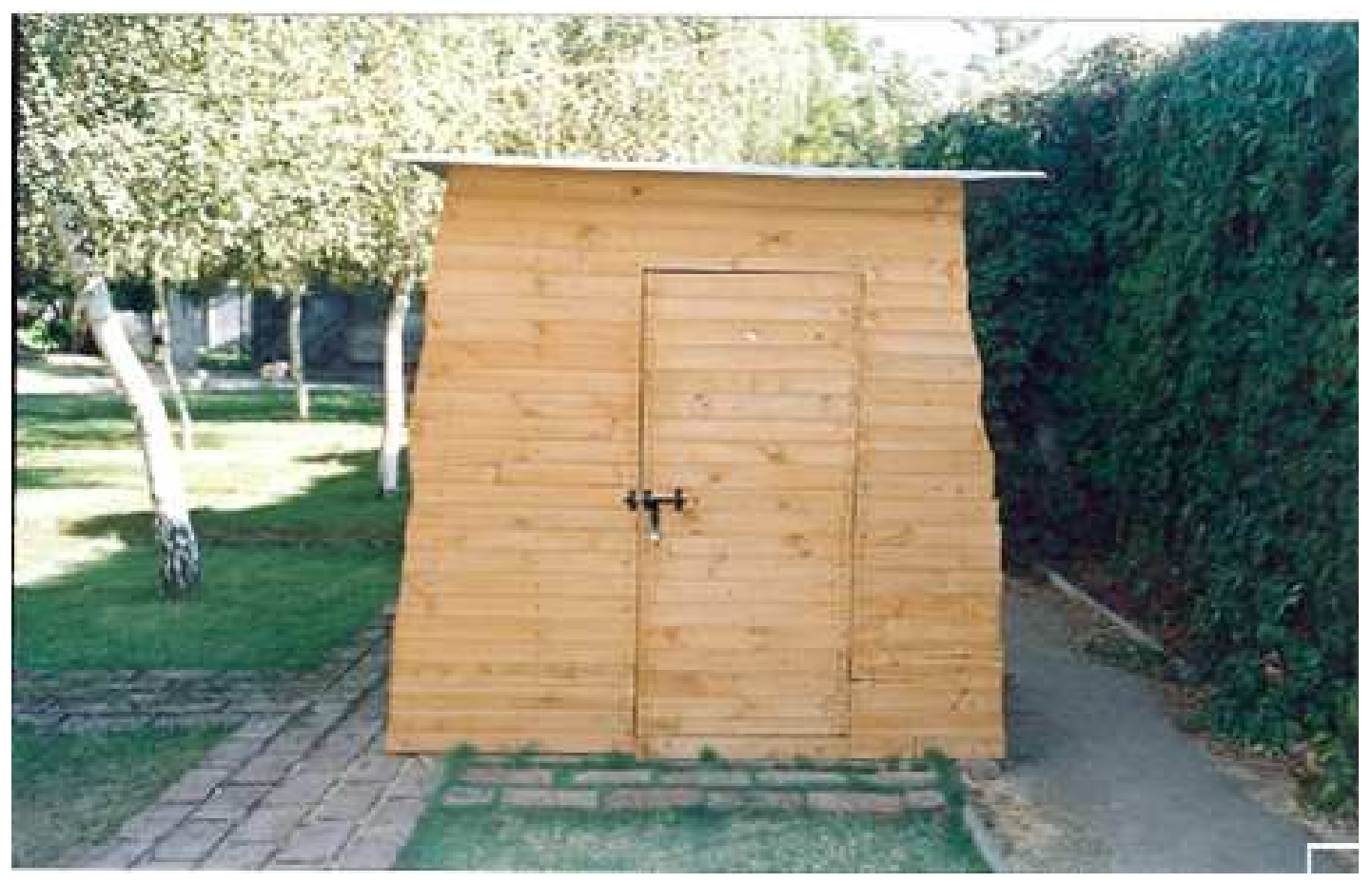

Réplica de Casa Corvi, Parque Por la Paz Villa Grimaldi (Santiago de Chile) donde se hacinaban generalmente de 6-8 presas.

El centro de tortura y reclusión Londres 38, fue una de las casas secretas de la DINA y uno de los lugares en donde se aplicó con mayor frecuencia la tortura sexual. Paradójicamente el recinto fue la antigua sede del Partido Socialista durante la década de los sesenta. Con el golpe militar, la Dirección de Inteligencia Nacional confiscó el inmueble para transformarlo en uno de sus recintos operativos. Londres 38 operó desde diciembre de 1973 hasta septiembre de 1974, pudiendo albergar en su interior hasta 100 detenidos. Algunos testimonios son contundentes a la hora afirmar el uso de estas prácticas.

Erica Hennings Cepeda ${ }^{497}$, militante del Movimiento de Izquierda Revolucionaria, estuvo recluida en este centro dónde permaneció 13 días. La DINA detuvo un día antes a su marido, miembro del Comité Central del MIR. Ella argumenta que los agentes no tenían constancia de su militancia en el partido y que la capturaron para utilizarla como un "instrumento de presión” para obtener información de su marido. La joven, sufrió la parrilla, golpes, insultos y vejaciones sexuales. Además, según su testimonio la

${ }^{497}$ Ver Archivo Digital de la CODEPU, Santiago de Chile, p.1864. 
amenazaron frecuentemente con la vida de su hija que apenas contaba con tres años de edad.

Por su parte, Nelly Andrade Alcaino ${ }^{498}$, militante del Partido Socialista fue detenida el 27 de enero de 1974 y llevada al centro de tortura Londres 38 donde permaneció una semana. Allí estuvo en régimen de incomunicación hasta que fue trasladada al recinto Tejas Verdes en donde sufrió diferentes agresiones de carácter sexual y cuyas secuelas todavía permanecen en la actualidad: "Tengo discopatía lumbar, quistes en el ojo izquierdo y en el riñón, gastritis crónica, colón irritable y he tenido varias depresiones desde que salî" 499

El Campamento de Prisioneros $\mathrm{N}^{\mathrm{o}} 2$ de la Escuela de Ingenieros Militares conocido como Tejas Verdes ${ }^{500}$ funcionó desde el 11 de septiembre de 1973 hasta mediados de 1974. El centro fue un lugar de formación y adiestramiento de futuros oficiales dedicados a la inteligencia y la lucha anti-subversiva y se utilizó como campo de prisioneros políticos.

El recinto albergaba varias celdas de un metro de ancho por uno treinta de largo. Los presos solían estar en régimen de incomunicación, sin comida ni agua, durante períodos prolongados de tiempo. En este campo los consejos de guerra fueron habituales (cientos de presos fueron ejecutados) lo que dejó pocos testigos, para que las Comisiones de la Verdad esclarecieran los hechos.

El testimonio de Margarita Durán Gajardo ${ }^{501}$, militante del Partido Comunista y recluida durante un mes en Tejas Verdes confirma el uso frecuente de la tortura sexual. Durán, fue violada delante de su pareja y de su padre y le aplicaron corriente en sus

\footnotetext{
${ }^{498}$ Ver Archivo Digital de la CODEPU, Santiago de Chile, p.1865.

${ }^{499}$ Ibíd., p.1872.

${ }^{500}$ Los principales responsables de tortura en Tejas Verdes son Manuel Contreras, David Adolfo Mirando Morales, Mario Alejandro Jara Seguel, Vittorio Orvietto Teplintzky, Patricio Carranca Saavedra, Raúl Pablo Quintana Salazar, Ramon Luis Carriel Espinosa, Nelson Patricio Valdés Cornejo, Jorge Manuel Alarcón Villalobos, Fernando Cerda Vargas, Ezequiel Oliva, Raúl Díaz Reyes y Claudio Erich Kosiel Horning.

${ }^{501}$ Ver Anexo. Entrevista No 29.
} 
órganos genitales. Como consecuencia de los hechos sufrió una infección vaginal sin recibir ningún tratamiento sanitario:

-"La mayoría de las mujeres fuimos violadas, muy pocas se escaparon de los vejámenes sexuales...en Londres 38 y Tejas Verdes estos métodos fueron muy comunes, a mi me violaron delante de mi compañero para que hablara, esto era una práctica común, es decir, buscar la debilidad de la persona. Esto ocurrió especialmente en el primer período, nosotros fuimos los conejillos de indias, ellos aprendieron a torturar con nosotros"

Finalmente mencionar otros dos centros característicos de la represión específica de género: La Venda Sexy, un recinto de la DINA situado en Santiago (Irán 3037) cuyos "métodos de tortura se diferenciaban del de otros recintos en cuanto que se enfatizaban las vejaciones de tipo sexual. La violación de las detenidas y otros abusos sexuales por parte de los guardias y agentes eran prácticas corrientes" ${ }^{, 503}$. El Buque Esmeralda ( $L a$ Dama Blanca), habilitado para funcionar como centro de tortura en la región de Valparaíso. Y por el que pasarían decenas de opositoras:

-"Nos hicieron salir con las manos en la nuca y nos subieron a un camión que paró en La Esmeralda...ahí empezó mi calvario, me empezaron a gritar puta, perra marxista, me pegaban culatazos y me tiraron por unas escaleras a una bodega...lo más terrible para mí, pues tenía 18 años y era muy tímida, fue cuando me hicieron desnudarme delante de todos los marinos con pasamontañas. Lo único que hacía era llorar y cuando me pasaban la bayoneta por mi cuerpo gritaba...,504

-"Los verdugos me sacaron la ropa a tirones, quedé desnuda de la cintura para arriba, me pusieron una placas en los senos y me daban descargas eléctricas. Donde yo estaba había solamente mujeres, en la enfermería, arriba en mi litera, había una niña que nunca le vi la cara, entraba uno con pasamontañas y la manoseaba, mientras él hacía eso a mí me pisaba las manos con sus bototos"

\footnotetext{
${ }^{502}$ Ibíd.

${ }^{503}$ Ver Informe de la Comisión Nacional de Verdad y Reconciliación, Santiago de Chile, febrero de 1991, p.468.

504 Información recogida en Azúa Ríos X., "La amnesia Nacional: el caso del buque Esmeralda"; Santiago 2001, p. 107.

${ }^{505}$ Ibíd., p. 108.
} 


\title{
4.9 La perspectiva de género en las investigaciones sobre violaciones de derechos humanos: del Informe Rettig al Informe Valech (1991-2011).
}

\begin{abstract}
-"El cuerpo femenino ha sido y es un escenario más del campo de batalla, una posesión enemiga más a destruir con el fin de alcanzar la victoria...la violación de mujeres y niñas es la que se ha manifestado como una potente y eficaz arma de guerra, venganza y humillación en el desarrollo de los conflictos armados"
\end{abstract}

El plebiscito de 1988 inició la transición política en Chile y el progresivo desmantelamiento de la estructura institucional de la dictadura. Cuando Patricio Aylwin asumió la presidencia de la República en 1990, algunos sectores de la sociedad civil y política dieron por finalizada la transición. Sin embargo, quedaba pendiente abordar el saldo represivo que los diecisiete años de dictadura habían dejado en el país atendiendo a la variabilidad de los hechos.

La cuestión de la violación de los derechos humanos en Chile se trató, en un primer momento, bajo un clima de presiones por parte de los funcionarios y personal militar todavía muy presente en las instituciones y en el ámbito judicial. Por este motivo, la primera comisión encargada de elaborar un informe sobre la violencia política y la desaparición forzada de personas tuvo esta limitación que trajo consigo importantes lagunas en la tarea investigadora.

En 1991 se publicó el Informe de la Comisión Nacional de Verdad y Reconciliación (ICNVR, Informe Rettig ${ }^{507}$ ) que establecía una primera aproximación de la represión con resultado de muerte o desaparición durante la dictadura introduciendo la variante sexo-género. Concretamente, sólo se reconocía la desaparición o ejecución de 126 mujeres pertenecientes a las diferentes formaciones políticas de la oposición. Esta cifra

\footnotetext{
${ }^{506}$ Ver Suárez Leonardo E, "La violación como crimen de guerra en el derecho internacional humanitario: la justicia olvidada" en La Violación como arma de guerra, Ed. Tiempo de Paz, № 84, primavera 2007, p. 7.

${ }^{507}$ El Informe de la Comisión Nacional de Verdad y Reconciliación (9 de febrero de 1991) también conocido como Informe Rettig, estuvo coordinado y sesionado por el jurista Raúl Rettig Guissen (19092000), quien fuera embajador en Brasil durante el gobierno de Salvador Allende Gossens (1970-1973) y presidente del Colegio de Abogados de Chile hasta 1987.
} 
aumentó significativamente en 1996 cuando salió a la luz una actualización del informe incorporando decenas de nuevos casos.

Así, el Informe sobre Calificación de Víctimas de Violaciones de Derechos Humanos y de la Violencia Política (Nunca más en Chile) recogía 191 casos de activistas asesinadas. Tres años después, esta versión volvería a ser corregida aumentando los casos a 199 de las 3197 víctimas reconocidas oficialmente. Esta cifra se estima inferior a las que baraja las diferentes agrupaciones de mujeres que todavía operan en Chile (500 asesinatos y/o desapariciones forzadas de mujeres)

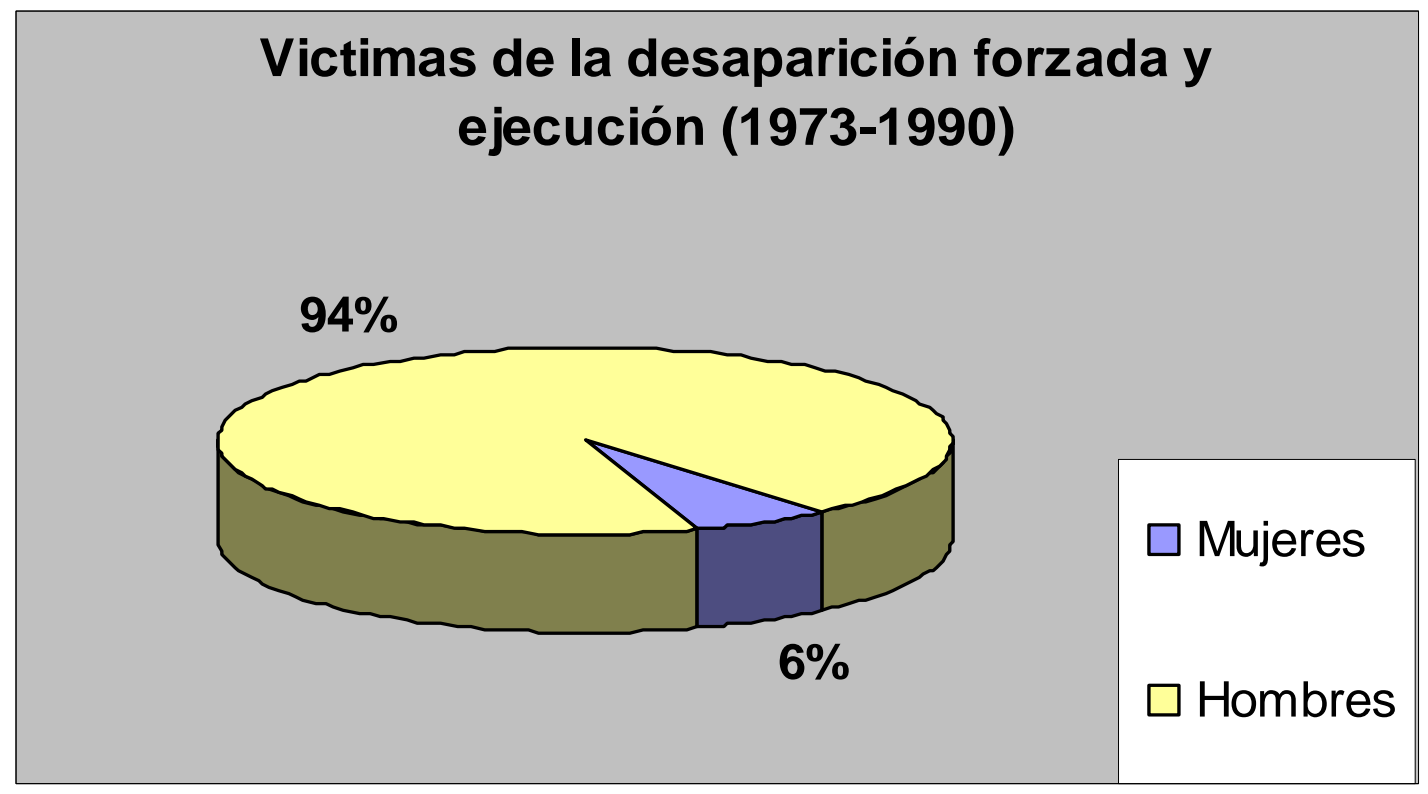

Fuente: Elaboración propia a través de los datos obtenidos en el Informe de la Comisión Nacional de Verdad y Reconciliación, Santiago de Chile, 1991.

En cualquier caso, pese a estos primeros esfuerzos, las investigaciones dejaron de lado la cuestión de la tortura y la represión sufrida por quienes sobrevivieron a la reclusión; en este punto entraba la invisibilización sobre lo que ocurrió con las prisioneras en los centros de detención.

Hay que recordar que durante los diecisiete años de dictadura, diversas agrupaciones de derechos humanos ya habían denunciado la situación que sufrían las presas políticas, la 
desaparición de mujeres embarazadas y la práctica de la tortura sexual en los recintos de la DINA ${ }^{508}$ y la $\mathrm{CNI}^{509}$.

El alcance que la represión tuvo sobre las mujeres causó un gran impacto social cuando los primeros testimonios empezaron a publicarse en diversos medios de comunicación internacionales. Las atrocidades cometidas contra las prisioneras políticas mostraron que esta clase de prácticas no obedecían a hechos aislados y espontáneos del personal militar de bajo rango sino que se trataba, más bien, de una estrategia calculada operativa en todos los niveles:

-“Instada a tener relaciones sexuales con la promesa de una pronta liberación; obligada a desvestirme, acariciada en los pechos y amenazada de recibir las visitas nocturnas del interrogador; golpes de electricidad en la espalda, vagina y ano; ratones y arañas fueron instaladas y dispuestos en la vagina y ano...; se obligó a dos médicos prisioneros a sostener relaciones sexuales conmigo, ambos se negaron, los tres fuimos golpeados simultáneamente; fue conducida a lugares donde era violada incontables y repetidas veces..."

Existen casos de agentes y soldados que trabajaban para la dictadura y que cuestionaron o se negaron a cumplir las órdenes de sus superiores por ir en contra de sus principios morales, lo que les costó la muerte, la tortura o su degradación como fórmula preventiva para que otros no siguieran su ejemplo: "En la Villa torturaron y colgaron de un árbol a un joven soldado por negarse a torturar a una mujer embarazada, lo tuvieron ahí durante días hasta que falleció"

\footnotetext{
${ }^{508}$ La Dirección de Inteligencia Nacional se creó formalmente el 14 de junio de 1974. Sus principales recintos fueron Tejas Verdes, Cuatro Álamos, Londres 38, José Domingo Cañas, Villa Grimaldi y La Venda Sexy. Los métodos más utilizados fueron la parrilla o aplicación de electricidad, colgamientos, hundimientos en el agua o submarinos, golpes de todo tipo, tortura psicológica y tortura sexual. Ver Agger I. y Jensen S. B., Trauma y cura en situaciones de terrorismo de Estado: derechos humanos y salud mental en Chile bajo la Dictadura Militar, CESOC, Santiago de Chile, 1996, pp. 104-107.
}

${ }^{509}$ La Central Nacional de Informaciones se creó en agosto de 1977, previa disolución de la DINA y funcionó hasta febrero de 1990. La CNI fue el principal organismo del Estado a cargo de la represión política durante el período 1978-1989. Según el informe Rettig, las acciones fueron mucho más selectivas. Ver Informe de la Comisión Nacional de Verdad y Reconciliación, Santiago de Chile, febrero de 1991, p. 627.

${ }^{510}$ Informe de la Comisión Nacional sobre Prisión Política y Tortura, Comisión Nacional sobre Prisión Política y Tortura, Ministerio del Interior, Santiago de Chile, 2004, pp.243-244.

${ }^{511}$ Ver Anexo. Entrevista No 2. 
Durante la década de los noventa, las agrupaciones continuaron trabajando para que la represión sufrida por las presas no quedara impune, recopilando numerosos testimonios a lo largo del país.

Con la detención de Augusto Pinochet en Londres (octubre de 1998), se abrieron nuevos cauces legales iniciando un nuevo impulso en el estudio de las violaciones de los derechos humanos en Chile, sumado a la presión mediática internacional que exigía aclarar los hechos y condenar a los culpables. Finalmente, en marzo de 2001 una comisión encabezada por el obispo Sergio Valech propuso al gobierno de Ricardo Lagos (2000-2006) la puesta en marcha de una investigación que abordara el verdadero alcance de la tortura en el país, incluyendo esta vez la perspectiva de género.

De esta manera, la Comisión Nacional Sobre Prisión Política y Tortura, se creó mediante el decreto 1.040, de 26 de septiembre de 2003, y fue presidida por Monseñor Sergio Valech Aldunate (Santiago, 1927). Valech fue el último vicario de la Fundación Vicaría de la Solidaridad (antiguo Comité Pro-Paz), organismo encargado de asesorar y atender a las víctimas de la dictadura. Asimismo, la Comisión estuvo compuesta por destacadas expertas en Derechos Humanos como María Luisa Sepúlveda Edwars y Elizabeth Lira Kornfeld.

El gobierno de la concertación no hizo oficial este proyecto hasta 2003 y un año después (noviembre de 2004) se publicó el Informe de Nacional sobre Prisión Política y Tortura, conocido como Informe Valech.

La aparición de este documento pionero supuso, entre otras cosas, el reconocimiento de la tortura sexual en Chile como estrategia organizada, definida y aplicada contra las mujeres en la mayoría de los lugares de detención de la dictadura. Pero también conllevó la puesta en marcha de un programa de apoyo estatal para las víctimas a través de indemnizaciones ${ }^{512}$, cumpliendo de esta forma, parte de las demandas de reparación de las agrupaciones y organizaciones sociales.

\footnotetext{
${ }^{512}$ El exmandatario Ricardo Lagos Escobar, en su discurso de presentación de la Comisión Valech, dijo que las víctimas iban a recibir una "reparación austera y simbólica" como parte de la responsabilidad institucional en materia de DDHH. Tras diversas negociaciones, se estableció una ayuda mensual de 120.000 pesos chilenos a todas aquellas personas que sufrieron el rigor de la tortura y la prisión durante la
} 
De los 28.459 casos que recogió la Comisión Valech (incluida la etapa de reconsideración, 2006), 3.621 corresponden a mujeres (12.5 por ciento del total de las declarantes), cifra que muchas organizaciones no comparten por considerar que cientos de casos quedaron fuera de la investigación (limitación de plazos):

-"Se estima que la cantidad de mujeres violadas es muy superior a los casos en que ellas relataron haberlo sido, por las consideraciones anteriores y porque existen numerosos testimonios de detenidos que señalan haber presenciado violaciones, cometidas en una gran cantidad de recintos de detención"

-"El 20\% de los prisioneros políticos fueron mujeres; se calcula que no menos de 30 mil de ellas pasaron por las cárceles; la mayor parte de ellas fueron torturadas"

\section{Víctimas de la Tortura y Prisión política según sexo (1973-1990)}

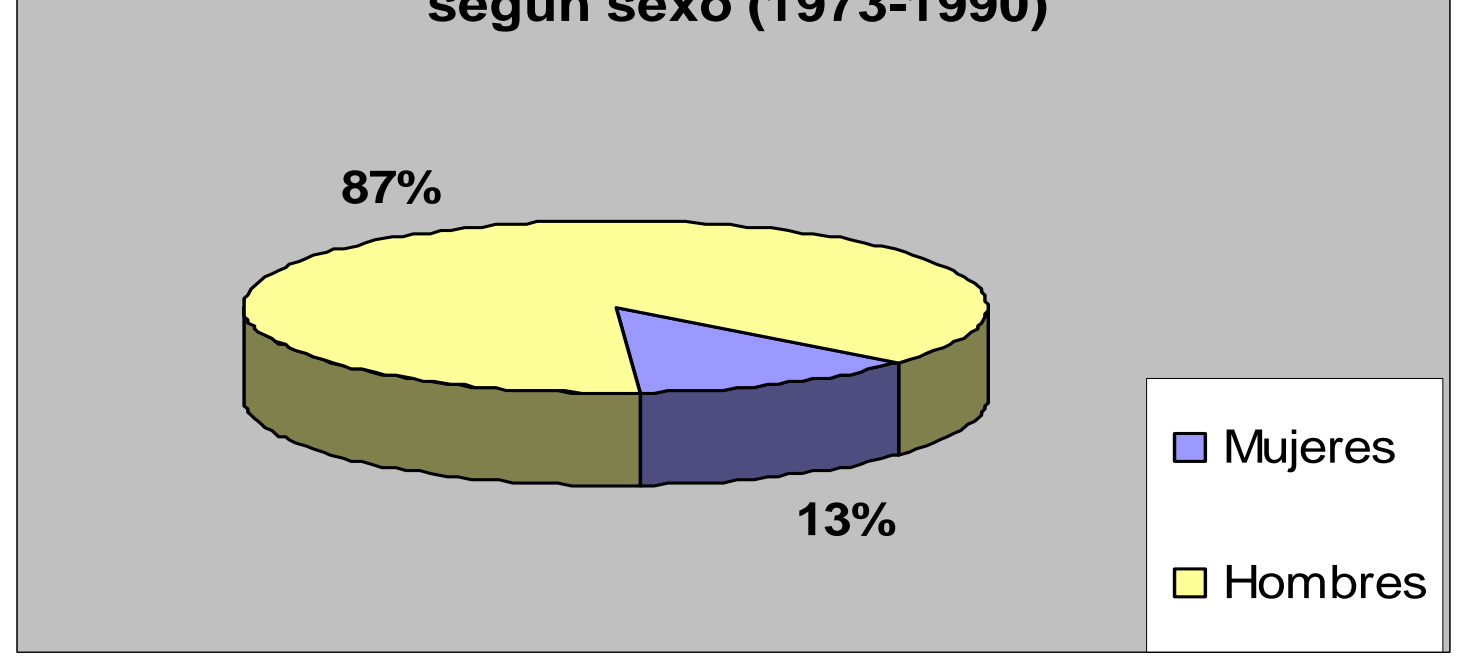

Fuente: Elaboración propia a través de los datos obtenidos en el Informe de la Comisión Nacional sobre Prisión Política y Tortura, Santiago, 2004.

dictadura militar. Ver Verdugo P., De la Tortura no se habla, Ed. Catalonia, Santiago, diciembre de 2004, p. 11 .

${ }^{513}$ Informe de la Comisión Nacional sobre Prisión Política y Tortura, Comisión Nacional sobre Prisión Política y Tortura, Ministerio del Interior, Santiago de Chile, 2004, p. 252.

514 Ver artículo de María Elena Carrera en Cuadernos de Orientación Socialista, № 8, septiembre de 1981, Berlín, p. 44. 
En relación a la tortura sexual, 316 mujeres alegaron haber sido violadas y cerca de 3000 haber sufrido algún tipo de agresión o vejación sexual. Especial crudeza adquieren los casos de mujeres embarazadas que fueron detenidas ya que un total de 229 denunciaron que cayeron presas en estado (11 de ellas reconocieron que sufrieron violaciones y agresiones sexuales). Debido a estos actos algunas tuvieron abortos y otras quedaron embarazadas por sus captores: "Debido a las torturas sufridas, 20 abortaron y 15 tuvieron a sus hijos en prisión. 13 mujeres dijeron expresamente que quedaron embarazadas de sus violadores. De esos embarazos, 6 llegaron a término"

Un ejemplo lo encontramos en el caso de la ex-mirista Cecilia Bottai Monreal detenida cuando estaba embarazada de cuatro meses por agentes de la DINA, y trasladada el 16 de septiembre de 1975 a Villa Grimaldi. Bottai sufrió todo tipo de golpes, colgamientos, quemaduras con cigarrillos, posturas forzadas, interrupción del sueño, desnudo, suspensión de comida durante varios días y tortura con golpes de electricidad. Como consecuencia de la tortura tuvo un aborto alegando que sus torturadores le pusieron electricidad premeditadamente en la vagina para producirle la interrupción del embarazo:

-"Este dolor nunca lo voy a olvidar. Como mujer no puedo olvidarlo, es una cruz que una debe llevar toda la vida. Me provocaron el aborto estando amarrada en un catre metálico sabiendo que me estaban poniendo electricidad con el objetivo tan criminal y atroz que una lo único que sentía era una tremenda impotencia por no poder salvar a mi hijo, ${ }^{, 516}$

Aunque ella no sufrió violación coital explica que el hecho de que la desnudaran, sufrir tocamientos y atentar contra su maternidad, fueron elementos claros para considerarse víctima de la tortura sexual, lo que le llevó a presentar su caso a la Comisión Valech. Bottai, deja constancia de que la experiencia en reclusión, tuvo secuelas físicas y psicológicas que afectarían enormemente su vida personal y profesional: "Al dolor y sufrimiento derivado de la experiencia represiva hay que añadir el terrible trauma que significa vivir en el exilio con un proyecto de vida interrumpido",517

\footnotetext{
515 Ver Informe de la Comisión Nacional sobre Prisión Política y Tortura, Comisión Nacional sobre Prisión Política y Tortura, Ministerio del Interior, Santiago de Chile, 2004, p. 253.

${ }^{516}$ Ver Anexo. Entrevista $N^{\circ} 11$.

${ }^{517}$ Ibíd.
} 
Otro caso revelador lo encontramos en el relato de Nubia Becker Equiluz ${ }^{518}$ (activista del Movimiento de Izquierda Revolucionaria), detenida y trasladada a Villa Grimaldi por el comando Halcón de la DINA, la noche del 29 de enero de 1975. Allí permaneció detenida durante 21 días. Sufrió desnudos, golpes de electricidad en órganos genitales, golpes y amenazas constantes en los interrogatorios (le pedían nombres y direcciones del grupo político-militar al que pertenecía).

Becker hace especial hincapié en la práctica de la tortura psicológica contra las mujeres mediante el uso de los niños como mecanismo de presión y amedrentamiento para obtener información. Según ella, la maternidad fue una pauta utilizada por los agentes de la DINA puesto que no concebían el hecho de que una mujer embarazada o con hijos estuviera militando en un partido de extrema izquierda o simplemente que no estuviera casada.

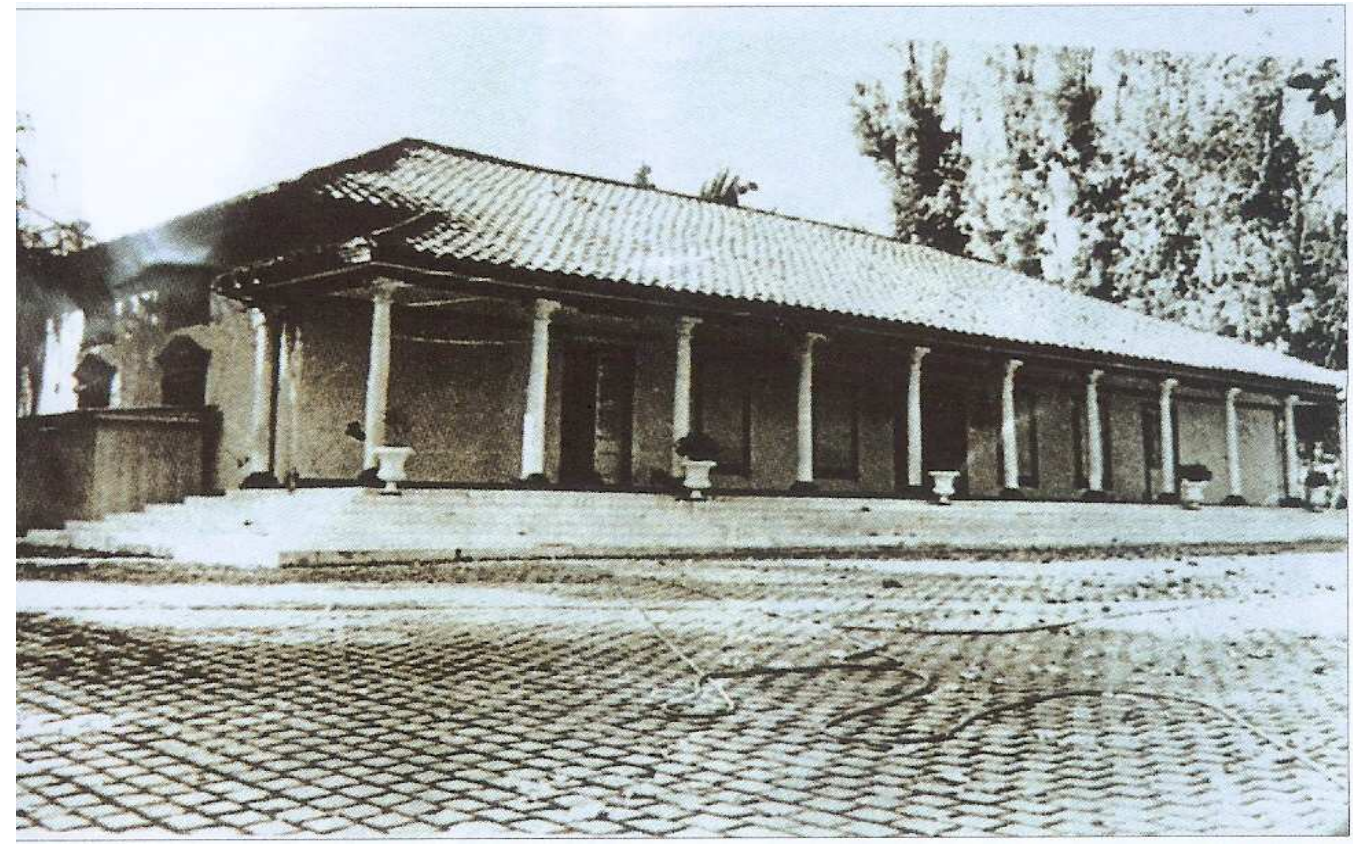

Centro de Tortura Villa Grimaldi ${ }^{519}$ (José Arrieta 8200, Santiago de Chile).

Fuente: Informe Valech, p. 465.

\footnotetext{
${ }^{518}$ Ver Anexo. Entrevista No 2.

519 Según el Informe Valech, en el Centro de Tortura y Reclusión Villa Grimaldi (Santiago de Chile) estuvieron detenidas varias mujeres embarazadas que recibieron el mismo trato que el resto de los presos "sin consideración alguna por su condición", las vejaciones y violaciones sexuales también fueron una práctica corriente en el centro. IV; p.443.
} 
Efectivamente, el Informe Valech viene a constatar estos hechos como elementos presentes en la mayoría de los centros y campos de concentración y afirma que las consecuencias de estas prácticas represivas fueron irreparables.

El ICNPPT establece hasta trece tipologías de tortura sexual:

1. Agresión verbal con contenido sexual.

2. Amenazas de violación de su persona o de familiares suyos.

3. Coacción para desnudarse con fines de excitación sexual del agente.

4. Simulacro de violación.

5. Obligación de presenciar u oír la tortura sexual de otros detenidos.

6. Obligación de ser fotografiadas en posiciones obscenas.

7. Tocamientos.

8. Introducción de objetos en ano o vagina.

9. Violación en todas sus variantes (penetración oral, vaginal, anal).

10. Violaciones reiteradas, colectivas o sodomíticas.

11. Forzamiento a desarrollar actividades sexuales con otro detenido.

12. Introducción de ratas, arañas u otros insectos en boca, ano o vagina.

13. Violaciones con perros raza bóxer adiestrados para este tipo de tortura.

Fuente: Elaboración propia a partir de los datos ofrecidos por el Informe de la Comisión Nacional sobre Prisión Política y Tortura, Comisión Nacional sobre Prisión Política y Tortura, Ministerio del Interior, Santiago de Chile, 2004.

También se incluyen testimonios de menores que estuvieron en prisión. Un ejemplo lo encontramos en uno de los primeros casos del Informe Valech correspondiente a una mujer menor de edad detenida en septiembre de 1973 y llevaba al Regimiento de Ingenieros de Tejas Verdes: 
-"Me pusieron en una especie de camilla amarrada de manos y pies con las piernas abiertas. Un hombre comenzó a darme pequeños golpes con su pene sobre mi cuerpo, me preguntó de qué porte me gustaba..., [...] en seguida ordenó que me pusieran corriente en los senos, vagina y rodillas [...] fui recibida por el suboficial [...] el que al verme comentó que si se diera vuelta la tortilla no querría que esto le pasara a su hija $[\ldots . .,]^{, 520}$

Por otra parte, el Informe Valech establece diferentes períodos de las detenciones de opositoras. Entre el 11 de septiembre y el 31 de diciembre de 1973, 1.174 mujeres fueron detenidas (52.2 por ciento) mientras que entre enero de 1974 y diciembre de 1977 la cifra descendió a 926 (27.2 por ciento). Los datos se reducen sustancialmente en el tercer período (1978-1990) tiempo en el que 700 mujeres fueron capturadas (20.6 por ciento).

\begin{tabular}{|l|c|c|}
\hline \multicolumn{2}{|c|}{ Distribución víctimas de la prisión política y tortura por sexo } \\
\hline Período & Mujeres (\%) & Hombres (\%) \\
\hline 1973 & 9.7 & 90.3 \\
\hline $1974-1977$ & 17.6 & 82.4 \\
\hline $1978-1990$ & 19.3 & 80.7 \\
\hline
\end{tabular}

Fuente: Elaboración propia a partir de los datos ofrecidos por el Informe de la Comisión Nacional sobre Prisión Política y Tortura, Comisión Nacional sobre Prisión Política y Tortura, Ministerio del Interior, Santiago de Chile, 2004.

La comisión muestra una cuantificación por edades en el momento de la detención. Concretamente, 1.464 mujeres (43.1 por ciento) estaban en edades comprendidas entre los 21 y los 30 años, 387 presas entre 18 a 20 años (11.4 por ciento), 1.757 mujeres (22.3 por ciento) entre 31 a 40 años y 421 mujeres (13.3 por ciento), entre los 41 y 50 años.

${ }^{520}$ Ibíd., p. 243. 
Por tanto, más de la mitad de las prisioneras no superaba los treinta años, lo que indica que se trataba de una generación muy joven (cuyo punto álgido fue el gobierno de Allende -1970-1973-) que no había tenido tiempo de adquirir experiencia política.

Otro dato sorprendente es el número de mujeres que fueron detenidas siendo menores de edad (212), lo que viene a significar un 6.3 por ciento del total de las presas. El cuadro estadístico se cierra con otras cifras referentes a mujeres mayores de edad (51-60 años) con un total de 112 (3.3 por ciento) y mujeres sin una edad determinada (16.1 por ciento).

Lo inquietante de estas cifras es que si sumáramos las mujeres que cayeron presas siendo menores de edad y aquellas con edades comprendidas entre los dieciocho y los treinta años, la cifra ascendería a 2.063, es decir, el 60.7 por ciento del total de las detenidas.

En cuanto a la filiación política se refiere, el Partido Comunista, el Partido Socialista y el Movimiento de Izquierda Revolucionaria fueron los más afectados. 751 militantes del PC fueron detenidas y torturadas (22 por ciento del total). Le sigue el Partido Socialista con 577 detenidas (17 por ciento) y el MIR con 263 ( 7.8 por ciento).

También, aparecen unas cifras "ambiguas" catalogadas como "simpatizantes de izquierda" (442 detenidas, 13 por ciento) y sin militancia política reconocida (1.179 mujeres, 34.7 por ciento). Cierran el cuadro las mujeres militantes del MAPU (75 detenidas, 2.2 por ciento), Partido Radical (37,1 por ciento), Democracia Cristiana (13.3 por ciento) e Izquierda Cristiana (12 por ciento).

Por otra parte, el informe recoge algunos testimonios de varones que fueron víctimas de la tortura sexual. Aunque el porcentaje es muy bajo (menos del 1 por ciento), es presumible que pudieran existir más casos no reconocidos que no entraron a formar parte del documento. Un ejemplo revelador es el testimonio que se refleja a continuación perteneciente a un hombre detenido en octubre de 1973 y recluido en la Base Aérea Maquehua (IX Región). 
-"De manera especial me golpeaban los testículos con una especie de regla, lo que me provocaba unos dolores insoportables. Todo esto, siempre estando yo desnudo y vendado. Durante el proceso de tortura también me introdujeron un palo por el ano, producto de lo cual tuve desgarros que me provocaron hemorragias por varios días, tanto anales como por vía oral" ${ }^{\prime 521}$

El testimonio de Nieves Ayress Moreno, estudiante de arte y periodismo en la Universidad de Chile y militante del Movimiento de Izquierda Revolucionaria, refuerza el hecho de que en Tejas Verdes también existió la tortura sexual con animales:

-“Tejas Verdes era el lugar donde entrenaban a los militares para ser torturadores, y ahí sufrí torturas brutales. Me forzaban a hacer actos sexuales con un perro que había sido entrenado para participar en torturas. Colocaban ratas adentro de mi vagina, y luego me daban choques con electricidad. Al recibir el choque, las ratas se desesperaban y hundían sus garras en la carne de mi vagina. Se orinaban y defecaban en mi cuerpo, introduciéndome el virus toxoplasmosis. Los torturadores me violaron en muchas oportunidades, y me tocaban sexualmente, insultándome, y forzándome a tener sexo oral con ellos" ${ }^{, 522}$

Finalmente, otro testimonio revelador es el de Mauricio Carvallo, torturador y funcionario de la DINA entre 1974-1975. En una entrevista concedida al diario La Nación expone algunas de sus experiencias como agente de la Dirección de Inteligencia Nacional.

En los últimos años Carvallo ha colaborado activamente con jueces y abogados que trabajan en pro de los derechos humanos; esta aportación ha supuesto un impulso fundamental en la aclaración de numerosos casos de torturados y detenidosdesaparecidos.

Carvallo, se encargó de los procesos interrogatorios en los centros de tortura Londres 38, Venda Sexy y Villa Grimaldi. La importancia de los fragmentos de su testimonio reside en que se recogen algunos puntos clave que verifican el uso de animales en la tortura sexual contra las presas políticas:

\footnotetext{
${ }^{521}$ Ibíd., p. 244.

${ }^{522}$ Declaración de Luz de las Nieves Ayress Moreno en, El testimonio de una mujer que vivió el infierno, La Nación, 20 de Noviembre de 2004.
} 
-"La Venda Sexy era tristemente famosa por sus aberraciones sexuales y por un perro que violó a mujeres y hombres...El "Volodia"...era un gran perro policial. Lo más terrible ocurría de noche...los detenidos llegaban en muy malas condiciones físicas. Además, cuando debí "trabajar" a los detenidos era porque tenía dos oficiales encima, de quienes di sus nombres en los tribunales. Estuve obligado a ser malo, aunque no lo quise ${ }^{, 523}$

Finalmente, la Comisión refleja diferencias destacables en las secuelas entre hombres y mujeres estableciendo que mientras los hombres en general insistían en las secuelas física con prescindencia de alusiones a los sentimientos relativos a sus experiencias extremas, las mujeres eran más proclives a ocuparse también del costo emocional, refiriéndose con mayor profundidad a las secuelas psicológicas de la prisión política y tortura.

Más allá de este hecho revelador, el Informe Valech es determinante al alegar que estas experiencias causaron terribles efectos en las mujeres sobrevivientes sobre su autoestima, su sentimiento de dignidad, de integridad moral y emocional, su identidad, su capacidad para la intimidad sexual y, por ende, sobre las relaciones de pareja.

Queda suficientemente probado que el conjunto de las prácticas descritas, cuyo eje vertebrador fue provocar tormento en la sexualidad de la prisionera, fueron hechos frecuentes sin que la edad, la procedencia social, política o económica o estado de salud fueran condicionantes para evitarlas.

A pesar de la dureza de los testimonios el valor de los mismos es innegable y forma parte de los propios cimientos de los informes en la recuperación de la verdad y la justicia. Ahora queda por terminar de sanar las heridas abiertas en miles de mujeres que se comprometieron en la lucha por las libertades y la democracia en Chile. Para ello el Estado y sus instituciones han de comprometerse para que su recuperación finalice lo antes posible.

\footnotetext{
${ }^{523}$ Declaración de Mauricio Carvallo en www.memoriaviva.com/culpables/criminales.htm
} 


\section{*Etapa de reconsideración (2010-2011).}

En febrero de 2010, la presidenta de Chile, Michelle Bachelet Jeira (2006-2010), puso en funcionamiento una comisión encargada de abrir un nuevo plazo para el reconocimiento de las víctimas que no se presentaron o no fueron reconocidas por las anteriores (Rettig y Valech). Así, mediante el decreto supremo no 43 (13 de febrero de 2010) se creó la Comisión encargada de elaborar Informe para la Calificación de Detenidos Desaparecidos, Ejecutados Políticos y Víctimas de Prisión Política y Tortura.

Conforme al artículo $3^{\circ}$ transitorio de la Ley $\mathrm{N}^{\circ} 20.405$, ésta estuvo formada por los mismos integrantes de la Comisión Valech: Monseñor Sergio Valech Aldunate, María Luisa Sepúlveda Edwards, Miguel Luis Amunátegui Monckeberg, Luciano Fouillioux Fernández, José Antonio Gómez Urrutia, Elizabeth Lira Kornfeld, Lucas Sierra Iribarren y Álvaro Varela Walker.

La Comisión recibió 31.831 solicitudes de calificación de personas que declararon haber sido víctimas de prisión política y tortura, de las cuales se reconocieron 9795 (aproximadamente un tercio), y 622 casos de detenidos desaparecidos y ejecutados políticos (solo 30 calificaron). Por tanto, a los 28.459 casos reconocidos por la Comisión Valech en su primera etapa de reconsideración (2006) habría que añadir este aumento, lo que nos daría una cifra final de 38.254 víctimas. Por otra parte, habría que sumar treinta desapariciones forzadas más a las 3.195 reconocidas por la Comisión Rettig (Total: 3.225 )

Desde una perspectiva de género, el informe califica 1500 nuevos casos de mujeres, lo que supone un 16 por ciento del total. El perfil de las víctimas al momento de su detención coincide con el de las anteriores comisiones: mujer joven (20-35 años), mayoritariamente con formación académica y/o profesional y militante o simpatizante de las principales formaciones de izquierda que opositaron en clandestinidad (21 por ciento del Partido Comunista, 15 por ciento del Partido Socialista y 7 por ciento del MIR). 


\section{Víctimas calificadas por sexo}

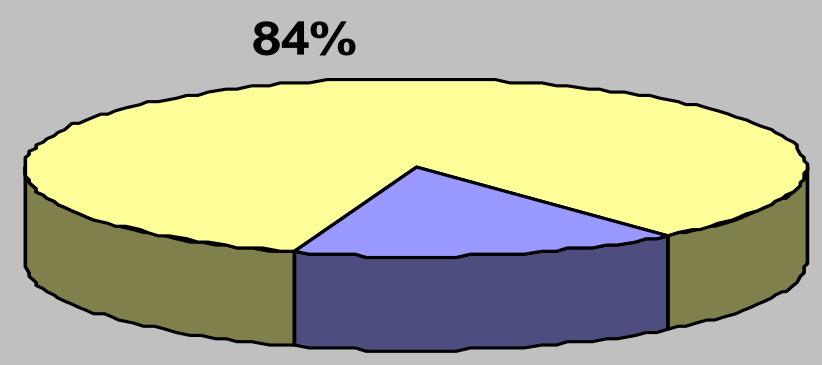

$16 \%$

\section{Mujeres}

Hombres

Fuente: elaboración propia a partir de los datos recogidos en Informe para la Calificación de Detenidos Desaparecidos, Ejecutados Políticos y Víctimas de Prisión Política y Tortura, Comisión asesora para la calificación de detenidos desaparecidos, ejecutados políticos y víctimas de la prisión política y tortura. Presidencia de la República, Santiago de Chile, Agosto 2011.

\section{Actividad laboral de las prisioneras}

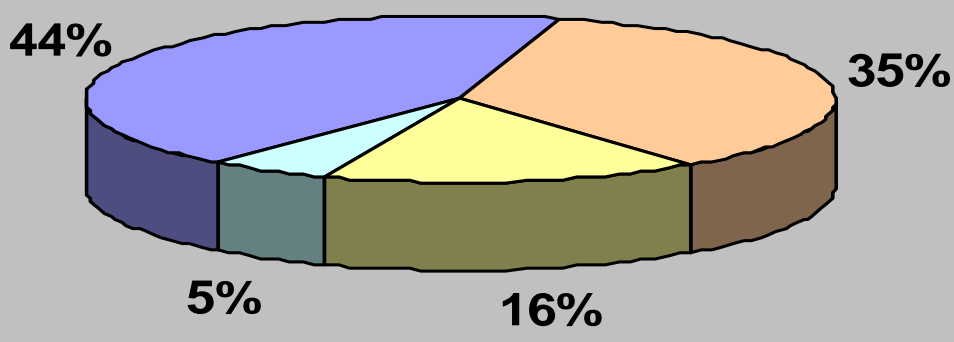

$\square$ Estudiantes

$\square$ Profesionales

$\square$ Ama de Casa

$\square$ No cualificadas

Fuente: elaboración propia a partir de los datos recogidos en Informe para la Calificación de Detenidos Desaparecidos, Ejecutados Políticos y Víctimas de Prisión Política y Tortura, Comisión asesora para la calificación de detenidos desaparecidos, ejecutados políticos y víctimas de la prisión política y tortura. Presidencia de la República, Santiago de Chile, Agosto 2011. 
Estos datos coinciden con el perfil de las mujeres que han sido entrevistadas en el marco de esta investigación y muestran que la realidad que sufrió el país entre 1973 y 1990 tuvo como consecuencia la violación de los derechos humanos de miles de ciudadanos y cuyo responsable fue el Estado y sus gobernantes. Por ende, la comisión insta a que sea éste el principal promotor y garante de la reparación de las víctimas: "Esta constatación refuerza la responsabilidad del Estado de Chile en relación con el reconocimiento y reparación de las víctimas",524

Precisamente, en los períodos de irrupción militar como cortapisa a los intentos de democratización, ampliación de derechos de ciudadanía y de transformación social en un determinado país, las mujeres han sufrido y sufren un doble handicap que las sitúa en una situación de especial vulnerabilidad e invisibilidad por su condición de género, en donde el factor sexual viene a ser un elemento determinante a la hora de reproducir dicho sistema de dominación. Ello obliga a repensar y a buscar un nuevo enfoque en el estudio de las violaciones de los derechos humanos allí donde se produzcan, como paso previo a la reconstrucción de la memoria histórica en términos de equidad y objetividad.

Entrevistadas que prestaron testimonio en la Informe Valech (2004-2011).

\begin{tabular}{|l|c|}
\hline \multicolumn{1}{|c|}{ Nombre } & Caso \\
\hline $\begin{array}{l}\text { AGUILERA JARAMILLO, JUANA } \\
\text { ROSA. }\end{array}$ & $\mathrm{N}^{\mathrm{o}} 377$ \\
\hline $\begin{array}{l}\text { ANDRADE ALCAINO, NELLY } \\
\text { PATRICIA. }\end{array}$ & $\mathrm{N}^{\mathrm{o}} 1276$ \\
\hline BECKER EGUILUZ, NUVIA BETSIE. & $\mathrm{N}^{\circ} 2980$ \\
\hline BOTTAI MONREAL, MARÍA CECILIA. & $\mathrm{N}^{\mathrm{o}} 3274$ \\
\hline BRINKMANN SCHEIHING, BEATRIZ. & $\mathrm{N}^{\mathrm{o}} 3437$ \\
\hline BRITO VÁSQUEZ, LUCRECIA. & $\mathrm{N}^{\mathrm{o}} 3491$ \\
\hline DURÁN GAJARDO, MARGARITA. & $\mathrm{N}^{\mathrm{o}} 7583$ \\
\hline
\end{tabular}

${ }^{524}$ Ver Informe para la Calificación de Detenidos Desaparecidos, Ejecutados Políticos y Víctimas de Prisión Política y Tortura, Presidencia de la República, Santiago de Chile, Agosto 2011. www.comisionvalech.gov.cl/InformeComision/Informe2011. 


\begin{tabular}{|c|c|}
\hline $\begin{array}{l}\text { GARCÍA RAMÍREZ, MERCEDES } \\
\text { MIREYA. }\end{array}$ & $\mathrm{N}^{\mathrm{o}} 9606$ \\
\hline $\begin{array}{l}\text { GEORGE-NASCIMENTO LARA, } \\
\text { XIMENA. }\end{array}$ & No 9807 \\
\hline GÓMEZ TAPIA, MARÍA PETRONILA. & $\mathrm{N}^{\mathrm{o}} 10033$ \\
\hline $\begin{array}{l}\text { GONZÁLEZ GONZÁLEZ, CECILIA } \\
\text { MORELIA. }\end{array}$ & $\mathrm{N}^{\mathrm{o}} 10263$ \\
\hline HENNINGS CEPEDA, ERIKA CECILIA. & $\mathrm{N}^{\mathrm{o}} 11103$ \\
\hline HERRERA HERRERA, FIDELIA. & $\mathrm{N}^{\mathrm{o}} 11405$ \\
\hline IGLESIAS SALDAÑA, MARGARITA. & $\mathrm{N}^{\mathrm{o}} 11850$ \\
\hline LIZAMA LEIVA, ROSA ELVIRA. & $\mathrm{N}^{\mathrm{o}} 13210$ \\
\hline MARDONES ORMEÑO, EVA. & $\mathrm{N}^{\circ} 14060$ \\
\hline MASON PADILLA, LILIANA MIREYA. & $\mathrm{N}^{\mathrm{o}} 14370$ \\
\hline MENA YÁÑEZ, MARGARITA. & $\mathrm{N}^{\mathrm{o}} 14770$ \\
\hline $\begin{array}{l}\text { MUÑOZ CATEJO, AURELIANA } \\
\text { ANGÉLICA. }\end{array}$ & $\mathrm{N}^{\mathrm{o}} 16080$ \\
\hline $\begin{array}{l}\text { PALESTRO CONTRERAS, SANDRA } \\
\text { AQUILINA. }\end{array}$ & $\mathrm{N}^{\mathrm{o}} 18035$ \\
\hline PÉREZ VALDÉS, LELIA MATILDE. & $\mathrm{N}^{\mathrm{o}} 18892$ \\
\hline $\begin{array}{l}\text { ROMERO MÉNDEZ, MARGARITA } \\
\text { VALERIA. }\end{array}$ & $\mathrm{N}^{\mathrm{o}} 21571$ \\
\hline SALINAS FARFÁN, MARÍA ALICIA. & $\mathrm{N}^{\mathrm{o}} 22276$ \\
\hline TORRES MUÑOZ, PATRICIA. & $\mathrm{N}^{\mathrm{o}} 24439$ \\
\hline $\begin{array}{l}\text { ZALAQUETT DAHER, PATRICIA } \\
\text { ANGÉLICA. }\end{array}$ & $\mathrm{N}^{\mathrm{o}} 26846$ \\
\hline
\end{tabular}




\section{CONCLUSIONES}

La presente investigación ha tratado de afrontar dos retos fundamentales: por un lado, vislumbrar cuál fue el papel de la mujer dentro de la órbita de la izquierda chilena entre 1970 y 1990 y, por otro, abordar cuáles fueron las consecuencias de su compromiso político, utilizando la perspectiva de género como eje vertebrador del análisis. Precisamente, son estas cuestiones las que menos visibilidad tienen en los estudios de la historia reciente de Chile, una circunstancia que bien valía la pena aprovechar por un sentido de equidad en la producción del conocimiento histórico.

¿Por qué Chile? El florecimiento de las libertades político-sociales durante el gobierno de Salvador Allende Gossens (1970-1973) y la irrupción, poco después, de una de las más sangrientas dictaduras militares en América Latina podía ser el escenario idóneo para abordar dichos objetivos. Ambos acontecimientos se sitúan en un periodo de tiempo relativamente corto que incluye importantes avances y retrocesos en relación a los derechos de las mujeres y nos permite poder contar con testimonios directos del presente para compararlos con los que se recopilaron en el pasado.

En efecto, dos décadas intensas repletas de episodios paradigmáticos y desconocidos podían encerrar información nunca anteriormente analizada a través de las experiencias concretas de cada entrevistada, un argumento con suficiente peso para iniciar este trabajo. En cualquier caso, los testimonios y la información estudiada nos han permitido llegar a una serie de conclusiones solo generalizables a los casos analizados.

Conviene recordar que gran parte de la información atañe a las trayectorias políticas y vitales de mujeres de diferentes generaciones, procedencia socioeconómica y formación política aunque con un nexo en común: vivieron una misma época y participaron de una u otra forma en el espacio político de la izquierda cuyo coste más importante fue sufrir la represión. Esta heterogeneidad de experiencias permite contar con una gran riqueza de matices de gran utilidad para una reconstrucción más precisa de los hechos. 
En el transcurso del pasado siglo XX las mujeres en Chile, al igual que ocurrió en otros muchos países, comenzaron a participar en el escenario político, a organizarse y luchar por sus demandas igualitarias tras siglos de subordinación e invisibilidad. El punto clave de este proceso fue la llegada al poder de Salvador Allende en 1970, un momento propicio para la eclosión de una generación de mujeres que transgredirían, sin lugar a dudas, los espacios que por tradición se las asignó (Ángel del Hogar).

Pero el renacimiento de la participación política femenina durante los años de la Unidad Popular (1970-1973) fue el culmen de un largo proceso que comenzó décadas atrás gracias la génesis de una generación de mujeres que se movilizó por el derecho a sufragio durante los años treinta y cuarenta.

No obstante, una vez logrado su aprobación en 1949, dicho movimiento fue disolviéndose para permanecer en la sombra durante las siguientes dos décadas. Ambas generaciones se verían abocadas años después a hacer frente a un enemigo en común, pero con una experiencia y una perspectiva de los hechos que las diferencia en algunos detalles.

En esta línea, la generación de mujeres más longeva (las sufragistas ${ }^{525}$ ) se muestran menos críticas en relación al desarrollo de los derechos de las mujeres en los partidos de la izquierda chilena, percibiendo que las relaciones entre hombres y mujeres fueron razonablemente equitativas. Para ellas los logros alcanzados para mejorar el bienestar de las chilenas fueron muchos, especialmente en la época de Allende pero también a partir de 1990 con la restitución de la normalidad democrática. Su visión la fundamentan en la comparativa de cómo vivían las mujeres a comienzos de siglo (mucho más subyugadas) con las que vivieron en las décadas de los años setenta y ochenta.

Sí coinciden con las demás en que, durante la dictadura, las militantes sufrieron una represión específica por su condición de género, independientemente de su papel o la información que pudieran poseer sobre sus organizaciones políticas.

\footnotetext{
${ }^{525}$ La presente investigación cuenta con varios testimonios de mujeres que comenzaron su militancia política durante en el período comprendido entre 1935 y 1949 (PS o PC, no en el MIR, porque su formación es posterior -1965- ) y que a su vez participaron en movimientos autónomos de mujeres por el derecho a sufragio, tales como el MENCH (1935).
} 
Por el contrario, la generación más joven (las que en 1970 tenían edades comprendidas entre los 15 y 30 años) entiende que la mayoría de las militantes no tuvieron las mismas oportunidades de promoción que las de sus camaradas varones y que tan solo, un porcentaje minoritario de ellas (mujeres excepcionales) y tras mucho esfuerzo, pudieron participar en los órganos de poder.

Llama la atención que buena parte de ellas (especialmente las que se exiliaron) pudieron formar parte de agrupaciones específicas de mujeres, sobre todo durante la década de los ochenta (doble militancia), circunstancia que en algunos casos terminó por distanciarlas de sus organizaciones políticas al tomar conciencia de que estaban siendo discriminadas. De hecho, son ellas las que consideran que bajo los gobiernos de Salvador Allende siguieron existiendo muchos obstáculos que impedían que las mujeres tuvieran visibilidad y protagonismo, independientemente de las medidas que se pudieran emprender en favor de las chilenas.

Pero lo cierto es que durante los tres años del gobierno de la Unidad Popular miles de mujeres accedieron a la educación superior, un espacio inmejorable para politizarse y convertirse en activistas en un contexto de apertura social insólito en el país. En este sentido, el nexo de unión entre mujer y actividad política se dio fundamentalmente por su entrada en contacto con el movimiento estudiantil, muy politizado por sus vinculaciones directas con los partidos. De hecho, la universidad fue un lugar idóneo para el reclutamiento de jóvenes militantes y una forma rápida de consolidar la base social de la izquierda, circunstancia que explicaría que buena parte de las entrevistadas accedieran a la militancia desde los campus.

Se puede afirmar que la mayoría de las mujeres que entraron a militar en el Movimiento de Izquierda Revolucionaria, el Partido Comunista y el Partido Socialista durante aquellos años, lo hicieron generalmente a través de un contacto masculino: un familiar (padre o hermano -siguiendo la tradición política familiar), un compañero sentimental o amigo.

Los relatos dan cuenta de que algunas mujeres que procedían de familias conservadoras (incluso de militares) se empezaron a interesar por el activismo político de izquierdas gracias a compañeros comprometidos que habían conocido en el aula. En otras palabras, 
ellos las iniciaron, lo que no quiere decir que hubiera casos de mujeres que hubieran tenido el mismo acceso de forma independiente.

Curiosamente, aquellas mujeres que tuvieron una relación sentimental con dirigentes masculinos fueron las que desempeñaron puestos de responsabilidad en sus formaciones, lo que no significa que no hubieran hecho méritos para lograrlo. Ello da cuenta de que, al menos, esta circunstancia sí se configuró como una vía de entrada más directa a la hora de formar parte de la vida partidaria.

En cualquier caso, también hay que tener en cuenta que Allende favoreció a las mujeres para que se formaran académicamente, lo que propició un clima idóneo para que muchas se animaran a incursionar en política. Fue en este punto cuando se produjo la primera transformación importante en cuanto a relaciones de género se refiere. $\mathrm{Su}$ acceso a la formación implicó su politización y por ende un incremento de su presencia en el espacio público.

De hecho, la incorporación de las mujeres a los partidos políticos alcanzó picos nunca anteriormente registrados, ni siquiera cuando miles de mujeres, décadas atrás, se movilizaron por el derecho a voto. Como muestran las fuentes, participaron activamente en la consolidación del proyecto popular (por ejemplo, formando parte de organización y difusión en las campañas electorales de Allende de 1969 y 1973) y, después de los triunfos electorales, como parte integrante del gobierno (senadoras, diputadas, regidoras y funcionarias)

Sin embargo, esta apertura no significó un cambio en las relaciones estructurales de poder entre hombres y mujeres. Si bien ellas accedieron a un mundo hasta entonces monopolizado por varones, lo cierto es que continuaron fuera de la toma de decisiones y de los puestos de relevancia.

Paradójicamente, las militantes jugaron un papel protagónico en el trabajo social de base y en los puestos intermedios de gestión y coordinación, sin los que Allende difícilmente hubiera podido llevar a cabo sus proyectos o tener la difusión propagandística que tuvo. 
En lo referente a las cifras, la participación política femenina en la izquierda más representativa (Partido Socialista, Partido Comunista y Movimiento de Izquierda Revolucionaria) varió dependiendo de cada caso entre el veinte y treinta por ciento. Por el contrario, su representación en los órganos de decisión (cúpulas) nunca superó el 5 por ciento.

Por consiguiente, las mujeres siguieron ocupando un lugar vital en el funcionamiento orgánico de sus organizaciones pero sin tener una contrapartida en los espacios de poder y casi siempre bajo su rol tradicional de género: gestoras y administradoras, cuidadoras, educadoras, enlaces de información, etc.

Pese a que la mayoría de las mujeres en aquel tiempo no disponían de una conciencia igualitaria (feminista) que les permitiese movilizarse como colectivo específico para plantear sus demandas, sí fueron advirtiendo con los años algunas de las desigualdades más cotidianas que solían darse con frecuencia en el devenir militante.

En este contexto, cuyo origen se remonta a una organización social y política panhistórica basada en el dominio masculino (Patriarcado), era muy complicado cuestionar unos roles de género muy interiorizados tanto en hombres como en mujeres. En caso de hacerlo, las resistencias y obstáculos que opusieron los hombres desanimaron a muchas de ellas a continuar con sus reivindicaciones de igualdad. Un recurso recurrente para evitar incorporar sus demandas era que la prioridad debía centrarse en el derrocamiento de la dictadura, y que solo después se producirían los cambios hacia una igualdad plena.

De hecho, las fuentes corroboran que cuando una mujer exigía las mismas oportunidades en el partido solía ser rechazada o estigmatizada: si iba a las reuniones del partido con sus hijos, si demandaban participar en puestos de mayor representación, si querían ejercer el derecho a voto en la toma de decisiones, si no estaban casadas y tenían compañeros sentimentales dentro o fuera de la organización, etc.

Muchas de ellas sólo años después y en el exilio, gracias sobre todo al contacto con otras mujeres con experiencia feminista, pudieron incorporar una mirada crítica hacia sus formaciones que cambiarían para siempre su compromiso político y la forma de relacionarse con sus compañeros. 
Con las políticas de Allende en lo referente a las mujeres ocurrió algo parecido. Desde una panorámica general se mejoró su situación jurídica en todos los ámbitos (laboral, familiar, sanitaria y social), se aplicaron medidas para favorecer su educación e integración sociolaboral y se mejoró sustancialmente su calidad de vida (alimentación, sanidad, higiene, medidas de protección a la infancia, etc.).

No conviene olvidar que algunas de las medidas para favorecer la igualdad de género quedaron inconclusas con la irrupción del golpe militar y otras tantas nunca llegaron a aplicarse por la labor dinamitante de la oposición (divorcio, medias anticonceptivas, etc.).

Pese a estas circunstancias, la mayoría de las entrevistadas se muestran críticas en relación a los cambios y pervivencias de género que se dieron en un momento de profundas convulsiones sociales, y que daban cuenta de un país ideológicamente dividido.

Según su óptica, la labor de Allende, aunque bienintencionada, tendió a reproducir los esquemas de dominación masculina y patriarcal por dos motivos: las medidas aplicadas reproducían los roles y espacios tradicionalmente asignados a las mujeres (hogar, maternidad, cuidados, infancia, etc.); su carácter tenía que ver más con la protección social que con el fortalecimiento de su independencia (se protege a las mujeres pero no se estimula su autonomía, por ejemplo, a través de programas de inserción laboral y formación profesional). Ello contrasta cuando advierten que en esos años sí se impulsó la participación política y la educación de las mujeres en Chile, aunque quizá no con la profundidad que hubieran deseado.

Dicho de otra manera, perciben que se mejoró la situación de miles de mujeres socialmente desprotegidas pero sin cambiar su lugar de siempre, y sin tampoco favorecer la igualdad de oportunidades para aquellas que habían logrado posicionarse en el espacio público (igualdad salarial, derecho a baja por maternidad, etc.)

Sin embargo, una parte minoritaria de ellas se muestra más benevolente, sobre todo las que tenían formación universitaria y/o profesional y accedieron a puestos de responsabilidad en las instituciones del Estado (diputadas, senadoras, regidoras; también 
hubo un incremento del 30 por ciento de funcionarias y profesionales de diversos ámbitos como salud, educación y servicios). Esto nos hace pensar que el grado crítico en relación a los logros alcanzados depende en buena medida de la evolución de la trayectoria personal de cada entrevistada.

En cualquier caso, la irrupción del golpe militar tras tres años en los que el gobierno popular no gozó de la estabilidad social y económica para llevar a buen puerto sus políticas, neutralizó de raíz todos los procesos de cambio, por lo que resulta imposible saber hasta dónde hubiera llegado Allende en el desarrollo de los derechos de las mujeres.

Para la mayoría de las militantes la llegada de Pinochet al poder fue una interrupción de sus vidas personales y profesionales en toda regla, en un momento de plenitud (siete de cada diez militantes detenidas tenían edades comprendidas entre los 15 y 30 años) y libertad que ya nunca volverían a tener, pero también el inicio de un sentimiento permanente de temor a la captura y a que sus seres queridos se vieran afectados por la represión.

No obstante, casi todas han reflejado que desde el principio quisieron participar activamente en la lucha contra la dictadura militar, guiadas por un sentimiento ético para construir una sociedad más justa en Chile y la restitución de la normalidad democrática. Reconocen que el transcurso de los acontecimientos y sus dimensiones las sobrepasaron en todos los sentidos, lo que se tradujo en un estado de shock y agonía permanente que en muchos casos las llevó a tomar decisiones arriesgadas o equivocadas según su opinión: "creo que fue un error estar tanto tiempo separada de mi hija"526.

Lo que parece quedar claro es que, a pesar de las dificultades y limitaciones para dar una respuesta eficaz a los golpistas, las activistas desde el primer día entraron a formar parte de los focos de resistencia, principalmente en las universidades, en los cordones industriales o fábricas y en las poblaciones de las periferias urbanas. Desde allí, y con el escaso material de defensa del que dispusieron (armas ligeras y artesanales) poco pudieron hacer ante el envite militar.

${ }^{526}$ Ver Anexo. Entrevista No 3 . 
En los días que siguieron el golpe fueron frecuentes los operativos de las fuerzas armadas en estos lugares, utilizando todos los medios disponibles para lograr el control social y territorial del país. Así, los testimonios dan cuenta de la presencia de helicópteros, vehículos blindados y grupos de élite de las fuerzas armadas contra una juventud sin experiencia que aguardaba a una ayuda gubernamental que nunca llegó.

Todas coinciden en que se esperaban recibir apoyos logísticos para dar una respuesta armada a Pinochet, por lo que el contexto no fue de guerra civil -dos bandos enfrentados-, sino más bien el de un Estado militarizado reprimiendo a la oposición.

Frecuentemente, tras rodear y balear los focos de resistencia, los operativos finalizaban en pocas horas dejando un alto coste en vidas humanas y detenciones tras de sí (las Comisiones Nacionales de Verdad y Reconciliación estimaron que solo en los primeros meses de la dictadura fueron asesinadas 1500 personas y detenidas alrededor de 20.000).

Las mujeres que pudieron evitar la captura, con el transcurro de los días, se vieron abocadas a tener que esconderse, huir del país (especialmente tras comprobar que sus nombres aparecían en los bandos militares que requerían la personificación de las personas buscadas) o vivir una vida clandestina precaria. Esta situación de acorralamiento no evitó que cientos de mujeres continuasen con su compromiso político bajo múltiples formas.

Desde una perspectiva general, el gobierno popular y los partidos políticos que lo apoyaron, pronto quedaron neutralizados o fragmentados por la acción de una maquinaria bélica demoledora a la que fue imposible hacer frente. Dicha circunstancia dejó a la militancia desprotegida y sin prácticamente recursos para reorganizarse. Fue en este punto donde el papel de las mujeres adquirió una relevancia especial al constituirse como piezas clave en la reconstrucción de las organizaciones opositoras y bajo condiciones muchas veces infrahumanas.

De hecho, ellas han reflejado que pasaron largos períodos de tiempo sin suficiente alimento y apoyos médicos en las casas de seguridad o de allegados especialmente en los períodos comprendidos entre 1974-1977, tiempo en el que la DINA desarrolló sus 
operativos más importantes y en donde las medidas de seguridad y aislamiento fueron muy restrictivas para evitar que se produjeran detenciones en cadena.

¿Por qué fue importante la aportación de las militantes? Primeramente, porque bajo "el paraguas del rol femenino que reproducían" (madres con hijos, seductoras con los militares, amas de casa desinteresadas por la política....), estuvieron menos sujetas a la sospecha y por tanto sus posibilidades de caer detenidas fueron menores que las de sus compañeros (los dirigentes), lo que les otorgó una mayor libertad de acción. Pero también, porque la mirada militar patriarcal tendió a infravalorar la importancia de las mujeres en la oposición, circunstancia que se dio sobre todo en los primeros meses de la dictadura. Posteriormente, los represores se dieron cuenta de la estrategia y llevaron a cientos de mujeres a la tortura o desaparición forzada.

Conviene recordar que las detenciones de los hombres tuvieron especial intensidad en los primeros meses tras el golpe, debido a su papel protagónico en el movimiento opositor, pero con el tiempo fueron decreciendo. Todo lo contrario ocurrió con las mujeres, que fueron mayormente detenidas transcurridos los primeros años de la dictadura. Así, en 1973, cerca del 90 por ciento de las detenciones realizadas fueron de hombres, cifra que descendió significativamente a un 75 por ciento a partir de 1978 .

En cambio, las mujeres detenidas a partir de 1980 pasaron de ser del 10 por ciento al 23 por ciento, un incremento significativo que podría explicar su progresivo liderazgo en la oposición a Pinochet. Concretamente, ellas asumieron un papel protagónico en los trabajos de enlace o distribución de información, una aportación fundamental para el funcionamiento de los partidos en la clandestinidad.

En segundo lugar, porque buena parte de los militantes varones (dirigentes) fueron detenidos cuando no asesinados o expulsados de Chile, lo que generó un vacío de poder tácito en las organizaciones que lideraban. En este contexto coyuntural, se abrieron las puertas para que algunas mujeres que estaban en la retaguardia pasaran a militar en primera línea, una circunstancia forzada porque la propia supervivencia de los partidos dependía de ello. 
En los testimonios queda suficientemente reflejado que fueron varias las mujeres las que tuvieron un claro protagonismo, por ejemplo, en los grupos político militares, en los comités centrales, o en el aparato logístico (casas de seguridad, organización de encuentros clandestinos, suministro de armamento, etc.) y muchas veces coincidiendo con una "baja masculina".

El compromiso político de las entrevistadas, además, sobrepasó fronteras. La oposición de las exiliadas se incrementó al disponer de mayores recursos y libertad para operar desarrollando actividades como la denuncia internacional, la captación de fondos para los represaliados, la difusión en los medios de comunicación de las violaciones a los derechos humanos de la dictadura o como nexo de unión entre los focos de resistencia en Chile y la militancia en el exterior.

Fue en este contexto donde ellas desarrollaron un trabajo de incalculable valor para las comisiones de verdad, justicia y reparación nacidas años después en su objetivo de esclarecer el alcance de la represión sobre la población civil. En efecto, la recopilación de información en las cárceles sobre la tortura, la desaparición forzada de personas y la identidad de los responsables fue asumida mayormente por las mujeres, y esto se debió fundamentalmente a dos causas.

La primera, porque al tener menos responsabilidades políticas en los partidos de la izquierda tuvieron más posibilidades de sobrevivir (los agentes represores no dejaron de percibir a las prisioneras como "subversivas secundarias") y, por tanto, de configurase como testigos directos de los hechos.

En segundo lugar, porque la tradición cultural pudo favorecer que las mujeres reprodujeran el rol de cuidadoras de los otros: mujeres que buscan a sus maridos detenidos y emprenden un arduo camino de denuncia, madres que pierden a sus hijos (detenidos o asesinados) y asumen la responsabilidad de encontrarlos y velar por su memoria, hijas que tienen a sus padres desaparecidos y en su etapa adulta pasan a formar parte de los procesos judiciales abiertos contra Pinochet, especialmente tras su detención en Londres en 1998, etc. 
Por otro lado, una parte de la militancia que vivió el exilio pudo desarrollarse personal e intelectualmente en el ámbito del feminismo internacional (principalmente en Gran Bretaña, Canadá, Francia y Suecia) al entrar en contacto con grupos y redes de mujeres feministas. Ello imprimió en las militantes una nueva mirada que traerían de vuelta a Chile a partir de 1988 (tras el triunfo del NO en el plebiscito) y que serviría para la reactivación del movimiento feminista chileno en la década de los noventa.

La acogida de sus ideas en los partidos fue en la mayoría de los casos negativa, cuando no obviada. Entre ellas destacaron el establecimiento de cuotas paritarias, el reconocimiento de iguales derechos en el funcionamiento interno, la organización de departamentos específicos sobre mujer, además de otras demandas relativas al espacio privado como derechos sexuales y reproductivos, divorcio, protección estatal a las mujeres víctimas de la violencia de género, etc. La mayoría de estas demandas solo empezaron a considerarse bien entrada la democracia, especialmente a partir de la llegada a la presidencia de la República de Ricardo Lagos (2000-2006).

Precisamente, dichas resistencias, que provenían tanto de los dirigentes como del grueso de la militancia que habían optado por quedarse en el país (aislado durante casi dos décadas y ajeno a los cambios que se producían en el exterior) son las que reprochan las entrevistadas, ya que sintieron que su aportación y compromiso político no fue correspondido a la hora de ser tomadas en cuenta.

Esta situación generó un distanciamiento cuando no una ruptura con sus formaciones y el inicio de una nueva andadura política, esta vez, en agrupaciones sociales lideradas por mujeres o bien en organizaciones feministas (Mujeres por la Vida, MENCH 83- La Morada, Agrupación de familiares de detenidos-desaparecidos, etc.). En otras palabras, su activismo se transformó pero no se interrumpió.

Por otra parte, en lo que se refiere a las consecuencias y efectos más directos que sufrieron las entrevistadas por su participación política, se puede afirmar que, aunque fueron múltiples, todas ellas tuvieron un elemento en común: la discriminación y la violencia por razón de sexo como eje transversal de las dificultades con las que se encontraron en su devenir militante. 
En la relación con sus partidos se reflejan dos hechos muy concretos: ellas, en su mayoría, sienten que fueron discriminadas al no gozar de los mismos derechos que sus compañeros a pesar de que sus aportaciones a la "causa" fueron semejantes y con riesgos parecidos para su salud e integridad personal.

Se podría decir que los costes que tuvieron que asumir cientos de mujeres por comprometerse políticamente contra la dictadura no difirió mucho al de sus compañeros de filas (salvo en la tortura), pero con la diferencia de que las cúpulas de la izquierda no tomaron en cuenta este hecho como un sacrificio de la militancia femenina que bien merecía ser "recompensado", por ejemplo, garantizando la igualdad de oportunidades en la realidad partidaria.

Tras finalizar la dictadura, los hombres volvieron a tomar el protagonismo y liderazgo político mientras que muchas mujeres pasaron a "un segundo plano" después de haber militado "en primera línea". No obstante, la primera década de siglo XXI parece haber dejado síntomas de cambio en esta tendencia con ejemplos tan simbólicos como el de Michelle Bachelet (ex militante del Partido Socialista, torturada y sobreviviente de Villa Grimaldi) que ocupó la presidencia de la República entre 2006 y 2010, o el de Soledad Alvear, candidata presidencial por el Partido Demócrata Cristiano en las elecciones presidenciales de 2005 .

Lo que parece quedar claro es que la dinámica de los partidos de izquierdas, en cuanto a la militancia femenina se refiere, en el período estudiado, estuvo centrada en la jerarquía y el monopolio del poder masculino. Porque desde el mismo nacimiento de las organizaciones fueron los hombres los que marcaron las reglas (fundadores), y fue extraordinariamente complicado que las mujeres pudieran disponer de los mismos privilegios.

Por tanto, su incorporación a los puestos de responsabilidad fue muy lenta y muchas veces forzada por las circunstancias coyunturales (un clima de represión o bien de apertura política) ya que quienes ostentan el poder por lógica histórica, en principio, no lo ceden por iniciativa propia. 
Sin tenerse en cuenta sus demandas y sin disponer de una representación equitativa en la propia estructura de las organizaciones de la izquierda, algunas mujeres tuvieron que afrontar otro obstáculo por su condición de género: el acoso y/o violencia sexual por parte de algunos de sus camaradas con los que tuvieron que convivir en la clandestinidad o en el exilio.

No son pocos los relatos de mujeres que apuntan a que se produjeron episodios que atentaron contra su integridad física y moral en un contexto en donde difícilmente pudieron defenderse. Todo apunta a que la presión para tener relaciones sexuales con una compañera de militancia fue una pauta constante, especialmente en períodos de convivencia clandestina en donde el aislamiento podía durar meses. A veces se producía la circunstancia de que una mujer tenía que convivir, por exigencia del partido o de la propia situación, con un grupo de hombres estando en minoría, circunstancia que favorecía la aparición de estos episodios.

En este sentido, las que lo experimentaron entienden que sus compañeros tenían integrados en sus esquemas culturales lo que denominan débito sexual de la mujer hacia los otros, sobre todo si ella no estaba "formalmente en pareja". En caso de negarse a mantener relaciones sexuales, sufrirían el descrédito de sus camaradas cuando no todo tipo de descalificaciones sobre su persona ("se inventó que me prostituía porque no quise acostarme con él"527).

Por consiguiente, en un contexto de convivencia partidaria, se esperaba que las mujeres asumieran el rol de cuidadoras de las necesidades vitales de los hombres, entre ellas las sexuales, pero también otras como la alimentación, aseo, cuidado de los hijos y apoyos médicos: "recuerdo, que el rol de la mujer en el exilio era hacer empanadas, un rol que jamás estuve dispuesta a asumir. Yo era el bicho raro...las prioridades pasaban por el compañero, es decir, de apoyo al hombre" ${ }^{\text {528 }}$. En estas circunstancias, además de verse sobrecargadas por el trabajo doméstico que sus compañeros no hacían, tenían que lidiar con una tensión constante en una situación que ya de por sí sola era complicada.

\footnotetext{
${ }^{527}$ Ver Anexo. Entrevista No 26.

${ }^{528}$ Ver Anexo. Entrevista No 10.
} 
Se podría decir que algunas militantes se vieron forzosamente abocadas a desempeñar el rol de ama de casa u objeto sexual más allá de poder desarrollarse como "militante de pleno derecho", y en donde, como han reflejado, muchas veces no eran conscientes de estos esquemas sexistas ni de que también ellas mismas los reproducían.

Así, solo años después podrían ir poniendo palabras a lo vivido gracias sobre todo al apoyo de redes de mujeres que contaban con experiencia en el saber feminista: "con el paso de los años una puede hacer ciertas críticas y reconocer que fallaron muchas cosas...en la vida que llevábamos en la clandestinidad que fue muy dura y una se sentía muy desamparada por los propios compañeros de partido" ${ }^{\text {"529. }}$.

En lo que se refiere a la represión ejercida por los agentes y cuerpos de seguridad de la dictadura hacia las militantes de la izquierda opositora no varío sustancialmente a la de los hombres en sus líneas estructurales: persecución, captura, prisión, tortura, desaparición forzada, exoneración y exilio.

Sin embargo, ha quedado comprobado que sí existió una diferencia sustancial en lo que se refiere a la tortura recibida: la condición sexual fue utilizada como método de represión, un hecho intensificado, además, por un contexto cultural de dominación masculina arraigado en las Fuerzas Armadas desde antaño.

Se podría afirmar que las militantes que cayeron presas, en su mayoría, sufrieron un tipo de represión específica aunque con múltiples variables. Esta especificidad se dio por diferentes razones. La primera, por el marcado carácter sexual que existió en los procesos de detención, interrogatorios y reclusión. Este hecho vino parejo con la reproducción cultural de la mentalidad clasista y patriarcal a la hora de establecer las rutinas carcelarias (por ejemplo, las prisioneras de los estratos sociales más bajos sufrieron un trato más vejatorio si cabe que las militantes de familias acomodadas).

En cualquier caso, las prisioneras sufrieron algún tipo de tortura o vejación de carácter sexual independientemente de su procedencia social o política. Aunque los presos

${ }^{529}$ Ver Anexo. Entrevista No 11. 
sufrieron en algunos casos este tipo de degradación, lo cierto es que no fue una práctica frecuente o por el momento no se ha podido comprobar lo contrario.

En segundo lugar, esta diferenciación se sostiene por otro tipo de represión específica, como es el quebranto psicológico aplicado a las presas por su condición de madres. La amenaza constante contra la integridad de sus hijos para la obtención de información en los procesos interrogatorios fue un hecho usual.

Asimismo, la mujer fue utilizada como instrumento de presión por las autoridades de los centros de detención para sonsacar información a los presos políticos, que por lo general eran los cabecillas y dirigentes de las organizaciones opositoras y, por tanto, los depositarios de la información vital. De esta forma, se amenazaba al militante con violar a su compañera, esposa, hermana o madre si no colaboraba con los agentes.

Especial simbolismo tuvieron los casos de mujeres que cayeron detenidas estando embarazadas. En los testimonios recogidos se relatan varios ejemplos de prisioneras que perdieron a sus bebés por un aborto provocado premeditadamente durante los interrogatorios ("sabía que estaba embarazada de cuatro meses y siguió torturándome" ${ }^{, 530}$ ). El método utilizado era conocido como la parrilla, basado en la aplicación de corriente eléctrica en los órganos genitales de la prisionera que permanecía amarrada a un catre metálico.

En los casos de embarazos que siguieron su curso durante la reclusión aparece otra grave consecuencia fruto de la tortura: el deterioro de la presa, tanto físico como psicológico, afectó a su embarazo y el posterior desarrollo integral del menor. De hecho, recientemente se están comenzando a estudiar los efectos que estas experiencias tuvieron en los hijos de las mujeres torturadas (algunas entrevistadas han descrito, fuera de grabación, episodios postraumáticos como estrés, cuadros depresivos, ansiedad, trastornos de conducta, etc.)

\footnotetext{
${ }^{530}$ Ibíd.
} 
Por otra parte, numerosos ${ }^{531}$ estudios han constatado que la violación ha sido utilizada como arma de guerra contra la población civil femenina desde tiempos inmemoriales, y cuya finalidad fue siempre la satisfacción de los deseos de quienes tenían el poder pero también como una forma de humillar al enemigo derrotado a través de la apropiación de "sus mujeres" (motín de guerra).

Todavía no existe una cuantificación precisa de las prisioneras que fueron violentadas en su sexualidad durante los diecisiete años de dictadura militar, sobre todo por las dificultades que entraña el abordaje del tema. Un ejemplo lo encontramos en las resistencias a la hora de hablar, recordar y reconocer lo vivido que suelen ser habituales entre las víctimas, tal y como lo reflejan diversas investigaciones ${ }^{532}$ sobre el impacto de la represión en la salud de los perseguidos.

Pero también otros factores podrían alterar las cifras reales como el fallecimiento de muchas mujeres que ya no pueden declarar o el hecho de que otras tantas vivan en el extranjero y no hayan participado de los procesos de calificación.

Si bien las últimas actualizaciones de la Comisión Valech estiman que fueron alrededor de 4000 las mujeres que fueron víctimas de algún tormento sexual, lo cierto es que la cifra podría duplicarse tal y como aseguran las agrupaciones en defensa de los derechos de las mujeres existentes en Chile.

Otro factor a tener en cuenta es el grado de planificación de la represión hacia las mujeres sustentada en varios hechos analizados. Uno de los más reveladores es el que tiene que ver con el adiestramiento y uso de animales para atormentar sexualmente a las prisioneras, una experiencia que ha dejado una huella irreparable en quienes la sufrieron.

También, se ha comprobado la presencia usual de personal médico y enfermeras durante las sesiones de tortura, sobre todo con aquellas presas que estaban en estado de

\footnotetext{
531 Tokar y otras, Ese infierno: conversación con cinco mujeres sobrevivientes de la ESMA, Ed. Sudamericana, Buenos Aires, 2001.

${ }^{532}$ Ver Inger Agger, PH. D. y Sören Buus Jensen, M.D., Trauma y Cura en situaciones de terrorismo de Estado: Derechos humanos y salud mental en Chile bajo la dictadura militar, Ed. Chile-América CESOC, Santiago de Chile, 1996, p.275-290.
} 
gestación o malheridas. De esta manera, se podía contar con el asesoramiento y apoyo sanitario para saber hasta cuando y cómo torturar.

La represión y el maltrato hacia las mujeres en todas sus formas ha de ser interpretada como toda agresión física, psicológica y moral planificada y aplicada en base a su condición de género, más allá de cualquier otra consideración. Pero, ¿cómo explican lo sucedido las propias entrevistadas? Para la mayoría, los agentes represores trataban de justificar sus actos bajo la argumentación de que era el castigo por militar en la subversión y haber dejado de ser mujeres normales (perfecta casada), lo que las convertía a sus ojos en "prostitutas y malas madres desviadas por la influencia del marxismo".

Al desposeerlas de su condición de mujer "normal", los agentes se sintieron legitimados para acometer sobre ellas todo tipo de aberraciones a modo de castigo, aunque no faltaron quienes se excusaron bajo el principio de la "obediencia debida",533. Pero además, ellas representaban un referente femenino demasiado trasgresor con el sistema de valores tradicional que la dictadura quiso reimplantar tras los intentos fallidos de Allende por equiparar los derechos de hombres y mujeres.

La documentación de la época, incluidos los propios discursos de Pinochet, apuntan a que la dictadura tuvo especial interés en poder obtener el control social, religioso y político de las mujeres, razón que explicaría la creación de la Secretaría Nacional de la Mujer (SENAM, noviembre 1973), desde donde se impulsaría su rol tradicional: ama y gestora de la economía familiar -agentes de consumo- y trabajadoras en los sectores intermedios: manufacturas, servicio doméstico, administración, enfermería y enseñanza, entre otros.

Todo modelo o referente femenino contrario al ideario pinochetista sería aplacado bajo la creencia de que por encima de todo debía preservarse el orden natural de las cosas impuesto por Dios, lo que era utilizado para otorgarse la legitimidad necesaria para justificar sus acciones represoras. Bajo este prisma, la ley natural otorgaba lugares y papeles diferenciados a hombres y mujeres en base a su propia idiosincrasia. Así, ellas

${ }^{533}$ Ver García, P., El genocidio en Guatemala a la luz de la Sociología Militar, SEPHA, Guatemala, 2005. 
debían ocupar el espacio doméstico y desarrollarse como madres y buenas esposas, y ellos (soldados) proteger el orden tradicional de género utilizando la violencia si fuera necesario.

En cualquier caso, tal y como demuestran las fuentes, la dictadura no dejó de culpabilizar a la izquierda por considerar que su influencia llevó a miles de chilenas al sufrimiento por ocupar espacios que no les correspondían: "nos castigaban por ser malas madres, la mentalidad era muy clara, nos decían que nos pusiéramos en el lugar que nos correspondía, que la política no era para las mujeres" ${ }^{, 534}$.

Por todo lo expuesto, se puede afirmar que toda una generación de mujeres jóvenes que vivieron un despertar político y social durante los intensos años de la Unidad Popular, se vio abocada años después a sufrir la persecución y represión por su compromiso político, o bien a renunciar a sus expectativas vitales.

Llama la atención que buena parte de las militantes que tenían un título universitario o bien una profesión, al salir de prisión, no pudieron encontrar un empleo acorde a su formación por estar fichadas, lo que les obligó a trabajar en oficios no cualificados (servicio doméstico, fábricas de producción en línea, etc.) o en la economía sumergida.

Alrededor de un treinta por ciento de las mujeres entrevistadas ha reconocido haber pasado en los últimos años por serias dificultades económicas al haber estado en paro durante prolongados periodos de tiempo. En otras palabras, no pudieron reconstruir sus vidas laborales tras la dictadura por la falta de oportunidades pero también por no encontrarse en condiciones idóneas para hacerlo.

Concretamente, el deterioro y los problemas de salud que las presas desarrollaron, a consecuencia de la tortura y las situaciones infrahumanas por las que tuvieron que pasar durante años, condicionó sus vidas para siempre, incapacitándolas en muchos casos para llevar una vida normal.

\footnotetext{
${ }^{534}$ Ver Anexo. Entrevista $N^{\circ} 4$.
} 
Sin apoyos de sus partidos ni de los gobiernos en democracia, tuvieron que refugiarse en organizaciones sociales y redes de mujeres para recuperarse y esperar más de una década para recibir prestaciones institucionales. Pese a todas las dificultades, ellas sobrepasaron el lugar victimario para configurarse como sujetos activos de lucha y transformación social, dejando tras de sí un valiosísimo legado contra la impunidad de los militares.

Ha quedado de manifiesto que con la irrupción de la dictadura y en un escenario donde la dominación masculina campaba por doquier, las activistas pudieron adquirir un liderazgo y protagonismo en la lucha opositora ocupando espacios hasta entonces vetados para ellas. Pero, tal y como muestra la historia reciente del siglo XX, una vez pasada la tormenta y en donde se agradeció la aportación y sacrificio de las mujeres, la inercia cultural de siglos de subordinación las devolvió a su lugar de siempre: "Fue el movimiento de mujeres el que puso en marcha la idea de democracia en el país y en la casa...pero los movimientos de mujeres no pudieron capitalizar este fenómeno con la llegada de la Democracia y el engaño de las propuestas de la Concertación"

Esta circunstancia no resignó a la mayoría de las militantes que tarde o temprano encontraría nuevas fórmulas de compromiso y activismo exentas de jerarquías masculinas: "Terminé trabajando en el Instituto de la Mujer en donde entré en contacto con feministas radicales. Allí pude reflexionar sobre la problemática entre hombremujer" ${ }^{236}$.

Podemos concluir con que los procesos de transformación hacia la equiparación de los derechos de las mujeres a lo largo de los siglos se han producido de una forma abrupta y forzada, debido a las múltiples resistencias generadas por los hombres a la hora de ceder sus espacios de privilegio, y Chile no fue una excepción. Los testimonios, tanto orales como escritos, verifican que las mujeres tuvieron que sufrir obstáculos añadidos por su condición de género, tanto en la militancia como en la reclusión, y solo tras años de esfuerzo y movilización colectiva, pudieron visibilizar y exigir el reconocimiento de sus derechos.

\footnotetext{
${ }^{535}$ Ver Anexo. Entrevista No 7.

${ }^{536}$ Ver Anexo. Entrevista No 10.
} 
Afortunadamente, son cada vez más los historiadores que se suman a incorporar una nueva mirada no sexista a la hora de historiar. Por una cuestión de equidad, en el relato de la historia reciente de Chile, es necesario incorporar las aportaciones que las mujeres hicieron por la construcción de un país en donde las libertades y los derechos de la ciudadanía estuvieran garantizados. Contar lo invisibilizado es dar voz a las mujeres que se configuraron como sujetos activos en el devenir político y social del país, pero también es recordar el alto coste que tuvieron que pagar por su compromiso. 


\section{FUENTES Y BIBLIOGRAFÍA:}

\section{Entrevistas:}

\begin{tabular}{|c|c|c|}
\hline Nombre Completo & Fecha Entrevista & Formación Política \\
\hline $\begin{array}{l}\text { 1) SANDRA AQUILINA } \\
\text { PALESTRO CONTRERAS }\end{array}$ & 12 de noviembre de 2003 & $\begin{array}{l}\text { Movimiento Izquierda } \\
\text { Revolucionaria, MIR. }\end{array}$ \\
\hline $\begin{array}{l}\text { 2) NUVIA BETSIE } \\
\text { BECKER EGUILUZ }\end{array}$ & 12 de noviembre de 2003 & $\begin{array}{l}\text { Movimiento Izquierda } \\
\text { Revolucionaria, MIR. }\end{array}$ \\
\hline $\begin{array}{l}\text { 3) ROSA ELVIRA } \\
\text { LIZAMA LEIVA }\end{array}$ & 11 de diciembre 2003 & $\begin{array}{l}\text { Movimiento Izquierda } \\
\text { Revolucionaria, MIR. }\end{array}$ \\
\hline $\begin{array}{l}\text { 4) MARGARITA } \\
\text { VALERIA ROMERO } \\
\text { MÉNDEZ }\end{array}$ & 13 de enero de 2004 & $\begin{array}{l}\text { Movimiento Izquierda } \\
\text { Revolucionaria, MIR. }\end{array}$ \\
\hline $\begin{array}{l}\text { 5) MARIA ALICIA } \\
\text { SALINAS FARFÁN }\end{array}$ & 16 de enero de 2004 & $\begin{array}{l}\text { Movimiento Izquierda } \\
\text { Revolucionaria, MIR. }\end{array}$ \\
\hline $\begin{array}{l}\text { 6) LUCRECIA BRITO } \\
\text { VÁSQUEZ }\end{array}$ & 21 de enero de 2004 & $\begin{array}{l}\text { Movimiento Izquierda } \\
\text { Revolucionaria, MIR. }\end{array}$ \\
\hline $\begin{array}{l}\text { 7) MARGARITA } \\
\text { IGLESIAS SALDAÑA }\end{array}$ & 28 de enero de 2004 & $\begin{array}{l}\text { Movimiento Izquierda } \\
\text { Revolucionaria, MIR. }\end{array}$ \\
\hline $\begin{array}{l}\text { 8) ERICA HENNINGS } \\
\text { CEPEDA }\end{array}$ & 8 de marzo de 2004 & $\begin{array}{l}\text { Movimiento Izquierda } \\
\text { Revolucionaria, MIR. }\end{array}$ \\
\hline $\begin{array}{l}\text { 9) PATRICIA } \\
\text { ZALAQUETT DAHER }\end{array}$ & 7 de abril de 2004 & $\begin{array}{l}\text { Movimiento Izquierda } \\
\text { Revolucionaria, MIR }\end{array}$ \\
\hline $\begin{array}{l}\text { 10) LILIANA MASON } \\
\text { PADILLA }\end{array}$ & 17 de mayo de 2004 & $\begin{array}{l}\text { Movimiento Izquierda } \\
\text { Revolucionaria, MIR. }\end{array}$ \\
\hline $\begin{array}{l}\text { 11) CECILIA BOTTAI } \\
\text { MONREAL }\end{array}$ & 18 de mayo de 2004 & $\begin{array}{l}\text { Movimiento Izquierda } \\
\text { Revolucionaria, MIR. }\end{array}$ \\
\hline $\begin{array}{l}\text { 12) LELIA PÉREZ } \\
\text { VALDÉS }\end{array}$ & 17 de junio de 2004 & $\begin{array}{l}\text { Movimiento Izquierda } \\
\text { Revolucionaria, MIR. }\end{array}$ \\
\hline $\begin{array}{l}\text { 13) JUANA AGUILERA } \\
\text { JARAMILLO }\end{array}$ & 20 de mayo de 2005 & $\begin{array}{l}\text { Movimiento Izquierda } \\
\text { Revolucionaria, MIR. }\end{array}$ \\
\hline $\begin{array}{l}\text { 14) NELLY ANDRADE } \\
\text { ALCAINO }\end{array}$ & 20 de mayo de 2004 & $\begin{array}{l}\text { Partido Socialista de Chile, } \\
\text { PSCH. }\end{array}$ \\
\hline $\begin{array}{l}\text { 15) BERTA ECHEGOYEN } \\
\text { BONET }\end{array}$ & 2 de diciembre de 2004 & $\begin{array}{c}\text { Partido Socialista de Chile, } \\
\text { PSCH. }\end{array}$ \\
\hline
\end{tabular}




\begin{tabular}{|c|c|c|}
\hline $\begin{array}{l}\text { 16) CARMEN LAZO } \\
\text { CARRERA }\end{array}$ & 13 de diciembre de 2004 & $\begin{array}{l}\text { Partido Socialista de Chile, } \\
\text { PSCH. }\end{array}$ \\
\hline $\begin{array}{l}\text { 17) XIMENA GEORGE- } \\
\text { NASCIMENTO LARA } \\
\end{array}$ & 21 de diciembre de 2004 & $\begin{array}{l}\text { Partido Socialista de Chile, } \\
\text { PSCH. }\end{array}$ \\
\hline 18) JUANA ANDREANI & 22 de diciembre de 2004 & $\begin{array}{c}\text { Partido Socialista de Chile, } \\
\text { PSCH. }\end{array}$ \\
\hline 19) PAULINA WEBER & 6 de enero 2005 & $\begin{array}{c}\text { Partido Socialista de Chile, } \\
\text { PSCH. }\end{array}$ \\
\hline $\begin{array}{l}\text { 20) MIREYA GARCÍA } \\
\text { RAMÍREZ }\end{array}$ & 7 de enero de 2005 & $\begin{array}{c}\text { Partido Socialista de Chile, } \\
\text { PSCH. }\end{array}$ \\
\hline $\begin{array}{l}\text { 21) ANGÉLICA MUÑOZ } \\
\text { CATEJO }\end{array}$ & 9 de Enero de 2005 & $\begin{array}{l}\text { Partido Socialista de Chile, } \\
\text { PSCH. }\end{array}$ \\
\hline $\begin{array}{l}\text { 22) NATACHA MOLINA } \\
\text { GARCÍA }\end{array}$ & 11 de enero de 2005 & $\begin{array}{l}\text { Partido Socialista de Chile, } \\
\text { PSCH. }\end{array}$ \\
\hline $\begin{array}{l}\text { 23) CECILIA MORELIA } \\
\text { GONZÁLEZ }\end{array}$ & 13 de enero de 2005 & $\begin{array}{l}\text { Partido Socialista de Chile, } \\
\text { PSCH. }\end{array}$ \\
\hline $\begin{array}{l}\text { 24) CATALINA PALMA } \\
\text { HERRERA }\end{array}$ & 24 de enero de 2005 & $\begin{array}{l}\text { Partido Socialista de Chile, } \\
\text { PSCH. }\end{array}$ \\
\hline $\begin{array}{l}\text { 25) CECILIA SUÁREZ } \\
\text { INDARTE }\end{array}$ & 8 de marzo de 2005 & $\begin{array}{l}\text { Partido Socialista de Chile, } \\
\text { PSCH. }\end{array}$ \\
\hline 26) ELINETT WOLFFR & 13 de marzo de 2005 & $\begin{array}{l}\text { Partido Socialista de Chile, } \\
\text { PSCH. }\end{array}$ \\
\hline $\begin{array}{l}\text { 27) FIDELIA HERRERA } \\
\text { HERRERA }\end{array}$ & 15 de marzo de 2005 & $\begin{array}{l}\text { Partido Socialista de Chile, } \\
\text { PSCH. }\end{array}$ \\
\hline 28) LUISA ESTACNO & 13 de mayo de 2004 & $\begin{array}{l}\text { Partido Comunista de Chile, } \\
\text { PCCH. }\end{array}$ \\
\hline $\begin{array}{l}\text { 29) MARGARITA DURÁN } \\
\text { GAJARDO }\end{array}$ & 17 de mayo de 2004 & $\begin{array}{l}\text { Partido Comunista de Chile, } \\
\text { PCCH. }\end{array}$ \\
\hline $\begin{array}{l}\text { 30) MARGARITA MENA } \\
\text { YÁÑNZ }\end{array}$ & 3 de junio de 2004 & $\begin{array}{l}\text { Partido Comunista de Chile, } \\
\text { PCCH. }\end{array}$ \\
\hline $\begin{array}{l}\text { 31) VIRGINIA } \\
\text { GONZÁLEZ EVIA }\end{array}$ & 5 de enero de 2005 & $\begin{array}{l}\text { Partido Comunista de Chile, } \\
\text { PCCH. }\end{array}$ \\
\hline $\begin{array}{l}\text { 32) MARIA EUGENIA } \\
\text { PUELMO }\end{array}$ & 12 de enero de 2005 & $\begin{array}{l}\text { Partido Comunista de Chile, } \\
\text { PCCH }\end{array}$ \\
\hline $\begin{array}{l}\text { 33) RUTH LILIANA } \\
\text { CARMONA SOTO }\end{array}$ & 3 de marzo de 2005 & $\begin{array}{c}\text { Partido Comunista de Chile, } \\
\text { PCCH }\end{array}$ \\
\hline $\begin{array}{l}\text { 34) TATIANA ROJAS } \\
\text { ORELLANA }\end{array}$ & 3 de marzo de 2005 & $\begin{array}{l}\text { Partido Comunista de Chile, } \\
\text { PCCH }\end{array}$ \\
\hline
\end{tabular}




\begin{tabular}{|l|c|c|}
\hline $\begin{array}{l}\text { 35) MARÍA PETRONILA } \\
\text { GÓMEZ TAPIA }\end{array}$ & 10 de marzo de 2005 & $\begin{array}{c}\text { Partido Comunista de Chile, } \\
\text { PCCH }\end{array}$ \\
\hline $\begin{array}{l}\text { 36) ELENA ROJAS } \\
\text { ARAYA }\end{array}$ & 11 de marzo, 2005 & $\begin{array}{c}\text { Partido Comunista de Chile, } \\
\text { PCCH }\end{array}$ \\
\hline $\begin{array}{l}\text { 37) NINA SALINAS } \\
\text { 38) CLAUDINA GARCÍA } \\
\text { SANTANA }\end{array}$ & 11 de marzo de 2005 & $\begin{array}{c}\text { Partido Comunista de Chile, } \\
\text { PCCH }\end{array}$ \\
\hline $\begin{array}{l}\text { 39) MARCELA SHULTZ } \\
\text { MORALES }\end{array}$ & 14 de marzo de 2005 & $\begin{array}{c}\text { Partido Comunista de Chile, } \\
\text { PCCH }\end{array}$ \\
\hline $\begin{array}{l}\text { 40) PATRICIA } \\
\text { CONOMAN CARRILLO }\end{array}$ & 1 de abril de 2005 & $\begin{array}{c}\text { Partido Comunista de Chile, } \\
\text { PCCH }\end{array}$ \\
\hline $\begin{array}{l}\text { 41) ELIANA ARANIBAR } \\
\text { FIGUEROA }\end{array}$ & & $\begin{array}{c}\text { Partido Comunista de Chile, } \\
\text { PCCH }\end{array}$ \\
\hline $\begin{array}{l}\text { 42) JULIA URQUIETA } \\
\text { OLIVARES }\end{array}$ & 6 de abril de 2005 & $\begin{array}{c}\text { Partido Comunista de Chile, } \\
\text { PCCH }\end{array}$ \\
\hline $\begin{array}{l}\text { 43) EVA MARDONES } \\
\text { ORDEÑ }\end{array}$ & 7 de abril de 2005 & $\begin{array}{c}\text { Partido Comunista de Chile, } \\
\text { PCCH }\end{array}$ \\
\hline $\begin{array}{l}\text { 44) PATRICIA TORRES } \\
\text { MUNOZ }\end{array}$ & 29 de abril de 2005 & $\begin{array}{c}\text { Partido Comunista de Chile, } \\
\text { PCCH }\end{array}$ \\
\hline
\end{tabular}

Archivos consultados:

-ARCHIVO DE LA CORPORACIÓN NACIONAL PARA LA DEFENSA DE LOS DERECHOS DEL PUEBLO (CODEPU, Santiago de Chile).

-ARCHIVO DE LA FUNDACIÓN VICARÍA DE LA SOLIDARIDAD (Santiago de Chile).

-ARCHIVO RETTIG (Santiago de Chile). 


\section{Referencias Bibliográficas:}

AGRUPACIÓN DE FAMILIARES DE DETENIDOS-DESAPARECIDOS, ¿Dónde están?: Mujeres chilenas detenidas-desaparecidas, Homenaje en el Día Internacional de la Mujer, Santiago de Chile, 1986.

AGUADO, A., Culturas políticas y feminismos, Fundación Instituto Historia Social, Madrid, 2010.

AHARONIAN, A. y otras, Vivencias: un taller para la memoria, Primer Encuentro Latinoamericano de Sobrevivientes de la Tortura, FLACSO, Santiago de Chile, 2003.

ÁLAMOS, L. y otros, Infancia y Represión, historias para no olvidar: Experiencia clínica con niños y familias que han vivido la represión política, Fundación PIDEE, Santiago de Chile, 1992.

ARÓSTEGUI SÁNCHEZ, J., La historia vivida sobre la historia del presente, Alianza, Madrid, 2004.

AYLWIN, O., Desafíos para un nuevo Contexto, Comisión chilena de Derechos Humanos, 1991, Santiago de Chile; dentro de estas obras estudiamos los trabajos de: Verónica Matus, Derechos Humanos, Derechos de las mujeres (p.141-151); Ximena Bunster: Tortura de las prisioneras políticas (151-163).

ALLENDE, B. M., Chile, treinta años después, El PAÍS, 29, 1, 2000.

AMORÓS, C., Historia de la Teoría Feminista, Instituto de Investigaciones de la UCM, Madrid 1994.

ARÁNGUIZ, F., Las Mujeres en Movimiento (1988-1998), una reflexión acerca de las demandas de las mujeres y la incidencia de las políticas públicas, Santiago, 2002.

ARRATE, J. y ROJAS E., Memoria de la Izquierda Chilena, Tomo I (1850-1970) y Tomo II (1970-2000), Javier Vergara Editor, Grupo Z, Santiago de Chile, 2003. 
ARRIAGADA, G., Por la razón o por la fuerza: Chile bajo Pinochet, Ed. Sudamericana, Santiago de Chile, 1998.

AHUMADA, E. y otros, Chile: La memoria prohibida, Tomos: I, II y III, Pehuén, Santiago de Chile, 1989.

BELMAR HIP, C., Huellas y miradas de una pasado reciente, pp. 185-213, en C. CAMPOS LUQUE, C., y GONZÁLEZ CASTILLEJO, M., Mujeres y Dictaduras en Europa y América: un largo camino; Atenea, Universidad de Málaga, 1996.

BULTMANN, I., ¿Democracia sin movimiento social?: Sindicatos, organizaciones vecinales y movimientos de mujeres en Chile y México, Nueva Sociedad, Caracas, 1995.

BUNSTER, X., La Tortura de Prisioneras políticas: un estudio de esclavitud sexual femenina, Taller de la Red Feminista Internacional Contra la Esclavitud Sexual Femenina y el Tráfico de Mujeres, Rótterdam, 1983.

COLlYeR, P., Presas Políticas de Quillota: Bajo la mano dura de la Marina, ANÁLISIS, No 291, 7-13 de agosto de 1989, pp.23-25, Fundación Vicaría de la Solidaridad, Chile.

CAMACHO PADILLA F., "Combates entre la memoria y la historia de Chile: conflictos sobre el pasado reciente", Review of Latin American Studies, Issue № 5 , Stockholms Universitet, 2009.

CAMUS, M., Presas políticas: Recuerda que estamos aquí, ANÁLISIS, No 287, 10-16 de julio de 1989, pp. 22-23, Fundación Vicaría de la Solidaridad, Chile.

CASTILLO VERGARA, M., Una experiencia terapéutica con mujeres que sufrieron en sus cuerpos y en sus mentes la violencia política, Instituto Latinoamericano de Salud Mental y Derechos Humanos (ILAS), Santiago de Chile, 1991.

CASTILLO VERGARA, M., Violencia sexual y represión política, ILAS, Encuentro Internacional sobre Sexualidad Humana y Educación Sexual, Santiago, Enero 1989. 
CASTILLO VERGARA M., Soledad Larraín, Entre el miedo y la esperanza, Instituto de la Mujer, Trabajo presentado en el XXII Congreso Interamericano de Psicología por la SIP, Buenos Aires, Junio de 1989. Más.

CASTILlO VERGARA M., Mujer y Represión Política, ILAS, Santiago, 1990.

CASTILLO VERGARA M., Proceso terapéutico en mujeres afectadas por la represión política, ILAS, Santiago, 1994.

CAVALlO A., Salazar M. y Sepúlveda O., La Historia oculta del régimen militar, memoria de una época 1973-1988, Mondadori, Santiago de Chile, 2001.

CHANEY, E., Supermadre, la Mujer dentro de la política en América Latina, Fondo de Cultura Económica, México, 1983.

CHUCHRYK, P.M., From Dictatorship to Democracy: The Women's Movement in Chile, pp. 65-95, en Jaquette, J.S., The Women's Movement in Latin America, Participation and Democracy, Oxford, 1994.

CLEARY, E., El papel de las mujeres en la política de Chile: Acerca del proceso de emancipación de mujeres chilenas durante la dictadura militar de Pinochet, ISISinternacional, Santiago de Chile, 1987.

COMITÉ DE COOPERACIÓN PARA LA PAZ EN CHILE, COPACHI, La situación general de la mujer bajo el gobierno militar de chile, Santiago, 1975.

COMISIÓN NACIONAL DE VERDAD Y RECONCILIAZCIÓN (CNVR), Informe de la Comisión Nacional de Verdad y Reconciliación, Santiago, Febrero de 1991; Volumen I, II y III.

COMISIÓN NACIONAL SOBRE DESAPARICIÓN DE PERSONAS (CONADEP), Informe de la Comisión Nacional sobre la Desaparición de Personas (Nunca Más); Eudeba, 1985, Buenos Aires, Argentina. 
COMISIÓN NACIONAL SOBRE PRISIÓN POLÍTICA Y TORTURA, Informe sobre Prisión Política y Tortura (Informe Valech), Ministerio del Interior, Santiago de Chile, 2004.

COMISIÓN NACIONAL SOBRE PRISIÓN POLÍTICA Y TORTURA, Informe para la Calificación de Detenidos Desaparecidos, Ejecutados Políticos y Víctimas de Prisión Política y Tortura, Ministerio del Interior, Santiago de Chile, 2011.

COLLIER S. y SATER W. F., Historia de Chile (1808-1994), Cambridge University Press, UK, 1996.

CORPORACIÓN JOSÉ DOMINGO CAÑAS 1367, Una experiencia para no olvidar, Santiago 2001, Consejo de Monumentos Nacionales, Ministerio de Educación Chile, Chile.

CORREA S. y otros, Historia del Siglo XX chileno, Ed. Sudamericana, Santiago de Chile, 2001.

CORVALÁn, L., El gobierno de Salvador Allende, LOM ediciones, Santiago de Chile, 2003.

COVAS S., MARAVALL J., BONINO L., "Hombres con valores igualitarios: historias de vida, logros alcanzados y cambios pendientes”, Ministerio de Igualdad, Gobierno de España, Madrid, 2009.

CUESTA BUSTILlO, J., Memoria e Historia, Marcial Pons, 1998.

DE RAMÓN A., Historia de Chile: desde la invasión incaica hasta nuestros días (1500-2000), Catalonia, Santiago de Chile, 2004.

DOCUMENTO, Demandas de las mujeres a la democracia, La Época, 1 de Julio de 1988. 
DOCUMENTO, Vida Cotidiana y Violencia, ISIS-internacional, Santiago de Chile, 1986.

DÍAZ, M., Efectos Psicológicos de la Tortura Sexual en Mujeres: Una reflexión de nuestra experiencia terapéutica a treinta años del golpe militar, ILAS, Santiago de Chile, 2003.

DORFMAN, A., La muerte y la doncella, Colección Septiembre, LOM ediciones, Santiago, 1997.

EKAIZER, E., Yo, Augusto, Ed. Aguilar, Buenos Aires, 2003.

ELIZABETH, J., Mujeres, Género y Derechos Humanos, en Construir la Democracia: derechos humanos, ciudadanía y sociedad en América Latina, Venezuela: Nueva Sociedad, 1996, Fundación Vicaría de la Solidaridad.

ERAZO, V., La Morada Feminista, Santiago de Chile, Diciembre 1998 en http/www.fempress.cl.

ERGAS, Y., El sujeto Mujer: el feminismo de los años sesenta-ochenta, pp. 593-621, en Duby G., Perrot M., Historia de las Mujeres, tomo 5: El siglo XX, Taurus, Madrid 2001.

FALCON, L., "Los planteamientos del Movimiento Feminista en Latinoamérica en referencia con el poder político", en Mujer y Poder Político, Vindicación Feminista, Madrid, 1992.

FERNÁNDEZ, D., La Iglesia que resistió a Pinochet: Historia, desde la fuente oral, del Chile que no puede olvidarse, IEPALA, Madrid, 1996.

FLORES OLVÁREZ, S. y otras, Relato de Urgencia/Resistencia de la Mujer Chilena durante el período de 1973-1995, Universidad de Playa Ancha, Valparaíso, 1999. FOLGUERA CRESPO, P., Cómo se hace Historia Oral, Eudema, UAM, 1993. 
FOLGUERA CRESPO, P., El feminismo en España: dos siglos de historia, Ed. Pablo Iglesias, Madrid, 2007.

FOXLEY, A. M., Mujeres del Chile militar, HOY, No 549, 25 de enero de 1988, pp. 910, Fundación Vicaría de la Solidaridad, Santiago de Chile.

FRÜHLING, H., "De la Dictadura a la Democracia: El derecho y el cambio social en la región andina y el cono sur sudamericano", en Caminando hacia la Justicia, Fundación FORD, Santiago de Chile, 2001.

GAMBONA, A., Un viaje por el infierno, Tomos: I, II, III y IV, Serie Testimonios, Ed. Antártica, Santiago de Chile, 1984.

GARCÍA, P., El genocidio en Guatemala a la luz de la Sociología Militar, SEPHA, Guatemala, 2005.

GALLARDO, E., La mujer chilena y el feminismo, Chile-América, Centros de Estudios y Documentación, Santiago de Chile, 1980.

GONZÁleZ, P. y FOnTAINE, T., Los mil días de Allende, Tomos I y II, Centros de Estudios Públicos, Santiago de Chile, 1997.

GRAU DUHART, O., El erógeno herido, FLACSO, Santiago de Chile, 2003.

HOBSBAWN, E., Age of Extremes. The Short Twentieth Century 1914-1991. Vintage Books, New York, 1996.

HUNEEUS, C., El régimen de Pinochet, Ed. Sudamericana, Santiago de Chile, 2002.

HUNEEUS, C., Chile: un país dividido, Ed. Catalonia, Santiago de Chile, 2003.

IGLESIAS, M. y otros, Género y globalización: Mujeres: feminismo, paridad, discriminación, violencia y sexismo, Ed. Aún creemos en los sueños, Santiago de Chile, 2003. 
INGER AGGER, Ph. D. y SÖREN BUUS JENSEN, M.D., Trauma y Cura en situaciones de terrorismo de Estado: Derechos humanos y salud mental en Chile bajo la dictadura militar, Ed. Chile-América CESOC, Santiago de Chile, 1996.

JAQUETTE, J. S. y SHARON L. WOLCHIK, Women and Democracy: Latin America and Central and Eastern Europe, The Johns Hopkinsg University Press, London, 1998.

JIMÉNEZ POLANCO, J., La representación política de las Mujeres en América Latina, pp. 12-14.

KATZ, C., Chile bajo Pinochet, Crónicas Anagrama, Barcelona 1998.

KAVANAGH, D., Thatcherism and British politics, the End of Consensus?, Oxford University Press, New York, 1990.

KIRKWOOD, J., Ser Política en Chile: las feministas y los partidos, FLACSO, Santiago, 1986.

KIRKWOOD, J. y otros, Y hasta cuándo esperaremos mandar-dirun-dirun-dán: mujer y poder en América Latina, Ed. Nueva Sociedad, Caracas, 1989.

LEÓN, M., The Women's Movement in Latin America: Participation and Democracy, Tm Editores, Colombia, 1994.

LAGARDE, M., Mujeres cuidadoras: entre la obligación y la satisfacción, Congreso Internacional SARE 2003, Emakunde, Vitoria-Gasteiz, 2004.

LETELIER, F., Chile: La respuesta de la Mujer Politizada a la Dictadura, en M. Schuler, Poder y Derecho: Estrategias de las Mujeres del Tercer Mundo, OEFInternacional, Santiago de Chile, 1987, pp. 150-156.

LOVEMAN, B. y Lira E., Las ardientes cenizas del olvido: Vía chilena de Reconciliación Política (1932-1994), LOM ediciones, Santiago de Chile, 2000. 
LUNA, G. y M., Desde las orillas de la política: género y poder en América Latina, Institut Catalá de la Dona, Barcelona, 1996.

MARAVALL J., La mujer en la lucha política contra el franquismo: el caso del Partido Comunista de España (1960-1975), A 70 años de la Guerra Civil en España: Un recorrido a través de la memoria histórica y literaria, Universidad de Estocolmo, 2006.

MATUS, V., y GÓMEZ DE LA TORRE, M.: Mujeres, Memoria y Derechos Humanos, Programa de Mujeres, Comisión Chilena de Derechos Humanos, Santiago de Chile, 1994.

MIRANDA, A., Sólo cambia el color de los barrotes, ANÁLISIS, N 217, 7 de marzo de 1988, pp. 19-20, Fundación Vicaría de la Solidaridad, Santiago de Chile.

MOLINA, G., Movimiento de Mujeres en Chile (1983-1986): desafios y problemas de una nueva identidad femenina, ISIS-internacional, Santiago de Chile, 1986.

MONTOYA VÉLEZ, M. E., Rompiendo el silencio, yo te acuso Pinochet, TallerEditorial La Correa Feminista, Centro Cultural Creatividad Feminista, México, 1999.

MORGAN, R., FALCON L., Mujeres del Mundo, Vindicación Feminista, Madrid, 1993, Chile, pp. 227-234.

MOULIAN, T., Chile actual, anatomía de un mito, Arcis Universidad, Ed. LOM, Chile, 1998.

OLAVARIA, J., El sexismo, tortura y mata: Política de género y represión política hacia las mujeres en Chile, Seminario "Derechos Humanos de las mujeres víctimas de la represión política, Instituto de la Mujer y Corporación la Morada, Biblioteca Nacional, 26 de Septiembre 2003, FLACSO, Santiago de Chile.

OLEA, R. y GRAU O., Volver a la Memoria, Estudios de Género, La Morada, LOM ediciones, Santiago, 2001. 
OLEA, R, Femenino y feminismo en transición, Ed. Escrituras de la Diferencia Sexual, Santiago, La Morada, 2000.

OLEA, R. y OYARZÚN K., Mujeres y Política, Santiago, 2000.

OXMAN, V., Documentos de Trabajo, № 21, La Violencia Sexual en Chile, Servicio Nacional de la Mujer, SERNAM, Santiago de Chile, 1992.

PALESTRO, S y otras, Una Historia necesaria, Mujeres en Chile: 1973-1990, Santiago, 1994.

PALESTRO, S., Mujeres en Movimiento (1973-1989), Serie Estudios Sociales, FLACSO, Santiago de Chile, 1991.

PEÑA, P., "Fui violada y torturada", en ANÁLISIS, 9-15 de noviembre de 1987, pp. 2931, Fundación Vicaría de la Solidaridad, Chile.

PÉREZ, M. P., CASAÚS, M., La mujer Latinoamericana ante el reto del siglo XXI, IX Jornadas de Investigación Interdisciplinarias sobre la Mujer, Instituto universitario de estudios sobre la Mujer, UAM, Madrid, 1993.

PISSCHEDA, G., Panel: Educación Popular y Liderazgo de las mujeres en la construcción de la Democracia en Educación Popular y liderazgo de las mujeres en la construcción de la Democracia Latinoamericana; Red de Educación Popular de Mujeres, CEAAL, Quito, 1990.

PORTALES, F., Chile: Una democracia tutelada, Ed. Sudamericana, Santiago de Chile, 2000.

PORTUGAL, A. y TORRES C., Por todos los medios: Comunicación y Género, Ediciones de las Mujeres, ISIS-internacional, Santiago de Chile, 1996.

PRATS C., Memorias: testimonio de un soldado, Pehuén Editores, Santiago de Chile, 1985. 
PRECHT BAÑADOS, C., ¿Dónde están?, Tomos: I, II, III y IV, Arzobispado de Santiago, Vicaría de la Solidaridad, Santiago de Chile, 1978.

PRESOS POLÍTICOS, Sesiones de entrevistas con ex detenidos políticos, Fundación Vicaría de la Solidaridad, Santiago de Chile, 1980.

RYAN, B., Feminism and the Women's Movement: dinamics of change in social movement ideology and activism, New York and London, 1992, Chapter 3, Resurgence of Feminism: The Contemporary Women's Movement, pp. 39-53.

RICHARD, N., La problemática del Feminismo en los años de la transición en Chile, Universidad Arcis, Santiago, 1997.

RIDDELL, P., The Thatcher Era and its Legacy, Blackwell, Oxford, UK, 1993.

RODRÍGUEZ, L., A quién quiera escuchar, Fundación Laura Rodríguez, Santiago, 1992.

RODRÍGUEZ, R. y otros, Las mujeres en América Latina: una aproximación necesaria, Fundación CIPIE, C. Estudios Iberoamericanos, UAB, Barcelona, 1990.

RODRÍGUEZ, C. y otras, "Seis años de situaciones represivas sobre la mujer en Chile”, Círculo 73, Mimeo, Santiago, 1973

ROJAS, A., Prisioneras de coronel no tienen quién les escriba, ANÁLISIS, Nº 192, 14 Septiembre, 1987, pp.26-27. Fundación Vicaría de la Solidaridad, Santiago de Chile.

ROJAS, C., Recuerdos de una Mirista, Carmen Rojas, Santiago, 1978.

ROJAS, G. E., Tejas Verdes: mis primeros tres minutos, Ed. Seminario 90, Santiago de Chile, 1989. 
ROJAS, P. y otras, Todas íbamos a Ser Reinas: estudio sobre diez mujeres embarazadas que fueron detenidas y desaparecidas en Chile, CODEPU, LOM ediciones, Santiago de Chile, 2002.

SALAZAR, G. y PINTO, J., Historia Contemporánea de Chile IV, Hombría y Feminidad, LOM ediciones, Santiago de Chile, 2002.

SECRETARÍA EJECUTIVA PARA AMÉRICA DE SOLIDARIDAD CON CHILE, Trabajo presentado a la Reunión de la CEPAL-OEA, Violación de los Derechos de la Mujer en Chile, México, Casa-Chile, marzo 1977.

SECRETARÍA NACIONAL DE GOBIERNO, Libro Blanco: del cambio de gobierno en Chile: 11 de Septiembre de 1973, Ed. Lord Cochrane, Santiago de Chile.

SOTO A., "La larga sombra del dictador", Review of Latin American Studies, Issue N ${ }^{\circ}$ 5, Stockholms Universitet, 2009.

SOTO A., ¿Atado y bien atado?: institucionalización y crisis del franquismo, Ed. Biblioteca Nueva, Madrid, 2005.

SOTO L., Una dama de lila y negro: de cómo una niña que no podía soñar se hizo mujer, luchó por los Derechos Humanos, denunció al psicópata de Viña y ganó un sillón en el Senado, Planeta, Santiago de Chile, 1991.

TOKAR y otras, Ese infierno: conversación con cinco mujeres sobrevivientes de la ESMA, Ed. Sudamericana, Buenos Aires, 2001.

VALENZUELA, M., Mujeres del Chile Militar, POLÍTICA, № 549, 25 al 31 de enero de 1988, Fundación Vicaría de la Solidaridad, Santiago de Chile.

VALDÉS, H., Tejas Verdes: Diario de un Campo de Concentración en Chile, LOM Ediciones, CESOC, Santiago de Chile, 1996.

VALDÉS, T., Las Mujeres en la Dictadura Militar, FLACSO, Santiago de Chile, 1987. 
VALDÉS T., "Entre la modernización y la equidad: mujeres, mundo privado y familias", en Chile en los noventa, Dolmen Ediciones, Santiago de Chile, 1998.

VALDÉS, T., De lo social a lo político: la acción de las mujeres latinoamericanas, LOM ediciones, Santiago de Chile, 2000.

VAlENZUELA, A., El quiebre de la Democracia en Chile, Ed. Universidad Diego Portales, Santiago de Chile, 2003.

VENEROS, D., Allende, Ed. Sudamericana Señales, Santiago de Chile, 2003.

VENEROS D., Perfiles Revelados: historias de mujeres en Chile, Ed. Universidad de Santiago, Santiago de Chile, 1997.

VIDELA, P., Bordando la vida. Historias de vida de cuatro mujeres que transformaron su dolor y su lucha en semillas de esperanza, Fundación Vicaría de la Solidaridad, Santiago de Chile, 1996.

VILlAnUEVA P., Cuadernos de Orientación Socialista, № 19, Santiago de Chile, noviembre 1984.

WINN P., "El pasado está presente: historia y memoria en el Chile contemporáneo", en Historizar el pasado vivo en América Latina.

http://etica.uahurtado.cl/historizarelpasadovivo/es_contenido.php 
-"Las mujeres en la izquierda chilena durante la Unidad Popular y la dictadura militar (1970-1990)".

Doctorando: Javier Maravall Yáguez.

Director de Tesis: Álvaro Soto Carmona.

Departamento de Historia Contemporánea.

Universidad Autónoma de Madrid (UAM), 2012.

Proyecto financiado por la Agencia Española de Cooperación internacional (AECI), Ministerio de Asuntos Exteriores, Gobierno de España, 2003-2005. 


\section{Las mujeres en la izquierda chilena durante la Unidad Popular y la dictadura militar (1970-1990) \\ ANEXO: ENTREVISTAS}

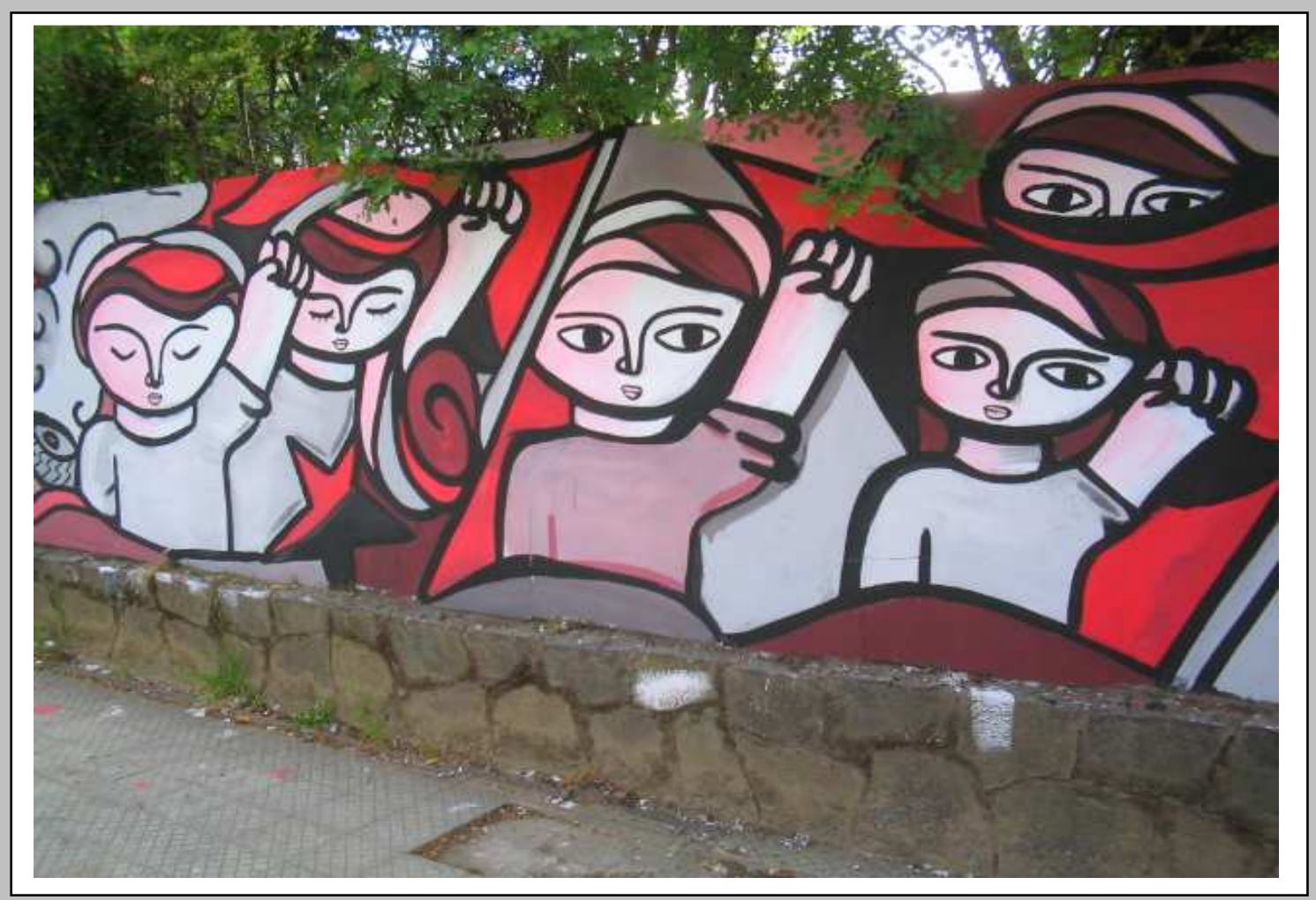

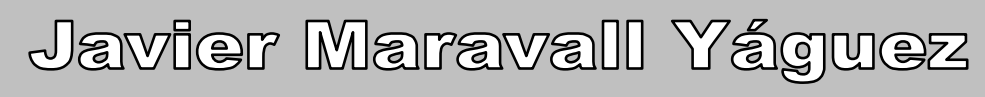




\section{MOVIMIENTO DE IZQUIERDA REVOLUCIONARIA}


1 Entrevista a SANDRA AQUILINA PALESTRO CONTRERAS, realizada el día 12 de noviembre de 2003, Santiago de Chile. Palestro estuvo presa en el Estadio Nacional de Chile durante el mes de Octubre de 1973. Fue militante del Movimiento de Izquierda Revolucionaria y actualmente es miembro activo de diferentes organizaciones de Derechos Humanos que operan en Chile.

\section{1 ¿Cuál fue la tónica predominante en el tratamiento a las presas políticas durante la dictadura militar?}

Hubo un clasismo marcadísimo en el tratamiento a las presas políticas, en el Estadio Nacional, las mujeres que llegaban con abrigo de piel y sombrero eran tratadas de manera bien distinta que las compañeras de las poblaciones rurales. Sí hubo un trato diferenciado a las mujeres de apariencia de clase más alta.

El machismo de los agentes represores se dio más en la textura psicológica, es decir, primero en las amenazas por lo que una mujer representaba allí; te decían "-te podemos matar pero afuera está tu hijo-”. El elemento psicológico fue fundamental, te humillaban con tu cuerpo desnudo, que al final iban a ser perjudicados tus padres, tus hijos, etc.

2 ¿Se podría decir que desde la óptica de los torturadores la mujer "subversiva" representaba un modelo demasiado transgresor que había que castigar?

Quizá esta visión sea más sofisticada de lo que en realidad fue, quizá se trató de un machismo más grueso, más primitivo. Los agentes no relacionaban toda esa cuestión, era una mezcla de machismo primitivo y de un miedo del ser humano por estar rodeado de mujeres.

La mayoría de las mujeres recluidas en el Estadio Nacional éramos muy jóvenes y en ocasiones nos decían “-no quiero maltratarte más porque tengo hijas como tú-”. No hubo esa elaboración tan racional de que tú eras una parte fundamental del enemigo como elemento reproductor. Había diferencias entre los torturadores, quizá algunos actuaron con esa racionalidad y frialdad. 
Otra cuestión a la que aludían fue el hecho de que constantemente nos llamaban putas, con hijos bastardos y quizá, en este sentido, sí aludían al enemigo. Éramos no tanto las reproductoras del enemigo sino las tontas útiles del enemigo, como las putas del enemigo, quizá fue esta la visión que tuvieron los militares de la Junta.

3 ¿La tortura sexual fue una pauta constante en el trato a las presas o por el contrario también fue un hecho generalizado con los presos masculinos, es decir, se dieron casos de violaciones a los presos varones?

No fue una pauta generalizada. Conozco un solo caso de violación a un hombre que es bastante conocido públicamente, fue realizado por una mujer soldado. Fue un caso excepcional. Incluso no fue un hecho generalizado en las mujeres. Yo estuve en octubre de 1973 en el Estadio Nacional y sólo una compañera relató haber sido violada. En nuestro caso, hablando desde la generalidad, se trató más de actos lascivos más que de violación, es decir, de tocamientos con una connotación más lasciva y de amedrantamiento que de violaciones y daños físicos, fue algo más psicológico.

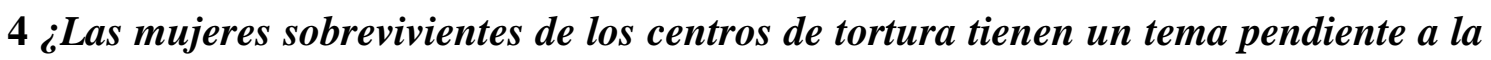
hora de visualizar estas experiencias sufridas?

Todas somos parte de ese mismo pudor. Mi compañera Nubia es sobreviviente de Villa Grimaldi, llevamos siete años trabajando juntas y nunca hemos hablado de este tema. Esta es la parte más importante, es decir, ¿por qué nos cuesta tanto?; no haber relatado esta cuestión todavía a treinta años del golpe es un tema pendiente.

5 En el Chile actual, cuando todavía se está debatiendo la ley del divorcio, cuando todavía no se puede hablar de aborto como un hecho normalizado y legal, la existencia de acoso sexual en las empresas, la falta de equidad salarial entre trabajadores y trabajadoras en un régimen democrático, etc., ¿es esto un lastre que viene de los tiempos de la dictadura?, ¿de aquí puede venir la dificultad de visualizar los hechos ocurridos con las mujeres de la oposición?

Claro, este es el punto más importante, es decir, revelar las causas culturales de esta omisión. En treinta años yo he hablado tres veces de la tortura. La instauración de la 
Junta supuso a todos los efectos un retroceso para la mujer, y esto, ha traído muchas consecuencias que podemos ver hoy día en la sociedad chilena.

6 ¿Sería impensable que desde la institucionalidad democrática chilena actual se reconociera el hecho de que ciertos colectivos de mujeres sufrieron este tipo de tortura?

Es impensable porque es impensable para los hombres, la institucionalidad está comandada por los hombres. Lo más importante es saber por qué las mujeres no han visualizado esto, incluso una vez finalizada la dictadura.

7 ¿Que influencia tuvieron las mujeres pro-dictadura, es decir, aquellas mujeres de las clases medias urbanas, de los sectores gremialistas o del ámbito castrense que presionaron en su día a los militares para que intervinieran en el gobierno de Salvador Allende?

Fue un sector minoritario, no tuvieron ningún peso. En ese tiempo todo estaba cambiando para la mujer (a nivel internacional) y es obvio que su discurso fue insignificante, no valía nada, conforme se fueron propagando más y más las ideas feministas las mujeres pro-dictadura se fueron retirando, sus discursos resultaban casi ridículos.

Podemos decir que no tuvieron ningún papel importante dentro del gobierno pinochetista. Quizá Mónica Madariaga, (ministra de Justicia y artífice de la Ley de Amnistía sobre los crímenes ocurridos entre 1973-1978) tuvo algo de relevancia pero no representaba en absoluto el punto de vista mayoritario de las mujeres, siempre se vio como un símil de Margaret Thatcher. En cambio Lucia Hiriart sí que representó el discurso de la mujer tradicional. A parte de estos dos casos no hubo más mujeres visibles bajo la esfera de la Junta.

8 ¿Qué papel tuvieron las mujeres sobrevivientes, ante el avistamiento del plebiscito de 1988, en la recuperación de la memoria y en la lucha por un sistema democrático? 
Fue un movimiento importante y bien articulado, con contenidos cada vez más amplios, más progresistas, más feministas. Con las primeras elecciones presidenciales, es decir, con el primer gobierno democrático, hubo un grupo de mujeres que tuvieron una promoción desde los partidos políticos. Fue una primera oleada de mujeres que entraron en el gobierno. Aquí es dónde el movimiento de mujeres comenzó su declive, volvieron a los partidos políticos como su militancia política prioritaria con lo que el movimiento de mujeres se quedó desarticulado.

\section{9 ¿La aparición del SERNAM conllevó per se la división del Movimiento de Mujeres al dejar fuera a muchas de ellas de esa "nueva institucionalidad democrática"?}

El Sernam y sus primeros temas de actuación fueron los que se proponían dentro del Movimiento de Mujeres en un primer momento. Después, esto cambió y se entró en la dinámica gubernamental con su propia agenda, no necesariamente emanada de un movimiento social. El tema sexual entendido como la tortura sexual no fue una demanda que incorporara la agenda del Sernam, esta cuestión sólo la recogió el movimiento feminista chileno.

10 Con todo lo expuesto, ¿podemos alegar que se establecieron pautas específicas a la hora de reprimir a las mujeres militantes de la oposición durante la dictadura?

Indudablemente hubo una diferenciación. La represión hacia los hombres no aludía a la cuestión emocional o sentimental. Fue una represión directa para la obtención de información, fue brutal, de dolor físico. Pero el tratamiento hacia las mujeres tenía que ver más con la tortura emocional, con el manejo de los sentimientos, apelar a una tortura psicológica por una parte y por otra, a la humillación de tu cuerpo, estar desnuda frente a ellos era una parte de la tortura, ellos decían cosas respecto de tu cuerpo, es el cuerpo, la emoción y el sentimiento acompañado también de una brutalidad. La diferencia residió en esa cuestión psicológica de la que ellos (los agentes militares represores) eran muy conscientes de que tenían que utilizar con las presas. 
2 Entrevista a NUVIA BETSIE BECKER EGUILUZ, realizada el día 12 de noviembre de 2003, Santiago de Chile. Becker es sobreviviente del Centro de Tortura Villa Grimaldi. Fue militante del Movimiento de Izquierda Revolucionaria.

\section{1 ¿De qué manera afectó la instauración de la dictadura a las mujeres de la izquierda política?}

Recién se está intentando hacer una serie de estudios sociológicos e históricos sobre la represión hacia la mujer en Chile a partir de nuestras propias experiencias. Nosotras sufrimos de una manera muy especial en las cárceles porque estábamos en una situación mucho más marginal, fuimos más insultadas y poco toleradas. Éramos peligrosas para el sistema autoritario. Con los hombres hubo mucha violencia pero no les molestaban por cosas tan nimias. A nosotras nos violentaban por cualquier cosa, su objetivo era devolvernos al redil, convertirnos en mujeres sumisas fuera de toda actividad política y "subversiva".

Las mujeres tuvieron un gran papel en la búsqueda de los detenidos desaparecidos puesto que ese rol de búsqueda era más tolerado que lo realizara una mujer que un hombre. Pensaban que por el hecho de ser mujeres el movimiento de recuperación de la memoria y justicia iba a ser menos importante porque ante los ojos de los militares esa actividad estaba más acorde con el rol de la mujer (las madres buscando a sus hijos y esposos etc.). Las presas también asumieron la labor de recoger y denunciar las desapariciones, es decir, los compañeros y compañeras que no llegaban a un destino, que desaparecían.

La estructura patriarcal hizo que la mujer retrocediera cualitativa y cuantitativamente en los logros de la liberación femenina. Hoy en día vemos algunas consecuencias del régimen autoritario, tenemos un lastre a nivel social y económico.

\section{2 ¿Se estableció una política de represión específica con las presas?}

Evidentemente. Se cortó de raíz con un proceso de liberalización de la mujer iniciada en los años sesenta que conllevó a una mayor participación de la mujer en el ámbito 
universitario, laboral, político, etc. La mujer empezó a acceder a otro tipo de sexualidad, de amor libre, de liberalización de las relaciones sexuales. La Junta cortó con este proceso reformador en el que se empezaba a hablar de cuestiones tan fundamentales como el aborto, igualdad, en definitiva, de una nueva reproductividad.

El cierre brutal a este proceso se dio con la implantación del régimen militar, la vuelta a la esfera doméstica, la sumisión y los valores más tradicionales de la idea de familia y marianismo. Hoy en día hay ciertas cuestiones que todavía perduran, incluso en algunos sectores denominados "progresistas". Es decir, esa moralina de lo que ha de ser la mujer chilena.

3 ¿Se establecieron en los centros de tortura alguna diferencia de clase entre las presas, es decir, hubo el mismo trato para las mujeres de procedencia social baja y las mujeres de clase alta?, ¿los torturadores fuerons clasistas o machistas?

No, fueron más machistas que clasistas. Yo milité en el MIR en el cual había militantes de diferentes clases, especialmente de clase media, estudiantes, profesionales, etc. También hubo presencia de campesinos y mapuches pero no se establecieron diferencias de trato.

Por el contrario, sí se establecieron diferencias con las mujeres militantes del MIR, con las jóvenes que se salían de ese rol, pero daba igual su procedencia social a diferencia de lo que pasó con la dictadura peruana, en donde las diferencias socioeconómicas fueron fundamentales a la hora de reprimir. Es decir, a los blancos ricos no se les reprimió de la misma manera. En cambio en Chile la segregación fue fundamentalmente sexual, la diferencia de trato vino dada más por la cuestión genérica. La gente que desaparecía no sólo era pobre cómo en el caso peruano, desaparecían profesoras, estudiantes, militantes de clase media, etc.

\section{4 ¿Hasta que punto la tortura sexual y emocional fue una pauta generalizada en los procesos de represión con las mujeres?}

Sin duda fue una pauta bastante generalizada; en los primeros años las violaciones fueron mucho más constantes, con el tiempo esto fue cambiando. Empezó a salir a la luz 
los casos de tortura sexual y a partir de aquí se pasó a la amenaza psicológica. A mí me tocó vivir en un centro de tortura en donde vivieron niños. Se presionaban a las madres con los niños, que lloraban viendo como torturaban a sus padres, fue un tratamiento de choque. Hubo varios aspectos, uno fue la tortura sexual entendida como la supremacía del macho sobre la hembra como castigo.

Nos trataban de prostitutas, como animales que nos apareábamos sin estar casadas, ese tipo de expresiones como que éramos unas sueltas, un tratamiento muy soez, por el propio hecho de habernos metido en la política. Esto era un castigo.

Existió una tortura hacia la mujer con todo aquello que tenía que ver con el tema de la maternidad, es decir, la amenaza con los hijos fue una de las torturas psicológicas de género más brutales.

Ante ellos éramos malas madres, no solían amenazar a los hombres con sus hijos. Nos daban más duro en el plano emocional, en el plano maternal. La conducta que teníamos que tener era mucha más dura, es decir, a la hora de exigirnos cosas. Un ejemplo lo encontramos en el castigo con el régimen de visitas, es decir, pasábamos por los lugares de aislamiento como parte de ese castigo y, esto, se convirtió en una forma de hostigamiento constante. Nos decían que éramos unas cualquiera, que nuestros hombres nos engañarían con otras.

\section{Entonces, ¿existió una doble represión?}

Claro, éramos un mal ejemplo para la sociedad y esto debía de cortarse. Recuerdo una expresión de un comandante de carabineros de Tres Álamos que nos dijo: “-las mujeres que andan metidas en política cuando pasan por aquí salen cambiadas, no salen igual de cómo entraron--".

\section{6 ¿Cuál es el reto pendiente que tienen las mujeres sobrevivientes de los procesos de tortura?}

El testimonio es fundamental, es necesario visualizar no sólo el tema de la tortura sino por qué se dio así, las razones de ese corte con ese proceso de liberación comenzado en 
los años 60. Hay que visualizar este contexto, es decir, en la situación en la que las mujeres fuimos presas, en esa necesidad por cortar con ese proceso reformador. Quizá en este punto esté la clave para entender el comportamiento que tuvieron con nosotras. 
3 Entrevista a ROSA ELVIRA LIZAMA LEIVA, realizada el 11 de diciembre de 2003, Santiago de Chile. Lizama, fue militante del Movimiento de Izquierda Revolucionaria durante el período 1974-1988. Estuvo detenida en el centro Villa Grimaldi, presa en Cuatro Álamos y exilada en Francia, Cuba, Nicaragua, Argentina y Uruguay. Actualmente es funcionaria pública en el Ministerio de Sanidad de Chile.

\section{1 ¿Cómo fueron sus inicios en el Movimiento de Izquierda Revolucionaria?}

Yo nací y me crié en Santiago, en un barrio del margen de la ciudad, en el Sur. Fui a estudiar a Concepción. Entré en la universidad en el año 67, el MIR había nacido en Concepción en el año 65; tuvo su nacimiento en el medio estudiantil, con algunos intelectuales y ex militantes del PC e incluso algunos trotskistas.

Mi origen es de una familia muy modesta. La conciencia de mi estado de pobreza la tenía pero no de conciencia política. Mi ingreso a la universidad me rompió el velo. Me rodeé de gente con anhelos de justicia y sensibilidad social, gente del MIR.

Yo estudié Servicio Social. En 1971 hice mi Tesis y en marzo de 1972 obtuve mi título. En septiembre del 72, a petición de un sindicato de una empresa constructora, empecé a trabajar (Compañía de Acero del Pacífico, en la ciudad de Calca Guana). En esta empresa constructora éramos 1200 trabajadores, de los cuales 1000 eran obreros. Yo era la asistente social de ese personal y al mismo tiempo militaba en el MIR.

\section{2 ¿Bajo que circunstancias estuvo el 11 de septiembre de 1973?}

Durante 1973 yo viajaba a Santiago todos los fines de semana puesto que mi madre había enfermado de cáncer. La última vez que yo vine a Santiago fue a mediados de agosto. A partir de esta fecha hubo muchas dificultades para conseguir pasajes, muchos atentados en las carreteras de los grupos de ultraderecha como Patria y Libertad; en septiembre del 73 conseguí dos pasajes para el día 11 en la mañana muy temprano.

Llegamos a la terminal de buses (Concepción), allí nos dijeron que había problemas con el autobús porque se había producido un atentado en la carretera con lo que me dirigí al trabajo. Cuando llegamos, sobre las ocho y media de la mañana, me encontré con la 
puerta cerrada y los trabajadores afuera junto a los infantes de marina. Yo pensé que era un registro de los famosos cordones industriales; ya habían allanado varias industrias gracias a la Ley de Control de Armas aprobada un mes antes en el Parlamento.

- ¡Nos vienen a allanar!-, pensé. Nos hicieron pasar. Una vez dentro, vi cómo segregaban a la gente según a la compañía que pertenecieras; a los de la compañía del acero nos hicieron sentarnos en el suelo.

Un marino nos dijo que las damas nos sentáramos en una vereda. Sacaron una lista y comenzaron a nombrar gente (los principales dirigentes sindicales, de empleados y obreros y delegados de sección) y colocarnos en un lugar separado del resto. Yo todavía pensaba que todo aquello era un allanamiento.

Nos amenazaron con que el que estuviera en la lista y no apareciera iba a sufrir las mil penas del infierno. Aún así, algunos compañeros lograron escapar entre la gente y afortunadamente nadie dijo nada en ese momento. A los que nos quedamos nos llevaron a una camioneta y nos llevaron a la Base Naval y allí me separaron de los hombres. Yo era la única mujer.

En el cuartel de la Base me encerraron toda la tarde en una pieza y estuve allí sola varias horas. Al atardecer me sacaron al patio y allí me encontré con mis compañeros. Nos llevaron a todos al embarcadero para subirnos a una lancha y allí nos encontramos con cientos de personas donde reconocí a compañeros de la universidad.

Nos subieron a culatazos a las embarcaciones. Antes, a mi me pasaron a una pieza donde me ocurrió algo muy desagradable. Un marinero me hizo sacarme la ropa, un poncho que llevaba, y me toco entera; fue algo muy desagradable.

Finalmente, nos llevaron a la Isla Quiriquina, una escuela naval para jóvenes grumetes que funciona hasta hoy día. Allí nos hicieron entrar a un gimnasio que estaba repleto de gente, unas ochocientas personas. Nos separaron a los hombres de las mujeres; nosotras éramos unas 20, una mínima parte de todo el conjunto de los presos de la isla. Dormíamos en los dormitorios que ocupaban los profesores de los cadetes. 
Al día siguiente nos enfilaron para pasar a declarar donde había tres escritorios, uno de la marina, otro del ejército y otro de carabineros. La metodología era según qué cuerpo te hubiera detenido te correspondía una mesa u otra. A mi me tocó con los marinos. Allí había un oficial de unos cincuenta años vestido con sus galones y a su lado había otros dos hombres vestidos de civil y miembros del Servicio de Inteligencia Naval.

Me preguntaron con sendas afirmaciones como -usted es del MIR- a lo que yo contesté con un rotundo NO; entonces -usted es del Partido Comunista-, también contesté con una negativa; el tipo se enojó, yo contesté nuevamente que yo era simpatizante de la izquierda pero que no militaba en ningún partido.

El oficial me llevó a un lugar separado del escritorio donde me dijo -Señorita, yo a usted la voy a dejar en libertad-, yo sentí por primera vez que estaba junto al "bueno"; posteriormente comprendí que cuando te empezaban a hablar con amabilidad sentía mucho miedo puesto que era un síntoma negativo. Me puse muy tensa pensando que dónde estaba la trampa.

Firmé un papel y regresé al continente con el oficial. Allí me dijo -la dejé pensativa-, a lo que contesté -estoy preocupada porque dicen que hay toque de queda y no sé como voy a volver a mi casa-, a lo que el me contestó -no se preocupe que nosotros la vamos a dejar-, lo que me dejó más preocupada.

En la Base Naval ocurrió algo muy particular, allí me nombraron por mi nombre y me hicieron entrar en un dormitorio donde me encontré con nuevas presas. Allí pasamos la noche; a la mañana siguiente nos llevaron de regreso a la Isla Quiriquina en donde el oficial me comentó -usted de vuelta de nиevo- a lo que yo contesté encogiéndome de hombros.

Nuevamente, hice la fila en las mesas de interrogación; dicho oficial me dijo -he recibido órdenes de que usted tiene que permanecer aquí-. Esto significó que me quedé allí hasta el 31 de Diciembre de 1973 (casi cuatro meses).

El 29 de noviembre falleció mi madre estando allí lo que me hizo entrar en una profunda tristeza; cuando salí en libertad el 31 de diciembre lo hice en régimen de 
libertad condicional; sin haber tenido un proceso, estuve detenida por la Ley de Seguridad del Estado lo que significaba estar firmando durante los siguientes nueve meses todos los sábados en la comisaría de carabineros más cercana a mi domicilio (mi estado era "activista política" en régimen condicional).

Al término de los nueve meses viajé con mi pareja a Santiago en dónde estuve vagando de casa en casa por miedo a ser detenida nuevamente. Allí nos casamos para conseguir el estado legal de "esposa de", puesto que en los meses de mi detención en Quiriquina no pude informar a nadie de mi presencia.

\section{3 ¿Cómo fue su detención y su encierro en el centro de tortura Villa Grimaldi?}

En Santiago nos integramos al trabajo partidario. En agosto de 1974 quedé embarazada y en febrero de 1975 me detuvieron en la calle con siete meses de embarazo. Había quedado con una compañera del MIR a las doce de la mañana para un traspaso de información, era mi enlace.

En el mismo lugar de la cita avisté a un hombre de unos cuarenta años bien fornido que se dirigió a mí tomándome bruscamente por los brazos y diciéndome -ipolicía!-. Yo pedí auxilio pero unos instantes después otros cuatro hombres me agarraron y me metieron en un auto. Allí me pusieron un scotch en los ojos y lo último que alcancé a ver fue la avenida Grecia, donde estaba el Estadio Nacional.

Nos dirigíamos hacia la cordillera pero en ese momento me hicieron agachar la cabeza. Sentí que llegábamos a un lugar en donde escuché la apertura de un portón, acto seguido me bajaron violentamente del auto en donde pude notar que pisaba gravilla. Había un hombre que supongo que dirigía el operativo de detención puesto (le llamaban teniente Marcos) que gritaba (dando órdenes) - isi no habla a la parrilla con ella!- (un catre metálico donde te aplicaban corriente).En medio de los gritos pude escuchar música, era una canción de Serrat, Mediterráneo. 


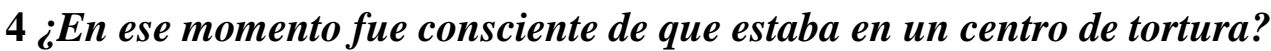

No, eso lo supe después. En ese momento lo que sentía era un profundo terror por lo que le pudiera pasar a mi marido y a mi guagüita (bebé). Después me metieron en una oficina, me empujaron y me tiraron a un sillón estando yo vendada. Me empezaron a preguntar por mi marido, su nombre y su paradero. Yo contesté que no lo conocía. Ante esta negativa vino el primer bofetón; tú no sabías de dónde venía. A la segunda negativa vino otro bofetón. En este momento, yo sentí que alguien lloraba en esa habitación. Escuché la voz de mi compañera con quién me había citado que decía -ipor favor no le peguen! -

Yo pensaba que le habían detenido en el lugar donde a mi me apresaron. Más tarde supe que a ella le habían detenido dos días antes. Ella aguantó dos días de tortura intensa, la torturaron mucho. Ella debió tener mucho miedo, me denunció.

Lo terrible es que cuando estás en esa situación tu mente empieza a armar con rapidez lo que vas a decir y cómo lo vas a decir para que no afecte a la gente de tu alrededor. Yo tengo que asumir que yo entregué a mi pareja como mi compañera me entregó a mí. Para mi fue muy terrible pensar que mi compañera denunciara a toda mi familia porque si caía mi marido caía mi hermano y toda mi familia.

El momento máximo de terror fue cuando sentí la posibilidad de perder a mi hija. Sentí verdadero pánico. Asimismo, sentía mucho miedo cuando me hablaban suave o amigablemente, pensaba, ¿qué me va a pasar?, ¿cuál es la trampa?.

\section{5 ¿En su situación de embarazo de siete meses y siendo militante del MIR, en qué condiciones vivió en Villa Grimaldi?}

A mi me metieron a una casa Corvi, son unas piezas de un metro por un metro de superficie, con un agujero en la puerta de unos cinco centímetros para respirar. Para dormir tenía que encogerme.

Tras estar un día allí abrieron la puerta y me sacaron, todo era oscuro porque estaba con vendas. Sentía que me llevaban por un pasillo y me llevaron a una pieza donde, por 
debajo de la venda, puede alcanzar a ver un escritorio y cuatro hombres. Uno de ellos estaba tumbado en un catre metálico con las manos detrás de la nuca que me iba preguntando algunas cosas sobre mi familia. En un momento me preguntó que donde había conocido a mi compañera del MIR con la que me tenía que encontrar para el traspaso de información. Antes de que yo respondiera el tipo dio una orden para que trajeran a mi compañera y la preguntaron que cómo me había conocido a mi y si yo era del MIR. Ella contestó, -no, ella no es del MIR, ella simpatizaba con nosotros pero no es militante-, - ¿y el marido?- (preguntaron los milicos) -no, el marido sí es de MIR-.

Después de esto me sacaron de la pieza. No me parrillaron. Me metieron a una pieza con más mujeres vendada. En ese instante sentí que alguien me tomaba la mano y me dice -tranquila, tranquila-, y me acuesta en su cama. Hacía mucho frío. En Peñaloén hace mucho frío, incluso en las noches de verano. Creo que también era una mezcla de miedo. En la pieza de tortura sentí tanto miedo que no podía controlar el movimiento de mis piernas cuando estaba sentada. Me puse las manos sobre las piernas para tratar de esconder mi miedo.

En la pieza de las mujeres estuve unos cuatro días. Las mujeres que estaban allí me comentaron que habían pasado más embarazadas y que tras estar unos días se las habían llevado a Tres Álamos, el campo de prisioneros donde uno era reconocido como preso político.

Efectivamente, a los cinco días nos sacaron en la noche. De allí nos llevaron a Cuatro Álamos, un recinto de Tres Álamos, también a cargo de la DINA, donde estaban los presos en régimen de incomunicación. En Cuatro Álamos tú seguías siendo un preso no reconocido, es decir, seguías desaparecido. La diferencia era que estábamos sin vendas, encerradas en piezas. Allí estuve cuatro días. En la pieza de al lado estaba Laurita Allende, la hermana de Salvador Allende. Lo bueno de Cuatro Álamos era que nos duchábamos, todos los días, era como un regalo en esas circunstancias.

Una mañana nos sacaron de allí a mí, a una compañera y un compañero y nos llevan de vuelta a la Villa Grimaldi. Cuando llegamos nos trasladaron a otro lugar, a la Torre. Me metieron en un cuarto muy reducido donde tenías que agacharte para entrar (una especie de Zulú con una trampilla). Estaba en el tercer nivel. Allí éramos un total de 18 
personas. En mi pieza me topé con otra mujer quién me dijo que mi marido estaba en el segundo piso.

Era una estructura de madera que nos permitía comunicarnos entre nosotros porque las paredes eran muy finas. Había una celda un poquito más amplia donde había un compañero que rogó al guardia que nos cambiara para que yo y mi compañera estuviéramos más cómodas. Ella también estaba embarazada, de un mes, pero no dijo nada. A ella la torturaron mucho, la colgaron, era una mujer grande, maciza, debió ser horrible. Su compañero, el que nos cedió su celda más amplia, desapareció.

Estuvimos en esta celda algo más amplia donde pudimos recostarnos con mayor facilidad para dormir. Después de una semana, una mañana, sentimos mucho ruido y movimiento. Empezaron a nombrar gente por sus números, yo tenía el 944, nunca se me ha olvidado. Nombraron a mis dos compañeros militantes del MIR con los que había hecho el recorrido de vuelta de Cuatro Álamos a Villa Grimaldi. Once de los 18 que estábamos allí se los llevaron fuera de la Torre. Estos once formaron parte de la lista de los 119 detenidos-desaparecidos. Los pudimos reconocer por la lista que apareció en un diario brasileño en el que apareció un titular que decía "Miristas se matan entre ellos por rencillas internas”, fue todo un montaje.

Los que estábamos en la torre se suponía que éramos los condenados a muerte. Recibíamos un trato diferenciado. Éramos los últimos en comer, la comida nos llegaba fría y nos sacaban sólo una vez al baño, o en la mañana muy temprano o tarde en la noche. Pero también esto dependía del guardia que nos tocara puesto que en ocasiones nos tocaba un soldado que nos daba un trato mejor, es decir, comida caliente. Una vez nos llevó al baño para que nos aseáramos y laváramos nuestra ropa interior. Un día apareció un cepillo de dientes que utilizábamos los dieciocho, esto nos pareció una maravilla.

Un día sentí mucho movimiento, como si alguien importante viniera a la Torre. Alcancé a ver a un hombre macizo que se acercó a mi y me preguntó - ¿cuántos meses de embarazo tiene usted?-, -siete-, contesté. Más tarde volvió con más soldados. Intuí que era alguien importante por el trato que los soldados tenían con él, la forma respetuosa con la que los subordinados se dirigían a él. Abrieron nuestra celda y el tipo se dirigió a 
mi compañera (la embarazada de un mes), yo estaba tirada en el suelo y pude verle la cara. Era un hombre de unos cincuenta años. Después supe que era el General Contreras.

Después de esto hubo un hecho sorprendente que me ocurrió. Me sacaron al patio y me sentaron un día entero en una silla al sol para que descansara. Creo que yo recibí un trato especial porque era casada y estaba embarazada. La mayoría de mis compañeras convivían con su pareja sin estar casadas, era muy común, y el trato con ellas fue mucho peor. Aunque no es un hecho generalizable puesto que otras compañeras casadas también recibieron un trato humillante.

Creo que yo tuve la suerte de llegar en un momento a la Villa Grimaldi en el que habían ocurrido ya muchos excesos con las mujeres y las autoridades habían sustituido a la guardia responsable de dichos abusos. Recuerdo que un mes antes de llegar, durante el año nuevo, la guardia se emborrachó y fuero a buscar a las mujeres entre las cuales había dos embarazadas, las desnudaron para violarlas. Se salvaron porque justo llegaba una nueva presa y la violaron a ella. Se "divirtieron" con ella. Esto se supo y hubo medidas y a esta guardia la sacaron. Yo caí en ese estado de cosas y el exceso fue menor, por lo menos conmigo. La compañera que me delató no lo pudo soportar, cuando empezaron a pegarme, que me pasara lo mismo que a ella.

\section{6 ¿Qué significó para usted Villa Grimaldi?}

La Villa fue un centro de tortura, un centro clandestino de exterminio. Mucha gente murió o partió de allí para ser asesinados en otro lugar. Es difícil contar esto sabiendo lo que pasaba allí, sabiendo que tú pasaste por ese horror sin sufrir la tortura por esas circunstancias que me tocaron vivir. Hay gente que me pregunta-entonces, ¿no te pasó nada, no te pusieron corriente, no te violaron?-; pero yo fui testigo de todo eso. Otra cosa fue la tortura psicológica, el terror que pasé por miedo a perder a mi hija, por miedo a desaparecer mientras escuchaba los gritos desde mi celda. 


\section{7 ¿Cómo vivió esa tortura psicológica y el hecho de estar embarazada?}

Por supuesto que fue una tortura psicológica. Estuve encerrada en la torre pensando que me iban a desaparecer, con la incertidumbre de no saber que iba a pasarme.

\section{8 ¿Cómo fue su salida de Villa Grimaldi?}

Después de la torre me encerraron en una celda de hombres. A ellos los sacaron a trabajar y yo me quedé sola encerrada. Estuve dos días encerrada sin ir al baño. Me pusieron después de dos días en una silla al sol durante varias horas. Un guardia me dijo -usted señora creo que se va libre-. Antes de esto, un reconocido torturador, el Troglodita, llegó con una compañera, Gladis Díaz, miembro del Comité Central, a la que había torturado ese mismo día. La detuvieron con su compañero que también sigue desaparecido.

Al día siguiente entró en nuestra celda una mujer que me dijo que el teniente Marcos quería hablar conmigo, el jefe del operativo. Yo reconocí a la mujer entre el hueco de la venda, por su físico, supe que se trataba de una compañera de la Universidad de Concepción. Ella fue una de las mujeres a las que torturaron mucho para pasar, posteriormente, a ser colaboradora de la DINA, funcionaria incluso hasta finales de la dictadura.

Esta mujer entregó a muchos dirigentes del MIR puesto que ella los conocía. Pude notar que ella se inclinaba y susurraba al odio del teniente Marcos quién me pregunto si era familiar de Nelson Gutiérrez, un miembro de la Comisión política del MIR de Concepción. Yo contesté que no era ni familiar ni amiga de él. El era muy conocido en el ámbito universitario de Concepción y, simplemente, dije que le conocía por su popularidad. Mientras esto sucedía empecé a pensar que esta mujer no se iba a detener nunca porque sabía quién era yo.

Finalmente, me llevaron de regreso a la celda con la incertidumbre de que se iba a saber toda la verdad sobre mí. Al día siguiente se llevaron a Gladis para seguir torturándola. Esa misma tarde me subieron a una camioneta y partí de la Villa. Había pasado un mes desde que entré, desde el 3 de Febrero de 1975 hasta el 28 del mismo mes. 


\section{9 ¿Dónde la llevaron?}

Me llevaron a Tres Álamos, donde por fin sería recocida como presa política. Entré en el pabellón de mujeres. Allí me recibió una compañera que también estuvo presa en la Isla Quiriquina. Todas me preguntaban si había visto a sus compañeros o familiares. Fue muy curioso, todas querían saber.

Estuve allí hasta que nació mi hija el siete de Mayo de 1975. Me trasladaron al hospital Soto del Río, curiosamente el mismo hospital donde falleció mi madre. Entré en el parto habiendo perdido mucho peso por mi reclusión. Afortunadamente, mi hija nació sin complicaciones. Estuve rodeada de matronas y todas me preguntaban cómo era la vida en el campo de prisioneros, esto me sirvió de terapia, hablar para distraerme de los dolores.

Mi marido estaba en Tres Álamos, en el pabellón de los hombres, le habían sacado de la Villa tres días antes que a mí. Tuve dificultades en contactar con él. En el hospital estuve algo más de un mes. A mi no me dieron de alta en cierto tiempo porque me hicieron cesárea y los médicos se hicieron responsables de mi. Cuando salí y llegué de nuevo a Tres Álamos me enteré que me había expulsado del país y que tenía que quedarme presa hasta que un país me diera asilo.

10 ¿Creé que las mujeres presas embarazadas tuvieron un trato diferenciado de las otras presas políticas?

Creo que no hubo un trato especial. Lo que me pasó a mí, también les ocurrió a compañeras que no estaban embarazadas, no había una regla, esa era la lógica, era aleatorio.

11 ¿Recuerda algún caso de alguna mujer embarazada detenida en Tres Álamos o Villa Grimaldi que recibiera malos tratos o tortura?

Conozco dos compañeras embarazadas que estuvieron antes que yo en Villa Grimaldi y perdieron a sus bebés antes de nacer. Tuvieron un aborto provocado por los golpes que recibieron. 


\section{2 ¿En qué circunstancias partió al exilio?}

Hasta que un país no nos acogiera no podíamos abandonar Chile. Había un organismo internacional, el CIME (Comité Intergubernamental de Migraciones Europeas) que se encargaba de conseguirnos visa. Finalmente, Francia me dio asilo. Salí el 1 de octubre de 1975, mi hija tenía cinco meses cuando salí de Chile. Viajé con otra compañera del MIR. Nadie nos explicó el proceso de acogida. Yo llevaba conmigo 50 dólares que mis compañeras en un acto de solidaridad recogieron para mi partida.

Yo sólo tenía pasaporte para salir de Chile, no podía volver. En Francia nos recibió una ONG, Francia Tierra de Asilo. Hicimos todas las gestiones administrativas para obtener el régimen de refugiadas políticas. Fuimos a Burdeos puesto que los centros de refugiados de París estaban repletos de exilados.

En el centro nos encontramos con compañeros del MIR y militantes del Partido Socialista. Los voluntarios del centro eran católicos, esa solidaridad cristiana. Yo llevaba bajo el brazo mi título universitario que me acreditaba como asistente social. Yo no hablaba francés, recordaba las lecciones que había recibido en el Liceo pero no hablaba. Me hicieron una entrevista y en un mes recibí un programa de formación en el Instituto de Formación del Trabajador Social. En noviembre del 75 recibí mi equivalencia de mi título.

Tuve que aprender el idioma a marchas forzadas. No sé cómo lo hice. En enero del 76 empecé a trabajar como asistente social.

\section{3 ¿Qué tipo de militancia política realizó desde el exilio?}

Yo trabajaba y militaba al mismo tiempo. Organizaba toda la relación con los militantes en el exilio, la recaudación de dinero, armar las reuniones pertinentes para difundir lo que estaba ocurriendo en Chile. Fue una actividad muy intensa. Había un comité de chilenos y trabajábamos desde allí respetando y conviviendo con la pluralidad de diferentes partidos que se agrupaban en dicho comité. La prioridad era difundir lo que estaba pasando en Chile y el apoyo económico. 
Por otra parte mi marido llegó a Francia en diciembre del 76, hubo una amnistía y cerraron los campos de prisioneros. Juntos, seguimos trabajando en el MIR desde el exilio. Después estuve cinco años en Cuba. Durante todos esos años empezaron a darse muchas discrepancias internas sobre cuál debía ser la vía de actuación prioritaria. Coexistían dos líneas ideológicas dentro del MIR después de las grandes pérdidas de militantes. Habíamos perdido dos Comités Centrales y había que cambiar nuestra forma de actuar.

En este sentido, existían dos opciones, el MIR militar y el MIR político. Yo me quedé en el lado político. Mi marido se salió del MIR, él se fue a Nicaragua y yo decidí que quería volver a Chile con mi hija pero en una situación legal. Desde Cuba no podía hacer ninguna gestión. Por esta razón me fui a Nicaragua, país que todavía mantenía relaciones diplomáticas con Chile.

En Nicaragua la mayoría de los militantes miristas eran de la otra opción pero no tuve ningún problema con ellos. Pudimos convivir. A esas alturas sentí que estaba tocando fondo. No era por la lucha, sino más bien porque yo quería estar en Chile. En el exilio no tuve mayores problemas pero sentía que debía volver a mi país y continuar la lucha política desde allí.

\section{4 ¿Cómo fue su regreso a Santiago?}

Yo regresé a Chile el 31 de diciembre de 1987. Desde Nicaragua me fui a Buenos Aires donde estuve tres meses y de allí partí a Uruguay, en donde fue más fácil conseguir los papeles. Mi hija y mi marido ya estaban en Chile. En febrero del 87 hubo una serie de negociaciones y empezaron a retornar a Chile algunos exiliados. Yo salí en la segunda tanda (lista) de exiliados que podían retornar. Una vez en Chile acudí a todos los organismos de derechos humanos para contar mi situación y lo vivido.

Llegué a Santiago en plena campaña ante el plebiscito. En este momento en el MIR había una situación de mucha inestabilidad y mala convivencia. Estos fueron mis últimos momentos de militancia en el Movimiento de Izquierda Revolucionaria. 
15 ¿Tuvo en este periodo, ante el avistamiento del cambio democrático, una conciencia feminista definida?, ¿sintió algún tipo de discriminación de género en el MIR?

Yo me siento muy orgullosa de lo que fue mi militancia política en el MIR. Me rodeé de gente muy honesta y con gran transparencia, gente con grandes inquietudes culturales. En esos años no tuve una conciencia feminista, ahora la tengo, pero si la hubiera tenido me hubiera ido muy mal. Era vergonzoso, en el MIR si se dio dicha discriminación. Eran tremendamente machistas, espantosamente machistas. Eran muy atrasados en algunos aspectos. Mi conciencia feminista fue tardía.

Quizá empecé a darme cuenta en Francia en donde iba a muchas reuniones del partido en París. Recuerdo una asamblea en dónde se tenía que elegir la dirección del MIR en Francia. Había un grupo de mujeres que empezaron a reivindicar el voto para una mujer para ocupar la directiva del partido. Yo en ese momento no compartí eso. Yo no tenía en ese momento esa conciencia feminista.

16 ¿Creé que las mujeres militantes del MIR sufrieron algún tipo se represión específica por parte de los militares?, ¿habría que hacer un especial reconocimiento a su labor dentro del partido?

Si observas el muro que hay en Villa Grimaldi la mayoría de las victimas son militantes del MIR y del Partido Comunista. Cuando yo estuve en Tres Álamos la mayoría de las mujeres eran militantes del MIR. Las mujeres fueron las que dirigieron, principalmente, esa política de solidaridad y búsqueda de información de nuestros compañeros desaparecidos. Se establecía lazos de solidaridad entre ellas. Ellas construyeron la denominada carreta común, una forma de distribuir los alimentos recibidos en los centros de detención para compartir los alimentos y enseres recibidos por los familiares. Este hecho no se dio de esa manera en los hombres.

En mi estancia en la Quiriquina llegamos a estar un máximo de 47 mujeres. Los hombres con mucha facilidad se deprimían. Mis compañeros de mi empresa lo pasaban muy mal. En cambio las mujeres tenían un estado de ánimo mucho más activo y animoso. 
Quizá entre los hombres existía la preocupación de qué iba a pasar con sus esposas, si iban a poder salir adelante sin ellos. La sociedad estaba pensada así, ellos eran los jefes de hogar, y su gran angustia era pensar cómo iba a sobrevivir su familia. Sin embargo, pudieron sobrevivir, y no sólo eso, sino que les enviaban paquetes de comida a sus maridos presos.

Yo me replanteé muchas veces esta cuestión, es decir, por qué la mujer ante las adversidades mantenían un espíritu animoso y activo. La conclusión es que a los hombres les constaba enormemente deshacerse de la idea de que habían dejado de ser los proveedores. Las mujeres que estábamos allí éramos la minoría, una minoría de mujeres que nos habíamos salido del redil, de ese esquema de la esfera doméstica. Habíamos salido para participar en la política. Eran mujeres que se habían atrevido a salirse de las normas, de la casa, de la familia.

\section{7 ¿El factor sexual fue importante en esta distinción?}

Creo, sinceramente, que la mayoría de mis compañeras fueron violadas o agredidas sexualmente. Yo nunca pude hablar de esto con ellas. Nunca pregunté, me enteré después de amigas mías que años después testimoniaron el horror que vivieron. Con la conciencia que tengo hoy en día, si tú me preguntaras si volvería hacer lo mismo te diría que sí, pero de otra forma. No hubiera dejado sola a mi hija, estando embarazada me arriesgué a la actividad clandestina y soy consciente del riesgo que esto suponía para una mujer embarazada. Arriesgué no sólo mi vida, también la de mi hija. Vivíamos en una vorágine.

Lo único que tengo claro es que lo que hicimos bien o mal lo hicimos honestamente. Lo terrible es que un ser humano lucha para vivir y no para morir. Yo me siento más humana. Yo soy una convencida de estar totalmente en contra de hacer cualquier aberración como la que hicieron con nosotros. Yo no quiero venganza.

Manuel Contreras, exjefe de la DINA, está hoy día en arresto domiciliario. Ha sido procesado y condenado por el caso Letelier, a seis años, una mínima condena en muy buenas condiciones. Sin embargo, ha estado preso. Antes de eso, con una soberbia inusual, él dijo ante los medios de comunicación que él, como general de la República, 
no iba a pasar ni un solo día en la cárcel. Pues estuvo seis años. Asimismo, tiene que aceptar ser careado con la gente que le acusa. Este individuo fue dueño absoluto de nuestras vidas, tenía el poder de desaparecer a quién quiso como jefe máximo.

Hoy día esto ha dejado de ser una realidad y además está obligado a responder en cierta forma a la Justicia. Siento que hemos logrado más de lo que esperaba, no lo que yo quería porque mi sueño es verlo a él y a muchos más en un tribunal que les juzgue, procese y sancione. Y sobre todo, yo quiero saber que pasó con los compañeros. Siento dos cosas cuando me encuentro con los familiares de detenidos desaparecidos, una, que yo podría ser uno de ellos y eso me hace sentir una emoción por estar viva, otra, una profunda tristeza porque siento que el duelo sólo podré hacerlo el día que sepa que pasó con ellos. Sé que no los vamos a encontrar...porque los tiraron al mar. 
4 Entrevista a MARGARITA VALERIA ROMERO MÉNDEZ, realizada el día 13 de enero de 2004, Santiago de Chile. Romero fue militante del Movimiento de Izquierda Revolucionaria durante el período 1970-1981. Estudió medicina en la Universidad de Concepción y estuvo presa en la base naval de Talcahuano durante el mes de febrero de 1974. En 1975 partió al exilo hacia Bélgica donde permaneció hasta 1988, momento en el que regresó a Chile para dedicarse de lleno a la denuncia de las violaciones de los derechos humanos durante la dictadura.

\section{1 ¿Cómo fueron sus inicios en el Movimiento de Izquierda Revolucionaria?}

Yo provenía de una familia de clase media acomodada. Mi padre, fue un padre machista como la mayoría de los padres chilenos. Mi madre, siendo también machista, trató de darme una educación para que pudiera ser independiente. En este sentido, yo tuve ese espíritu en mi ámbito familiar, ese espíritu de que el hombre y la mujer debían ser iguales pese a la concepción tradicional de mi familia.

Yo estudié en la universidad de Concepción, en dónde el MIR dio sus primeros pasos. En un primer momento, no tuve una conciencia política bien definida, sin embargo, al rodearme de un entorno en el que mis propios compañeros militaban y tenían una serie de inquietudes supuso el impulso necesario para integrarme en las filas del MIR. 1969 fue un año de integración en el ambiente mirista, es decir, un año de prueba, de rodaje. En 1970 pasé definitivamente a la militancia política.

\section{2 ¿Cómo reaccionó su familia ante sus actividades políticas?}

Yo nunca le dije a mi padre que era militante del MIR, pero él sabía que tenía compromiso político, pero no me impuso nada. Él era un comerciante y un hombre de derechas de corte filo-democratacristiano, de una familia católica. Es decir, yo no crecí en un ambiente de izquierdas, sin embargo, no me reprocharon que yo tuviera una militancia política. Cuando me detuvieron, ellos se movilizaron para sacarme y hacer todo lo posible por recuperarme. Lo mismo hicieron con mi hermana, quién estuvo detenida en Villa Grimaldi.

3 ¿Sufrió algún tipo de discriminación a la hora de acceder a los puestos de responsabilidad del MIR o al asumir tareas de mayor compromiso? 
No. Yo me sentía muy libre en lo que hacía. Milité con hombres y siempre tuve la sensación de tener una relación de igual a igual. Pero esto fue con militantes de base. Esto no ocurrió con los dirigentes masculinos del MIR. Tenía esa sensación de que hablaban de ti como la mujer chiquitina, la compañera que había que proteger.

Quizá antes del golpe sí noté algún tipo de discriminación, pero era más bien una cuestión de antigüedad en el partido para asumir responsabilidades mayores. Con el advenimiento del golpe se estableció un ritmo vertiginoso de los acontecimientos, es decir, te caían las responsabilidades encima y nadie te venía a decir que no hicieras esto por el hecho de ser mujer.

Sin embargo, lo cierto es que en el MIR no hubo mucha militancia política femenina. Eran los hombres quienes teorizaban o tomaban las decisiones más fundamentales. Quizá, en este sentido, los hombres monopolizaban las iniciativas y el conocimiento partidario al igual que los cargos de dirección. De todas formas, creo que vivimos en un ambiente que no estaba excesivamente contaminado por el machismo nacional.

\section{4 ¿En qué circunstancias cayó detenida?}

En ese período yo estaba trabajando en una unidad de organización del MIR cuyo objetivo era la conexión con los diferentes compañeros y dirigentes que habían caído presos o que estaban siendo buscados. En la semana de mi detención muchos compañeros habían caído. Yo estuve recorriendo las comunas y los pueblos de alrededor para desconectar a la gente, para advertirles del peligro que corrían, es decir, evitar un efecto dominó para que no cayera toda la estructura que operaba en Concepción.

En uno de esos días, llegué a mi casa y me encontré con más de diez agentes vestidos de civil distribuidos por las tres plantas del edificio. Tenían metralletas y me obligaron violentamente a abandonar mi casa. Yo les pedí que me mostraran la orden de detención pero obviamente hicieron caso omiso a mi exigencia. Me metieron en un auto en donde me vendaron y amarraron. 
Primeramente, me llevaron a un lugar entre Concepción y Talcahuano (esto lo supe después), una especie de recinto en dónde pude avistar que había un gran número de detenidos. En ese momento, sentí mucho miedo porque sabía lo que les había ocurrido a algunos compañeros detenidos, sabía que los habían torturado y que mis captores conocían mi militancia en el MIR porque encontraron diversa documentación en mi domicilio.

Es una sensación de soledad, de incertidumbre. Estaba sola y no tenía a quién recurrir. Sólo contaba con mis recursos para enfrentarte al interrogatorio, es decir, lo que tienes que decir y lo que no puedes decir bajo ninguna circunstancia. Esta era la consigna del partido y en ese momento tenía que aplicarla en absoluta soledad.

Yo sabía que estaba a la merced de gente que podía hacer lo que quisiera contigo, tanto físicamente como psicológicamente. Sabía que no iba a ver ningún tipo de misericordia, y esto había que afrontarlo.

La segunda terrible impresión fue que me dejaron amarrada, sentada y vendada en una silla. Yo sentía que a mi alrededor sólo había vacío. Sin embargo, empecé a escuchar voces y pude oír que había una mujer que parecía estar entre los agentes. Ahí me sentí totalmente desconcertada, no podía concebir que hubiera una mujer que pudiera ser torturadora y guardiana nuestra. Fue un sentimiento de incredulidad. Yo, sin tener una conciencia feminista en ese momento, no podía imaginarme a una mujer torturando (era agente de la DINA).

Ella me pegó en los oídos cuando estaba amarrada. Cuando te golpean en los oídos te quedas en un estado de atontamiento total. Pegarme en los oídos al mismo tiempo me hizo sentirme todavía más perdida de lo que estaba, perdí el equilibrio y la capacidad auditiva durante un tiempo.

\section{5 ¿Cómo llegó a la base naval de Talcahuano?}

Tras estar unas horas en este lugar nos sacaron a mí y a otro grupo de prisioneros para llevarnos a la base naval de Talcahuano. Cuando yo llegué había más de cien detenidos, estaban en un gimnasio que habían habilitado como centro de detención y reclusión. 


\section{6 ¿Hubo una política diferenciada con las mujeres detenidas?}

No. Es posible que en algún sector de la base sí ocurriera esto, pero yo estuve sentada en los graderíos del gimnasio junto a otros prisioneros. Pude notarlo por las voces porque yo no veía nada porque estaba vendada. De allí nos llevaban a los interrogatorios. Teníamos números y cuando nos llamaban tenías que levantarte, si no lo hacías te llevaban bruscamente a una sala donde no sólo te interrogaban, eran piezas habilitadas para la tortura.

Sin embargo, ser mujer tenía una complicación extra, es decir, en la medida en que la política estaba enfocada al abuso sexual. De partida te hacían desvestirte quedándote en un estado de indefensión total. Yo no creo que haya ninguna mujer detenida que no la haya sido desvestida ni manoseada. Eso de partida, después recibías todo tipo de insultos machistas, destinados a humillarte por tu físico o cualquier defecto que tuvieras. Te manoseaban.

Esto fue un proceso generalizado para todas nosotras. Fue una forma específica de torturar a la mujer física y psicológicamente. La violencia sexual era constante. Después seguían con los golpes y las cargas de electricidad en tus zonas más sensibles, en tus genitales. También los colgamientos eran frecuentes.

7 Una compañera suya comentó que había sentido que por el hecho de ser una mujer casada había recibido un trato diferencial mejor que otras compañeras que mantenían relaciones sentimentales con sus respectivas parejas, es decir, ¿ser “esposa de" suponía un estatus por el cuál una se podía librar de estas vejaciones?

Yo creo que sí. Eso es cierto. Esto tiene que ver con la cultura propiamente chilena, es decir, el hecho de que fueras una mujer casada te colocaba en ese status de "señora". Esto te daba algo más de respeto que aquellas mujeres solteras que anduvieran militando.

Además, hubo otro factor importante, esto es, tu procedencia sociocultural y económica. Yo tuve la ventaja de que en ese momento era estudiante de medicina y provenía de una familia tradicional y católica, era casi doctora. Esto significaba un mayor respeto, 
especialmente un respeto que no recibían por ejemplo las mujeres pobladoras de procedencia social más humilde. Lo que me salvó a mi de muchas cosas, concretamente de la violación, fue mi situación de clase media acomodada, estudiante universitaria de una carrera con cierto prestigio.

\section{Es decir, ¿se establecieron pautas de clasismo a la hora de tratar a las prisioneras políticas?}

Claro. Fue un clasismo absoluto. Una mujer rural, pobladora o mapuche recibía un trato mucho más duro. La mayoría de ellas eran violadas sistemáticamente sin ningún tipo de cortapisa. A nosotras no nos violaron, aunque si nos violentaron sexualmente en la medida que te manoseaban o humillaban por tu anatomía, además de ponerte electricidad en tus zonas más íntimas. Pero el trato más vejatorio la recibieron aquellas mujeres de procedencia social más baja. Sin embargo, esto no ocurrió en las casas de reclusión de la DINA puesto que allí, normalmente, no se hacía distinción alguna a la hora de torturarte. Eran más pautas aleatorias sin ningún tipo de esquema previo.

En este sentido, el hecho de quién te detuviera marcaba estas diferencias. En la base naval de Talcahuano existía una oficialidad con prácticas y valores diferentes a los agentes de la DINA. El Servicio de Inteligencia Regional estaba conformado por militares marinos, carabineros e investigaciones. Pero esa oficialidad de la marina dio un toque de clase y control con las prácticas destinadas a los presos. Aunque fueran muy duras también.

\section{0 ¿Cómo definiría la tortura psicológica a la hora de amedrentar a las presas?}

Ellos insistían en tu familia, te preguntaban con quién vivías, para encontrarles y detenerles. El objetivo era que tú entregaras a la gente que te rodeaba porque daban por hecho de que estaban dentro de la esfera política a la que pertenecías. Utilizaban mucho las relaciones sentimentales que tuvieras con tu pareja, y en ese sentido te presionaban.

\section{1 ¿En qué circuntancias salió de la base naval de Talcahuano?}


Yo salí en libertad condicional después de haber estado incomunicada y desaparecida durante dos meses. Pero a mis compañeras y a mi nos liberaron con la llegada del verano para que pudiéramos reintegrarnos en nuestros estudios universitarios.

Sin embargo, tras unas semanas en libertad condicional (tenía que firmar todos los días) un compañero me dio un recado: tenía que salir de Concepción inmediatamente porque la DINA me andaba buscando. Esto era consecuencia de una política de recuperación de algunos presos que habían sido liberados y que la DINA quería volver a interrogarlos. De hecho, algunos compañeros fueron detenidos y hoy siguen desaparecidos.

Con esta situación decidí marcharme a Santiago. Allí, en la clandestinidad, busqué un lugar donde refugiarme durante unos meses. En Santiago, entré en contacto con un obispo luterano que creó el Comité Pro-Paz en Chile. Ellos me ayudaron a asilarme en la embajada del Vaticano. En este momento, es decir, en 1975, las embajadas estaban resguardadas por los militares. Era muy difícil entrar. Yo y una compañera (Margarita Iglesias) tuvimos que saltar una verja de un edificio contiguo a la embajada. Esto supuso mi liberación definitiva.

\section{2 ¿Cómo fue el proceso de exilio?}

A mí me consiguieron una visa para ir a Bélgica. Mi familia pudo enviarme la documentación necesaria para poder adaptarme a esta nueva situación, es decir, documentación académica, etc. Fue un proceso muy difícil porque la DINA solía esperar a los exiliados en el aeropuerto, podían agarrarte en cualquier momento. Cuando llegué a Bélgica estaba completamente sola.

\section{3 ¿Cuál fue su prioridad una vez que llegó al país de acogida?}

La prioridad era denunciar lo que estaba pasando en Chile y ponerme en contacto con mis compañeros. El mundo tenía que conocer el horror que se estaba viviendo en el país. Ya no sólo la cuestión de los detenidos desaparecidos sino también la misma situación del pueblo chileno que vivía en una cárcel en dónde una no sabía si alguien iba a hablar mal de ti y te iban a denunciar. Este clima fue una política de la dictadura, es 
decir, que el conjunto de la población sitiera un miedo atroz. Fue un momento de dura represión y oscurantismo cultural. Chile en ese período retrocedió medio siglo.

Yo tenía una experiencia de militancia en pro de los derechos de la mujer que desarrollé en Bélgica. Allí trabajé con asociaciones de mujeres en pro de los derechos reproductivos, el aborto, o en centros de planificación familiar.

\section{4 ¿Cómo fue su regreso a Chile?}

A mi regreso, en marzo del 88, yo no reconocí nada. Cuando yo me fui todavía existían unos lazos de solidaridad en la sociedad chilena. A mi regreso sentí que eso había sido aplastado.

El objetivo en ese momento era derrocar a la dictadura y recuperar todo lo perdido. Yo volví precisamente por esta razón. Por la necesidad de denunciar lo que nos había ocurrido, no sólo a mí y a mi marido, sino al conjunto de mis compañeros.

Asimismo, me integré en asociaciones de derechos humanos y a todas aquellas actividades pro-democráticas. Además, estaba el tema de convencer a la gente de que debían votar. Como médico, entre a formar parte de un departamento del colegio médico que estaba trabajando por los derechos humanos; se llamaba Comisión de Solidaridad con los médicos víctimas de la represión. Estuve trabajando mucho tiempo con ellos. Llegamos a publicar un libro-homenaje a los médicos asesinados durante la Junta. Finalmente, realizamos una labor de ayuda a los médicos retornados del exilio.

\section{5 ¿Qué legado dejó la Junta militar respecto a la situación de la mujer tras diecisiete años gobernando?}

Ninguno. El desarrollo económico y las políticas de la dictadura no favorecieron en absoluto el acceso de la mujer al ámbito público. Esto fue más bien un trabajo realizado por las propias mujeres que empezaron a tener mayores posibilidades a partir del año 90. Fueron organizaciones de mujeres que trabajaron en la oposición bajo lazos de solidaridad con objetivos claros, es decir, desde la recuperación de la memoria, búsqueda de familiares detenidos desaparecidos o exigencias de una democratización 
del país. En definitiva, las mujeres tuvieron un papel muy importante en la oposición ideológica a la Dictadura en un momento en el que el país estaba totalmente dividido.

Los avances con respecto a la situación de la mujer se han dado en los últimos años, especialmente en el ámbito público y político. Sin embargo, la mentalidad del chileno en el ámbito laboral es muy difícil de cambiar. Quizá la esperanza de ese cambio esté en las nuevas generaciones de chilenos.

16 Hoy en día, tras el paso de los años, ¿cuál es su visión sobre cómo afectó la represión a la mujer? ¿Podríamos establecer una especificidad en este sentido?

El conjunto de los agentes que estaban integrados en el aparato represivo de la Junta les costó mucho asumir que hubiese mujeres que pensaran políticamente por sí mismas. Esto influyó mucho a la hora de rebajar a las mujeres detenidas, es decir, a la hora de torturarlas o de violentarlas sexualmente. La mentalidad era muy clara, nos decían que nos pusiéramos en el lugar que nos correspondía (esfera doméstica), que la política no era para las mujeres.

De todas formas, en mi caso fue algo diferente puesto que fue mi profesión y mi procedencia socioeconómica la que me salvó de otras agresiones mayores. Si yo hubiera sido una pobladora o mujer rural probablemente me hubiera acarreado otro tipo de represión (violación sexual).

Sin embargo, todas las mujeres con las que he podido conversar a lo largo de estos años fueron maltratadas por el hecho de tener una militancia política, dado que ese rol no estaba destinado a la mujer, y esto fue un elemento clave a la hora de torturar a dichas mujeres.

17 ¿Podemos alegar que la tortura sexual fue una pauta constante en las prácticas represoras de la dictadura?

Todas las mujeres que conozco fueron violentadas sexualmente. Era casi un ritual, una forma de comenzar el interrogatorio. Generalmente, si tú estudias los testimonios de aquellos hombres que han sobrevivido a la represión política y la tortura podrás ver que 
en la mayoría de los casos los interrogatorios comenzaban con golpes o insultos. Con las mujeres, el interrogatorio comenzaba con desvestirlas y manosearlas sexualmente. Aquí se establece una diferenciación de partida muy importante puesto que, desde mi punto de vista, creo que fue un proceso generalizado que viví y vivieron todas mis compañeras.

18 ¿Se ha visualizado lo suficiente la aportación y las represión sufrida por el conjunto de mujeres que tuvieron algún tipo de militancia política en la oposición?

No. De hecho hoy en día podemos ver mucha discriminación lo que refleja la falta de equidad a la hora de tratar y reconocer el trabajo de la mujer. Hay discriminación laboral (las mujeres perciben un salario menor $-40 \%$, desempeñando la misma función que los hombres), hay discriminación jurídica, en los derechos reproductivos, etc. Esto es una realidad que esconde una falta de reconocimiento del papel que la mujer ha tenido en la sociedad chilena. Las mujeres todavía tienen que luchar y trabajar enormemente para reivindicar sus derechos. Yo tengo muchas esperanzas en las nuevas generaciones de jóvenes, puesto que creo que tienen otra visión de las cosas.

A nivel de reconocimiento de la aportación de las mujeres en los movimientos políticos, especialmente en el MIR, no existe ningún tipo de trabajo al respecto. De hecho, ahora se está empezando a trabajar sobre el MIR y su historia, pero hasta hace bien poco no existía nada al respecto. Se está trabajando con la recuperación de la memoria. Debería hacerse un reconocimiento global del conjunto de los militantes, sin discriminar a la mujer. Es cierto que en la historia del MIR han debido existir algunas discriminaciones genéricas a la hora de acceder a los puestos de dirección. Sin embargo, la teoría del MIR parte por reconocer a todos sus militantes por igual.

Finalmente, debería hacerse un reconocimiento global de todo el conjunto de mujeres que militó en los diferentes partidos del disentimiento político, porque, efectivamente, la mujer jugó un papel fundamental, especialmente en la denuncia de los derechos humanos y en la recuperación de la memoria y el paradero de sus familiares detenidos desaparecidos. 
5 Entrevista a MARIA ALICIA SALINAS FARFÁN, realizada el 16 de enero de 2004, Santiago de Chile. Salinas fue militante del Movimiento de Izquierda Revolucionaria durante el período 1970-1990. Estuvo recluida en el centro Villa Grimaldi durante el mes de enero de 1975.

\section{1 ¿Cómo fueron sus inicios en el Movimiento de Izquierda Revolucionaria?}

Yo provengo de una familia políticamente militante de izquierdas. Mi padre fue dirigente nacional de la CUP y mi madre fue la primera mujer que estuvo en el Comité Central de las Juventudes Comunistas.

Mis primeros pasos fueron a nivel estudiantil. Fui dirigente en el Liceo en dónde estudié. Me relacionaba mucho con jóvenes de izquierdas por la militancia de mi padre. Empecé a militar en los denominados grupos de choque, en dónde participábamos en las manifestaciones, tirábamos cócteles molotov, etc.

En 1967 comencé a leer y formarme. Esto me ayudó a formarme una conciencia más seria a la hora de participar en la lucha política. Desde la Federación de Estudiantes de Secundaria empecé a participar de forma más constante. Toda esta actividad me preparó a nivel ideológico para mi posterior militancia en el MIR.

En aquel tiempo yo era bastante agitadora, quizá porque tenía ciertas facilidades de comunicación. Yo comencé mi actividad política con un grupo de seis compañeras de las que tres aún siguen desaparecidas.

\section{2 ¿Cómo entró en el MIR?}

Yo entré en el MIR en el año 68, concretamente en la Brigada de Secundaria. Desde allí nosotras hacíamos un trabajo a nivel de Liceo y formación política. A partir de aquí me propusieron integrarme en de forma completa en el partido. Entre los años 1969-1970 me tocó participar en tomas de terrenos junto con el movimiento poblador.

Todo este compromiso empezó a crearme ciertas dificultades en mi familia. Si bien mis padres eran políticamente activos, en mi casa yo era la única mujer. Mi compromiso no 
gustaba nada a mi padre. En este sentido, siempre sentí como mujer una cierta discriminación, porque creo que no era usual que una mujer en aquel tiempo tuviera una militancia tan activa. Lo común era que las mujeres de mi edad se dedicaran a otras cosas. Esto, sin lugar a dudas, fue una gran dificultad para mí.

Tras terminar el Liceo comencé a estudiar Pedagogía lo que supuso tener que combinar el estudio con la militancia política. En este momento (1971) colaboré con el Movimiento Campesino Revolucionario (MCR) con el tema de los terrenos y la alfabetización. Asimismo, estuve trabajando en los Talleres del MIR, en dónde fabricamos explosivos. Allí aprendí un trabajo de precisión. Recuerdo que era la única mujer en estos talleres.

A finales de 1972 me mandaron a trabajar Rancagua (VI Región) para fortalecer el trabajo partidario. La idea era abrir un frente de trabajo en la zona porque faltaba organización del campesinado. Logramos formar un grupo importante, el Comando Comunal, donde participaban los sindicatos, estudiantes y pobladores. También participamos en el Cordón industrial de Rancagua, fue una actividad muy intensa para mí en la lucha obrera y ser consciente de cuáles eran sus urgencias y demandas.

En 1973 comencé a trabajar en el sector de comunicaciones del MIR. Este trabajo consistía básicamente en la distribución de información a los militantes. Teníamos centrales telefónicas para desarrollar con más fluidez las redes del partido. Todo esto tenía que compaginarlo con mis estudios y en ocasiones no resultaba nada fácil.

\section{3 ¿Sintió algún tipo de discriminación de género a la hora de desempeñar las funciones asignadas en la militancia mirista?}

En relación a la cuestión de género creo que las mujeres, que militábamos por aquel entonces, teníamos una mayor disciplina y disposición para asumir la tarea que se nos asignara. Para los hombres quizá era más sencillo hacer carrera en el MIR. Mis prioridades no eran tanto llegar a ser dirigente del partido sino más bien el trabajo de base, es decir, en tareas cerradas porque es lo que mejor hacía. 
Sin embargo, quiero destacar que en este tiempo yo no tenía una conciencia feminista definida, el tema de género no causaba problemas. Quizá era un tema de procedencia social, de clase, lo que marcaba las diferencias en el MIR.

\section{4 ¿En qué situación estuvo el 11 de septiembre de 1973?}

El 11 yo estaba trabajando todavía en comunicaciones. Por la mañana me mandaron al Cordón San Joaquín para asistir a una reunión de los partidos de izquierda. Por el golpe la reunión se postergó a la tarde para luego volverse a suspender. Ese día me junté con mis compañeros y compañeras para hablar con los militantes socialistas. Ellos nos comentaron que iban a traer las armas para organizar la resistencia y que nos iban a facilitar a nosotros armamento. Sin embargo, finalmente no pudimos contar con su apoyo puesto que la mayoría de las fábricas estaban tomadas con lo que la movilización era muy complicada.

Ante esta situación nosotras decidimos apoyar a los obreros y quedarnos con ellos pese a que las fábricas estuvieran tomadas. Comunistas y Socialistas se replegaron y tan sólo algunos miristas nos quedamos. El objetivo era sacar de las fábricas que aún no estaban tomadas todo el material comprometedor y necesario para militar, es decir, máquinas de escribir, mimeógrafos, etc. Los militares fueron allanando paulatinamente las fábricas, esto nos daba un margen de tiempo para irnos replegarnos conforme los milicos avanzaran.

\section{5 ¿Cuáles fueron las consignas del MIR en los primeros días del golpe?}

Ninguna. No recibimos ningún tipo de comunicación. Todo quedó suspendido. Durante los primeros días los acontecimientos se desataron con gran rapidez. Nosotras acabamos en la fábrica Valdiviana (17 de Septiembre), era cómo el último reducto que faltaba por tomar, pero finalmente también cayó. En este momento, tuvimos que huir hacia la Panamericana y desde allí nos replegamos a nuestras casas para esperar a que se normalizara la situación.

\section{6 ¿Cómo caíste presa?}


Estuve un tiempo viviendo en la casa de mis padres para después mudarme con mis compañeros a otro lugar clandestino. Desde allí seguí militando en el MIR, contactando con gente y con tareas asignadas. En estas condiciones estuve más de un año. En 1974 comenzaron a buscarme a mí y a otros compañeros que trabajaban conmigo. Finalmente, me detuvieron el 2 de enero de 1975.

El día de mi detención yo tenía que acudir a un punto, esto es, un enlace como parte de mi trabajo de comunicación en la Fuerza (aparato militar del MIR). Antes había caído mi compañero con quién vivía, Felipe, que era jefe de la Fuerza y uno de los militantes más buscados por la DINA. El día en qué yo caí llevaba conmigo documentación de lugares de encuentro y listas de nombres de compañeros. Esta información tenía que pasarla a un compañero. El problema es que ese día no di el rodeo de seguridad que solíamos dar en los encuentros clandestinos para asegurarnos de que no nos esperaban. Cuando me di cuenta de que me estaban esperando fue demasiado tarde.

Me tomaron bruscamente llamándome por mi nombre. Sabían quién era yo. Me metieron en una camioneta en dónde me topé con un compañero que estaba en pésimas condiciones. Me amarraron y me taparon los ojos con un scotch. Durante el viaje te pegaban mientras te preguntaban tu nombre y a qué te dedicabas. Aturdida, no sabía a dónde me llevaban. Sólo pude notar un camino de tierra.

Nos bajaron en un lugar. Allí nos recibió el jefe de la DINA, el general Marcelo Moren Brito. A patada limpia, me trasladaron a una salita de tortura. Yo no tenía idea de dónde estaba, me llamó especialmente la atención el portón de la entrada. Efectivamente, era Villa Grimaldi, pero en aquél momento desconocía totalmente mi paradero.

A mi me llevaron directamente a la sala de tortura, después de quitarme mis pertenencias. Allí, Moren Brito, me hizo desvestirme. De hecho el me dijo - “desnúdate porque te vamos a violar". Me amarraron a una parrilla sin ropa, amarrada y con un casco con electrodos que te ponían en la frete, en la nariz, en la boca, en tus zonas íntimas, etc. Esta tortura la acompañaban con la introducción de objetos en los conductos vaginales y anales...qué más te puedo decir sobre esto... 


\section{7 ¿Creé usted que se establecieron pautas de castigo específicas con las presas políticas?}

Sí. Ellos te trataban como prostitutas. Te preguntaban cuestiones sobre tu vida privada cómo “-¿Con cuantos te has acostado?” mezclándolas con preguntas más serias sobre tu militancia o tus compañeros. ¡Qué importancia tenía tu vida sentimental o sexual con tus actividades políticas!. Asimismo, cuándo te desnudaban para torturarte solían hacer comentarios sexistas cómo - "esta es nadadora, nada por delante y nada por detrás".

Ellos de alguna manera tenían que violentarte sexualmente. Por ejemplo, en la Venda Sexy había perros, yo tengo varias compañeras a las que violaron con perros. Sin embargo, en Villa Grimaldi utilizaban otros métodos cómo meterte en la vagina unas llaves con corriente, etc. Otro ejemplo lo encontramos en los hechos ocurridos en el fin de año de 1974, en dónde violaron a dos mujeres que estaban embarazadas.

Es importante alegar que en nosotras crecimos en una sociedad terriblemente machista. Las mujeres militantes teníamos que transgredir muchas normas arraigadas en la sociedad chilena. En otras palabras, nosotras éramos una generación transgresora, muy pocas de nosotras se casaron, es decir, convivíamos con nuestras parejas y esto, sin duda, era una trasgresión en toda regla.

Por otro lado la autoridad patriarcal en este país era incuestionable. Qué las mujeres militaran en política, que fueran marxistas y que anduvieran con armas era demasiado para los militares. Estas cosas se suponían que formaban parte del campo masculino. Los torturadores pensaban realmente que nosotras éramos diabólicas porque se suponía que las mujeres eran las transmisoras de los valores de la sociedad.

Éramos mujeres contranatura. Y esto explica el nivel de ensañamiento que hubo contra la mujer militante, en términos de disminuirla como persona, cómo ser humano. Nosotras tuvimos que ganarnos un espacio que tradicionalmente había estado vetado para las mujeres, y que sólo ganamos con la política de retorno. Los militares tenían que castigar esta cuestión, es decir, esta trayectoria. Simplemente, el hecho de desnudarte y tocarte era un síntoma de este objetivo de anularnos. 


\section{8 ¿Qué importancia tuvo la procedencia socioeconómica de las mujeres militantes a la hora de recibir un trato distinto?}

Bueno, esto es una cuestión bastante compleja. Tenemos casos diferentes, como el de Gladis Díaz, una mujer profesional e importante con familia acomodada (de carabineros) y ella fue igualmente torturada. Quizá en el trato verbal si se establecieron pautas diferenciadas. Los torturadores eran muy clasistas y a la hora de conversar con ellas era diferente que conversar con una mujer de clase baja. Efectivamente, hubo una diferencia de clase en el trato, no en la tortura.

Tenemos el caso del torturador Romo, es decir, él sólo se relacionaba o conversaba con la gente del Comité Central del MIR. En otras palabras, ellos se "entendían" con los dirigentes, aunque también les torturasen. Esto, claramente, es un reflejo del clasismo profundo que existía en Chile.

Otro ejemplo lo tenemos en el caso de una hija presa en Villa Grimaldi e hija de un almirante de la Marina, la María, que hoy está desaparecida. El Romo iba todos los días a la María Isabel, - “hoy día estuve con tu papá en el Ministerio de Defensa pero todavía no hemos puesto el recurso de amparo"-.

\section{9 ¿Podemos decir que la tortura sexual fue una carga extra en los procesos de} reclusión de las mujeres militantes de la oposición?

Yo creo que si. Mira, los torturadores decían que las mujeres aguantaban más la tortura que los hombres. Tenemos un doble juego, por un lado, el afán de disminuir a las mujeres como seres pensantes, y por otro, la idea de que las mujeres tenían una fortaleza extra a la hora de aguantar o resistir una situación adversa.

En términos ideológicos había una elaboración de descategorizar a estas mujeres como tales, esto es, puesto que se trataba de jóvenes mujeres que fueron a la universidad, independientemente del sector social del que provinieran, que tenían una participación activa en la política, que andaban incluso con armas...todo esto violentaban enormemente a los militares porque rompía con la concepción tradicional que ellos destinaban al papel de la mujer en la sociedad chilena. 
10 ¿Qué papel tuvo la amenaza psicológica y el uso de la mujer en los procesos de tortura para la obtención de información?

Esto fue una práctica generalizada pero utilizada tanto con las mujeres como con los hombres. Además, por lo general, las presas políticas en su mayoría todavía no eran madres, hubo algunos casos de mujeres embarazadas o mujeres con hijos, pero el grueso de las presas eran mujeres jóvenes sin hijos.

En Villa Grimaldi hubo casos de mujeres embarazadas que recibieron el mismo trato que el resto. En general, no hubo un trato especial con ellas de respeto o condescendencia.

\section{La represión de la mujer bajo la dictadura ¿es un tema que todavía está pendiente} en los estudios sobre las violaciones de Derechos Humanos en este país?

Sólo con la política de retorno se empezó a estudiar el tema de represión y el género. Creo que en el retorno empezó a incluirse el tema específico en la represión y en la militancia política. En mi caso, sólo cuando regresé a Chile comencé a pensar y concienciarme sobre mi posición como mujer en el MIR, y en cómo mi militancia había cambiado mi vida. Yo acepté retornar a Chile con mi hijo, pero un compañero de la dirección del MIR habló con mi pareja sobre el papel que yo debía desempeñar a nivel partidario en mi regreso del exilio.

En otras palabras, decidieron por mí sin preguntarme cuales eran mis proyectos o mis prioridades en Chile. Esto es una muestra de cómo las militantes, de alguna forma, estaban en un segundo plano a la hora de decidir las condiciones y el trabajo partidario en el retorno. Yo no quería sentirme como "mujer de", sino como una militante más del partido, y esto no lo permití bajo ninguna circunstancia.

12 En teoría, el MIR establecía el principio de equidad con todos sus militantes, independientemente de su sexo, ¿esto se dio también en la práctica?

En la práctica no. Claro que hubo discriminación. Quizá fue una mezcla ya no tan sólo por ser mujer sino que entraban en juego otros factores como tu juventud, o tu 
procedencia social. Pero todas estas cuestiones empecé a verlas muchos años después, cuando volví del exilio.

\section{3 ¿Qué opinión te merece la presencia de mujeres en el aparato represor?}

Ellas no tenían ningún poder de decisión en el aparato. En Tres Álamos quizá las mujeres fueron especialmente duras en el tratamiento a las presas políticas. En este sentido, ellas tenían un trato muy negativo con nosotras, nos limitaban muchas actividades, visitas, etc. Creo que estas mujeres nos veían a nosotras como un poco más culpables, es decir, había más permisividad con ciertas actitudes con los hombres que con las mujeres presas. En este país, un hombre podía tener varias relaciones con mujeres, pero una mujer no, esto era profundamente trasgresor y negativo a los ojos de las mujeres integrantes del aparato represor. Quizá nosotras éramos la antitesis de lo que para ellas debía ser una mujer.

Podríamos decir, efectivamente, que esto fue un elemento más de esa reproducción del sistema patriarcal en los centros de reclusión. Ciertamente, no sé si este hecho fue algo consciente o inconsciente pero igualmente se dio. El problema de fondo creo que fue el temor que producía que una mujer en aquella época pensara (políticamente) y que cuestionara el sistema de dominación patriarcal.

\section{4 ¿Qué tareas partidarias desempeñó en el exilio?}

Nosotras nos exiliamos en Suecia. Desde allí realizamos varias actividades para denunciar lo que estaba ocurriendo en Chile como giras por la televisión, entrevistas, etc. Éramos las primeras presas políticas que salíamos de las casas de tortura. Durante los dos primeros años de exilio, nos centramos, fundamentalmente, en el tema de la denuncia; fuimos a Ginebra, hicimos informes para diferentes foros, querellas, etc.

15 ¿Cuál ha sido el papel de la mujer en la recuperación de la memoria histórica de Chile?

La mujer ha jugado un papel importantísimo en la memoria y en la denuncia. La memoria del hombre está basada en todas aquellas cuestiones práctico-políticas, es 
decir, de documentación y análisis de hechos históricos concretos. Sin embargo, la mujer ha tenido más capacidad para buscar otros aspectos de la memoria; quizá más emocionales o afectivos.

Un ejemplo de esto lo encontramos con la división del MIR en 1987. En este momento, la mujer militante jugó un papel fundamental en términos de tratar de recuperar la política del MIR. El partido había entrado en un proceso de moderación con vistas, incluso, de integrarse en el gobierno de la Concertación. En este proceso, la mayoría de las mujeres miristas trataron de ganar espacios en los debates sobre cuál debía ser el rumbo del partido ante el avistamiento del plebiscito y el cambio democrático.

La mayoría de mis compañeras apostaban por no perder la esencia tradicional del partido, es decir, su carácter revolucionario. Aquí es donde entra en juego es perspectiva específica, esto es, no perder la esencia del MIR, su tradición y su lucha sin entrar en debates puramente ideológico-estratégicos de cómo debía adaptarse el partido ante la nueva situación que se avecinaba.

A mediados de la década de los ochenta, las mujeres estaban ganando importantes espacios, proceso que se vio interrumpido en cierta forma al ser desplazadas por los hombres a la hora de debatir sobre las cuestiones fundamentales del partido. Hubo una disminución de lo que la mujer tenía que decir acerca del futuro del MIR. Hay algunas compañeras que no piensan así, que creen que dentro del MIR se dieron las mismas posibilidades para hombres y mujeres. Sin embargo, yo creo que esto no fue así.

\section{7 ¿Qué consecuencias ha tenido los diecisiete años de gobierno militar en la situación general de la mujer chilena?}

Este es un tema en el que he pensado mucho. Creo que es necesario hacer una revisión que arranca en la década de los sesenta, puesto que, es a partir de ese momento cuando la mujer empieza a ganar mayores niveles de participación, de acceso a la educación, al proceso productivo, etc. Sin duda, hubo un gran avance de la mujer que culminará en 1973 con la llegada del golpe. 
La Junta militar trató de cortar de raíz con este proceso de cambio, es decir, colocar a la mujer en la posición más tradicional. Podríamos hablar de una minimización de la mujer. El hombre siempre fue proveedor de la casa y, en este sentido, los cambios que se venían produciendo en los años anteriores al golpe entraban en completa contradicción con esta concepción.

Durante el gobierno militar, la mujer tuvo que asumir en ciertos momentos el papel de proveedora (especialmente asumiendo subempleos), puesto que sus maridos estaban cesantes. Esto no era lo que quería la Junta, pero inevitablemente se dio un fenómeno que ponía en entredicho ese papel asignado a la mujer que la relegaba al ámbito doméstico. La actitud de muchos hombres que estaban desempleados fue sentir que habían perdido todo, que habían perdido su papel de proveedores.

Con todo esto, podemos decir que el hombre en cierta forma quedó paralizado con la represión juntista. Por el contrario, la mujer vivió una reactivación importante para sobrevivir. Sin embargo, esto no fue un avance, porque la mujer no se activó en beneficio propio, sino por una cuestión de sobrevivencia. 
6 Entrevista a LUCRECIA BRITO VÁSQUEZ, realizada el miércoles 21 de enero de 2004, Santiago de Chile. Lucrecia Brito fue militante del Movimiento de Izquierda Revolucionaria durante el período 1970-1988. Estuvo presa en el centro Villa Grimaldi, en Cuatro Álamos y Tres Álamos. Asimismo, estuvo exiliada en Francia durante el período 1978-1993.

\section{1 ¿Cómo fueron sus inicios en el Movimiento de Izquierda Revolucionaria?}

Mis inicios en el compromiso político fueron muy tempranos, concretamente en el año 1968 cuando yo tenía tan sólo 15 años. Mi participación comenzó desde la Iglesia Joven, donde estaban los Curas para el Socialismo. Allí se enfrentaban a lo que era la iglesia más tradicional, el celibato, etc. Desde allí reflexionábamos mucho sobre los temas sociales y políticos. Había una gran influencia de la guerrilla, de Camilo Torres. Esto me dio la base reflexiva para continuar después en la política.

Yo me crié en barrios muy modestos. Mi madre era profesora y siempre participaba mucho desde el punto de vista social, es decir, con sus alumnos que solían estar en muy malas condiciones. Mi madre al ser profesora de Magisterio, un gremio que, históricamente, ha sido muy combativo en Chile, me influyó mucho en la inquietud de movilizarme por las cuestiones sociales.

A los quince años conocí a mi primer gran amor; él militaba en un movimiento que tenía tendencias guerrillas con influencias de la guerrilla del Che Guevara, es decir, las FARC (Fuerzas Armadas Revolucionarias de Chile).

Ante esta influencia yo empecé por decisión propia a militar en las FARC en el 71. En este momento cayeron presos muchos de los militantes de esta organización. A partir de este hecho, yo decidí que el partido con el que más me identificaba era el MIR, sencillamente porque visualicé que era muy importante trabajar con el movimiento de masas y no aislarse.

Mi ingreso en el MIR fue una decisión política, es decir, no fue una experiencia romántica. La izquierda tradicional no me convencía. En este orden de cosas, yo comencé a trabajar en el ámbito universitario a partir del 72. En este año, empecé a 
trabajar en el MUI (Movimiento Universitario de Izquierdas) en la Universidad Técnica del Estado en Santiago. Mi labor consistía en el trabajo con los pobladores y trabajo voluntario como agitadora y constructora del movimiento social. Siempre fui consciente de la necesidad de trabajar con la gente, es decir, estar en pleno contacto con las masas.

\section{2 ¿En qué circunstancias estuvo el 11 de septiembre de 1973?}

El golpe quebró todo. El MIR decidió que no se exiliaba. Yo tampoco pensé asilarme de Chile. Seguí trabajando políticamente de manera sostenida componiendo el movimiento de masas, creando condiciones para el trabajo clandestino, haciendo propaganda, estudiando, formándonos políticamente, etc.

En 1974, conocí a otra pareja, Alejandro. Me casé con él porque en ese momento era una buena opción para no llamar la atención. Fue un graso error, porque el hecho de casarnos creo que supuso un elemento más para que los militares nos ubicaran. El 31 de diciembre del 74 caí detenida junto con mi compañero en manos de la DINA y me llevaron presa a Villa Grimaldi.

\section{3 ¿Cómo fue su experiencia en Villa Grimaldi?}

Yo llegué a la Villa embarazada de seis meses. El día que caí coincidió con la decisión mía de abandonar el MIR, fue demasiado tarde, justo ese día me fueron a buscar. Se produjo una debacle a raíz de la caída de Miguel Enrique. La gente empezó a perder la confianza y empezaron a pensar que era mejor salvar la vida y colaborar con la DINA. Fue un período muy difícil, mi compañero se quebró a consecuencia de la tortura. El dio el paradero de varios compañeros, fundamentalmente, los que trabajaban conmigo. Esto fue un choque muy fuerte para mí.

Yo estuve 20 días en la Villa. Después pasé a Cuatro Álamos, donde estuve en régimen de incomunicación para pasar después a Tres Álamos y a Pirque. En total, estuve siete meses detenida. Tuve a mi hijo estando en prisión. Finalmente, salí libre cuando mi hijo cumplió cuatro meses. Tuve suerte porque en ese momento había mucha presión internacional, de la Cruz Roja y de otros organismos, sobre todo con las mujeres 
embarazadas o con hijos. Puedo decir que mi hijo me salvó de estar más tiempo recluida.

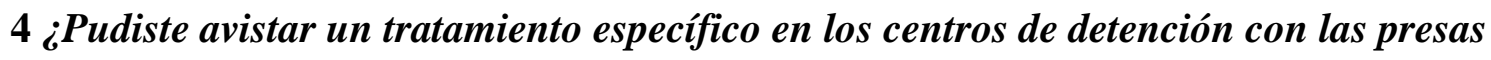 políticas?}

Bueno, creo que siempre hubo una mirada absolutamente patriarcal en la represión a las mujeres. Objetivamente, siempre he pensado que desde la tortura que se le inflinge a la mujer tanto a nivel verbal, físico o psicológico de partida es ejercida desde esa mirada patriarcal. Para ellos era doblemente terrible que una mujer, que debía estar en su casa siguiendo los patrones de una mujer tradicional, estuviera militando y en otro tipo de cuestiones fuera de la órbita doméstica.

\section{5 ¿Podemos hablar de machismo en los centros de tortura?}

Por supuesto. Las mujeres se dividían en mujeres y en putas. Yo me casé para estar dentro de la categoría de señora. El 31 de diciembre violaron a la mayoría de mis compañeras, es decir, el manoseo, la violación eran prácticas fundamentalmente dirigidas a la mujer. Asimismo, en ciertos momentos ellos nos miraban como presas con cierta fragilidad y se enternecían con nosotras. Esto a mi me sirvió, pero también correspondía a un elemento más de esa mirada patriarcal.

\section{6 ¿La clase socioeconómica jugó un papel importante a la hora de hacer distinciones de trato a las presas?}

Objetivamente, a nivel de trato verbal, esto se daba con frecuencia, es decir, las mujeres de procedencia social baja recibieron un trato más desfavorable. Sin embargo, la tortura fue la misma para todas. Cuando te violan no hay diferencia social, cuando te ponen corriente tampoco hay diferencia social ni de edades.

Existía una diferencia de trato con aquellas mujeres conocidas en el ámbito público, es decir, con ellas se cuidaban a la hora de cometer excesos. Pero a decir verdad, el factor fundamental a la hora de ser torturada era tu compromiso político. Hay compañeras que venían de una clase social acomodada o alta pero que fueron martirizadas y 
desaparecidas igualmente. Quizá en el trato verbal sí hubo diferencias pero en la tortura no.

\section{7 ¿Que papel jugó en el proceso de tortura el amedrantamiento psicológico entendido} como la amenaza a la mujer por su condición de madre?

Fue una pauta muy generalizada. Hay casos históricos conocidos, como el de Lumi Videla, que torturaron a su hijo delante de ella. Efectivamente, a algunas presas les llevaron a sus hijos a las casas de tortura para utilizarlos como mecanismos de presión. Yo recuerdo el caso de una niña con síndrome de down, hijo de un preso político, que junto a la madre, fue utilizado para quebrar su padre.

Hubo un caso muy emblemático, el de la familia Aires, en donde los torturadores llegaron a utilizar de una forma aberrante estos aspectos sexuales...hicieron que el padre violara a la hija como forma de tortura.

Si una analiza estos detalles de la represión se puede ver una mirada absolutamente machista y patriarcalista hacia la destrucción de la mujer. Para mi la tortura que más terror me causó fue las amenazas con mi hijo, ellos me decían que si no hablaba iban a matar a mi hijo. Yo incluso llegué a pensar que prefería que mi hijo no viviera en ese mundo de horror, es decir, que no llegara a nacer en ese submundo que significaban las casas de tortura en donde una no sabía si iba a estar viva al día siguiente.

Antes de que yo llegara hubo dos mujeres que las hicieron desaparecer porque habían muerto en la sala de tortura estando embarazadas. Quizá, estos hechos hicieron que la DINA suavizara sus hostigamientos con las presas políticas embarazadas. Esta fue la razón por la cuál yo pude sobrevivir y librarme de la electricidad, junto con mi compañera embarazada también, Patricia Guzmán.

\section{8 ¿Cómo fue su experiencia con las otras presas?}

Existió bastante solidaridad entre nosotras. Una solidaridad implícita en el sentido en que las antiguas nos informaban a las que llegábamos, es decir, cómo funcionaba ese lugar, cuidados mutuos, etc. Cuando alguien venía de la tortura se la consolaba y 
apoyaba para curarla dentro de lo posible. Hubo momentos en que cantábamos, que conseguíamos que algún guardia nos dejara fumar, averiguar a quién habían tomado, etc.

Sin embargo, nunca hablábamos de nada comprometedor porque lo primero que se instala en un lugar de represión es la desconfianza, en el sentido en que tú no sabes hasta qué punto va a resistir la otra persona la tortura y no denunciarte a ti o a tus compañeros. Una tenía que aprender a vivir en esas condiciones.

9 En el centro de tortura Villa Grimaldi hubo presencia de mujeres integrantes del aparato represor, ¿qué trato recibieron de su parte?

Yo vi guardias mujeres que eran realmente estúpidas. Eran mujeres jóvenes pero bien tontas. Se preocupaban por su estado físico, nos preguntaban por sus peinados, etc.

\section{0 ¿Cómo fue su experiencia en Cuatro y Tres Álamos?}

En Cuatro Álamos la situación fue mucho mejor. Por lo menos no dormíamos al lado de una pieza de tortura, nos podíamos bañar, comer en un plato, es decir, un clima menos tenso. Aunque te podían llevar de vuelta a cualquier casa de tortura de la DINA, una se sentía con más esperanza y posibilidades de vivir.

Finalmente, en Tres Álamos hubo mejores condiciones. La familia podía visitarte. Las presas nos organizábamos (Consejo de Ancianas y Carreta Común), donde se distribuían los alimentos, donde se establecían unas prioridades de convivencia, entre ellas, un trato especial con las mujeres embarazadas o con hijos. Incluso, por parte de los carabineros, hubo un respeto mayor con las embarazadas. La vida en Tres Álamos era muy activa, teníamos discusiones políticas, actividades culturales, deportivas, talleres literarios, etc.

11 ¿Hicieron algún tipo de labor de recopilación de información sobre los detenidosdesaparecidos al interior de las cárceles? 
Esa labor yo la hice a partir de mi puesta en libertad, una vez que salí de Pirque, un campo de concentración en la misma localidad con ese nombre. En prisión, era muy difícil hacer alguna actividad relacionada con el trabajo político porque todo estaba bajo sospecha y nos arriesgábamos a caer presas de nuevo en alguna casa de la DINA.

Cuando salí de Pirque, en julio de 1975, yo volví a ver a las compañeras y allí nos enteramos de todo el proceso de desaparecimiento de nuestros compañeros. Pudimos ver que en la lista de los 119 desaparecidos estaban la mayoría de nuestros compañeros. Esto fue un sock muy fuerte para mí, no podía reaccionar.

\section{2 ¿En qué circunstancias partió al exilio?}

Yo no me planteé salir de Chile. Cuando salí libre comencé a trabajar en la Vicaría de la Solidaridad y con los familiares de detenidos desaparecidos. Durante un tiempo fui el nexo con los presos políticos y los compañeros y familiares que estaban fuera.

Mi objetivo era poder reinstalarme en Chile y seguir con la militancia. La tarea era reconstruir el trabajo partidario. Es decir, resistir a la dictadura. En este sentido, desde la Vicaría trabajé como auxiliar de enfermería, tenía un salario suficiente para sobrevivir. Evidentemente, esta labor la hice en la más absoluta clandestinidad, incluso con los mismos compañeros puesto que en cualquier momento podían ser apresados y hablar.

En 1977 hubo un nuevo golpe represivo en donde cayeron dos compañeros. En este momento se estaba reorganizando la acción militar y yo empecé a tener diferencias sobre las vías de actuación partidaria. Había dos posturas básicas, la acción armada y la acción de la reconstrucción de masas. Yo era partidaria de la segunda opción. No podíamos arriesgar todo lo que habíamos construido. El hecho de que estos compañeros cayeran y desaparecieran significó la posibilidad de que la DINA tuviera información de mis actividades. El MIR me dijo que tenía que salir del país a la mayor brevedad posible.

De esta forma, en agosto de 1978 salí del país a través del Servicio de Migraciones Europeas, con destino a Francia. Yo salí nuevamente embarazada de mi segunda hija, Violeta. En Francia estuvimos en una casa de acogida para los refugiados perteneciente 
a los Curas por el Socialismo, lo que resultó ser una experiencia muy positiva. Hasta 1993 no pude volver. De hecho, yo aparecí en las últimas listas de retornados.

\section{3 ¿Qué tareas partidarias desepeñó en el exilio?}

Primero tuve que aprender el idioma. A partir de este momento tuve que compaginar el estudio y trabajo con la militancia. Después de muchos avatares conseguí trabajar como auxiliar de enfermería al convalidarme mi diploma de tres años.

Yo no dejé nunca de militar. Durante todo el exilio yo milité intensamente. Yo era la jefa política del MIR en Lyón. Trabajábamos, fundamentalmente a nivel de partido, formación de los compañeros, agenda de denuncia, de conformación de comités de solidaridad, infraestructura para enviar y recibir información de Chile, recaudación de fondos, etc.

Trabajé también el comité de familiares de detenidos-desaparecidos en el exilio, en asociaciones de presos políticos, es decir, trabajo social y de solidaridad.

En los últimos años del exilio trabajé mucho con mujeres, concretamente en el Colectivo de Mujeres Franco-Chilenas (COMFCH), conformadas por las mujeres del exilio. En esta agrupación femenina había cierto elitismo, la mirada era puramente feminista y en ocasiones veían con recelo el trabajo en el MIR.

Sin embargo, esta experiencia me ayudó a conformar una conciencia feminista lo que me ayudó a poder ver ciertas realidades que antes no apreciaba, entre ellas el patriarcalismo y la problemática en el MIR.

Empecé a ser consciente de la doble carga de la mujer militante, teníamos que ser dueñas de casa, madres y militantes. Yo sentí mucha discriminación, especialmente en mi estancia en Lyón. La mayoría de mis compañeros no soportaban tener a una mujer como jefa.

Yo conformé una agrupación en mi barrio de mujeres franco-chilenas, pero con una mirada mucho más política que feminista, aunque se impulsaba la labor de establecer la 
igualdad en la lucha partidaria. Fue una época en la que me fui integrando en la reflexión feminista, y, obviamente, me encontré con mucha oposición no sólo de mis compañeros sino de muchas mujeres del partido.

\section{4 ¿Hubo discriminación de género en el MIR a la hora de acceder a puestos de mayor responsabilidad?}

Yo no sé si a nivel estructural porque yo no milité en la comisión política del Comité Central del MIR. La verdad es que yo como militante no sentí discriminación a nivel de partido. Quizá porque yo siempre me sentí libre por la educación que recibí, en esta línea, quizá yo era bastante segura y no dejé que me rechazaran por ser mujer. Sin embargo, eso existía.

\section{5 ¿Qué legado ha dejado la Junta Militar, tras 17 años de gobierno, con respecto a la situación general de la mujer?}

La dictadura transmitió un discurso absolutamente contrario al proceso de liberación que se dio durante los gobiernos de la Unidad Popular. El discurso oficial de la dictadura no era otro que colocar a la mujer en el ámbito doméstico, es decir, de la mujer madre, esposa, de la mujer procreadora y dueña de hogar.

Por el contrario, las mujeres que habían sido golpeadas por la represión empezaron a salir a la calle y a tener una participación en la movilización de la oposición muy considerable. Con la llegada de la Democracia hubo un cierto repliegue de la mujer al hogar, en el sentido que los hombres volvieron a monopolizar el espacio público sin contar con la aportación que las mujeres hicieron a nivel sindical y social.

Sin embargo, la mujer en los últimos años si es cierto que ha ganado espacios importantes en el ámbito público y estatal. De hecho, en la actualidad tenemos dos candidatas a la presidencia de la República y muchos hombres están dispuestos a votarlas. Además, hay otro problema, la mujer chilena, históricamente, ha tendido a favorecer a la derecha, hoy en día creo que esto ha cambiado. 
16 ¿Qué papel ha tenido la mujer en la recuperación de la memoria y en la lucha de los Derechos Humanos en Chile?, ¿podríamos destacar un cierto liderazgo en este trabajo?

Creo que la mujer ha tenido un liderazgo importante porque hay una cuestión de roles fundamental. Tradicionalmente, la mujer en Chile ha tendido ha ser mantenedora de la cultura y las tradiciones, por ende, en la cuestión de la memoria, creo que la mujer ha guardado la memoria y ha sido muy combativa, no sé si por una cuestión cultural y de roles asignados tradicionalmente o porque son características de las chilenas.

Las que empiezan a salir a la calle en reclamo por los hijos y los esposos desaparecidos, las que empiezan ha realizar informes y recopilar fotos y fichas son las mujeres, en su mayoría. En este orden de cosas, el machismo tiene una doble faz, la mujer madre, la mujer esposa e hija se siente con menos peligro de enfrentarse a la represión por reclamar el paradero de un ser querido. Este factor fue utilizado por la mujer.

En la militancia, las mujeres han mantenido la memoria del ser colectivo, a nivel de las organizaciones de presos políticos, uno puede ver que se reúnen mucho más las presas políticas (ex) que los presos. La mujer mantiene la cultura de la sobrevida, es decir, la cultura de seguir hacia adelante pese a las dificultades, cosa que no suele darse en el grueso de los hombres.

Finalmente, en la construcción del movimiento político y en su dirección los hombres pugnaban por los puestos de responsabilidad. Las mujeres, ciertamente, creo que no estaban interesadas en esto, las prioridades solían ser otras.

17 ¿Creé que la izquierda ha reconocido suficientemente la aportación de la mujer en la lucha contra la dictadura?

Objetivamente la mujer tiene mucho camino que recorrer en este sentido. Creo que no es sólo una problemática de falta de reconocimiento en Chile, sino una cuestión mundial. Hay un desfase terrible entre la historia del hombre y la historia de la mujer. Recientemente, se está trabajando por vitalizar el papel de la mujer en la historia chilena, sin embargo se trata de un trabajo muy simbólico y minoritario. Además, está la 
otra mirada de algunas agrupaciones de mujeres muy elitista que mantiene una mirada que excluye a la mujer del pueblo.

\section{8 ¿Qué tareas partidarias desempeñó al regresar del exilio?}

Lo más importante, en un principio, fue cerrar página. Creo que el exilio ha sido un fenómeno poco estudiado en el sentido del proceso tan doloroso que supone adaptarte y vivir en un país que no es el tuyo y por obligación. Yo pude reinsertarme en Chile pero no sin dificultad.

Mi prioridad era adaptarme y recomponer mi memoria para después poder luchar por la memoria colectiva. Mi idea era seguir trabajando por una verdadera democracia en Chile. Creo que la democracia en Chile ha supuesto un paso fundamental para crecer democráticamente. No me desespera que queden muchas cosas por hacer y que la sociedad no cambie de un día para otro.

Creo que nosotros sufrimos una derrota enorme. Mientras no exista un análisis serio de parte de la izquierda, una autocrítica de nuestros aciertos y errores, no podremos dar un salto cualitativo.

Desde hace años estamos trabajando por recuperar la memoria de la represión, no sólo la nuestra sino la de todo un pueblo. Es en este punto donde también queda mucho por hacer.

\section{9 ¿Cómo ve a las nuevas generaciones de mujeres chilenas?}

La mujer chilena, por lo general, ha sido y es una mujer combativa. Sin embargo, todavía queda mucho por hacer. Hubo un gran vuelco cuando Augusto Pinochet fue arrestado en Londres. En este sentido, esto produjo un cambio a nivel de apertura social, esto ayudó a superar muchos miedos. Esto ayudó mucho a las mujeres, es decir, a la hora de expresarse y reivindicar sus derechos. Sin embargo, esto no significa que todavía no haya que superar una cierta desmovilización de la mujer y ciertas influencias que todavía hoy día ejerce la iglesia católica en cuestiones tan fundamentales como el aborto o el divorcio. 
7 Entrevista a MARGARITA IGLESIAS SALDAÑA, realizada el 28 de enero de 2004, Santiago de Chile. Iglesias fue militante del Movimiento de Izquierda Revolucionaria y estuvo detenida en la Academia de la Fuerza Aérea durante tres meses para pasar, posteriormente, al exilio durante el período 1975-1990. Actualmente, es profesora de Historia en el Departamento de Género de la Universidad de Chile.

\section{1 ¿Cómo fueron sus inicios en el Movimiento de Izquierda Revolucinaria?}

Durante el gobierno de la Unidad Popular, como gran parte de los jóvenes de aquella época, me incorporé a todas las actividades sociales y políticas desde el Liceo. La primera consecuencia de esto fue mi expulsión, lo que me impidió terminar los estudios de secundaria con regularidad.

A partir de 1973, yo seguí trabajando en las asociaciones políticas de los estudiantes ligados al MIR. Opté por quedarme en Chile en el momento del golpe (esta era la consigna del partido) para organizar la resistencia. Estuve trabajando en tareas de resistencia clandestina hasta el año 75, puesto que en ese momento de detuvieron.

Concretamente, a mi me detuvo un comando de la fuerza aérea y me llevaron a la Académica de Guerra donde permanecí tres meses recluida para posteriormente expulsarme del país hacia Francia, vía Nunciatura Apostólica.

Viví en el exilio durante el período 1975-1990. Durante estos años participé en las acciones de apoyo de la resistencia con los movimientos sociales franceses. Esta actividad tuve que compaginarla con mis estudios y el aprendizaje del idioma. Desde el año 90 lo primero que hice fue tratar de reinsertarme profesionalmente en el país cosa que me costó mucho. En 1999 conseguí incorporarme en la Universidad de Chile como profesora de Historia.

Volver a Chile fue volver a reconocer el país, y por otro lado, supuso un intento de recuperación de la memoria histórica y de los Derechos Humanos. Formalmente, dejé de militar en el Movimiento de Izquierda Revolucionaria en 1983, aunque mantuve contacto con los antiguos compañeros para difundir desde Francia los sucesos que estaban ocurriendo en Chile. Asimismo, me gané un proyecto con la Cooperación 
Internacional con grupos de trabajos holandeses para poner en marcha varias revistas que tratasen la cuestión de género (Análisis y Página Abierta).

Con el retorno, el conjunto de exiliados tuvo grandes dificultades de adaptación profesional y social. De hecho, el Estado no reconocía nuestra situación de exiliados y, en este sentido, no dio facilidades para una mejor adaptación a los retornados. El primer reconocimiento que a nivel estatal se hizo sobre las víctimas de la represión fue el informe Rettig. Sin embargo, dicho informe no incluía la cuestión de los retornados.

Hemos tenido que esperar hasta hace bien poco el reconocimiento institucional a través del Comisión de Reconocimiento de los Presos Políticos (sobrevivientes de la dictadura). El impulso de este proyecto se dio a raíz de la detención de Augusto Pinochet en Londres.

Fue importante y sintomática la querella presentada por el conjunto de los exmilitantes del MIR en 2000 por genocidio. Esta fue la primera vez que un partido presentó una querella de estas características. La razón de esta acción novedosa fue que al salir los resultados de la Mesa del Diálogo, el último intento de buscar un punto final en Chile desde el punto de vista institucional, se minimizó toda la cuestión de la represión de la DINA contra los miristas. Esto significó el catalizador para presentar la querella. En otras palabras, aunque en 2000 el MIR ya no existía, nosotros tuvimos un reencuentro para protestar por las carencias (hay 700 militantes del MIR detenidos-desaparecidos) de los resultados de esta Mesa que se suponía que era una vía de "reconciliación nacional".

\section{2 ¿Cuándo empezó a interesarte por los derechos de las mujeres?}

Yo nunca he militado en movimientos feministas, no me considero feminista. Sin embargo, en la vida asociativa política yo siempre he tenido presente los derechos de las mujeres. Quizá por la educación que recibí en mi familia, en donde tuve plena libertad, siempre di por sentado que debía existir una equidad genérica.

En los años de gobierno de la Unidad Popular la prioridad era el cambio estructural, en donde se daba por hecho que esto iba a llevar per se la liberación de la mujer. Pero hasta 
el exilio, creo que nosotras no empezamos a tomar una conciencia del problema de género, de los propios derechos de la mujer en los partidos políticos y en la sociedad. Aquí, seguramente, coincidíamos con el movimiento feminista, pero no éramos claramente feministas, creo que el feminismo es una opción política más.

En París nosotras hicimos un Comité de Mujeres chilenas en donde nos planteábamos de qué forma debíamos recolocar a la mujer en el conjunto de los movimientos políticosociales. Es decir, creíamos que no era necesario ser feministas para cambiar las cosas en el partido y en la vida social; en este punto, bastaba con reflexionar sobre nuestros derechos y nuestra posición dentro de la vida partidaria. Aún así, intercambiamos posiciones con el movimiento feminitas y aprendimos mucho.

En esos años empezó a darse una transformación radical en la concepción de la mujer. Visualizábamos un hecho que se repetía con frecuencia, esto es, la mayor adaptabilidad que las mujeres de la militancia tenían ante los cambios adversos. Fueran o no fueran las mujeres feministas, lo ciertos es que ellas, en el exilio, eran las primeras en aprender el idioma, en la inserción social, en la sobrevida, etc. No hacía falta tener una conciencia feminista para darse cuenta y valorar estos cambios.

\section{3 ¿Pudo avistar a nivel de partido algún tipo de discriminación de género a la hora de acceder a las responsabilidades políticas?}

No se si del acceso formal. El MIR era uno de los movimientos más avanzados del pensamiento de la izquierda. Teóricamente, desde la base, una no tenía restricciones para acceder a los puestos de dirección. Sin embargo, el peso de las mentalidades, es decir, el peso sociocultural, era de tal magnitud que la tendencia era a que las mujeres cumplieran el trabajo de apoyo a los hombres.

Yo luché contra esta concepción dentro del MIR y esto me creó ciertas dificultades. Además, esta situación no se veía a primera vista en el trabajo diario, salvo en sutilezas de arraigamiento cultural. El conjunto de las militantes pensábamos que la problemática tradicional entre hombre y mujer se resolvería con la apuesta general de cambio que el partido planteaba. En este sentido, sólo con el paso de los años empezará a darse un planteamiento genérico a nivel político partidario. 
Otra cuestión era el tema de los hijos y las responsabilidades domésticas. Normalmente, si en una pareja de militantes había hijos de por medio era la mujer quién debía de hacerse cargo de ellos. En el MIR este problema se discutió. Concretamente, se creó un proyecto de Hogares Colectivos para los hijos de los compañeros y compañeras que decidieran volver a Chile desde el exilio político. Esto posibilitaba que la mujer pudiera reincorporarse a la lucha con mayores facilidades. Esto no quita que en lo cotidiano pesara mucho el tema de la masculinidad, el machismo, etc.

\section{4 ¿Creé que se establecieron pautas específicas de castigo con las presas políticas en los años de dictadura?}

La represión misma igual en el momento de actuar quizá no estaba pensando en estas cuestiones. Sin embargo, el contexto sociocultural en el que se desarrollaba esto sí fue importante. A la hora de asesinar a la gente esto no se tuvo en cuenta, pero a la hora de poder proteger a los que sobrevivimos sí hubo una diferencia. En la Fuerza aérea en donde yo estuve presa, la proporción de mujeres era muy minoritaria. Ahora, dentro de la tortura y la represión, la vejación sexual juega un papel muy fuerte.

Creo que hay un cierto castigo, no muy consciente quizá en el momento, dirigido a la mujer. Un ejemplo lo encontramos en el trato dirigido a la mujer militante presa como prostitutas, es decir, este fue un hecho que ocurría con mucha frecuencia.

La vejación sexual se ejerció igualmente para los presos y presas. En este punto, se conoce menos la vejación sexual masculina porque los hombres hablan menos, es decir, para las mujeres esto ha sido traumático pero entra dentro de esa humillación histórica que han sufrido desde siempre. Para los hombres, sin embargo, esto fue quizá un hecho más novedoso lo que conllevó a una dificultad a la hora de reconocerlo.

De todas formas, sí hubo una especificidad en el caso de la mujer, en el sentido de que había un reproche por parte de los militares de no ser las mujeres que debíamos ser. Nos acusaba de que nuestras relaciones amorosas eran disolutas, que teníamos amantes, etc. En este línea, apareció también una diferencia de clase, recuerdo que a mí me decían que por qué andaba metida en política si yo era una estudiante de clase media que no lo necesitaba. 
5 ¿Qué opina de la utilización de los hijos como forma de amedrantamiento y mecanismo para obtener información en los interrogatorios?, ¿esto fue una hecho generalizado con las presas que cayeron estándo embarazadas o con sus hijos?

Yo conozco un caso muy relevante de una presa a la que DINA amenazó utilizando a su hijo. Sin embargo, también hay algunos casos en donde se detuvieron a hijos de hombres como forma de presión y amedrantamiento psicológico.

Otra cosa muy distinta, son los casos de mujeres que fueron violadas por agentes de la DINA y quedaron embarazadas. También están los casos de aquellas mujeres que fueron detenidas estando embarazadas. Tenemos el caso de la Peña Solari, que no se sabe lo qué paso con su hijo. Otras mujeres perdieron a sus bebés como consecuencia de la tortura recibida. Es decir, estas cosas sí tenían que ver con un cierto icono por alterar el rol materno de las mujeres o usar su maternidad para castigarlas por no ser las madres que "tendrían que haber sido".

6 ¿Creé que en los proceso bélicos y en la instauración de regímenes militares la mujer recibe una carga extra en términos de represión?

Creo que esa carga extra de la que se habla mucho se produce más bien en las guerras abiertas en donde la mujer puede tener un costo mayor. En los casos de proyectos políticos, partidos o movimientos es difícil discernir, porque aquí están buscando aniquilar a las personas, sean hombres o mujeres. Las formas de tortura serán las que culturalmente puedan situar al prisionero o prisionera en una situación de humillación mayor, es decir, dependiendo en que contexto nos movamos.

No tengo muy claro qué es lo que juega más en el caso chileno, es decir, si tiene más peso el imaginario colectivo de la preponderancia masculina u otras cuestiones.

Lo que está claro, es que en la tortura la derrota militar juega un papel fundamental, es decir, el torturador te está tratando bajo un parámetro muy masculino que es el militar. En esta concepción de lo militar la mujer no tiene cabida, con lo que te tratan como un hombre, pero añadiendo, por otra parte, las vejaciones sexuales como la violación, el uso de animales, la introducción de objetos en la vagina, etc. 
Quizá, el tipo que ejecuta esta tortura no es consciente en el momento de estas cuestiones, pero igualmente puede tratarse de una acción-reacción hacia el útero materno, hacia la sexualidad de las mujeres, hacia ese ser reproductivo, etc. Esta actitud era la que preponderaba en la década de los setenta en el contexto latinoamericano, es decir, la identificación de la mujer cómo madre.

\section{7 ¿Qué papel ha jugado la mujer en la recuperación de la memoria histórica? ¿Podemos hablar de un cierto liderazgo en este sentido?}

El hecho de jugar a ser mujer fue el principio de la asociación de madres de detenidosdesaparecidos. Ellas optaron por dejar a los hijos al margen y jugar con su condición de madres porque sentían que además con eso se protegían. Es decir, lo pensaron a la hora de articular el movimiento de familiares de detenidos-desparecidos.

En el primer momento, creo que fue una reacción vital en la defensa de la vida. Pero conforme fue pasando el tiempo, creo que desarrollaron la denominada política de los vientres. En otras palabras, el primer movimiento reactivo importante fue el de los familiares, el segundo el de las mujeres, y este último logró poner en movimiento a toda la resistencia social. Esto es muy llamativo y ha sido muy poco estudiado, es decir, la política de los vientres compuesta por mujeres que no están muy politizadas y que se ven en la necesidad de actuar en lo público para defender la vida y por lo tanto hacen política, y una política muy movilizadota propia de las mujeres y que después va a permitir la reactivación del movimiento social.

Más tarde, a partir de la década de los ochenta van aparecer estos nuevos feminismos (como un intento de recuperar los primeros feminismos de la década de los treinta). Pero será el conjunto del movimiento de mujeres las que pondrán en marcha la idea de democracia en el país y en la casa. Este factor fue, sin duda, un elemento muy movilizador en la década de los ochenta.

Los movimientos de mujeres no pudieron capitalizar este fenómeno con la llegada de la Democracia y el engaño de las propuestas por parte de la Concertación. Con la división de las mujeres se perdió esta fuerza movilizadota. Muchas de las mujeres de la 
intelectualidad optaron por integrar la problemática de la mujer en la agenda política de la Concertación.

Evidentemente, hay que reconocer que en la cuestión de derechos se ha avanzado muchísimo, pero este hecho ha tenido un costo fatal, es decir, la dispersión de los movimientos sociales, incluido el movimiento de mujeres.

Es cierto que hubo ciertos acuerdos justo antes de la llegada de la democracia entre mujeres de diferentes sectores sociales. Sin embargo, posteriormente esto se cortó porque unas pasaron a formar parte del gobierno de la Concertación y otras a trabajar desde diferentes organizaciones no gubernamentales. Esto, sin lugar a dudas, creó una división en el movimiento de mujeres en Chile.

Las consecuencias de este proceso han sido la falta de coordinación entre las mujeres y la división de opiniones a la hora de aplicar políticas dirigidas específicamente a la mujer. Tenemos como ejemplo un ridículo proyecto de ley de divorcio, la falta de equidad e la hora de percibir los salarios en el desempeño de idénticas funciones, etc.

En definitiva, en las prácticas sociales la discriminación de género es una realidad que sigue existiendo hoy día y que, además, se conforma como un fenómeno encubierto por el éxito económico de la década de los noventa. La detención de Pinochet dejó entrever algunas problemáticas que antes no se visualizaban, y no sólo en el tema de la mujer, sino en otros aspectos también fundamentales como la desigualdad en la distribución de la riqueza, la situación de los jóvenes con menos recursos, los mapuches, etc. 
8 Entrevista a ERICA HENNINGS CEPEDA, realizada el 8 de marzo de 2004, Santiago de Chile. Hennings fue militante de las Juventudes Comunistas (1967-1972) para pasar posteriormente a militar en el Movimiento de Izquierda Revolucionaria. Estuvo recluida en los centros Londres 38 y Tres Álamos. Asimismo, estuvo exiliada en Francia durante el período 1974-1983. Actualmente es miembro de la Asociación de Familiares de Detenidos-desaparecidos.

\section{1 ¿Cómo fueron sus inicios en la movilización política?}

Yo soy originaria, por parte de madre, de una familia ligada al Partido Comunista. Por otra parte, la familia de mi padre era de derechas y bastante reaccionaria, sin embargo mi padre fue rupturista con el estilo de vida de su familia. Crecí escuchando las dos versiones.

A partir del año 67 empecé el acercamiento al PC. Además, mi hermana mayor fue militante. En 1968 estaba muy ligada al mundo estudiantil y a la militancia política comunista. Mi labor era realizar informes desde la dirección de estudiantes del Liceo, actividad de calle, etc.

En este mismo contexto, participé en una gran huelga del magisterio en donde los estudiantes se organizaron para apoyar la huelga de los profesores. Tomamos el Liceo Gabriela Mistral, en donde había muchos jóvenes socialistas, comunistas, etc. Precisamente, en esta toma, fue donde conocí a Alfonso C., quién después fue mi marido y que hoy día está desaparecido.

Hubo un momento en el que mi pareja se pasó de las Juventudes Comunistas al Movimiento de Izquierda Revolucionaria. Esto, en un principio, no me gustó dado que en aquellos momentos existían muchos conflictos entre el PC y el MIR. Sin embargo, con el tiempo yo fui viendo cosas dentro de las Juventudes Comunistas (JC) que no me terminaban de gustar, es decir, ciertos rasgos de autoritarismo, cuestiones de organización, dirección y estructura. Quizá en este punto, empecé a ser más permeable a lo que el MIR planteaba.

Después de participar activamente en la campaña de Allende, entré en la Universidad para estudiar castellano y Educación Física y seguí estando ligada al Partido Comunista. 
Es importante decir que el MIR fue contrario de participar en la campaña electoral del gobierno popular por no creer en los mecanismos electorales.

Sin embargo, en la Universidad y pese a estas diferencias comencé a entrar en contacto con miristas. Fue una primera aproximación y el comienzo de mi alejamiento con las JC. En este sentido, comencé mi militancia en el MIR cómo estudiante, a partir de 1971. El proceso de ingreso al MIR fue muy exigente, tenía que pasar por todas las etapas y dar pruebas de cierto comportamiento comprometido. No fue fácil. Asimismo, los dos siguientes años significaron consolidarme dentro del partido y trabajar a nivel poblacional.

Siempre preferí trabajar con las poblaciones que militar en un GPM (Grupo Político Militar) donde mi pareja era dirigente. Puedo decir que quizá esta fue mi primera reivindicación como mujer al querer desempeñar una militancia independiente.

\section{2 ¿En qué circunstancias estuvo el 11 de septiembre de 1973?}

Al momento del golpe yo estaba casada y tenía una hija de cuatro meses. Mi marido estaba militando en el Comité Regional-Santiago con muchas responsabilidades partidarias. El día del golpe, la mayoría de los miembros de este comité se reunieron en nuestra casa. De todos los que nos reunimos todos están desparecidos o muertos excepto un compañero y yo.

En esos momentos teníamos que decidir la estrategia que debíamos seguir. Decidimos seguir en la lucha y juntos. En los primeros días el partido estaba muy desperdigado. Después de dos meses pudimos hacer un trabajo de recuperación de los GPMs pese a que empezábamos a conocer el alcanza que estaba teniendo la represión sobre muchos de nuestros compañeros y en todos los partidos de la izquierda. Las dificultades para rearmar el MIR fueron enormes, las dificultades para poder vivir aumentaban cada día. Las casas eran inseguras y los recursos para subsistir eran muy pocos. Además, estaba el hecho de tener una hija de pocos meses lo que suponía una dificultad extra.

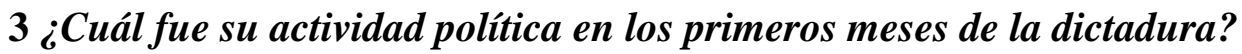


Mi rol hasta la fecha de mi detención fue el de compañera-militante de mi esposo, es decir, yo era el enlace de los contactos, escribía a máquina las cartas de comunicación, los barretines (documentos), y claro está, cuidar a mi hija. Recuerdo haber utilizado los pañales de mi guagua para esconder los boletines y la documentación de los contactos. Pero la función más arriesgada que se me asignó fue la de llevar y recoger la información de los contactos entre compañeros, es decir, lugares de encuentro, hora, etc.

\section{4 ¿Cómo fue su detención?}

Yo caí un día después que mi marido. Recuerdo que llegaron agentes de la DINA a buscar a Alfonso a la casa de mi hermano en un operativo muy grande. Pudimos convencerles de que me llevaran a la casa de mis padres con mi hija. Yo quedé bajo arresto domiciliario. Al día siguiente regresaron a buscarme. No quise asilarme en ese momento porque consideré que no podía asilarme dejando a mi esposo, pensé que mi rol en el partido no era tan importante como el de Alfonso.

De la casa de mis padres me trasladaron a la Londres 38. La razón que me dieron de mi detención es que mi marido no había querido hablar en toda la noche por lo tanto me llevaban a mi para que yo hiciera algunas preguntas a mi marido. En otras palabras, ellos marcaron ya mi rol, es decir, mi utilización como "esposa de" puesto que la DINA no tenía constancia de mi militancia política, para ellos era simplemente la esposa de un dirigente mirista.

Siempre creía que ser casa legalmente podía ser un punto a favor en comparación de otras mujeres miristas que no estaban en este estado legal. Sin embargo, en mi caso esto no supuso ninguna diferencia a la hora de recibir un trato mejor.

\section{5 ¿Cómo fue su experiencia en Londres 38?}

Para mi esto fue muy terrible. El primer encuentro brutal lo tuve con Romo. Al llegar ya pude ver el panorama de desolación puesto que pude alcanzar a ver debajo de la venda a muchos presos vendados en muy malas condiciones. A mí me sentaron junto con otras mujeres. 
El mismo día de mi detención me llevaron a una pieza donde estaban torturando a mi marido. Lo único que me pidieron a mí fue decir mi nombre. Alfonso se dio cuenta de mi presencia y esto lo desesperó. El decía -ella no tiene nada que ver-.

Después me llevaron a una pieza en el piso justo que estaba debajo de donde estaba Alfonso. En esta pieza me obligaron a desvestirme. Yo pude ver entre medio de la venda que armaban un catre, en dónde me amarraron...fue brutal...mucho de connotación sexual evidentemente... yo me resistí. Yo no sabía que Alfonso estaba arriba y que estaba oyendo lo que me hacían. Después, sólo recuerdo que quise ponerme el poncho para vestirme y el Guatón Romo no me dejó. Todo esto se repitió muchas veces.

Alfonso estaba muy mal, lo torturaron mucho. En esta situación a mí nunca me preguntaron nada, no me interrogaron. Siempre me usaron como instrumento... yo era un instrumento más de tortura para Alfonso. Esto lo he pensado mucho durante los últimos años.

6 ¿Podemos decir que se establecieron mecanismos de presión hacia los presos con sus mujeres aunque estas no tuvieran una militancia política constatada?

Yo sentí que era un instrumento, un instrumento vivo. La DINA no sabía nada de mi militancia en el MIR. Entonces esto se dio en mi caso. Es decir, a mi me impusieron este rol. Esto era una manipulación constante, es decir, ellos me decían -de ti depende la vida de Alfonso, de tu hija, de tu familia-. Se suponía que ellos me utilizaban para sonsacar información a mi marido, porque Alfonso tenía información valiosísima que ellos querían tener a toda costa.

\section{7 ¿Cuánto tiempo estuvo recluida?}

Alfonso estuvo 13 días en Londres 38. Lo torturaron mucho. La DINA sabía que era el dirigente más importante que tenían en el centro. Asimismo, mi marido siempre negó su militancia política, incluso a pesar que una compañera nuestra se quebró y contó que Alfonso era miembro del Comité Central del MIR. 
Yo estuve recluida tres días más que Alfonso. A mi me hicieron una ficha de mis antecedentes, familia, estudios, etc. Yo siempre estuve convencida de que iba a salir libre porque sabía que la DINA no tenía la información sobre mi militancia.

\section{8 ¿Cómo fue su salida de Londres $38 ?$}

Tres días después de la salida de mi marido, a mí me trasladaron a Cuatro Álamos para luego pasar a Tres Álamos. Fue la última vez que le vi. Desde mí salida de Londres 38 yo comencé a tener un rol de testigo, nadie reconocía la detención de mi marido. De hecho, en Tres Álamos nos organizamos las mujeres, para poder idear una estrategia para buscar a nuestros detenidos-desaparecidos. Éramos muy jóvenes, muchas de nosotras éramos estudiantes universitarias. Tuvimos dos visitas, el ministro del Interior, Benavides, y un general del Ejército. Nos organizamos para enfrentar la visita de estos señores para exigir información sobre los detenidos no reconocidos. Yo fui la portadora para expresar esta demanda.

Por otro lado, hay que decir que el $80 \%$ de las mujeres recluidas eran miristas (MIR) y el otro $20 \%$ militantes del Partido Comunista. Es curioso porque las rencillas que existían entre ambas formaciones políticas desaparecieron completamente en Tres Álamos.

El objetivo era poder intercambiar información con los hombres para tener una visión más completa de lo que había sucedido.

\section{9 ¿Cómo fue el trato que recibieron en Tres Álamos?}

Eran muy discriminadores en el plano de clase y en el machista. Aunque éramos vigiladas por mujeres carabinero existían hombres que estaban a cargo de los puestos mayores, es decir, comandantes, jefes de sección, etc. En esta línea, trataban de seducirnos y manipularnos.

10 ¿Podemos hablar de machismo como un elmento presente en los centros de detención? 
Mira, en Londres 38 los agentes del la DINA discriminaban especialmente a las mujeres militantes que convivían con sus parejas. Las trataban de putas. Pero además también hubo discriminación de clase. Creo que el trato a una mujer rural de procedencia sociocultural baja era el foco de mayor represión. En mi caso yo sabía el papel que tenía que jugar para sobrevivir, es decir, el papel de mujer-esposa y madre de una hija que no sabía nada de cuestiones políticas, etc.

Por otra parte, existía una tendencia de maltrato a las mujeres por su físico, digamos que resaltaban los signos característicos del cuerpo, mediante una burla de degradación de la mujer con un claro carácter sexual.

11 Sin embargo, en su caso, estar legalmente casada no significó poder evitar la represión ¿qué explicación le da a este hecho?

Yo hecho una cierta elaboración de este hecho y todavía no llego a comprender lo ocurrido. Quizá el hecho de tener un rol de instrumento para la tortura de mi marido significó que la prioridad era usarme a mí como mecanismo para sonsacar información a mi esposo. Lo demás no importaba.

\section{2 ¿Cómo fue su salida de Tres Álamos?}

Después de estar tres meses y medio en Tres Álamos, en noviembre del 74 salí expulsada a Francia. Desde el exilio mi trabajo consistió en apoyar a la resistencia y lucha por los detenidos-no reconocidos. Todavía en ese tiempo hablábamos en esos términos. Asimismo tuvimos varias audiencias con políticos, gente de la cultura, trabajo testimonia por diferentes organizaciones de Derechos Humanos en Europa, etc. En 1976 decidí cortar con esta actividad, aunque sin dejar mi militancia en el MIR. En este sentido aposté por acercarme al trabajo Sindical.

13 ¿Creé que se establecieron una discriminación de género en el MIR a la hora de acceder a las responsabilidades políticas?

Yo asumí el hecho de seguir militando sin separarme de mi hija. Aquí tuve algún problema, porque algunos pretendían que nosotras cuidáramos a los hijos para que otros 
se centraran solamente en la militancia política. Precisamente esto fue el catalizador de mi rebeldía de carácter feminista.

Este hecho se reflejó con mi entrada en algunos grupos de reflexión sobre el papel de la mujer en la militancia política. Cuestionábamos el rol que se nos imponía a las mujeres en el MIR. Éramos simplemente “compañeras de” que asumíamos responsabilidades de apoyo o papeles secundarios. Asimismo, esto hecho también nos hacía cuestionarnos nuestras relaciones de pareja.

\section{4 ¿Cómo fue su regreso del exilio?}

Yo volví a Chile en 1983. Mi voluntad con el retorno fue claramente de jugar un papel activo en la justicia para los detenidos-desaparecidos. Nada más llegar a Santiago me reincorporé al MIR "abierto", entendido como el MIR no clandestino aunque el funcionamiento si lo fuera. En otras palabras, lo configurábamos aquellas personas que integraban las diferentes asociaciones de estudiantes, de Derechos Humanos, etc. Desde el MIR recibíamos ciertas orientaciones para enfocar las protestas.

\section{5 ¿Cuales fueron sus objetivos una asentada en Santiago?}

Formar un frente fuerte contra la dictadura. Yo seguí trabajando conjuntamente con los pobladores y las asociaciones de Derechos Humanos como la Asociación de Detenidosdesaparecidos. Asimismo, formé parte de las Comisiones Anti-represivas. Fue un trabajo muy activo y heterogéneo.

16 ¿Creé que hubo un cierto liderazgo del Movimiento de Mujeres en la lucha contra la dictadura y en el trabajo de los DDHH?

Las mujeres tuvieron un rol muy activo en toda esta movilización anti-dictadura. Es decir, la mujer en todo lo que fue el movimiento de protesta tuvo un rol decisivo. La razón de este hecho es que en las poblaciones los hombres cuando no estaban presos estaban cesantes con lo que la mujer se vio en la situación de tener que salir a la calle a luchar por el marido preso o detenido-desaparecido, a buscar trabajo, a organizarse con otras mujeres, etc. 
Precisamente, esta es la paradoja, la mujer durante la dictadura se movilizó enormemente ocupando un espacio público como nunca. Sin embargo, lo relevante fue la gran importancia que tuvieron en el movimiento de protesta contra el régimen militar.

Hay un hecho significativo que me gustaría mencionar. Lo cierto es que las mujeres que participaron en la lucha contra la dictadura recibieron un tipo de represión diferente del que hubieran podido recibir los hombres. En otras palabras, los militares o carabineros aunque sí que reprimían a las mujeres que se movilizaban, lo hacían de una forma menos brutal por esa concepción machista de verlas como "sujetos menos peligrosos", "locas" o simplemente como "madres" en busca de sus hijos o sus maridos.

Evidentemente, esto no supuso que las mujeres no sufrieran represión a la hora de manifestarse, a mi de hecho me golpearon mucho, pero yo también era más joven. Con las mujeres de mayor edad quizá sí se estableció ese hecho de verlas como madres, como si el "paco" (carabinero) se enfrentara con su mamá.

\section{Recapitulando, ¿usted creé que la Junta Militar diseñó pautas específicas de castigo dirigidas a las presas políticas?}

Claramente hubo una carga sexual extra. No en todos los casos se produjeron violaciones a las mujeres presas, sin embargo sí se promovían determinados comportamientos con las mujeres. Desde luego, en mi caso esto fue así, es decir, una decisión elaborada de cómo actuar con las mujeres.

Cuando yo trabajé con algunos equipos de salud mental pude ver un hecho significativo con respecto a los hombres que habían sido torturados. En este sentido, nos dimos cuenta que algunos habían sido torturados sexualmente y hubo grandes dificultades por su parte para visualizar estas experiencias.

Respecto a la mujer, creo que los desnudos, los manoseos, la humillación de la anatomía femenina, etc., fueron hechos constantes que se daban en los centros de reclusión con las mujeres presas. Además fue un tipo de tortura o humillación muy elaborada, salvo algunos casos, pero lo cierto es que sí había un trato desde los organismos de inteligencia para obtener información de las presas. Era un ritual, un ritual en el 
contexto de la tortura. Creo que todo este espectro respondió a un intento de derrumbar los logros que el conjunto de mujeres habían conseguido en los años anteriores. No podían soportar nuestros avances.

18 ¿Se ha reconocido lo suficientemente desde la Izquierda la aportación de la mujer en la lucha contra la dictadura y la represión específica que sufrió?

Creo que sí hay un reconocimiento pero con cierta manipulación. En el ámbito de los Derechos Humanos sí que hay reconocimiento, pero no hay políticas dirigidas a la mujer que respondan a ese reconocimiento.

El gobierno ha instrumentalizado mucho el tema de la mujer, especialmente a la hora de reconocer la aportación del movimiento de mujeres al proceso democratizador. Es positivo que hagan homenajes, monumentos, etc., pero ese reconocimiento a la mujer ha de estar acompañada de políticas estatales específicas: divorcio, derechos reproductivos, aborto, discriminación salarial y laboral, etc. Hay algunos avances pero creo que el movimiento de mujeres luchó mucho para conseguir un régimen democrático que atendiera también sus demandas, y en el plano jurídico, desgraciadamente esto ha quedado pendiente, en un segundo plano. 
9 Entrevista a PATRICIA ZALAQUETT DAHER, realizada el 7 de abril de 2004, Santiago de Chile. Zalaquett fue militante del Partido Socialista (1972-1973) y del Movimiento de Izquierda Revolucionaria (1974-1977) y estuvo presa en el centro Borgoño durante el año 1984.

\section{1 ¿Cómo fueron sus inicios en la movilización política?}

Yo soy hija de padres inmigrares, libaneses. Recuerdo los valores que recibí de mi madre, siempre basados en el aprecio humano. Por otra parte, mis hermanos mayores tuvieron una activa militancia política en los momentos previos a la elección de Allende. Ellos fueron un modelo a seguir para mí. Asimismo, esto suponía un contraste con la educación que yo recibí en el colegio de monjas. De hecho, a mi hermana y a mi nos expulsaron del colegio por mostrar consignas a favor de Salvador Allende.

En el momento del golpe yo cumplí diecisiete años, período en el que empecé a militar en la Juventud Socialista. A partir ahí la vida se volvió muy complicada para mí porque el golpe coincidió con mi último año de Liceo y con mi participación en el movimiento estudiantil.

Todos los dirigentes del Partido Socialista comenzaron a desaparecer. Nosotros, los jóvenes nos quedamos en una situación de desamparo y esto me produjo una enorme decepción. Yo milité en el Partido Socialista durante el período 1972-1973. Era parte de una sección juvenil y nuestra labor consistía en el trabajo poblacional, ecuación política, alguna toma de universidad, tareas de agitación y trabajo estudiantil

\section{2 ¿Cuándo empezó su militancia en el Movimiento de Izquierda Revolucionaria y qué tareas partidarias desempeñó?}

A partir de 1973 empecé a plantearme un acercamiento al Movimiento de Izquierda Revolucionaria (MIR). Mis primeros contactos con el MIR coincidieron con mi llegada a la Universidad.

Mis primeros momentos en el MIR pasaron por desempeñar tareas que no me gustaban mucho, como pasar documentos a máquina, buscar casas secretas, etc. En otras 
palabras, tuve una primera militancia esporádica, de ayuda. Yo siempre sentí una gran simpatía por el MIR, tenía una mística y una presencia especial.

Uno de mis hermanos mayores se involucró con la Vicaría de la Solidaridad y fue expulsado de Chile, y esto fue un golpe muy fuerte para mí, lo que significó un elemento más para seguir con la lucha política.

Mi conexión principal con el MIR fue a través de un compañero mirista (Nelson), el que sería después el padre de mi hija. Con él hice una intensa labor de propaganda, editar el periódico El Rebelde, reclutar personas, etc.

Yo tenía abierto un sumario por mi participación en el movimiento universitario lo que me hizo tomar precauciones, aunque no usé nunca doble identidad porque no era perseguida, pero sí me replegué a la militancia clandestina.

Durante el período 1974-1977 mi labor como ayudante en el MIR y junto a mi compañero consistió en el trabajo con obreros industriales, tomar contacto con ellos y averiguar lo que pasaba en las industrias para después pasar al trabajo poblacional. También organizamos la primera toma de terreno bajo dictadura, la toma de La Victoria.

Hay que tener en cuenta que nosotros no éramos profesionales del MIR, es decir, militantes en sentido estricto, puesto que el partido no tenía la suficiente estructuración en aquel momento para reclutarnos, pero sí hicimos una colaboración con el partido desempeñando estas funciones. Es decir, nuestro trabajo no era dirigido desde el MIR sino algo más espontáneo.

3 ¿En que situación (presencia, participación política, etc.) estaba la mujer en el MIR?

Bueno, en el trajo poblacional tuvimos varias reuniones con mujeres rurales. Ellas nos contaban a la violencia a la que estaban sometidas con sus parejas. Por otra parte, el modelo ideal de militante que imperaba en esa época era el de hombre militante. 
Recuerdo que sentí mi primera discriminación dentro del partido cuando quise tener un hijo y algunos compañeros me dijeron que eso no podía ser posible al ser incompatible con la militancia política.

\section{4 ¿La maternidad supuso una discriminación de género en la toma de responsabilidades partidarias?}

Creo que el problema de la maternidad fue una dificultad para las mujeres miristas. Mi marido era miembro del comité regional y después del Comité central. Cuando tuve a mi hija parecía que tuviera que asumir los cuidados del bebé. Esto me causó mucha rabia y frustración. Recuerdo que mandé una carta al jefe de mi marido expresando mis derechos a ejercer una militancia política como cualquier otro compañero.

La respuesta suya fue que yo abría un problema de seguridad al ser pareja de un miembro de la Dirección. Es decir, mi posición era de mujer de un militante del MIR que ejercía un papel de ayudista. Esto, efectivamente, fue una pauta constante dentro del partido.

\section{5 ¿Dentro de la estructura del MIR la presencia de mujeres en los puestos relevantes fue significativa?}

Siempre fue minoritaria, aunque si que las hubo, aunque tuvieron que romper con su condición de mujer, de madre. Ser una mujer con responsabilidades en el MIR significaba asimilarse al hombre y desgastarse en su condición específica como mujer.

\section{6 ¿Hubo algunas políticas dirigidas a la mujer desde el MIR?}

Políticas de género no. Sí había algunas acciones destinadas a la mujer pero como sector social. Para hablar de políticas dirigidas específicamente a la mujer tendría que haber habido un debate interno dentro del MIR como el problema del sistema patriarcal. Esto directamente ni se debatía.

Aunque ello no quería decir que no se identificara el problema de la mujer en dictadura.

Hubo una plataforma de lucha que incluía demandas como equidad salarial, 
establecimiento de salas cuna, etc. Pero eran reivindicaciones de la mujer en el ámbito económico.

En el plano cultural, ideológico y social este debate nunca se dio. En otras palabras, eran propuestas puntuales pero en ningún caso un debate sobre la condición de la mujer dentro de ese sistema patriarcal que de alguna manera la relegaba siempre a desempeñar un papel de secundariedad. La dominación patriarcal no fue tema de debate.

En la cárcel yo empecé a leer cosas y a discutir con mis compañeras de estos temas. Es decir, fue más una iniciativa que partió de nosotras desde esa experiencia colectiva de la represión.

\section{7 ¿Cómo la detuvieron?}

A mi compañero y a mí, después de un tiempo, nos mandaron a Concepción. Allí seguí con mi labor de propaganda pero sin desempeñar tareas fundamentales. En 1984 hubo un tremendo golpe represivo a la estructura del MIR en el sur. En ese momento fue cuando asesinaron a muchos compañeros entre ellos mi marido. A mí, junto a otras compañeras, me detuvieron.

En agosto de 1984, rodearon mi casa y me tomaron presa. A mi hija se la llevaron a un hogar infantil de carabinaros. A mi me trasladaron a Borgoño, un centro de tortura y reclusión. Después me devolvieron a una cárcel de Concepción donde había una sección de mujeres. Allí me encontré con tres militantes miristas que habían estado en Italia exiliadas y entraron en contacto con el feminismo. Desde ese momento empecé a tomar una cierta conciencia sobre la condición de la mujer.

\section{8 ¿Considera que se diseñaron pautas específicas de castigo dirigidas a las presas políticas?}

Claramente sí. Desde mi experiencia te puedo decir que me encontré con militares que me decía “¡Cómo arriesgaste a tu hija por estar en esta gueá!”, es decir, que cómo rompía con el sagrado rol de la mujer buena y maternal sostenedora del hogar. 
Yo no fui violada pero sí vejada, el hecho de desnudarte y humillarte con tu cuerpo lo sufrí y claramente esto tenía una connotación sexual, genérica. Intentaban constantemente demostrarte que por haber transgredido tu papel femenino pasivo y acatador de la voluntad del hombre ibas a recibir un castigo. Se reían y te decían "Trataste de hacerte la guerrillera y ahora estas cazada como mosca porque eres una pobre mujer".

9 ¿Qué importancia jugó la procedencia socioeconómica y el estado legal de las mujeres presas a la hora de recibir un trato u otro?

Creo que las mujeres que tenían una menor formación recibían un autoritarismo mayor. Incluso dentro del MIR las mujeres que más discriminación recibieron fueron aquellas que tenían un menor grado de educación, ya no tanto su procedencia socio-económica sino más bien los recursos de lenguaje, en el plano emotivo o en el de las reivindicaciones para sortear estos problemas.

10 ¿Hubo algún tipo de reconocimiento desde el MIR a "sus mujeres" militantes por sufrir, en cierta medida, otro tipo de dificultades y represión con respecto a los hombres?

Por supuesto que no. Tengo la sensación de que las mujeres que tuvieron que dejar de ser militantes para ser madres vivieron una problemática diferente que no ha sido reconocida como tal. Hubo un proyecto destinado a las mujeres denominado "Proyecto Hogares en Cuba".

Con la operación retorno muchas mujeres dejaron en Cuba a sus hijos para continuar su militancia política en Chile. Este proyecto fue un fracaso puesto que se dejaron al cargo de otros el cuidado de los hijos y los responsables no siempre estaban preparados para desempeñar la labor de educar y cuidar hijos. Años después se comprobó que estos niños sufrieron unos traumas irreparables.

11 ¿Cómo fue su salida de la prisión? 
Bueno, mi primer objetivo fue venir a buscar a mi hija y tratar de cerrar heridas. La separación forzada con mi hija fue la huella más profunda que me dejó la represión.

Después trate de seguir con la militancia política a través de mi participación en los organismos de Derechos Humanos. Entré en contacto con mujeres del MIR, muchas de ellas feministas para realizar un trabajo colectivo con el Comité de Defensa de los Derechos de la Mujer (CODEM), organismo creado por el MIR.

Nuestra labor era realizar talleres, charlas sobre la problemática de la mujer, escuelas, actividades varias, etc. Sin embargo, con la división que hubo en el MIR, en la segunda mitad de los ochenta, las políticas dentro del CODEM fueron desplazando el tema de la mujer por el debate sobre el posicionamiento de las militantes a un sector u otro (vía política o militar).

\section{2 ¿Qué importancia tuvieron las mujeres sobrevivientes en el movimiento de los}

\section{Derechos Humanos?}

Desde el comienzo de la dictadura, las mujeres, en la búsqueda de los detenidosdesaparecidos, han tenido un claro liderazgo al igual que en la contribución a la democracia. Sin embargo, hay un punto en el que entro en contradicción, es decir, me da la sensación de que existe una tendencia de recordar o reconocer la labor de aquellas mujeres que o bien, eran vistas bajo el prisma de mujer metralleta (una mujer militar, una "no mujer") y las mujeres que han sido torturadazas y violadas.

Por este motivo, no se incluye a todo un conjunto de mujeres que no estuvieron en estas dos circunstancias y no se las recuerda de la misma manera. Es decir, ¿es que para ser recordada tenías que haber sido torturada o violada o simplemente haber caído muerta?

Yo lamento haber aportado más como militante que como militante-mujer. El aporte de las mujeres del MIR debería haber sido dar una lucha política, ideológica y humana en el interior del partido para cambiar no sólo las políticas sino las propias relaciones entre los militantes que tenían que ver mucho con el autoritarismo, el machismo exacerbado y la falta de comprensión. 
No pudimos hacer un cambio cultural dentro del partido y menos en el conjunto de la sociedad chilena. El SERNAM (Servicio Nacional de la Mujer), a treinta años del golpe todavía no lo ha logrado.

Las mujeres salieron a defender los derechos humanos porque se vieron afectadas directa o indirectamente por la represión al perder a hermanos, compañeros, hijos o esposos. Su rebeldía comenzó haciendo huelgas de hambre, encadenándose, denunciando a ONGs las detenciones y desapariciones de sus familiares, etc. Esto significó que muchas mujeres que, sin participar necesariamente en la política, asumieran un papel activo que en definitiva era político al desarrollar una movilización nunca visto en Chile.

Yo conocí a muchas mujeres familiares de detenidos-desaparecidos o de ejecutados políticos con un tremendo desgaste por su implicación en el trabajo de los Derechos Humanos. Esto, significó que su vida quedaba hipotecada a la lucha por la justicia. Esto supuso que algunas de estas mujeres asumiera en rol de "mujeres de" o "esposas de", dejando de esta forma sus propias vidas en un segundo plano.

Por esta razón, incluso podríamos decir que el modelo patriarcal se reprodujo en el ámbito de las mujeres del movimiento por los Derechos Humanos. Es sintomático que muchas de estas compañeras murieran de cáncer o por otras enfermedades. Esto quizá pudo ser un síntoma de esa tristeza o frustración por haber relegado sus vidas a esta lucha. 
10 Entrevista a LILIANA MASON PADILLA, realizada el 17 de mayo de 2004, Santiago de Chile. Mason fue militante del Movimiento de Izquierda Revolucionaria durante el período 1970-1990 y estuvo recluida en el cuartel de la Fuerza Aérea de Chile (FACH) durante los últimos tres meses de 1974. Asimismo, estuvo exiliada en Canadá durante el períodol 1975-1990.

\section{1 ¿Cómo fueron sus inicios en el Movimiento de Izquierda Revolucionaria?}

Yo me crié en una familia laica, lo que supone un punto divergente con la generalidad chilena. Mi padre era sindicalista y mi madre profesional, sin militancia partidista pero de izquierdas. Esto significó crecer bajo unos principios muy determinados que influyeron mucho en mi formación política.

En 1970 cumplí quince años, con lo que yo pertenezco a una que bajo mi punto de vista creció sintiéndose capaces de cambiar el mundo. A esta edad yo tenía ya una conciencia de que el cambio era posible.

Yo no llegué al MIR por mi familia. Yo estudiaba teatro y desde esta actividad accedí a las poblaciones en donde comencé a conocer miristas. Concretamente, comencé mi militancia en el MIR en el año 70. Mi familia me respaldo claramente.

Comencé a trabajar en el sector estudiantil. Durante los tres años del gobierno de la Unidad Popular mi experiencia estuvo centrada en la movilización estudiantil, aunque también compaginándolo con el trabajo poblacional.

\section{2 ¿En qué situación estaban el conjunto de mujeres militantes dentro del MIR?}

En este momento, no existía conciencia de género en general por parte de las mujeres. Se entendía que las mujeres tenían el mismo derecho a participar en política como los hombres, claro está después de dejar todo arreglado en la casa.

Yo recuerdo una experiencia en el MIR con una compañera, asistente social, que en un momento determinado me planteo organizar a las mujeres. A mí me pareció una excelente idea y empezamos a contactar a mujeres de la población para organizarnos en 
el Frente de Mujeres Revolucionarias. A los quince días de funcionamiento los compañeros de la dirección nos dijeron que esto no era la prioridad, jesto no es un problema de hombres y mujeres sino de lucha de clases!, decían. No tuvimos ningún éxito, y el argumento fundamental es que era un problema de clases y no de género y que después de que lográramos avanzar en este sentido podríamos trabajar las demandas particulares.

3 ¿Se pusieron en práctica algunas políticas específicas dirigidas a la militancia femenina desde la dirección mirista?

La mujer dentro del MIR siempre era concebida como madre. Sí existían demandas en el partido en lo referente a la mujer, pero siempre bajo en su función de madre, como plantear la necesidad de guarderías, alimentación, familia, etc.

Perspectiva de género no hubo en el partido, y si la hubo fue invisible. Las reivindicaciones no eran de género. No estaba incorporada la idea de que las mujeres tuvieran demandas propias, salvo ya digo, en lo referente a su condición de madre. Por otro lado, también faltó el debate y la discusión sobre la perspectiva de género.

Sin embargo, la militancia en el MIR estaba compuesta de manera equitativa entre mujeres y hombres. Pero cuando analizabas la pirámide la mayoría de los cargos de más responsabilidad recaían en los hombres. De hecho, en el Comité Central recuerdo que sólo hubo dos mujeres, y en la Comisión Política ninguna.

Los roles eran muy específicos, eran roles de mujeres. Pero concentrándonos en el periodo de la Unidad Popular, momento en el que desarrollaba trabajo poblacional los propios campesinos si me pusieron dificultades a la hora de desarrollar mi trabajo, concretamente en la viña, puesto que tradicionalmente las mujeres no limpiaban la viña, eran pequeños choques, que al final se iban superando.

En el partido si que existió un muro de machismo porque esa discusión de género nunca llegó a debate.

4 ¿En qué circunstancias estuvo el 11 de septiembre de 1973? 
Al momento del golpe yo militaba en un sector estudiantil. Después del 11 de septiembre me incorporé a otras tareas dentro del partido, propaganda, agitación, etc. En ese momento las mujeres asumimos el rol de correo, facilitadota de casas, de fachada, etc. Mirado desde hoy, indudablemente los roles eran absolutamente sexistas pero en ese momento ni se planteaba porque la debacle era tan grade que en realidad esto daba lo mismo. Las mujeres con las que trabajé fundamentalmente tenían tareas de correo, enlaces, transporte, fachada de aparentar ser esposa de, etc.

A nivel de vocabulario nosotras hablábamos de compañeros, ya que este término nos agrupaba a nosotras también. La urgencia del momento estas cosas ni se planteaban.

Sí se produjo una situación. En la medida que fueron cayendo los principales líderes las mujeres comenzaron a adquirir tareas de mayor responsabilidad, no a nivel publico, sino a nivel de partido. La relación hombre-mujer preso era de más de dos tercios de diferencia.

\section{5 ¿Cómo cayó presa?}

Yo estuve en la clandestinidad un año. Caí presa en octubre de 1974, no caí en la DINA sino en la SIFA (Servicio de Inteligencia de la Fuerza Aérea), servicio encabezado por Cevallos. Ellos de dedicaron, fundamentalmente, a desmantelar la Fuerza Central y los aparatos militares del MIR. La SIFA no estaba interesada en los militares de base ni en los cuadros medios.

Las mujeres que caímos en la SIFA fuimos muy pocas. De 100 presos que tuvo este servicio, éramos cuatro mujeres, aunque algunas si pasaron temporalmente otras. Nosotras estuvimos tres meses allí.

\section{6 ¿Cómo fue el trato que recibieron?}

Desde el punto de vista del trato a las mujeres en la SIFA no hubieron grandes diferencias en relación a los hombres. Uno de los temas más complicados ha sido el tema de las violaciones. 
Yo parto de la siguiente base, cualquier tipo de tortura que implique la introducción de objetos, ya sea en el ano o en la vagina ya es una forma de violación. Cuando colocaban corriente tanto a hombres como a mujeres siempre había algún tipo de introducción de algo en el ano. Por lo tanto, desde este punto de vista muy técnico, hombres y mujeres fueron violados, fueron penetrados de alguna manera.

Indudablemente, en las mujeres hay un contexto que es diferente, que es cultural, que es el hecho del manoseo, el abuso, etc. Esto se utilizó en la SIFA. Hay compañeras que fueron violadas, yo fui objeto de abuso. Por esta razón hay una connotación cultural con las mujeres que tiene que ver mucho con la reacción que uno tiene frente a ese tipo de situaciones. Muchas mujeres estaban "dispuestas" a que les pusieran corriente pero no a que las violasen. Este era el límite. Esto es horrible, es decir, estar dispuesta a algo terrible por haber algo más terrible todavía.

\section{7 ¿Qué factor imperó más entre las mujeres presas a la hora de ser torturadas, el de género o el de clase?}

La SIFA fue muy diferente en términos de cómo enfrentó el trato a los presos políticos. Cuando allanaron mi casa se llevaron a todo el mundo, mi padre, mi madre, mi hermano y yo. Tiempo después cuando me encontré en el exilio con mi madre, ella me cuenta que en el interrogatorio que le hizo Cevallos, éste le dijo "su hija está tomando pastillas anticonceptivas". Es decir, como es posible que esta muchacha tenga esto, en otras palabras, su hija es una prostituta.

Creo que tanto el patriarcalismo como el clasismo fueron dos factores presentes en la SIFA, pero que indudablemente tenían que ver con quién te interrogaba y en qué momento lo hacían. La SIFA fue muy inteligente en buscar cual fue el elemento que iba a pesar más en la persona.

Con los años, supe que un compañero me entregó con todos mis datos y antecedentes. Ellos sabían todo de mí, mi extracción de clase, etc. Indudablemente, el factor de clase jugó un rol, fundamentalmente frente a los guardias. Todo se resumía en esto, si uno era arrogante con un guardia uno iba a tratarte de forma más sumisa, y más sabiendo que 
una tenía educación y venía de la burguesía. En términos generales, el factor de clase primó.

De todas formas, hay que hacer una distinción entre las dinámicas que se daban en la SIFA y en la DINA. Normalmente, los agentes de la Dirección Nacional de Inteligencia tenían un menor grado de formación. El personal de la SIFA fue diferente. Nosotras fuimos reprimidas por un aparato de inteligencia en donde los militares rasos eran la minoría.

En cambio, en la DINA primaban, dentro de los agentes represores, sectores marginales. La DINA captó a muchos miembros que no necesariamente pertenecían al ejército y que los incorporaron allí por su capacidad de reprimir. En la SIFA, sólo el hecho de tener una formación marcaba la diferencia, lo que no quiere decir que se cometieran atrocidades.

Un ejemplo muy sintomático es el caso de Cevallos. El siempre comentaba que había tenido una formación en Inglaterra y de haber estado en Panamá, en términos de preparación como oficial de inteligencia. El decía, "en la DINA son unos brutos, yo soy del mismo nivel que ustedes, yo leo, yo soy capaz, por lo tanto no me engañen porque al final los voy a descubrir".

En lo referente a la mujer, yo conviví con una compañera que sí fue increpada constantemente por ser casada y militante al mismo tiempo. Cevallos bajaba a los subterráneos para increparla por haber abandonado su hogar.

\section{8 ¿Qué papel jugó la utilización de los hijos en la tortura con las presas políticas?}

En la SIFA, no recuerdo casos de hombres que hayan sido chantajeados con los hijos, aunque después me enteré que sí hubo casos de chantaje a los presos. Sin embargo, creo que este facto se daba más con las mujeres, por lo menos desde mi experiencia.

En el caso de la mujer se uso el tema de los hijos, fue una experiencia muy traumática. Cevallos iba siguiendo a un compañero y en un momento determinado en un allanamiento a su casa encontró una foto de una niña. EN la prisión, estaba la madre de 
este compañero y Cevallos entró a la celda y le tiró la foto en su falda. Ella se puso blanca al mirarla, y Cevallos exclamó ¡Ya, gracias!, no necesitaba saber más. Hay claramente un elemento de inteligencia que operaba con cierta especificidad con las presas. Cevallos sabía que como madre iba a tener una reacción.

En el caso de mis padres el tema de los hijos también fue usado como mecanismos de presión. Les hacían oír mis interrogatorios, les presionaban conmigo, porque era su hija.

En cambio con mi hermano, que también estuvo detenido, esto no se hizo. Claro, hay un uso de los hijos para sacar información, y especialmente con las mujeres.

\section{9 ¿Podemos hablar, entonces, de una estrategia específica a la hora de reprimir a las presas políticas?}

Creo que nada de lo que pasó en este país fue producto del impulso loco de alguien. Quizá los primeros días, las ejecuciones sumarias, etc., fueron producto de un descontrol de los oficiales. Sin embargo, dentro de lo que eran los aparatos represivos no creo que nada estuviera hecho al azar. En otras palabras, hubo una clara planificación y a una elaboración de con quiénes se iban a encontrar, de buscar nuestras debilidades, de hecho, es sintomático que el modus operandi de los represores coincidieran con los manuales de la CIA.

Hay una anécdota que corrobora esto. Un mes después de caer, un día un oficial me sacó de la celda y me llevó a un segundo piso; comenzó a abusar de mí sexualmente. Yo me puse a gritar y el escándalo fue enorme; el tipo me golpeó mucho pero en ese instante apareció un oficial y le ordenó que me dejara tranquila. No se muy bien lo que pasó porque estuve dos días inconsciente.

Fue Fuentes Morrison, connotado asesino, pero él le dio la orden de parar. Pero lo que es indudable es que ese abuso no era parte de ningún interrogatorio, y probablemente por esta razón lo pararon. Esto nos da la idea del nivel de estructuración y organización de un proceso planificado, es decir, de una estrategia de cómo tratar a los presos, a las mujeres, etc. 


\section{0 ¿En qué circunstancias salió de la SIFA?}

A mi me trasladaron a La Correccional porque era la única mujer menor de edad (19 años) y además yo caí presa junto con grades dirigentes con lo que yo no era una gran prioridad para el Consejo de Guerra. Cevallos a mi me amenazó con entregarme a la DINA, me decía “a mi no me interesáis, pero la DINA se va a encargar de ti”. Sin embargo, no se que me salvó de eso, no había un lógica porque muchos de mis compañeros desparecieron teniendo menores responsabilidades partidarias que yo.

Hay un elemento que da muestra de ese grado de planificación. Yo sufro de epilepsia, y Cevallos utilizó mucho conmigo esto contra mí, él me decía "la corriente eléctrica es lo peor que te puede pasar a ti”. El sabía de mi problema y me negó mis medicamentos, con lo que una tiende a pensar el grado de conocimiento y organización con los presos.

Después de la estar en la SIFA salí a la COF (Correccional) en donde estuve un mes. En la COF primó el factor de clase. El trato que recibíamos las presas por parte de las monjas dependía mucho de nuestra procedencia socioeconómico. Recuerdo a una hija de un exmarino y a ella le dieron una sala especial y un trato claramente distinto.

Después pasé a Tres Álamos en donde viví una experiencia dual con las presas. Primero, porque el factor de género primó mucho. El comandante Conrrado Pacheco nos formaba todas las mañanas y nos increpaba diciéndonos que éramos unas putas, que habíamos votado a las familias, que nos habíamos metido con extremistas, etc. Esto fue una cosa sistemática, que sin embargo no ocurría con los hombres. El discurso estaba basado en nuestro pecado de ser mujeres metidas en política y además con extremistas.

En segundo lugar, el factor de clase también existió en Tres Álamos pero fundamentalmente con la guardia. El trato a las presas con formación universitaria y una profesión era de señoras. Por el contrario, el trato para el resto era distinto.

11 ¿Cómo fue la convivencia entre las presas? ¿Hicieron alguna labor de recopilación de información sobre las experiencias vividas, es decir, lugares por los que habían pasado, a quiénes vieron, etc.? 
La mayor parte de las mujeres éramos miristas, con lo que el discurso era el mismo. Había compañeras del PC que tenían otros puntos de vista al igual que las mujeres socialistas. Pero el noventa por ciento éramos militantes del MIR. Esto no ocurrió con los hombres. Además, las pequeñas diferencias que pudiera haber con las mujeres se iban superando, cosa que entre los presos solían ser trabas bastante difíciles de superar.

No sé si las mujeres fueron más heroicas que los hombres, pero por el mero hecho de tener menos responsabilidad política las mujeres estuvieron más unidas. En este sentido, organizamos una estructura que funcionaba para ordenar información y dirigir la vida interna en el campo. Esto permitió crear grupos de talleres de tejido y bordado, lo que, por otra parte, significaba reproducir el rol de siempre. Nosotras asumimos este rol con toda naturalidad y nadie cuestionó esta tarea.

Sin embargo, esta organización solidaria permitió una clara organización de las mujeres, para reivindicar mejoras en las condiciones en el interior de Tres Álamos, castigos impuestos, etc. Esta movilización no se dio con los hombres, quizá por que eran más, o no supieron superar las diferencias.

\section{2 ¿Qué opinión imperaba entre las presas los casos de compañeras quebradas por la} tortura que habían optado por colaborar con la represión?

Bueno, hay que establecer una diferencia entre aquélla que entrega información bajo la tortura y la que da el paso a la colaboración posterior a la tortura. Esto último caso fue el de la Flaca Alejandra y Luz Arce, que aunque una pueda entender que en el momento de la tortura pudieran dar información, pero que claramente, su voluntada fue la de continuar colaborando, aquí es, precisamente, donde establezco esa diferencia. Dar ese paso implicaba que la propia voluntad entraba en juego.

En el primer caso, se cometió un grave error con los compañeros y compañeras que hablaron en la tortura, porque en vez de recuperarlos los hundimos. Tardamos mucho tiempo en asumir este error, porque hay que recordar que éramos extremadamente jóvenes y se nos escaparon muchas cosas. 
El MIR fue el primer partido que a la juventud le dio un rol que implicaba tomar decisiones, lo que no ocurría en el PC o en el PS en donde la experiencia y la edad eran factores imperantes. Esto, claramente, significó una clara diferencia a la hora de tomar decisiones, reflexionar con los problemas, etc.

Las mujeres en su conjunto lograron organizarse mucho más que los hombres aunque el nivel de discusión política de las presas era menor.

\section{3 ¿Podemos hablar de los inicios de una toma de conciencia feminista entre las presas políticas?}

Yo creo que las mujeres que tuvieron hijos en este período sí se replantearon sus relaciones de pareja y el mismo hecho de conjugar la militancia política con la maternidad. La crianza del hijo, en estas condiciones, supuso que algunas compañeras reflexionaran sobre su propio rol como mujer y como militante. Este no fue mi caso porque yo no tuve hijos en este periodo. Yo no asumí una conciencia de género sino más bien una conciencia de lucha política contra lo que nos estaba sucediendo.

Sin embargo, si empezamos a asumir la conciencia de que el peso de la familia comenzaba a centrarse en las mujeres. Muchos de los hombres estaban presos con lo que las responsabilidades iban quedando en manos de las mujeres, lo que implicó que las mujeres fueran a buscar trabajo, a buscar una fuente de ingreso. Pero esto no fue más allá de cubrir unas necesidades básicas, lo que significa que no creo que podamos hablar de un nivel de conciencia específica de género en ese momento.

Sí hubo un punto de inflexión que fue precisamente la ausencia del marido o el pater familias que impulsó el acceso de la mujer a la esfera pública. En mi caso, mi padre estuvo dos años preso, y a él le preocupaba mucho el hecho de que mi madre estuviera trabajando y asumiera las responsabilidades de proveedora que anteriormente habían recaído sobre mi padre.

En todo caso, este reemplazo fue momentáneo, porque la mujer en vez de aprovechar este cambio, con el paso del tiempo, volvió a desempeñar su rol tradicional. 
Hay un factor sintomático de esto, es decir, hubo mucho nacimiento en los primeros años noventa, lo que significó que muchas mujeres optaron por tener hijos pasada la represión y abandonar las otras tareas desempeñadas bajo dictadura.

\section{4 ¿En qué circunstancias salió de prisión?}

Yo salí muy enferma, con mi problema de la epilepsia. Ocasionalmente, me llegaban las pastillas, pero no seguí un tratamiento adecuado lo que me trajo muchos problemas. Recuerdo cuando vino la Comisión de Derechos Humanos de la OEA, a tres compañeras y a mí nos trataron de internar en diversos hospitales para dejar en prisión a las que estaban sanas.

En mi caso, me intentaron ingresar en el hospital psiquiátrico. Yo sabía a través de una compañera médica que algunos presos políticos habían terminado allí y habían sido sometidos a experimentos. Para mí, terminar en el psiquiátrico era lo peor que podía ocurrirme. Afortunadamente, pude hablar con un médico quién entendió que mi situación no era la adecuada para ingresarme en dicho centro.

Finalmente, a mi me dieron la libertad pero con decreto de expulsión. Salí a Canadá en agosto de 1975. Precisamente, será en el exilio donde me enfrenté por primera vez a la perspectiva de género. Concretamente, en septiembre de 1975 (Año Internacional de la Mujer), asistí a una conferencia con un grupo de mujeres en donde se cuestionaba la condición de mujer en la dictadura.

Fue un choque muy fuerte, porque yo no tenía en mi esquema mental, primero, una conciencia de género, y segundo, lo que esto implicaba, es decir, una crítica al MIR.

En Canadá seguí con mi militancia política hasta 1989. Yo estuve en el exilio hasta 1991. En este período fui integrando elementos que ayudaron a reafirmar esta perspectiva de género y la capacidad de realizar una crítica a la vida partidaria.

Sin embargo, esta adquisición de conciencia de género no supuso trasladar unas propias demandas al interior del MIR, porque, al igual que otras compañeras, yo tenía muy 
presente que la principal lucha era el derrocamiento de la Junta Militar y que después, veríamos otras cuestiones más específicas.

Sí me ocurrieron cosas que me marcaron como mujer militante. Recuerdo una ocasión que viajé a Nicaragua para asistir a una conferencia y dejé a mi hija de meses con el padre y fui objeto de innumerables críticas de los compañeros y compañeras del MIR.

\section{5 ¿Cuáles fueron sus tareas partidarias en el exilio?}

Yo asumí puestos de dirección. El hecho de ser mujer no me impidió seguir con mi militancia política, pero no se sí fue por la situación de excepcionalidad, es decir, que muchos compañeros estaban presos o desaparecidos y que era necesario la participación de las mujeres en los puestos de responsabilidad, o bien por mi insistencia en continuar mi trabajo partidario pese a las críticas y al hecho de tener una guagua. Recuerdo, que el rol de la mujer en el exilio era hacer empandas, un rol que jamás estuve dispuesta a asumir. Yo era el bicho raro. No recuerdo a más compañeras en las direcciones.

Hubo un punto de inflexión cuando el MIR se planteó el retorno y el qué hacer con los hijos de los retornados. Yo fui muy crítica con la política del MIR, aún sin tener todavía a mi hijo. La mayoría de mis compañeras quedaban en el exilio a cargo de los hijos mientras que sus compañeros o maridos regresaban a Chile para continuar con la lucha política.

Las compañeras que se quedaban asumieron en muchas ocasiones el rol de "viudas de mártires”. En este punto, adquirí una fuerte conciencia de género. Esto desató discusiones muy intensas, donde hombres y mujeres se reafirmaron en la idea de que las mujeres debían asumir la perspectiva de ser viudas dolientes a las que se le estaba negado el derecho a emparejarse de nuevo, a tener una vida afectiva. Esta discriminación fue un detonante claro para revelarme contra un rol que yo no estaba dispuesta a asumir bajo ningún concepto.

El sistema de los hogares de Cuba fue el colmen de todo este proceso. Fue un claro desastre, muy dolorosa para los hijos que tenían que separarse de sus padres y convivir con gente que no necesariamente era la idónea. 
La norma era, si la pareja partía y tenían hijos, los hijos se iban a estas hogares, si no se optaba por esta vía el hombre partía y la mujer se quedaba en el exilio cuidando de los hijos. Las compañeras que se revelaron contra este modus operandi fueron tremendamente criticadas y repudiadas, tanto por hombres como por mujeres de la militancia mirista.

Yo cuando llegué a Canadá quise formarme, quise estudiar y no quedarme en esta situación. En el partido me sugirieron que estudiara enfermería, nada más alejada de mis expectativas. En este momento, el MIR sacó una nota en la que se sugería una serie de carreras para sus militantes, concretamente, para la mujer, enfermería, asistente de cocina, etc. Esto fue algo muy simbólico sobre la concepción de los roles genéricos dentro del MIR.

De hecho, muchos dirigentes miristas estaban casados con mujeres que no desempeñaban una militancia política, y si la había, las prioridades pasaban por el compañero, es decir, de apoyo al hombre.

Éramos pocas las mujeres que estaban dispuestas a militar activamente en el MIR, pero esto, pasaba claramente por no tener hijos. Mi hijo nació en 1981, y recibí muchas críticas cuando delegué el cuidado de mi hijo a mi compañero para poder desarrollar mis responsabilidades políticas.

16 ¿Se produjo algún tipo de confrontación entre las mujeres que habían vivido una experiencia en el exilio con las que se habían quedado en Chile a la hora de plantear reivindicaciones de género?

Indudablemente, hubo muchas diferencias. El exilio significó, entre otras cosas, adquirir una visión critica de los roles que las mujeres tenían asignados en el interior del partido. Las mujeres que se quedaron en Chile, en su mayoría, no adquirieron una conciencia de género, con lo que ellas no se sentían oprimidas dentro de esa especificidad.

El exilio dio una visión más abierta sobre las relaciones de género. Precisamente, los foros de discusión entre las mujeres miristas ayudó en buena medida a adquirir esa 
conciencia, claro está que no todas las mujeres aprovecharon estas circunstancias para introducir un cambio o una crítica del MIR.

Cuando el CODEPU organizó en 1984 un departamento de trabajo con mujeres, se creó un espacio para visualizar algunas reivindicaciones de género que implicaba, asumir algunos problemas que las mujeres tenían dentro de la militancia política como en el contexto de la represión.

Muchas ideas fueron incorporadas por mujeres que habían estado fuera de Chile y que venían con nuevas perspectivas, que no siempre eran bien recibidas. Pero, tuvo que ser en el CODEPU en donde se empezaron a plantear estas cuestiones, y no en el interior del MIR.

En un momento muy determinado tuve que optar por ser dirigente del partido o mi relación de pareja. Mi compañero también estaba en un nivel de dirección en el MIR, aunque yo estaba por encima de él. Esto era fue una situación excepcional. Durante mucho tiempo no tuve problemas con esto, pero en un momento sí que se planteó un problema con mi pareja. Yo opté por salvar mi relación y no asumir más responsabilidades en el partido porque ello conllevaba problemas en mi vida afectiva.

Se me planteó la responsabilidad de trabajar en Naciones Unidas, esto implicaba muchas cosas, entre ellas, el grado de frustración de mi pareja, porque él también tenía capacidad para hacerlo. Yo decidí que la tomara él y seguir con mi militancia política. El problema de fondo fue el cuidado del hijo.

\section{3 ¿Cómo fue su regreso a Chile?}

En 1989 me separé de mi pareja y me desligué del MIR. En 1990 regresé a Chile sin tener muy claro lo que iba a pasar. El retroceso cultural que pude ver a mi regreso fue tremendo. Mi primer choque fue cuando fui al Ministerio para realizar una entrevista de trabajo, y lo primero que hizo el tipo fue invitarme a comer. Esto supuso un sock muy fuerte para mí y hay cosas que una no está dispuesta a tolerar. Fueron unos años muy difíciles, de reflexión sobre lo que había sido mi vida y mi adaptación a una realidad muy diferente a la que había dejado. 
Finalmente, terminé trabajando en el Instituto de la Mujer en donde entré en contacto con feministas radicales. Allí pude reflexionar sobre la problemática entre hombremujer, que al fin y al cabo, la superación de la misma no pasa por la imposición de un grupo sobre otro, sino por el entendimiento sabiendo que lo que nos separa no son las pequeñas diferencias sino más bien la cuestión de cómo asumir el manejo del poder. 
11 Entrevista a CECILIA BOTTAI MONREAL, realizada el 18 de mayo de 2004, Santiago de Chile. Bottai fue militante del Movimiento de Izquierda Revolucionaria y estuvo presa en los centros Villa Grimaldi, Cuatro Álamos y Tres Álamos. Partió a Italia en calidad de expulsada, en donde permaneció desde 1976 hasta 1991. A su regreso participó activamente en diversas agrupaciones de derechos humanos.

\section{1 ¿Cómo fueron sus inicios en el Movimiento de Izquierda Revolucionaria?}

Yo vengo de una familia en donde siempre hubo mucha sensibilidad con los problemas sociales. Mi tía pertenecía al Partido Comunista. Mi madre, sin pertenecer a ningún partido político, siempre me transmitió valores de solidaridad. Mi madre nos crió con mucho esfuerzo ya que mi padre falleció cuando yo tenía sólo cuatro años. Recuerdo que mi madre nos decía que teníamos que ser independientes en nuestras vidas.

Durante los gobiernos de Salvador Allende, cuando estaba en el cuarto año en la escuela dental de la Universidad de Chile, tuve mi primera experiencia en la movilización político-social. En este tiempo llegaron los brasileños que provenían de las cárceles de Brasil. Desde esta experiencia de solidaridad supe que la incorporación al trabajo político me interesaba enormemente.

Asimismo, compaginé esta labor con la militancia en el Movimiento de Izquierda Revolucionaria. Ellos aceptaron, por decirlo de alguna manera, la doble militancia. Concretamente, un mes antes del golpe de Estado me incorporé plenamente a la militancia en el MIR.

Mi labor dentro del partido fue variada. En los comienzos realicé tareas de enlace y de seguridad con el Comité Central. También trabajé en labores relacionadas con mi profesión, es decir, en el tema de la salud como dentista.

En febrero de 1974 yo me fui de casa porque tenía miedo de involucrar a mi familia. En mayo, cayó detenida la persona con la cual yo trabajaba con lo que tuve que estar en la más absoluta clandestinidad porque sabía que me estaban buscando. No pude sacar mi título de graduación de egresada en medicina. Sin embargo, seguí realizando una labor de apoyo sanitario. 
En septiembre del 74 me puse a vivir con un compañero. En este período a mi mamá la tomaron presa, al igual que a mi primo, a mi cuñado y a mi hermana que estaba embarazada, porque la DINA fue a mi casa a buscarme. Yo no supe de este hecho hasta mucho después.

A mi hermana la torturaron estando embarazada; la preguntaban por mi paradero. Ellos querían saber ante todo dónde estaba porque yo era la única militante en el MIR. Por lo que supe después, el guatón Romo (conocido torturador de la Villa Grimaldi) fue en varias ocasiones a mi casa.

En enero del 75 nació el niño de mi hermana en Tres Álamos. A partir de ahí la pusieron en libertad al igual que a mi madre para posteriormente volverlas a detener y llevarles a Villa Grimaldi. Mi familia cayó presa porque alguien habló sobre mí, aún sabiendo que yo no estaba. Destruyeron a toda mi familia.

Yo no supe nada de este proceso de detenciones hasta que ellos salieron definitivamente de prisión. A mi mamá la torturaron mucho en Villa Grimaldi, casi la mataron. Una de las cosas más difíciles que me tocó vivir fue, precisamente, la detención de mis familiares, esto me produjo un dolor enorme. De hecho, mi madre falleció tiempo después como consecuencia de los efectos de la tortura.

\section{2 ¿En qué circunstancias cayó presa?}

A mi me detuvieron en septiembre de 1975, un año después de que la DINA llegara a mi casa. Yo caí por una persona que habló sobre mí. En este sentido, mi círculo empezó a cerrarse por las diversas detenciones. Lo cierto es que en un momento estuve muy desamparada porque no sabía en dónde refugiarme, es decir, no tenían ninguna casa de seguridad donde ir. A mi marido le detuvieron, el también cayó por otro compañero.

A mi me llevaron al centro de tortura Villa Grimaldi, en donde permanecí dos meses. Me sentí muy decepcionada porque el partido no me ayudó lo suficiente. Después de haber pasado más de un año en la clandestinidad me quedé aislada y sin un lugar en donde refugiarme. En este punto, puedo establecer un punto de crítica con el MIR 
porque, en cierto sentido, su desorganización no pudo darme una vía de salida a mi situación.

Me pasé tres días en la calle caminando sin encontrar una casa. No me ayudaron, y después yo supe que ellos dijeron que yo era muy peligrosa y que tenían que dejarme, según el MIR mi situación era demasiado arriesgada y que podía comprometerlos.

A mí no me dejaron asilarme porque dijeron que no era conveniente. Después supe, que dos meses después de estar detenida, dos dirigentes del Comité Central del MIR se asilaron. Yo me planteé ¿por qué ellos sí y yo no?. Creo que el excesivo estructuralismo del MIR, así como el de otros partidos, quitó cierta humanidad a la militancia política.

\section{3 ¿Cómo fue su experiencia en Villa Grimaldi? ¿Pudo ver un trato diferente con las presas políticas?}

El hecho de que las parejas estuvieran casadas legalmente daba un cierto respeto. Las personas que no eran casadas solían ser mayormente maltratadas. En cuanto a la tortura creo que fue igual para los hombres que para las mujeres.

Sin embargo que a nosotras, por el hecho de ser mujer tuvimos un problema diferente, que fue la violación sexual. Desnudarte y ponerte electricidad por todo tu cuerpo y tu sexo fue una realidad. Esto también lo sufrió el hombre, pero creo que las mujeres fuimos más vulnerables que los hombres, por lo menos en el aspecto sexual.

Cuando yo caí detenida yo tenía más de dos meses de embarazo. A mi me pusieron electricidad en la vagina y me provocaron el aborto. El Romo, me puso electricidad precisamente para provocarme el aborto. Este dolor nunca lo voy a olvidar. Como mujer no puedo olvidarlo, es una cruz que una debe llevar toda la vida. Me provocaron el aborto estando amarrada en un catre sabiendo que me estaban poniendo electricidad con un objetivo tan criminal y atroz que una lo único que sentía era una tremenda impotencia por no poder salvar a mi hijo. 
La mujer fue más vulnerable por esto. En Chile hay diez mujeres embarazadas detenidas-desaparecidas. Pero, muchas mujeres, pasaron lo mismo que pasé yo, perder al hijo por la tortura, que no sale en ningún reportaje.

Entre las mujeres se estableció una relación de humanidad que recuerdo muy bien. De hecho, incluso en ocasiones guardábamos comida para los compañeros que estaban en peores condiciones que nosotras.

También en la Villa fueron muy clasistas. Yo era casi doctora y el trato, a pesar de que nos torturaran igual, era diferente. Un soldado me comentó una vez que le diera una lista de lo que necesitábamos. Nos dejaron lavarnos lo que nos pareció maravilloso a las mujeres por la cosa del período. Nos dieron ropa y cepillos de dientes (uno para cada cinco personas). Trajeron las cosas de mi casa, esto creo que fue un acto clasista porque no se dio con otros compañeros.

Creo que a muchos hombres también los violaron. Pero al mismo tiempo hay un hecho muy claro. Primero hay que analizar que es la tortura. Para mí el hecho de desnudarte es un atento contra tu sexualidad. Solamente esto ya es una violación de tu identidad, de tu sexualidad y tu privacidad. Ellos podían hacer lo que quisieran con tu cuerpo.

Luego está el tema de la tortura psicológica, que en mi caso, me afectó mucho más. En este sentido, quizá las mujeres visualicemos más esto que los hombres. A los compañeros quizá les da más pudor hablar de esto.

\section{4 ¿Cómo fue su salida de Villa Grimaldi?}

No se que me salvó. Yo pensé que me iban a matar. El Romo me llamó después de haberme torturado mucho. Físicamente estaba muy mal, pero peor estaba psicológicamente. El quería que yo dijera que Patricio, mi compañero, hablara. A él lo torturaron mucho. De hecho, lo torturaron tanto que tuvieron que llevarle al hospital para que se recuperara y seguir torturándole después.

No había lógica. El Romo me dijo "usted tiene las cartas" a lo que contesté "no tengo ninguna, usted tiene mis cartas". Yo sabía que el Romo había torturado a mi madre y a 
mi hermana pero no dije nada. Yo pensé que después de esta conversación me iban a matar, pero me mandaron a Cuatro Álamos en donde me dejaron sola.

Después me llevaron a Tres Álamos en donde estuve siete meses. Tuve mucha tristeza por la pérdida de mi bebé y a esto había que añadirle la preocupación por la situación de mi marido y mi familia.

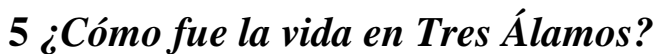

La convivencia con las mujeres en Tres Álamos fue muy buena. Yo cuidé la guagua de otra mujer. Creo que las diferencias políticas no supusieron ningún problema a la hora de relacionarnos entre nosotras. Asimismo, creo que nadie podía juzgar a las quebradas porque la tortura fue muy dura. No todas pudieron aguantar la tortura sin dar información. Lo que hay que condenar es el atropello de los derechos humanos y al que tortura, nunca a quién es torturado.Las mujeres tuvimos una estructura muy buena de trabajo y solidaridad. Los hombres eran más desorganizados que nosotras. Distribuíamos las cosas según las necesidades de cada una.

\section{6 ¿En qué circunstancias salió de prisión?}

Yo salí en a finales de 1975. Pero siempre me siguieron. Empezaron a amenazarme con mi familia para que saliera del país. La Cruz Roja, tras varios avatares, me ayudó mucho. El MIR me dijo que si me exiliaba me echaban del partido. Si hubiera podido irme antes lo hubiera hecho. Finalmente, en 1976 salí exiliada a Roma en calidad de repatriada porque mi familia era italiana. Yo lo único quería era irme de Chile.

Sin embargo, cuando llegué a Italia los compañeros del MIR me recibieron. Yo seguí trabajando durante un tiempo en el MIR, pero poco a poco me fui desligando el partido porque mi prioridad fue reconstruir mi vida y ocuparme, después del regreso de mi marido, del hijo que venía en camino. Tuve que elegir entre la militancia política o mi vida personal y elegía la segunda aunque sin desconectarme de todo el tema de los Derechos Humanos. 
Yo trabajé con mujeres comunistas porque nunca fui sectaria. Me unía más el sentimiento de solidaridad y humanidad que las diferencias políticas. Juntas empezamos hacer juntas cuatro diarios llamados Voz de la Mujer. Fue un trabajo realizado desde la clandestinidad que recogían diferentes testimonios de mujeres de varios estratos sociales que hablaban de sus experiencias bajo la represión.

Yo planté al partido la iniciativa de las mujeres con este trabajo. De forma oficial no pusieron ningún problema, pero en la práctica, cuando mandamos los diarios, empezaron los problemas. De hecho, alegaron que no era adecuado en ese momento plantear demandas del género femenino. Era una propuesta de varias mujeres que opinaban sobre la dictadura y sobre lo que podían aportar a la lucha partidaria, que no interesó en absoluto a los jefes.

Yo vi mujeres que estaban a cargo de importantes responsabilidades políticas. Lo que no significa que no viviéramos algún tipo de discriminación por ser mujer. Yo siento que podría haber ayudado más en algunas cuestiones, como en mi experiencia en el tema de la seguridad por lo que aprendí con los refugiados brasileños. En algunas ocasiones, ellos no me escucharon, y no sé si esto fue por el hecho de ser mujer o porque simplemente no creían necesaria mi aportación.

Para mí, la militancia política en el MIR fue un período fundamental en mi vida. Éramos muy jóvenes y con unos ideales de cambio que nos hacía dar nuestra vida por ese cambio. Sin embargo, esto no quita que una, con el paso de los años pueda hacer ciertas críticas y reconocer que fallaron muchas cosas. Concretamente, en la vida que llevábamos en la clandestinidad que fue muy dura y en algunos casos una se sintió muy desamparado por los propios compañeros de partido. 
12 Entrevista a LELIA PÉREZ VALDÉS, realizada el 17 de junio de 2004, Santiago de Chile. Valdés fue militante del Movimiento de Izquierda Revolucionaria y estuvo presa en el centro Villa Grimaldi. Asimismo, estuvo exiliada en Venezuela durante el período 1976-1986.

\section{1 ¿Cómo fueron sus inicios en el Movimiento de Izquierda Revolucionaria?}

Mis abuelos fueron de origen campesino, mi padre profesor primario y mi madre dueña de casa. Mi procedencia es humilde pero el hecho de ser hija de un profesor marcó una diferencia en mi caso, especialmente en el tema de formación cultural y política.

Estudié en el colegio Darío Salas, un liceo de izquierdas en donde todo el movimiento estudiantil de los sesenta estaba a flor de piel. En 1971 me acerqué a la vida política dentro del Liceo, es decir, a los centros de alumnos, consejos de curso, movilizaciones en protesta por la guerra de Vietnam, etc.

En ese año yo me acerqué al FER, al Frente de Estudiantes Revolucionarios para pasar a ingresar, con catorce años, en el MIR. En ese momento en el que la Unidad Popular ya estaba funcionando, nosotros nos dedicábamos a fortalecer la militancia en el MIR a través de la venta del periódico El rebelde en las industrias. Esta fue una de las tareas principales que yo desarrollé pero también hice tareas en el movimiento pobladores donde se hacía trabajo de alfabetización y voluntario. Teníamos contactos con el Frente de Trabajadores Revolucionarios (FTR) y con el Movimiento de Pobladores Revolucionarios (MPR), ambos frentes vinculados con el MIR y principal vía de fortalecimiento del mismo.

En 1972 comencé otra tarea de mayor relevancia al participar en la tarea de fortalecimiento de los Comandos Populares. Este trabajo tuve que compaginarlo con mis estudios y con las actividades de la Federación de Estudiantes de Secundaria (FESEC) que estaban dirigidas a que el MIR se incorporara en el contexto de la izquierda política, es decir, en el gobierno de la Unidad Popular.

Yo inicié el proceso natural dentro del MIR que pasaba primero por ser simpatizante, después aspirante y después militante en el año 72. Mi tarea fundamental fue siempre en 
el área estudiantil pero con algunas responsabilidades dentro de los comités locales, de hecho fui jefa del GPM N7 (Grupo Político-Militar) de la zona centro, en donde teníamos reuniones todas las semanas sobre las tareas y posicionar al MIR en el ámbito estudiantil, en el mundo obrero y en pobladores.

\section{2 ¿Tuvo algunas dificultades a la hora de acceder a las responsabilidades políticas partidarias por ser mujer?}

En los primeros años de mi militancia yo no tenía la percepción de que hubiera discriminación en el MIR. Sin embargo, con el paso de los años pude darme cuenta de que el tema de la mujer no estaba planteado. En teoría nos considerábamos iguales, y el feminismo se veía como una problemática burguesa.

Mis compañeras desempeñaron siempre una militancia de base y en algunos casos en los cuadros medios, pero no había una presencia equitativa de la mujer en los puestos de dirección del partido.

\section{3 ¿Qué tareas partidarias estuvo desempeñando en el momento del golpe militar?}

El 11 de septiembre yo estaba en clase dando una prueba. Nosotros tratamos de organizar la resistencia, que era básicamente quedarnos en el colegio y esperar instrucciones que nunca llegaron.

Cuando se inició el bombardeo en la Moneda abanamos el Liceo para dirigirnos a un lugar previamente concertado para esperar instrucciones del MIR. Este lugar, era en la Alameda, cerca de la Universidad de Santiago. Mandamos unos contactos para recibir información pero horas después mis compañeros y yo caímos presos.

\section{4 ¿Cómo fue su detención?}

La primera vez que caí presa fue en la madrugada del 12 de septiembre del 73. Fui traslada al Estadio Chile junto con 18 militantes del MIR. Éramos cuatro mujeres y una de ellas fue asesinada. El trato fue terrible porque nos acusaban de francotiradores y que 
estábamos condenados a muerte. Sin embargo, tuvimos la suerte de que hubo un cambio de oficialidad y esto se paró.

En la fase de los interrogatorios hubo un tratamiento diferenciado con las mujeres porque la agresión sexual fue una experiencia vivida por la mayoría de nosotras. Descalificaciones por no estar en la casa, que debíamos dedicarnos al cuidado de los hijos, este era el discurso que se daba. Además nos utilizaron como conejillos de indias, ya que hay que tener en cuenta que en los primeros días del golpe la tortura no estaba todavía muy definida. Experimentaron con nosotros.

\section{5 ¿Usted creé que se establecieron pautas de castigo específicas con las presas políticas?}

En mi experiencia en el Estadio de Chile esto si que ocurrió. A nosotras nos violaron delante de ellos, una forma de demostrar su poder a nuestros hombres, era una forma de derrotar a nuestros compañeros como hombres.

Mientras fuimos agredidas sexualmente ningún compañero dijo nada. 25 años después conversando con un amigo le dije "cuando me violaron delante de ti tu no hiciste nada”. La respuesta era que no se podía, pero cuando tuvo hambre si pudo protestar.

\section{6 ¿En qué circunstancias salió del Estadio Nacional?}

Hubo mucha movilidad de los oficiales, y en este contexto muchos soldados y suboficiales quemaron expedientes, entre los cuales estaba el mío y el de algunos de mis compañeros. En estas condiciones salimos en libertad porque no tenían pruebas fehacientes de nuestras actividades. Cuando nos preguntaron que por qué habíamos caído presos nosotros alegamos que por haber violado el toque de queda.

Cuando salí del Estadio, el 22 de septiembre de 1973 me contacté con mi familia y con el MIR. Me reinicié en tareas de propaganda, conseguir locales y financiación desde la clandestinidad (asaltos a bancos). Asimismo, continué con mis estudios. 
La idea era crear pequeñas acciones de resistencia y hacer una valoración del estado en el que se encontraba en MIR en Santiago. En ese momento, pasé del GPM No 7 al No 9 en donde Lucrecia Brito era la dirigente con mayor peso.

En el GPM 9 había pocas mujeres. Cuando Lucrecia cayó detenida en el año 74 yo me cambié de estructura, al denominado grupo de apoyo de dirección. Además, mi pareja era miembro de este núcleo y la consigna del MIR era que todas las parejas se reagruparan en las mismas estructuras de trabajo para que en el caso de caer uno preso no se produjera el efecto dominó.

Mi labor era de reconexión porque el MIR había recibido golpes muy fuertes por la represión y estaba muy disperso. La idea era trabajar en reconectar a la gente y tareas de infraestructura, es decir, conseguir lugares seguros.

\section{7 ¿Cómo fue su segunda detención?}

Yo volví a caer presa en el año 75 momento en el que hirieron a Pascal Allende y Gutiérrez. Esto produjo un sock, porque posteriormente se exiliaron y ellos se asilaron con lo que generaron una situación compleja porque la política del MIR era no asilarse. Asimismo, cuando cayó Mayoco cayeron todas las estructuras del MIR, el Comité Central, los comités regionales, locales, con lo que yo caí también.

En octubre del 75 caí presa junto con mi marido. Nos trasladaron a Villa Grimaldi y allí estuvimos tres meses. Al principio estuve en la celda de las mujeres pero allí no había nadie de mi estructura.

En Villa Grimaldi desarrollamos estrategias de sobrevivencia elementales como la comunicación, romper el cerco de aislamiento al que estábamos sometidas, pasar información sobre compañeros, números de teléfono, que otras prisioneras habían pasado por allí, las características de los guardias, etc.

También estrategias de higiene como el cuidado de unas a otras, no consumo de agua después de haber recibido corriente eléctrica, el tema de la menstruación, etc. Fue una 
acumulación de experiencias que permitieron que hubiera un grado de salud mental y apoyo afectivo en el contexto de la represión.

\section{8 ¿Cómo fue el trato que recibieron las mujeres presas de Villa Grimaldi?}

A nosotras nos trataron como putas, especialmente a las que no eran casadas. Yo estaba legalmente casada y utilizaron este hecho también, es decir, dijeron a mi marido que yo tenía un amante. Ellos manejaban el concepto de que yo era "una mujer casada, no como las otras que convivían con varios".

Yo recibí un trato diferenciado en algunas ocasiones respecto a otras compañeras que no estaban casadas. De hecho, a mi me decían "señora". Sin embargo, no siempre recibí una relación de respeto por ser casada porque estando embarazada en la Villa me produjeron un aborto fruto de la tortura.

La mujer recibió una violencia específica porque los hombres podían estar embarazados y esto, sin duda, marcó la diferencia. Ellos encontraron en mi casa los papeles del médico en donde decía que yo tenía ocho semanas de embarazo. Fue un nivel de desquiciamiento agotador, te decían "Flaca tenés que cuidarte porque estáis embarazada" pero luego me torturaban igual.

Sin embargo, hubo factor importante, es decir, entre los guardias y soldados había diferentes formas de actuar. Los más mayores solían ser más paternalistas y te trataban como si fueras su hija. Pero esto no fue lineal, puesto que cuando ellos no conseguían la información que querían te torturaban sin más miramientos.

En una ocasión llegaron a la Villa dos compañeras prostitutas, aquí la diferencia de trato fue impresionante. El guardia estaba indignado porque mezclaron a estas mujeres "con sus niñas", es decir, nosotras, las prisioneras políticas.

Nos trajo jabón, toallas limpias, nos permitieron un aseo general porque querían dejar claro que nosotras éramos diferentes a las prostitutas. Pero también, a las mujeres que no estaban casadas las trataban de prostitutas hasta que llegaron las prostitutas reales entonces se "convirtieron en sus niñas". 
Muchas mujeres utilizamos un rol, nuestro rol de "pobrecita, la esposa que llora" para evitar más tortura y violencia. Estas cosas dieron resultado porque conseguimos un trato más permisivo, nos sacaban más tiempo al patio, en el baño, etc. Ahora, cuando se daban cuenta de la utilización de estos personajes nos golpeaban con más fuerza.

\section{9 ¿Qué opinión el merece el tema de las quebradas?}

Este es un tema muy difícil porque ellas no se quebraron de un día para otro, hubo todo un proceso. La diferencia está en que algunas de ellas se constituyeron en agentes y participaron en la represión. Hubo una etapa que fueron mis compañeras pero cuando pasaron a colaborar dejaron de serlo, es decir, se transformaron en agentes con sueldos y regalías y por tanto con la misma responsabilidad en la represión.

Bueno, también hubo quebrados, como Snaider, un instructor militar del MIR que pasó a colaborar activamente con la DINA tras haber presenciado torturas a su hijo pequeñín.

\section{0 ¿Hubo mujeres de la DINA que participaron en la tortura?}

Si. Yo recuerdo un caso de una mujer que era muy competitiva. En una sesión de tortura que le hicieron a mi marido (le tenían colgado) recuerdo que ella dijo "paren....se salió un electrodo". Ella trataba de demostrar que era competente para participar en la represión de la DINA, es decir, era el cliché de una mujer en un ambiente masculino que lucha por integrase.

\section{1 ¿Cómo fue su salida de Villa Grimaldi?}

Me trasladaron a Cuatro Álamos en diciembre del 75. Allí estuve un par de semanas y luego me llevaron a Tres Álamos en donde estuve un año presa.

Mi experiencia en Tres Álamos fue muy mala. En Villa Grimaldi tuve mejor relación con mis compañeras porque en Tres Álamos las relaciones fueron mucho más rígidas por parte del MIR. Mis compañeras de partido te evaluaban en términos de si tu habías hablado o no y a partir de ahí establecían una relación contigo. Yo me sentí en muchas ocasiones aislada entre mis compañeras, existía mucho temo a las mujeres que podían 
expresar opiniones críticas. Me sentí tremendamente sola, hasta que descubrí a otras compañeras en mi misma situación. Hay que tener en cuenta que éramos muy jóvenes, yo tenía dieciocho años.

12 ¿Cómo fue la organización y la convivencia de las presas políticas en Tres Álamos?

Había una carreta grande del MIR y otras más pequeñas del Partido Comunista y el Partido Socialista. Entre las diferentes carretas había tensiones. En las carretas pequeñas las compañeras comían mejor y en las grandes la situación era peor, habían muchas mujeres que procedían de las provincias que no recibían ropa ni alimentación porque no tenían acceso a lo que llegaba del exterior. En este punto sí se establecieron muchos lazos de solidaridad entre la gente más desfavorecida en el interior de la cárcel. Siempre tuve la sensación de que algunas presas estaban en un status superior al nuestro.

También se pusieron en marcha las salas cuna para que las madres pudieran organizarse mejor y cuidar a los hijos con mayor facilidad. Esta experiencia solidaria fue voluntaria y nos unió a muchas de nosotras, cosa que no ocurrió en el pabellón de los hombres.

13 ¿Creé que las mujeres presas tuvieron un mayor grado de organización a la hora recuperar todos los datos que reconstruyeran lo que había sucedido con la represión?

Creo que sí hubo un grado de liderazgo entre las mujeres. Se aprovechó mucho el traspaso de información entre unas y otras. Las mujeres fueron más organizadas porque había, por lo general, una sola línea. En cambio, los hombres discutían más, había más diferencias ideológicas.

14 ¿En qué circunstancia salió en libertad y cuáles fueron los objetivos que se planteó a partir de ese momento?

Yo salí el 10 de septiembre del 76. A partir de ese momento me dieron treinta días para que saliera del país bajo amenaza. En octubre del 76 partí a Venezuela. Allí continué mi militancia en el MIR y con mis estudios universitarios. Además, entré en contacto con un grupo de mujeres y fue el comienzo de mi formación en el tema de género, es decir, 
de concienciarme sobre mi condición de mujer. Yo siempre pensé que el feminismo era una cosa de la burguesía, pero en el exilio tuve un inicio de la conciencia feminista. Fue un proceso de descubrimiento que se tornó en una dicotomía puesto que empecé a ver que se podía hacer otro tipo de política lo que suponía que yo me planteara algunas dudas sobre el funcionamiento del partido.

Empecé a plantearme que había una deficiencia muy grande en el conjunto de los partidos marxistas, primero desde el punto de vista ideológico porque el tema de la mujer está supeditado al tema de clase, y segundo, que el tema privado es un tema político también.

Las primeras críticas al MIR fueron recibidas con bromas entre mis compañeras, yo me lo tomé con calma porque no quería salir del partido por no quedarme desamparada.

15 ¿Qué opina sobre la política de retorno planteada por el MIR y el proyecto Hogares Cuba?

Yo renuncié al MIR cuando se me planteó quedarme en Cuba cuidando niños o retornar a Chile para continuar con el trabajo político. La idea era regresar al país y dejar a los hijos en Cuba. Yo me negué rotundamente a abandonar a mis hijas. Yo siento que fue una política equivocada, no se podía pedir a las personas renunciar a la reconstrucción de sus vidas, porque ser madre y tener hijos es parte de ese proceso de vida.

Se forzó a las personas para que tomaran caminos que atentaban contra su estabilidad emocional. No fue una política correcta. Fue una experiencia atroz. Además, hay que tener una cosa en cuenta que es el tema de los hijos y las consecuencias que este proyecto tuvo para ellos. Los apartaron de su familia y después les sacaron de la otra familiar para reinsertarlos de nuevo en su familia original. Este proceso fue muy doloroso para los hijos e incluso para los padres.

Creo que el MIR fue un partido tremendamente patriarcal, que jamás consideró la perspectiva de género ni se flexibilizó frente a otros movimientos nuevos y otras perspectivas que introducían elementos de critica como el movimiento feminista, el movimiento ecologista, movimientos de jóvenes. Es decir, no incorporó nuevas ideas y 
esto generó muchos desastres en la vida de las personas y la génesis de mucha conflictividad interna a nivel partidario.

\section{6 ¿Cómo fue su regreso del exilio?}

En 1986 se dieron las condiciones para que yo regresara a Chile. No me integré en el partido sino en el movimiento social, me integré en asociaciones de mujeres, en las marchas de las cacerolas, es decir, en el tejido social y no en la vida partidaria.

\section{7 ¿Creé que el conjunto de los partidos de la izquierda chilena ha reconocido el} papel y la aportación de la mujer en la dictadura militar?

No. Y sí se ha hecho ha sido desde una perspectiva paternalista frente a la realidad de que en Chile existió un movimiento de mujeres independientes de las organizaciones políticas o que trató independizarse de éstas para trabajar en la oposición al régimen.

La participación mayoritaria de las mujeres no se hizo desde el ámbito partidario sino más bien desde la resistencia y la sobrevivencia en otras organizaciones independientes como el MENCH, CODEPU, etc. Desde los partidos se aprovechó de una forma muy oportunista la potencialidad de la mujer en la lucha contra la dictadura pero sin incorporar la perspectiva de género que incluía demandas específicas.

Esto, ha supuesto que se dejaran de lado muchas cuestiones fundamentales en lo referente a la mujer en la transición democrática: a nivel laboral yo vivo la discriminación porque tengo que adaptarme a los moldes de imagen que se piden.

Las leyes laborales son tremendamente discriminatorias con la mujer en lo referente a la maternidad, salario, etc. Tampoco hay igualdad de oportunidades a la hora de estudiar o acceder a un puesto relevante. Todos estos lastres han sido la consecuencia de no haber incluido las demandas y los derechos de la mujer en la construcción democrática. 
13 Entrevista realizada a JUANA AGUILERA JARAMILLO, 20 de mayo de 2005, Santiago de Chile. Aguilera fue militante del Movimiento de Izquierda Revolucionaria. Estuvo detenida en el cuartel Borgoño para pasar después a la Correccional Femenina (COF) en donde permaneció casi cuatro años. Exiliada política en Francia, desempeñó una intensa tarea en la Comisión Europea para la Solidaridad con Chile (COSECH) y fue una de las fundadoras de la Agrupación de ex Presos Políticos. Asimismo, ha formado parte de la Comisión encargada de redactar el Informe sobre Prisión Política y Tortura (Informe Valech, 2004).

*(Por motivos técnicos la presente entrevista no ha podido ser transcrita en su totalidad)

\section{1 ¿Qué tareas partidarias desempeñó en los primeros años de clandestinidad?}

En 1979 el MIR comenzó a incorporar la propaganda armada en el sentido de impulsar asaltos, bombas, etc. En esa época las mujeres estuvieron trabajando en una red para transportar material, armas, etc.

Mi trabajo en el MIR fue básicamente en labores de propaganda. Llevábamos los comités de residencia al uso de las prácticas de guerra psicológica. Es decir, hacíamos bombas de ruido o una bomba falsa como guerra psicológica. También llamábamos a los medios de comunicación para decir que "la resistencia popular había colocado una bomba en tal lugar". Esto lo hicimos con los Comités de Defensa Universitarios.

Yo trabajé mucho en la reproducción de material, especialmente en la resistencia sindical y poblacional. Generamos una red de ayudistas que tenían que ser la gente más firme ideológicamente para que pudieran resistir un interrogatorio o la reclusión. Teníamos que establecer una red para montar un taller para reproducir propaganda ( $E l$ Rebelde), guardar material y esconder gente.

La otra red que construimos fue en la universidad que tenía que ver más con los recursos, concretamente para conseguir espacios y vehículos.

En 1980, el MIR hizo un asalto en AGAS (a un camión blindado), un supermercado para paralizar el propósito de la Comisión Hortuza para generar una nueva constitución 
política. Pinochet ya había hecho un llamado para deponer las armas. Esa noche reventaron seis bombas en Santiago.

Los medios de comunicación dieron mucha cobertura a este episodio alegando que "el extremismo aún seguía vivo”. La dictadura estaba muy acostumbrada a reprimir en las fábricas y en las poblaciones cercando los lugares y deteniendo gente. A partir de esta operación sorpresa, la estrategia de la dictadura cambió. En abril de 1980 el MIR asaltó tres bancos lo que hizo que la represión se intensificara.

\section{2 ¿Usted participó en esta estrategia político-militar del MIR?}

El compañero con el que vivía, Fernando Alba, empezó a ser seguido por la CNI. Él era miembro de la Comisión Política y trató de romper el cerco cambiando los puntos de contacto. Yo hablé con él y decidimos separarnos porque yo sabía que seguía el cerco. Llegué a la casa con su hermano y pudimos ver que habían registrado nuestra vivienda. Salimos de ahí y justo aparecieron miembros de la CNI y nos detuvieron. Eran muchos, incluso hubo disparos. En ese momento estábamos yo y el hermano de mi compañero. Después me enteré que a él también lo había detenido horas antes.

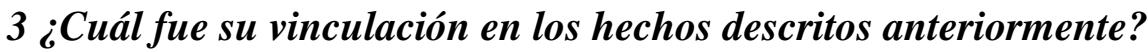

Nosotros habíamos participado en las trasmisiones de Radio Liberación, un medio del MIR clandestino que apareció en 1980. La CNI nos apuntó con sus armas y nos filmaron, salimos en la televisión y en los diarios.

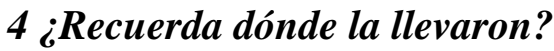

Cuando nos detuvieron, nos golpearon, nos amarraron y nos esposaron. Nos pusieron scoch en los ojos y nos trasladaron en autos separados. Durante veinte minutos nos dieron varias vueltas. Creo que nos llevaron al cuartel Borgoño. Allí vivimos la rutina de siempre: golpes, electricidad, tortura...

Creo que estuvimos trece días cuando lo legal eran cinco. De mí no sabían nada pero creo que cuando siguieron a mi compañero a su departamento me vieron entrar. Cuando 
yo llegué yo prendí la luz y él estaba en su casa con las luces apagadas. Cuando calló mi compañero encontraron mucha documentación.

En el interrogatorio me preguntaron sobre mi militancia y mis tareas políticas. Inventé toda una historia para explicar mi participación en la radio clandestina del MIR. A los cuatro días ellos me dijeron que me felicitaban porque tenía una gran capacidad para mentir.

Yo sentí que había más presos en otras piezas. En un momento nos pusieron a todos en una habitación muy grande y pude ver a Fernando. Él me dijo que habían caído todos los compañeros de enlace, incluidas dos mujeres.

Cuando supe todo esto tuve que aprenderme los nombres de los demás por si acaso alguien desaparecía o era ejecutado. Ellos no sabían nada de mí salvo que era la mujer de Fernando. Lo importante era que no nos vincularan con los asaltos a los bancos y las bombas y que pensaran que éramos simplemente estudiantes de izquierdas.

Uno de nuestros compañeros empezó a delatarnos. Se quebró en la tortura y empezaron a salir a la luz todos los nombres de los diferentes cuadros, algunos episodios de bombas, etc. Involucraron a una mujer que no estaba detenida y yo la conocía de la clandestinidad pero cuando me nombraron su nombre dije que no la conocía y en ese momento lo creía así, porque yo la conocía por su nombre clandestino.

\section{5 ¿En qué circunstancias salió de Borgoño?}

Del cuartel Borgoño nos mandaron a la cárcel para seguir todo el proceso que pasaba por la Fiscalía Militar y la Corte de Apelaciones. Nos encontramos dos armas, una era el arma de mi padre que yo había prestado a un compañero y la otra era de otro compañero. También encontraron abundante documentación como el diario El Rebelde y material de la radio clandestina.

Nos procesaron. A los ayudistas los liberaron y a nosotros nos dejaron en proceso, es decir, a Fernando, Inés, Pedro y a mí. El fiscal dijo que yo podía saber más cosas por vivir con mi compañero. Esto ocurrió en mayo de 1980. 
Después, nos llevaron a la COF (Correccional Femenino). En septiembre, nuestros abogados de la Vicaría de la Solidaridad pidieron la libertad para Inés y para mí. El fiscal dijo que a Inés la dejaban libre porque su participación había sido mucho menor pero que a mi me volvían a encerrar dos meses más porque entendía que yo tenía información vital que entregar.

En noviembre de ese mismo año mi abogado volvió a pedir la libertad. El fiscal me dijo “-su compañera Inés volvió de nuevo a la clandestinidad... ¿quién me asegura que usted no vaya a hacer lo mismo?, usted se queda en prisión hasta que finalice el proceso-".

Estuve casi cuatro años en la cárcel y el fallo final fue 101 días de reclusión. Cuando mi abogado reclamó a la Corte de Apelaciones me expulsaron del país y el cónsul de Francia en Chile me dio una visa para salir a Paris en 1984. Me tocó cumplir cuatro años de pena de extrañamiento que me dio el ministro de la Corte de Apelaciones, actual presidente de la Corte Suprema.

\section{En los cuatro años de reclusión en la COF ¿siguió desempeñando tareas políticas? ¿Hubo alguna organización de las presas en este sentido?}

Teníamos un solo grupo formado por muy pocas mujeres, unas seis. Hacíamos artesanía, tejíamos, bordábamos, sacábamos árboles como castigo de la superiora, María Paz Venegas, quién nos mandaba recoger piedras. Esa era parte de la terapia que nos hacía ella.

En 1982 llegaron compañeras de la Fuerza Central, Miriam Ortega, Cecilia Madrigal, etc. A ellas las pusieron en un módulo para presas peligrosas. Tuvimos contacto con ellas e hicimos varias huelgas de hambre para dejar de hacer trabajos forzados. Hicimos denuncias y en 1983 el Vaticano amonestó a la monja que dirigía la COF. Fuimos trasladadas a la cárcel de San Miguel, un centro de reclusión de hombres delincuentes comunes. Fuimos trece mujeres con dos niños. Nuestra primera semana fue insoportable. No nos dejaron dormir porque se trataba de hombres que llevaban encarcelados muchos años y ellos sólo nos veían como mujeres. 
Esto fue un castigo. Nosotras rompimos nuestras sábanas e hicimos cortinas para que no nos vieran. No teníamos privacidad. Estuvimos tres días sin dormir y desesperadas les mostramos varios bebés y ellos empezaron a entender que no podían tratarnos de esa forma.

Recuerdo que un grupo entró a nuestra celda y la mujer guardia no hizo nada para evitarlo. Cuando llegaron nosotras nos enfrentamos a ellos diciéndoles: "somos presas políticas, no somos sus mujeres y ustedes no nos pueden tocar. Si nos hacen algo ustedes tendrán que rendir cuentas con nuestros compañeros". Afortunadamente, este argumento nos ayudó para que nos dejaran tranquilas. Al final, ellos se unieron a nuestras protestas, recuerdo que cantaban con nosotras “Los presos unidos jamás serán vencidos..."

Por otra parte, la convivencia con las otras presas no fue muy buena. Las compañeras del PC no solían juntarse con nosotras. Teníamos muy mala fama y en raras ocasiones hablaban con las miristas.

\section{7 ¿Creé que hubo una represión específica dirigida hacia las presas políticas en los centros de detención de la dictadura?}

Desde que entré a formar parte de la Comisión Ética (Comisión Valech) empecé a reflexionar sobre este tema. Hubo grupos de mujeres como La Morada y el Instituto de la Mujer que nos dieron información sobre el tema de género. Ellas hicieron una investigación y me entregaron muchos testimonios que reflejan que efectivamente hubo una represión diferente para la mujer, tanto militante como sin actividad política.

Tenemos casos de mujeres que fueron tomadas como rehenes porque sus maridos eran militantes y se las devolvieron todas violadas y golpeadas como una forma de humillar a esos hombres "que querían cambiar la sociedad y ni siquiera podían proteger a sus propias mujeres".

Luego está toda la agresión sexual hacia la mujer militante porque ellos querían demostrar que estas mujeres no valían nada. Además, estaban los vejámenes como forma de humillar a una mujer por haber desafiado a los militares. La represión recoge 
los patrones culturales machistas de la sociedad que ponía a la mujer en una situación de vulnerabilidad terrible.

\section{8 ¿Usted sufrió este tipo de represión?}

Yo sufrí mucha humillación de este tipo. Esta humillación no sólo tiene que ver con la violación sino con toda una serie de amenazas psicológicas. Lo primero que yo viví es que me metieron los dedos en mi vagina y mi ano porque pensaban que podía tener algo escondido allí. Luego todo lo que pasó con mis pechos, con mi cuerpo, la relación con los animales que ellos solían "trabajar con las mujeres".

\section{9 ¿Cré que el clasismo también fue un factor determinante con las mujeres presas a} la hora de ser torturadas?

Sí. Yo para ellos era una tonta porque estaba metida en política. Decían que me había metido en una tontera y había echado a perder mi vida. Fueron a la casa de mis padres y yo había guardado mucha documentación allí. Me pegaron y me pusieron en la parrilla diciéndome que "cómo me había metido en política teniendo a mis padres en la casa llorando".

La extracción social tuvo un peso muy fuerte. Yo tengo rasgos mapuches y todo eso contó a la hora de torturarme y aplicarme corriente. Ellos decían que "me iban a dejar buena para que no pudiera reproducirme más porque cosas tan horribles no podían seguir existiendo".

Otras amigas de la Fuerza Central del MIR discutieron conmigo sobre estos temas. Pensábamos que lo importante era proteger la información independientemente de lo que pensaran y nos hicieran. Esta fue una opción y un sistema de protección.

10 ¿Qué opinión tiene sobre las presas que se quebraron por la tortura y decidieron colaborar? 
La Flaca Alejandra cayó presa por cheques cuando yo estaba en la COF. El partido había dicho que la Flaca Alejandra era un "ser que había que eliminar" y nosotros estábamos allí con ella. Ella estuvo una noche en la COF, ya había sido funcionaria de la DINA y había caído por unos cheques falsos. No supimos que hacer. Hoy día la Flaca Alejandra está alojada en un hotel en la Isla de Pascua, un compañero mío se topó con ella.

En esa época te hubiera dicho que habría que eliminarla, como pensábamos todos. Hoy día, después de haber pasado por distintas situaciones de la vida, pienso que fueron momentos muy duros y que uno se enfrentaba en soledad a la tortura y que cada uno tiene que enfrentar lo que hizo. Creo que la Flaca Alejandra y la Luz Arce tienen más penas que yo cuando piensan en su pasado.

\section{1 ¿Qué visión tiene sobre el proyecto Hogares Cuba que puso en marcha el MIR?} ¿Hubo una discriminación de género al no facilitar de la misma forma el retorno a mujeres y hombres de su partido? ¿Hasta que punto la maternidad supuso una carga extra para la mujer a la hora de desempeñar las tareas partidarias?

No conozco en detalle la experiencia. Nosotras tuvimos una discusión en la cárcel con compañeras que venían de Cuba y que habían dejado sus hijos en estos hogares. Otras compañeras tuvieron bebés en las cárceles, Rita Peña, Marta Soto e Inés Peiró. La discusión era sobre la necesidad o no de sacar los bebés de la cárcel. Yo defendí la postura de que la guagua debía quedarse donde la madre estuviera. Discutimos mucho sobre este tema.

Lo que se hasta ahora es que la mayoría de los niños que se separaron de sus padres tienen mucho más conflictos que el Manuel y la Elisa que se criaron en la cárcel hasta los tres años.

Por otra parte, el retorno clandestino se planteó como algo voluntario, independientemente de que fueran hombres y mujeres. No se si esto se dio en la práctica. La política de retorno del MIR fue el gran error del partido porque supuso el aniquilamiento de sus cuadros, es decir, la pérdida de toda una generación de jóvenes que ya habían pasado por la tortura, la prisión y el exilio. Mandarlos a morir fue un 
error y más en el momento en el que empezaban a movilizarse otros grupos de oposición a la dictadura.

12 ¿Cómo fue su experiencia en el exilio? ¿Participó en alguna agrupación de DDHH?

Estuve siete años en el exilio. En 1984 la dictadura publicó una lista de personas no deseadas en Chile en la que yo aparecía. En Francia, trabajé en la Comisión Europea para la Solidaridad con Chile (COSECH) en donde además de denunciar las violaciones a los DDHH hacíamos todo un trabajo con los refugiados políticos.

También, quise sanarme y tener un hijo. Al principio fue complejo porque tuve que tratarme mucho por mis experiencias en la tortura pero siempre tuve claro que debía salir adelante y que no me la podían ganar.

Instaurada la democracia nos reunimos en París con el embajador de Chile, Figueroa, que estaba encargado de recopilar información y buscar gente para la elaboración del Informe Rettig.

Finalmente, en 1991 regresé a Chile. Me fui a San Felipe y entré en un grupo que hacía seminarios de exiliados políticos. En 1998 formamos la Agrupación de Expresos Políticos y fui dirigente nacional hasta que en 2001 entré a formar parte de la Comisión Valech.

13 ¿Cuáles serían los elementos más relevantes y positivos de su militancia política dentro del Movimiento de Izquierda Revolucionaria y aquellas cuestiones que le hubiera gustado que hubieran sido diferentes?

Yo creo que las mujeres en el MIR han hecho grandes aportes. Recuerdo una reunión en el exilio que hicieron las mujeres que habían estado presas. Fue una decisión que partió de una iniciativa propia sin depender de ninguna dirección del partido. Nosotras tratamos de ser buenas militantes y buenas madres cómo cualquier otra mujer de otros partidos. 
Tratamos de superar la mentalidad patriarcal que en aquellos momentos se respiraba en todas partes. Como mujeres del MIR, creo que tuvimos mucha firmeza en muchas cosas. Los compañeros tuvieron una forma de pensar distinta hacia la mujer, es decir, a diferencia de nosotras, ellos no se relacionaban con las compañeras de igual a igual.

Asumir tareas y escribir documentos parecía ser una tarea de hombres. Les costaba reconocer que entre las compañeras podía ver mucha capacidad intelectual. Mi última experiencia con un mirista fue con Ricardo F. con quién he trabajado en la Comisión Valech. Él me decía "por qué no le dices al guatón (mi compañero) que escribiera unos papelitos sobre esta idea”.

Yo me ponía a trabajar en ello y él siempre me decía que mi compañero tenía que echarle un vistazo y ampliarlo. Hablé con mi pareja para que le explicara a Ricardo que yo podía hacer ese trabajo sola, además él estaba trabajando conmigo. Este es un ejemplo de una mentalidad que perdura hasta hoy día entre muchos compañeros.

En lo positivo, puedo destacar la valentía del MIR y la dignidad para enfrentar a la dictadura. En términos personales destaco la alegría con la que vivimos nuestra militancia, incluso la motivación en los malos momentos como en la tortura o la cárcel. Éramos jóvenes alegres y con muchas ganas y energías de trabajar. 


\section{PARTIDO SOCIALISTA CHILENO}


14 Entrevista a NELLY ANDRADE ALCAINO, realizada el 20 de mayo de 2004, Santiago de Chile. Andrade es militante del Partido Socialista y estuvo recluida en los centros Londres 38 y Tejas Verdes. También, participó activamente en diversas organizaciones de derechos humanos y movimientos sociales.

\section{1 ¿Cómo fueron sus inicios en la movilización política?}

Yo nací socialista, porque mi padre y mi madre eran militantes socialistas. Yo me crié en torno a una familia de socialistas. Mi padre y mi abuelo fueron dirigentes sindicales. En 1966, cuando tenía catorce años, ingresé a la Juventud Socialista de Chile.

Yo compartí mi militancia con compañeros del Partido Comunista. En 1970 formamos el Comité Juvenil de la Unidad Popular en donde la convivencia entre socialistas y comunistas fue siempre constructiva.

En los primeros años, empecé trabajando en el grupo de propaganda, especialmente en el período electoral. Partí como brigadista para pasar después a ser secretaria política, lo que hoy en día llamamos el presidente de un grupo de jóvenes que trabajábamos durante el período 1970-1973.

En mi casa siempre se hicieron reuniones. En la campaña electoral Allende y su hermana, Laurita, nos vinieron a visitar. Mi casa era muy conocida en la población como sede de militantes.

\section{2 ¿En qué circunstancias estuvo el 11 de septiembre de 1973?}

El golpe de Estado me sorprendió con veinte años. Por aquel entonces era novia de un compañero comunista de la población de la Legua y dirigente de la sección juvenil de la Central Unitaria de Trabajares.

El 11 de septiembre tuvimos una reunión los militantes del partido de mi sector. En Santiago estaban divididas las comunas por cordones industriales. Nosotros pertenecíamos en el cordón Maipú-Cerrillos. Estuvimos en contacto con compañeros de una fábrica porque estaban atrapados. Ellos esperaban nuestras instrucciones. Del 
propio partido recibimos la instrucción de esperar a unos compañeros que traerían armas pero ellos nunca llegaron.

En estos primeros días comenzaron los allanamientos y las detenciones. Esto nos obligó a desarrollar una labor de búsqueda de nuestros compañeros. Fueron dos meses muy difíciles porque no había donde ir. Finalmente, decidimos dejar libertad de acción, que la gente hiciera lo que tuviera que hacer. Esto significó una dispersión del partido.

\section{3 ¿Cómo fue su detención?}

En enero de 1974 fui detenida y llevada a Londres 38, o la casa del terror, en donde estuve cinco días. Allí me torturaron físicamente y psicológicamente. Después me llevaron al campo de prisioneros de Tejas Verdes en donde permanecí un mes. También fui muy torturada allí. Salí libre sin cargos. Durante mucho tiempo estuve con una laguna mental muy grande y con mucho miedo.

Cuando salí lo primero que hice fue buscar a mi compañero detenido-desaparecido; de esta forma conocí a las compañeras de la Agrupación de Detenidos-Desaparecidos.

\section{4 ¿Cómo fue su experiencia en Londres 38 y Tejas Verdes? ¿Creé que las mujeres presas sufrieron un trato específico?}

A mí siempre me amenazaron con que me iban a violar delante de Gerardo, mi compañero. También me amenazaban con mis padres y mi familia. Sufrí simulacros de fusilamientos. Recuerdo que con un revólver me decían que tenía una bala y me la ponían en la boca o en la sien.

Sistemáticamente, nos degradaban a las mujeres, nos trataban de prostitutas, nos rebajaban mucho. Todo lo que nos decían era para anularnos psicológicamente. En mi caso me manosearon mucho. En las sesiones de tortura una estaba desnuda, te toqueteaban, te metían los dedos en la vagina...incluso un día me hicieron masturbarme. 
A algunos hombres también se los violaban. Pero con las mujeres era con más bronca, con más odio. Yo recuerdo haberle dicho a un torturador que "su madre también era mujer”...la respuesta fue sacarme la cresta.

Solía haber un torturador que iba de bueno. Te preguntaba que hacías metida en política. Para ellos era muy chocante que estuviéramos metidas en política.

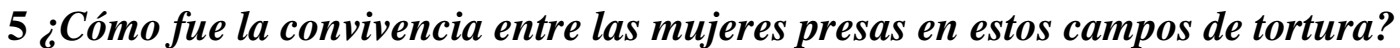

Cuando estuve en Tejas Verdes a nosotras nos daban una comida algo mejor que a los compañeros. Guardábamos el trozo de carne para los hombres.

En los baños, que los llamaban pozos negros, había un hueco que comunicaba con el baño de los hombres. Desde allí comenzamos el contacto para saber que compañeros había y a quiénes habían visto. Quizá la labor de lucha comenzó en el interior de los campos.

Yo logré sacar una carta a mi familia en dónde yo informaba sobre quiénes estaban y quienes no estaban para que lo comunicaran al resto de las familias. Siempre tuvimos esa preocupación. Asimismo, cuando alguna compañera salía de Tejas Verdes informaba sobre quiénes estaban y qué compañeros y compañeras no habían vuelto.

\section{6 ¿Cómo fue su salida de Tejas Verdes?}

Después del 74 el partido estaba totalmente desarticulado, no había dirección política. A partir de ese momento empezó comenzó una lenta reorganización. Cuando yo salí de Tejas Verdes seguí trabajando como pude en la lucha política pero sin militar en el partido.

Durante el período 1978-1980 nació la coordinadora del Partido Socialista. Toda mi familia participó en esta organización, siempre en la clandestinidad. Nunca dejé de estar en contacto con el partido. Yo me planteé seguir trabajando, en comedores infantiles, en el trabajo de colaboración con la Vicaría de la Solidaridad, etc. 
Pero, contestando a tu pregunta, mi prioridad al salir en libertad fue buscar a mi compañero detenido-desaparecido. En ningún momento pensé en exiliarme, porque yo sentía que en Chile es dónde había que estar y sobre todo por saber que había sido de mi pareja. Podría haber estudiado en el extranjero y haber tenido oportunidades de trabajo pero siempre tuve claro que debía permanecer aquí.

Hasta el plebiscito del 88 yo participé en casi todas las movilizaciones pro-democráticas y sociales. En las ollas comunes, en la asociación de detenidos-desparecidos, en la organización de ejecutados políticos, de expresos, etc. Yo hasta en octubre de 2002 no pedí el reingreso al Partido Socialista, pero siempre me sentí socialista y nunca dejé de trabajar.

7 ¿Qué opinión tiene usted acerca de la movilización política de las mujeres sobrevivientes? ¿Creé que se produjo un cierto liderazgo de las militantes en este sentido?

Por un parte, los compañeros estaban, en su mayoría, presos, en el exilio o en la clandestinidad. La organización de mujeres, estuvo compuesta básicamente por mujeres que no necesariamente militaban en alguna organización política. Eran las compañeras, las madres, las hermanas, etc. de algún militante. Pero ya te digo, la mayoría de las mujeres que fueron pioneras en la organización contra la dictadura fueron mujeres que no militaban.

Muchas de las mujeres que se vieron afectadas por la pérdida de un familiar o compañero optaron por salir de la casa y, no sólo trabajar en el tema de los derechos humanos o en la movilización política, sino en la búsqueda de su sustento, de un trabajo.

La mujer se colocó como bandera de la lucha por los derechos humanos, y objetivamente, esta aportación no se ha visto reflejada en la distribución equitativa entre hombres y mujeres en los puestos laborales de todos los sectores.

\section{8 ¿En qué situación estuvo la mujer militante dentro del Partido Socialista?}


En primer lugar, el Partido Socialista, que yo sepa, no ha hecho ningún tipo de reconocimiento expreso de la aportación de la mujer militante en los años de dictadura y, además, de ese liderazgo del que yo te hablaba.

Lo más importante que ha hecho el Partido Socialista fue cundo propuso a Isabel Allende como presidenta de la cámara de diputados. Fue un acto de justicia para con las mujeres.

Sin embargo, en el conjunto de los partidos políticos el tema Mujer no ha ocupado la importancia que debiera haber tenido en relación al aporte que la mujer militante ha tenido en los años de dictadura y en la construcción de la Democracia en Chile. No estamos representadas.

Una cosa es que haya candidatas mujeres, pero en su globalidad, a nivel partidario, la mujer no está representada de forma equitativa. Si esto ocurre hoy en día, uno puede pensar que hace veinte años esto todavía estaba más arraigado.

La reflexión que yo puedo hacer de mi militancia política es que yo comencé siendo una joven idealista que tenían sueños de construir una patria más justa en donde los jóvenes pudiéramos tener más oportunidades.

Nosotras éramos muy idealistas, y creo que en los años de la dictadura y el reencuentro con esta democracia me deja un sabor muy amargo por no poder cumplir mis sueños. Parece que este mundo no es para las mujeres, es un mundo en dónde los hombres pueden seguir monopolizando el acceso a las oportunidades.

Cuando se necesita a la mujer como bandera para conquistar los derechos democráticos ella adquiere un papel relevante pero parece que luego se la relega a su papel tradicional, es decir, a la crianza de los hijos y al hogar. Esta decepción no sólo me viene de los gobiernos democráticos que hemos tenido, sino del propio partido.

9 ¿Cuáles fueron las demandas específicas de la mujer que en el proceso de transición democrática se dejaron olvidadas? 
Principalmente, el tema de los derechos humanos. En esta línea a nosotras no nos han reconocido esa especificidad en la tortura que recibimos. Ni te hablo del tema de las indemnizaciones. Nosotras perdimos muchas demandas y beneficios pese a nuestro trabajo realizado durante muchos años.

Cuando te hablo de beneficios me refiero a tener un sistema de salud gratuito, un sistema educativo público de calidad y gratuito para nuestros hijos, y sobre todo el tema laboral con la mujer, que hoy en día todavía hay una clara discriminación de género.

Finalmente, el tema de las pensiones, creo que las mujeres que sufrieron tortura necesitan una garantían de tener una vejez tranquila. En mi caso, desde que cumplí treinta años he tenido muchos problemas en las rodillas porque estuve mucho tiempo colgada. Esto, significa gastos en medicinas y en definitiva una situación especial que el Estado ha de reconocernos.

Lo que es terrible es que muchas mujeres piensen que estábamos mejor en dictadura, porque, alegan, que por lo menos en aquellos años recibíamos la ayuda internacional, la solidaridad de muchas ONGS, los médicos de la Vicaría, etc. Este muy decepcionante que esta opinión impere sobre muchas de mis compañeras. 
15 Entrevista realizada a BERTA ECHEGOYEN BONET, 2 de diciembre de 2004, Santiago de Chile. Echegoyen fue militante del Partido Socialista durante el período 1966-1985. Asimismo, participó activamente en diversas agrupaciones de derechos humanos.

\section{1 ¿Cómo fueron sus inicios en el Partido Socialista?}

Empecé desde el ámbito estudiantil. En 1959, fui dirigente y ocupé un cargo dentro del Liceo de Niñas. Después entré en la universidad. Allí pasé a formar parte del Movimiento Universitario de Izquierda en donde se agrupaban muchos estudiantes sin una militancia política concreta.

Vengo de una familia socialista. Recién entré a militar en el partido en 1966. A partir del año $69 \mathrm{mi}$ militancia se intensificó. Milité activamente en la segunda campaña electoral de Salvador Allende. Tuve cargos diversos. En esa época eran cargos seccionales (ahora son comunales) pero, en definitiva, trabajé mucho en la base (centros de madres, juntas de vecinos, etc.).

Asimismo, trabajé en todo lo que tuviera que ver con el abastecimiento en la población Juan Antonio Río (Norte de Santiago), donde vivía, es decir, participé tanto en las JAP (Junta de Abastecimiento y Precios) como en el abastecimiento directo que eran dos formas que el pueblo tenía para abastecer sus necesidades básicas y como forma de enfrentar el acaparamiento de mercaderías por parte de comerciantes y clase acomodada.

También hay que mencionar que el Partido Socialista en esa época funcionaba de una forma bastante desordenada. En el tema del abastecimiento hubo dos políticas muy concretas: la política de las JAP y el Abastecimiento Directo.

2 ¿En qué situación (presencia, participación política, etc.) estaba la mujer militante del Partido Socialista en los años de la UP?

Creo que siempre la mujer estuvo excluida en los órganos de decisión del partido. Las mujeres aparecieron en la esfera público y política en pequeñas pinceladas como algunas diputadas como Maria Elena Carrera o Carmen Lazo. Era una proporción 
irrisoria. Sin embargo, en la base tenía fuerte presencia. Ejemplo de ello son los centros de madres de la época.

\section{3 ¿En qué situación estuvo el 11 de septiembre de 1973?}

Yo desempeñaba una doble actividad en el partido: En las JAP y en los Centros de Madres. Cuando llegó el golpe, mi marido, dirigente del partido, tuvo que exiliarse y yo partí con él en diciembre del 73. No volví a Chile hasta en enero de 1985, momento en el que mataron a mi hijo. Con su muerte yo asumí el rol que la gran mayoría de las mujeres en este país tuvieron, es decir, el rol de madres en busca de sus hijos y familiares, en la búsqueda de la verdad y la justicia. Además, mi marido cayó preso con lo que yo tenía un doble motivo para estar luchando en la calle.

\section{4 ¿Cómo fue su militancia en el exilio?}

Estuve exiliada en Cuba. Allí seguí en el partido aunque empecé a tener diferencias con la política oficial. El PS rompió la alianza tradicional que tenía con el Partido Comunista aliándose con otros sectores para formar la conocida Concertación. Esta ruptura se materializó con la salida del Partido Socialista del MDP (Movimiento Democrático Popular) en donde se agrupaban diversos partidos de la izquierda como el PS, PC, MIR, etc. El PS se desligó de esta alianza y esto precipitó mi salida del partido.

\section{5 ¿Cómo fue su regreso a Chile?}

Cuando regresé del exilio me incorporé a CODEPU (Comité de Defensa de los Derechos del Pueblo) y a la Agrupación de Familiares de Ejecutados Políticos (AFEP). En el CODEPU tuve varios cargos, fui secretaria ejecutiva, vicepresidenta nacional. Trabajé allí hasta 2002.

\section{6 ¿Cuál es su visión sobre el papel de la mujer en la organización de Agrupaciones de Derechos Humanos en Chile?}

La mayor parte de los presos fueron hombres por ser éstos los principales dirigentes de los partidos de la oposición. Por esta razón, fueron las mujeres las que se organizaron con más fuerza y activismo por los DDHH. 
Las mujeres fueron el verdadero motor en la lucha por la verdad y la justicia en este país. En la Agrupación de Ejecutados Políticos éramos 40 mujeres (muchas de ellas socialistas) y un hombre. La mujer demostró gran valentía movilizándose contra la dictadura. Sin lugar a dudas, nosotras fuimos las constructoras del movimiento social más importante en Chile, el movimiento de mujeres.

Sin embargo, también hay que mencionar que a partir del plebiscito de 1988 las organizaciones que el pueblo se había dado como ollas comunes, comprando juntos, etc., se disolvieron. La gente se replegó a sus casas y las organizaciones se disolvieron. Desgraciadamente, muchas de estas agrupaciones se desnaturalizaron porque tomaron un carácter dirigido a conseguir el triunfo del NO a la continuidad de la Junta. De hecho, muchos dirigentes del Partido Socialista llamaron a la desmovilización de sus militantes una vez conseguido el objetivo del plebiscito.

Las mujeres que participaron en el movimiento femenino, Mujeres por la Vida, el MEMCH83 (Movimiento pro Emancipación de la Mujer), etc., perdieron mucha fuerza al replegarse. Hoy día el MEMCH existe pero sin la fuerza que tuvo en tiempos de dictadura.

\section{En el plano de la represión, ¿creé usted que las mujeres militantes del Partido} Socialista que cayeron presas, recibieron una represión específica?

Sin duda. A las mujeres las violaban como regla general. Prácticamente todas fueron violadas y sufrieron otros tipos de vejámenes. El Informe sobre Prisión Política y Tortura (Informe Valech) constata este hecho. Creo que algunos hombres también sufrieron la tortura sexual. Las presas sufrieron en su gran mayoría este tipo de tortura.

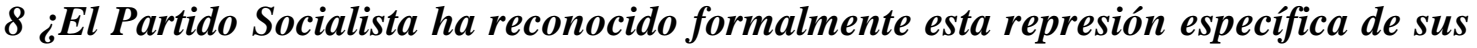 militantes femeninas?}

Siempre va a ser necesario reivindicar el trabajo y la entrega de la mujer en el partido. La mujer es madre, esposa, trabajadora y ha jugado un rol muy importante en el partido. Creo que en el Partido Socialista ha tendido siempre a no valorar adecuadamente las posibilidades de la mujer. Quizá con la candidatura de Michel Bachelet esto está cambiando pero ello no quita que falte reivindicar el papel de la mujer socialista. 


\section{9 ¿Qué elementos positivos y negativos destacaría de su militancia política dentro del}

\section{Partido Socialista?}

En lo positivo, creo que mi militancia contribuyó enormemente a mi formación política e intelectual. Me sirvió para acercarme al pensamiento marxista y poder tener los elementos de análisis para comprender mejor la realidad de este país. Mi activismo durante el gobierno de la Unidad Popular supuso para mí una experiencia inolvidable, enriquecedora de la que siempre voy a estar orgullosa.

En lo negativo, mis diferencias con el partido y sus políticas que me han llevado a alejarme. Considero que el PS al no desvincularse o más bien no presentar alternativas al modelo económico de mercado hace que tenga carencias muy fuerte en su política social.

Finalmente, decir que el gobierno de Ricardo Lagos, pese a impulsar la Comisión de Investigación de Prisión Política y Tortura para la elaboración del Informe Valech, no ha cerrado del todo este tema porque en dicho informe no aparecen los culpables de las violaciones de los DDHH. Esto, sin duda, viene a significar que el informe sea un trabajo incompleto lo que me hace discrepar tanto a mí como a mis compañeras de CODEPU en la idea de que el ciclo sobre prisión política y tortura esté cerrado. 
16 Entrevista realizada a CARMEN LAZO CARRERA, 13 de diciembre de 2004, Santiago de Chile. Lazo concurrió a la fundación del Partido Socialista en 1933, de larga trayectoria política fue regidora por Santiago entre 1943-1947 y diputada durante 1960-1970. En 1991 fue nombrada miembro del Comité Central del PS.

\section{1 ¿Cómo fueron tus inicios en el Partido Socialista?}

Yo nací en la Pampa, en Chuquicamata. Siempre me he sentido perteneciente a la clase obrera. A mi padre le amenazaron con despedirle porque yo entré a militar al Partido Socialista. Mi compromiso con la clase obrera empezó siendo yo una adolescente. Entré a militar en 1936.

Llegué a ser regidora por Santiago siendo muy joven, entre 1943-1947, cuando a penas tenía veintitrés años. En ese tiempo pertenecía a la Juventud Socialista. Nosotros luchamos contra el nazismo en la época de González Formaré, estamos hablando de los años treinta.

En una ocasión se manifestaron un grupo de 63 jóvenes nazis, el presidente Arturo Alessandri ordenó a carabineros que metieran a estos sesenta jóvenes en el Edificio del Seguro (Actual Ministerio de Justicia) y los balearon a todos. La lucha que nosotros hacíamos era más pacífica.

Yo fui la primera mujer miembro del Comité Central del PS en 1940. También estuve en la Comisión de Cultura de la Cámara de Diputados. Después fui directora del Teatro Municipal donde conocí mucha gente de la cultura.

También trabajé con mujeres comunistas en un movimiento que dirigía Elena Cafarena y Amanda Labarca, es decir, con el MENCH (Movimiento de Emancipación de la Mujer). Después de vivir todo el proceso de lucha por el derecho a voto de la mujer (1949) terminé de retirándome del MENCH por la influencia que tenía del PC.

En 1963 tuve la oportunidad de ver la documentación de la CIA, el Plan Camelot. Ya la CIA estaba trabajando en Chile por si llegaba Allende al poder. En el gobierno de 
Eduardo Frei Montalva llegué a la cámara por primera vez. También estaba Laura Allende, quién después fue presa y torturada durante la dictadura.

2 ¿En qué situación (presencia, participación política, etc.) estaba la mujer militante del Partido Socialista en aquellos años?

Allende tenía muy claro que la mujer chilena tenía que jugar un papel activo en su gobierno. En Chile el machismo consuetudinario ha estado muy arraigado en la sociedad.

El gobierno de Salvador Allende elaboró 40 medidas. En ellas se recogían muchos proyectos que beneficiaban a la mujer y a los niños. En 1964, cuando Allende todavía era candidato, estuvimos en Calama y me di cuenta de la inquietud que él tenía por la situación tan precaria de las mujeres obreras y de los sectores populares. Recuerdo que la derecha sacó unos afiches que decían "Cuidado mujer con tus hijos que el comunismo se los llevará a la Unión Soviética”.

\section{3 ¿Qué tipo de militancia desempeñó en los años de la Unidad Popular?}

Yo me he declarado siempre marxista-leninista y durante el gobierno de Allende fui diputada por el PS. Siempre supe que los cambios propuestos por la UP iban a ser muy difíciles de materializar por la fuerte oposición de la derecha y el ejército. Desde los años cincuenta estuve muy vinculada con Allende. Fui oradora en sus discursos, estuvimos en las luchas de la Pampa Salitrera. Recuerdo que a él le llamábamos "Pije", que significaba alguien demasiado arregladito, atildado, engominadito. Fuimos muy amigos, anduvimos y recorrimos mucho juntos.

Por otra parte, estudié Seguridad Social, estudiaba de noche. Esto me ayudó mucho a la hora de desempeñar mi cargo de diputada durante el gobierno de la Unidad Popular. En esos años recuerdo los constantes conflictos entre los diferentes sectores con conformaban la UP. Parte del partido estaba en contra de Allende. Era aquél sector que postulaba el lema de "Avanzar sin transar". Ellos en buena medida dificultaron las relaciones con la Democracia Cristiana. 


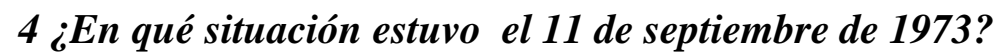

El 11 de septiembre, en uno de los primeros bandos de la Junta, salió mi nombre y el de otras compañeras más como el de Laura Allende Gossens (Diputada por el segundo distrito de Santiago fue elegida en 1971 miembro del Comité Central del PSCH. Exiliada en Cuba en tiempos de dictadura se suicidó en la Habana el 24 mayo de 1981) y con la Maria Elena Carrera (Ingresó en el PSCH en 1950 sucediendo en el Senado a su esposo fallecido. Asimismo, fue candidata a senadora por Santiago en 1989).

Nos llamaron a las tres, teníamos que presentarnos al Ministerio de Defensa. El partido me dijo que me exiliara el mismo día del golpe. Estuve catorce años exiliada en Venezuela. Yo tenía un pariente en el cuerpo de Carabineros que facilitó mi salida.

\section{5 ¿En qué circunstancias partió al exilio?}

Fui muy disciplinada y partí al exilio el mismo día del golpe. Me fui directamente a la Cristalería de Chile en donde me esperaban compañeros y dirigentes. Nada más entrar me preguntaron que dónde estaban las armas para organizar la defensa del gobierno popular. Mi reacción fue: "Compañeros, ¿ qué armas?, si no hay ningún armamento", el Partido Socialista no tenía un brazo armado y además esta era la excusa del ejército para allanar las sedes y aplicar toda su política represiva.

Muchos compañeros querían partir hacia la moneda para defender al presidente casi con las manos vacías. Supe en todo momento que eso era una locura porque no podíamos hacer nada frente a las ametralladoras y los tanques.

Por otra parte, la propia Junta empezó a divulgar que a mi me habían tomado presa junto con Altamirano. Hubo toda una política desde el Ministerio del Interior para que todos los dirigentes y peces gordos nos presentáramos allí.

Me trasladé a la embajada de Colombia junto con mi marido, Miguel Morales (Intendente de Allende). Allí había 180 personas hacinadas. Finalmente, partimos a Bogotá y de allí a Venezuela en donde nos recibió el presidente Carlos Andrés Pérez. 
En el exilio trabajé como Jefe del Servicio Social de un Hospital de Caracas. No pude acostumbrarme bien a la vida en Venezuela.

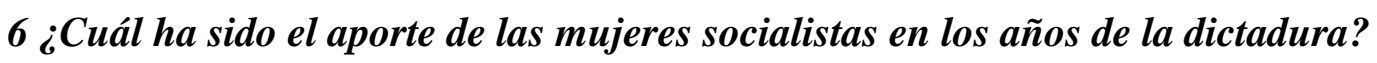

Las mujeres fueron muy heroicas. Conozco muchos casos de mujeres que partieron al exilio y aportaron mucho al partido. Por otro lado, muchas de ellas se quedaron trabajando en la clandestinidad asumiendo también la tarea del cuidado de los hijos.

Ningún gobierno democrático ha hecho justicia histórica con el aporte de las mujeres que lucharon contra la dictadura. Muchas compañeras han sido olvidadas y han perdido todas sus oportunidades laborales porque su lucha dejó en segundo plano su vida privada.

Yo he luchado todo lo que he podido por la situación de las mujeres. Después de la dictadura las mujeres se desmovilizaron mucho. Un ejemplo bien significativo lo tienes en la experiencia de mi hermana. Ella vivía en la comuna de Conchalí, un sector muy popular de Santiago. Aguantó el golpe con mucha valentía y ella me contaba que los carabineros llegaban a las poblaciones en la noche y sacaban a todos los sospechosos. Las mujeres supieron mantener el silencio.

Las mujeres que han sufrido la represión son muy cuidadosas a la hora de hablar. Yo he conversado con muchas compañeras de provincia y he podido comprobar que las militantes más humildes vivieron experiencias terribles de represión. 
17 Entrevista realizada a XIMENA GEORGE-NASCIMENTO LARA, el 21 de diciembre de 2004, Santiago de Chile. George-Nacimento es militante del Partido Socialista desde 1970. Estuvo recluida en diferentes centros y vivió el exilio durante 19 años. Actualmente es miembro de la Comisión Nacional de Medio Ambiente del gobierno de Chile.

\section{1 ¿Cómo fueron tus inicios en el Partido Socialista?}

Yo vengo de una familia que nunca tuvo militancia política. Sin embargo, varios de mis tíos fueron militantes comunistas. Mi padre, aún sin tener militancia política siempre fue un hombre de izquierdas.

Yo entré a los 13 años a militar clandestinamente a la Juventud Comunista (JC), esto fue en el año 57. Durante dos años milité en el Liceo pero terminé muy desilusionada porque en una huelga de canillitas (suplementeros o vendedores de diarios) teníamos órdenes de tirarles vitriolos (vidrios). En este punto yo empecé a cuestionar una orden del partido que de alguna manera atentaba contra mis principios. Hasta aquí llegó mi militancia en la JC.

Poco tiempo después me vinculé al Partido Socialista pero no fue hasta el exilio cuando mi militancia tomó un carácter más sólido. Yo regresé a Chile en diciembre 1992 momento en el que militancia fue más secundaria, aunque nunca dejé de estar vinculada al PS. Actualmente trabajo en la Comisión Nacional de Medio Ambiente en donde desarrollo otro tipo de militancia, también política, pero sin estar estructurada a nivel partidario.

\section{2 ¿Qué tipo de militancia desempeñó en los años de la Unidad Popular?}

En ese período yo era estudiante. En 1970 yo tenía 26 años y en ese año yo tuve un acercamiento al maoísmo para pasar posteriormente a mi militancia en el Partido Socialista.

3 ¿En qué situación (presencia, participación política, etc.) estaba la mujer militante del PS en los años de la UP? 
Siempre ha habido una predominancia masculina dentro del partido, esto es indiscutible. Sin embargo, creo que en los años de la Unidad Popular hubo una cierta apertura en dónde la mujer se vinculó mucho más a la política. Hubo un despertar político de las mujeres en el PS. Las mujeres salieron a trabajar políticamente en las JAP, en las agrupaciones vecinales, etc.

Otra cosa es la presencia de la mujer en los órganos de decisión partidaria, creo que esto no se dio con tanta fuerza. Las mujeres estuvieron vinculadas en el plano local.

\section{4 ¿En qué situación estaba el 11 de septiembre de 1973?}

En ese momento yo estaba estudiando en la universidad, en la Escuela de Economía Política y simultáneamente estudiaba en la Escuela de Geógrafos. Además tenía un niño chico. Mi actividad política estaba vinculada en el plano estudiantil.

Yo fui detenida un mes del golpe y estuve presa durante un año. Estaba acusada de estar vinculada al Partido Socialista. Estuve recluída en varios lugares, en la Escuela de Suboficiales de Carabineros, en Investigaciones, en el Estadio Nacional y finalmente en la Casa Correccional de Mujeres.

\section{5 ¿Cómo recuerda la reclusión de las presas políticas?}

En la cárcel de mujeres, donde más tiempo estuve (noviembre del 73 hasta octubre del 74) se produjo una división entre las mujeres del partido comunista y las presas políticas de otros partidos. Las presas del PC se aislaron mucho de nosotras. En cambio las mujeres del PS y del MIR estuvimos más unidas y vinculadas. Creo que también fue un problema de seguridad y sobrevivencia.

\section{6 ¿Qué opinión tiene sobre las presas que se quebraron por la tortura?}

Creo que la responsabilidad de la seguridad de los militantes no es de los individuos que están presos sino del propio partido. Creo que fue una barbaridad entregar la responsabilidad de la seguridad del PS a los militantes presos. La seguridad tiene que ser parte de la organización propia y si un individuo es hecho preso y torturado el 
partido tiene que hacerse cargo de la seguridad de los militantes que estén en riesgo y nunca delegar esa responsabilidad en la persona que esté recluida.

Estimo que el quiebre de algunas personas es un límite humano y yo no estoy en condiciones de juzgar que es lo correcto y lo que no. Aquellas personas que defienden con tanta rigidez ese aguante estoico de la tortura creo que son personas que o bien no han pasado por esa experiencia o bien se han apresurado a juzgar y analizar los acontecimientos.

Además, no hay que olvidar quienes fueron los responsables últimos de crear esa situación de quiebre y la caída de otros militantes. El que tú hayas estado en posición de entregar información clave y que finalmente la hayas entregado no es por no tu falta de responsabilidad partidaria, es porque en un contexto de tortura nadie conoce su propio límite hasta que no la sufres. Si el partido no quiere ponerse en riesgo si detienen a un militante, ha de saber compartimentar la información clave para minimizar el riesgo, pero nunca delegar tal responsabilidad a la presa.

Una puede aguantar 24 horas para que al resto de los compañeros les de tiempo a trasladarse a otro lugar, pero en ningún caso aguantar más tortura de la necesaria. Es muy injusto el rechazo hacia los que colaboraron, porque además la culpa con la que éstos tuvieron que cargar durante años fue un auténtico castigo. Nadie puede pedirle a otro ser humano que aguante la tortura.

\section{7 ¿Cómo salió de la Correccional de Mujeres?}

El fiscal, Ronaldo Omelo, me informó que tenía un decreto de expulsión y que me exiliara antes de que este decreto saliera porque lo más probable es que me detuvieran de nuevo. De esta forma comencé mi exilio, primero partiendo a Argentina pero de allí pasé a Italia porque me pusieron una bomba en mi domicilio en el marco de la Operación Cóndor. Finalmente me trasladé a Inglaterra en donde estuve 19 años exiliada.

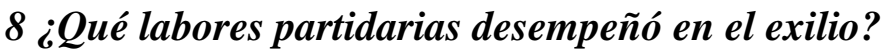


Cuando llegué a Italia me vinculé fuertemente al Partido Socialista, recorrí el país haciendo manifestaciones y discursos públicos, es decir, fue el comienzo de una militancia más estructurada. En Inglaterra continué trabajando en la misma línea. Hay que recordar que en esta época el partido se dividió, el sector de Altamirano y el de Almeida. Yo me quedé con el primero.

En Londres existía un organismo denominado "Chile Democrático", que venía a ser la coordinadora de todo el exilio. Se dio una alianza entre el Partido Comunista y el MIR mientras que el PS quedó a un costado.

Por otra parte, yo fui la primera coordinadora de la Casa de la Cultura Latinoamericana que se creó en Londres. Hubo un período en el que fui la encargada del Partido Socialista en Gran Bretaña, fui parte de la regional Europa-África. Esta época fue el período en el que se inició la convergencia del bloque socialista.

9 La represión de la dictadura afectó especialmente a los Comités Centrales y a las Comisiones Políticas de los diferentes partidos de la izquierda chilena en donde la mayoría de los cargos partidarios eran ocupados por hombres. Esta situación creo un vacío de poder dentro de los partidos. En el caso del Partido Socialista, ¿esto significó que las mujeres tuvieran un mayor acceso a las responsabilidades partidarias, o por el contrario su situación no cambió sustancialmente?

La mirada de la mujer estuvo más enfocada a la lucha contra la dictadura que a ocupar un espacio en la vida política in senso estricto. No había, salvo pequeños grupos, un quehacer hacia la lucha de género dentro del PS.

Hubo algunos grupos de mujeres socialistas que trabajaron en el tema de género y ese trabajo se materializó años después en la creación del Instituto de la Mujer, pero en ningún caso hablamos de la mayoría de las mujeres del partido.

10 ¿Usted desarrolló una conciencia de género en sus años de exilio que propiciara algunos elementos críticos hacia su partido? 
Yo fui miembro del grupo de Mujeres Latinoamericanas en Londres. Allí se establecieron foros de discusión de diversa índole. Hoy todavía sigo trabajando con ellas. Sin embargo, esta actividad no estuvo enfocada a la vida partidaria. No hubo un debate en esta organización de la situación de la mujer dentro del Partido Socialista chileno.

\section{1 ¿Cómo se incorporó la cuestión de género en el PS una vez instaurada la democracia en Chile?}

Bueno, ahí que decir que existió y aún existe una tremenda deficiencia en el partido en este terreno. Sí es cierto que el PS tuvo una iniciativa en este sentido que se materializó en la incorporación del 30\% de las mujeres militantes en los diferentes órganos. Esta cuota de participación, insuficiente, significó un cierto esfuerzo pero en ningún caso tuvo los frutos esperados para una definitiva incorporación de la mujer en las decisiones políticas fundamentales. La prioridad fue otra.

\section{2 ¿La mujer militante del Partido Socialista sufrió una represión específica por su condición de mujer en los años de dictadura?}

Yo no creo que la mujer socialista haya sufrido un tipo de represión más intensa que la sufrida por las mujeres miristas o comunistas. Creo que la memoria histórica de lo que pasó con las mujeres militantes que fueron presas, independientemente de su militancia política, ha sido poco reconocida.

Hasta hoy, el PS (también otros partidos, pero por separado) realiza diversos actos en el Estadio Nacional para recordar lo sucedido el 11 de septiembre. En estos actos, las mujeres que habíamos estado presas en este lugar, exigimos que este acto también recordara a las mujeres que había estado allí recluidas, concretamente en la zona de la piscina.

Hoy día se hace un acto específico en este lugar para recodarlas. Este tipo de cosas han sido elementos que las mujeres hemos ido ganando poco a poco con los años. Sin embargo, creo que hemos sido las grandes olvidadas, especialmente en los primeros años de la democracia. 
Hay otro elemento que me gustaría destacar respecto a la problemática de la mujer militante y es el tema de los hijos. Aunque las mujeres socialistas no nos vimos en esa disyuntiva de tener que mandar, como las miristas, a sus hijos a Cuba para volver a Chile en la clandestinidad, lo cierto es que las mujeres hacían triple jornada, la laboral, la doméstica y la política. Creo que hubo muchas socialistas que tuvieron que renunciar a su militancia o a sus hijos por no poder compaginar ambas cosas. En general, la mujer se encargaba de los hijos como algo natural lo que venía a significar una carga extra que los hombres no tenían.

13 ¿Qué elementos positivos y negativos destacaría de su militancia política dentro del Partido Socialista?

Yo soy parte del PS y me siento representada por él. Creo que a diferencia de otros partidos, el Partido Socialista se ha caracterizado por tener una mayor tolerancia y amplitud para poder aceptar la discrepancia. Mi militancia en este partido ha significado poder contribuir con cuestiones tan importantes como la justicia social y la sensación de aporte para cambiar las cosas.

En lo negativo, creo que el PS hoy día es menos leninista y más copular, creo que se ha dañado mucho a la militancia de base. Hoy día hablamos de una cúpula que dirige una base informe. Falta esa movilización social, incorporar a la juventud, que la base del partido tenga más presencia y fuerza. Asimismo, creo que la mujer ha de apostar por contribuir en la construcción de las nuevas generaciones del partido. 
18 Entrevista realizada a JUANA ANDREANI, 22 de diciembre de 2004, Santiago de Chile. Andreani, es militante del Partido Socialista desde 1968 y fue miembro del Frente Agrario Joven. Asimismo, fue integrante del Comité Central del PS y desempeñó una intensa labor en la Agrupación de Detenidos-Desaparecidos, organización de la que forma parte desde 1976.

\section{1 ¿Cómo fueron sus inicios en el Partido Socialista?}

En mi época del Liceo, yo tenía un profesor de historia que era socialista. Sus clases me gustaban mucho. Con trece años, quedé muy influida por sus charlas sobre una sociedad distinta, más justa. Yo crecí con mis abuelos que eran muy conservadores pero también muy solidarios.

En 1968 entré a la Universidad, a los dieciocho años, y empecé a vincularme con el partido. Estudiaba y a la vez trabajaba en el ámbito campesino y en el movimiento sindical. Mis tareas consistían en la alfabetización de adultos.

\section{2 ¿Qué tareas partidarias desempeñó en los años de gobierno de la UP?}

Quiero destacar primero un hecho histórico que fue fundamental para entender la movilización política y estudiantil de aquellos años. A partir de 1965, se produjo en Chile la reforma universitaria que venía a significar un auténtico cambio de generación en cuanto a la forma de pensar y actuar.

La juventud venía demando más libertad y autonomía en la universidad. Las mujeres, en esos años, empezaron a ganar espacios y esto impulsó una solidaridad nunca vista hasta ese momento, no sólo en la universidad sino también en el ámbito sindical y campesino.

3 ¿En qué situación (presencia, participación política, etc.) estaba la mujer militante del Partido Socialista en los años de la UP?

La participación en los partidos políticos era muy débil. Militar en el ámbito público era ser demasiado liberal, independientemente de que fueras de izquierdas o de derechas. El 
peso de la religión católica era muy fuerte y a estas mujeres se las veía fuera de su ámbito natural, es decir, del doméstico.

Sin embargo, el porcentaje de mujeres en las tareas de base y en el trabajo poblacional era alto aunque en otros ámbitos del partido la mujer estaba muy invisibilizada.

A mi me tocó vivir el gobierno de la UP como mujer joven. Pude ver como las mujeres sí tuvieron mucha participación en los programas de Salvador Allende, especialmente en los trabajos voluntarios de las poblaciones más pobres (Juntas de Vecinos, Ollas comunes, etc.).

No nos sentimos marginadas ni excluidas del proyecto de Allende. Además, el presidente creó la Secretaría de la Mujer, una institución que abría un nuevo ciclo en donde los temas de género empezaban a tratarse por primera vez. De hecho, algunos sectores de mujeres tuvieron mucho miedo por las medidas de la UP porque vieron amenazada su calidad de vida.

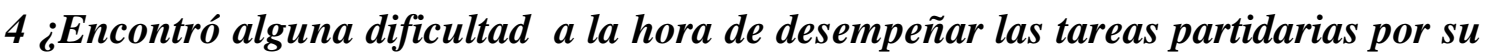 condición de mujer?}

No tanto con los campesinos. Ellos tenían una mentalidad muy sana y no tuve grandes dificultades. Sin embargo, con los propios compañeros del partido, con los que iba a trabajar al campo, sí que se dieron algunas situaciones machistas. Además, había un tema de competencia en los trabajos partidarios.

\section{5 ¿En qué circunstancias estuvo el 11 de septiembre de 1973?}

Yo había pasado por algunos cargos de la dirección de la juventud. El 11 de septiembre era dirigente regional. Hacía pocas semanas que mi hija había nacido. También, fui encargada nacional del Frente Agrario Joven y trabajaba en la Confederación Campesina, la organización más importante de los trabajadores rurales. Yo llevé todo el trabajo del área de la mujer y fui miembro del Comité Central en varios períodos. 
Con el golpe, tuvimos que asumir la responsabilidad del partido porque la generación más adulta o bien cayó presa o salió al exilio. Finalmente, después de unos días, pasé a la clandestinidad con mi hija.

Reconstruimos el partido, yo fui parte de la dirección del Comité Central en la clandestinidad. Estuve trabajando con Carlos Lorca, secretario general de la juventud y diputado del PS en el gobierno de Allende. También estuve con Ezequiel Ponce, secretario político de organización del partido, Ricardo Lagos, Octavio Boettinguer, Alejandro Parada, Michelle Peña (estaba embarazada cuando la tomaron presa y nunca supimos de su hijo), etc. Hoy la mayoría de ellos son detenidos desaparecidos o ejecutados, todos tenían menos de treinta años.

\section{6 ¿Qué tareas fue desempeñando en el trabajo clandestino? ¿Tuvo problemas de represión?}

Yo fui parte de una estructura muy cerrada y compartimentada. Tuvimos muchos problemas represivos. En 1975, mi primer enlace que fue Ariel Mancilla, cayó preso. Al día siguiente la DINA fue a buscarme a mi casa. Nosotros nos habíamos recogido a una casa de seguridad. Logré salvarme y escapé, sin mi hija que estaba con mi familia, completamente sola.

Estuve viviendo sin el apoyo de mis compañeros por el riesgo que suponía contactar conmigo. En más de una ocasión tuve que andar sola por las calles con toque de queda. A mi me perseguía el guatón Romo (Osvaldo Romo, principal torturador de la DINA) y en más de una ocasión intentó raptar a mi hija para que yo me entregara. En una oportunidad la tuvo en sus brazos pero se confundió con unos sobrinos que yo tenía y no quiso correr el riesgo de detener a un niño que no fuera el mío.

De esta manera tan terrible viví la clandestinidad. Casi todos mis compañeros fueron cayendo. Solo quedamos cuatro, entre ellos una compañera que fue muy torturada (la reventaron un pulmón), Sara Montes, que finalmente pudo salir al exilio. 


\section{7 ¿Creé que parte de las mujeres militantes del PS en tiempos de dictadura tuvieron que renunciar a su militancia política por el cuidado de sus hijos? ¿Podríamos decir que hubo una carga extra en este sentido?}

Ser mujer y hacer política se transformaba en algo fácil y difícil a la vez. Fácil, porque podías tener la cobertura de ser mujer y pasar desapercibida. Difícil, porque el tema de los hijos y la amenaza para que tu te entregaras fue una realidad. Solían torturarte en presencia de tus niños y esto ocurría siempre con las compañeras.

Es posible que muchas compañeras estuvieran consignadas a la función de madre. Siento que también el cuidado de los hijos, mientras tu compañero estaba militando, fue una responsabilidad política también.

Ciertamente, la cultura católica y convencional de Chile, tuvo un gran efecto en las mujeres, pero no se hasta que punto fue responsabilidad de los compañeros del partido o de la mentalidad de la sociedad.

Personalmente, no me he sentido discriminada en el Partido Socialista, es decir, el machismo creo que existió pero no tanto con los compañeros sino en la sociedad generada por la dictadura. He tenido muy buena relación con los hombres del PS. Nada es gratis en el partido, todo hay que pelearlo y no vas a conseguir un cargo si no te lo trabajas.

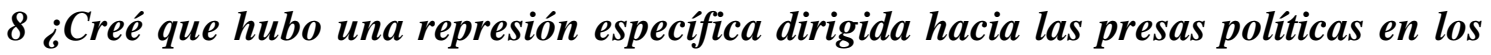
centros de detención de la dictadura?

Por supuesto. Especialmente con las mujeres de las poblaciones. Ellas fueron muy maltratadas. Las mujeres que opinaban un poco distinto corrían el riesgo de ser cesantes en los hospitales, los colegios, etc. También las mujeres que cayeron detenidas fueron muy humilladas. Tenemos dos elementos, primero el maltrato hacia las mujeres más humildes y luego su condición de mujer militante que rompía con los valores de la dictadura. 
La CNI y la DINA actuaron con una brutalidad terrible. Las compañeras que sufrieron abusos sexuales tuvieron que soportar no sólo una tortura física sino también una violación de su ideología, de su trasgresión. La parte sexual era la parte débil de la presa y esto lo aprovecharon muy bien. Fueron auténticos salvajes que castigaron duramente a las mujeres que pensaron diferente, a las mujeres de la izquierda. Te violaban para que nunca más fueras socialista, comunista o mirista.

\section{9 ¿Qué opinión tiene sobre las presas que se quebraron por la tortura?}

Mira, yo viví bien de cerca dos situaciones que tienen que ver con tu pregunta. Lo que te pedía el partido es que te aguantaras un par de días para hacer los movimientos necesarios para trasladar a la gente a otras casas o lugares de seguridad. Esta fue la consigna.

Sin embargo, con el tiempo nos fuimos dando cuenta de que nos enfrentábamos a unos salvajes sin freno alguno. Esto, nos hizo comprender el hecho de que no todas las personas que caían presas podían soportar tanta tortura. Te daba rabia esta situación porque caían amigos y compañeros pero entendíamos la desesperación de algunos compañeros después de haber soportado tanto dolor.

Recuerdo que en una ocasión en la que un compañero que había quedado en reunirse con otro, cayó preso porque la DINA lo estaba esperando. Ellos sabían el momento y el lugar en donde esta persona iba a aparecer. Ahora es ejecutado político. Yo viví muy de cerca este episodio y lloré mucho por la pérdida de un amigo, pero con el tiempo entendí que la tortura no era soportable para los seres humanos.

En más de una oportunidad la Luz Arce y la Flaca Alejandra me delataron y fueron a buscarme a mi casa. Se disfrazó de muchas cosas para poder localizarme. Yo todavía tengo mucha rabia con ella. No sé por qué decidió colaborar con la DINA. No puedo hacer un juicio de valor pero la Luz Arce llegó a mi casa fingiendo para conseguir que yo cayera presa.

\section{0 ¿Tuvo alguna vinculación con las agrupaciones de DDHH?}


Trabajé con mujeres visitando a presos políticos por todas las cárceles del país. Las mujeres tuvieron un gran aporte en los Derechos Humanos. Yo trabajo desde el año 76, cuando desaparecieron la mayoría de mis compañeros, en la Agrupación de DetenidosDesaparecidos. Siempre quise saber que había pasado con Ariel, Carlos, Ezequiel, Octavio, Ricardo...

11 ¿Cuáles serían los elementos más relevantes y positivos de su militancia política dentro del Partido Socialista y aquellas cuestiones que le hubiera gustado que hubieran sido diferentes?

Cuando yo entré el PS era un partido al servicio de la clase, de los trabajadores. La mayoría de las reivindicaciones iban encaminadas a defender a los más desprotegidos. Esto fue hasta 1973. Después, muchos compañeros se fueron distanciando de estas ideas.

En lo positivo puedo decir que gracias al partido he podido mantenerme en mis valores y en mis convicciones. Yo pertenezco a una generación que ha trabajo mucho para que en Chile tengamos libertades. 
19 Entrevista realizada a PAULINA WEBER, 6 de enero 2005, Santiago de Chile. Weber es militante del Partido Socialista y realizó un intenso trabajo en el Departamento de Extranjería durante el gobierno de la Unidad Popular ayudando a los refugiados políticos. Estuvo exiliada en Ecuador y la RDA durante el período 19731985. Asimismo, participó en la fundación y organización del Movimiento Proemancipación de la Mujer (MENCH83) y desarrolló una importante labor en pro de los derechos de las mujeres.

\section{1 ¿Cómo fueron sus inicios en el Partido Socialista?}

Yo estudié derecho y cuando entré en la universidad también trabajé en el servicio de salud, como procuradora en las cuestiones jurídicas. A mi me tocó ser delegada de menores y tenía que ir a las cárceles a visitar a los menores delincuentes.

Tenía que realizar un seguimiento con los jóvenes. Esto empezó a darme una visión de la justicia social y a concienciarme políticamente. Tenía que hacer un informe social sobre las condiciones de vida de estas personas. Lo que más me motivó fue esta experiencia para empezar a militar en el Partido Socialista.

\section{2 ¿Qué tipo de militancia desempeñó en los años de la Unidad Popular?}

Cuando entré al PS ocupé rápidamente cargos directivos. Primero, porque yo daba el perfil de mujer dirigente por mi experiencia en la Salud. Trabajé en la democratización de la salud en Chile y contra la jerarquización de los servicios sanitarios.

En el gobierno de Allende yo era cuadro dirigente y también me pusieron a cargo de los exiliados políticos de América Latina (Brasil, Nicaragua, Bolivia, Uruguay, etc.). Llegaron grupos muy numerosos y en condiciones muy penosas. Además, los militares siempre quisieron tener el control del departamento de Extranjería porque pensaban que desde fuera podían llegar grupos subversivos.

3 ¿En qué situación (presencia, participación política, etc.) estaba la mujer militante del PS en los años de la UP? 
Desde muy pronto tuve una conciencia de que se tenía que luchar por una justicia social que incluyera también a las mujeres. Durante el período de la Unidad Popular los grupos de mujeres se había nucleado entorno a los roles tradiciones de la mujer. En definitiva, los centros de madres tenían un sello muy tradicional en relación al rol doméstico que tenían que desempeñar las compañeras. Se organizaban reuniones y se debatían temas entorno a estos problemas del ámbito doméstico y económico.

Las mujeres, en ese tiempo, eran la retaguardia de los varones en el funcionamiento interno del partido. Los profesores en la universidad no tenían reparo en alegar que las mujeres estábamos peor dotadas que los hombres en la política.

Escuché a catedráticos hablando sobre lo diferente que era la inteligencia de la mujer con respecto a los varones porque en nosotras la parte emocional y afectiva estaba mucha más reforzada careciendo de la frialdad y la objetividad. Este discurso lo adornaban con expresiones muy sutiles. Chile ha sido terriblemente conservador con respecto a los derechos y posibilidades de las mujeres.

Las mujeres jugábamos un papel revolucionario en donde no sentíamos ninguna discriminación porque no nos planteábamos funciones de liderazgo en el partido. No reconocíamos o no nos dábamos cuenta de nuestra discriminación. Eran temas que no se debatían.

En las reuniones, las opiniones de las mujeres eran menos consideradas que la de los hombres. Esto incluso ocurre hoy día. Sólo se consideraban las ideas se eran expresadas por un varón. Había muchos hombres incapaces de desempeñar las tareas políticas y nadie cuestionaba que esto fuera porque eran varones. Sin embargo, si una mujer se equivocaba era por el hecho de ser mujer y no por ser persona.

\section{4 ¿En qué situación estuvo el 11 de septiembre de 1973?}

Yo partí al exilio a finales de octubre de 1973. Me refugié en una embajada. Detuvieron a mi padre y a mi hijo de 11 años. Los sacaron a punta de metralleta de mi casa. Yo era un objetivo muy claro de la dictadura. Si no me hubiera refugiado seguramente ahora 
sería detenida-desaparecida. Salí a Ecuador, aunque estuve en vigilancia permanente. Posteriormente me fui a Alemania en calidad de expulsada (RDA).

\section{5 ¿Qué tareas partidarias desempeñó en el exilio?}

Por cosas de la vida, me puse a trabajar en una Federación de Mujeres y tuve que ponerme al día en todo lo referente a la cuestión de género. A partir de esta experiencia fui tomando conciencia de los problemas de las mujeres.

Yo cumplí un papel importante en la Solidaridad con Chile. El exilio chileno tuvo la característica de tener mucho compromiso político, los grupos de solidaridad se formaron muy rápidamente. Hacíamos informes relacionados con los atropellos a los Derechos Humanos.

Además, tuve la oportunidad de entrevistarme con víctimas y familiares que sufrieron la represión. Paralelamente, trabajé con lo que estaba pasando con las mujeres en Chile. No éramos, precisamente el sexo débil...había una fortaleza muy grande entre todas las compañeras.

Por tanto, en el exilio tomé conciencia de género y la convicción de dedicarme a temas de género. Soñaba en crear una casa de la mujer en Chile, en aprovechar en entregar herramientas a las mujeres más desamparadas.

\section{6 ¿Cómo se materializaron los elementos críticos hacia su partido en la cuestión de género?}

Yo escribí diversos documentos que recogían la cuestión de género. Los partidos siempre habían cuestionado el papel de la mujer, su derecho a voto en las decisiones tomadas en las direcciones, etc. La visión siempre fue muy conservadora. En la época de la dictadura, el PS hizo oídos sordos a estas demandas, sólo la lucha contra el régimen militar era el objetivo y cualquier otra cosa significaba una desviación.

Las mujeres fuimos muy instrumentalizadas por el partido. También nosotras nos dejamos llevar en muchas ocasiones. Las organizaciones de mujeres, conscientes o 
inconscientemente, nos transformamos en agrupaciones que asumían una gran heterogeneidad de cosas que no sólo pasaban por el trabajo político, sino por el derecho a la vida, a la solidaridad, a la justicia, etc.

El hecho de ser mujer fue aprovechado por nosotras a la hora de enfrentarnos con los militares. Esto nos daba cierta impunidad en el momento de increparles puesto que a sus ojos "pegar o maltratar a una mujer" públicamente era deshonroso para un soldado. Esta estrategia la utilizamos muy bien. Es decir, hicimos cosas que si las hubieran hecho los hombres posiblemente los hubieran matado o detenido.

\section{6 ¿En qué circunstancias regresó del exilio?}

Yo regresé a Chile en 1985. Tuve mucha enemistad con los compañeros del partido por el tema de las mujeres. Era muy complicado porque mientras nosotras desempeñábamos tareas de solidaridad no había ningún problema, pero cuando cuestionábamos temas de liderazgo al interior del partido los conflictos aparecían.

Había muy pocos recursos para trabajar nuestros temas. Las prioridades eran otras según ellos y esto nos dejaba muy poco margen para trabajar. Nos imponían sus criterios y había una clara manipulación. Cuando volví a Chile yo ya estaba fuera del partido pese a que siempre me he considerado socialista.

Yo tenía la L en el pasaporte que quería decir que tú estabas en una lista de la gente que no podían entrar al país. Mi madre, cuando me visitó en el exilio, se dio cuenta de los problemas reales que teníamos. En otras palabras, había muchas limitaciones a la hora de comunicarnos y adaptarnos al ritmo de vida en el extranjero.

El 1 de enero del 85 me dejaron entrar a Chile y en marzo ya estaba en Chile. A partir de ahí enfoqué todo mi trabajo en el MENCH (Movimiento Pro-Emancipación de las Mujeres en Chile.

7 ¿Considera que hubo una represión específica dirigida hacia las presas políticas en los diferentes centros de detención de la dictadura? 
Nosotras tuvimos la percepción, desde el comienzo, de que las mujeres era torturadas en los cuartes y en las cárceles como a los hombres pero con un adicional sexual que se produjo con todas las presas. No todas las mujeres fueron violadas pero en prácticamente todos los casos (y he trabajado con muchos testimonios) hubo agresiones, abusos y tocamientos de carácter sexual.

Creo que en el período de la dictadura a los militantes de la izquierda política no se les veía como personas sino como "humanoides". Dentro de una concepción muy machista y patriarcal las mujeres presas rompían con los cánones tradicionales. La mujer tenía que quedarse quietita en casa sin meterse en líos. La independencia política de la mujer los enfurecía aún más y el castigo recaía en su sexualidad.

Este hecho, no se trabajó durante la dictadura. Muchos años después, se empezó a reflexionar sobre la tortura sexual como una forma de represión específica. En 1987, hicimos un seminario en un colegio (Compañía María) en donde mujeres muy jóvenes dieron sus testimonios que reflejaban todo tipo de atrocidades de carácter sexual en la tortura. Hay una falta de memoria histórica en estos temas.

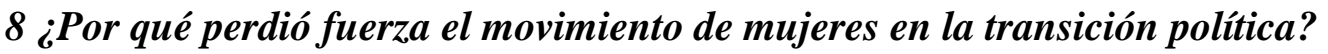

Hubo un conjunto de cosas. Por una parte, por la necesidad de retomar los proyectos personales. Esto fue muy legítimo. Se perdió todo el trabajo voluntario y de compromiso. Se pensó que ya se había dado bastante y que la democracia debía asumir el trabajo político y social.

Asimismo, hubo un tremendo agotamiento por supeditar tu vida a la causa. Hubo una generación cansada que no tuvo relevo porque el miedo causó auténticos estragos en la sociedad. Todavía ese temor está enquistado en Chile.

También, existió una captación por parte de los partidos de gente para trabajar en los municipios. El modelo político no incluía el movimiento social dentro de sus programas. Se excluyó a gran parte de la ciudadanía en la gestión de gobierno. 
Los ciudadanos pasaron a ser objetos de la política y dejaron de ser actores sociales. No se abrieron canales de interlocución porque había demasiados problemas con la derecha y los poderes fácticos. Las mujeres aceptamos esto, en un principio, por miedo y agotamiento. Esto tuvo una consecuencia muy grabe para nosotras: se bajó el perfil de las demandas y se nos excluyó.

Nos cansamos de pedir entrevistas con los presidentes, incluso lagos, ha rechazado un encuentro en reiteradas ocasiones. En estos momentos, tenemos una ministra estupenda pero ella puede llegar hasta donde le dejan.

Ahora con la candidatura de Michel Bachelet se abren nuevas perspectivas y posibilidades. Pero queda el interrogante de si ella va llevar a cabo las demandas necesarias.

\section{9 ¿Qué elementos positivos y negativos destacaría de su militancia en el Partido Socialista?}

Yo destaco el compromiso político de la militancia de la izquierda de este país. Supeditamos nuestros proyectos personales a un objetivo común y colectivo para construir una sociedad más justa. Sentimos, durante el gobierno de la UP, que podíamos alcanzar ese sueño, lo teníamos como una prioridad.

Yo pagué un costo muy alto por esto porque tuve problemas con mis hijas. Recuero que uno de ellas me dijo en una ocasión que "tenía los valores trastocados" porque me ocupaba más de las cosas externas que de mis propias cosas personales. Se sintió muy abandonada porque priorizaba las reuniones del partido y el trabajo político a las cosas familiares como los cumpleaños, etc.

Teníamos la urgencia y un compromiso permanente por salvar vidas y esto dejaba en un plano secundario la vida familiar o personal. Fueron actos de mucha heroicidad pero con un alto costo en lo privado.

Al partido puedo recriminarle la ceguera con la mujer. La falta de obejitivdad con nuestras realidades y de reproducir los discursos conservadores de siempre. 
20 Entrevista realizada a MIREYA GARCÍA RAMíREZ, 7 de enero de 2005, Santiago de Chile. García es militante del Partido Socialista y vicepresidenta de la Agrupación de Familiares de Detenidos-Desaparecidos. Estuvo recluida en la Isla Quiriquina y en la base naval de Talcahuano durante los años 1973 y 1974.

\section{1 ¿Cómo fueron sus inicios en el Partido Socialista?}

Yo tenía 14 años cuando ingresé a las Juventudes Socialistas. Me críe en un ambiente familiar muy propicio para militar. Mis inicios coincidieron con el triunfo de Salvador Allende, es decir, entré en una fecha sumamente fructífera en términos de militancia.

\section{2 ¿Qué tipo de militancia desempeñó en los años de la Unidad Popular?}

Desarrollé todas las tareas partidarias que en la JS se realizaban en esos años. Personalmente, participé en todo lo que tenía que ver con trabajo voluntario en poblaciones, alfabetización a campesinos, trabajo y movilización estudiantil en el Liceo, etc. Estas tareas se compaginaban con el estudio puramente político, leíamos mucho y teníamos charlas.

\section{3 ¿En qué situación (presencia, participación política, etc.) estaba la mujer militante} del PS en los años de la UP?

Hubo una fuerte presencia y participación de las mujeres en el ámbito partidario. Pero no todas las mujeres militantes de esos años siguieron la vida partidaria porque el golpe de Estado significó una clara ruptura en los partidos y muchas de mis compañeras fueron poco a poco replegándose fuera de la órbita política.

Las mujeres socialistas, durante los tres años del gobierno de la Unidad Popular, fueron muy activas y comprometidas con el proceso de la Unidad Popular pese a que el tema de género en aquella época no era una prioridad. El tema mujer no era un objetivo dentro del PS, más allá de la cuestión de género todas nos sentíamos militantes.

También hay que recordar la presencia del Frente de Mujeres Socialistas (FMS) que desarrolló una intensa actividad. Pero insisto, las prioridades eran otras, es decir, 
estábamos preocupados en enfrentar el desabastecimiento, la oposición de la derecha, los paros, defender el gobierno popular.

\section{4 ¿En qué situación estuvo el 11 de septiembre de 1973?}

El día del golpe yo estaba en mi casa porque sabía que me estaban buscando en el Liceo. Durante los siguientes días viví una situación de total incertidumbre. La JS se quedó absolutamente aislada y sin dirección.

Me detuvieron el 19 de septiembre de 1973 en la ciudad de Talcahuano y estuve nueve meses recluida en la base naval de Talcahuano y en la Isla Quiriquina. Ahí conocí a Rosa Elvira Lizama, militante del Movimiento de Izquierda Revolucionaria (MIR).

Yo sufrí todo el proceso de detención característico de la Fuerza Armada de Chile. Estuvimos en pésimas condiciones, pero esas mismas condiciones generaron fuertes lazos de solidaridad y apoyo mutuo entre las presas políticas que estuvimos allí. Con el paso de los años he llegado a la conclusión de que las presas tuvimos más fortaleza que los hombres sufriendo la misma represión.

\section{5 ¿En qué circunstancias salió de prisión?}

Yo salí el 13 de abril de 1974 con libertad condicional. Tenía que firmar todos los días en una comisaría. Después vinieron otras detenciones. Tuve que salir de Chile exiliada pensando que iba a estar poco tiempo fuera de mi país, solo lo necesario para reponerme de mi experiencia en prisión. Mi vida estuvo marcada por la represión que yo sufrí, por la represión que mi padre vivió y por la desaparición de mi hermano en el año 1977.

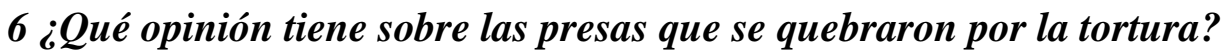

Es muy difícil entrar a cuestionar lo que pasó con determinadas mujeres durante la represión y la reclusión. Fueron circunstancias especialmente duras. Las mujeres fuimos vulneradas y reprimidas por nuestra condición de mujer. No es fácil soportar la tortura. Prefiero no entrar en juicios de valor con aquellas compañeras que se quebraron. Desde el punto de vista humano es muy difícil condenar a una compañera que lo pasó tan mal. 
Lo que no puedo comprender es como algunas mujeres y también hombres se convirtieron en colaboradoras.

\section{7 ¿Qué tareas partidarias desarrolló en el exilio?}

Participé en todas las tareas de solidaridad con Chile. Estuve exiliada en México y en Suecia. Regresé a Chile en 1987. Desde 1977 formé parte de las diferentes agrupaciones de DDHH que existían en el exilio y también en los Comités de Solidaridad del exterior.

Durante muchos años seguimos el tipo de militancia que habíamos desarrollado en Chile, creo que esto fue un error porque las circunstancias en el exilio eran completamente diferentes. Seguimos realizando congresos y debatiendo documentos y esto no tenía mucho sentido en el exterior.

\section{8 ¿Sintió en algún momento algún tipo de discriminación de género en el Partido} Socialista durante su militancia en el exilio?

Creo que en el exilio se reprodujeron las mismas actitudes, aquellas negativas y positivas. Un ejemplo de "discriminación" puede ser que el Partido Socialista no organizó ningún tipo de política de retorno para nosotras. La mentalidad machista, patriarcal, operó en todo momento en el partido. Precisamente, eran los hombres los que tenían que volver a Chile mientras que las compañeras se tuvieron que quedar en el exilio cuidando a los hijos.

Los compañeros regresaban solos y algunos hacían vida de solteros junto con la vida de militante clandestino. Además, por lo general, muchas mujeres tuvieron que compaginar su militancia con el trabajo, que en la mayoría de los casos era muy precario. Esta mentalidad relegaba a la mujer a un segundo plano en tanto se suponía que ella no era tan capaz para enfrentar la dictadura como sí lo eran los varones.

\section{9 ¿Cómo fue su regreso del exilio?}

Fue traumático. Yo no pude volver a Chile hasta 1987 porque tenía prohibida la entrada. Tenía mi pasaporte marcado con una "L", que significaba: No puede entrar a su país. 
Cuando llegué todo había cambiado, no encontré a mi círculo de amigos, me encontré con mis padres que estaban absolutamente dañados con la desaparición de su hijo. Fue un momento muy difícil.

No tuve problemas de inserción política porque inmediatamente me integré a la Agrupación de Familiares de Detenidos-Desaparecidos para luchar por encontrar a mi hermano. Sin embargo, sí tuve problemas de adaptación a todo lo que era la vida cotidiana en el país.

10 ¿Usted desarrolló una conciencia de género que propiciara algunos elementos críticos hacia su partido?

Yo siempre he creído en la igualdad entre hombres y mujeres. No me siento identificada con el Movimiento Feminista. Lo que sí te puedo decir es que el Movimiento de Mujeres fue duramente golpeado y que en el proceso de transición a la democracia los partidos políticos de izquierda se olvidaron del aporte que las organizaciones lideradas por las mujeres a la hora de planificar los objetivos partidarios ante el nuevo escenario político.

9 La represión de la dictadura afectó especialmente a los Comités Centrales y a las Comisiones políticas de los diferentes partidos de la izquierda chilena en donde la mayoría de los cargos partidarios eran ocupados por hombres. Esta situación creo un vacío de poder dentro de los partidos. En el caso del Partido Socialista ¿esto significó que las mujeres tuvieran un mayor acceso a las responsabilidades partidarias, o por el contrario su situación no cambió sustancialmente?

La mujer tiene condiciones especiales para luchar por la vida cuando este derecho es vulnerado, porque ella es portadora de vida. Creo que las mujeres se centraron más en esto que en la militancia partidaria propiamente tal.

También es cierto que el $90 \%$ de los detenidos-desaparecidos fueron hombres y esto significó que las madres, las esposas o las hermanas de los desaparecidos se movilizaran con mucha fuerza. 
Además, muchas mujeres actuaron bajo los parámetros machistas de que la represión les iba a afectar menos por el hecho de ser mujeres. Se pensaba que la mujer podía arriesgar más sin ser tan duramente tocada por la represión; esto fue un claro reflejo de la reproducción de la mentalidad machista por las propias mujeres a la hora de movilizarse.

\section{0 ¿Cómo fue la convivencia entre las compañeras de la Agrupación de Detenidos- desaparecidos? ¿Pudieron superarse las diferencias ideológicas ante la heterogeneidad de sus integrantes?}

Hasta hoy un gran problema de la Agrupación es el de las hegemonías partidarias. Sí se superaron las diferencias a la hora de definir cuál era el objetivo que no era otro que la lucha contra la dictadura y el derecho a exigir verdad y justicia por las desapariciones de nuestros familiares.

Sin embargo, ha existido una pugna entre los partidos a la hora de controlar y dirigir las agrupaciones. El Partido Comunista sigue siendo el partido que controla esta organización y esto ha creado muchos conflictos puesto que la Agrupación es un espacio en donde conviven familiares militantes y familiares desvinculados de los partidos.

\section{1 ¿Hubo una represión específica dirigida hacia las presas políticas en los diferentes centros de detención de la dictadura?}

Sin lugar a dudas. Precisamente el Informe Valech ha confirmado lo que ya sabíamos. La mujer sufrió una represión especial. No sólo en Chile, en todos los conflictos armados las mujeres sufren de una manera distinta. Aunque la Comisión sobre Prisión Política y Tortura no recoge la totalidad de los casos, puesto que mucha gente no ha declarado (faltó tiempo, faltó discutir muchas cuestiones y otro tipo de reconocimiento más profundo hacia las mujeres torturadas), creo que sí tiene importancia ya que ha reflejado esta realidad específica.

Chile es un país extremadamente machista y clasita. Esto significó que incluso entre las presas políticas se establecieran diferencias de trato. Creo que las mujeres de extracción 
socioeconómica baja fueron más humilladas. Las mujeres pobladoras o mapuches recibieron un trato mucho más degradante.

Aunque la tortura traspasó las clases sociales, en otros aspectos, como en el trato verbal o cotidiano, las presas más humildes fueron más maltratadas. También no era lo mismo estar casada o ser compañera de un militante. Las Fuerzas Armadas chilenas son extremadamente conservadoras en este sentido.

14 ¿Cuáles serían los elementos más relevantes y positivos de su militancia política dentro del Partido Socialista y aquellas cuestiones que le hubiera gustado que hubieran sido diferentes?

En lo positivo, mi experiencia en los años de gobierno de la UP. Sentí que fue una militancia de toda una generación de jóvenes que luchamos para que en este país hubiera cambios sociales y económicos de envergadura.

En lo negativo, creo que el Partido Socialista sigue viendo a la mujer como un acompañamiento a la política y no como un actor con voz y voto. La mujer sigue relegada a un ámbito de secundariedad, pese a que tenemos dos candidatas a presidentas de la República. La realidad del conjunto de las militantes sigue estando marcada por la mentalidad machista que en definitiva significa no tener la misma presencia en los órganos de decisión del partido que los hombres. 
21 Entrevista realizada a ANGÉLICA MUÑOZ CATEJO, 9 de Enero de 2005, Santiago de Chile. Muñoz es militante del Partido Socialista desde 1969. Se formó en tareas de inteligencia político-militar en Alemania Oriental y Bulgaria. Asimismo, estuvo presa en la Correccional para mujeres (COF). Actualmente, su marido, Alejandro Parada, está detenido-desaparecido.

\section{1 ¿Cómo fueron sus inicios en el Partido Socialista?}

Yo comencé a militar a las Juventudes Socialistas cuando tenía 16 años. Esto fue en 1969. Entré por amigos militantes que me animaron a integrarme en el partido. Mis primeras actividades empezaron con el paro de la Universidad Técnica de Santiago, es decir, en el ámbito estudiantil.

También participé en las campañas por Salvador Allende. Mi aporte se centró básicamente en rallados en las paredes, tareas de propaganda, conversaciones con los sindicatos obreros para dar a conocer el programa de la UP, etc.

\section{2 ¿Qué tareas partidarias desempeñó en los tres años de gobierno de la UP?}

Durante el gobierno de la Unidad Popular llegué a desempeñar el cargo de secretaria del partido en el departamento de organización del Comité Central; trabajaba en la tercera comuna del PS en Santiago desempeñando tareas de base.

\section{3 ¿Cómo recuerda la presencia de la mujer en el partido durante esa etapa?}

En los años de la UP la presencia de la mujer fue significativa pero nunca hubo una entidad organizada dentro del partido que recogiera cuestiones de género. El partido era quién programaba los objetivos políticos, las prioridades, etc. Creo que los partidos de izquierda han tenido en mente la posibilidad de realizar proyectos para la mujer, pero esto no se reflejó en la práctica. En Chile, la cultura patriarcal ha estado muy arraigada en la sociedad y esto también se reflejó en los partidos.

\section{4 ¿En qué circunstancias estuvo el 11 de septiembre de 1973?}


El 11 de septiembre yo estaba en el Comité Central. Aquel día la comunicación dentro del partido fue muy defectuosa. Yo desarrollé la labor de contactar con los compañeros de los distintos comunales del país. La orden era quemar toda la documentación y archivos del Comité Central.

Posteriormente, me trasladé a un punto de encuentro (Industria FENSA, Fábrica Enlozados SA) en el que se tenían que concentrar todos los dirigentes del PC, el MIR y el PS. Esto fue un desastre, solo nos juntamos 50 compañeros y permanecimos encerrados tres días esperando instrucciones. La única persona del Comité Central del PS fue Ezequiel Ponce, hoy detenido-desaparecido. Sólo teníamos dos pistolas calibre 22 para defendernos con lo que no pudimos hacer mucho.

A partir de ese momento pasé a la clandestinidad con mi marido. Nos casamos para tener una situación "regular". Mi casa estaba arrendada por el PS, era una casa de seguridad. El 14 de diciembre del 73 me casé con mi marido, Alejandro Parada, y el 30 de julio del 74 detuvieron a mi esposo cuando allanaron mi casa.

Participaron, en el operativo, agentes de seguridad del Estado (DINA) entre los que participaron Eduardo Correa Castro y otros veinte agentes más. Llegaron armados y su entrada en la casa fue muy violenta, incluso nos dispararon. En la misma casa empezó el interrogatorio a mi marido y a mi, allí aplicaron métodos de tortura contra Alejandro estando yo presente. Buscaban armamento, documentación y dinero.

Durante el tiempo que vivimos en esa casa recibimos a muchos compañeros que estaban en clandestinidad para que se pusieran en contacto con sus familiares...repartíamos material e información, plata, etc. Esa fue nuestra labor hasta la detención de Alejandro (él formaba parte del Comité Central del PS en la clandestinidad junto a Carlos Lorca, Ariel Mancilla, Ricardo Lagos y Ezequiel Ponce).

Cuando detuvieron a mi marido (momento en el que tenía ocho meses de embarazo) me desconecté del partido (aunque di aviso a la Comisión Política sobre la detención de Alejandro para que dicha estructura no cayera) y me dediqué exclusivamente a buscarle. Me integré al comité Pro-Paz para posteriormente pasar a formar parte de la Agrupación de Familiares de detenidos-desaparecidos por orden del partido. Fui 
también parte de la dirección de la Agrupación. En otras palabras, aunque no cumplí tareas a nivel clandestino del PS nunca dejé de estar en contacto con ellos.

La detención de mi esposo estuvo muy vinculada a Luz Arce porque ella trabajaba en el Comité Central, en donde nosotros también trabajábamos. Ella nos conocía perfectamente. De hecho, después del golpe tuvimos contacto con ella, tuvimos una reunión en donde participó Luz Arce.

Ella entregó información sobre el paradero de Alejandro Parada, incluso lo reconoce en su libro ("Ese Infierno"). Tengo sentimientos encontrados respecto a esto. Intento comprender en que circunstancias estuvo para dar información vital sobre los compañeros. Sin embargo, lo que lamento profundamente es que continuó colaborando con la DINA en calidad de funcionaria. Ella incluso sabía que yo estaba embarazada de ocho meses.

\section{5 ¿En algún momento cayó presa?}

Estuve detenida muchas veces, concretamente en la Comisaría $\mathrm{N}^{\circ} 1$ de la Comuna de Santiago porque la Agrupación estaba ubicada en el centro. En una ocasión estuve bastante tiempo detenida (1979) porque, junto a unos compañeros (3 hombres y 60 mujeres), nos encadenamos al congreso y allí me detuvieron.

Tras pasar una semana en comisaría nos trasladaron a la COF (Correccional de Mujeres) y allí estuvimos 20 días aproximadamente. Tratamos de estar activas y organizamos diferentes talleres de artesanía, reuniones, etc. Una vez en libertad, me incorporé de nuevo en la Agrupación y comencé a visitar diferentes organismos y cárceles para denunciar la detención y desaparición de mi marido.

\section{6 ¿Creé que hubo una represión específica hacia las mujeres presas políticas?}

Por mi condición de presa política yo presenté mi testimonio en la Comisión sobre Prisión Política y Tortura (Informe Valech). La conducta machista, muy arraigada en las Fuerzas Armadas, motivó a que en la práctica se reprimiera a las presas con un fuerte componente sexual. La tortura fue una política planificada, pero en el caso de las 
mujeres sí hubo un componente diferenciador por el peso de esta mentalidad. Creo que la tortura sexual se dirigió hacia las presas independientemente de su condición social o económica.

Este tipo de represión también vino dado por el comportamiento de las mujeres funcionarias del Cuerpo de Carabineros. Ellas nos increpaban con insultos y vejaciones verbales. Nos decían que nuestros maridos detenidos estaban con otras mujeres en el extranjero, es decir, fue todo un mecanismo machista destinado a infravalorarnos como mujeres.

\section{7 ¿Cómo fue su experiencia en la reclusión?}

En la comisaría N1 de Santiago recibí malos tratos y vejámenes como manoseo y abuso de mi anatomía femenina. Asimismo, sufrí aislamiento, privación del sueño, privación de las necesidades más básicas. Recuerdo que nos mantenían de pie durante horas sin dejarnos ir al baño.

La tortura psicológica también fue frecuente, nos amenazaban con hacernos desaparecer y torturar a nuestros familiares. La DINA fue a ficharnos, nos tomaban fotos y las huellas dactilares. Los dos primeros días en la comisaría nos dieron muy pocos alimentos, bajé de peso y me llené de piojos y ladillas. Sin embargo, todo este maltrato reafirmó mis convicciones para seguir luchando contra la dictadura.

8 ¿Qué opina sobre la labor de las mujeres presas en el interior de las cárceles? ¿Se superaron las diferencias ideológicas a la hora de organizarse?

Sí. La mujer se organizó mucho mejor y estableció mecanismos de solidaridad. Hubo una identificación de género. Desde mi experiencia en la cárcel puedo decir que las mujeres nos organizamos en la lucha contra la dictadura. Otra cosa son las diferencias en la cotidianeidad fuera de la cárcel, en las diferentes agrupaciones. Por ejemplo, la Agrupación de Familiares de detenidos-desaparecidos está impulsada y dirigida por compañeras del Partido Comunista y esto actualmente ha creado algún conflicto con otras mujeres. 
Además hay algo que quiero reflejar, las mujeres que rehicimos nuestra vida sentimental fuimos tremendamente criticadas y discriminadas al interior de la Agrupación. Imperó la idea de "viuda doliente" o el "luto eterno por el compañero" dentro de toda esa influencia del ideario patriarcal de muchas compañeras.

\section{9 ¿En qué medida su embarazo afectó a su militancia política? ¿Pensó en algún momento abandonar el trabajo clandestino?}

No. Estaba convencida de que lo que estábamos haciendo era absolutamente necesario. La capacidad de entrega fue muy grande. Mi convicción era muy fuerte y pensaba que lo correcto era continuar la lucha. Tampoco pensé en el exilio, entre otras cosas porque Alejandro estaba desaparecido y no podía renunciar a su búsqueda.

Sin embargo, el PS jamás desarrolló una política para que las mujeres que tuvieran hijos pudieran integrarse adecuadamente a la actividad política a diferencia del MIR. Yo tuve la suerte de contar con el apoyo económico y familiar para compaginar mi maternidad con mi militancia (también debo agregar que el PS me apoyó económicamente, pero esto no se dio con la mayoría de las compañeras madres).

El aporte con más cuerpo que se ha dado dentro del PS sobre la cuestión de género fue el de Julieta Kirkwood, ella planteó esta problemática en el ámbito socialista. De hecho, al PS le ha costado mucho reconocer el aporte de las mujeres militantes y creo que esto ha ocurrido igualmente en el conjunto de los partidos de izquierda.

Tan sólo a finales de la década de los noventa las mujeres han ido abriéndose un espacio dentro del partido que las ha colado en mayores cuotas de representación pero en ningún caso alcanzando niveles equitativos en los puestos de dirección con respeto a los hombres.

\section{0 ¿Cómo continuó su militancia en los siguientes años?}

Continué mi militancia siguiendo una doble estrategia. Por un lado, ocupando un espacio en el ámbito público, es decir, como mujer de un detenido-desaparecido miembro de la Agrupación y por otro, desarrollando un trabajo partidario clandestino. 
En 1984 el partido me pidió que saliera del país con rumbo a Italia para posteriormente pasar a Bulgaria. Allí estuve a cargo de un grupo político-militar.

También estuve en Alemania oriental durante tres meses aprendiendo estrategias de inteligencia. Mi formación militar, concretamente en el uso de armamento no me sirvió de mucho. Sin embargo, mi aprendizaje en tácticas de espionaje me ayudó mucho para mi posterior labor en Chile.

Durante un año nos preparamos militarmente para regresar a Chile y plantear nuevas estrategias. Cuando regresé a Santiago, en 1985, me desvinculé de la Agrupación para centrarme de lleno a las labores de enlace entre la Comisión Política del Partido Socialista en el interior de Chile con el PS en el exilio. En ese tiempo, el partido estaba dividido, yo pertenecía a la facción de Clodomiro Almeida (sector que no excluía la lucha armada).

Mi tarea consistió en recopilar toda la información y mandarla al exterior en microfichas. En esta tarea trabajé entre 1985 y 1994 completamente sola. Además, mi segunda tarea consistía en velar por la seguridad del Comité Central de partido. Hasta 1994 estuve a cargo de la seguridad junto con otros compañeros.

Finalmente, con la llegada de la democracia seguí trabajando activamente en el PS hasta 1998. Mi tarea estuvo centrada en el Departamento de Finanzas del partido. Después conseguí un trabajo relacionado con los Derechos Humanos en el Ministerio del Interior hasta hoy en día. 
22 Entrevista realizada a NATACHA MOLINA GARCÍA, 11 de enero de 2005, Santiago de Chile. Molina es militante del Partido Socialista desde 1967. Tuvo que vivir el exilio durante siete años en Costa Rica y México. Cofundó la Federación de Mujeres Socialistas (FMS) y participó en la creación del Instituto de la Mujer.

\section{1 ¿Cómo fueron sus inicios en el Partido Socialista?}

Yo entré en el PS cuando tenía 13 años, es decir, en 1960. Tenía un pololo que era socialista y mi madre también era militante. Mi primer trabajo fue en la Juventud Socialista (JS) y junto a un grupo de compañeros y compañeras fundamos la JS de la Comuna de Nuñoa.

Posteriormente pase a la militancia en el ámbito universitario, en la escuela de Sociología de la Universidad de Chile en donde el movimiento estudiantil fue muy intenso. Desde allí participé en muchas actividades y movilizaciones como las campañas por la candidatura de Salvador Allende. También recuerdo mi entrada en la brigada universitaria en donde se vivió con intensidad la revolución cubana. Fue un tiempo en el que nos formamos en la teoría para pasar después a la práctica.

\section{2 ¿Qué tareas partidarias desempeñó en los tres años de gobierno de la UP?}

Fui dirigente estudiantil pero poco tiempo; también dirigente comunal. Aunque mi compañero fue "el dirigente", yo fui la "esposa del dirigente". Él fue dirigente en la universidad y miembro del Comité Central en varias ocasiones.

Mi inicio en la política tuvo que ver con el inicio de la gran mayoría de las mujeres vinculadas a los partidos, es decir, la familia, el compañero y la universidad fueron las grandes influencias a la hora de determinar la militancia.

\section{3 ¿Cómo recuerda la presencia de la mujer en el partido durante esa etapa?}

Absolutamente tradicional, con una estructura patriarcal. Como yo era compañera de un dirigente y en muchas ocasiones, sin ni siquiera darme cuenta yo vivía el acoso sexual al 
igual que muchas de mis compañeras. No teníamos ni conciencia ni conocíamos estos conceptos.

\section{4 ¿Qué opina de la gestión de la UP con respecto al tema de la mujer?}

Fue muy tradicional también. Recuerdo una anécdota, en uno de los intentos del golpe de Estado, estábamos en la calle, durante el Tancazo. Allende salió al balcón y se dirigió a la población una vez pasado el peligro: "Compañeros, la sedición ha sido aplacada...vayan a sus casas y besen a sus mujeres”. Nosotras, un grupo de mujeres que estábamos allí nos preguntamos: “y nosotras quiénes somos, a quiénes vamos a ver”. Esa era la mentalidad de Allende, la mentalidad de la época.

En aquellos días yo trabaja en la Corporación de la Reforma Agraria (CORA) y claro, como era mujer, la labor que me correspondía no era tanto la de expropiar fundos pero sí encargarme dentro de la estructura de los asentamientos (había un comité de producción, uno de defensa, de bienestar) de tareas tradicionalmente asignadas a las mujeres. Concretamente, nosotras trabajábamos en el comité de bienestar, compuesto en su mayoría por mujeres.

Yo era profesional, universitaria y el impacto que tuve al entrar en contacto con mujeres rurales fue tremendo. Nosotras teníamos grandes planes para que la mujer se incorporara al proceso de reforma agraria y lo que ellas querían era solamente cocinar mejor para sus maridos y tener la casa lista.

Las mujeres no tenían conciencia de clase en esos años. De hecho, no hubo ninguna política que pensara en las mujeres, sólo se pensaba en el conjunto de la familia a la hora de hacer política. Lo que sí es rescatable de Allende es que en su acción hacia las mujeres y hacia las madres se intentó restituir su dignidad pero siempre desde su rol tradicional.

Allende perdió las elecciones por culpa de las mujeres porque estaban muy manipuladas por la derecha. El conjunto de las mujeres chilenas estaban por un cambio, pero la transformación que la izquierda les ofrecía era la revolución, un cambio que alteraba la cotidianidad de las mujeres o así era percibido. 
Hubo una tremenda manipulación con las mujeres para ponerlas en contra de Allende ante la opinión pública; un ejemplo de ello lo encontramos en la significación de las marchas de las Ollas Vacías, mujeres en su mayoría de clase alta, pero también mujeres de clase media que fueron impregnadas de ese temor a perder su cotidianidad, sus alimentos, la seguridad de sus hijos por la llegada del marxismo. La derecha utilizó el sistema patriarcal para utilizar a las mujeres como un movimiento político.

\section{5 ¿En qué circunstancias estuvo el 11 de septiembre de 1973?}

Trabajaba en la Corporación Agraria. Mi marido era subdirector en el Instituto de Capacitación (INACAP). Ambos militábamos en nuestros trabajos. Para el golpe yo no alcancé a ir a mi trabajo y tuve que regresar e ir al INACAP. Desde allí nos fuimos todos los socialistas al cordón Vicuña Maquena con la intención de defendernos militarmente. Sin embargo, los medios eran inexistentes, no teníamos armas y nuestro entrenamiento había sido insuficiente.

Estuvimos dos días en el cordón hasta que se levantó el toque de queda y de allí me fui a mi casa a recomponer un poco mi situación y buscar contactos. A mi marido le buscaban. Yo no quería irme fuera de Chile, pero finalmente Julieta Kirkwood nos ayudó a exiliarnos en octubre del 73. Mi madre estaba presa en el Estadio Nacional, a mi marido le buscaban con lo que el panorama era muy complicado. La FLACSO (Facultad Latinoamericana de Ciencias Sociales) nos asiló en Costa Rica.

Este tipo de decisiones fueron las que muchas mujeres tomamos en aquella época bajo la influencia y predominio del criterio de nuestros maridos. Quedarse en Chile significaba romper la relación de pareja. La decisión de salir del país fue de mi marido y no mía. Viví en Costa Rica cuatro años y siete en México. En 1979 partí a México y tuve una fuerte vinculación con el movimiento de mujeres aunque mi primera aproximación al feminismo fue teórica.

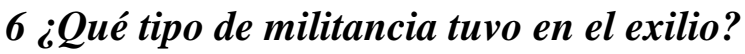

La solidaridad con Chile, sobre todo en Costa Rica. Hacer denuncias a nivel internacional y recoger a muchos exiliados chilenos. En enero del 74, recuerdo que nos 
invitaron a un congreso sobre Chile en el que yo tuve que realizar una ponencia sobre la mujer y el golpe de Estado. Antes de comenzar recuerdo que nos dijeron que tenían una sorpresa preparada para nosotras....pusieron el discurso de Allende, fue muy emotivo. También trabajé mucho con las presas que venían de Chile. Teníamos redes de apoyo y de denuncia que cubrían el área de Costa Rica-Panamá-USA.

Por otra parte, en México comencé a compaginar mi militancia política con mi toma de conciencia feminista. Constituimos un grupo con argentinas, chilenas y mexicanas destinado a pensar temas de exilio y mujer. Fue un grupo que empezó ligado a la revista FEM en donde estaba Teresita de Barbieri y otras mujeres destacadas. Empezamos a escribir pequeños artículos que tocaban temas de reflexión feminista.

En la medida en que yo me acerqué al feminismo intenté quedarme en un sector que no me aceptó por ser feminista. Posteriormente, me acerqué a la Renovación Socialista (RS), en donde tuve un ambiente más propicio, lo que no quiere decir que el feminismo estuviera presente en la RS. No tuvimos en este periodo la oportunidad de poner sobre la mesa nuestras demandas, fue un momento de toma de conciencia, tuvimos que esperar a regresar a Chile para poder realizar un trabajo más concreto.

\section{7 ¿La renuncia a la militancia política por el cuidado de los hijos fue una realidad presente en las mujeres-madres del Partido Socialista?}

Yo tuve tres hijos y en ningún momento dejé de trabajar o estudiar mi tesis de postgrado. No sé si hubo una renuncia pero sí hubo una clara postergación de la maternidad. Ninguna de nosotras dejamos de militar por nuestros hijos. Solíamos compaginarlos. Mis prioridades siempre fueron la maternidad, el trabajo y la militancia.

Recuerdo anécdotas muy reveladoras sobre mi función de madre-esposa y militante del PS. En Costa Rica muchos de los dirigentes que venían de Europa y Chile pasaban por mi casa. Yo era una militante con cierta experiencia, había cofundado la Juventud Socialista y llevaba muchos años en la militancia universitaria, pero resulta que cuando llegaban los dirigentes la comida la hacía y la servía yo y nadie me preguntaba mi opinión. Instintivamente, estas realidades me llevaron a tener un acercamiento al feminismo. 


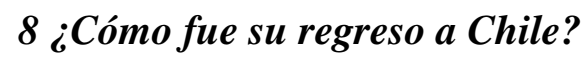

Yo salí en la tercera lista, en el año 1982. En 1983 se produjo el III encuentro feminista en Lima, yo tenía muy buenas amigas allí, muchas de ellas socialistas. Cuando salió la lista yo no tenía plata, pero afortunadamente me invitaron al encuentro y se hicieron cargo de los costes de viaje. Me pagué el pasaje desde Lima a Santiago y vine con mi hijo.

En Chile hice todos los trámites necesarios para que mi marido se viniera y tener mis papeles en regla. Una vez superado este trámite regresé a México y pasados unos meses me respondieron (finales de 1983) que a mi me permitían regresar a Chile pero a mi marido no. Acordamos que yo regresaría con mis tres hijos e intentaría conseguir el permiso para mi esposo.

En 1984 ingresé en una ONG socialista llamada Vector, dirigida por Cloromido Almeida. Entré allí con una beca para realizar un trabajo sobre la mujer y el exilio dirigida por Julieta Kirkwood. Posteriormente, me fui enfocando más en temas de capacitación sindical.

Tuve un retorno positivo, uno político (me recibió el partido) y otro feminista (la Academia de Humanismo Cristiano tenía un grupo de mujeres, desde allí salió el grupo La Morada y el Centro Estudios de la Mujer).

\section{9 ¿Este fue su inicio en la práctica feminista?}

Sí. Nosotras nos dimos cuenta de que movimiento de mujeres y el feminismo era un movimiento muy poco político, muy centrado en la lucha o bien por los derechos de las mujeres o por los talleres de autoconciencia. Esto estaba muy bien pero no era suficiente. Los espacios de mujeres eran espacios vacíos políticamente. Nosotras fundamos una ONG denominado Instituto de la Mujer, todavía funciona hoy en día.

10 ¿Existió un desajuste o desencuentro entre aquellas mujeres socialistas que estuvieron en el exilio y habían retornado con nuevas ideas con las compañeras que 
se quedaron en Chile trabajando en la clandestinidad a la hora de abordar la problemática de género en el PS?

Por supuesto. En el PS se criticó mucho las ideas que algunas militantes traían desde el exilio. De hecho, algunas compañeras y yo encontramos muy tradicional la estructura de poder del partido cuando retornamos a Chile. Nuestro discurso era muy distinto, queríamos que el PS reconociera que la lucha no era sólo superar la cuestión de clases sino también había que abordar la subordinación de la mujer en todos los aspectos, este debía ser un debate que estuviera presente en el retorno de la democracia. Esto debía tener una repercusión orgánica dentro del partido, por ello nosotras constituimos la Federación de Mujeres Socialistas (FMS, 1986).

Algunas mujeres se opusieron a esta gestión, como Carmen Laso, mujeres absolutamente tradicionales que no lograban entender nuestras posiciones. Dimos una pelea muy fuerte para que se instaurara una cuota mínima de participación. La FMS como no tenía transversalidad tuvo muchas dificultades en su funcionamiento. Hoy en día está la Vicepresidencia de la Mujer, pero tiene los mismos problemas que tuvo la FMS.

Nosotras nos volcamos en participar en las "Demandas de las Mujeres a la Democracia". Después del plebiscito las mujeres constituimos la Concertación de Mujeres por la Democracia y a la vez se estaban organizando los equipos de mujeres de los diferentes partidos de la concertación, es decir, no había un vínculo orgánico entre ambas iniciativas u organizaciones.

Precisamente, los partidos de la concertación constituyeron una Comisión de Mujeres, no elegidas sino designadas, y fueron designadas aquellas mujeres que tenían vínculo con sus partidos ya que generaban una mayor confianza. Ahí estuve yo, Soledad Larraín, Mariana Aylwin, Claudia Serrano, etc. En esta comisión había mujeres que venían del Movimiento Feminista y otras que no. Había socialistas, radicales, independientes y feministas. El trabajo que se inició a partir de 1988 terminó con la creación del SERNAM (Servicio Nacional de la Mujer) en 1990.

11 ¿Por qué la mujer fue punta de lanza en la organización de agrupaciones de DDHH? 
La fuerte presencia de las mujeres en la lucha por la democracia estuvo muy vinculada a la violación de los Derechos Humanos en este país. La represión afectó principalmente a los hombres y muchas mujeres quedaron en una situación muy complicada, lo que vino a significar que terminaran involucrándose en un entorno más allá del cotidiano o familiar, es decir, en el espacio público mediante la denuncia de la represión.

Además, había otra vertiente de mujeres con maridos detenidos-desaparecidos, presos o cesantes, que se quedaron en una situación de pobreza extrema y tuvieron que organizarse entorno a su propia sobrevivencia, de ahí la organización de ollas comunes, talleres, etc.

Estos dos movimientos, el de los DDHH y el movimiento popular de mujeres, crearon un tipo de hacer política, una manera de ganarse un espacio en lo público que los hombres no vivieron con tanto protagonismo.

Las escuelas tradicionales de hacer política en Chile fueron el movimiento sindical y el estudiantil. Por ende, estos movimientos de mujeres rompían con la forma tradicional del quehacer político. Un claro ejemplo de esto lo tenemos en la Agrupación de Familiares de Detenidos-Desaparecidos.

Desafortunadamente, el movimiento de mujeres y la solidaridad que hubo entorno a las diferentes agrupaciones se disipó con la llegada de la democracia; esto se dio porque con el cambio democrático, la legalización de los partidos y la aparición de instituciones como el SERNAM, la fuerza del movimiento de mujeres se quebró al aparecer diferencias sustanciales en el quehacer político.

Si tú has luchado durante diecisiete años frente a un Estado que es enemigo y de la noche a la mañana esta realidad cambia, ese Estado se vuelve amigo...uno tiene que mudar de comportamiento, adaptarse a la nueva realidad sociopolítica. Las mujeres que lograron adaptarse a este proceso fueron aquellas que de alguna forma se institucionalizaron y siguieron trabajando de otra forma, desde otra realidad. Otras mujeres no entendieron este proceso y en este punto fue cuando aparecieron las grandes diferencias. 
12 ¿Usted cree que hubo una represión específica dirigida a las presas políticas por parte de la DINA, la CNI y los diferentes cuerpos de seguridad de la dictadura?

El factor género predominó sobre otros factores como el de clase a la hora de torturar. Fueron demasiadas las mujeres violadas y vejadas sexualmente. La violencia sexual en la dictadura fue un elemento presente y muy invisible. El informe Valech constata claramente este hecho. Ahora bien, el informe sobre Prisión Política y Tortura es tan sólo el primer paso en el reconocimiento de esta especificidad. Recomponer la memoria es un proceso complejo y largo y el Informe Valech de ninguna forma cierra el capítulo sobre prisión y tortura y mucho menos sobre la tortura sexual. La Comisión Valech no recogió en su totalidad los casos de tortura y reclusión, estamos hablando de 27 mil casos reconocidos pero claramente mucha gente quedó fuera.

\section{3 ¿Qué elementos positivos y negativos destacaría de su militancia política dentro del Partido Socialista?}

El partido me ha entregado mucho aprendizaje, ha sido una parte muy importante de mi vida. Sin embargo, creo que en el partido ha predominado la estructura patriarcal y el predominio masculino. La mujer tiene que luchar doblemente para ganar espacios. Aunque hoy en día haya un respeto mayor hacia las mujeres, la estructura de dominación sigue estando copada por los hombres. Dentro de PS hay parlamentarios que se opusieron férreamente a la ley del divorcio. Por tanto, el cambio de mentalidades es un proceso muy lento y todavía queda mucho por hacer. 
23 Entrevista realizada a CECILIA MORELIA GONZÁLEZ GONZÁLEZ, 13 de enero de 2005, Santiago de Chile. González es militante del Partido Socialista desde 1969. Estuvo detenida en el Estadio Chile y desempeñó una intensa labor partidaria en la clandestinidad. Elegida miembro del Comité Central en 1990 y 1992, defendió el establecimiento de la cuota mínima de representación para la mujer.

\section{1 ¿Cómo fueron sus inicios en el Partido Socialista?}

Yo empecé a militar en las Juventudes Socialistas (JS) con dieciséis años, en 1969. En ese año entré a estudiar ingeniería textil en la Universidad Técnica del Estado. Eran las postrimerías del gobierno de Eduardo Frei Montalva y tiempos revueltos en el ámbito estudiantil por la reforma universitaria.

\section{2 ¿Qué tipo de militancia desempeñó en los años de la Unidad Popular?}

Yo era parte de la brigada universitaria socialista. Las labores que desempeñábamos estuvieron centradas en el trabajo voluntario. Trabajé en una fábrica llamada Textil Progreso. También viajábamos al sur del país para realizar trabajos de alfabetización, asesoramiento a los trabajadores, organización, etc.

Asimismo, trabajé en las JAP (Junta de Abastecimiento Popular) para contrarrestar el acaparamiento. Realizábamos muchas tareas de apoyo al gobierno de la Unidad Popular, participábamos en las marchas, en los mítines, etc.

3 ¿En qué situación (presencia, participación política, etc.) estaba la mujer militante del Partido Socialista en los años de la UP?

Nosotros teníamos una mirada sesgada en el ámbito estudiantil. Las mujeres teníamos una participación incipiente en la política. Aunque el número era muy bajo el compromiso de trabajo era muy grande.

El tema de la visión de género en Chile es algo más actual. El gobierno de la UP desarrolló políticas en defensa de la dignidad de la mujer como jefa de hogar y de los 
niños (Las Cuarenta medidas del la UP). Fueron medidas en términos de protección. La participación política y laboral era muy escasa.

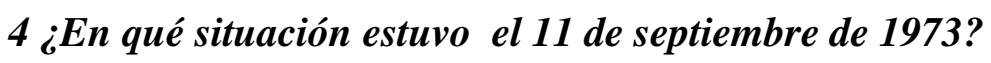

El 11 de septiembre fue un día muy extraño. El día anterior nosotros habíamos estado haciendo rallados en la universidad. Recuerdo que esa noche circulaban muchas patrullas militares.

Nuestra universidad fue asaltada el 11 de septiembre y cientos de estudiantes fueron detenidos. Yo estuve presa en el Estadio Chile, formo parte del Informe Valech junto con mi compañero y mi padre. Fui fuertemente golpeada, tuve tres simulacros de fusilamientos, fuimos muy maltratadas. Nos agredieron mucho, yo tenía diecinueve años.

Ese martes en la mañana escuché la radio de mi partido (Radio Corporación) y la noticia del levantamiento. Me trasladé a la universidad (actual Universidad de Santiago, USACH, Estación Central). Había mucho desconcierto entre mis compañeros. Lo primero que hicimos fue eliminar toda la documentación personal que nos vinculara al partido. Los carnés, documentación, informes con nombres, etc., los quedamos. Nos preparamos haciendo bombas molotov para una posible defensa.

Desde el techo de la universidad pudimos divisar la columna de humo que provenía de La Moneda. Pasamos la noche allí y a la mañana siguiente fuimos rodeados por los militares, por el Regimiento Arica $N^{\circ} 2$ de la Serena. Andaban con uniforme de combate y un distintivo naranja al cuello.

Nos bombardearon y balearon. Dos compañeros murieron y otros quedaron mal heridos al interior del recinto universitario. No alcanzamos a utilizar los cócteles molotov porque la correlación de fuerzas era muy desigual. Entraron en la universidad con mucha violencia y con gran apoyo logístico porque tenían ametralladoras, francotiradores y vehículos de asalto. Nos golpearon mucho y allí mismo nos hicieron varios simulacros de fusilamiento. Éramos aproximadamente 1200 estudiantes, entre hombres y mujeres. Recuerdo que había como trescientas mujeres. 
Nos trasladaron a las mujeres por separado hasta el Ministerio de Defensa. Éramos sobre todo militantes del PS, PC y MIR. No recuerdo a ningún demócrata cristiano.

Después nos llevaron hasta el Estadio Chile. Nos dejaron en unas graderías y pasaron muchas cosas terribles. Afortunadamente, yo sólo estuve 24 horas y me dejaron libre en el momento del toque de queda. Creo que soltaron a varias personas porque no sabían muy bien que hacer con los presos. Los militares ocuparon todos los centros que pudieran respaldar al gobierno de Salvador Allende.

Después del diecisiete de septiembre se programó mucho mejor el tema de los reclusos porque el país estaba controlado. Empezaron las persecuciones y los allanamientos.

\section{5 ¿Cómo fue su experiencia en el Estadio Chile?}

No fuimos bien tratadas. Yo fui golpeada fuertemente. No pude sentarme durante tres meses. Todavía tengo secuelas. Otras mujeres fueron violadas y terriblemente golpeadas.

La violencia sexual fue una política de represión y hostigamiento hacia las mujeres. También a los hombres los violaron, pero en menor proporción. Una de mis compañeras volvió a la universidad para recoger unas cosas después de haber estado detenida en el Estadio Chile y la detuvieron de nuevo...le fue pésimo, la violaron y abusaron de ella sistemáticamente. La violación sexual fue algo constante durante la dictadura.

Nosotros recibimos culatazos y varios golpes. Yo soy hija de militar y creo que a nosotras nos soltaron porque había rumores de que habían mujeres detenidas hijas de militares.

\section{6 ¿Cómo fueron los siguientes meses? ¿Qué tareas partidarias desempeñó en la clandestinidad?}

Yo me incorporé a la red clandestina de la JS y me puse a trabajar como enlace. Este trabajo consistía en construir un tejido para pasar información, microfilmes y documentación. Tenía dos nombres y dos apellidos, es decir, un nombre chapa. 
Nunca pensé en el exilio aunque mi padre si lo hizo porque estuvo detenido. El estuvo en Tejas Verdes y en cuanto salió decidió irse a Australia para proteger a su familia.

7 ¿Renunció en algún momento a su militancia política en aras del cuidado de sus hijos o viceversa?

Nunca renuncié a la militancia. Me casé en 1973 y sí que renuncié a tener un frente propio de trabajo. Mi compañero fue asesinado en julio de 1989. Nuestras hijas eran muy pequeñas, nacieron en el 77 y en el 78 respectivamente.

Muchas veces nos sirvieron para encubrir muchas actividades. Por ejemplo, la primera estampilla que salió en Chile decía "la resistencia vive” y tenía la cara de Allende. Nosotros comprábamos papel engomado, éramos especialistas en propaganda. Después, en el traslado, comprábamos paquetes de detergente, lo vaciábamos y lo rellenábamos con estampillas. Posteriormente, el paquete lo colocaba en el carrito de mi hija para poder disimular a la hora de hacer las entregas. Muchas mujeres renunciaron a la militancia pero otras no.

\section{8 ¿Participó en alguna agrupación de DDHH?}

Al principio no. No obstante, cuando mataron a Raúl, el 8 de Julio del 89, entré a formar parte de la Agrupación de Ejecutados Políticos. Sin embargo, duré muy poco tiempo, es decir, fue una decisión personal porque sentí que yo era incapaz de asumir lo que ya había allí.

Las mujeres de la agrupación tenían una carga muy grande y yo quería trabajar y luchar contra la dictadura pero no alcanzaba para todo. Yo era padre y madre. Mis hijas tenían 11 y 12 años, era una edad muy complicada; me quedé prácticamente sin recursos y además tenía que hacer frente a una tragedia familiar.

9 ¿Qué actitud tuvo el partido ante su situación familiar? ¿Recibió algún tipo de ayuda económica del PS? 
Hubo muchas declaraciones pero ninguna acción. No participaron en el apoyo laboral y económico. No aportaron nada a la educación de mis hijas puesto que no recibieron ninguna ayuda o consideración especial. El partido fue muy ingrato en este sentido. Sin embargo, seguí militando. Creo que intenté hacer caso omiso a un resentimiento hacia el PS.

\section{0 ¿Usted desarrolló una conciencia de género que propiciara algunos elementos críticos hacia su partido?}

Sí, pero fue algo progresivo. A partir de 1990 fui miembro del Comité Central (CC). Hubo un gran esfuerzo de unidad por parte de la facción de Clodomiro Almeida. Yo participé en el congreso celebrado en Valparaíso “Unidad Salvador Allende” en 1990 y ahí fui elegida miembro del CC. Dos años después, en otro congreso, salí reelegida.

En este tiempo todavía no tenía una posición de género definida. Pensaba que la lucha de las mujeres debía integrarse en la lucha general del partido. Hasta 1990, el tema de género, no era una cuestión preponderante en el PS. Además, no había que luchar por ganarse un espacio.

A partir del congreso de la Serena (1992), empecé a tener una conciencia de género bien estructurada. Hasta esa fecha había varios grupos feministas que operaban entorno al partido. Tenía mis dudas con estas agrupaciones. Pero con el tiempo empecé a desconfiar de la política del PS con respecto a la mujer.

En el congreso de la Serena me pidieron que participara en la defensa del la discriminación positiva dentro del partido. La competencia entre hombres y mujeres empezó a tornarse en una realidad cotidiana. Una sentía que después de haberse jugado el pellejo aparecían compañeros desconocidos que salían adelante. Esto fue el detonante para convencerme de que militaba en un partido machista. Había hombres que sin rodaje político aparecía como personas nuevas y ocupaban cargos de responsabilidad. A partir de este momento me convertí en activista de género.

Empezamos a estar arrinconadas dentro del partido hasta que llegó la cuota de participación que por lo menos nos dio un cierto espacio, aunque no el suficiente. 
11 ¿El partido Socialista ha reconocido suficientemente la aportación de sus mujeres en la lucha contra la dictadura? ¿Se han visualizado los problemas específicos que ustedes pudieron tener en esos años por su condición de mujer o madre?

Muy poco. Yo soy delegada oficial para el congreso que el partido va a celebrar este mes (28, 29 y 30 de enero en el edificio Diego Portales); Desde 1990 en adelante yo he sido delegada oficial en todos los congresos. En todos los eventos siempre hemos tenido dificultades a la hora de defender y mantener el espacio reservado a las mujeres (discriminación positiva) puesto que para los hombres esto significa quitarles terreno. $\mathrm{Si}$ no tuviéramos hoy día el 30 por ciento de cuota no tendríamos representación.

Te explico como funciona: Nosotros tenemos una dirección general que está compuesta por gente de diferentes regiones que forman el Comité Central. Luego hay una dirección regional (13 regiones) y de ahí dependen las direcciones comunales. En cada comuna hay representación del PS.

A nivel comunal, ninguna mujer tiene problemas de representación porque ahí se hace todo el trabajo "chico" o de base, es decir, el trabajo duro. Pero a nivel regional a las mujeres les cuesta llegar porque entre los hombres se da una solidaridad de género que a las mujeres todavía nos cuesta tener. Los hombres se ponen de acuerdo, hacen listas, "tu votas por mi y yo por ti”. Si no tuviéramos acción positiva no tendríamos representación política en el partido.

12 ¿Cuáles serían los elementos más relevantes y positivos de su militancia política dentro del Partido Socialista y aquellas cuestiones que le hubiera gustado que hubieran sido diferentes?

El partido me ha dado la voluntad de luchar siempre por conseguir más cosas, mayores mejoras sociales en este modelo de sociedad de mercado libre. El coraje, el tesón fue un aprendizaje de tantos años en el PS.

En lo negativo puedo decir que el Partido Socialista ya no es una organización política multiclasista, creo que ha perdido mucha base de los trabajadores y obreros. Además, el 
PS es un partido conservador en muchos aspectos como el de género. Quedan muchas cosas por cambiar.

El partido ha renunciado a parte de sus principios y está centrado en ocupar el gobierno y el acceso al poder, es decir, se han dejado de lado algunas cosas vitales como la democracia interna, terminar con el control de la opinión, el acceso de la mujer a los puestos de responsabilidad, etc.

Actualmente, hay un estancamiento en el tema de género, hay que llegar a la paridad, al 50 por ciento de la representación política (concejalas, parlamentarias, alcaldesas, etc.). Las mujeres socialistas hicieron grandes esfuerzos contra la dictadura en los años setenta y ochenta y por ello merece tener un espacio propio en iguales condiciones. 
24 Entrevista realizada a CATALiNA PALMA HERRERA, 24 de enero de 2005, Santiago de Chile. Palma es militante del Partido Socialista desde 1967. Cayó presa en Argentina bajo la Operación Cóndor para pasar después al exilio en Gran Bretaña. Asimismo, participó activamente en la Fundación Vicaría de la Solidaridad y en la creación de la Federación de Mujeres Socialistas (FMS).

\section{1 ¿Cómo fueron sus inicios en el Partido Socialista?}

Yo venía simpatizando por razones familiares con la Democracia Cristiana, sin embargo, una vez que entré a la universidad esto cambió. Allí me encontré con amigos comunes que estaban en el PS.

Teniendo una sensibilidad social, ingresé al partido por mi círculo de amigos. Trabajé en el núcleo de la Escuela de Sociología en donde tuve una intensa etapa de aprendizaje teórico-político. Empecé a militar en 1967. Compaginé mi militancia con el estudio y el trabajo. Siempre ligué mi militancia en el trabajo poblacional y la solidaridad de las familias más deprimidas.

2 ¿En qué situación (presencia, participación política, etc.) estaba la mujer militante del PS en los años de la UP?

No había ninguna conciencia o visión crítica de género. No se cuestionaba las tareas de la mujer en el partido. No había ninguna conciencia feminista entre nosotras.

Las mujeres trabajábamos en el tema de las comunicaciones, haciendo revistas, folletos, propaganda diversa, etc. Hicimos mucho trabajo en las áreas campesinas para la implementación del programa de la Unidad Popular. La idea era incorporar a los campesinos al proceso de elección democrática.

Recuerdo que las mujeres tenían muchas dificultades a la hora de ejercer el derecho a voto puesto que casi siempre tenían que cuidar de sus hijos. Nosotras tratamos de ayudarlas haciéndonos cargo de sus tareas domésticas para que fueran a votar. Aquí empecé a darme cuenta de algunas situaciones injustas que en la cotidianidad sufrían las mujeres. 
El gobierno de la UP puso en marcha algunas políticas hacia las mujeres pero siempre en la órbita de la familia. No hubo ninguna profundización en el tema de género.

\section{3 ¿En qué situación estuvo el 11 de septiembre de 1973?}

Estuve con mi pareja. El día anterior tuve una reunión en la que tuvimos mucha tensión por lo que se venía. Recuerdo que coincidió con mi cumpleaños. El martes 11 fuimos a la universidad para ver cómo estaba la cosa y tratar de rescatar algunos documentos y material.

En los siguientes días entré en un grupo que asilaba a gente. Yo asilé a Natacha Molina, Julieta Kirkwood y éramos miembros del Partido Socialita de diferentes regionales para facilitar el exilio a los compañeros más perseguidos.

Yo salí en enero de 1975. Hasta esa fecha mi trabajó clandestino se centró en asilo, reorganización partidaria, contactos en el Comité Central, en los regionales y viajar a Argentina para organizar un aparato para sacar gente. Me esperó un grupo de compañeros en la frontera de Argentina. Crucé caminando la cordillera de los Andes. Fue muy duro, parecía que no iba a llegar nunca.

\section{4 ¿En algún momento cayó detenida?}

Sí. En noviembre del 75 caíamos presos en Buenos Aires bajo la Operación Cóndor. Esto lo sé porque había tipos que en los interrogatorios no hablaban y además tenían todos nuestros antecedentes. Estuve un año presa, hasta 1976.

Primero estuve en Coordinación Federal y luego en Villa Devoto. En julio del 76 me sacaron junto con otra compañera, había mucha presión internacional. A las cuatro de la mañana nos cachearon y nos soltaron. Salimos en una lista chilenos que quedaban en libertad en un diario y mi mamá viajó para verme. Yo estuve presa con Jimena Zavala.

\section{5 ¿Cómo fue su experiencia en la reclusión?}


Primero nos aislaban, después nos metían en la leonera en donde estábamos todas las mujeres, chilenas, argentinas, etc. Después nos trasladaron a Villa Devoto y allí separaban a hombres y mujeres en diversos pabellones.

Las mujeres del PRT (Partido Revolucionario de los Trabajadores) tenían toda una rutina. Se levantaban a las cuatro de la mañana para leer sus libros y documentos. Tenían unos barretines para esconderlos. Yo me negué a ese tipo de rutina. Hacíamos ejercicio y después limpiábamos las celdas de los chinches. Teníamos también lectura de diarios y nos distribuíamos las tareas.

En el interrogatorio a mi me trataron como una terrorista. Estabas amarrada y con los ojos vendados. Pensaban que nosotros formábamos parte de la Coordinadota Armada de América Latina.

\section{6 ¿Qué opinión tiene sobre las compañeras que se quebraron en la tortura y pasaron a colaborar y ser funcionarias de la DINA y de la CNI?}

El partido tenía la consigna de que si caías presa y no soportabas la tortura podías "largar" nombres pero siempre de dirigentes, es decir, de la cúpula y no de la base porque esa era la forma de poder reconstruir el partido. Sin embargo, una cosa es lo que puedas decir bajo la tortura y otra es colaborar después de la tortura.

\section{7 ¿En qué circunstancias salió de prisión?}

Salimos de desde la cárcel al aeropuerto y de allí nos expulsaron a Londres. Llegué a fines de octubre de 1976. Yo tenía una beca de estudios y me esperaron en el aeropuerto para llevarnos a un hotel. Después me fui a lugar en donde tenía la bacante como becaria en la Universidad. Allí había comités de acogida, etc.

Seguimos trabajando en el exterior. Nos juntamos la gente de la coordinadora que se encargaban de reorganizar el partido a partir de los comités regionales. Seguimos existiendo en el exterior. Teníamos dos comisiones, la de Chile y la de Inglaterra. 


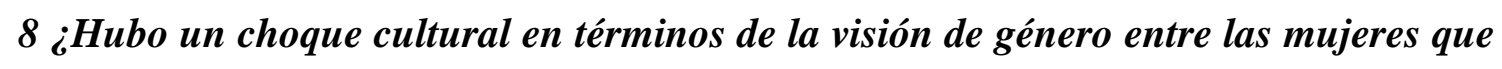

vivieron el exilio y las que se quedaron? ¿Ustedes vinieron con una visión crítica que les trajo rechazo en el partido?

Las mujeres que estuvimos en el exilio tratamos de juntar a varias compañeras de las diferentes tendencias del Partido Socialista. Generamos una organización de las mujeres con planteamientos de autonomía y de estrategias de poder. Entre 1983-1985 se empezaron a organizar desde organismos no gubernamentales estudios de la mujer.

Sin embargo, al haber incorporado ideas nuevas, muchos compañeros y compañeras las rechazaron porque alegaban que se alejaban mucho de la realidad de Chile.

Yo llegué a Inglaterra a fines de 1976. Mi preocupación allí fue la sobrevivencia. Yo escribí a Julieta Kirkwood diciéndole que "la papa para conseguir fondos era el tema de la mujer”. Así se formó el Círculo de Estudios de la Mujer (CEM); yo me siento parte de ese proceso. En una de las revistas de Furia se rescata este episodio. En ese tiempo nos definamos feministas socialistas y socialitas feministas.

9 ¿Qué visión tiene sobre la situación de algunas compañeras de su partido que tuvieron que renunciar a su militancia política por el cuidado de sus hijos? ¿Este hecho se dio con frecuencia?

Siempre se daba que las mujeres participaban menos que los hombres. Yo era soltera y sin hijos y tenía todo el día para militar. Pero las compañeras que eran madres si tuvieron muchas dificultades a la hora de trabajar en el partido.

En Bermingham, se realizó un encuentro de la Organización de Mujeres Latinoamericanas y allí se produjo un problema entre las chilenas. A mi me expulsaron del partido del núcleo de Gran Bretaña por incorporar a un grupo a mujeres lesbianas. Los compañeros eran terriblemente machistas. De hecho yo tuve un novio inglés y fui muy criticada por mis compañeros chilenos por no relacionarme con un compatriota.

La toma de conciencia feminista empezó en Inglaterra, en la universidad. Pero fue un proceso lento porque al principio pensaba que la lucha de género era una desviación de 
la lucha de clase. Esto fue cambiando con el tiempo. Entré a un grupo de mujeres de la Socialist Society. Aquí empezó mi toma de conciencia aunque no he sido militante de ningún grupo feminista.

\section{0 ¿Cómo fue su regreso a Chile?}

Regresé a Chile en 1983 para ir a un encuentro feminista realizado en Lima. No pude entrar a Chile y me deportaron a Buenos Aires en donde estuve dos meses hasta que salió un decreto que me permitía volver. Durante ese tiempo fui a Lima en donde pude juntarme con muchas mujeres socialistas.

Posteriormente, trabajé en la Vicaría de la Solidaridad, organizando a las mujeres que pertenecían a diferentes agrupaciones de base. En 1985 me incorporé al proceso de reunificación del Partido Socialista. Formamos un grupo de mujeres del sector renovado del partido.

Más tarde, fundamos la FMS (Federación de Mujeres Socialistas). Generamos una serie de propuestas de género para la democracia: la idea era crear una institución de mujeres (el SERMAM) y unas medidas encaminadas a establecer la discriminación positiva al interior del PS.

\section{1 ¿El Partido Socialista, ha reconocido suficientemente la aportación de sus mujeres durante los años de la dictadura?}

En el discurso sí aunque todavía no es una cosa totalmente internalizada. De todas formas, las mujeres necesitan una organización interna fuerte que no se ha dado en el partido. La persona que está a cargo de las mujeres en el PS no estuvo en las luchas de las mujeres y no tuvo una conciencia de género. Está ahí porque ladea la posibilidad de estar en la Comisión Política.

Durante la dictadura, los hombres tendieron a militar en organizaciones como partidos políticos y sindicatos. Las mujeres tenían una fuerte presencia en el trabajo de base, en el movimiento social (comedores populares, ollas comunes, talleres solidarios, etc.). 
Desde allí se gestó todo un movimiento de resistencia cuyo objetivo era terminar con el régimen dictatorial pero con otros matices porque algunos grupos ya incluían algunos temas de género en su lucha. En este sentido, puedo decirte que el PS no ha valorado suficientemente esta lucha.

Además, el partido es una estructura muy concentrada y centralizada en donde el poder está en manos de muy poca gente, son lo que negocian los puestos, los candidatos, etc. Hoy día tenemos el 30\% de representación de las mujeres pero esto no se materializa en los puestos importantes como en las alcaldías, concejalías, en los diputados, etc. 
25 Entrevista realizada a CECILIA SUÁREZ INDARTE, 8 de marzo, 2005, Santiago de Chile. Suárez, militante del Partido Socialista, tuvo una destacada actividad política en el ámbito estudiantil. Estuvo detenida por la CNI y Carabineros y tuvo que salir al exilio en dos ocasiones. Asimismo, fue una de las fundadoras de Mujeres por la Vida y participó en la creación de la Corporación de la Defensa de los Derechos del Pueblo (CODEPU, 1984).

\section{1 ¿Cómo fueron sus inicios en el Partido Socialista?}

Yo nací en el partido. El día que nací, mientras operaban a mi madre, mi padre estaba en la sala de espera en reunión de la dirección regional del partido. Soy hija de socialistas. Desde los doce años, antes del gobierno de la UP, ingresé a militar en al Juventud Socialista (JS). Viví todo lo que fue las movilizaciones estudiantiles.

El 11 de septiembre yo había cumplido recién los 16 años, es decir, cuando llegó Allende al poder tan sólo tenía 13 años. Además, mi padre fue ministro del interior (Jaime Suárez Bastida) y secretario general de gobierno en la UP.

Yo fui una dirigente de la juventud de rango medio metida en los temas estudiantiles. A principios de 1973 mi padre fue candidato a senador por Bío-Bío (Región-MayecoCautín) y luego electo. Me fui con él a Temuco y me quedé estudiando. Mis tareas a nivel partidario cambiaron un poquito. En esa época estaba el Frente Interno que venía a ser una organización de la defensa del gobierno contra los grupos de ultraderecha (Ronaldo Matus, Patria y Libertad, etc.). Yo entré a colaborar pero ten en cuenta que solo tenía dieciséis años.

\section{2 ¿En qué circunstancias estuvo el 11 de septiembre de 1973?}

Yo vivía en una residencia de estudiantes en Temuco. El cuatro de septiembre hicimos una marcha en conmemoración de la victoria de la UP. Marchamos rodeados de milicos. El sábado 9 tuvimos una peña en el local del partido. Todos teníamos la sensación de que algo venía. 
Llegó el martes 11. Un grupo uniformado allanó el liceo. Hicieron una revisión y se fueron. Ahí nos enteramos de lo que estaba pasando. Hubo un toque de queda, sólo recuerdo que no pudimos salir durante dos días.

Los días siguientes hicimos un recuento de la gente que estaba detenida hasta que llegó la FACH a la casa donde yo arrendaba. Mi padre estaba muy buscado por militares. Estuve un tiempo en el regimiento de Temuco. Después regresé a Santiago, mi padre estaba asilado en la embajada de Perú, mi madre y mi hermano se habían asilado con mi padre pero cómo ellos nos sabían de mí salieron de la embajada.

Estuve un tiempo circulando por el país hasta que finalmente hubo una presión muy fuerte por parte de mis padres para salir de Chile. Nos fuimos a Perú en diciembre de 1973 donde estuvimos dos meses hasta que el partido envió a mi padre a Moscú. Finalmente, partimos todos a la URSS.

\section{3 ¿Continuó su militancia en el exilio?}

Estuve unos cinco años hasta que retorné a Chile. En Moscú seguí con mi militancia. Estuve en preparación político militar a la vez que estudié Economía Política en la universidad. En 1979 retorné a Chile.

Carlos Altamirano decidió en un momento que tres personas regresaran a Chile: Ricardo Núñez (actual presidente del PS), Morada y Yo. Estábamos viviendo un proceso de división del partido, un conflicto entre Carlos Altamirano y Clodomiro Almeida.

La división estaba marcada por un famoso documento llamado el documento de marzo (salió en marzo del 74). Fue redactado por la dirección del partido y refleja todo un análisis del gobierno de la UP y una evaluación de las causas de la derrota. Yo fui crítica del documento porque no compartí el contenido del por qué habíamos fallado. Este documento marcó claramente la división del PS.

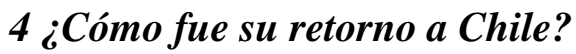


En el $24^{\circ}$ congreso del PS se trataron los temas de reunificación de los grupos del Partido Socialista. Mi viaje a Chile se debió entre otras cosas para organizar este congreso en la clandestinidad. Cuando terminó el congreso a mi me tocó la misión de salir al exterior para hablar con Altamirano y trasmitirle las resoluciones y decisiones que salieron en el congreso.

Después del congreso tuvimos otra división. Todos los esfuerzos para superar las divisiones del PS se fueron al traste. La nueva división se produjo por las dos formas de entender la lucha contra la dictadura: un sector (en donde yo me quedé) que era identificado como "la chispa" (recordando a un grupo de socialistas que empezaron a sacar un diario clandestino en los primeros meses del golpe) que nos caracterizada por admitir todas las formas de lucha, nuestra consigna era "álzate Chile" y otro, que no admitía la política de rebelión popular. Hicimos una operación de propaganda activa para impulsar el alzamiento armado.

Empecé a escribir en la Revista Análisis y a tomar algún protagonismo en el ámbito público. Yo fui entrando en el sector más ultra del partido. También Fabiola Letelier me invitó a formar parte en CODEPU. También formamos un Comité de Solidaridad con Nicaragua.

Creamos un comité operativo cuando fue nombrado Rodolfo Ceguel, en 1983, presidente de la Confederación de Trabajadores del Cobre. Empezamos a pensar en la necesidad de generar grandes movilizaciones. Yo fui la única mujer del comité operativo.

\section{5 ¿Cómo recuerda la presencia de la mujer en el trabajo clandestino?}

El tema de género lo asumí muchos años después. Yo era de las que pensaba que la emancipación de la mujer pasaba por la liberación de la clase obrera. Este cuento me lo creí muchísimos años. Después desarrollé mi visión de género. Había compañeras que trabajaban en la comisión política y desempeñaban tareas bastante importantes pero sin tener una visión de género. 
6 ¿Se sintió discriminada en algún momento en el partido por su condición de mujer? ¿cré que las compañeras que tuvieron hijos tuvieron algunas dificultades en este sentido?

De las mujeres que yo he conocido creo que nadie renunció a su militancia en aras del cuidado de sus hijos. Quizá algunas sí optamos por postergar la maternidad, como fue mi caso. Otras compañeras decidieron separarse de sus hijos y no asumir su maternidad por las tareas políticas, otras consiguieron hacer ambas cosas. Creo que el rol de la mujer fue fundamental y muy importante en la lucha contra la dictadura.

Con el advenimiento de la democracia, todos los hombres volvieron a ocupar sus lugares y esto creó un problema en el rol protagónico de las mujeres. Yo pasé varias etapas, fui una de las fundadoras del Movimiento Democrático Popular. Varias mujeres nos sentábamos en los cuarteles de la CNI donde algunas de nosotras habíamos sido torturadas ahí.

\section{7 ¿Cómo fue su experiencia en la reclusión?}

Me volvieron a detener en 1983, me detuvo carabineros y la CNI. Carabineros me protegió. Tuve la suerte de que cuando me detuvieron había un conflicto entre ambas organizaciones.

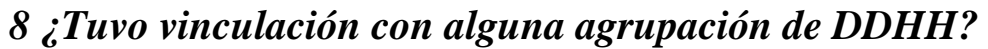

En términos de trabajo de mujeres nosotras hicimos una experiencia que marcó este país. Las mujeres que nos reunimos no veníamos de un trabajo previo. En 1983, en Concepción, Sebastián Acebedo se quemó a lo bonzo porque su hijo estaba detenido. Eso nos impactó mucho. Nos juntamos y organizamos un movimiento que luchara por la vida, mujeres que no veníamos del trabajo de mujeres.

Yo soy una de las fundadoras de Mujeres Por la Vida (Patricia Verdugo, Fani Poyarolo, Mónica González, etc.). Queríamos invitar a otros grupos de mujeres para organizar el Caupolicanazo de Mujeres; en Santiago había un teatro llamado Caupolicán. El 29 de diciembre de 1983, hicimos un acto de mujeres para presentar la agrupación Mujeres 
por la Vida. Fueron más de nueve mil mujeres. Ninguna de nosotras trabajábamos temas de género.

9 ¿En ningún momento tomó conciencia de que por ser mujer podía tener ciertos problemas específicos en su trabajo partidario? ¿Qué opina de aquellas mujeres que tuvieron que renunciar a su militancia política en aras del cuidado de sus hijos o viceversa?

Mira, fue todo un proceso de mentalización que comenzó en 1985, momento en el que tuve que salir de nuevo al exilio (Buenos Aires, BA). Después regresé a Chile en 1988 para votar en el plebiscito. A comienzos de 1984 cayó parte de nuestra dirección y salió un bando de la CNI en donde había instrucciones para detenerme. Afortunadamente, me avisaron a tiempo mis compañeros.

En 1985 estaba preparándome para volver a Chile. En esos tiempos se estaba planteando ya el proceso de reunificación del partido y yo quedé embarazada y esto me generó un conflicto enorme.

Este hecho cambio bastante mi perspectiva sobre la militancia, empecé a verme más como un ser humano que como una militante o una máquina. Mi padre siempre me molestó porque no me arreglaba. Me acordé de esos momentos en los que la militancia estaba por encima de todo. Tuve una concepción muy cerrada y dura en la militancia.

Todo esto cambió con mi maternidad. En una oportunidad llegó Mónica González, y me comentó que mis ojos tenían otra expresión, con más vida; me dijo: - "tus ojos muestran que eres otra persona, has logrado transformar tu militancia en vida”-.

Yo vivía sola en BA con mi hija. Mi compañero vivía en Santiago y viajaba clandestinamente para vernos. En Argentina conseguí una beca de Naciones Unidas muy importante para trabajar para el gobierno de Alfonsín. Estuve haciendo una investigación sobre las cuenteas patrimoniales. Mi trabajo fue publicado por la CEPAL. Este elemento me hizo ver que mi potencial no sólo debía estar enfocado en la política sino también en otros temas. 
A partir de aquí empecé a preocuparme más por el tema de las mujeres. De hecho, estuve hartas horas conversando con Sergio Aguiló, actual diputado del Partido Socialista, yo le manifestaba mi preocupación sobre qué rol iba a desempeñar la mujer con la llegada de la democracia. Me preocupaba que los espacios logrados se perdieran.

\section{0 ¿Creé que el Partido Socialista ha reconocido suficientemente la aportación de la mujer militante en los años de la dictadura?}

No. Creo que no ha habido ningún reconocimiento. Si alguien dice que sí creo que es algo más coyuntural. El caso de Michel Bachelet es muy claro. Se ve este ejemplo como un fenómeno social alegando que precisamente ha llegado ahí por el apoyo de la sociedad.

En otras palabras, de manera muy oportunista mucha gente de este partido habla de que el PS ha tenido mucho que ver con este fenómeno y que ha impulsado el papel de la mujer en el partido. Esto es falso, son declaraciones oportunistas.

En el PS existe la discriminación positiva del 30\%. Pero rara vez se aplica. Creo que la cuota de representación es algo muy importante porque ha dado cabida a muchas mujeres. Aunque a veces el mecanismo es dudoso porque se dan cargos no por capacidades.

No hay un reconocimiento de lo que significa la presencia de la mujer en este partido. Fuera del fenómeno de Michel está el problema de que no tenemos ninguna senadora, sólo una diputada. Nuestras candidatas a alcaldesas fueron muy pocas. Tenemos más que suficientes recursos humanos, mujeres preparadas para legislar y gobernar.

Con la llegada de la democracia no tuve ningún cargo en el partido porque consideré que mi aportación había finalizado en la política. Pensé que era tiempo de dedicarme a otras cosas, a temas que me interesaban como el Medio Ambiente. Creo que hay muchas mujeres anónimas que no están en el partido y que aportaron grandes cosas al PS. 
26 Entrevista realizada a ELINETT WOLFFR, 13 de marzo de 2005, Santiago de Chile. Wolffr es militante del Partido Socialista desde 1971 y estuvo exiliada en la RDA, Cuba, Nicaragua y URSS. Asimismo, fue miembro del Comité Central desde 1985 hasta 1990.

\section{1 ¿Cómo fueron tus inicios en el Partido Socialista?}

Yo empecé a incorporarme a la política en los años setenta. Mi padre fue militante del Partido Socialista. Tenía 13 años de edad. La situación política en el país era de bastante convulsión y era difícil quedarse al margen de la situación política que se vivía.

Mi ingreso fue muy tímido por la edad que tenía. Mi padre era amigo personal de Allende y asumió el cargo de intendente de la provincia de Bio Bio. Su compromiso con el gobierno de la UP era absoluto.

Mi vida política comenzó en donde yo vivía, en Concepción. Nosotras éramos seis mujeres en la familia. En 1971 mi padre supo que me estaba metiendo en política. Yo fui la primera de mis hermanas que empezó a militar.

No tuve ningún problema con mi padre en este sentido, él era una persona muy liberal, nos educó en un ambiente de mucha libertad, aunque siempre tuvo la preocupación de lo que me podía pasar si entraba en política. De hecho, antes del gobierno de la UP a nosotros nos increparon mucho por ser hijas de un militante socialista, en una oportunidad a mi me golpearon en la calle. En 1973 atentaron en mi casa los militantes de Patria y Libertad, nos quebraron los vidrios e incluso balearon la casa.

\section{2 ¿Qué tipo de militancia desempeñó en los años de la Unidad Popular?}

En los años de la UP yo ingresé a la Juventud Socialista. Mis tareas consistían en toda la movilización estudiantil a nivel de Liceo. Hacíamos manifestaciones de apoyo al gobierno, peleábamos por mejores condiciones en la Educación, etc.

Hubo una fuerte organización de los alumnos en donde se discutía mucho sobre la situación política por la que el país estaba atravesando. También realizamos trabajos 
con las Juntas de Vecinos, en los alzamientos campesinos, con los pobladores, etc. Por otra parte, trabajé en las JAP, en el abastecimiento. Desde sábado a domingo teníamos turnos para ayudar a distribuir los alimentos más básicos.

\section{3 ¿Sintió en algún momento discriminación por su condición de mujer en el Partido Socialista?}

No entiendo las cuotas de acción positiva para la mujer. Nunca he apoyado esta iniciativa. Yo me he sentido discriminada en el partido en sucesivas ocasiones pero creo que esa no es la vía para solucionar la discriminación en el partido. Los cargos de responsabilidad del partido han de ser por capacidad no por discriminación positiva.

\section{4 ¿En qué situación estaba el 11 de septiembre de 1973?}

Ese martes estuve en Los Ángeles junto a mi familia. Mi padre vino venir el golpe de Estado y nos trasladamos todos allí. El domingo 9 yo tenía que ir a Concepción y mi padre no me dejó ir por esta razón.

Mis padres salieron esa mañana a trabajar. Yo me quedé en la casa. Mi padre se fue a la intendencia. Todo el centro estaba tomado por los militares. A mi padre lo pararon los carabineros en varias ocasiones diciéndole que se fuera de la zona. Él era muy conocido allí y los militares le rogaron que se fuera "porque tenían instrucciones muy claras sobre que hacer con él". El era dirigente y un conocido socialista.

Finalmente, en la intendencia le dijeron -"Don Federico, si usted entra le detendremos"-. Mi padre decidió marcharse porque se dio cuenta de la magnitud que el golpe de Estado estaba teniendo.

Mi padre estuvo varias horas desaparecido. Yo me quedé en mi casa escuchando la radio con mis hermanas. Nos afectó mucho el último discurso de Allende, ahí supe que todo se había terminado y el peligro que mi papá corría.

El 12 de septiembre mi padre cayó detenido, lo fueron a buscar a las once de la mañana a mi casa pero ahí no estaba, pero horas después lo encontraron junto con otros 
dirigentes. Después, supe que a mi padre lo torturaron mucho. En febrero de 1974 fue expulsado del país. Mi mamá también cayó presa el 20 de septiembre. Ella era funcionaria pública.

Recuerdo que durante esos días de ausencia de mis padres por mi casa pasaron muchos militantes socialistas que venían a pedir instrucciones. Iba anotando todos los nombres y recados de los compañeros. Ese trabajo tuve que asumirlo sin saber muy bien cuando iban a regresar mis padres. En aquel momento sólo tenía quince años.

A partir de ahí una agrupación de menores llegó a mi casa para hacerse cargo de mí y de mis hermanas. Alegaron que mis padres nos habían abandonado. Yo me negué rotundamente a ir con ellos. Posteriormente, mi tía se vino a vivir con nosotros.

\section{5 ¿Qué ocurrió cuando liberaron a sus padres de prisión?}

El cinco de febrero de 1974, una vez que mi papá salió preso, nos expulsaron del país. Salimos exiliados a Buenos Aires. Yo nunca quise salir de Chile. La salida al exilio fue un proceso bien difícil. Primero nos trasladamos a Santiago y allí estuvimos varios días en una casa de acogida de la Agrupación Padre Hurtado. Allí estuvimos ocho familias. Ese refugio en teoría era para extranjeros y los militares quisieron en varias ocasiones entrar a buscarnos. Gracias a la insistencia de Naciones Unidas pudimos salvarnos. Posteriormente pasamos cinco meses en Argentina.

En Buenos Aires nos recibió ACNUR. Estuvimos en un refugio en la calle Brasil. Eran una casa para 35 personas pero estuvimos hacinados durante cuatro meses más de 150 refugiados políticos. Tuvimos muchos problemas para que nos dieran asilo político en otro país. Finalmente, nos sacaron funcionarios alemanes por nuestros vínculos familiares. Partimos a la RDA en donde estuve un año y medio.

\section{6 ¿Cómo fue su militancia en el exilio?}

En Alemania me incorporé a la vida partidaria. Estuve un año y medio en la RDA. De esa época recuerdo que la militancia se enfocó mucho entorno a la solidaridad con Chile y el drama de los DDHH. En ese tiempo aproveché también para estudiar y formarme 
políticamente. Estuve en varios cursos de marxismo organizados por la Juventud Socialista. Allí terminé Enseñanza media. Después elegí estudiar una carrera técnica, comunicaciones y electrónica.

Paralelamente, continué con la militancia en el partido, iba a reuniones para estar al día de todas las actividades. A principios de 1975 llegó un grupo de dirigentes del partido para conversar con todos los militantes. Ellos querían encontrar a gente que estuviera dispuesta a retornar a Chile y formarse militarmente.

Ellos buscaban a militantes jóvenes. Me preguntaron muchas cosas pero sobre todo temas relacionados con la lucha armada. Yo di a entender que estaba de acuerdo con la formación militar y la necesidad de instaurar otro tipo de oposición a la dictadura. Les dije que estudiaba para ser técnica en electrónica.

Unos meses después, en verano, este grupo volvió y me entrevistó de nuevo. Me plantearon que se iba a organizar un grupo para la formación de cuadros militares en Cuba. Yo dije que sí estaba dispuesta. Además insistieron en que parte de esa formación iba a centrarse en el tema de las telecomunicaciones.

Ellos me dijeron que se iban a encargar de toda la documentación y que el viaje sería en agosto de 1975 porque el curso empezaba en la Habana a principios de septiembre. Yo pensé que el curso duraría de cuatro a seis meses.

Mi principal problema para participar en este proyecto fue que no era mayor de edad y necesitaba la autorización de mi padre. De hecho, estos dirigentes no sabían que yo sólo tenía dieciséis años. Tenía que viajar el 30 de agosto...cuatro días antes del viaje, con toda la documentación preparada los dirigentes se dieron cuenta de mi edad. Entonces me dijeron que era absolutamente necesaria una carta de autorización familiar. Mi padre ya sabía todo y aunque estaba en desacuerdo no me puso mayores dificultades. Al final todo se resolvió y partí a Cuba.

\section{7 ¿Cómo fue su formación y militancia político-militar en Cuba?}


A través de Beatriz Allende me recibieron en Cuba porque en un principio estuvieron a punto de devolverme a la RDA. En primer lugar partí al Comité Chileno de Solidaridad. Ellos me recibieron con mucha precaución. Un día después, uno de los dirigentes del partido me llevó a la Escuela Militar en donde me hicieron un chequeo médico y una entrevista personal.

El director de la Escuela me dijo: “ ¿Usted sabe a lo que viene?”, yo le dije que sí, que venía a prepararme para retornar a Chile. Acto seguido él me dijo: "Esto es una Escuela de formación miliar regular en donde se imparten carreras de ingeniería de cinco años y usted está aquí por solicitud del Partido Socialista de Chile”.

Me explicó que había Tanque y Transportes, Artillería e Ingeniería en Telecomunicaciones y que yo tenía un cupo para esta última. Me dijo que disponía de un tiempo para tomar la decisión. Para mí esto fue un choque muy grande porque yo pensaba que iba a estar sólo unos meses.

Éramos diez mujeres en la escuela, cinco en telecomunicaciones, cuatro en artillería y una en tanque y transportes. Yo decidí quedarme porque pensé que era una buena oportunidad.

La formación fue dura, de cadetes. El ejercicio físico fue muy difícil para mí. Los ramos de la carrera también fueron complejos, mucha matemática y física. Como estudiantes de ingeniería teníamos también formación en el armamento, una vez al mes teníamos ejercicios. La formación fue muy completa, nos estaban preparando para ser oficiales de ingeniería.

Cuando terminé mi formación en Cuba la idea era regresar a Chile para aplicar mis conocimientos para luchar contra la dictadura. Cuando terminé mi carrera quise regresar a Alemania en 1980 para juntarme con mi familia. No me dejaron entrar y decidí ir a Nicaragua porque eso me acercaba más a Chile.

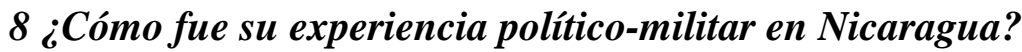


Quise prestar mis servicios en este país como ingeniería de telecomunicaciones. Allí estuve trabajando en el ejército sandinista. Mi labor fue la formación de personal y en unidades de apoyo táctico. Allí estuve hasta 1983.

Fue un período muy difícil. Las condiciones fueron muy adversas. Yo sentí que me había formado en Cuba para regresar a Chile y me encontré en otro país. Estaba en calidad de funcionaria con un sueldo y el aprendizaje fue muy positivo pero la sensación que tuve todo el tiempo fue que debía estar en Chile trabajando contra el régimen de Pinochet.

En Nicaragua era la única mujer vinculada al partido socialista que había terminado su formación académica-militar. El PS no me había dado otra alternativa, ellos querían que estuviera en Alemania asumiendo un cargo administrativo pero mi conciencia me llevó a Nicaragua para aportar algo más concreto.

Después de tres años, quise regresar a Chile con un grupo de compañeros. Resolvimos que antes de regresar iríamos a Guatemala para formar una escuela militar y a cambio de eso, tras seis meses, ellos nos deberían ayudar a retornar a Chile. Todo estaba listo cuando llegó el primer llamado del partido para regresar a Chile. Tenían que regresar cinco compañeros socialistas con formación militar. Esto fue en los primeros meses de 1983.

Yo sabía que en el siguiente llamado me podía tocar a mí. Después llegó el segundo llamado y ahí entró mi grupo excepto yo. Uno de los compañeros del grupo finalmente no fue, entonces ahí yo vi la posibilidad de entrar.

Sin ninguna explicación no me dejaron partir en el grupo de retornados. Tuvimos una reunión con Cloro Almeida (secretario general de una de las secciones del PS) y él no supo darme ninguna explicación sobre la negativa a que me incorporara al grupo. Finalmente, tuve una larga conversación con Almeida y él me dijo que yo no podía regresar a Chile por la relación que yo tenía con mis compañeros socialistas. 


\section{Entonces, ¿tuviste dificultades en tu formación militar por tu condición de mujer?}

En todos los ramos de las fuerzas armadas cubanas había mujeres, eran minoría pero había una presencia femenina. Hubo muchos chilenos que entraron a la Escuela para formarse militarmente. Comunistas, socialistas y miristas. La mayoría entraron a escuelas de mando. Las mujeres estaban en su mayoría estudiando en escuelas técnicas.

En Nicaragua, con los llamados del partido para retornar, se produjo una situación que tiene mucho que ver con la discriminación por mi condición de mujer. Mis compañeros habían decidido que yo no podía retornar porque había "desconfianza política hacia mí".

Yo viví dos situaciones en Nicaragua con estos compañeros porque me acusaron de “prostitución”. Pidieron mi expulsión del partido. Evidentemente, no me prostituí. La rivalidad hizo que mis compañeros me descalificaran criticando mi vida privada... yo no tenía pareja estable ni era casada y utilizaron este argumento para dejarme fuera del grupo.

Para mí fue muy decepcionante escuchar todo esto. Después de tantos años formándome para el partido y que las explicaciones fueran que no regresaba Chile por "puta"... Almeida pudo darse cuenta de la poca consistencia de estas acusaciones. Se suponía que mi formación me daba los requisitos necesarios para regresar a luchar contra la dictadura. Don Cloro reconoció que no podía incorporarme a este contingente por mi condición de mujer.

Luego ahí toda una serie de episodios que tuvieron que ver con esto. Todos los compañeros que compartieron esos años conmigo en Nicaragua trataron de tener relaciones sexuales conmigo y yo rechacé a la mayoría de ellos. Esta situación machista derivó a que ellos hicieran lo imposible para que yo no formara parte del grupo que debía retornar. Al final, Almeida me incorporó al contingente pero la decepción que yo tuve con mis compañeros fue tremenda por su comportamiento tan deshonesto.

También recuerdo que antes de regresar a Chile tuvimos un curso de formación en Moscú, un curso de estrategia y trabajo conspirativo. Yo era la única mujer y éramos 
todos oficiales con formación militar. Me formé como radiotelegrafista en código Morse.

En esos ocho meses también se produjeron situaciones muy delicadas con mis compañeros. Durante mucho tiempo mis compañeros tocaban mi puerta con la única intención de acostarse conmigo. Tuve que ser muy firme y esto me creó muchos problemas. Ellos me dijeron "es complicado que usted sea la única mujer que esté aquí, o lo resolvemos o usted tendrá que irse a otro lugar".

\section{0 ¿Cómo fue su regreso a Chile?}

Llegué a Chile en octubre de 1984 y ahí me incorporé al trabajo clandestino. Lo relevante de este proceso fue que después de haberme formado cinco años en Cuba, tres en Nicaragua y ocho meses en Moscú, cuando llegué a Santiago no hubo un plan estructurado por parte del partido para incorporarme a la lucha y asumir unas tareas político-militares claras. Nada de esto ocurrió. En otras palabras, no pude aplicar mis conocimientos a la lucha contra la dictadura.

Estuve un mes en la clandestinidad con identidad falsa completamente desvinculada del partido. Posteriormente, mi trabajo clandestino consistió en visitar varias poblaciones de Santiago en donde se estaban preparando diversas movilizaciones, en la población la Victoria. Sin embargo, desgraciadamente, el partido no supo estructurar una política clara para aplicar la formación que había adquirido.

El PS me preguntó que era lo que yo quería hacer. Esto fue un sock muy grande porque yo pensaba que las instrucciones iban a ser claras. A partir de ahí, mis contactos con el partido fueron mensuales. Entré en contacto con los compañeros de mi contingente y me dio la sensación de que ellos estaban en la misma situación.

A partir de este momento me planteé entrar a militar con los compañeros del Frente Patriótico Manuel Rodríguez. Sin embargo, desistí porque éramos nosotros los que debíamos formar una política propia. Esto fue un fracaso. No teníamos ni la infraestructura ni el apoyo ni llegamos en el momento apropiado. En esa etapa política que estaba viviendo el país la estrategia había cambiado. 
Posteriormente, me incorporé a la Comisión Política del Partido. Allí me encontré con muchos problemas derivados de mi disconformidad por la situación tan desordenada del partido y la sensación de que me habían dejado de lado. Esto significó salirme para incorporarme en el trabajo orgánico del partido: propaganda, organización de movilizaciones, etc. Finalmente, mi trabajo clandestino se cerró con mi participación en el aparato ideológico y mi posterior incorporación en el Comité Central tras el congreso del PS realizado en 1985. Fui miembro del CC hasta 1990. 
27 Entrevista realizada a FIDELIA HERRERA HERRERA, 15 de marzo de 2005, Santiago de Chile. Herrera es militante del Partido Socialista desde 1936 y fue miembro del Comité Central del partido durante el período 1970-1990. Asimismo, estuvo presa en el centro Villa Grimaldi durante un año y ocho meses para pasar posteriormente al exilio en Suecia.

\section{1 ¿Cómo fueron sus inicios en el Partido Socialista?}

Yo ingresé a las Juventudes Socialistas en 1936 siendo estudiante de secundaria en un Liceo de Valparaíso. Eran los preludios de la Segunda Guerra Mundial y en España, la guerra civil, hizo que nosotros nos identificáramos con la II República. Hacíamos marchas, todos los días había una agitación desde el ámbito estudiantil. Allí me empecé a contactar con los compañeros socialistas y comunistas por la creación de los Frentes Populares.

Después de un tiempo conversando con los diferentes dirigentes decidí ingresar al Partido Socialista. Cuando entré al partido éste tan solo tenía tres años de vida. Mi militancia comenzó en aquel momento hasta hoy en día.

\section{2 ¿Cuales fueron sus tareas partidarias?}

Antes la militancia era muy distinta de lo que es hoy en día. Cuando yo entré había que hacer todo un trabajo previo de dedicación, disciplina y cumplimiento con todas las tareas que te asignaban. Esto te iba dando posibilidades de tener cierto reconocimiento de los dirigentes para así ir ascendiendo.

Después de treinta años de militancia, en un congreso muy importante realizado en la Serena (1970), en donde se eligió a Salvador Allende como candidato indiscutible del partido, yo pasé a formar parte del Comité Central del Partido Socialista.

También quiero destacar mi experiencia en Cuba en los años cincuenta con todo el proceso revolucionario y la llegada de Fidel al poder. Viví toda la campaña de Santa Clara con el Ché. Mi marido fue cónsul allí. 


\section{3 ¿Qué tipo de militancia desempeñó en los años de la Unidad Popular?}

Fueron tiempos de cambio y de mucha efervescencia política. Yo fui amiga personal de Salvador Allende. Yo era de Valparaíso y el compañero Allende vivió mucho tiempo allí. Cuando llegué a las Juventudes Socialistas él era el secretario provincial del partido en Valparaíso.

Fue una relación de amistad que se mantuvo durante muchos años. Cuando llegó al gobierno él me nombró directora general de la Junta Nacional de Jardines Infantiles. Siempre supe que el triunfo de Allende significaría la posibilidad de una fuerte reacción de la derecha y del ejército.

\section{4 ¿En qué situación (presencia, participación política, etc.) estaba la mujer militante del Partido Socialista en los años de la UP?}

Muy importante a pesar de que durante muchos años la mujer no tuvo derecho a voto. En los años de la Unidad Popular la mujer tuvo un gran aporte en los partidos políticos. Las mujeres socialistas ayudaron mucho a que las elecciones fueran transparentes, ellas tuvieron un papel fundamental al estar presentes y atentas a que no hubiera los "acarreos" o lo que es lo mismo, fraude electoral mediante el pago de plata para votar a un partido.

Por otra parte, hay que recordar que en este tiempo las mujeres tenían derecho a opinar pero no a votar. Sin embargo, las mujeres sí tuvieron una presencia importante en todas las esferas del partido, desde la base hasta los Comités Centrales.

En el gobierno de Allende hubo algunas mujeres con cargos de representación como el caso de Carmen Lazo, diputada de la UP.

Respecto a mi trabajo te puedo decir que los Jardines Infantiles fue un proyecto que abarcó todo el país. Anteriormente, estos jardines eran pequeñas empresas privadas y lo que se hizo fue "estatizarlos" para extender por todo Chile la posibilidad de que las mujeres pudieran enviar a sus hijos a estos jardines de forma gratuita. 


\section{5 ¿En qué situación estuvo el 11 de septiembre de 1973?}

Sabíamos que el golpe venía. En ese momento era miembro del Comité Central y el 11 de septiembre no pensé en exiliarme sino quedarme en Chile. La consecuencia de esto es que estuve presa en la Villa Grimaldi y en otros centros de la DINA durante un año y ocho meses. Antes de caer presa yo seguí durante un tiempo trabajando en la clandestinidad.

Hicimos un trabajo de solidaridad con los compañeros que se habían quedado desamparados desde el golpe. Establecíamos lazos y ver la forma de juntar recursos económicos para ayudar a los militantes.

En 1975 caí presa en manos de la DINA. Durante muchos meses me siguieron hasta que finalmente me detuvieron en la calle. Se acercaron dos personas y me obligaron a subir a una camioneta. Desde allí me llevaron a la Villa Grimaldi. Unos días después detuvieron a mi hija y a mi marido, ambos eran militantes socialistas. Ellos salieron antes que yo y estuvieron muchos meses buscándome.

\section{6 ¿Cómo fue su experiencia en la reclusión?}

La experiencia en Villa Grimaldi fue terrible. Pude ver a muchos compañeros socialistas que hoy en día están desaparecidos. A mí me torturaron mucho, me aplicaron corriente eléctrica. Te desnudaban y te ponían en un catre metálico. Fue terrible. Estuve mucho tiempo aislada pero aún así fui testigo de cómo desaparecieron muchos compañeros.

No te puedo decir cuanto tiempo estuve en la Villa, una perdía la nación del tiempo. Lo que se es que tras unos meses me trasladaron a Cuatro Álamos y Tres Álamos. Allí estábamos muchos militantes jóvenes. Recuerdo que había muchas mujeres del MIR.

Allí nos organizamos en la Carreta Común. Esto fue una organización para poder amparar a las familias más humildes. Muchas mujeres estuvieron en condiciones muy precarias y nosotras hacíamos un fondo común para repartir las cosas. 
Gracias a Orlando Letelier pude salir de prisión. Él hizo toda una campaña desde Estados Unidos para que me liberaran. Salí a la luz pública y mi familia pudo localizarme y luchar para que me soltaran.

En diciembre de 1976 salí de prisión. Mis hijos ya estaban es Suecia y sólo mi marido me esperaba para exiliarnos. La embajada sueca estuvo atenta de mi salida y ellos me acompañaron al aeropuerto.

\section{7 ¿Qué labores partidarias desempeñó en el exilio?}

En el exilio seguí siendo miembro del Comité Central del partido en el exterior. En Suecia realicé todo un trabajo político enfocado en la denuncia al atropello de los Derechos Humanos en Chile y en todo lo que tuvo que ver con la organización por la Solidaridad con los exiliados políticos. En 1988 regresé a Chile con mi marido para el plebiscito.

Cuando llegué a Chile entré en contacto con todas las organizaciones de DDHH para dar cuenta de la experiencia que viví en Villa Grimaldi. Por cosas de la vida, supe quién había sido la persona que me había torturado. Reconocí su voz. Esta persona en una oportunidad estuvo en mi departamento (porque había quedado en manos de la DINA) y olvidó su documentación con todos sus antecedentes en la mesa del teléfono. Él se llamaba Germán María Muñoz, él hace poco tiempo atrás se suicidó. También participé en el Informe Rettig y últimamente en la comisión sobre prisión política y tortura.

\section{8 ¿Qué elementos positivos y negativos destacaría de su militancia política dentro del Partido Socialista?}

Mi militancia en el partido me ayudó mucho en toda mi formación personal. Conocí a muchos intelectuales y viví momentos muy intensos. En lo negativo podría decirte que yo siempre he recibido el apoyo y el reconocimiento desde la base, desde mi comunal. Creo que en las altas esferas del partido todavía no se termina de reconocer a ciertas mujeres y al aporte que éstas han tenido en el PS. 


\section{PARTIDO COMUNISTA DE CHILE}


28 Entrevista a LUISA ESTACNO, realizada el 13 de mayo de 2004, Santiago de Chile. Estacno es militante del Partido Comunista y estuvo detenida en el centro Tejas Verdes y en el Estadio de Chile. Hoy en día participa activamente en el trabajo poblacional en Santiago de Chile.

\section{1 ¿Cómo fueron sus inicios en la movilización política?}

Desde muy joven empecé a conocer lo que era la movilización social y las huelgas por que mi marido era trabajador de la empresa MADECO. Al llevar seis meses de casada se produjo una huelga general en dicha empresa. Allí conocí lo que era la Olla Común y la lucha que existía de las mujeres. MADECO era una empresa de hombres, pero la lucha en la calle la solían dar ellas puesto que las mujeres no corrían ningún riesgo de ser despedidas.

Por otro lado, yo empecé a trabajar en mi barrio en el trabajo poblacional. Dio la casualidad de que allí vivían varias familias pertenecientes al Partido Comunista. Mi marido también era comunista pero en ningún momento me sentí presionada para ingresar en la militancia del PC.

Yo ingresé en el Partido Comunista en 1969, coincidiendo con la lucha electoral para que fuera posible un gobierno de la Unidad Popular. Poco a poco empecé a desarrollar una sensibilidad en la necesidad de trabajar en la militancia política. Desde pronto, yo participé en diferentes movilizaciones de mujeres.

\section{2 ¿En qué circunstancias estuvo el 11 de septiembre de 1973?}

Al momento del golpe éramos gente muy joven y no supimos lo que iba a suponer la dictadura. Siempre pensamos que iba a ser algo transitorio para dar paso a un gobierno de la Democracia Cristiana.

El 13 de septiembre de 1973 mi marido cayó preso por la Fuerza Aérea (FACH). A partir de este momento yo comencé a ver que se trataba de una dictadura atroz. Todos los compañeros del MADECO cayeron, comunistas, miristas y socialistas. 
La DINA me vino a buscar el 18 de Enero de 1974. Yo estuve en Tejas Verdes tres meses, un campo de formación de torturadores dirigido por Manuel Contreras.

Posteriormente, pasé a la Correccional (COF) y después me llevaron seis meses al Estadio de Chile y de allí a Cuatro Álamos. Yo perdí a mi hijo, porque estando detenida tuve un aborto.

Después de Cuatro Álamos estuve en tratamiento psiquiátrico para vencer el miedo. En 1976 volví a incorporarme en la clandestinidad para combatir la dictadura. Me incorporé en labores de propaganda. Antes de mi detención fui dirigente de una comuna, presidente de un Centro de Madres y de la JAP (Junta de Abastecimiento y Precios).

A partir de 1976 mi labor consistía en la distribución de propaganda, un grupo muy aislado dentro del PC cuyo objetivo era la distribución nacional. Esta labor la continué hasta 1986, momento en el que volví a caer presa.

En ese año cayó el Comité de Producción de propaganda del periódico de PC, El Siglo. Todos los miembros cayeron presos. Un muchacho nos delató al ser intensamente torturado y dio la dirección de nuestra casa clandestina. La CNI vino a buscarnos (al equipo de distribución) y estuvimos 17 días en Borgoño en donde me torturaron siete días y luego me dieron un tratamiento con drogas.

3 ¿Cómo viviste esas experiencias en los centros de tortura y reclusión? ¿Cómo mujer, sufriste algún trato diferente al de tus compañeros de militancia?

En Tejas Verdes, ellos no tenían claro quién era yo. Querían que diera información sobre gente del MIR. Además, en esa experiencia los mecanismos de defensa que desarrollé hicieron que olvidara todos los nombres que pudiera saber; no me acordaba de nadie. Después de la tortura me dejaron en un socavón tirándome agua permanentemente. Recuerdo que escuché voces de niños, yo pensé que me estaba volviendo loca, pensé que era todo fruto de mi cabeza. 
Sin embargo, después supe que la DINA te ponía voces de niños como un claro maltrato psicológico para que una asociara esas voces con sus hijos. Una no era capaz de distinguir, en esas condiciones, de quiénes eran las voces. Te ponían una grabadora. Ellos me decían “'habla porque sino le va a pasar lo mismo a tus cabros chicos que lo que a ti!'”. Los agentes de la DINA manejaban perfectamente la cuestión de los hijos con la mujer.

Quizá si hubo otra carga adicional para la mujer, es decir, la violación. En Tejas Verdes me tuvieron tres meses aislada y desconcertada. Todo ese tiempo estuve con una compañera, Rebeca Espinosa, detenida desaparecida, pero no pude ver a otras presas hasta ocho días antes de salir de allí. Mis recuerdos allí son muy difusos porque yo siempre estuve tirada en el suelo llena de moratones.

Yo necesité durante mucho tiempo olvidar que había sido torturada porque si no el miedo me impedía hacer cualquier cosa. Necesité una terapia de convencimiento, para vencer el miedo y superar ese mecanismo de autodefensa que a mí me duró diez años.

Cuando caí presa por segunda vez en el 86 no recordaba que antes había estado presa en el 74. Para hacer mis declaraciones respecto a la querella de Tejas Verdes junto al CODEPU, tuve que estar con psicólogas, Margarita y Marisol, ellas me ayudaron a retomar todo el tema de Tejas Verdes sin que me doliera.

Mi peor experiencia fue la pérdida de mi hijo por la tortura. Esto me lo deben, voy a querellarme contra quien haga falta. Tengo la esperanza de que se haga justicia con esto.

De la experiencia vivida en 1986 puedo recordar algo más. Allí "te sacaban la cresta" pero recuerdo que las mujeres empezaron a recopilar información y entrar en contacto con las diferentes organizaciones de Derechos Humanos.

\section{4 ¿En que situación estaba la mujer dentro del Partido Comunista en los tiempos de la clandestinidad?}

Creo que la mujer participó activamente en el partido y no hubo ningún tipo de discriminación a la hora de participar. Muchas compañeras aún teniendo inexperiencia 
en la lucha política no dudaron en ir a las manifestaciones y en luchar contra la dictadura.

Sin embargo, creo que las mujeres del PC nos dividimos, las mujeres del ámbito poblacional y del ámbito de la sobrevivencia y las mujeres que dentro del partido tenían cargos de importancia (algunas llegaron a desempeñar responsabilidades en el Comité Central).

5 Entonces, las mujeres del Partido Comunista ¿no tuvieron dificultades para desarrollar la militancia política por su condición de mujer?

Los partidos son partidos, son instrumentos de cambio. La vida personal debemos lidiarla solas. Yo compaginé mi militancia con mi maternidad sin más problemas. Mi familia me apoyó enormemente porque yo debía hacerme cargo del trabajo partidario, pero sin olvidar que yo imponía que horarios tendría para ocuparme de mi hijo. Evidentemente, esto dependía en buena medida de las circunstancias de cada una. Sin embargo, nunca dudé de que mi prioridad principal fuera el cuidado de mis hijos.

Finalmente, quiero destacar la colaboración que tuve con las mujeres militantes del MIR. Podíamos tener nuestras discrepancias políticas pero nunca perdimos el objetivo común que era luchar contra la dictadura y establecer lazos de solidaridad entre nosotras. 
29 Entrevista a MARGARITA DURÁN GAJARDO, realizada el 17 de mayo de 2004, Santiago de Chile. Durán fue militante de las Juventudes Comunistas y estuvo recluida en los centros Londres 38 y Tejas Verdes para pasar después a la Correccional de Mujeres y Tres Álamos. Asimismo, estuvo exiliada en Argentina y en Canadá durante el período 1975-1990.

\section{1 ¿Cómo fueron sus inicios en el Partido Comunista?}

Mi padre fue militante del Partido Comunista y participó mucho en la acción sindical en los años de González Videla. En 1964 fue dirigente de las Juventudes Comunistas. En este sentido, desde muy temprano pude vivir una realidad política muy concreta que me hizo entrar a la militancia activa a los diecisiete años, en 1969.

En ese año, empecé a participar en el ámbito universitario. Mi participación consistía en el tema de las reivindicaciones de los campesinos, en el tema de los jardines infantiles, en tomas de universidades, huelgas, etc.

En 1973 participé en diversos trabajos voluntarios, en la venta del diario, en tareas específicas con los obreros en el tema de la producción, etc.

Cuando vino el golpe de Estado, en la Legua hubo un enfrentamiento muy fuerte acompañado con allanamientos y mucha gente detenida.

En diciembre de 1973 caí con mi compañero a quién mataron. Yo estuve detenida unos días y después de salir volví a caer detenida en enero de 1974 y a partir de ese momento estuve detenida hasta partir al exilio hacia Argentina. Allí, durante tres años, pude continuar mi militancia política como enlace entre Buenos Aires y Santiago.

\section{2 ¿Cómo fue tu experiencia en la reclusión?}

Primero estuve en Londres 38 para pasar después a Tejas Verdes, la Casa Correccional y Tres Álamos. Personalmente, el tema de la liberación femenina, la liberación sexual, etc., nos afectó mucho al conjunto de mujeres presas. La mayoría de las mujeres fuimos violadas, muy pocas se escaparon de los vejámenes sexuales. 
Hubo un machismo fue fuerte en los centros de tortura y reclusión, daba igual la procedencia social de cada una, todas fuimos tratadas de igual forma.

Algunas de mis compañeras optaron por colaborar con la DINA para salvarse de la tortura puesto que en Londres 38 y Tejas Verdes estos métodos fueron muy comunes. Yo no suelo a entrar en valoraciones sobre el tema de las quebradas porque una tenía que vivir esa experiencia para darse cuenta de que no estábamos preparadas para soportar esa experiencia.

De hecho, yo tengo una compañera a la que amenazaron con violar a su hija y decidió colaborar. Era muy fácil quebrarse en esas circunstancias. Yo no puedo juzgar por esto.

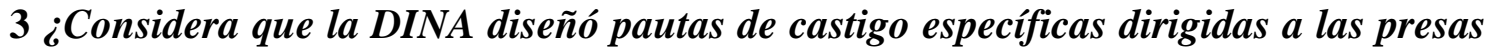 políticas?}

Sí. En mi caso, a mi me violaron delante de mi compañero para que hablara, esto era una práctica común, es decir, buscar la debilidad de la persona. Esto ocurrió especialmente en el primer período, nosotros fuimos los conejillos de indias, ellos aprendieron a torturar con nosotros.

Con el tiempo, la DINA diseñó pautas específicas de castigo. Ellos sabían perfectamente como hacernos hablar, a quienes preguntar etc. La CNI tomó el relevo de este trabajo.

A los agentes represores les chocaba mucho que las mujeres estuvieran tanto o más preparadas que los hombres. Concretamente, según dicen, las mujeres resistieron mucho más la tortura que los hombres. Las mujeres tuvieron mucha fuerza en todos los sentidos. Ellas fundaron la Asociación de Detenidos Desaparecidos en el 75.

\section{4 ¿En qué circunstancias salió de Tres Álamos?}

Yo salí de prisión en octubre de 1974 en calidad de expulsada. Estaba en muy malas condiciones, había perdido a mi compañero, es decir, fue un periodo muy duro, y en 
Argentina se me vino todo abajo. Tuve fuertes depresiones, pero esto no me impidió continuar con mi militancia política.

El golpe de 1976 me pilló en Buenos Aires. Yo también había tenido contactos con los Montoneros, con lo que tuve que salir definitivamente a Canadá por miedo a caer de nuevo presa.

\section{5 ¿Cómo fue su experiencia en el exilio?}

Nunca me adapté a Canadá. Aprendí inglés y francés y trabajé pero fueron años muy difíciles. Estuve en la provincia Alberta, cerca de Vancouver. Trabajé una temporada en un taller de costura compaginándolo con mi aprendizaje de inglés. Posteriormente, viajé a Montreal en donde me casé y me quedé embarazada de Cristián.

Durante mucho tiempo tuve que necesitar el apoyo de psiquiatras y psicólogos para superar todo lo que me había sucedido. Entre 1974 y 1980 estuve viviendo como en el Limbo.

Nunca dejé de participar activamente en el movimiento político. Trabajé en grupos de solidaridad desde donde mandábamos ropa y plata a la Vicaría de la Solidaridad. Asimismo, estuve trabajando en una agrupación denominada "Detenidos-desaparecidos del Tercer Mundo" donde desarrollamos una labor de denuncia y solidaridad.

\section{6 ¿Cómo fue su regreso del exilio?}

Regresé a Chile en 1982, cuando salieron las primeras listas de gente aceptada. Fue un año muy duro porque era muy difícil encontrar trabajo con lo que tuve que regresar de nuevo a Canadá.

Nuevamente, regresé a Chile en 1986. En ese año hubo un atentado contra el general Augusto Pinochet, en el que familiares míos estaban implicados en el Frente (Frente Patriótico Manuel Rodríguez, FPMR). Bajo estas circunstancias tuve que regresar de nuevo hasta que volví definitivamente en 1990. 


\section{7 ¿Qué aportación creé que tuvo la mujer dentro del Partido Comunista en los años de la dictadura militar?}

Creo que tuvo una participación importantísima. Especialmente en la Agrupación de Detenidos-Desaparecidos, puesto que fueron las mujeres comunistas, en su mayoría, las que impulsaron este organismo. En los sindicatos y en el movimiento poblacional, las mujeres militantes del PC fueron fundamentales.

En lo que fue el ámbito interno del PC, lo cierto es que hubo discriminaciones pero ya no tanto de género, sino en el tema de la alternancia de poder. En la dirección del Partido Comunista siempre estuvieron los mismos y en cierta forma hubo una clara discriminación para que otros pudieran acceder a las responsabilidades políticas.

Te puedo decir que, en la experiencia del exilio, muchas mujeres militantes del PC se separaron de sus maridos al decidir no soportar ciertas cosas. Muchas de ellas decidieron continuar sus estudios y no someterse a su papel tradicional. En este punto, hubo un cierto cambio.

Las mujeres que estuvieron en el exilio cambiaron su mentalidad al cuestionar sus roles, y esto se puede ver por ejemplo en mis hermanas, que se han quedado estancadas en algunas cuestiones muy básicas.

Creo que las mujeres comunistas al igual que las miristas supieron superar sus diferencias a la hora de plantear objetivos comunes, lo que por otra parte, no sucedió con los hombres que, normalmente, eran mucho más sectarios.

Esto, sin duda, significó que la lucha y la movilización política de las mujeres fueron mucho más efectivas y reales. Hay que recordar que las primeras denuncias de las violaciones de Derechos Humanos las hicieron las mujeres, tanto desde el exilio como en Chile.

Desde mi experiencia, esto lo viví en la Correccional con las compañeras. Había una monja, a la que llamábamos "la monja fascista" a quién logramos expulsar de la 
dirección, precisamente, por esta acción colectiva que unía al conjunto de mujeres en un objetivo común. 
30 Entrevista a MARGARITA MENA YÁÑEZ, realizada el 3 de junio de 2004, Santiago de Chile. Mena fue militante de las Juventudes Comunistas y del Frente Patriótico Manuel Rodríguez. Asimismo, estuvo recluida en la Correccional Femenina de Santiago (COF) desde septiembre de 1987 hasta diciembre de 1989.

\section{1 ¿Cómo fueron tus inicios en el Partido Comunista?}

Mis inicios fueron bastante precoces. Yo entré a militar en las Juventudes Comunistas a los trece años. Mi familia siempre fue socialista y desde muy temprano fui muy consciente de que había que enfrentar el régimen militar. Mi hermano fue detenido en el año 76, en uno de los episodios más negros cuando desapareció mucha gente del comité central del Partido Comunista de Chile.

Con 18 años, ingresé en el Frente Patriótico Manuel Rodríguez. Esta agrupación nació el 13 de diciembre de 1983, como una apuesta para hacer frente a los aparatos represores. En un principio yo entré realizando una labor de reflexión sobre las estrategias que debíamos seguir. Este año coincidió con el inicio de las protestas a nivel poblacional y en las urbes. Fue un año en el que los índices del paro se dispararon.

Por una parte, mi militancia en las Juventudes Comunistas fue básicamente de propaganda. También desempeñé un cargo en el comité regional y tuve a mi cargo varios comités locales que representaban a las diferentes poblaciones. Concretamente, yo dirigí el Comité Regional Joven Guardia, que abarcaba varias comunas de Santiago. Yo llevaba las tareas que había que hacer al comité regional y de allí se distribuían a los comités locales.

Por otra parte, en el Frente Patriótico Manuel Rodríguez, después de una labor de estudio sobre las tácticas políticas a desempeñar, pasé a trabajar en la denominada militancia de choque. Esto consistió en la formación de cuadros político-militares. Nos guiábamos mucho por las tácticas de defensa de Vietnam, Nicaragua, etc. Tuvimos varios cursillos militares en las montañas, con armamento y manejo de explosivos que por lo general era muy antiguo y con un deficitario mantenimiento. 
2 ¿En que situación estaba la mujer en las Juventudes Comunistas y en el Frente Patriótico Manuel Rodríguez?

La militancia de la mujer en el Partido Comunista siempre fue notoria y fundamental. En los cuadros militares los compañeros fueron bastante machistas. La presencia de una mujer en la formación militar era algo muy complicado. En mi caso, me encontré con mucho rechazo por parte de los hombres, tanto en los cuadros militares como en los comités locales en donde yo desempeñaba una labor de difusión de la información partidaria.

Hubo muy pocas mujeres en el ámbito militar. Nuestro caso no era como en Nicaragua en donde la mujer soldado fue siempre una realidad.

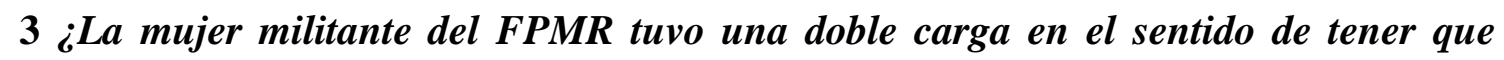
asumir también las tareas domésticas y el cuidado de los hijos?

Yo no tuve hijos en aquel momento, pero muchas de mis compañeras tenían que trabajar, ocuparse de las labores de la casa y además militaban en los cuadros militares. Esto era admirable. También, hubo compañeras y compañeros que descuidaron a los hijos para desempeñar una plena militancia en el Frente.

Nunca hubo un debate o reflexión a nivel de partido sobre la condición de la mujer militante. El objetivo principal era echar a Pinochet y desestabilizar su gobierno, echando abajo torres de alta tensión, atentando contra cuarteles de la CNI, etc. Las preocupaciones eran otras porque el objetivo ni se cuestionaba. Quizá con el paso del tiempo una se plantea estas cosas.

\section{4 ¿Existió discriminación de género en la JC y en el FPMR?}

Quizá en los cuadros militares sí. No tanto en las Juventudes Comunistas. Mis compañeros siempre me veían como una mujer delicada, que no podía desempeñar un trabajo miliar. 
Yo tuve que demostrar constantemente que podía manejar un fusil, y que sí tenía las capacidades para defenderme de la represión de la dictadura. Bueno, de hecho los mejores francotiradores en Vietnam fueron mujeres y esto lo utilizábamos mucho para acallar las críticas.

Yo participé en varios atentados a cuarteles de la CNI. En cada destacamento, que solían ser de diez personas, sólo había dos mujeres, es decir, un veinte por ciento. Aún siendo minoría participamos activamente en las acciones militares de mayor riesgo.

Además, la mujer tenía una ventaja en estas acciones, es decir, el tema de la imagen que al fin y al cabo significaba un recurso táctico. Recuerdo que nos hacíamos las coquetas para poder entrar en algún sitio y sacar información, es decir, a nosotras nos dejaban entrar en todas partes porque los militares no pensaban que una mina bonita pudiera estar metida en un grupo de extrema izquierda que atentara contra la CNI.

\section{5 ¿En algún momento cayó presa?}

Sí. Yo caí con dos compañeros caminando por la vía pública. Nos rodearon unos hombres vestidos de civil en septiembre de 1987. Íbamos armados pero no pudimos hacer nada porque a escasos metros había un jardín infantil, con lo que el costo de un enfrentamiento era muy alto. Nos vendaron tras ensañarse con nosotros, sobre todo por andar con armas, granadas de mano, un fusil, etc. La detención fue muy brusca y dolorosa. Yo pensé que nos iban a matar por la violencia con la que actuaron con nosotros.

Posteriormente, nos llevaron a una comisaría en donde estuvimos tres días. Nos entrevistó el Grupo Especializado de Explosivos de Carabineros (El GOPEC) y miembros de la Central Nacional de Informaciones (CNI).

A mi me tuvieron amarrada a un pilar en un patio interior del recinto. Recibí muchos golpes y pasé mucho frío. A mis compañeros los llevaron a otra sala. También me hicieron falsos fusilamientos, patadas, etc. El GOPEC se cebó bastante con nosotros, en cambio, la policía de investigaciones fue algo diferente pero igual duro. 
En los interrogatorios se daba mucho la presencia del agente malo y el bueno. Yo recuerdo que uno se ponía por atrás y me decía al oído "pucha, tú eres joven, eres una buena moza, por qué estas metida en esto, sólo dime los nombres y todo saldrá bacán”.

Después me llevaron a la Correccional, la COF, en donde estuve un año y siete meses. Llegué con muchas fracturas y pérdida parcial de la audición producida por los golpes en los oídos (me aplicaron la técnica del teléfono). Allí estuve en régimen de incomunicación en unas celdas muy pequeñas sin derecho a visitas y con sólo una comida al día.

\section{6 ¿Creé que la Junta Militar diseñó unas pautas específicas a la hora de reprimir a las presas políticas?}

Sí. Chile ha sido siempre un país muy machista. Ellos tenían mucha rabia de que una mujer fuera capaz de estar en un grupo militar y enfrentar la dictadura. Los tipos de la CNI, tus torturadores, te preguntaban por qué no estabas en tu casa cuidando de tus niños. Por esto se ensañaron con las compañeras. Muy pocas salieron de las cárceles sin haber sido violadas o violentadas sexualmente. También usaban métodos como el manoseo constante, insultos, vejaciones de carácter sexual, etc. Esto era un castigo habitual.

Yo sentí el miembro de uno de ellos muy cerca de mi pierna. Creo que yo me salvé de la violación porque estaba con la menstruación y andaba muy sucia porque no había tenido la oportunidad de asearme.

Además, practicaban mucho la tortura psicológica, es decir, la amenaza con tus padres y familiares. A mi me amenazaban con que iban a matar a mi madre. Ellos sabían toda tu vida, donde trabajabas, cuánta gente vivía en tu casa.

\section{7 ¿Cómo fue la convivencia con el resto de las presas?}

Al principio fue terrible, especialmente con las presas comunes. Primero, porque el lesbianismo existía y esto fue muy chocante para mí. Sin embargo si tuve muchas 
muestras de solidaridad. Segundo, porque el nivel de violencia y delincuencia era un hecho constante en algunas de las presas.

También hicimos un trabajo social, enseñábamos a leer a las mujeres más marginadas y realizábamos charlas sobre cuestiones puramente relacionadas con la mujer como enseñar los métodos de prevención de embarazos, etc.

\section{8 ¿Qué opinión tiene sobre las presas politicas que se quebraron en la tortura?}

Bueno, creo que la tortura es terrible y no todo el mundo puede soportarla. En el caso de la Flaca Alejandra y Luz Arce simplemente ellas no tuvieron los recursos necesarios para soportar la tortura. La Flaca debe estar muy mal, porque cayó todo el aparato central del MIR. Es muy difícil soportar tanta vejación. Creo que uno no puede criticar a las quebradas, somos seres humanos y yo no soy quién para juzgarlas, de hecho, creo que ellas son víctimas. Hay compañeras que en este tema son mucho más duras, pero yo creo que cada ser humano tiene su punto de quiebre.

\section{9 ¿En qué circunstancias salió en libertad?}

Yo salí en libertad condicional el 13 de diciembre de 1989. Quise ocupar mi tiempo de libertad en todo menos en política. Dentro de la cárcel me di cuenta de que yo no había disfrutado de mi juventud por habérsela dado a la causa política.

No obstante, denuncié mi causa a la CODEPU y seguí en contacto con organizaciones de Derechos Humanos. En el ámbito del partido el Frente tuvo una división y un conflicto muy fuerte de la que yo no quise participar. No estaba en condiciones de seguir con la lucha armada. Yo solo quería querellarme contra las personas que me torturaron.

\section{0 ¿Qué secuelas ha tenido como consecuencia de su experiencia en la tortura?}

A nivel psicológico siempre este asunto me va a acompañar. La tortura y la experiencia traumática no se sí es posible superarla del todo. Para mi fue complicadísimo exteriorizar lo que yo viví, encontrar pareja, todo. Yo me sentí muy aislada al salir de 
prisión. Además, una tiene antecedentes por la Ley Antiterrorista y esto me ha dado muchas complicaciones a la hora de encontrar trabajo.

11 ¿Creé que desde el Partido Comunista se ha hecho un reconocimiento de la situación por la que pasaron las presas políticas? ¿siente que no se ha valorado sufcientemente su aportación al partido?

Bueno, Gladis Marín es la cabeza del PC en este país. Creo que el partido sí ha reconocido la labor de la mujer, por lo menos unos mínimos de la aportación de la mujer en la política, pero igual siento que hay una deuda por parte de ellos.

Sin embargo, hoy por hoy, no hay ninguna instancia que reconozca que la mujer sufrió un tipo de represión política diferente. Mis hijos no pueden estudiar gratis en la universidad, no hay a nivel ni de gobierno ni de partido ninguna ayuda a las mujeres que sufrieron la represión. Sólo hay ONGS y agrupaciones feministas que reivindican esta cuestión.

Hay que tener en cuenta que la mujer tuvo mucho liderazgo en tiempos de dictadura. Tuvo que salir a la calle a protestar y buscar trabajo. Con la democracia, hubo un claro repliegue de la mujer a su rol tradicional, es decir, un estancamiento que también se trasladó al conjunto de las organizaciones de Chile que habían tenido un papel importante en la lucha contra el régimen militar. Esto ha sido una realidad y ha de reconocerse. 
31 Entrevista realizada a VIRGINIA GONZÁLEZ EVIA. Santiago de Chile, 5 de enero de 2005. González Evia es militante del Partido Comunista desde 1938. Asimismo, fue miembro del Comité Central desde 1960 hasta 1980 y tuvo que exiliarse a Bulgaria durante 1977-1982.

\section{1 ¿Cómo fueron sus inicios en el Partido Comunista?}

Yo soy hija de minero. Mi padre fue sindicalista. Yo desde muy niña iba a las reuniones sindicales. En 1938, con diecisiete años, di el paso para entrar en el partido sin pedir autorización de mis padres. Mi padre me advirtió que a los comunistas los detenían y los mataban y que si yo me quería arriesgar en eso...

Mi primer paso en el partido fue trabajar por la candidatura de Pedro Aguirre Cerda. En aquellos años el voto era individual, se imprimía y se repartía a la gente. Nuestro adversario era Gustavo R. Santa María, el candidato de la gran burguesía y la banca.

\section{2 ¿Cómo recuerda la presencia de la mujer en el partido durante aquellos años?}

En aquel entonces había mujeres en el Comité Central como María Ramírez o Eva Gómez. También estaba María Marchan, la suegra de Carmelo Soria, asesinado por la dictadura.

En el año 1935 se fundó el MENCH (Movimiento de Emancipación de la Mujer chilena), encabezada por Elena Cafarena y su secretaria, Olga Pobrete (profesora y dirigente universitaria), Lia Lafaye (presidenta de la Unión de Mujeres de Chile), etc.

Algunas de estas mujeres tuvieron una fuerte vinculación con el Partido Comunista como Elena Cafarena, que es casada con Jorge Gil, militante y abogado del partido y después miembro del Comité Central del PC. Aunque no militaran formalmente en el partido, sí que en la práctica se incorporaron a la lucha popular.

La presencia de la mujer en el partido era muy decidida, había mujeres obreras, profesionales, etc. Tenemos el ejemplo de la Julieta Campusano, senadora y miembro del Comité Central del Partido Comunista de Chile. 


\section{3 ¿Cómo continuó su militancia en los siguientes años?}

En el gobierno de González Videla (1946-1952), el trabajo partidario se intensificó. En 1948 los compañeros del partido nos dimos cuenta de que Videla había cambiado radicalmente sin cumplir sus promesas, incluso comenzó una persecución, hubo muchos trabajadores detenidos en el campo de concentración de Pisagua...desaforaron al diputado Pablo Neruda, etc.

En esos años yo viví esa represión, detuvieron a mi compañero y lo llevaron a Pisagua. Tuve que venirme a Santiago y luchar por la libertad de mi compañero y otros militantes. Realizaron una huelga de hambre.

Posteriorment, pasé a trabajar en la comuna de San Miguel como dirigente comunal del partido entre 1953-1959. Allí establecimos un comité de mujeres para organizar y mejorar las condiciones de vivienda, cesantía, salud, etc.

Empezamos a trabajar con algunas reivindicaciones dirigidas a mejorar la situación de las mujeres como el establecimiento de guarderías infantiles para las trabajadoras, el derecho a tener una silla en el trabajo, a la colación, etc.

Desde 1960 hasta 1980 fui miembro del Comité Central de PC. El gobierno de Allende fue una época muy bonita en donde se hicieron muchas cosas. En esos años ingresó mucha gente al partido, mujeres y hombres. En el partido llegamos a ser 200 mil militantes, la mitad jóvenes. El 20\% aproximadamente eran mujeres. En el Comité Central del PC éramos entre 20-30 mujeres de un total de 120 miembros.

Yo trabajé por la candidatura de Salvador Allende en 1952. Tuve un acercamiento a él y te pudo decir que él representaba todos los valores más humanos del pueblo chileno.

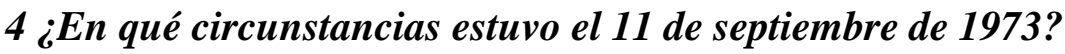

Estaba trabajando con los compañeros de la dirección del partido en Santiago. Yo pertenecía a la Comisión de Control de Cuadros, trabajaba con Rafael Cortés. Pasamos 
a la clandestinidad como pudimos. Se habían tomado unas medidas de seguridad pero temporales, no pensamos que el golpe iba a durar tanto.

Desde 1973 hasta 1977 estuve trabajando en clandestinidad. En ese año el cerco se estrechó mucho. Se optó porque tenía que salir al exilio. Estuve entre 1977 hasta principios del 82 en Bulgaria.

Además, estuve trabajando con las agrupaciones de ejecutados y detenidosdesaparecidos. Muchos de mi compañeros fuero asesinados o están todavía desaparecidos.

5 ¿Cré que se establecieron pautas específicas de castigo dirigidas a las presas políticas en los diferentes campos y centros de reclusión de la Junta militar?

Hubo un ensañamiento muy fuerte con la mujer. No se respetaron ni a las mujeres embarazadas. A Marta Ugarte Román, una mujer muy luchadora, profesora y soltera, cayó presa y se ensañaron con ella, la violaron y después la tiraron al mar. El mar la devolvió, apareció en la Playa la Ballena, en los Molles (ciudad de la Ligua, V Región, septiembre de 1976).

Se ensañaron con las mujeres porque las que sobrevivieron fueron violadas hasta con perros. Otras fueron madres de hijos de militares al ser violadas por varios... ¿quién es el padre?, no se sabe.

Querían impedir la independencia de la mujer, su autonomía política y de pensamiento. Querían acabar con su espíritu de lucha y los logros que habían conseguido.

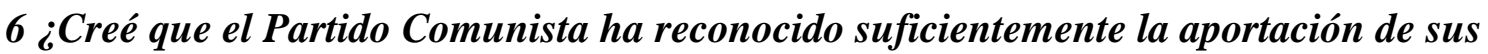 mujeres en tiempos de dictadura?}

La incorporación de la mujer en la actividad política se ha ido logrando paulatinamente en los últimos años. Se ha logrado mucha presencia de mujeres concejalas del PC. Tan sólo a partir de 1985 empezaron a trabajarse el tema de género. Pero aún así no es fácil 
porque hasta hoy la mujer tiene un doble trabajo, el doméstico y el partidario aunque últimamente el hombre empieza a incorporarse a las tareas del hogar.

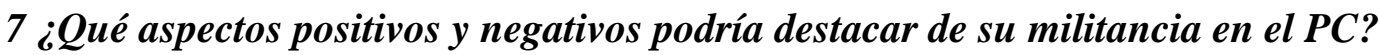

Puedo agradecer muchas cosas al Partido Comunista. El hecho de haber sido militante me permite valorar la vida, vivir junto con grandes sufrimientos que me dio la

dictadura. A mi compañero lo mataron y una tiene que reponerse....yo no se por qué estoy viva. Siempre me lo he preguntado y se lo agradezco al partido porque gracias a él pude conocer parte del mundo y sobrevivir. 
32 Entrevista realizada a MARIA EUGENIA PUELMO, 12 de enero de 2005, Santiago de Chile. Puelmo es militante del Partido Comunista desde 1966. Estuvo exiliada en Argentina e Inglaterra. Asimismo, participó en la Comisión Nacional de Verdad y Reconciliación (CNVR, 1991) encargada de elaborar el Informe Rettig.

\section{1 ¿Cómo fueron sus inicios en el Partido Comunista?}

En 1966 entré a las Juventudes Comunistas. Mi acercamiento fue por el tema de la paz y sobre todo el tema estudiantil. Había un gran revuelo con la reforma educacional, las universidades, etc. Yo estudiaba en un colegio privado, en donde estudiaba, por decirlo de alguna manera, la pequeña burguesía. Un grupo de amigas y yo formamos un centro de alumnos.

\section{2 ¿Qué tareas partidarias despeñó durante el período de la Unidad Popular?}

Básicamente participé en el movimiento estudiantil. Estaba en la universidad. Me tocó vivir las campañas electorales de Salvador Allende. En 1971 mi participación fue muy activa en la Juventud Comunista en todo lo que fue el trabajo voluntario, propaganda, en la difusión del programa de la UP, etc. En la universidad había una confrontación muy grande con la derecha, concretamente con Patria y Libertad. Nosotros participamos en la defensa de la reforma de la universidad.

\section{3 ¿En qué situación (presencia, participación política, etc.) estaba la mujer militante del Partido Comunista en los años de la UP?}

El partido, mirado con una perspectiva rigurosa de género, en ese tiempo se podría decir que no tenía una política de género. Pero en términos prácticos, la presencia de la mujer fue una realidad muy visible. Recuerdo a la Julieta Campusano y Mireya Balta, que eran mujeres líderes y muy entregadas a la causa comunista.

Ahora bien, en lo cultural, la militancia de las mujeres en política no era algo común, era algo "anormal" para la mentalidad de la época. En muchas oportunidades no ha considerado las dificultades culturales que las mujeres comunistas han tenido para desarrollarse plenamente en el PC. 
Por otro lado, el gobierno de la UP tuvo una especial sensibilidad por la educación y participación de las mujeres en lo público. Las mujeres trabajadoras recibieron becas para acceder a la universidad y esto se tornó en una prioridad para el gobierno.

Además, se incluyeron a muchas mujeres en la política, independientemente de su origen sociocultural. Hubo muchas compañeras jóvenes que se incorporaron a la vida pública, hubo diputadas, concejalas, etc. Ahora bien, nosotras nunca pensamos en términos de política de género, era algo más general. Nunca hubo una política de género consciente, eso no existió ni en la UP ni en el PC.

En cambio, en la derecha las mujeres se movilizaron muchísimo. Creo que eso fue un fallo de la UP puesto que no se supo atraer a muchas mujeres que comenzaron a asumir una actitud derechista, golpista y no sólo mujeres de la burguesía, también de la clase obrera.

Cuando estaba en la universidad militaba en las Juventudes Comunistas. La secretaria de la Jota me llamó y me dijo que me iba a ayudar por una mala calificación que había tenido en una materia. Esto fue una clara preocupación por la persona, independientemente de los intereses de la revolución o del género.

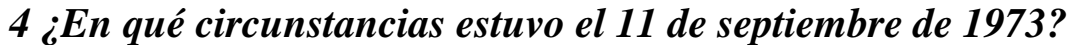

Estaba en la universidad. Sabíamos que iba a ver un golpe de estado, pero en la Jota nunca pudimos imaginar el alcance de la represión militar; pensábamos que iba a ser algo temporal. Hicimos una resistencia juvenil muy inocente.

A los pocos días del golpe cayó preso mi marido y también detuvieron a mi mamá, la llevaron al Estadio Nacional. Empecé a darme cuenta de que el asunto iba en serio. Además tenía un hijo y la sobrevivencia fue muy dura.

En octubre de 1974, tuve que partir al exilio por el tema de mi marido y mi mamá. Tuve que salir con mi familia primero a Argentina y después a Inglaterra. Me tocó vivir la experiencia del trabajo de la solidaridad con Chile. Fui parte de la dirección del partido 
en Gran Bretaña. Hasta 1987 no volví a Chile. En ese año todavía el partido estaba en la clandestinidad con lo que me tocó trabajar de nuevo con mucha cautela.

\section{5 ¿Cómo compaginó la militancia con su maternidad?}

Las mujeres comunistas en el exilio vivimos una contradicción. En Inglaterra nosotras trabajamos mucho para compartir las tareas domésticas y el cuidado de los niños con los compañeros pero, en la realidad, eran las mujeres quienes se ocupaban de estas cosas y en el partido vivíamos esta contradicción porque, además, a finales de los setenta el movimiento feminista británico tuvo mucha fuerza y algunas de nosotras estuvimos influidas por estas propuestas tan avanzadas, especialmente si una las comparaba con la realidad de las mujeres en Latinoamérica.

\section{6 ¿Creé que las mujeres que vivieron la militancia en el exilio tomaron una cierta} conciencia de género a diferencia de las compañeras que se quedaron en Chile? ¿Se le plantearon algunos problemas a su regreso en lo referente a esas dos visiones diferentes sobre el papel que la mujer debía desempeñar dentro del PC?

Sí. Absolutamente sí. En primer lugar, cuando regresé a Chile algunas compañeras y compañeros que se habían quedado tenían un cierto resentimiento hacia los exiliados porque según su criterio no habíamos tenido que vivir bajo la represión directa de la dictadura y por ende habíamos vivido en mejores condiciones que ellos.

Tuve que hacer un tremendo esfuerzo para entender esta visión de algunos compañeros y lograr puntos de encuentro. Lo cierto es que sí que había un rechazo a los compañeros que "veníamos de fuera y que decían cómo se tenían que hacer las cosas".

Esto se trasladó también al tema mujer. Esto fue muy difícil. Yo, al igual que otras compañeras que habíamos vivido en Europa habíamos tenido la posibilidad de estudiar, de ser parte de avances que para la mujer en Chile eran impensables. Eran códigos distintos, nosotras absorbimos otra mentalidad que pasaba por incorporar a la mujer plenamente en la vida partidaria. Incluso te diría que estas dos visiones siguen existiendo hoy en día. Yo me he encontrado recientemente con compañeras que se han negado a crear una comisión de mujeres independiente a la dirección de partido. 
Creo que ha faltado hacer una doble militancia de las mujeres en el PC, una política y una feminista. Se ha tendido ha mezclar las cosas lo que ha supuesto un claro error porque son dos luchas que, aunque compatibles, han de abordarse de forma independiente porque la problemática que se la plantea a la mujer requiere de un espacio específico. El partido no ha tenido la preocupación de crear estos espacios y aquí, también incluyo a muchas mujeres que se han negado a trabajar en este camino.

\section{7 ¿Creé que hubo una represión específica hacia las mujeres presas políticas en los años de dictadura? ¿Podríamos decir también que hubo un trato diferente a las mujeres según su clase y condición socioeconómica?}

No hubo diferencia de clase. El valor que se otorgaba a la mujer presa era nada. A las presas políticas se las trataba como algo desechable, precisamente, por su implicación política independientemente de su procedencia social. Las mujeres respetables bajo el prisma de los militares eran aquellas que se dedicaban a lo doméstico y al cuidado de su marido e hijos. En general, se veía a la mujer política cómo algo fuera de lo normal y por ende como elementos al que no se debía respetar por ir en contra de lo que se creía que era lo normal.

Además de sufrir la tortura la mujer tenía que soportar todo las agresiones por su condición sexual. Más aún, las mujeres en su calidad de presas recibían un trato diferente a los hombres en términos de recibir visitas, es decir, los hombres podían recibir a sus mujeres y a su familia porque se entendía que ellos necesitaban intimar con ellos.

Hubo una clara especificidad a la hora de reprimir a las presas políticas. Por ejemplo, la represión hacia las mujeres rurales del Paine fue absolutamente premeditado. En este caso se estudió claramente el perfil de estas mujeres a la hora de reprimirlas para establecer los mecanismos de tortura más eficaces. La DINA sabía perfectamente cual era la mejor forma de denigrar a las mujeres.

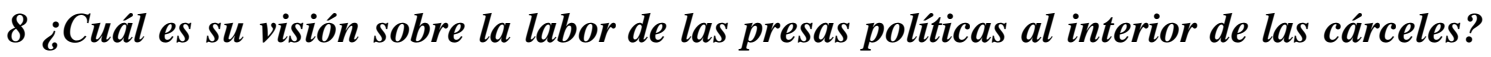
¿Considera que se superaron las diferencias ideológicas a la hora de desarrollar un trabajo contra la dictadura? 
Sí. Aquí sí quiero establecer un criterio de género absoluto. Las mujeres hicieron una política diferente al de los hombres. Este es un tema que no ha sido lo suficientemente tratado por la izquierda. Hay formas que tienen que ver con el acerbo cultural de las mujeres que sí es distinta al de los varones.

La unidad y la solidaridad entre las presas fue un claro ejemplo de esta diferencia. Se cuidaban los hijos unas a otras, se llegaban a acuerdos de organización con rapidez. Este forma de hacer política y de entendimiento perdura hasta hoy.

\section{9 ¿El Partido Comunista ha reconocido suficientemente la aportación de sus mujeres militantes en tiempos de dictadura?}

No lo suficiente. Ha habido reconocimiento a algunas células, comunas, etc. de algunas mujeres que trabajaron en clandestinidad. Ahora bien, un reconocimiento específico no sé si ha existido. Me temo que no.

Además, hay algo que últimamente está sucediendo en el partido. Recién muchas mujeres se están atreviendo a dar sus testimonios sobre lo que les pasó y esto creo que ha de valorarse más porque han sido muchos los miedos que han impedido a las compañeras prestar sus experiencias vividas en dictadura.

\section{0 ¿Por qué la mujer fue punta de lanza en la organización de agrupaciones de DDHH?}

La mayoría de las mujeres que participaron en las agrupaciones no estaban incorporadas en la política. Fue una organización espontánea que no atendía a razones políticas en sentido estricto sino más bien a la necesidad de vida por saber que había ocurrido con sus familiares.

Por otro lado, se incorporaron algunas mujeres que tenían experiencia de vida política ya que o bien habían militando junto con sus maridos o compañeros o bien venían de familias en la que algún miembro militaba en algún partido de izquierda. Ellas supieron juntarse con otras mujeres sin estas experiencias superando con ello las diferencias que pudieran existir. 
Por tanto, las agrupaciones tuvieron una génesis basada, por una parte, en la respuesta de mujeres afectadas por la represión en calidad de personas sin vinculación política y por otra parte, mujeres politizadas que dieron a la lucha contra la dictadura un carácter más político. Hoy en día todavía uno puedo ver que conviven estos dos tipos de mujeres en las agrupaciones de Derechos Humanos.

\section{1 ¿Qué tareas partidarias realizó al regresar del exilio?}

En 1987 regresé a Chile, momentos antes del plebiscito. En esa época yo era parte de la dirección regional del PC. Cómo partido nosotros no estábamos de acuerdo con esa salida política. Desgraciadamente, una parte de nuestros aliados (el Partido Socialista) se desmarcaron del PC quedándonos solos.

El PC tenía una apuesta política diferente a la postura de la concertación. Esto fue un sock muy fuerte para el PC porque en 1986, cuando empezó a vislumbrarse la salida política del plebiscito, el Partido Comunista tenía gente preparada para luchar, para enfrentarse a la dictadura y en unos meses nos quedamos completamente solos en la apuesta armada y de rebelión popular. Nos vimos abocados a un plebiscito que no quisimos desde un principio, de hecho, esto creó una fuerte crisis al interior del PC.

Para mí el plebiscito y los gobiernos sucesivos de la concertación no cumplieron con los objetivos de cambio que se esperaban. Yo seguí, sin embargo, trabajando en las poblaciones, haciendo talleres y trabajando con las mujeres. De hecho me movilicé mucho a favor de la campaña del NO aunque pensara que no era la mejor vía para seguir la lucha.

Asimismo, participé en la Comisión Rettig en los casos de muertes provocadas por agentes del Estado. Trabajé en la CNVR (Comisión Nacional de Verdad y Reconciliación) como asistente social e investigadora. Antes de esto, trabajé en la Vicaría de la Solidaridad preparando toda la información y el material que posteriormente se entregó a dicha Comisión.

12 ¿Qué elementos positivos y negativos destacaría de su militancia en el partido comunista? 
El PC me ha aportado una experiencia de vida muy emocionante. El ochenta por ciento de mi vida la he dedicado al partido. Gracias a esta experiencia he podido conocer realidades que de otra forma no hubiera podido, como la realidad del pueblo mapuche, de los trabajadores, de los campesinos, de las mujeres obreras, del alcance de la represión de la Junta, de las desigualdades que todavía perduran hoy en Chile. Este conocimiento fue algo muy positivo para mí a la hora de formarme en lo político y en lo humano.

En lo negativo...la falta de reconocimiento más específico a la militancia de las mujeres comunistas. Esto ha faltado en el partido. Falta abrir mayores espacios a las mujeres. Tenemos muchas mujeres militantes que están solas, que no reciben el apoyo suficiente del PC. Creo que el Partido Comunista debería recuperar el liderazgo en políticas de género y poder colaborar con otras organizaciones para reactivar el tema mujer que hoy por hoy sigue estancado (sexualidad de la mujer, desempleo, pobreza, prostitución, etc.). 
33 Entrevista realizada a RUTH LILIANA CARMONA SOTO, 3 de marzo de 2005, Santiago de Chile. Carmona es militante del Partido Comunista desde 1973 y estuvo detenida en el Cuartel de Investigaciones de Santiago.

\section{1 ¿Cómo fueron sus inicios en el Partido Comunista?}

Entré a militar en el año 1973, todavía estaba Allende. Tenía catorce años. Mis hermanos y mi padre eran militantes del partido. Éramos una familia comunista. Mi hermano, Lautaro Carmona, no quería que militara.

Entré a militar en un momento de mucha dificultad, en los últimos meses del gobierno de la Unidad Popular. Estaba en primero medio y en mí base nos dedicábamos a los trabajos voluntarios: repartir alimentos ante el desabastecimiento, trabajo poblacional, etc.

El 11 de septiembre fue un momento muy difícil. Esa mañana fui a la casa de nuestro secretario político. Nos reunimos unos cuarenta militantes. Supuestamente íbamos a organizarnos para defender al gobierno. Escuchábamos radio Moscú en donde se decían muchas cosas, como que se estaba organizando el ejército del general Prats.

Mi hermano era de la Jota (Juventudes Comunistas), militaba en un comité regional y pasó a la clandestinidad. Él les dijo a mis padres que no me dejaran salir de la casa.

2 ¿Cómo recuerda la presencia de la mujer en el partido durante los primeros días del golpe?

Primeros auxilios, andábamos con botiquín. Todo iba encaminado a ser ayudistas. En mi base no había armas y las compañeras éramos pocas, unas cinco.

\section{3 ¿Qué tareas partidarias desarrolló en la clandestinidad?}


Quedamos descolgados del partido durante unos meses. No sabíamos que estaba pasando. Yo militaba en una base de la Villa Olímpica. Hasta 1974, con quince años, no pude retomar mi trabajo. Un compañero me dijo que iba a volver a militar en esa base.

Las actividades que realicé fueron básicamente de propaganda. Salíamos a la calle a rallar las paredes, nos juntábamos varias parejas y planeábamos muy bien las tareas. Uno vigilaba, otro seleccionaba la calle, otro rallaba, etc.

Recuerdo un rallado que hicimos con aceite quemado que duró diez años y decía: "Lonquen barbarie fascista". En esa oportunidad estuve a punto de caer presa porque nos vio un vecino. También tirábamos panfletos cerca de los cuarteles de carabineros, era muy riesgoso pero éramos jóvenes y algo inconscientes.

En otra oportunidad nos fuimos a la población de Santa Julia, en Santiago, el primero de mayo de 1978. La idea era hacer un mitin relámpago. Llegamos a un lugar aplaudíamos y tirábamos propaganda para salir corriendo.

Durante muchos meses viví una doble vida. Por la mañana era estudiante de secundaria, sin hablar con nadie. Por la noche me dedicaba a trabajar en mi célula. Con los años fui asumiendo diferentes responsabilidades. Estuve en el Comité Local de Ñuñoa, después en el Comité Regional Cordillera, etc. En 1979 formamos un Centro Cultural (Amistad). La idea era ayudar a los comedores populares, hacer actividades, charlas, etc. También recibí cursos militares, salíamos a la montaña. Pero mi labor fue más de acompañante, como la mayoría de las mujeres.

En 1979 me casé y mi militancia cambió. Quedé embarazada y tuve que cuidar un tiempo de mi hija. Tuve que renunciar a mi militancia. Mi marido militó en el Frente Patriótico Manuel Rodríguez (FPMR) y murió al poco tiempo porque le explotó una bomba al manipularla.

Mi esposo, unos días antes de morir, escribió una carta a nuestra hija como intuyendo que pronto no estaría con nosotras, la he traído: 
-"Querida hija, yo quisiera que cuando estas palabras fuesen comprendidas por ti el mundo haya resuelto sus múltiples ecuaciones. Las últimas décadas han sido sangrientas, guerra tras guerra, han impedido el crecimiento humano. Los días son inmensos...en estos instantes nuestra patria vive bajo una bota militar, tu madre y yo luchamos como parte del pueblo, por la libertad, por un mejor mañana. El camino será duro, como la cara del burgués...mantén con firmeza tus convicciones, siembra en tu caminar amor y cosecha las experiencias que te ofrezca la vida...aprende a convivir con la libertad para que puedas disfrutar de ella, respeta al humilde y a los perseguidos..."

\section{4 ¿Cayó presa en alguna ocasión?}

En 1983, cuando murió Antonio (Toño), me tuvieron detenida durante tres días, estuve en Investigaciones, me hicieron muchos interrogatorios y yo negué mi vinculación con el Frente. Estuve tres días sin comer, pero no me torturaron. Fue muy terrible, tuve que ir a reconocer a mi marido. Afortunadamente me dejaron en libertad. Después fui a la Vicaría de la Solidaridad para prestar testimonio.

En los siguientes meses tuve que rehacer mi vida, fueron tiempos de mucho miedo. Además tuve otra complicación porque al estar fichada por investigaciones tuve dificultades para encontrar trabajo. Afortunadamente, pasé a ser funcionaria del partido y recibía una plata para poder vivir.

\section{5 ¿Creé que hubo una represión específica hacia las mujeres presas políticas del Partido Comunista?}

Mira, la tortura sexual fue una realidad. A mi hermana la detuvieron y llegó muy mal a la casa. Durante un tiempo no podía ni reconocer a su propia familia. Recuerdo su cara cuando llegó, estaba completamente pálida. Fue muy terrible superar el terror y encontrar nuevas fuerzas para vivir.

\section{6 ¿En qué consistió su militancia en los siguientes años?}

En 1984 me quedé viuda y estuve dos años con mi pena, con mi duelo. Después me volví a casar y seguí activa, siendo funcionaria del partido. En 1986 pasé a formar parte del PC, antes había estado en la Jota. 

en el Partido Comunista?

Sí existió el machismo en el partido. Muchas compañeras no pudieron militar por la oposición de sus maridos. Aunque también quiero decir que el partido siempre me ha dado estímulos para seguir trabajando. Creo que el machismo que hubo fue más una cuestión cultural de toda la sociedad que también se reproducía en el ámbito de la política.

Me sentí un poco discriminada cuando enviaron a mi marido a estudiar fuera y yo me quedé cuidado de mi hija. Incluso hoy en día es más difícil que una compañera se destaque en el partido, excepto el caso de Gladis Marín. 
34 Entrevista realizada a TATIANA ROJAS ORELLANA, 3 de marzo de 2005, Santiago de Chile. Rojas es militante del Partido Comunista desde 1969. Fue dirigente estudiantil en la Universidad Técnica de Santiago y estuvo exiliada en Ecuador. Actualmente es secretaria de género y de las minorías sexuales del PC.

\section{1 ¿Cómo fueron sus inicios en el Partido Comunista?}

Entré a las Juventudes Comunistas en 1969 porque mi familia era del PC, para mí fue lo normal. En el tiempo de la Unidad Popular fui dirigente estudiantil y secretaria de mi célula. Mis tareas principales fueron trabajo voluntario con pobladores y trabajadores.

2 ¿En qué situación (presencia, participación política, etc.) estaba la mujer militante del Partido Comunista en los años de la UP?

Las mujeres hacíamos aparentemente de todo. Pero en general los cuadros superiores eran ocupados por varones. Había pocas compañeras en cargos de dirección, tanto en el regional como en el central; Incluso en los equipos de autodefensa nosotras estábamos siempre atrás, en un segundo plano.

En las cuarenta medidas de la UP hubo proyectos referentes a mejorar la situación de la mujer que hoy día se está recuperando. Por ejemplo, desligar a la mujer del trabajo doméstico para facilitar su inserción en el ámbito laboral.

Mireya Balta, ministra del trabajo en aquella época, impulsó leyes que directamente favorecían a la mujer, auque siempre relacionándolo con la familia, como los jardines infantiles, la subvenciones a la jubilación de las dueñas de casa, etc.

\section{3 ¿En qué circunstancias estuvo el 11 de septiembre de 1973?}

El 11 de septiembre estaba en la Universidad Técnica de Santiago. Nos detuvieron y a las mujeres nos soltaron al día siguiente. Durante los dos primeros años en clandestinidad nuestra labor fue rearticular y mantener activa la organización. 
Yo estuve un año en el exilio, en Ecuador ( partió en 1976). Prácticamente, toda mi familia cayó presa. Nunca me adapté y volví en 1978 para pasar al trabajo clandestino. En 1980 pasé a militar al partido, en ese año el movimiento estudiantil empezó a ser muy fuerte. Trabajamos muy ligados a lo que fue la Coordinadora Nacional Sindical apoyando también las agrupaciones de detenidos-desaparecidos.

\section{4 ¿Creé que hubo una represión específica hacia las mujeres presas políticas en los años de dictadura? ¿Podríamos decir también que hubo un trato diferente a las mujeres según su clase y condición socioeconómica?}

Yo cuento con la experiencia de mi familia que estuvo presa. En el momento de la tortura creo que se fue más allá de las clases. Hay una mezcla de cosas. Cuando visitábamos las cárceles, cuanto una mejor vestida estuviera, mejor la trabajaban. Los militares tenían también muy asumido el tema de las clases y los rangos. El hecho de ser mujer también les ponía a los torturadores en una situación más cómoda puesto que la mujer tenía una vulnerabilidad en ciertos aspectos más aguda.

Tengo opiniones encontradas con respecto a la tortura sexual. También hubo compañeros que sufrieron este tipo de represión. Es cierto que la mujer era más vulnerable a sufrir la tortura sexual pero en ocasiones se iba más allá de la cuestión de género, es decir, de humillar al preso o la presa utilizando todos los medios de represión disponibles. También los compañeros han hablado menos que las mujeres sobre esta cuestión.

5 ¿Qué opinión le merece el tema de las mujeres presas que se quebraron en la tortura?

Nada justifica la colaboración con la represión. Sin embargo, creo que hay que estar en el momento de la tortura para tener todos los elementos de juicio. Yo no podría acusar a ninguna compañera que habló en la tortura, además, aquí también entra la cuestión de género ya que con ellas se dio una tortura bien diferente. Nosotras no estábamos preparadas para la tortura y situaciones límite. 


\section{6 ¿Las mujeres madres militantes en el PC tuvieron una doble carga a la hora de desempeñar el trabajo político?}

Mira, esto sigue pasando hoy en día, tal vez con menos frecuencia pero es una realidad. Los compañeros que vienen a las reuniones con sus hijos casi se les ven como mártires a diferencia de las compañeras que cuando acuden con sus cabros parece que vinieran sólo a molestar. Esto sigue pasando todavía. Sigue siendo muy difícil la militancia para las mujeres con hijos, sobre todo para las mujeres dirigentes. De hecho, sigue existiendo un abandono de la participación política de la mujer en aras del cuidado de sus hijos. Es una deuda que la izquierda tiene con las mujeres.

Yo fui muy criticada precisamente por esto. A nadie le importara que fuera una buena dirigente pero mis compañeros me veían como una mala madre porque no me ocupaba "los suficiente" de mis hijos. Llevaba a mis hijos a las reuniones y ellos me decían que les ponía en riesgo. Yo he sufrido discriminación en el partido, aunque haya tenido oportunidades de acceder a la militancia, pero precisamente por esta doble carga que yo tenía.

Trabajé en un comunal de la zona sur de santiago. Después fui parte del regional de la zona sur en los cordones industriales. También trabajé con el frente de profesionales (Comisión Nacional de los Colegios Profesionales). Los arquitectos, médicos, etc. eran varones mientras las ramas auxiliares como enfermería o asistente social eran copadas por las mujeres.

En estas tareas tuve un conflicto por el hecho de ser mujer. No era lo mismo ser una mujer blanca y profesional que una mujer morena, pobladora y mucho menos mapuche. Yo sufrí por mi procedencia social.

Hubo mujeres que pudieron estudiar en el exilio y pudieron cambiar el modelo tradicional, pero eso fue una minoría. Casi todas las compañeras tendían a reproducir el rol de siempre. A esto se añadía el tema de clase, es decir, las mujeres que llegaron con conocimiento feminista a las organizaciones tuvieron más posibilidades a la hora de desenvolverse que otras compañeras de procedencia social baja y sin estudios. El 
machismo junto al clasismo fueron las principales dificultades que tuvimos para abrirnos paso en todos los frentes.

En el comité regional en donde yo milité el cincuenta por ciento eran mujeres, ahora bien, habíamos pocas secretarias políticas. En los comunales la presencia femenina incluso era mayor. La mayoría de los dirigentes eran varones en los comités regionales y en central.

\section{7 ¿El Partido Comunista ha reconocido suficientemente la aportación de sus mujeres militantes en tiempos de dictadura?}

El partido en lo formal sí que ha reconocido el papel de la mujer en la lucha contra la dictadura pero siempre en su papel en la retaguardia del hombre. Se ha hablado mucho de las ollas comunes y del apoyo a los compañeros pero sigue habiendo una necesidad de demostrar las capacidades tradiciones de las mujeres. La izquierda suele movilizarse mucho el ocho de marzo pero es un trabajo muy coyuntural porque luego se pasa rápidamente al olvido.

En mi caso creo que se me ha visto como una militante conflictiva. Cualquier varón que tenga una personalidad como la mía, es decir, más reivindicativa se le ve cómo alguien brillante mientras que a nosotras se nos ha visto como neuróticas, histéricas o cualquier cosa.

Ahora bien, también hay que reconocer que el partido ha creado un espacio para las minorías sexuales. El Partido Comunista es la primera organización política que ha creado una Comisión Nacional de Minorías Sexuales. Aunque me gustaría que el proceso de género fuera más rápido de lo que es. Hay todavía que profundizar el cambio cultural en la cuestión de género.

8 ¿Qué opinión tiene sobre la organización de las presas políticas al interior de las cárceles? ¿Creé que se superaron con mayor facilidad las diferencias ideológicas con respecto a los varones? 
Creo que los hombres tuvieron más dificultades a la hora de organizarse al interior de las cárceles. Tuve la oportunidad de ver esto en mis visitas a los diferentes centros de reclusión. Esto se dio porque las mujeres que estuvieron recluidas no ocupaban cargos importantes de poder en los respectivos partidos.

Hubo una organización entre las mujeres mucho más fluida, sobre todo con el tema del cuidado de los hijos. Había menos conflictos porque nosotras no estábamos en el poder político. Los hombres reproducían y arrastraban sus discusiones de poder en la cárcel. 
35 Entrevista realizada a MARÍA PETRONILA GÓMEZ TAPIA, 10 de marzo de 2005, Santiago de Chile. Tapia es militante del Partido Comunista desde 1969. Fue dirigente estudiantil en la Universidad Técnica del Estado y miembro del Comité Ejecutivo de las Juventudes Comunistas. Asimismo, estuvo detenida en el Estadio Chile para pasar posteriormente al trabajo clandestino.

\section{1 ¿Cómo fueron sus inicios en el Partido Comunista?}

Mi padre y mi madre aunque no tuvieron una militancia orgánica dentro del PC, fueron personas que siempre estuvieron en contacto con gente del partido, ayudando y participando. Desde muy joven leía el diario El Siglo.

Desde temprana edad, quise conocer a la Juventud Comunista. Fui a un local del partido y me inscribí como militante comunista en 1969. En ese momento yo estudiaba en el Liceo y junto con mis hermanas nos integramos en el grupo comunista. Las tareas eran distribución y venta del diario, repartir propaganda y rallados. También participé en diversas concentraciones del partido en época de elecciones.

Posteriormente, ingresé a la Universidad Técnica de Santiago, allí estudié Castellano. Mis tareas se centraron en la campaña de Allende. Asistí a algunas charlas sobre el programa de la UP, fue un proceso de aprendizaje.

En la universidad técnica me tocó asumir la tarea de encargada de trabajo voluntario. Nosotras trabajábamos con los pobladores, en las tomas de terreno, distribución de la alimentación (abastecimiento). En la universidad hubo una actividad muy intensa, desde allí partíamos a las poblaciones. En 1972 viajé por un año a la Unión Soviética a la escuela del KOMSOMOL y regresé a Chile a principios del 73 para incorporarme de nuevo la política y al movimiento estudiantil.

\section{2 ¿En qué situación (presencia, participación política, etc.) estaba la mujer militante del Partido Comunista en los años de la UP?}

En ese tiempo no viví ningún tipo de discriminación en el partido por mi condición de mujer. De hecho, en el partido había una inquietud por impulsar la presencia de la mujer en las tareas partidarias. La participación de la mujer comunista en la universidad fue muy importante, ellas se jugaban el pellejo de la misma manera que los compañeros. 


\section{3 ¿En qué situación estuvo el 11 de septiembre de 1973?}

Ese día lo pasé en la Universidad Técnica. Como dirigente estudiantil yo tenía que estar de las primeras para dirigir las posibles movilizaciones. Llegué allí a las siete de la mañana. Vinieron muchos estudiantes militantes del PC y el PS. Esperamos allí durante varias horas esperando a que se organizara un ejército constitucionalista que defendiera el gobierno. Nos quedamos hasta la noche.

Después fue imposible salir, nos rodearon y nos dispararon. Al amanecer nos detuvieron y nos llevaron primero al Ministerio de Defensa y después al Estadio Chile. Recuerdo que uno de los dirigentes fue detenido y asesinado.

En el Estadio Chile (Estadio Víctor Jara) separaron a las mujeres de los hombres. Ahí nos identificaron, nos golpearon...Al paso de las horas empezó a llegar mucha más gente y a un grupo de mujeres y a mi nos dejaron en la calle en la hora de toque de queda.

Yo decidí caminar hasta mi casa, en la comuna de Maipú. Me desvinculé de la organización durante un tiempo para luego reencontrarnos con un grupo de compañeros a finales del 73. Ahí pase al trabajo clandestino.

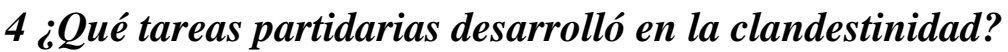

Yo desarrollé un trabajo de tipo gremial ayudando a los detenidos y manteniendo la lucha desde la universidad. Armamos un grupo con estudiantes que habían sido expulsados. Este trabajo lo desempeñé hasta 1976. Muchos de estos compañeros fueron detenidos y hoy en día están desaparecidos.

Yo estudiaba Pedagogía. Nos allanaron la casa. Yo salía muy temprano de mi casa y me hacía toda una rutina de trabajo. Me juntaba con los estudiantes.

En 1976 caí enferma, tuve una peritonitis muy grabe. Estuve hospitalizada durante seis meses, en ese periodo cayeron muchos compañeros. Cuando me recuperé volví a incorporarme al trabajo clandestino, desde junio de 1976 hasta 1978 momento en el que entré formalmente al Partido Comunista. Mis tareas fueron sobre todo de enlace y trabajo como encargada de un Comité Regional. Yo era parte de la dirección y desde ahí 
atendíamos a las células para la organización de actividades desde la clandestinidad. Utilizábamos nombres falsos porque sabíamos que nos andaban buscando.

Afortunadamente no me detuvieron. Siempre seguí trabajando y llegué a formar parte de la Comisión Ejecutiva de las Juventudes Comunistas. Me juntaba con gente de muy alta jerarquía del partido. Nunca volvía a los lugares en donde había estado. Era muy cuidadosa.

\section{5 ¿Cree usted que las presas política sufrieron una represión específica?}

Indudablemente. La DINA estudió muy bien el perfil de la mujer militante. Se trabajó mucho para diseñar un tipo de tortura que fuera demoledora para la mujer. Fue una tortura específica, no sólo dirigido a la cosa física, sino también a sus hijos, a la familia.

La represión afectó a todos los ámbitos de la mujer. Yo tengo una compañera comunista que cayó presa y entregó algunos nombres, pero el mío nunca lo entregó. Vivió experiencias de tortura terribles.

Hubo un claro desarrollo de la represión hacia las mujeres. Sabían perfectamente como torturarlas para que hablaran. Conozco a muchas compañeras que fueron violadas y sometidas a todo tipo de vejámenes.

Yo no tengo hijos a raíz de mi enfermedad pero vi a muchas compañeras que tenían ese drama. La mayoría de mis amigas trataron de conciliar las dos cosas, no se separaron de sus hijos y siguieron militando en clandestinidad asumiendo el riesgo que eso suponía.

\section{6 ¿El Partido Comunista ha reconocido formalmente esta represión específica de sus militantes femeninas?}

En términos teóricos sí. Pero no se ha recogido la experiencia de las vivencias de las mujeres y la aportación de las compañeras. Falta una valoración más práctica de lo que muchas mujeres sufrieron y vivieron en dictadura. queda mucho por hacer.

\section{7 ¿Qué tareas partidarias desarrolló en los años ochenta?}

Estuve un tiempo en Concepción desarrollando las mismas tareas. A mediados de 1985 me tuve que desvincular porque empecé a centrarme a mi actividad profesional. A mi 
me habían expulsado de la universidad pero nunca perdí la idea de terminar mis estudios.

Finalmente, obtuve mi título de profesora en otra universidad. Trabajé en un colegio y allí formé un sindicato de profesores durante varios años. Fue una situación muy difícil porque a muchos compañeros les echaron.

Estuve también vinculada a la Agrupación de detenidos-desaparecidos. Yo realicé un trabajo de orientación con ellos. Después, vino toda la campaña por el No en el plebiscito del 88. Trabajé en las mesas electorales.

\section{8 ¿Qué elementos positivos y negativos destacaría de su militancia política dentro del Partido Comunista?}

En el periodo de la clandestinidad el partido se cerró bastante. A pesar de que muchas mujeres trabajaron muy duro y aportaron a la lucha de la democracia, posteriormente la presencia de la mujer empezó a disminuir.

También hay un cierto machismo todavía, dado que las posibilidades para las mujeres son menores que las de los hombres. Esto hace que su papel sea secundario y creo que el partido debería abrirse más puesto que la mujer se ha ganado el derecho ha estar en todas partes. Hay una gran deuda con las mujeres comunistas. En la Comisión Política sólo ha estado Gladis Marín y hay un claro déficit de representación. No es posible que solo una mujer haya tenido representación en el órgano de decisión más importante del partido. 
36 Entrevista realizada a ELENA ROJAS ARAYA, 11 de marzo, 2005, Santiago de Chile. Rojas fue miembro de la Comisión Nacional de organización del Partido Comunista y asumió diferentes cargos partidarios en la clandestinidad. Asimismo, participó activamente en la Agrupación de Familiares de Presos Políticos (AFPP, 1974).

\section{1 ¿Cómo fueron sus inicios en el Partido Comunista?}

Quiero señalar que yo nací en un hogar comunista, mi padre era dirigente del salitre y mi madre era militante del partido. Fue la primera mujer que estuvo en el campo de concentración de Pisagua, durante la dictadura de González Videla, con la ley Maldita. También fue dirigente del salitre.

Mi madre, mi padre, yo y mi hermano estuvimos en ese campo de concentración. Fueron momentos muy duros sobre todo para mi familia. Yo tenía seis años y mi hermano siete; vivimos nuestros primeros años de enseñanza básica. En el campo de concentración había más de cincuenta maestros comunistas, artistas, etc.

En ese tiempo, la vida partidaria fue muy fuerte, se montó una escuela de cuadros muy importante en donde estaba Víctor Díaz, hoy detenido desparecido, el compañero Godoy y toda una serie de artistas e intelectuales.

Estos fueron mis inicios. En 1949, después de esta experiencia en el campo de concentración, regresamos a Santiago. Mi padre se incorporó a la imprenta clandestina del Partido Comunista que se llamaba Lautaro. Allí se editó un diario llamado Democracia en reemplazo del diario El Siglo que no se podía distribuir.

Mi padre se dedicó de lleno a la vida de la imprenta y mi madre se dedicó a las tareas del hogar y a nuestra educación. Mi padre fue, con el tiempo, uno de los precursores de la toma de terreno de la Victoria. Desde esa toma, vivimos allí hasta que llegó la dictadura de Pinochet. 
Allí éramos todos dirigentes del PC en la victoria, yo fui secretaria del Comité Local y mi padre era dirigente poblacional. La propia dirección del partido dictaminó que abandonáramos la casa y pasáramos a la clandestinidad.

Inmediatamente después del golpe salimos de la Victoria, junto con otros treinta compañeros responsables de la dirección regional de San Miguel. Fue allí donde me formé como dirigente del partido junto Gualdo Pizarro (hoy detenido-desaparecido), Víctor Cantero, etc.

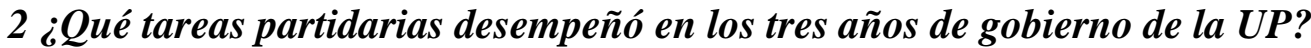

En el comité regional de San Miguel mi responsabilidad era ser encargada del trabajo con las mujeres, éramos una gran comisión encargada del trabajo femenino (Liliam, María Pardos, Sunilda Contreras, Yolanda Bésolo, etc.). Con nuestro trabajo nos habíamos ganado la presidencia de la Unión Comunal del Centro de Madres (con la compañera Beatriz Cepeda a la cabeza).

Las tareas fueron muy variadas. Trabajamos mucho en la construcción de las JAP (Junta de Abastecimiento y Precios) y contra el acaparamiento y el mercado negro. Aprendí muchas cosas, la fraternidad, el trabajo en equipo, etc. En XIV congreso del partido fuimos nombrados miembros del Comité Regional de San Miguel y allí estuvimos hasta 1973.

En nuestra dirección regional el grado de entrega fue muy grande. En Madeco, una de las industrias más importantes del cobre, estaba en manos de cuadros obreros. Yo viví todo ese proceso.

\section{3 ¿En qué situación (presencia, participación política, etc.) estaba la mujer militante} del Partido Comunista en los años de la UP?

Las mujeres tuvieron una participación fundamental. Por darte un ejemplo, recuerdo el ocho de marzo de 1972 cuando las compañeras comunistas tratamos de reunir a muchas mujeres para que superaran el tema del desabastecimiento. La derecha puso en marcha toda una propaganda para que los chilenos no consumieran productos procedentes de la solidaridad internacional (Rusia, China, Cuba, etc.). 
Estos productos solían estar envasados, uno de los más conocidos fue el Chancho Ching, eran de muy buena calidad. Muchas mujeres, influidas por estas campañas, no consumían estos productos y nuestra tarea consistió en convencerlas de que se trataba de comida en buenas condiciones.

También el trabajo de las mujeres comunistas en las JAP fue fundamental. Ellas dirigieron muchas campañas de educación y estrategias para superar el desabastecimiento. Educar, convencer e informar a las mujeres más desfavorecidas fue nuestra principal responsabilidad.

\section{4 ¿En qué situación estuvo el 11 de septiembre de 1973?}

Yo vivía en la Victoria, en la calle Galo González. Por aquellos días nuestra jornada era muy dura. A las siete de la mañana del 11 de septiembre un compañero golpeó nuestra puerta, era un trabajador encargado de distribuir el diario del partido y nos informó de que había golpe.

Nosotros estábamos preparados para luchar contra la burguesía, pero no contra un ejército. No estábamos preparados. En esa mañana yo tenía una reunión en Teatinos 416, con la Comisión Nacional Femenina. Llegué hasta la Alameda con Teatinos. No pude pasar y tuve que devolverme al Comité Regional que tenía dos locales, uno en el paradero 9 de la Gran Avenida y otro en el paradero 3.

En el local del paradero $\mathrm{n}^{\text {o }} 9$ llegó uno de nuestros senadores (Araneda) y otros compañeros de la dirección como Inés Cornejo. Éramos como 35 dirigentes en este local. En ese momento aparecieron doce militares armados y allanaron nuestro local. Buscaban armas. Lo único que encontraron fueron unos palos y un linchaco. Destrozaron todo el local, con todos los papeles y documentación de nuestro ordenamiento orgánico.

El plan era que si el golpe llegaba, la dirección del partido se separaría en equipos más pequeños. Cada uno de ellos tenía sus casas de seguridad para desempeñar su trabajo. A mi me tocó juntarme con el compañero Araneda, Vega y otros dos compañeros. Estuvimos en una casa del sector sur. Nuestra labor consistió en convencer a otros 
compañeros en abandonar las fábricas tomadas porque sabíamos que se iba a producir una sangría, el lema era abandonar las industrias y resguardarse, especialmente los dirigentes sindicales y sociales más relevantes.

\section{5 ¿Cómo fueron sus años en el trabajo clandestino?}

Fueron muy difíciles. Recuerdo que el compañero Víctor Díaz me llamó para entregarme la tarea de ser la encargada nacional femenina porque la compañera Inés Cornejo tenía que partir al exilio. Los cuadros menos conocidos debimos asumir las responsabilidades de los dirigentes más importantes. Tuvimos que aprender sobre el camino.

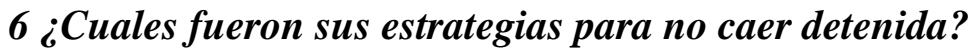

Puntualidad, fundamentalmente. Fui muy rigurosa al acudir a un punto de encuentro. Siempre traté de sintetizar al máximo los documentos. Tuvimos una red de apoyo no sólo de militantes comunistas sino de otros compañeros sin una militancia política. Había casas para guardar documentos y otras para alojar a los compañeros.

\section{7 ¿Tuvo que renunciar a su militancia en aras del cuidado de sus hijos o viceversa?}

Para cualquier mujer comunista ha sido muy difícil educar a nuestros hijos y formarlos en tiempos de represión. Yo tuve la suerte de haber tenido unos suegros y padres que me ayudaron mucho en este sentido. Sin embargo, mi hijo sí que me ha recriminado que durante un largo período lo dejé solo por mi implicación en la política. Sólo con el tiempo fueron dándose cuenta de las razones por las cuales yo tuve que perderme algunos momentos de su vida.

\section{$8_{¿}$ Cómo continuaron sus años en la militancia dentro del PC?}

Tuve la suerte de trabajar con mis compañeros Víctor Díaz y Zamorano con los que aprendí mucho. A finales de los setenta el partido realizaba cambios constantes en las tareas partidarias. Me nombraron secretaria del Comité Regional de Santiago y de Provincia (San Felipe). También fui miembro de la Comisión Nacional de 
Organización. Durante los años ochenta trabajé con la denuncia de la represión viajando a lo largo del país.

9 ¿Qué opina sobre la labor de las mujeres presas en el interior de las cárceles? ¿Se superaron las diferencias ideológicas a la hora de organizarse?

La dirección del partido en un momento me dio la responsabilidad de dirigir el Comité Local de los Derechos Humanos por la cantidad de presos comunistas que había en Santiago. De esta experiencia te puedo decir lo siguiente. Nosotros llegamos a tener 14 células del partido al interior de la cárcel que convivían perfectamente con militantes del MIR, del FPMR, etc. Tanto hombres como mujeres supieron organizarse, no sin dificultades, con el resto de los presos políticos.

En el caso de las mujeres yo visité la cárcel de Santo Domingo en muchas ocasiones. En una oportunidad dio a luz una compañera en el interior de la prisión. Ellas ganaron un espacio para que se sacara a la mujer de la cárcel hasta que se recuperara. Aquí sí que pudo haber un elemento diferenciador ya que muchas compañeras de otros partidos se hicieron cargo del cuidado del bebé, como si fuera suyo, independientemente de que tuvieran una militancia política distinta.

\section{0 ¿Creé que hubo una represión específica hacia las mujeres presas políticas?}

Debo decir terminantemente que en este país se usaron las técnicas de tortura más terribles contra la mujer de una forma sistemática. Se violaron mujeres con perros, se le metían ratas en la vagina y ninguna mujer podía salir de la cárcel como una mujer normal después de sufrir estas vejaciones.

¿Qué pasó con Águeda Jara, amiga mía, que vivió conmigo?, una mujer muy joven que cayó en el 73 a raíz de la caída del compañero Monte. Ella fue vejada, violada, por Gabriel Mena y doce bestias más. De esa vejación nació un hijo y de ella no se supo

nada más. Águeda fue una mujer que cuando cayó presa no había tenido relación alguna con un hombre. (Se interrumpe la transcripción de la entrevista a petición de la entrevistada). Se usaron todo tipo de torturas, vejámenes no sólo físicos hacia el cuerpo de la mujer, también psicológicos que nos ha dejado marcadas para el resto de nuestra vida. 


\section{1 ¿Qué opinión tiene sobre aquellas presas que se quebraron en la tortura y pasaron}

a ser colaboradoras de la DINA o la CNI?

Yo no las condeno a priori. Creo que hay mujeres que tuvieron más fortaleza que otras. Cuando a una la extorsionan con su hijo es muy difícil no quebrarse. Por otra parte, cuando tu te comprometes con una lucha hay que asumir ciertas cosas, pero también es cierto que flaquear con la tortura es algo muy humano. ¿Por qué unas compañeras hablaron y otras no?. Los casos de la Flaca y Luz Arce son muy conocidos pero creo que fueron la excepción porque la mayoría de las compañeras supieron aguantar sin dar ni un ápice de información.

\section{2 ¿Tuvo alguna participación en las agrupaciones de DDHH?}

Colaboré con muchas. Cuando se producía la caída de algún compañero o de alguna célula o grupo de dirección en la región de Santiago, había que tomar medidas rápidamente en la V región y en la VIII región. Esto era para que no se produjera el efecto dominó y cayeran más compañeros.

Cuando caían compañeros teníamos que cerrar filas. A mi me persiguieron hasta nueve miembros de la CNI. Gracias a los compañeros de la Jota (Juventudes Comunistas) puede evitar caer presa. Ellos me dejaron en manos de unos personeros de la iglesia. Con ellos viví tres meses. Durante ese tiempo no puede hablar con nadie. Mi mayor preocupación fue por mi hijo porque estaba participando en una huelga de hambre en la UTEM.

Después de este tiempo asumí tareas de DDHH. Trabajé con la Agrupación de Presos Políticos. Entraba mucho a las cárceles para ver en qué condiciones estaban los presos, recibíamos y administrábamos el apoyo de la Solidaridad Internacional, alimentos, ropa, etc.; organizábamos diversas actividades culturales y de apoyo a los compañeros y compañeras presos.

13 ¿Por qué la mujer fue punta de lanza en la organización de agrupaciones de DDHH? 
Por una sensibilidad especial. Madres, esposas, hermanas de detenidos, presos políticos, etc., supieron organizarse de una manera admirable. Las mujeres organizaron la Agrupación de Detenidos-Desaparecidos, la Agrupación de Presos Políticos, la Agrupación de Retornados, etc. En estas agrupaciones coexistían militantes del MIR, del PS, del PC y otras muchas mujeres sin militancia partidaria.

Las violaciones a los DDHH fueron contestadas por estas mujeres. Se dio una unidad muy fuerte entre ellas, sobre las diferencias políticas que pudieran haber, se supo poner en marcha toda una lucha destinada a liberar a los presos y a las compañeras, a exigir verdad y justicia.

\section{4 ¿Cuál ha sido la aportación de la mujer en el Partido Comunista en tiempos de dictadura?}

Creo que el partido, a diferencia de otras fuerzas políticas, ha incorporado en sus debates internos y de dirección un importante porcentaje de representación de las mujeres. Gladis Marín ha sido un claro ejemplo de cómo las mujeres han tenido cabida en el PC. Las mujeres comunistas hemos estado, por lo general, muy integradas en las mesas de diálogo del partido. Las mujeres han tenido una gran participación en la organización.

Ahora bien, es cierto que el partido no ha estado ajeno a las mentalidades machistas de la sociedad, de hecho, nosotras también hemos reproducido los roles tradicionales de la mujer. Sin embargo, las mujeres comunistas nos hemos ganado nuestro espacio en el partido. 
37 Entrevista realizada a NINA SALINAS, 11 de marzo de 2005, Santiago de Chile. Salinas es militante del Partido Comunista desde 1975 y fue miembro del Frente Patriótico Manuel Rodríguez (FPMR). Actualmente forma parte de la Comisión FUNA.

\section{1 ¿Cómo fueron sus inicios en el Partido Comunista?}

Mi padre fue militante del Partido Comunista aunque el venía de una familia de derechas. Mis inicios en la política no fueron en el PC. Mi primera militancia fue en las Juventud Demócrata-cristiana. A partir de 1973 empecé a participar en un grupo juvenil católico, muy reprimido posteriormente. Incluso algunos compañeros están detenidosdesaparecidos.

En 1975, con quince años participé activamente en el centro de alumnos del Liceo. Tuve que tener mucho cuidado porque en la directiva de alumnos desapareció gente. Incluso había profesores que eran agentes de seguridad de la DINA y de la CNI.

A los dieciocho año, en 1979, me casé y tuve dos hijos. Me dediqué a criarlos y durante tres años dejé de lado mi militancia y mis estudios. Luego estudié enfermería y me egresé.

En mayo de 1983 entré formalmente a militar en el Partido Comunista sin pasar antes por la Jota. Mi padre siguió militando en el partido y nuestro hogar se convirtió en una casa de seguridad para los compañeros.

Trabajé con el FPMR (Frente Patriótico Manuel Rodríguez) en un equipo sanitario. Fueron años muy duros. También realicé labores de enlace y aunque tuve formación militar (tuve conocimiento en explosivos) nunca llegué a desempeñar tareas de ésta índole. 


\section{2 ¿Qué tipo de trabajo clandestino realizó en el PC?}

Fue una militancia de mucho riesgo. Concretamente teníamos que estar cambiando de casa, nombre y apariencia. Hice labores de propaganda, enlace y sobre todo apoyo médico a los compañeros del Frente a partir de 1983.

Fui ayudista, nunca combatiente. Sin embargo, esta tarea me absorbió mucho, dejé gran parte de mi juventud en la militancia. El sesenta por ciento de los compañeros que conocí o están muertos, exiliados o son desparecidos.

3 ¿Cómo recuerda la presencia y la participación de la mujer en el Frente Patriótico Manuel Rodríguez?

Importantísima. Las compañeras generalmente organizaban las casas de seguridad. También todo lo que fue las visitas a las cárceles cuando algún compañero caía. Las mujeres fueron las primeras en organizar una manifestación por los detenidosdesaparecidos.

En el Frente, mis compañeras desempeñaron todo tipo de tareas: casa buzón, casa de seguridad, combatiente, parte sanitaria, ayudista, entre otras labores. Teníamos las mismas responsabilidades que los hombres.

En esos tiempos de clandestinidad nosotros vivíamos al límite. Cuando llegaba un compañero tenía todo servido, no sólo la comida, también en la cama. Nosotras de cierto modo nos entregamos a ellos, fue algo muy común, no sabíamos si al día siguiente íbamos a estar vivos.

La consecuencia de esto es que muchos compañeros sembraron muchos hijos. Algunos militantes que murieron tuvieron varias viudas con hijos de un mismo hombre. Esta realidad solo la pueden entender aquellas personas que vivieron esos días. Las mujeres en cierto modo fuimos un bálsamo para los hombres, curábamos sus heridas, les dábamos de comer, cariño, todo. 


\section{4 ¿Cayó detenida en algún momento?}

Sí. Estuve alrededor de treinta y seis veces detenida. La mayoría de las veces por desordenes o disturbios. También por llevar propaganda o documentación. A mi me torturaron, me dieron muchos golpes, no quizá como a otros compañeros, pero que me marcó mucho.

\section{5 ¿En qué medida afectó su maternidad a su militancia política o viceversa?}

No hay términos medios. Las compañeras del PC que fueron madres en aquella época o se hacían cargo de sus hijos o los "abandonaban" por la lucha. Personalmente, abandoné a mis dos hijos, a mi me pesa mucho esto pero ellos con el paso del tiempo han logrado comprender que esto fue algo necesario, que yo estaba muy convencida de que nadie podía desempeñar las tareas que tenía que hacer.

Esto fue la parte más terrible de mi vida. La casa de mi papá cayó, la allanaron. Lo que más me pesa es que en algunas ocasiones mi familia, mis hijos corrieron peligro por mi militancia.

\section{6 ¿Creé que hubo una represión específica hacia las mujeres presas políticas del} Partido Comunista?

En Chile hubo un genocidio contra todo aquel que estuviera en contra de la dictadura. Las mujeres sufrimos una parte de esta represión. El Guatón Romo (Osvaldo Romo, conocido torturador del Centro de Tortura Villa Grimaldi y miembro de la Dirección de Inteligencia Nacional, DINA), en reiteradas ocasiones ha dicho: -con las mujeres no podemos, ellas tienen los hijos y ellas resisten más el dolor, es más difícil que ellas hablen como los hombres-; esta frase se me quedó grabada en la cabeza.

Creo que las mujeres resistimos mucho. Pero la represión fue por igual. Fue una represión dirigida a la clase trabajadora. Creo que para nosotras fue más difícil, tuvimos que ser militantes, trabajadoras y madres. 
Conozco muchas compañeras que tuvieron a sus hijos en las cárceles, también a otras que fueron violadas y quedaron embarazadas, desaparecidas con sus bebés en sus vientres. Para mí es difícil ahondar más en este tema...porque a mi también me duele...no se si lo puedes entender.

\section{7 ¿Qué opina de las mujeres que se quebraron en la tortura y pasaron a colaborar estrechamente con la DINA y la CNI como el caso de Luz Arce y la Flaca Alejandra?}

Los seres humanos somos complejos. Nadie sabe hasta que límite puede estar su resistencia ante la tortura. El hecho de colaborar es también una forma de sobrevivir, de resistir. Algunas mujeres colaboraron y se convirtieron en funcionarias de los servicios secretos y estuvieron también involucradas en crímenes.

Sin embargo, se hace mucho hincapié en estas mujeres; no se ha hecho un catastro de los hombres que también participaron con la DINA, dieron información, etc. Se conocen estos casos puntuales de mujeres pero creo que hubo muchos hombres en esta situación.

Leí el libro de Luz Arce (Ese Infierno). No solidarizo con ella, no la justifico pero trato de tener una mirada de entendimiento, de comprender por qué terminó siendo colaboradora.

${ }^{¿}$ ¿Qué opina sobre la labor de las mujeres presas en el interior de las cárceles? ¿Se superaron las diferencias ideológicas a la hora de organizarse?

Hubo mucha solidaridad. Las compañeras caían presas y se ponían a trabajar, a redactar documentos, declaraciones, contactos. Yo estuve sólo una semana detenida pero no viví la reclusión como presa política aunque mis compañeras me contaron su trabajo en las cárceles.

Con quién tuve más contacto fue con los presos políticos. Creo que entre ellos hubo mucho compañerismo pero quizá los miristas que yo conocí fueron muy anticomunistas. Por otra parte, con las mujeres que conocí pude ver que este trato fue diferente, creo que 
ellas fueron mucho más cariñosas, hubo más respeto y la parte sentimental superó a las diferencias ideológicas.

\section{9 ¿Tuvo alguna vinculación con organizaciones de Derechos Humanos?}

Sí, con la Agrupación de Familiares de Presos Políticos. Conocí a los compañeros que escaparon por el túnel de la cárcel Pública. El partido colaboró mucho con las distintas agrupaciones de DDHH.

Quiero hacer una matización de género. Nosotras tenemos la experiencia de que cuando caía un compañero había muchas mujeres alrededor: sus hijas, sus hermanas, las madres, etc. En cambio, cuando caía una mujer nadie la iba a ver porque el trabajo de ayudista o de casa buzón no era considerado fundamental.

Esta realidad la viví yo. Hubo mucho machismo en este sentido, también entre nosotras, porque nos había educado así, para estar en todo momento con los compañeros caídos o detenidos. Las mujeres han dado un gran ejemplo de lucha en tiempo de dictadura, no solo en los partidos, también en las agrupaciones de DDHH.

\section{0 ¿Sintió algún tipo de discriminación a la hora de desempeñar las tareas partidarias en el Partido Comunista?}

Bueno, hay que distinguir dos etapas. En la clandestinidad todos desempeñamos labores parecidas. Nunca me sentí discriminada. Ahora bien, posteriormente, después del plebiscito y con la llegada de esta democracia sí he sentido discriminación. Pero creo que esto se ha dado en el conjunto de los partidos políticos de la izquierda.

Todavía falta mucha participación de las compañeras en el partido, equiparar la presencia de la mujer en los puestos de direcció. Realmente falta trabajar mucho en este aspecto.

Mira, te voy a dar un detalle, las mujeres que estábamos a cargo de las casas de seguridad siempre terminábamos lavando los platos y haciendo el aseo. Esa falta de 
equidad después de nuestra aportación en el partido hay que corregirla porque todavía hoy se repiten muchos de estos esquemas y roles.

Hay muchas mujeres que hipotecaron su vida al partido y a la lucha política y, esto hoy por hoy, no se ha reconocido lo suficiente. Para mi fue muy difícil criar a mis hijos, trabajar y ser militante. 
38 Entrevista realizada a CLAUDINA GARCÍA SANTANA, 14 de marzo de 2005, Santiago de Chile. García es militante del Partido Comunista desde 1956. Fue miembro del Comité Central desde 1975 hasta 1990 y desempeñó importantes responsabilidades en la Coordinadora Nacional Sindical y en la Central Unitaria de Trabajadores.

\section{1 ¿Cómo fueron sus inicios en el Partido Comunista?}

Yo soy del norte, de Tocopilla. Con quince años entré a las Juventudes Comunistas; en el norte los jóvenes se involucraron mucho en la política. Yo no pude terminar mis estudios, llegué hasta cuarto medio porque en mi casa sólo pudo estudiar mi hermano por falta de recursos económicos. Tuve que empezar a trabajar muy joven porque mi madre se quedó viuda a los veinticinco años; mi padre era minero y murió de silicosis.

Yo entré a militar en la Jota en 1956. Después conocí a mi compañero, Héctor Cueva, muy conocido en el movimiento sindical. Nos casamos y tuvimos cinco niños pero se nos murió una niña. Pronto nos mudamos a Antofagasta porque las condiciones de vida en Tocopilla eran muy difíciles. Mi marido era dirigente sindical en Pedro Valdivia, en los centros mineros aunque el era natural de Quillota (zona central de Chile).

En Antofagasta continué mi militancia en las juventudes comunistas. Mi educación familiar influyó mucho en mi decisión de continuar militando en la Jota. Mi abuela y mi tío eran militantes del PC. Mi abuelita ya me conversaba que en sus tiempos, Recabarren (fundador del Partido Comunista de Chile) había estado en su casa escondido.

En esa época tuve una amiga que vivía en el local del partido. Siempre iba a escucharla tocar el piano. Comencé a interesarme por el ambiente que se respiraba en el local del partido. Creo que esto fue importante también a la hora de decidirme a militar.

En las Juventudes Comunistas una tenía que hacer méritos para ir adquiriendo mayores tareas de responsabilidad. Recuerdo que eran seis meses de prueba para entrar. En ese período yo trabajé en la base, salía a la calle, vendía el diario El Siglo y participaba en las charlas. En mis primeros tiempos fui tesorera de mi Comité Local. 
En Antofagasta adquirí mayores responsabilidades. En un congreso realizado en 1961 fui designada para participar en el Comité Regional. Esto significó un paso importante en mi militancia. Para ese tiempo yo tenía dos niños con lo que, aún queriendo hacer más actividades como estudiar no pude por la carga tan grande que tenía.

Yo militaba, tenía dos niños y también cuidaba a mi marido. De hecho, tuve muchas dificultades con mi esposo por mi militancia porque él quería que dejara la Jota para cuidar a los hijos; yo me negué siempre.

En 1965 me nombraron secretaria de la juventud en Antofagasta, esto significaba que tenía que viajar a provincias, a los pueblos. Incluso viajé embarazada. De esa forma, sentía que salía de la rutina en la que la mayoría de las mujeres estaban sumidas, es decir, relegadas al hogar, a la casa mientras que el marido salía a trabajar. Siempre me rebelé contra esto. Una vez intenté separarme de mi marido por estas discrepancias.

Con algunas compañeras hablé de estos temas, de estas dificultades. Esto significó que nosotras empezáramos a participar mayormente de grupos de mujeres, centros de amigas las llamábamos, en donde dábamos las herramientas a las compañeras para que se libraran de la esclavitud de sus hogares. Muchas mujeres eran golpeadas, pasaban hambre, etc. Participamos en las Juntas de Vecinos, los Centros de Madres, etc.

En 1968 fui elegida miembro del Comité Central de la Jota. Tuve que viajar a Santiago, tenía veintidós años. Tres años después pasé al partido. A mi marido le nombraron dirigente nacional de la Federación de la Construcción en Santiago. Ambos crecimos juntos en nuestro compromiso político.

Cuando llegué a Santiago mis compañeros me mandaron a trabajar a la población la Victoria. Fue una experiencia muy terrible para mí. Yo en ese momento era muy inocente, era una mujer de campo. Sin embargo, hubo otras cosas positivas puesto que en esa población las tomas de terreno y la actividad política estaba a la orden del día. Asumir el cargo de secretaria del Comité Local de la Victoria fue una tarea bien difícil.

Esto significó ser funcionaria del partido a nivel de organización interna, trabajo en lo sindical, en lo político, en lo poblacional. Después pasé al Comité Regional que 
abarcaba toda la región sur. Casi todos mis compañeros están detenidos-desaparecidos. Fui a trabajar al frente de organización. Allí estuve trabajando cinco años, en los tres de la UP y algún tiempo en dictadura.

Este comité era el más grande de Santiago, constaba de siete comités locales y más de mil células. Había una dirección única designada por el Comité Central. Esto nos permitió tener concejales y diputados.

2 ¿En qué situación (presencia, participación política, etc.) estaba la mujer militante del Partido Comunista en los años de la UP?

Recuerdo que las compañeras dirigentes del PC por lo general eran casadas con miembros del partido que ocupaban importantes puestos de responsabilidad. Esto no las desligaba de sus tareas domésticas y del cuidado de los hijos. Yo tuve muchos desencuentros desagradables con mis compañeros.

Nosotras empezamos a trabajar con otras mujeres de otras formaciones políticas para influir a los diputados para que sacaran leyes que favorecieran a la mujer.

\section{3 ¿En qué circunstancias estuvo el 11 de septiembre de 1973?}

El día anterior nos llamaron desde el Comité Central avisándose que el golpe era inminente. El partido dictaminó que teníamos que ir a los centros de trabajo y orientar a los compañeros. Esto significó que debíamos buscar varios lugares o casas de seguridad para permanecer aproximadamente un mes. Teníamos la idea de que el golpe iba a durar poco, que iba a ser algo transitorio.

Nosotros teníamos una reunión el once de septiembre para analizar la situación. En el recorrido pasé por la industria Sumar, en donde trabajaban cinco mil obreros; estaba rodeada por los militares y sacaron a mucha gente a culatazos en un ambiente muy tenso, disparaban para todos lados. Yo me dirigía a la Legua en donde teníamos la reunión. Allí la organización del partido era más fuerte pero el riesgo era mayor también. 
Anduve toda la noche, incluso fui a la industria Madeco y me encontré con la misma situación. Finalmente, llegué a la reunión. Mi marido salió en el primer bando pero por Antofagasta. Ese día no aparecimos por casa. En la reunión me di cuenta de que no había ninguna clase de organización que hiciera frente a lo que estaba ocurriendo. Me mandaron a una casa de seguridad y antes de llegar pude ver que estaban los milicos. Teníamos un infiltrado en el partido porque algunos compañeros cayeron en esas casas de seguridad.

Esta situación nos obligó a reorganizarnos en pequeños grupos de confianza para evitar caer presos. En los Comités Locales pudimos replegarnos sin tantas dificultades pero en las otras instancias del partido fue mucho más complicado. En los primeros días cayeron muchos compañeros, sobre todo en Vicuña Maquena y en las empresas que habían pasado a lo social. Allí había muchos compañeros comunistas muy conocidos.

Mi marido cayó preso en 1975 y estuvo en Tres Álamos, Cuatro Álamos y Puchucabí hasta que le expulsaron en 1982, junto con Manuel Bustos porque ambos eran de la coordinadora. En el partido me dijeron que no podía seguir en el trabajo interno porque había muchos riesgos para mí y el resto de los compañeros. Yo atendía a muchos de los compañeros que estaban clandestinos.

Afortunadamente, no caí presa nunca. En 1975 mis compañeros me dijeron que iba a ser miembro del Comité Central del PC. Yo debía atender el área sur del país, viajar a las provincias en clandestinidad. Yo trabajaba con el compañero Américo Zorrilla, un viejo dirigente.

Durante dos años estuve desempeñando este trabajo. Mi único contacto o enlace era Américo, con lo que el trabajo estaba muy compartimentado para reducir el riesgo de caer detenida. Estuve trabajando hasta 1978 porque a finales del 77 cayeron muchos compañeros y hubo que rehacer todo. Estuve un mes en el exterior recibiendo un curso de seguridad.

Después de este período trabajé en lo sindical. Allí pude trabajar con mujeres algunos temas de género. Cuando se formó la Coordinadora Nacional Sindical se creó un departamento de mujeres para organizar el trabajo de todas las sindicalistas, del Mapu, 
del PS, etc. Debíamos recuperar los derechos laborales de las mujeres que había abolido con la dictadura y acabar con la discriminación laboral y la situación de precariedad. De esta forma pasé a ser dirigente sindical en San Felipe, en una empresa constructora.

Yo sabía que si me tomaban me iban a matar. Además mi marido había estado preso durante mucho tiempo hasta que fue expulsado del país. Habíamos decidido que en caso de que ocurriera esto él se iría sólo y eso ocurrió, salió a Brasil en 1982 para pasar después a Italia y Argentina. En Buenos Aires le descubrieron un cáncer al pulmón y que le quedaba poco tiempo de vida, falleció en 1985. Esto significó que yo tenía que salir fuera para verlo en Argentina. Los compañeros sindicales de la construcción le atendieron y se lo llevaron a Chile en sus últimos meses de vida.

En esos años yo trabajé mucho en la CUT (Central Unitaria de Trabajadores), en el trabajo sindical. Este trabajo consistía en ir a todos los sindicatos y participar en las asambleas y pelear con los empresarios. En algunas empresas había muchas mujeres trabajando. Pero las mujeres fueron entrando a trabajar en la construcción.

\section{4 ¿Después de la muerte de su marido decidió abandonar la militancia política?}

No, yo seguí siendo miembro del Comité Central (CC) del partido compaginando mi trabajo en el mundo sindical. En las elecciones de la CUT fui nombrada por el partido para dirigir el trabajo de la comisión sindical del PC. Teníamos relación con otros partidos porque la idea era establecer una política conjunta sindical.

Este trabajo lo desempeñé hasta 1990; en ese momento abandoné el CC y tres años después terminé también mi trabajo sindical. Volví al trabajo en mi Comuna. Llegué al límite de mi militancia en el partido, de hecho, tuve muchas discusiones fuertes a cerca de la necesidad de renovar el partido que yo defendía. Sólo quería militar en mi célula porque tuve un desgaste muy fuerte.

5 ¿Las mujeres madres militantes en el PC tuvieron una doble carga a la hora de desempeñar el trabajo político? 
Muchas compañeras renunciaron a la militancia política porque de lo contrario su hogar o su núcleo familiar simplemente se destruía. Esto ocurría mucho en las comunas. Además no se reconocían muchas capacidades que algunas compañeras tenían superiores al de los hombres en ciertas cuestiones. Algunas mujeres tenían mayores capacidades para asumir algunas tareas políticas.

Aunque el partido siempre dio a la mujer una importante participación en todos los organismos lo cierto es que en lo cotidiano muchas militantes tenían que renunciar a su trabajo en el PC por el cuidado de los hijos o del hogar.

También faltó una ayuda económica a las mujeres que tenían más dificultades para que pudieran desenvolverse con mayor facilidad. Esto lo discutimos mucho en el PC. Tan sólo contábamos con la ayuda internacional de algunas ONGS.

En el tiempo que yo fui miembro del CC (diez años) la presencia de la mujer era del 30\%. Estaba Julieta Campusano (senadora), Mireya Balta (ministra del trabajo y diputada), Inés Cornejo, Silvia Acosta, Gladis Marín etc.; eran mujeres con grandes compacidades políticas.

6 ¿Creé que hubo una represión específica hacia las presas políticas en los años de dictadura? ¿Podríamos decir también que hubo un trato diferente a las mujeres según su clase y condición socioeconómica?

Esto se dio mucho. La mayoría de las mujeres del partido que fueron detenidas terminaron asesinadas. Cuado tomaron a la Marta Ugarte sabíamos que la iban a matar al igual que otras compañeras. Las mujeres dirigentes eran un blanco de la dictadura. Recién las mujeres comunistas están ahora hablando sobre lo que les pasó. Cómo fueron torturadas y violadas. También está el tema de la separación de los hijos.

\section{7 ¿El Partido Comunista ha reconocido suficientemente la aportación de sus mujeres militantes en tiempos de dictadura?}

Encuentro terrible la discriminación positiva. En el partido no la hay. Pero la mujer tiene que hacer el doble para conseguir su reconocimiento, ayer y hoy. Las compañeras 
comunistas han demostrado de sobra su valía en tiempos de dictadura porque nosotras fuimos las que sostuvimos la casa, los hijos y gran parte de la organización y el partido no ha reconocido suficientemente este doble trabajo de la mujer.

Si hubiera habido un reconocimiento a estas alturas sería mayor la participación de la mujer en el PC. No podemos dejar a la mujer al margen de los procesos de cambio de este país. En Chile se han perdido tremendas oportunidades para la mujer por la ceguera de los partidos.

Yo me metí en el ministerio de defensa para protestar sobre la situación de mi marido. A él le quedaban cuarenta y cinco días de vida y debían facilitar su retorno del exilio porque nada malo podía hacerle ya al régimen militar. Ni siquiera en el entierro descansó en paz. Acudió mucha gente (los alemanes le hicieron una película) a la calle serrano. Los pacos robaron el cadáver y lo votaron en el lugar más recóndito del cementerio. Además tiraron bombas lacrimógenas y hubo una represión muy fuerte. Sólo en el entierro hubo doscientos detenidos. Tuve que enterrarlo yo sola al día siguiente. 
39 Entrevista realizada a MARCELA SHULTZ MORALES, 29 de marzo, Santiago de Chile 2005. Shultz es militante del Partido Comunista desde 1980. Asimismo, desempeñó diversas tareas en el Frente Patriótico Manuel Rodríguez combinando la militancia político-militar con las artes escénicas.

\section{1 ¿Cómo fueron sus inicios en el Partido Comunista?}

Yo pertenezco a una familia bien tradicional. Somos siete hermanos con un padre de derechas y una madre que siempre ha tenido una tendencia demócrata-cristiana. Sin embargo, en mi casa siempre se habló de política con lo que desde que era niña escuché mucha información, especialmente sobre los presidentes de turno.

Los domingos se transformaban en un debate político, algo fascinante para mí. Mi hermano era socialista y mi hermana militaba en el MAPU (Movimiento de Acción Popular Unitaria). Esto se transformaba en una discusión muy interesante. Yo fui la menor y observaba las discusiones y los diferentes puntos de vista.

En el tiempo del golpe yo era niña, preadolescente. El golpe afectó mucho a la familia, hubo un quiebre puesto que cada uno tomó posiciones diferentes. Mi hermano estuvo muy ligado al gobierno, perteneció a un grupo de diseñadores, el Grupo $\mathrm{N}^{\circ} 5$ encargado de los diseños para las casas populares, exposiciones, etc.

\section{2 ¿Cómo recuerda el 11 de septiembre de 1973?}

Tenía doce años. Recuerdo la cara de mi papá que estaba feliz y la cara de mi hermana que estaba llorando. Recuerdo que mi padre le dijo - jTu no sales de la casa!- y mi hermana replicó - ;Voy a salir a defender el gobierno de la Unidad Popular!-; no volví a ver a mi hermana hasta mucho tiempo después.

Los vecinos salieron y yo junto con un grupo de cabros nos subimos al techo y pudimos ver los aviones bombardeando la Moneda. Tenía una confusión de sentimientos muy fuerte. 
Otra hermana empezó a bordar una bandera chilena. Mi papá sacó una botella de champán para brindar. Cuando anunciaron la muerte de Salvador Allende mi hermana, contraria a la UP, se puso a llorar y dijo: ;yo no quería esto!-.

Mi hermano se fue a trabajar y cuando llegó a la pega se encontró con militares que le estaban esperando. Se lo llevaron al Estadio Nacional para pasar después a Chacabuco. Lo torturaron mucho, estuvo un año; cuando volvió (1974) del campo de concentración vi a mi hermano completamente delgado, con el pelo muy desordenado y los ojos desorbitados, esta imagen fue muy terrible para mi. Posteriormente, él se fue al exilio.

Días después apareció mi otra hermana y mi papá nos prohibió hablar con ella. Nosotros esperábamos a que mi padre se acostara para tocar la puerta de mi hermana; la sentíamos en la noche porque escribía en la madrugada.

Con la excusa de pedir un cigarro nos hacía pasar. Ella escribía documentos para la resistencia y trabajaba en un despacho de abogados. Nos dejó documentos sobre detenidos-desaparecidos. Ahí empezó nuestra educación subliminal en la política. Mi hermano también nos mandaba material desde el exilio.

Finalmente, tomé la decisión de luchar contra la dictadura. En el liceo comencé a contactar con compañeros contrarios a la dictadura. Nos hacía cantar el himno nacional cambiado ("los valientes soldados...”).

Otro hermano entró en la universidad y contactó con militantes del MAPU. Le pedí que me pusiera en contacto con ellos pero él se negó aunque me puso en contacto con un grupo de enseñanza media o centro de alumnos en donde había jóvenes militantes de varios partidos, de la juventud comunista, socialistas, miristas, etc. Yo tenía dieciséis años en 1977. Allí se discutía de política, hacíamos manifestaciones, etc. Tuve un romance amoroso con el presidente de este centro.

Cuando terminé la enseñanza media, en 1978, empecé a estudiar teatro en una academia alternativa donde estaban todos los profesores que habían echado de otras escuelas. Después supe que esa academia era del Partido Comunista. 
Allí, pude ver que había varios grupos que discutían y algo de esas charlas me sonaban del grupo de enseñanza media; reconocía discursos de miristas, comunistas, socialistas, etc. Al mismo tiempo, no dejé de participar en todas las manifestaciones contra la dictadura. Empecé a tener ganas de estar más activa y pertenecer a un partido político.

Me contacté con un compañero de curso de teatro y sentí que quería formar parte del PC. Le dije que quería conversar con él porque quería entrar en las juventudes. Él me miró con una cara de espanto que todavía la recuerdo. Me dijo: -¿Por qué hablas conmigo?, ¿por qué me lo dices a mí?-; yo contesté, -porque creo que tu eres de la jota. Finalmente, terminó diciéndome: -Bueno, voy a buscar a alguien que te pueda ayudar-

Creo que en un principio debieron sospechar de mí, en la posibilidad de que fuera una infiltrada. Unos días después me dijo que podía ponerme en contacto con alguien pero que antes de entrar tenía que hacer un trabajo, un análisis sobre temas políticos. Pedí a mi pareja que me ayudara. Me hicieron hacer varios trabajos sobre la dialéctica y otros temas muy complejos. También me preguntaron sobre mi historia y mi familia. Finalmente, entré en las juventudes en 1980.

\section{3 ¿Qué tareas partidarias desarrolló en la clandestinidad?}

Trabajé en la base de actores del partido. Existía el Comité Local de Artistas. Entré a militar en la base Venceremos. A los dos meses me hicieron orgánica, todo lo que tiene que ver con toda la estructura del partido, del funcionamiento, organizaciones de reuniones, contactos, medidas de seguridad, casas, etc.

Teníamos cierta libertad por el hecho de ser artistas porque podíamos ocultarnos mucho más. En 1982, apareció toda la parte de rebelión de masas, es decir, la política militar del partido.

A nosotros nos llegó un informe para participar. Era la aplicación de lo miliar. ¿Cómo íbamos a aplicar la lucha armada con el teatro?. A mí se me ocurrió una forma. Trabajamos a través de Augusto Boal, un autor brasileño de teatro panfletario. Aplicamos la técnica del teatro invisible, es decir, hacer propaganda a través de una performance en la calle. 
Nos convertimos en unidad de combate, pero siendo una unidad artística. Trabajábamos en las micros, en el metro, en la calle. Una vez entramos en un supermercado y me puse delante de todos. Una persona me dijo que tenía que esperar la fila para poder comprar, pero la idea era provocar un altercado, una reacción.

Te explico: Tomé una actitud prepotente diciendo que yo no iba a pagar ningún producto y no iba a esperar ninguna fila. Logré que todo el supermercado se pusiera en mi contra. En ese momento yo dije: -Ustedes no saben con quién están hablando-, todos se quedaron en silencio; saqué de mi bolso una cámara de fotos (sin rollo) y empecé a sacar fotos a toda la gente.

Después salí. Los cometarios fueron: -Esto es terrible, tiene que haber sido de la CNI, nos van a llevar presos, esto no lo podemos seguir aguantando-; se produjo toda una reacción de indignación. Incluso pensaron que iba a sacar un arma. Este fue el tipo de teatro que hice.

También participamos en las barricadas haciendo teatro. Nos poníamos de acuerdo con los compañeros que llevaban la parte militar de la resistencia en las poblaciones. Antes de que llegaran carabineros hacíamos un squech político. Cuando llegaba la policía la gente nos escondía en sus casas. Para mí fue un gran aliciente porque sentía que estaba aportando algo concreto contra la dictadura. Hicimos muchas giras por los sectores campesinos, por las poblaciones, hacíamos teatro político.

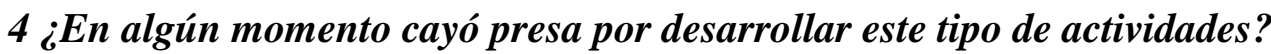

No. Yo vivía en una casa del barrio alto. Mi casa era la de un viejo momio, de mi padre. Podía pasar por cuica, por una mujer de derechas. Jugué un rol camuflándome en mi feminidad para evitar la captura.

\section{5 ¿Cómo continuó su militancia?}

Con el tiempo me fui a vivir con mi compañero sentimental. No quise que mi padre me encontrara. Mi padre me buscaba pero yo me arrancaba de él. Creo que fue algo irresponsable de mi parte, no tomaba precaución. Además quedé embarazada y tuve que 
compaginar mi militancia, el teatro con otros trabajos, hacía aseo. Cuando mi padre me encontró yo tenía ocho meses de embarazo. Incluso mientras estaba embarazada seguí haciendo rallados y acudiendo a las manifestaciones.

\section{6 ¿Cómo compaginó su militancia con la maternidad?}

Tuve a mi hijo y en los primeros meses me ví obligada a renunciar a mi militancia. Después, pasé a formar parte de la orgánica del Comunal, con responsabilidades mayores. Tenía que atender a compañeros e iba con mi bebé colgando. Después se rompió mi relación de pareja, me quedé completamente sola, caí en una depresión. Aún así, seguía teniendo vínculos.

Por otra parte, mi hermana comenzó a militar en el Frente Patriótico Manuel Rodríguez (FPMR) como ayudista. Un día llegó a mi casa un compañero que sabía toda mi situación y me dijo: -¿Tú estás desvinculada de la jota?-, yo contesté: -Sí, estoy con un problema personal importante- El me dijo: -Necesitamos tu ayuda, necesitamos una actriz, ¿nos puedes ayudar?-. Acepté. Necesitaba un estimulo, hacer algo que me sacara de mi depresión. Esto me hizo sentir muy bien.

El trabajo tenía que ver con la cosa militar. Trabajar con la dirección del Frente. Yo era rubia, de ojos claros, actriz y tenía que acompañar a los dirigentes a las reuniones, en el auto, como pareja. También tenía que llevar mensajes, pasar controles complicados, es decir, utilizar mi aspecto. Además podía actuar para resolver ciertas dificultades. Además también camuflaba a los compañeros buscados, los maquillaba, los transformaba completamente.

Desarrollé como artista toda una parte militar que interesó mucho a los dirigentes. Con el tiempo comencé a asumir responsabilidades mayores como hacer estudios de lugares o zonas para realizar reuniones y otro tipo de acciones.

\section{7 ¿De carácter político-militar?}


La dirección del Frente estuvo muy satisfecha con mi trabajo. Pasamos situaciones de peligro que puede superar. Como acompañante logré salvar muchos momentos difíciles en mi papel de actriz. Me dieron misiones un poco más complejas.

Me dieron una misión en el extranjero a mediados de 1984. Viajé con mi hijo de dos años. Todavía usaba pañales. Con otra compañera de la estructura, que también viajó con su hijo, jugamos el papel de mujeres que hacían turismo. Era una misión muy peligrosa. En una ocasión nos quedamos en un cerro aisladas y pudimos resolver muy bien la situación jugando nuestro rol de mujeres, con toda esta parte femenina, de seducción. Íbamos en una camioneta y nos paró la policía. Íbamos de Perú a Bolivia. En la frontera tuvimos un problema. Tuvimos que bajar un cerro para buscar un mecánico.

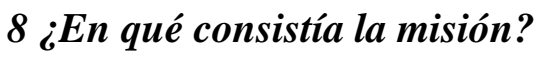

Yo nunca supe mucho... algo teníamos que entregar y algo teníamos que recibir... (Se interrumpe la trascripción de la entrevista a petición de la entrevistada).

\section{9 ¿Llegó a buen puerto la misión encomendada?}

Sí. Cuando regresé los compañeros valoraron la misión y determinaron que mi trabajo había sido bueno. Decidieron mandarme a un curso de formación militar a finales de 1984 y volví en 1986, esto fue en Cuba. Ese año el partido lo denominó como "el decisivo". Cuando volví a Chile vine con "la mochila puesta, con el fusil" para hacer la revolución.

Ese tiempo estuve separado de mi hijo. Cuando llegué fue muy difícil para mí. Sentí en parte que lo había abandonado. Él me mostraba juguetes que le había regalado, fue muy emotivo, como si me dijera -se que eres mi mamá, pero no te conozco, ¿quieres conocerme?-; me conmovió que no me reprochara nada. Tuve una depresión muy fuerte por haberme perdido varias etapas de su infancia.

Por motivos de seguridad, tuve que desvincularme con la estructura del partido. Después empecé a incorporarme de nuevo y aplicar todos los conocimientos que había adquirido. Más que nunca me vestía de forma muy femenina, muy coqueta, 
preocupándome mucho del maquillaje y asumía el rol de mujer linda con su carpeta de encuestadora.

\section{0 ¿Le dieron otras misiones de carácter político militar?}

Sí. Yo volví justo en el momento antes de que Pinochet sufriera el atentado. Fue muy a algunos para sacarlos del país o llevarlos a casas de seguridad. Era un trabajo muy peligroso por lo que tuve que interpretar ese papel, lo que también significaba que mi hijo podía correr peligro.

Después vino lo de Carrizal, cuando encontraron las armas. Esto creó un nuevo problema de seguridad. Siguieron a unos compañeros y otros cayeron muertos. Casi me cogieron. Recuerdo que tenía un encuentro con uno de ellos, Julián Peña Maltés, desaparecido hasta hora pero mi jefe me dijo que no fuera porque podía tener problemas. En dos ocasiones tuve que arrancarme con mi hijo.

Unos meses después pasé a ser miembro de la Dirección Nacional del Frente. Mi tarea tenía que ver con infraestructura, con las casas de seguridad, locales de reunión, apoyo a las unidades de combate y todo lo que tenía que ver con primeros auxilios.

Un día me dijeron que había llegado un informe. En todo este proceso existía la inteligencia y la contrainteligencia. Había una persona que tenía información directa en donde aparecía mi dirección, mi foto, mis datos, todo al igual que de otros compañeros. Se estaba preparando una segunda Operación Albania.

\section{1 ¿Qué estrategia siguió para no caer presa?}

Me fui en ese momento. Dejé de nuevo a mi hijo con mi hermana y mi madre sin poder despedirme. Estuve de casa en casa. Tuve que reinventarme. Cambié mi aspecto por completo. Estuve escondida hasta después del plebiscito.

Mis compañeros me llevaron a un sitio vendada porque cuanto menos supiera en donde estaba menos peligro correría. Era una parcela en donde había otro compañero refugiado. Allí estuve encerrada mucho tiempo. Para mí fue muy terrible por mi hijo. 
Fue una presión muy grande hasta que un día decidí volver a Santiago y refugiarme en una casa de seguridad.

Llamé a mi hermana para que nos encontráramos en el zoológico con mi hijo. Vi a mi hijo de lejos, no puede aguantarme y corrí a abrazarme pero él no me reconoció. Decidí llevarmelo a vivir conmigo y estuve un tiempo hasta que volví a mi casa a finales del 89.

12 Por lo que veo su militancia afectó a su maternidad ¿esto le trajo problemas posteriores en su relación con su hijo?

Afectó mucho. Yo sentía una gran culpabilidad aunque por otra parte sabía que había tomado una posición y que tenía que ser consecuente con esa decisión. El riesgo que él pudo tener en algunos momentos es lo que más me perjudicó.

Es difícil vivir la militancia clandestina porque uno tiene que esconderse de todo. Sabía que iba a llegar un momento en el que mi hijo me preguntara sobre estas ausencias.

Efectivamente ese día llegó. Mi hijo recordaba algunas cosas que no entendía: - ¿por qué me dejaste tanto tiempo sólo?-; le conté todo. Pero además le agregué que yo pensaba que nada justificaba dejar un hijo abandonado, ni siquiera la revolución. Le transmití que era muy consciente de que me había saltado etapas de su vida importantes. Mi hijo me contestó: -creo que hiciste lo que tenías que hacer y me siento muy orgulloso de tener una mamá como tu y puedo decir a mis compañeros que mi mamá luchó contra Pinochet y no todos mis compañeros pueden decir eso- Tenía doce años cuando se produjo esta conversación.

\section{3 ¿El PC ha reconocido esta carga extra de aquellas mujeres militantes que tuvieron} hijos en tiempos de dictadura?

Creo que no. Aunque hay compañeros que sí me han reconocido esta entrega y esta dificultad de las madres militantes. Trabajé siempre con hombres y de una u otra forma he sentido que no se ha recordado mucho mi labor o mi aportación. Me sentía como un adorno más que una compañera de igual a igual. Recuerdo que mis compañeros me 
decían: -tu nos alumbras el día- pero siempre con la sensación de jugar el rol tradicional de mujer. Esto lo sentí sobre todo en Cuba, cuando me mandaron a un curso de formación militar.

\section{4 ¿Esta realidad perdura hoy en día?}

Actualmente, soy encargada de Cultura del Comunal Santiago y aún así me veo como adorno. La mayoría son hombres, no creo que piensen en mi en como una persona que pueda hacer un aporte político, de seso, de cabeza; hay cierto machismo en la estructura partidaria.

Cuando los compañeros hablan de Gladis Marín algunos se dan cuenta de esto, del gran aporte que hizo una mujer a la historia del PC. Es ahora cuando el papel de la mujer en el partido se está tomando en cuenta. Sin embargo, siento que los compañeros están bastante más dormidos que nosotras. Generalmente, somos las mujeres las que llevamos más el callo a la política.

15 Anteriormente me comentaba que tuvo dificultades en Cuba por el hecho de ser mujer, ¿podría especificarlas?

Sí. Cuando llegué a Cuba me integré en un grupo de veinte en donde sólo éramos dos mujeres. Ella tenía 22 años y yo 24. Con mi aspecto físico empezó haber un problema de clase, me vieron cuica. Después supieron que era actriz, lo fue que peor, ellos me decían que qué hacía yo ahí. Además era mujer. Fueron muy arrogantes.

Hubo una clara discriminación, mi aspecto físico era bastante atractivo. Muchas veces me sentí acosada, y en algunos momentos en el que yo "aceptaba" esas insinuaciones, porque me gustaba un compañero, rápidamente los otros decían: -A esta le gusta el hueveo, es media puta-.

Incluso los profesores cubanos me dijeron en algunos momentos que yo estaba siendo discriminada y acosada. Había celos, me decía que me acostaba con los profesores para tener más nota. Para mí fue una prueba muy dura, tenía que demostrar que las cosas me las ganaba por mi esfuerzo. 
Mi compañera también vivió esta realidad. De hecho, creo que a ella la trataron peor porque era de origen más humilde. Le decía que tuviera cuidado con los elogios de los compañeros, que si se sentía abrumada con tanto hombre que la acosaba me lo dijera, porque algunos tenían buena intención pero otros no.

\section{6 ¿Estas experiencias le hicieron ser más crítica con el partido?}

En cierto sentido sí. Traté de conversar con los profesores cubanos para entender estos episodios. Ellos me decían que tenía que comprender la situación cultural que había en Chile. Además éramos las únicas mujeres. Igualmente fue difícil adaptarme a todo eso.

\section{7 ¿Cómo fue su regreso a Chile? ¿Qué tareas partidarias realizó?}

Cuando el PC se legalizó me llamaron para armar una comisión de cultura. Después de varias conversaciones decidí seguir trabajando en temas de seguridad. Me llamaron para instruir a compañeros para la seguridad de los dirigentes y los locales. Después trabajé en tareas administrativas en el local. Al mismo tiempo volví al teatro, para mí fue algo muy importante porque lo había dejado de lado.

\section{8 ¿Qué elementos positivos y negativos destacaría de su militancia en el Partido} Comunista?

Formé mi carácter en el Partido Comunista. La formación humana, intelectual y política la he recibido aquí. He aprendido mucho con mis compañeros. El partido ha sido como mi segunda familia. Es mi vida en realidad. Todavía me levanto por las mañanas pensando que todavía es posible cambiar el mundo.

En lo negativo, me hubiera gustado un mayor reconocimiento al trabajo de la mujer. Hay todo un discurso pero en la cotidianeidad esto no se refleja. Tiene que haber un análisis más profundo, quizá en lo sociológico, del papel que juega la mujer en el partido y sobre todo el tema de los hijos; ¿por qué tenemos que ocuparnos siempre de su cuidado solas? Seguimos teniendo un trabajo extra. 
40 Entrevista realizada a PATRICIA COÑOMAN CARRILLO, 1 de abril de 2005, Santiago de Chile. Coñoman es militante del Partido Comunista desde 1969. Desarrolló una intensa actividad sindical en la Confederación Textil en donde actualmente ocupa el cargo de presidenta. Estuvo detenida en el centro Borgoño y fue exiliada política en Bulgaria.

\section{1 ¿Cómo fueron sus inicios en el Partido Comunista?}

Yo tengo sangre mapuche. Mi apellido “Coñoman” significa Dueño de Cóndor y esto, desgraciadamente, ha supuesto una permanente discriminación a lo largo de mi vida. Desde muy niña sentí un rechazo por mi condición. A los diez años fui dirigente de un curso, en quinto de preparatoria. Me eduqué en la ciudad del Niño, en donde iban cabros de muy escasos recursos. Mi madre me crió sola, con mi hermana, vengo de una familia matriarcal.

En 1968, cuando llegué a la secundaria, empecé a conocer a las juventudes comunistas. En 1969, con dieciséis años, me casé y tuve mi primera hija. Mi compañero también estaba metido en política, en el MIR, aunque yo no supe nada de su implicación hasta después del golpe.

En aquel tiempo no teníamos donde vivir. Participamos en una toma de terreno, en un campamento llamado Venceremos. Esto fue momentos antes de las elecciones presidenciales de 1970. Cuando ganó Allende, decidimos quedarnos a vivir allí, hasta hoy día. De esta forma obtuve mi casa. Viví todo el proceso de autoconstrucción de los pobladores, de los trabajadores.

También viví todo el proceso de las JAP, era la delegada de mi manzana hasta que se produjo el golpe militar en donde recién comencé a trabajar en el sector poblacional. Pintar muros, trabajos de brigadas, etc.

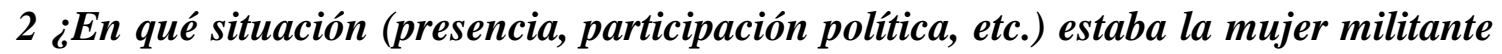
del Partido Comunista en los años de la UP? 
Había mucha protección hacia las mujeres. Discutíamos mucho con los compañeros sobre esto, es decir, sobre el por qué de esta protección tan fuerte hacia las mujeres de la jota. A mi personalmente no me gustaba.

\section{3 ¿En qué circunstancias estuvo el 11 de septiembre de 1973?}

Mi compañero trabajaba en El Teniente, en las minas de Rancagua. Para mí fue muy duro, porque era muy joven. El 11 de septiembre estaba en mi casa, en el campamento. Nosotros teníamos un megáfono en donde se ponían canciones, manifiestos, etc. Esa mañana no sonó. Tuvimos una reunión todos los delegados y ahí nos dijeron que había un golpe de estado.

Esto quedaba en el paradero 36 de la gran avenida. En frente estaba la Escuela de Aviación. Desde mi casa se podía ver cómo salían los aviones; sobrevolaban todo todos los sectores, especialmente sobre los fundos. Esto eran maniobras de intimidación.

Intenté comunicarme con mi compañero. Él me dijo que su militancia política podía afectar mi situación con lo que teníamos que ser muy prudentes.

Nos reunimos y tomamos medidas para limpiar la casa de documentos. Todos los dirigentes de la junta de vecinos huyeron de la población. Todo el mundo pensaba que iban a buscar a los dirigentes y que el resto de la población iba a estar segura. Pensar en estos términos fue muy ingenuo por nuestra parte porque pronto empezaron los allanamientos. Buscaban armas y nosotros no teníamos nada. Sólo algunos palos. Durante muchos días nadie se atrevía a hablar ni a salir. Pasamos mucho miedo. Yo tenía 20 años en el 73.

\section{4 ¿Cómo fue su militancia en la clandestinidad?}

Hasta el año 75 no empecé a militar clandestinamente. Primero, porque tenía dos hijos, segundo, porque mi marido estaba desaparecido. Apareció muerto en el callejón Lovalle. Él se llamaba Jorge Bastías. Durante más de un año estuve buscándole hasta que apareció. Además, tuve que ponerme a trabajar para mantenerme. La única persona 
que le buscó fui yo. Empecé a juntarme con otras mujeres que estaban en mi misma situación, el dolor nos unió.

Entré a trabajar en una fábrica de camisas, donde trabajaba mi madre. En Arrow. Reconocí a mi marido en una noche con toque de queda. Caminé toda la madrugada desde el paradero 36 hasta el centro, en el Instituto Médico Legal.

Me hicieron pasar a una sala en donde había muchos muertos, allí reconocí a compañeros de la Jota. Después reconocí a mi marido. Me dijeron que tenía media hora para enterrarle. Además, lo pusieron en un cajón con otros dos muertos más.

En este lapso tuve otra hija con lo que tenía que trabajar duro para mantener a mis tres guaguas. Desde el 75 al 77 estuve estudiando y trabajando a la vez. En estos dos años estuve muda, sin militar ni en el sindicato ni en el partido.

En 1979, en una convivencia que se hizo en el colegio, un profesor me preguntó que si estaba sola. Yo le conté que habían matado a mi marido. Desde ahí todo el mundo guardó silencio y la gente empezó a reagruparse entorno a mí. Empecé a contactar con socialistas y comunistas que querían reorganizarse.

Decidí contactar con gente que desde hacía varios años que no veía. Ahí me encontré con la juventud comunista clandestina. Ellos me invitaron a militar. Me propuse ser dirigente sindical y aquí mi vida cambió por completo.

\section{5 ¿Cómo afectó su maternidad en su militancia política o viceversa?}

Yo iba con mi hija a las reuniones. También mis compañeros la cuidaban. Traté de compaginar ambas cosas. Sin embargo fue difícil, porque una empieza a renunciar a algunas cosas con los hijos.

A finales del 79 la empresa supo de mi militancia y me despidieron. En este despido tuve que vagar por muchas empresas. Trabajaba de noche, de día, vendía pan amasado, cualquier cosa para mantener a mis hijas y nunca sin dejar de militar. Mi madre se hizo 
cargo de mis hijas y yo empecé a salir más de la casa. Estuve mucho tiempo separada de ellas. Si tengo una deuda con mis hijas es no haberlas visto crecer.

\section{6 ¿Cómo fue el proceso de incorporación al movimiento sindical clandestino? ¿Pudo compaginarlo con su militancia en el PC?}

Después de haber sacado un diploma de sastre (en maquinaria de industria textil) entré en otra empresa, Avandine, también de camisas. Allí tuve también muchos problemas. Me acusaron injustamente de robo y me despidieron, pero yo recurrí y gané el juicio a la empresa. Me dieron mucho dinero por daños y perjuicios. Ahí me di cuenta de que tenía que continuar siendo dirigente sindical. Seguí trabajando en las juventudes.

Llegaba muy tarde a la casa. En 1980, llegué a otra fábrica. El gerente me conocía porque el había trabajado en Arrow y sabía que yo tenía experiencia en las nuevas máquinas textiles. Me dijo: -te voy a contratar al tiro pero nosotros no queremos nada de política-. Yo le contesté que no se preocupara, que no causaría ningún problema.

Me incorporé muy rápidamente. Mi salario era relativamente alto en comparación con otras compañeras. Después de un año y medio se empezaron a producir algunas protestas al interior de la empresa. Yo distribuí propaganda porque de mí no sospechaban.

Hubo un proceso de negociación colectiva porque las condiciones de los trabajadores eran muy malas. Se produjo una huelga en la que yo participé activamente. Había mucha desconfianza entre mis compañeras porque mi situación en la empresa era bastante buena. Desde la gerencia me propusieron que si renunciaba al sindicato me nombrarían jefa de área, era un buen ascenso. Yo me negué rotundamente, el gerente me dijo: -Tú no puedes estar en huelga porque ganas mucha plata, te vas a arrepentir-; a partir de este hecho mis compañeras me respetaron mucho.

Entre medio de esto yo había entrado en contacto con la Federación de Madres de los textiles, (la FENATEC durante el gobierno de la Unidad Popular). Allí encontré a muchos compañeros comunistas, aunque era una organización independiente. Ellos me apoyaron en todo con la huelga. 
Me recomendaron que la directiva sindical había que cambiarla porque sino la huelga iba a fracasar. La idea era establecer un control sobre los trabajadores a la hora de firmar acuerdos con la patronal. En este proceso, los compañeros me enseñaron a negociar colectivamente, conocí a los compañeros de la construcción y me consolidé como dirigente sindical. Toda esta actividad la compaginé con mi militancia en la Jota. Estuvimos 35 días en huelga con una represión enorme.

\section{7 ¿La detuvieron?}

Sí. A partir de la huelga (1980) mi cara salió a la luz pública. De hecho, salí en un diario cuando nos fuimos a tomar la OIT (Organización Internacional del Trabajo).

Nosotros nos parábamos en frente de la fábrica y llamaban a carabineros. Ellos nos echaban agua hasta que nos tomaban presos. A mi me detuvieron en varias ocasiones. Paralelamente trabajé en las Olla común (en donde la mayoría éramos mujeres). Ellos sabían perfectamente a lo que me dedicaba.

Después de la huelga la federación me dijo que teníamos que aprender Defensa de Masas (autodefensa y el cuidado de los cabecillas). Me advirtieron de que tenía que tener mucho cuidado porque había salido en los medios. La CNI me había identificado a raíz de la huelga y me estaba buscando. Todo este proceso coincidió con la recomposición del movimiento sindical. Yo asistía a las reuniones de la Federación y del partido. Estaba segura de que me iban a despedir de la empresa.

Yo estuve presente en la firma del convenio colectivo. Pensé que me iban a despedir. Cuando entramos a la oficina el gerente ni siquiera me miró. No me despidieron pero me redujeron el trabajo lo que significaba cobrar menos salario.

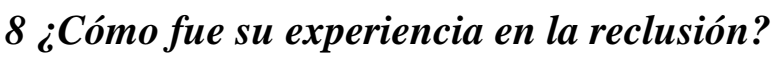

En otra protesta caí presa junto con otros dirigentes sindicales, entre los que se encontraban Manuel Bustos. Estuve cuatro días encerrada. Ahí supe lo que era el rigor de la reclusión. Te mentían en un pasillo y te pegaban, trataban de hacer mil cosas 
contigo, vejaciones hacia las mujeres, los propios carabineros te dejaban desnuda, te hacían vejaciones terribles. Esto me ayudó a ser todavía más rebelde.

\section{Cuando salió de prisión, ¿se reincorporó de nuevo al movimiento sindical?}

Salió un comunicado oficial dirigido a todos los dirigentes sindicales para presentarse en el Ministerio del Interior en donde aparecía mi nombre. Muchos dirigentes renunciaron y yo pasé a ser presidenta del sindicato. La empresa trató de despedirme pero yo estaba protegida por el fuero sindical.

Impusimos una demanda a la OIT porque a nuestras compañeras que estaban embarazadas las hacían trabajar de noche. En ese minuto, sin tener una conciencia de género, empecé a tener una sensibilidad especial con la situación laboral de muchas mujeres.

A partir de ahí seguí trabajando en la organización de la Confederación Con-Textil (actualmente soy presidenta), en junio de 1985. Un mes después la mayoría de los dirigentes estaban presos. Nos allanaron y nos quitaron todo el material. De la noche a la mañana tuve que hacerme cargo de la confederación a nivel nacional.

1985 fue un año en el que muchos compañeros cayeron. Tuve que salir de mi casa porque la allanaron varias veces. A mi hermana se la llevaron presa por la ley de control de armas, parece ser que encontraron un arma en la casa que era de mi hermano. Ella estuvo cinco meses presa.

\section{0 ¿La detuvieron de nuevo?}

Sí. Estuve deambulando por varias casas de seguridad del partido. Un día llegué muy temprano a la empresa para asearme y cambiarme de ropa. Llegué a las 6.50 de la mañana y el portero me dijo -el gerente de la empresa le está esperando en su despecho-; subí y mi jefe estaba blanco y tiritando; me dijo: -señorita, están allanando varias empresas y la están buscando a usted por eso he mando retirar su tarjeta, en cualquier minuto van a venir, váyase por favor-. 
Unos minutos después la CNI allanó la empresa. El gerente me dijo -Patricia, no comulgo con usted, se que es comunista pero dentro de la empresa no quiero muertosYo le dije que eso dependía de él, que no tenía a donde ir, estaba en una oficina en un tercer piso.

En ese momento él me dijo que bajara por unas escaleras que un auto me estaba esperando y que jamás dijera nada de lo ocurrido. Estaba todo preparado. Allanaron toda la empresa y se llevaron a muchos dirigentes sindicales.

Me metí en la maleta del auto. No se cuanto tiempo estuve allí pero cuando salí estaba cerca de Quilicura, hacia el norte. El chofer me dijo:-Patricia, la saqué de la empresa, yo no quiero una desaparecida más pero usted es peligrosa, yo la dejo aquí y usted se las arregla-.

Me recomendó que fuera a la Vicaría de la Solidaridad y eso hice. Puse un recurso de amparo y me dijeron que no podía quedarme allí. Hablé con varias compañeras de la Federación. Recuerdo que al día siguiente era ocho de marzo y habían organizado algunas movilizaciones. Me arriesgué a ir a la manifestación y me detuvieron.

La CNI me llevó al cuartel Borgoño. Me tuvieron cinco días en un calabozo. Allí sufrí todo el rigor de la tortura. En esos días no comí. Me pusieron arriba de una parrilla, me preguntaron muchas cosas, me metieron cosas por la vagina...

Perdí la noción del tiempo...lo que se es que desperté y vi una luz blanca. Pensé que estaba en una sala de tortura pero no...estaba en Bulgaria. En ese ínter tanto no sé lo que pasó conmigo, salí del país pero no sé en que condiciones... (Se interrumpe la transcripción de la entrevista a petición de la entrevistada).

\section{1 ¿Hubo entonces una clara estrategia para reprimir a las presas políticas?}

Sí. Lo primero que hacían era denigrarte como mujer. La violación para nosotras era algo habitual. Una perdía la noción, no sabías cuantos hombres estaban contigo. Yo trataba de no acordarme de eso y de no sentir, lo que por otra parte a ellos les enfurecía aún más. No conforme con eso ponían grabaciones con llantos de niños y también se 
escuchan voces que eran reales...probablemente de niños de otros presos que estaban en Borgoño y te decían: -ese es tu hijo y te lo vamos a violar-. Fue algo demasiado tenebroso, yo pesaba 32 kilos, tenía alopecia, andaba muy mal...

\section{2 ¿Cómo fue su experiencia en el exilio?}

En Bulgaria me enteré que Amnistía Internacional me había sacado del país. Tardé un mes en reaccionar. Pensaba que todavía estaba en la tortura. Estaba conectada a un suero, tuve que estar mucho tiempo rehabilitándome.

No podía caminar. Había muchos compañeros comunistas. Ellos me contaron todo, me dijeron que había llegado en muy mal estado por la tortura y que antes de ver a mis hijos tenía que recuperarme. También recibí tratamiento psicológico. Estuve en Bulgaria seis meses. Regresé a Chile a finales de 1986, de forma clandestina. Con otro nombre, otro pasaporte, cambié de imagen...

Quería ver a mis hijos. No quise quedarme en Bulgaria. En esos meses entré en contacto con algunas organizaciones de la Solidaridad con Chile prestando mi testimonio.

\section{3 ¿En qué circunstancias regresó a Chile?}

Cuando regresé a Santiago estuve dos meses sin poder ver a mi familia por motivos obvios. Después pude ver a mis hijas pero siempre a dos cuadras de distancia. Estuve un año y medio viendo de esta forma a mi familia.

\section{4 ¿Se reincorporó a la militancia?}

Sí. La solidaridad internacional y el sindicato italiano me dieron un salario. Con el plebiscito del 88 la cosa empezó a cambiar para mí. Volví a mi empresa y mi jefe no pudo reconocerme. Le di las gracias por su ayuda y le expliqué todo. Le dije que necesitaba trabajar. Me aceptó de nuevo. Volví a la coordinadora sindical, a la jota y viví todo el proceso de reorganización de la CUT (Central Unitaria de Trabajadores). Cuando se armó la Central quedé siendo dirigente sindical. En 1988 me nombraron encargada de mujeres de la CUT. 
15 ¿Declaró para el Informe de la Comisión Nacional de Verdad y Reconciliación de $1991 ?$

$\mathrm{Si}$, fui a declarar por la muerte de mi marido. También he declarado en el Informe Valech.

16 ¿Qué elementos positivos y negativos destacaría de su militancia en el Partido Comunista?

El PC me arropó en algunos momentos difíciles pero una de las críticas que le hago a mi partido, siendo miembro de la dirección, es precisamente el tema de las mujeres. No sólo de lo que vivimos las militantes comunistas sino la situación laboral en la que la mayoría de nosotras estamos inmersas. He discutido mucho sobre mujer y temas laborales. No hay un estudio riguroso sobre este tema y siento que todavía hay una deuda pendiente con nosotras. 
41 Entrevista realizada a ELIANA ARANIBAR FIGUEROA, 6 de abril de 2005, Santiago de Chile. Aranibar, militante del Partido Comunista desde 1969, desempeñó el cargo de diputada durante el último gobierno de la Unidad Popular. Fue miembro del Comité Central del PC hasta 1992. Asimismo, estuvo exiliada en Bulgaria en donde desarrolló una intensa actividad en defensa de los derechos humanos.

\section{1 ¿Cómo fueron sus inicios en el Partido Comunista?}

Primeramente, fui dirigente de la Juventud Obrera Católica (JOCA); trabajé en las poblaciones y posteriormente pasé a la Acción Católica, esto fue en 1969. Siempre fui una muchacha activa. Después, conocí a José Vaives, (Checho, fue subsecretario nacional de las juventudes comunistas, hoy detenido desaparecido). A través de él, fui a una actividad organizada por comunistas y socialistas. Desde el principio me inquietó más conocer a los compañeros de la Jota. En ese tiempo era muy restringido entrar a las juventudes, tenía quince años.

Forjé una gran amistad con Gladis Marín cuando trabajé en la Comuna de Conchalí, en El Salto. Ella me asesoraba en el trabajo de masas. Organizamos una huelga del Cemento Melón. Llevábamos víveres a los trabajadores. Mi trayectoria en la Jota fue muy activa.

Después pasé a ser miembro del Comité Local de mi comuna para después ser del Comité Regional de Santiago. En las JC llegué a ser miembro de la Comisión Ejecutiva y hasta hace tres años fui miembro del Comité Central (CC) del Partido Comunista (tengo 20 años de militancia en el CC).

Durante el gobierno de la Unidad Popular pasé a ser candidata a diputada por las juventudes comunistas, éramos cuatro candidatos, Gladis Marín, yo, Alejandro Rojas y el Vichiani. Dentro de la UP, cumplimos varias responsabilidades en todo el proceso, estuvimos en los trabajos voluntarios, en las campañas, en poblaciones. También trabajé con el ministro del Interior, en Lampa y Curacabí, para ver los problemas de los trabajadores (tenían problemas con el suministro de agua y luz). 
Trabajé con Víctor Jara, miembro del Comité Central del PC, en las poblaciones para ganar votos en la campaña de la UP. Una faceta que nadie conocía es que él tenía una renoleta (un auto) y salíamos mucho y un día terminamos sin quererlo en donde él nació (El Monte, cerca de Santiago). El me contó que allí se crió, vivió con el papá, etc.

Finalmente, en 1973, con diecinueve años, salí elegida diputada. Fueron unos años muy intensos, de mucha actividad política. Salí en la lista con la Laurita Allende, la hermana del presidente. Hicimos muchas actividades juntas.

\section{2 ¿En qué situación (presencia, participación política, etc.) estaba la mujer militante} del Partido Comunista en los años de la UP?

Había un gran movimiento de mujeres. Yo fui encargada de mujeres en el Comité Regional, después miembro de la Comisión Nacional de Mujeres de la Jota. Asimismo, fui encargada de mujeres del Comité Regional Oeste del partido. Siempre tuve una vinculación muy fuerte con el trabajo de mujeres. Incluso hoy día soy presidenta del MODEMO (Movimiento Democrático por la Mujer).

Los objetivos principales de la UP respecto a las mujeres eran muy avanzados. Se plantearon muchos temas que incluso hoy día están candentes. El divorcio, la igualdad laboral, etc., fueron algunas de las reivindicaciones que nosotras planteamos al gobierno. Pero sobre todo creo que hubo una presencia bien importante de las mujeres en el trabajo poblacional.

\section{3 ¿En qué circunstancias estuvo el 11 de septiembre de 1973?}

El día del golpe a mi me tocó viajar a Calera, fuera de Santiago. Tenía un acto como diputada. Suspendí el viaje y me dirigí a ECA (donde guardaban los alimentos), en Quinta Normal, en donde me esperaban todos mis compañeros comunistas. Desde el primer día supe que la represión iba a ser terrible y traté de aconsejarles para que se replegaran a las casas de seguridad. La primera reacción de ellos fue negativa, querían defender la Moneda. Conseguí convencer a unos cuantos y a los minutos aparecieron los militares. Nos salvamos de milagro, escapamos por un pasillo subterráneo. 
Esa tarde, me disfrazaron y me llevaron a una casa del partido. La junta me buscaba, más por ser secretaria de la Jota que por diputada de la UP. Llegué a una casa de los compañeros de Lo prado. Allí me recibieron asustados por mi presencia. Uno de ellos dijo -nadie debe decir que la compañera Eliana está aquí-. Tuve que vagar de casa en casa más de dos meses. Tuvieron muchos problemas conmigo, hasta que me asilé en la embajada de Finlandia en los primeros días de noviembre de 1973; recuerdo que era el día de los muertos.

En la embajada tuve que esperar hasta el ocho de marzo para conseguir el salvo conducto. Estuve casi cinco meses viviendo allí, hacinados y en muy malas condiciones. Fui de las últimas en salir.

En Finlandia estuve varias semanas (coincidí con el general Carlos Prats, días antes de que fuera asesinado, en un acto con el presidente) y después pasé a la RDA otros meses. Después me fui a Hungría y me tocó organizar la Jota en el exilio y el trabajo con la solidaridad con Chile.

Conmigo estuvo Gladis Marín, trabajamos juntas, ella vivía en Moscú pero nos veíamos con frecuencia. En Hungría estaba la dirección de la juventud y en la URSS la del partido. Estuve en el exilio hasta 1979, cinco años; después regresé a Chile clandestinamente.

El partido me puso la condición para retornar a Chile de que no podría ver a mi familia. Me prepararon muy bien para que no me descubrieran (no puedo contar eso). Antes de regresar a Chile pasé por Italia, Francia, España y Argentina. Entré por los andes, en bus.

En la clandestinidad trabajé en varias cosas. Tuve un encuentro en Irarázaval con Gladis Marín, ella también regresó en esos días. Nunca caí presa. Yo tenía un equipo de trabajo y cayeron muchos compañeros. En la primera actividad clandestina que hice con Gladis estuve a punto de caer presa cuando los pacos (carabineros de Chile) entraron en un bus que tomamos. Mantuvimos la calma y no pasó nada. 
En los siguientes meses pasé a ser la secretaria de las juventudes comunistas y lo compaginé con otras actividades. Después entregué mi cargo a Lautaro Carmona para ser la encargada orgánica del PC. A partir de ahí hasta el plebiscito asumí varios cargos, muchos de ellos relacionados con el trabajo con mujeres.

\section{4 ¿Por qué la mujer fue punta de lanza en la organización de agrupaciones de} DDHH?

Las mujeres jugaron un papel fundamental en los tiempos de la dictadura. Fueron líderes en el movimiento de DDHH porque los compañeros estaban presos. Se agruparon una gran heterogeneidad de mujeres entorno a la lucha por la verdad y justicia. Hermanas, esposas, hijas, etc., jugaron un papel importantísimo especialmente con los presos. Se sacó a mucha gente de prisión gracias a la lucha de estas mujeres.

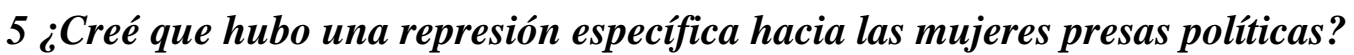

Se dio bastante, sí. Personalmente, tengo amigas que las violaron e incluso tuvieron hijos de militares. Tengo una compañera que vive todavía en Hungría y tiene un hijo nacido de un milico. Muchas mujeres fueron violadas. Imagínate que las metían hasta ratones en la vagina.

\section{6 ¿El Partido Comunista ha reconocido suficientemente la aportación de sus mujeres militantes en tiempos de dictadura?}

No se ha peleado suficiente en el partido por mejorar la situación de la mujer. Ha faltado fuerza a la hora de impulsar el papel de las compañeras. Cuesta mucho, incluso hoy día, cambiar de mentalidad. Ahora la cosa está cambiando. Sin embargo, no he sentido discriminación por el hecho de ser mujer, a mi me tocó trabajar con hombres, sobre todo cuando asumí el cargo de secretaria de la juventud.

Mis padres eran comunistas y nos educaron para tener una conciencia de clase. Somos seis hermanos y todos somos comunistas. 
42 Entrevista realizada a JULIA URQUIETA OLIVARES, 7 de abril de 2005, Santiago de Chile. Urqueta fue miembro del Comité Central y de la Comisión Ejecutiva de las Juventudes Comunistas hasta 1989. Desde la década de los noventa viene desempeñando una intensa labor como abogada de derechos humanos trabajando simultáneamente en el Comité de Defensa de los Derechos del Pueblo (CODEPU) y en el departamento jurídico del Partido Comunista de Chile.

\section{1 ¿Cómo fueron sus inicios en el Partido Comunista?}

Mi participación política comenzó a temprana edad, cuando era adolescente en la secundaria. Con doce años empecé a vincularme a las Juventudes Comunistas. Yo tenía una cercanía al partido porque mi madre fue una fiel allendista durante muchos años y participó activamente en las campañas de Salvador.

Esta fue una primera forma de acercamiento a la política; el segundo elemento fue mi hermana mayor, quién había ingresado a la Jota y tenía amigos comunes conmigo. Ella me animó mucho a entrar en la militancia. Para mí fue muy difícil mantenerme al margen de esta participación.

\section{2 ¿Qué tareas partidarias desempeñó en los años de la Unidad Popular?}

Fueron unos años muy intensos. Durante el año 1972 vivimos momentos de grandes transformaciones, con tomas de terreno, huelgas en la universidad, etc. Los jóvenes tuvimos mucha participación en el ámbito estudiantil y en el trabajo voluntario, especialmente en los sectores rurales y poblaciones.

Con doce años ingresé en la Jota, en la base de la Villa Olímpica, en la comuna de Nuñoa (Santiago). Allí trabajé hasta hoy día junto con otros compañeros. Nosotros pertenecemos a la generación del VII Congreso de la Juventud Comunista (en donde se reeligió como secretaria general a Gladis Marín), es decir, el último congreso que la Jota realizó en la legalidad, después vino el golpe y el VIII congreso no vino hasta 1989.

\section{3 ¿En qué circunstancias estuvo el 11 de septiembre de 1973?}


El 11 de septiembre de 1973 yo estaba en Valdivia. A las pocas horas supimos que se suicidó nuestro tío, para nosotros esto fue muy impactante. Yo soy sobrina de Augusto Olivares, periodista y amigo íntimo de Salvador Allende, quién se suicidó junto con él en la Moneda. Augusto murió poco antes que el presidente.

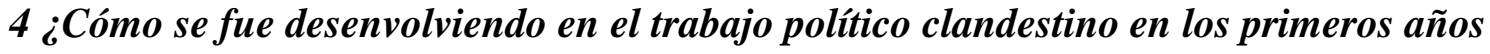 de la dictadura?}

Hasta 1978 fue el período más duro de la dictadura. En este tiempo me dediqué a estudiar y me desvinculé completamente de la política porque no había muchas posibilidades de trabajar. En Valdivia sólo pudimos desarrollar alguna actividad antidictatorial, en el centro de alumnos, denunciar situaciones, pero no mucho más, era un ámbito muy restringido.

Estudié Bachillerato en Ciencias Sociales en la Universidad Austral (Valdivia). Allí me di cuenta que mi vocación verdadera era el derecho. En 1978 postulé a la Universidad de Chile para estudiar en Santiago y quedé seleccionada con lo que me trasladé a la capital. A partir de aquí empezó otra vez mi actividad política.

Por otra parte, mi padre fue oficial de la Fuerza Aérea (Dirección de Aeronáutica que era la parte civil), pero siempre fue un hombre democrático. En marzo de 1973 le nombraron jefe del aeropuerto de Pichoi (Valdivia). Mi padre mantuvo su cargo pero a mi madre la exoneraron por su implicación durante la UP.

En la facultad de derecho pude reencontrarme con algún compañero de mi base y me invitaron a participar nuevamente en la Jota. Pasé de esta forma al trabajo clandestino. Fui teniendo distintas responsabilidades, dirigente pública, dirigente de la Agrupación Cultural Universitaria, etc.

Estuvimos muy influidos por la revolución nicaragüense, leíamos mucho a Omar Cabezas. Me tocó vivir la lucha por la democratización de los centros de alumnos de la universidad (fui secretaria del regional de la dirección de los estudiantes comunistas de la universidad de Chile), protestas, paros, la recuperación de la $\mathrm{FECH}$, etc. El costo de 
esta movilización fue la pérdida las carreras de muchos alumnos, incluso la muerte de algunos de ellos.

\section{5 ¿Cómo recuerda la presencia de la mujer en el trabajo político clandestino?}

Las mujeres en la escuela de Derecho éramos minoría pero fuimos las más combativas, de hecho hubo muchas dirigentes destacadas, tanto en la jota como en el movimiento estudiantil. Había un fuerte compromiso de las compañeras, en la escuela de derecho, que hoy día mantienen cargos importantes en el ámbito público.

Nosotros funcionábamos en una base. Teníamos un sistema de vínculo, había un compañero que recibía la orientación de la estructura superior y él nos atendía a nosotros. Por razones de seguridad no podíamos saber los nombres de los dirigentes, salvo los que eran públicos. La represión era muy fuerte y todas las precauciones eran pocas.

En cuarto de carrera (1981-1982), cuando empezaron las primeras grandes protestas en el país, logramos tener un funcionamiento más amplio. Hubo una gran marcha del hambre (24 de marzo de 1983); el día previo a mí me tocó mi primer enfrentamiento con la CNI. En el verano del 83 me tocó asumir los trabajos voluntarios de la Universidad de Chile y fuimos a Cañete (VIII Región), una zona mapuche. Llegamos unos trescientos estudiantes con muchas ganas de trabajar con ellos y ayudar a los más humildes. El partido convocó la marcha del hambre como una forma más de lucha contra la dictadura.

\section{6 ¿Estuvo presa en algún momento?}

Nunca caí presa. La vez que estuve más cerca fue cuando terminé los trabajos voluntarios y regresamos al local de la calle Brasil. Nos esperaban unos tipos camuflados de la Central Nacional de Informaciones (CNI). Afortunadamente no me detuvieron porque andaban buscando a otros dirigentes.

\section{7 ¿Llegó a despeñar cargos de responsabilidad en el Partido Comunista?}


Fui parte, hasta 1989, del Comité Central y miembro de la Comisión Ejecutiva de la Jota. Yo me desarrollé fundamentalmente en el ámbito estudiantil y juvenil. Mi vinculación real con los DDHH empezó a partir de 1992, coincidiendo casi con el paso formal al Partido Comunista (1990). En ese momento, me licencié como de abogada, porque durante diez años estuve centrada en la política.

En 1992 entré en el CODEPU (Comité de Defensa de los Derechos del Pueblo), en el departamento jurídico. A partir de ese momento empecé a asumir las primeras querellas por casos de detenidos-desaparecidos. Este trabajo he seguido hasta hoy. Trabajé en el caso de los 21 detenidos-desaparecidos del caso de Parral.

Teníamos un equipo jurídico de abogados: Alberto Espinoza, Fabiola Letelier, Gutiérrez, etc. Teníamos una actividad de denuncia permanente incluso una vez finalizada la transición. Durante el mandato de Enrique Graus, ministro del Interior durante el gobierno Aylwin, se aplicó una represión hacia las movilizaciones de las organizaciones de DDHH. Hubo mucho abuso de poder por parte de la policía de investigaciones. En esos años presentamos muchas querellas sobre tortura a la vez que organizamos conferencias de prensa para difundir la lucha contra la impunidad.

También hay que recordar el trabajo por los presos políticos en los primeros años de la democracia. Hasta el año 94 no finalizamos el proceso de indulto. Nos tocó visitar las últimas cárceles hasta que se liberó a la última presa política (Velinda Subiqueta) en la prisión de Santo Domingo.

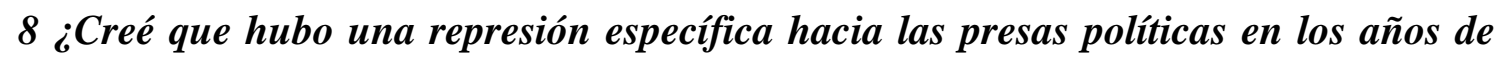
dictadura? ¿Podríamos decir también que hubo un trato diferente a las mujeres según su clase y condición socioeconómica?

Yo creo que no hubo una represión selectiva hacia las mujeres. Lo que sí creo es que la condición de mujer las hacía mucho más débiles en la tortura, es decir, hubo un ensañamiento con ellas en términos de abuso sexual que en el caso de la mujer fue muy característico. En cuanto a métodos de tortura las mujeres sufrieron unas vejaciones muy específicas que pasaban por las violaciones, la electricidad en los genitales, abusos sexuales, etc. 
Durante el primer período de la represión dictatorial, que recayó sobre todo en las mujeres del MIR y del PC, esta realidad sí se dio con mucha frecuencia. Al momento de ser detenidas las mujeres sufrían un abuso mayor por su condición de mujer. Además, los servicios de seguridad se desesperaban ante el comportamiento de valentía que demostraban algunas mujeres con lo que aplicaban cualquier método de tortura para someterlas.

\section{9 ¿Cuál es su visión sobre la renuncia de algunas mujeres del partido a la militancia} en aras del cuidado de sus hijos o viceversa? ¿Esto se dio con frecuencia o fueron hechos muy puntuales?

En primer lugar, luchar contra la dictadura implicaba una decisión personal muy compleja. Todas las que nos comprometimos con la lucha política no se hasta que punto éramos conscientes de los riesgos que ello implicaba. Una tomaba las precauciones pero no siempre eran suficientes.

El riesgo de vida era una cosa permanente, es decir, obviamente hubo muchas renuncias de algunas militantes en cuanto al hecho de tener hijos porque era un riesgo doble. Era una entrega diaria y no había mucho tiempo para dedicarse al cuidado de los hijos y a la familia. A una le absorbía el trabajo político las veinticuatro horas.

Por otra parte, muchas compañeras asumieron también su vida personal, concretamente, su condición de madres cómo algo con muchas limitaciones. Un ejemplo de ello lo encontramos en las compañeras que se fueron al Frente Patriótico Manuel Rodríguez (FPMR) porque en muchos casos tuvieron que renunciar al cuidado de sus hijos siendo estos criados por otras personas. El caso de Gladis Marín es paradigmático puesto que ella tuvo que renunciar a ver a sus hijos durante muchos años.

También, las relaciones de pareja fueron muy efímeras porque muchos partían al exterior a diferentes cursos y las relaciones afectivas simplemente se interrumpían. Era muy difícil llevar una vida normal ante la amenaza permanente de la represión.

10 ¿En algún momento de su militancia tomó conciencia de género ante situaciones de discriminación para la mujer implicada en el trabajo político? 
He tenido acercamientos hacia el movimiento de mujeres. Creo que ciertos grupos de mujeres jugaron un rol importante en la lucha contra la dictadura como Mujeres por la $V i d a$, el $M E N C H$, etc. Ahora bien, dentro de la lucha no había mucha diferencia entre ser hombre o mujer. El compromiso político solía superar estas barreras aunque creo que habría que hacer una distinción de género porque no todas las mujeres tuvieron las mismas oportunidades en muchos terrenos.

Yo no comparto la discriminación positiva porque esto encubre ciertas debilidades que algunas mujeres puedan tener en ciertos momentos, es decir, no por el hecho de ser mujer una tiene que asumir cargos de responsabilidad, esto debiera valorarse en términos de preparación profesional y no de género.

\section{1 ¿El Partido Comunista ha reconocido suficientemente la aportación de sus mujeres militantes en tiempos de dictadura?}

En el partido ha habido un reconocimiento y una preocupación por las mujeres dirigentes. No se aplica el criterio de la discriminación positiva como en otras formaciones políticas. Ha habido un claro esfuerzo en desarrollar el papel de las mujeres trabajadoras y rurales y construir un espacio para ellas dentro de la participación partidaria.

12 ¿Qué elementos positivos y negativos destacaría de su militancia en el Partido Comunista?

Ser parte de PC me ha dado la posibilidad de participar en los procesos de cambio de la Historia de Chile. Una se siente protagonista por haber estado en la participación política y no haberse quedado al margen. Siento que he aportado algo a la lucha contra la dictadura.

El partido me ha aportado un desarrollo personal, intelectual y humano que no hubiera tenido de otra forma. La militancia en el PC me ha ampliado la perspectiva de cómo funcionan las cosas en el mundo. Luego está la sensación de haber aportado algo importante en el partido en todo lo referente a la lucha contra la impunidad, al trabajo por los DDHH. 
El Partido Comunista ha tenido y tiene una posición firme en impedir la impunidad de los responsables de las violaciones de los derechos humanos. Esta ha sido gran parte de la lucha del partido, una lucha muy decidida que se sigue manteniendo hasta hoy. Además, parte de la política del PC ha sido el trabajo en equipo con otras organizaciones como el CODEPU para interponer querellas y seguir trabajando activamente por llevar a delante todos los casos de torturados, exiliados, exonerados y detenidos-desaparecidos.

Todo esto me ha dado una formación profesional y humana que para mí es tremendamente valiosa y que, además, ha venido acompañada de la toma de conciencia de que hay que transformar muchas cosas del sistema de derecho que hoy impera en esta democracia.

Entiendo que algunas compañeras tanto del PC como de otras formaciones políticas que lucharon contra la dictadura tengan una sensación de que han sido olvidadas por sus partidos porque durante la dictadura perdieron sus proyectos de vida, sus proyectos laborales. Pero no creo que esto sea responsabilidad de los partidos, creo que esta deuda la ha de asumir el conjunto de la sociedad o el gobierno para facilitar que estas personas reconstruyan sus vidas de la mejor forma posible. 
43 Entrevista realizada a EVA MARDONES ORDEÑO, 19 de abril de 2005, Santiago de Chile. Mardones es militante del Partido Comunista desde 1969. Trabajó activamente con el movimiento obrero y estuvo detenida en la base naval de Talcahuano, la Isla Quiriquina y el Fuerte Borgoño. Asimismo, estuvo exiliada en Buenos Aires durante el período 1979-1987. Fue coordinadora de la Fundación Vicaría de la Solidaridad, Santiago de Chile.

\section{1 ¿Cómo fueron sus inicios en el Partido Comunista?}

Desde muy chica tuve inquietudes sociales, un poco influenciada por el entorno en el que vivía; nací en una ciudad muy pequeña, en la provincia de Concepción (VIII Región). Esta provincia siempre se caracterizó por ser muy revolucionaria porque siempre se han producido conflictos de carácter social al ser una zona industrial.

En Tomé estaban las industrias textiles en donde trabajaban más de cuatro mil obreros. En esta provincia también estaban las minas de Lota, Coronel, Talcahuano, etc. Recuerdo que los mineros hacían sucesivas huelgas. En este contexto, empecé a sentir esta inquietud de por qué sucedían estas cosas.

Por otra parte, en mi casa se hablaba de política. Mi padre fue un destacado dirigente con muchas inquietudes; él militaba en el Partido Radical, de aquellos militantes del Frente Popular en la época de Pedro Aguirre Cerda.

Además mi madre, sin ser una mujer militante en la política tuvo también mucho interés en estas cuestiones. Ella en la época de la lucha por el sufragio femenino (1949) fue una mujer con mucho sentido de la igualdad en el derecho a voto. Me llevaba a muchas reuniones.

Con el tiempo, como estudiante de Liceo y después universitaria, estas inquietudes se fueron agrandando. Tuve muchos contactos con los mineros porque me tocó hacer prácticas con ellos, en las compañías y escuchaba sus condiciones de trabajo y toda esa rebeldía. Yo sentí la injusticia social con esta experiencia. También me impactó los accidentes que se producían en las minas por el gas grisú. Morían centenares de trabajadores en el fondo de la mina. 
Estando en la universidad, comencé a conocer las actividades de algunos compañeros. Concretamente, en la Escuela de Trabajo Social, conocí a un compañero militante del Partido Comunista. También tuve el referente de algunos familiares que militaron en el PC y fueron deportados durante la dictadura de Gabriel González Videla (estuvieron en el campo de Pisagua, uno de mis primos estuvo detenido y nunca supimos lo que pasó con él).

En 1969, estando en la universidad, pasé formalmente al partido sin pasar antes por las Juventudes Comunistas; esto fue justo antes de las elecciones presidenciales. Fui muy admiradora de Salvador Allende.

\section{2 ¿Qué tareas partidarias desempeñó en los tres años de gobierno de la UP?}

Mi trabajo fue muy activo desde el principio. Entré en una célula para realizar tareas de tipo social. Mi trabajo consistía en hacer prácticas en la fábrica textil de Tomé. Las tareas fueron sobre todo trabajo poblacional, en el movimiento estudiantil, recoger las inquietudes de los trabajadores de la industria textil, etc.

3 ¿En qué situación (presencia, participación política, etc.) estaba la mujer militante del Partido Comunista en los años de la UP?

La imagen que tengo de las mujeres con el triunfo de Allende es de un gran deseo de participar, de hacer cosas, de euforia. Fueron años de mucha alegría y esperanzas, parecía que las cosas en Chile iban a cambiar sustancialmente.

\section{4 ¿En qué situación estuvo el 11 de septiembre de 1973?}

Ese día fue un momento muy trágico. Esa mañana me dirigía hacia la industria textil de Tomé. A las once de la mañana, cuando estábamos trabajando nos dijeron que había golpe militar. Estaba en el consejo de trabajadores. Los militares habían acordonado toda la zona, toda la costa de Tomé. Los marinos de la base naval de Talcahuano habían tomado toda la provincia. 
Nos reunimos todos los dirigentes para ver que hacíamos. Esperábamos instrucciones del partido. Sabíamos que el presidente del sindicato también fue detenido al igual que otros dirigentes regionales del partido y que los estaban llevando a la Isla Quiriquina.

A las tres de la tarde nos fuimos de la fábrica porque se suspendieron todas las tareas. Esa misma tarde nos juntamos un grupo del PC par ver que se podía hacer. Esperamos al día siguiente y volvimos a la fábrica y nos encontramos con que estaba rodeada de militares que estaban deteniendo a mucha gente. A mi no me dejaron entrar en la fabrica.

Yo era funcionaria de la fábrica, encargada del departamento social y me puse a discutir con ellos. Un militar me miró y me preguntó que qué me pasaba. Yo le expliqué todo y él me llevó a la oficina y me dijo que no me preocupara porque no me iba a pasar nada. Me explicó que se estaban estudiando los antecedentes de los trabajadores de la fábrica pero que yo debía estar tranquila.

\section{5 ¿No la detuvieron?}

Sí. Unos días después regresé a la fábrica. A las once de la mañana llegó una patrulla en un jeep y me sacaron de mi oficina. Me encañonaron con sus metralletas y me metieron en el auto. Eran de la Armada pero me llevaron a un cuartel de carabineros.

Allí me dijeron que me iban a llevar a otro sitio para tomarme declaración y que al día siguiente iba a estar de vuelta. Esa noche, a las once de la mañana del 3 de octubre me sacaron de carabineros junto con otros compañeros. Me llevaron a un muelle y me embarcaron en una lancha (pensé que nos iban a tirar al mar y me puse muy nerviosa). Esa noche me trasladaron al apostadero naval donde estaban las oficinas de la Armada. Era la única mujer, el resto eran compañeros dirigentes del PC. Reconocí a muchos de ellos.

\section{6 ¿En dónde estuvo presa?}

En la base naval de Talcahuano que estaba en tierra y luego en la isla Quiriquina, muy cerca. Recuerdo que estaba lleno de grumetes muy jóvenes que cantaban himnos. Había 
mucho movimiento de soldados que iban y venían de la Isla Quiriquina. En el apostadero nos trasladaron a todos para tomar declaración en las oficinas. Antes me pusieron de espaldas en una pared.

A mis compañeros también los pusieron contra la pared. Los patearon. Yo fui testigo durante un buen rato. Después me llevaron a una oficina sobre las dos de la madrugada, aunque una perdía la noción del tiempo. Entré a una sala donde había dos tipos, un suboficial y un soldado.

Lo primero que me dijeron fue que me desnudara, que me sacara la ropa. Yo no entendía nada. En ese momento supe que clase de tipos eran. Mi reacción fue muy violenta porque bajo ningún concepto quería que me vulneraran mi dignidad como mujer...afortunadamente no me obligaron a desnudarme.

Posteriormente, me llevaron por unos pasillos y abrieron una puerta y me metieron en una sala (antiguos camarotes de los grumetes) plagada de mujeres. Fue algo dantesco, estaban hacinadas y tiradas en el suelo.

Al día siguiente empezó el calvario. Nos sacaron a todas las compañeras y nos llevaron al gimnasio del apostadero naval. Pasamos con nuestras pertenencias en fila como en esa película del Holocausto. Nos ficharon, nos tomaron fotografías y nos dieron una tarjeta con nuestros datos.

Lo más terrible es que empezamos a ver a compañeros que salían de la tortura. Recuerdo que a un compañero lo trajeron entre dos milicos. Estaba como un guiñapo. Lo habían molido y torturado, estaba deforme e irreconocible. En ese momento supe el alcance de lo que había pasado. Este compañero se acercó a mí y me dijo -perdóname-. Ahí le reconocí. Le habían tenido tres días y tres noches en la tortura. Después me dijo algo terrible: -yo di tu nombre, me exigieron que tenía que dar un nombre- (Se interrumpe la trascripción de la entrevista por motivos de seguridad de la persona entrevistada y de las otras que están implicadas en los sucesos descritos).

A partir de este suceso a mi me llevaron a Consejo de Guerra. Estuve un mes en este lugar para pasar después a la Isla Quiriquina. Me trasladaron de noche y desde el 
desembarco hasta el otro gimnasio de la isla había que andar un buen trayecto. Un soldado se acercó a mí y me dijo al oído. -tenga cuidado porque algo va a pasar ahora.

Me hicieron un simulacro de fusilamiento junto con otras compañeras. Fue terrible, nos quebraron nuestra voluntad. Pensé que ahí se acababa todo. Nos pusieron contra la pared y nos manosearon. Te manoseaban entera, de una forma muy grosera.

Después nos llevaron a una sala donde había un escritorio. Nos ficharon de nuevo. Teníamos que llevar a todas partes nuestra tarjeta de identificación. Apareció un sargento y dijo: -¿Quién es Eva Mardones?-. Empecé a rezar a dios por si acaso. Después me preguntó: -¿Cómo le han tratado?- Yo contesté que bien....después me revisó el bolsito mostrando una sonrisa. Después dio una orden para que me llevaran a una sala que también estaba lleno de mujeres hacinadas.

Se repitió la misma escena. Mujeres durmiendo en el suelo, ropa interior colgada, algo horripilante. Nadie me ofreció un lugar, me miraban desconfiantes. Cuando una nueva venía se pensaban que podía ser una infiltrada. Sólo una mujer campesina me ofreció un espacio en su colchoneta. Se dio una cuestión de clase muy fuerte.

En los siguientes días estuvimos allí. También en algunas ocasiones me incomunicaban por un día en una celda. Un día me avisaron para ir al apostadero naval para devolverme a la base naval para llevarme a Consejo de Guerra. Me interrogaron varios días y noches. Me preguntaron cuántas veces había estado en Cuba, en la URRS, nombres, etc.

El comandante Acuña estaba a cargo del consejo. El se ponía muy tenso al no dar nombres. Me hicieron jurar la Biblia y me interrogaron, entre el ellos el subsecretario del Ministerio de Justicia.

Después me incomunicaron. Yo era la única mujer dirigente con consejo de Guerra. Esa incomunicación duró diecisiete días. Estuve encerrada en un cuarto de dos metros cuadrados con una ventanita chica. El comandante Gajardo era uno de los violadores. Trató de abusar sexualmente de mí en varias ocasiones. Reaccioné muy violentamente diciendo que prefería que me mataran antes de que me violaran. El tipo no se atrevió a violarme pero se puso muy violento conmigo. 
Enfrente de ese cuartito había una sala en donde se violaron a muchas mujeres. Muchas de ellas eran compañeras de Tomé. Eran niñas pobres. Se aprovecharon mucho de ellas, algunas lloraban mucho.

\section{7 ¿Qué trato recibió durante esos días?}

A mi me torturaron en el plano psicológico. No me aplicaron corriente eléctrica. La Cruz Roja inspeccionó el lugar pero no los calabozos donde estaba la gente hacinada. Ellos no pudieron ver las condiciones en las que los presos estábamos.

Mi experiencia más traumática fue cuando me sacaron a otra pieza en donde me tuvieron tres días. Esa pieza estaba llena de ratas. Es algo de lo que no puedo hablar, se subían por todas partes... (Se interrumpe la trascripción de la entrevista respetando la voluntad de la entrevistada).

\section{$8_{\text {¿Qué le ocurrió cuando salió de la celda de incomunicación? }}$}

Después de esos diecisiete días me llevaron de nuevo a la Isla Quiriquina. Allí estuve varios meses. Me detuvieron el dos de octubre de 1973 y estuve hasta los primeros días de febrero en la isla (perdí la noción del tiempo, no sabría decirte en que día salí).

En ese tiempo pude ver cómo sacaron algunos compañeros y los fusilaron y otros murieron en la base (Fuerte Borgoño) por golpes de corriente. Fue el intendente Álvarez y el teniente Silva. Solían sacar a gente en la noche y en la mañana llegaban muy mal. Una vez nos sacaron a las dos de la mañana y nos metieron en una piscina sin agua y nos tenían varias horas de pie. También lo hacían por la mañana, a medio día cuando el sol era más fuerte. El cemento se calentaba y era como estar en un horno.

Recuerdo a la Rosa (Rosa Elvira Lizama, militante del Movimiento de Izquierda Revolucionaria chileno, MIR) que la tuvieron sujetando un remo al medio día. Estuvo varias horas a pleno sol aguantando el calor y el cansancio.

9 ¿Creé que hubo una represión específica hacia las presas políticas de la Isla Quiriquina? 
Sí. Recuerdo que a las presas para ducharnos nos llevaban a un lugar en donde salía agua helada del mar y nos tenían a todas desnudas allí y los soldados al lado mirando y riéndose de nosotras haciendo comentarios. Era una situación grotesca.

\section{0 ¿En qué circunstancias salió de prisión?}

En los primeros días de febrero un oficial me avisó en la noche (yo estaba durmiendo en el suelo con varias frazadas) y me dijo: - ¿la detenida Eva Mardones?, prepárese porque sale mañana a las siete de la mañana porque usted va a bajar a la base naval- No sabía lo que iba a pasar. Algunas compañeras me felicitaron porque decían que iba a salir libre por algún comentario de un oficial. Me prepararon una pequeña despedida.

A las ocho de la mañana llegué a la base. Pasé a la oficina y me dijeron que iba a salir en libertad. No podía creerlo. A medio día mis hermanas me vinieron a buscar. Finalmente, salí por la puerta de Los Leones. Fue muy emotivo. Incluso un soldado me dijo -si hay que levantar un monumento a una mujer es a usted-.

Quedé con arresto domiciliario. Tenía que ir todos los días sábado al cuartel más cercano. No podía salir de Tomé mientras no tuviera una autorización oficial. Pedí una autorización para ir a una parcela que tenían mis padres y tuve que pedir permiso en un retén de carabineros.

Quedé como un guiñapo por mi reclusión. Mi madre lloraba todos los días y tuve que descansar y reponerme durante varias semanas.

\section{1 ¿Cómo transcurrieron los siguientes meses?}

El 29 de abril de 1974 me detuvieron nuevamente. Me vinieron a buscar al domicilio de mi hermana. Vinieron agentes del la armada. Me llevaron a la comisaría de carabineros. Esa noche dormí en el calabozo. A la mañana siguiente me llevaron a otro retén que queda en Bellavista, en dirección a Concepción. Allí me vendaron y me metieron en un furgón con otros detenidos amontonados. Nunca supimos a dónde nos llevaban. 
Llegamos a un lugar, que no reconocí al principio, pero supe después que era el Fuerte Borgoño. Se oía el mar. Nos hicieron desfilar y nos amenazaron con tirarnos al océano. Nos interrogaron y nos maltrataron mucho. Nos decían que estábamos en Punta Arenas, para hacernos perder la noción del tiempo. Hubo mucha violencia. A mi me empujaron y me tiraban hacia un lado y hacia otro. Allí estuve dos días.

El 3 de mayo me llevaron a Tomé. Ahí decidí que tenía que salir del país. Seguía bajo arresto domiciliario pero lo violé y me escapé a Santiago. El Comité Pro-Paz me había hecho los contactos para poder salir de Chile.

\section{2 ¿Cómo fue su partida al exilio?}

Desde el Comité Pro-Paz se planificó mi salida. El destino era Buenos Aires para pasar posteriormente a México. En BA tuve algún problema de documentación y decidí quedarme un tiempo porque me sentí bien y me encontré con algunos compañeros del partido.

Un compañero me llevó a una organización que acogía a exiliados chilenos. Ellos tramitaron mi residencia y el permiso para trabajar. También recibí ayuda del Alto Comisionado de Naciones Unidas (ACNUR), un subsidio por tres meses. Conseguí trabajo y pude adaptarme. Me quedé varios años.

Entre medio (1979-1980) viajé a Europa, concretamente a Suiza. Regresé a la Argentina para quedarme de nuevo hasta 1987. Milité en el Partido Comunista Argentino, incluso entré en la dirección durante los años de la dictadura. Después se organizó el Partido Comunista chileno en Argentina con Julieta Campusano.

\section{3 ¿Qué tareas partidarias realizó en Argentina?}

A mi me tocó desempeñar unas tareas importantes...de las que no puedo hablar...

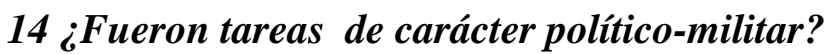

Sí. 


\section{5 ¿Cómo fue su regreso a Chile?}

Regresé a Chile a finales de 1987. El regreso fue traumático, me encontré con un país totalmente cambiado. Caminaba por la calle y tuve muchos problemas para encontrarme con mis compañeros. Sólo a través del Colegio de Asistentes Sociales pude vincularme de nuevo con mis amistades.

También me integré en una célula para participar en la PRP (Política de Rebelión Popular) desde la clandestinidad. Hicimos algunas acciones de carácter político-militar.

Participé activamente en la campaña por el NO. A partir de ahí me vinculé a la Vicaría de la Solidaridad para prestar mi testimonio. Asumí un cargo de responsabilidad en el equipo de Solidaridad de la Vicaría de la zona oeste.

Tuve una entrevista con el vicario. Él conocía mi historia y me dijo - no te voy a hacer ninguna pregunta, lo único que te voy a pedir es fidelidad con la institución que te recibe- yo contesté que no tenía ninguna duda sobre eso y que sería responsable en el desempeño de mis tareas.

Llegué a ser jefa del equipo de Solidaridad. Allí estuve tres años. Se portaron muy bien conmigo. Fueron unos años intensos pero muy traumáticos. Tuve que hacer dos terapias psicológicas porque me costó mucho adaptarme a todo. Finalmente fui precandidata a senadora por la IV región en 1996. 
44 Entrevista a PATRICIA TORRES MUÑOZ, 29 de abril de 2005, Santiago de Chile. Torres, con una destacada trayectoria en la lucha universitaria, es militante del Partido Comunista desde 1979. Ha sido integrante de la Comisión de Derechos Humanos Juvenil (CODEJU) y miembro del Comité Central de las Juventudes Comunistas. Asimismo, estuvo detenida en la Correccional de Mujeres (COF) y en el campo de concentración Pisagua. Torres, participó en diversas agrupaciones de mujeres e impulsó políticas de género en el seno de su partido.

\section{1 ¿Cómo fueron sus inicios en el Partido Comunista?}

Empecé a militar en 1979, estaba estudiando trabajo social en la Universidad de Chile. En esos tiempos era muy difícil entrar a militar porque los partidos estaban en la clandestinidad. En ese año yo terminaba mi carrera y hubo una movilización estudiantil contra la dictadura. En ese primer contacto pude percibir la situación tan injusta en la que estaban algunos estudiantes.

Me ofrecí para hablar con el presidente del centro de alumnos que era designado por la Junta y con la dirección de la Escuela de Trabajo Social. Me dieron con la puerta en las narices alegando que mis compañeros eran subversivos. A partir de este momento, empecé a participar en diversas asambleas en donde tuve la oportunidad de intervenir. En ese mismo período hubo elecciones para el centro de alumnos y me presenté y salí elegida presidenta de la Facultad de Ciencias Humanas.

Además tenía una hermana que estaba exiliada en Canadá y su marido era miembro del Partido Comunista. Este fue mi antecedente para acercarme al partido. De esta forma, encontré algunos compañeros que estudiaban en la universidad y que militaban en las Juventudes Comunistas. Hubo una serie de preliminares antes de entrar en al Jota.

\section{2 ¿Cómo recuerda la presencia de la mujer en el partido durante aquellos años?}

Al ingresar a la Jota yo tenía algunos prejuicios sobre la rigidez de esta formación. La mayoría de la gente que estaban militando en la célula de la universidad eran mujeres que venían de "carreras femeninas" como psicología o trabajo social. 
En un comienzo, no tuve conciencia de que por mi condición de mujer podía tener trabas a la hora de desempeñar el trabajo político. La mayoría de la gente que militaba en esas condiciones de represión ni se planteaba estos temas de género.

Yo era soltera pero tenía dos problemas, el primero que no podía andar por ahí sola muy tarde porque me arriesgaba a tener algún episodio desagradable. En las reuniones los hombres podían salir tarde pero yo vivía en San Bernardo (a $20 \mathrm{~km}$ de mi casa) con lo que no podía quedarme mucho tiempo. Esto venía a significar perderme las conclusiones de cada reunión y momentos importantes en la toma de decisiones.

Si había una mujer con hijos era imperdonable que llegara tarde o no llegara a la reunión por cuidar de sus cabros, es decir, no era una excusa para no asistir. No había ninguna consideración extra para aquellas mujeres que tenían ciertas dificultades.

Además, los hombres nunca asumieron esas responsabilidades domésticas a diferencia de las mujeres que tenían que estar en los dos frentes. Era muy complicado plantear estos temas porque estaba la urgencia de la represión y la lucha contra la Junta.

\section{3 ¿Qué tareas partidarias fue desempeñando con el tiempo?}

Al poco tiempo de ingresar en la Jota pasé a ser secretaria política. Había una estructura interna-clandestina y otra pública. Mi trabajo lo desempeñé casi siempre en lo público. Una no podía decir que era comunista sino presidenta de un centro de alumnos aunque compaginara ambas cosas en dichas reuniones con las organizaciones estudiantiles. Allí nos pasábamos información, distribuíamos tareas, etc. También hubo un momento en el que me empezaron a perseguir hasta que me detuvieron.

Por otra parte, participé en la Comisión Derechos Humanos Juvenil (CODEJU, creada en 1975) siendo miembro de la ejecutiva.

En 1981 fui expulsada de la universidad. Me empezó a perseguir la CNI. Estuve seis meses clandestina para pasar después a aparecer en público en una huelga de hambre en donde me sacaron y me metieron presa otra vez. 
En diciembre de 1980 hubo una orden de detención contra mí. La Jota me dijo que no me entregara y que pasara a la clandestinidad. Yo era muy conocida como dirigente estudiantil. La Jota me buscó las casas, me cambió de look, etc. En el equipo de seguridad la mayoría eran hombres.

En la clandestinidad se decidió que debíamos aparecer iniciando una huelga de hambre porque había muchos dirigentes que habíamos sido expulsados de la universidad y la CNI nos estaban buscando.

En la huelga de hambre nos tomamos la catedral de Santiago. A los nueve días de la huelga llegó la policía de investigaciones y nos tomaron presos. Tomaron la catedral con gases lacrimógenos. Quedamos cuatro presos, dos hombres y dos hombres. A nosotras nos llevaron a la COF (Correccional de Mujeres), allí continuamos la huelga de hambre, estuvimos diecinueve días.

\section{$4_{\text {¿Cómo fue su experiencia en la reclusión? }}$}

Fue una experiencia muy fuerte. A nosotras nos aislaron en un recinto de alta peligrosidad dentro de la COF. Allí convivíamos con presas con delitos de asesinatos y dos presas políticas del MIR con penas perpetuas (Miriam y Escobar por el asesinato de Roger Vergara). Ellas nos acogieron muy bien, tenían más experiencia que nosotras en la reclusión. Además la Jota organizaba visitas masivas de estudiantes que nos iban a ver, había mucha presión desde afuera.

Por lo general, había mucha cohesión en el interior de la cárcel. Nos llevaban comida y al final terminábamos distribuyéndola a las presas más humildes. No era fácil establecer lazos porque había mucha desconfianza por problemas de seguridad. Una no sabía al principio quién estaba allí y con quién se podía hablar. Sin embargo, logramos mucho respeto y una buena convivencia con las presas. De hecho, las presas nos cuidaron mucho cuando estuvimos en huelga de hambre.

Finalmente, salí el mes de junio de 1981. Nos dejaron en libertad bajo fianza firmando en la Fiscalía Militar. El proceso duró hasta 1989 donde nos dictaron sentencia. Estuvimos firmando en el Patronato de Reos durante un año y medio. Después armamos 
un grupo de estudiantes sancionados donde trabajábamos al alero de la Comisión de Derechos Juveniles (CODEJU).

5 ¿En qué circunstancias se reincorporó de nuevo al trabajo clandestino una vez que salió de prisión?

En 1982 la Jota nos planteó incorporarnos en la CODEJU como representantes de las Juventudes Comunistas. Fuimos dos mujeres dentro de ese equipo de trabajo. Allí estaban representadas todas las juventudes de los partidos de la oposición.

Este trabajo lo compaginé paralelamente con el trabajo clandestino del partido. En aquella época me nombraron miembro del Comité Central de la Jota. Éramos muy pocas mujeres en el CC, entorno al 20 por ciento.

A partir de 1983 el partido empezó a plantear acciones aisladas de carácter político militar y de rebelión popular. En este año se hizo una marcha del hambre convocada por el PC. El día antes de la marcha me tomó nuevamente presa la CNI, me tuvieron presa nueve días en un cuartel para pasarme después al Campo Pisagua (un campo de concentración histórico en el norte de Chile).

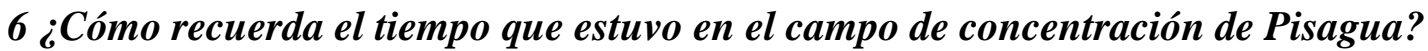

En Pisagua estuve tres meses. Éramos dos mujeres y treinta y tantos hombres. Casi todos presos de la marcha del hambre. Allí nos organizamos en un comité de presos para organizar la convivencia. Había estudiantes universitarios, trabajadores de la construcción, miembros de Partido Socialista. Allí desenterraron años después a varias personas detenidas-desaparecidas.

7 ¿Creé que hubo una represión específica hacia las presas políticas en los años de dictadura? ¿Podríamos decir también que hubo un trato diferente a las mujeres según su clase y condición socioeconómica?

Por supuesto que sí que hubo una política planificada y muy estudiada a la hora de torturar a las presas. La CNI lo que hacía precisamente era amenazar con violación o 
abuso sexual. Ellos hacían perfectamente la diferencia entre presos y presas. A una la acosaban, la abusaban sexualmente. No es que te trataran mejor o peor sino que utilizaban otro tipo de tortura contigo.

Carabineros tenían un comportamiento más decente con nosotras aunque hacían una distinción de clase a la hora de tratar a las presas. A las pobladoras las trataban especialmente mal porque no tenían la educación que nosotras. Los pacos eran terriblemente machistas, nos preguntaban por qué estábamos metidas en política, con una actitud totalmente paternalista.

Incluso los compañeros de partido eran muy paternalistas con nosotras. Recuerdo que en Pisagua en 1983 fue un lugar próspero con el Salitre para pasar después a ser una zona en ruinas, abandonada. Había muchas casas vacías y en muy mal estado. Nosotras nos instalamos allí. No teníamos ni platos para comer.

Un militar se instalaba siempre cerca de nosotras para hacerse el bueno, increpándonos constantemente como si fuéramos jovencitas "tontas". La idea era ablandarnos. El siempre se instalaba en mi celda del campo de Pisagua.

Ellos siempre tuvieron un modus operandi perfectamente calculado a la hora de torturar a los dos sexos. Sabían perfectamente lo que más nos dolía, es decir, todo lo relacionado con lo sexual. Con los hombres también hubo estas prácticas dirigidas a dañar su identidad sexual.

8 ¿Después de esta experiencia tuvo algún acercamiento con las agrupaciones de DDHH?

Después de abandonar el campo de Pisagua pasé a formar parte del Movimiento Democrático Popular (MDP) en donde estaban el Movimiento de Izquierda Revolucionaria (MIR), Partido Socialista (PS), MAPU, la Izquierda Cristiana (IC) y el Partido Comunista.

Era un proyecto democrático que aspiraba terminar con la dictadura. Yo ocupé parte del Comité Ejecutivo del Movimiento Juvenil Democrático-Popular (MJDP). Fui la única 
mujer que ocupó un cargo de tanta responsabilidad, no era lo normal, creo que me nombraron por mi trayectoria como dirigente pública. Hasta 1986 trabajé en el MDP hasta que se quebró. El MIR y el PC quedaron fuera de la Concertación.

Estuve trabajando en la Comisión de Derechos Juveniles; desde allí interpusimos muchas querellas por compañeros desaparecidos. Después de 1983, cuando empezaron a incrementarse las protestas en todo el país, hubo un importante giro en la denuncia a las violaciones de DDHH. La gente empezó a participar más en las movilizaciones, a salir a la calle, poner recursos de amparo, etc.

\section{9 ¿Volvió a caer presa?}

Sí. Caí presa en 1985. Carabineros me detuvo. Estuve en la comisaría, justo el mismo día que tomaron preso a José Miguel Parada y a Manuel Guerrero (Los degollados). A ellos los asesinaron y a mi me soltaron. Esto fue un duro golpe para el partido.

\section{0 ¿Desarrolló algún trabajo relacionado con el tema de género tras vivir estas} experiencias en la reclusión? ¿En qué momento empezó a tomar conciencia sobre los problemas específicos de las mujeres de su partido?

A mediados de 1985 la Jota me planteó trabajar en el Frente de Mujeres o en la Comisión Femenina de las Juventudes Comunistas. Empecé a trabajar el tema de género a finales de 1986. Siempre el discurso del partido había relegado a un plano secundario los problemas específicos de las mujeres. Yo hice varios escritos apoyando el impulso de una política firme de género ante la llegada de un cambio democrático.

También mantuve contactos con grupos feministas como La Morada y el FMS (Frente de Mujeres Socialistas). Empezamos a plantear que las reuniones al interior del partido debían acoger el problema de género como algo necesario para asumir un posible cambio hacia la democracia. Esto fue algo complejo porque en esos años todavía pesaba la mentalidad en el partido de que la mujer debía estar en la retaguardia. Esta palabra aparecía siempre en los discursos de los compañeros del PC, es decir, un discurso absolutamente patriarcal. 
Yo elaboré varios documentos respecto al rol de la mujer en el partido. Este trabajo fue rechazado en las reuniones. La idea era crear una Comisión de Mujeres al interior de la Jota que tuviera peso y relevancia en las decisiones de la Comité Central.

Los planteamientos que fui absorbiendo de La Morada fueron siempre rechazados. El asesoramiento de esta organización me ayudó a formular una crítica profunda al PC con respecto a la situación de la mujer en el partido. En una reunión del Comité Central en el que se estaba trabajando sobre el futuro programa del partido yo plante la necesidad de incorporar la discriminación positiva.

\section{1 ¿Qué reacción tuvo su partido al presentar estas propuestas?}

Recuerdo que el secretario de la Juventud golpeó fuertemente la mesa diciendo que “¡no permitiré reivindicaciones socialdemócratas!-”. Sólo tres personas del Comité Central apoyaron la iniciativa. El resultado fue que me sacaron de la Comisión, es decir, me echaron. Después me citaron para que saliera de las funciones de encargada de la Comisión de la Jota. A partir de ahí entré a formar parte del PC, es decir, pasé de la Juventud al partido pero volví a tener las mismas dificultades a la hora de plantear demandas de género.

Tan sólo en 1993 empezaron a considerarse algunas demandas de mujeres en el partido. Yo soy partidaria de la discriminación positiva porque al final lo que importa es favorecer la participación de la mujer en todos los ámbitos del. Sin embargo, reservar un cupo para integrar a las mujeres en la vida política no resuelve el problema de fondo que sigue siendo el peso de la mentalidad machista de la mayoría de los hombres.

Gran parte de los avances con respecto a la situación de desigualdad de las chilenas han sido provocados por las luchas de las organizaciones feministas y no de las formaciones políticas. Las mujeres de la izquierda política han reivindicado siempre sus problemas como trabajadoras y no como mujeres y esto es algo que necesariamente ha de cambiar para abordar de una forma seria y responsable las necesidades específicas que tenemos. 
-“Las mujeres en la izquierda chilena durante la Unidad Popular y la dictadura militar (1970-1990)".

Doctorando: Javier Maravall Yáguez.

Director de Tesis: Álvaro Soto Carmona.

Departamento de Historia Contemporánea.

Universidad Autónoma de Madrid (UAM), 2012.

Proyecto financiado por la Agencia Española de Cooperación internacional (AECI), Ministerio de Asuntos Exteriores, Gobierno de España, 2003-2005. 